\title{
CARBOHYDRATES IN SYNTHESIS
}

Pau1 W. Smith

St. Catherines College, Oxford.

D. Phil. Michaelmas Term, 1986

$\underline{\text { ABSTRACT }}$

The use of carbohydrates as starting materials for organic synthesis is illustrated by the synthesis of several polyhydroxylated piperidine, pyrrolidine, indolizine and pyrrolizidine alkaloids.

Nucleophilic displacement by azide ion at $\mathrm{C}-2$ in a D-glucose derivative, with subsequent intramolecular cyclisation through nitrogen onto the C-6 or C-5 position and functional group manipulation, led to the synthesis of: 1,5-dideoxy-1,5-imino-D-mannitol; 1,2,5-trideoxy-1,5-imino-D-arabinohexitol; 1,5-dideoxy-1,5-imino-D-glucitol; 2-Acetamido-1,5-imino-1,2,5trideoxy-D-glucitol; 2-Acetamido-1,5-imino-1,2,5-trideoxy-D-mannitol; (2S, 3R, 4R, 5S)-3,4,5-trihydroxypipecolic acid; (2S, 3R, $\overline{4 R}, 5 R)-3,4,5-$ trihydroxypipecolic acid and 2,5-dideoxy-2,5-imino-D-mannitol.

Nucleophilic displacement by azide ion at C-3 in a D-glucose derivative, with subsequent intramolecular cyclisation through nitrogen onto the C-6 position, produced the tosylate salt of 3,6-dideoxy-3,6-imino-1,2-0-isopropylidene- $Q-D-g l$ cofuranose, a highly divergent intermediate, from which the pyrrolidines: 1,4-dideoxy-1,4-imino-L-gulitol, 1,4-dideoxy-1,4-imino-D-Iyxitol and (2S, 3S, 4R) - 3,4-dihydroxyproline were prepared directly. Periodate cleavage of the $\mathrm{C} 1-2$ bond and a $2-\mathrm{C}$ chain extension from $\mathrm{C}-2$ with subsequent intramolecular cyclisation, produced the pyrrolizidine (1S, 2R, 8R) 1,2-dihydroxypyrrolizidine. An intramolecular Wadsworth Emmans cyclisation between a lactol at $\mathrm{C}-1$ and a phosphonate, produced by a DCC coupling of the amine with dimethoxyphosphinylacetic acid, led to the formation of the indolizine (1S, 2R, 8S, 8aR) - 1,2,8-trihydroxyoctahydroindolizine.

The synthesis of 1,4-dideoxy-1,4-imino-D-lyxitol, was achieved by connection of $\mathrm{C} 1$ and $\mathrm{C} 4$ of a $\underline{\mathrm{D}}$-mannose derivative through nitrogen.

Methyl 3,5-0-isopropylidene- $a$-D-xylofuranoside was elaborated to both enantiomers of 1,4-dideoxy-1,4-imino-arabinitol. The D-enantiomer was produced by introduction of a nitrogen between $\mathrm{C}-2$ and $\mathrm{C}-5$, the $\underline{L}-$ enantiomer by introduction of a nitrogen between $\mathrm{C}-1$ and $\mathrm{C}-4$.

$(2 R, 3 S, 4 R)$ - 3,4-dihydroxyproline was prepared from D-ribonolactone. The key step of the synthesis was a nucleophilic displacement by azide ion at $\mathrm{C}-2$ in which the stereochemistry was unexpectedly retained. 

C A R B O H Y D R A T E S I N S Y N T H E S I S

by

Paul W. Smith

St. Catherines College, Oxford.

Michaelmas Term 1986.

A Thesis submitted in partial fulfilment of the requirements for the degree of $D$. Phil.

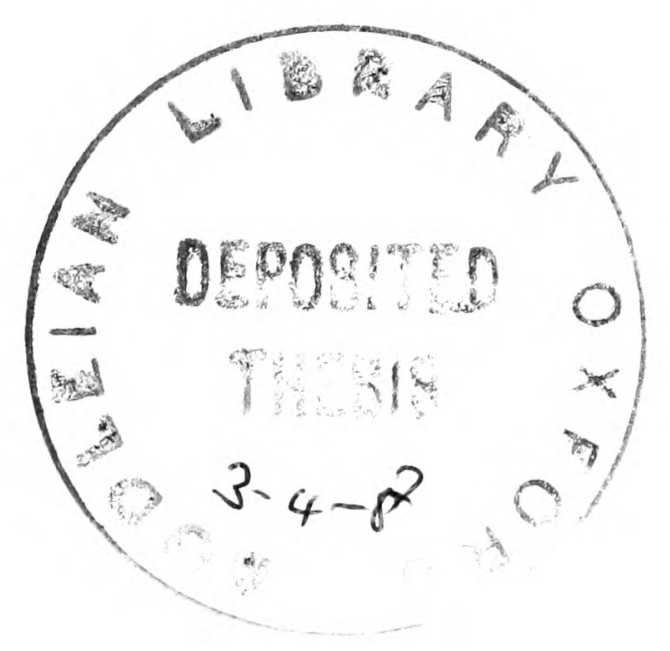




\section{ACKNOWLEDGEMENTS}

My sincere thanks go to my supervisor Dr George Fleet whose ideas and enthusiasm for the project were a constant source of inspiration. This space is much too small to sufficiently express my gratitude for his inestimable contribution.

I would also like to thank Mrs Elizabeth McGuiness, Dr Andy Derome, Dr Robin Aplin and the technical staff (Tina, Alan, Val and Mrs Shah) for running the spectra in this thesis, not forgetting the valuable contribution of Rob Young, without whom there would have been very few ${ }^{13} \mathrm{C}$ spectra.

I am extremely grateful to Chris Mathews for drawing all the diagrams in this thesis over many hours on the VAX terminal, and to Dr Charlie Laughton for writing the program used. I would also like to thank my mother for her invaluable contribution to the typing.

Finally I would like to thank all my many friends from the Perkin Lab- both past and present who have put up with me during the past three years; particularly Rob Lunn (excepting the countless occasions at which he beat me at squash and snooker), who must be the most tolerant person alive. 


\section{CONTENTS}

ACKNOWLEDGEMENTS

CONTENTS

ABBREVIATIONS

Note concerning nomenclature

GENERAL INTRODUCTION

Occurrence and biological applications

The role of the synthetic chemist

Structural relationship between inhibitors and the glycosidases whose hydrolysis they inhibit.

Current theories on the mode of glycosidase action and mechanism of inhibition.

Synthetic strategy

References

1. APPROACHES TO THE SYNTHESIS OF POLYHYDROXYLATED NITROGEN HETEROCYCLES

FROM D-GLUCOSE PART I : INTRODUCTION OF NITROGEN AT C-2

INTRODUCTION

Occurrence and biological action of the natural products

Previous synthetic work

RESULTS AND DISCUSSION

Retrosynthetic analysis

Synthesis i) Preparation of the bicyclic intermediates Methy1 ( $\underline{N}-$ benzyloxycarbonyl \& $\underline{N}-\underline{t}$-butyloxycarbony 1-3-0-benzy 1-2,6-dideoxy2,6-imino) $a$-D-mannofuranoside (1.10a and b).

ii) Synthesis of the piperidine alkaloids (1.1) - (1.7)

iii) Synthesis of the pyrrolidine alkaloid 2,5-dideoxy-2,5-iminoD-mannito1 (1.8). 
EXPERIMENTAL SECTION

General directions

General procedures for ion exchange chromatography

SUMMARY

REFERENCES

2. APPROACHES TO THE SYNTHESIS OF POLYHYDROXYLATED NITROGEN HETEROCYCLES

FROM D-GLUCOSE PART II : INTRODUCTION OF NITROGEN AT C-3.

INTRODUCTION

Occurrence, biological action and previous syntheses

RESULTS AND DISCUSSION

Retrosynthetic analysis

The syntheses

i) Preparation of the tosylate salt of 3,6-dideoxy-3,6-imino1,2-0-isopropylidene- $a$-D-glucofuranose (2.13).

95

ii) Synthesis of the pyrrolidines (2.1) - (2.3)

98

iii) Synthesis of the indolizidine (2.4)

103

iv) Synthesis of the pyrrolizidine (2.5)

107

v) Approaches to the synthesis of crotanecine (2.6)

EXPERIMENTAL SECTION

SUMMARY

REFERENCES

3. SYNTHESIS OF 1,4-DIDEOXY-1,4-IMINO-D-LYXITOL \& APPROACHES TO THE SYNTHESIS OF PYRROLIZIDINE ALKALOIDS FROM D-MANNOSE.

RESULTS AND DISCUSSION

Synthesis of 1,4-dideoxy-1,4-imino-D-1yxito1 (3.1) 
SUMMARY

REFERENCES

4. THE SYNTHESIS OF BOTH ENANTIOMERS OF 1,4-DIDEOXY-1,4-IMINO-

ARABINITOL FROM D-XYLOSE.

INTRODUCTION

Previous syntheses

RESULTS AND DISCUSSION

Retrosynthetic analysis

The synthesis

1,4-dideoxy-1,4-imino-D-arabinitol (4.1)

1,4-dideoxy-1,4-imino-L-arabinito1 (4.2)

EXPERIMENTAL SECTION

SUMMARY AND REFERENCES

5. APPROACHES TO THE SYNTHESIS OF DIHYDROXYPROLINES FROM DERIVATIVES

OF D-RIBONOLACTONE.

INTRODUCTION

Dihydroxyprolines in nature and previous synthetic work

Retrosynthetic analysis

Synthesis of the D-amino acid (2R, 3S, 4R)-3,4-dihydroxyproline (5.1)

Approaches to the synthesis of (2S, 3S, 4R)-3,4-dihydroxyproline (5.2)

from derivatives of $\underline{D}$-ribonolactone.

Approaches to the synthesis of (2S, 4S)-4-hydroxyproline (5.29)

EXPERIMENTAL SECTION

SUMMARY

REFERENCES 


\section{ABBREVIATIONS}

Ac Acetyl

AIBN 2,2' azo-bis-isobutyronitrile

Bn benzy 1

BOC t-butyloxycarbony1

BOM benzyloxymethy1

$\mathrm{Bu} \quad$ buty 1

$\mathrm{Bz} \quad$ benzoyl

DBU 1,8 -diazabicyclo $[5,4,0]$ undec-7-ene

DCC N, $N^{\prime}$-dicyclohexylcarbodiimide

DCM dichloromethane

DMAP 4-dimethylamino-pyridine

DMF dimethylformamide

Et ethy1

HOBT 1-hydroxybenzotriazole

Me methyl
MEM Methoxyethoxymethy 1

Ms methanesulphonyl

PCC pyridinium chlorochromate

$\mathrm{Ph} \quad$ phenyl

Pr propyl

PTC-Cl phenyl chlorothionocarbonate

py pyridine

TEA triethylamine

Tf trifluoromethanesulphony 1

TFA trifluoroacetic acid

THF tetrahydrofuran

Tr triphenylmethyl

Ts $\quad$-toluenesulphony 1

Z benzyloxycarbonyl 


\section{Note concerning nomenclature}

Throughout this thesis the names of the compounds are, as far as possible, derived from the appropriate sugar. Trivial names of the natural products are also used when relevant.

Note that in chapter 1 and 2 , hydrolysis and reduction of the acetal function in (1.10) and (2.13) inverts the numbering system. (Fig).

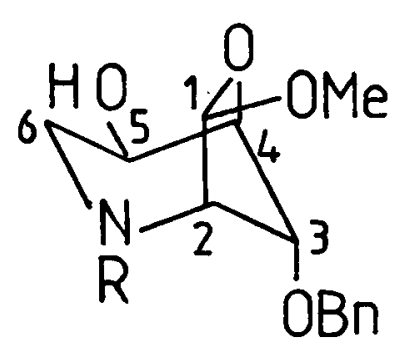

$(1.10)$

2,6-dideoxy-2,6-imino- $\underline{\text { D-mannofuranoside }}$

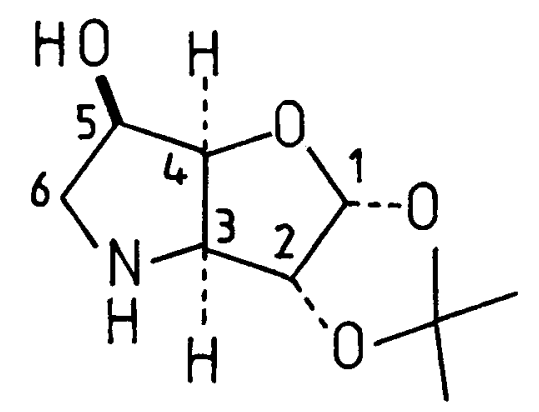

(2.13)

3,6-dideoxy-3,6-imino-D-glucofuranoside

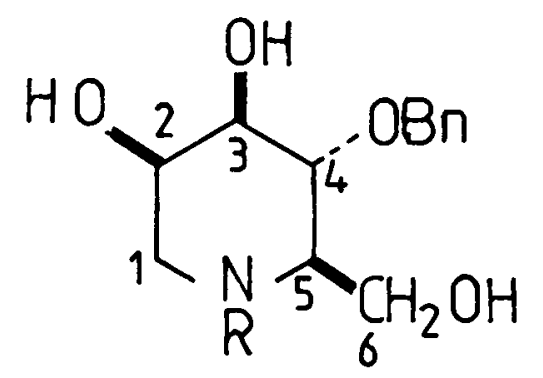

1,5-dideoxy-1,5-imino-Dmannitol

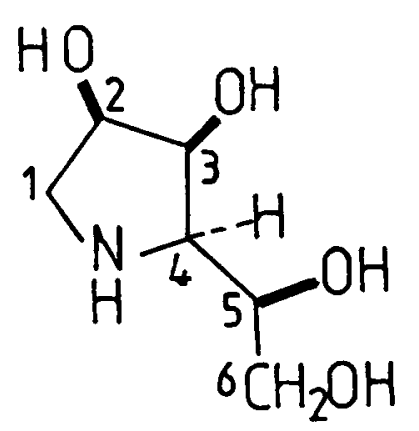

1,4-dideoxy-1,4-imino-Lgulitol 


\section{GENERAL INTRODUCTION}

This thesis describes approaches to the synthesis of some polyhydroxylated id piperidines, pyrrolidines and indolizfines.

\section{Occurrence and biological applications}

Several polyhydroxylated piperidine, pyrrolidine and indolizine alkaloids, which structurally resemble monosaccharides, have been isolated from plants and microbes 1 .<smiles>OCC1NC(CO)C(O)C1O</smiles>

(1)<smiles>OCC1NCC(O)C(O)C1O</smiles>

(5)<smiles>O=C(O)C1NCC(O)C(O)C1O</smiles>

(10)

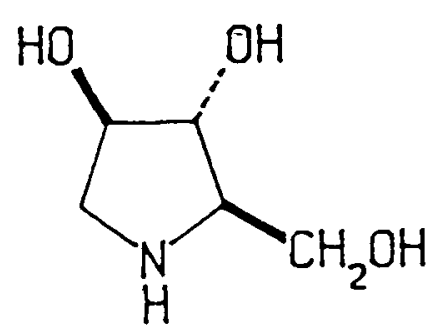

(2)<smiles>[R]C1C(O)CCNC1CO</smiles>

(6) $\mathrm{R}=\mathrm{H}$<smiles>OCC1NCC(O)C(O)C1O</smiles>

(4)

(3)<smiles>CC1CN2CCCC(O)C2[C@H]1O</smiles>

(8)<smiles>OC1CN2CCC(O)C2C(O)C1O</smiles>

(9)

(7) $\mathrm{R}=\beta$ - - -glucose 
Plants are believed to produce these compounds as part of their defence mechanism against insects and other predators ${ }^{2}$. The molecules have been found to be potent inhibitors of glycosidase enzymes from a variety of organisms $^{3}$.

Some insects are inhibited from feeding when the pyrrolidine (1) is incorporated into otherwise attractive food, but when force fed they are not harmed. (1) appears only to deter their choice. It may be that the food sensing organs of some insects contain a glycosidase and free sugars liberated by the action of this sensory glycosidase signal to the insect that the plant is worth eating. Compounds which produce this effect could be used as antifeedants for crop protection.

In insects an important reserve carbohydrate is the sugar trehalose which is broken down into two molecules of glucose by the glycosidase enzyme trehalase. The pyrrolidine (1) inhibits trehalase in the flesh fly. Since trehalose is not found in mammals, in principle,inhibitors of trehalase, like (1), could prove useful insecticides.

Deoxynojirimycin (1,5- dideoxy- 1,5- imino- D- glucitol) (4) inhibits glycosidases in the gut and, if given with food, reduces subsequent rise in the levels of glucose in the blood. Inhibitors of mammalian digestive disaccharidases ${ }^{4,5}$ which release sugars may find application in studies of hyperglycaemia, hyperlipidaemia and related disorders 6,7 .

Glycoproteins are proteins to which oligosaccharides are attached. They participate in many fundamental biochemical interactions such as cell recognition. The structures of glycoproteins are modified in nature by 
glycosidases which selectively remove monosaccharide units (trimming) ${ }^{8}$. Compounds like (1) - (10) and some synthetic analogues, which specifically inhibit particular glycosidases, have been used to modify these trimming reactions in a known way and thereby determine the extent to which the properties of the glycoprotein depend on the oligosaccharide side chain.

Inhibitors of glycoprotein processing have been used in other ways. For example swainsonine (8), when ingested by cattle, induces a neurological condition similar to the human hereditory disorder mannosidosis. Victims of mannosidosis lack a mannosidase enzyme and so oligosaccharides containing mannose are not broken down, but accumulate in cells. Swainsonine inhibits the action of a mannosidase 8,9 and so induces a similar accumulation of mannose containing oligosaccharides. It is currently being used in normal cell lines in order to gain a better understanding of the disease state. Similar disorders are caused by absence of other glycosidases, for example glucuronidase and iduronidase. The trihydroxypipecolic acid (10) has been found to inhibit both these glycosidases 10 and is now being used to study this disease state.

Since the compounds are highly specific in the enzymes which they inhibit, there are two further important potential uses. Attachment to affinity chromatography columns should enable separation and purification of enzymes, otherwise difficult to isolate. In addition, where several enzymes are present in a system and their individual role is unclear, specific inhibition of one enzyme should allow the behaviour of the other enzymes to be examined. In a recent development, swainsonine (8) was found to enhance the activities of the mouse immune system both in vitro ${ }^{11}$ and in vivo $\underline{\text { iv }}^{12}$. Some degree of 
immunosuppression commonly is associated with the infection and tumour disease processes. This then is a further area where these compounds may be of biological interest.

The role of the synthetic chemist

The role of the synthetic chemist in this area is an important one. The naturally occurring compounds are generally produced in only very small amounts and so the development of viable routes for the synthesis of reasonable quantities of the natural products is desirable. In addition to synthesising the natural products, the preparation and study of the biological properties of synthetic analogues is also of great interest. This should, ultimately, enable an infallible correlation between the structure of the inhibitor and the inhibited enzyme to be established, which in turn would allow future investigators to design the structures of new inhibitors for any desired glycosidase enzyme with certainty of success.

\section{Structural relationship between the inhibitors and the glycosides whose} hydrolysis they inhibit.

\section{i) Polyhydroxylated piperidines}

There is an excellent correlation between the structure of the polyhydroxylated piperidines and the corresponding glycoside whose hydrolysis they inhibit.

Deoxynojirimycin (1,5-dideoxy-1,5-imino-D-glucitol) (4) which is related to glucopyranosides (11) (by substitution of the pyranose oxygen with NH and deoxygenation at $\mathrm{C} 1$ ) inhibits the activity of glucosidases ${ }^{13}$. Deoxymannojirimycin (1,5- dideoxy- 1,5- imino- D- mannitol) (5) similarly related to mannopyranosides (12) inhibits mannosidases ${ }^{14}$. 
1,5- Dideoxy- 1,5- imino- L- fucitol (13), the corresponding L- fucose analogue ${ }^{15}$ is a potent and specific inhibitor of several $a$ - fucosidases. (Fig 2).<smiles>OCC1NCC(O)C(O)C1O</smiles>

(4)<smiles>[R6]C1OC(CO)C(O)C(O)C1O</smiles>

(11)<smiles>OCC1NCC(O)C(O)C1O</smiles>

(5)<smiles>[R6]C1OC(CO)[C@H](O)[C@H](O)[C@H]1O</smiles>

(12)<smiles>OC1CNC(O)C(O)C1O</smiles>

(13)<smiles>[R9]C1OC([125I])C(O)C(O)C1O</smiles>

$\underline{L}$-fucopyranoside<smiles>OCC1NCCC(O)C1O</smiles>

(6)

\section{FIG 2.}

In contrast, fagomine (1,5- imino- 1,2,5- trideoxy- $\underline{\text { D- }}$ arabino- hexito1) (6) deoxygenated at $\mathrm{C} 2$, does not produce any appreciable inhibition against a range of glycosidases ${ }^{16}$. For a number of glycosidases, interaction with the $\mathrm{C} 2$ hydroxyl has been found to be important ${ }^{17}$.

\section{ii) Other alkaloids}

A correlation appears to exist for the indolizine alkaloids. Castanospermine (9) in which the piperidine ring is related to glucopyranosides inhibits glucosidases ${ }^{18}$, and swainsonine (8), which contains a unit analogous to a mannofuranose, is a potent inhibitor of mannosidases ${ }^{8,9}$. (Fig 3). 
<smiles>OC1CN2CCC(O)[C@H]2[C@H](O)C1O</smiles>

(9)<smiles>OC1CCCN2CC(O)[C@H](O)C12</smiles>

(8)<smiles>[R9]C1OC(CO)C(O)C(O)C1O</smiles>

(11)<smiles>OCC(O)C1OC(O)C(O)[C@@H]1O</smiles>

$\mathrm{OH}$

mannofuranoside

\section{FIG 3}

The relationship in the pyrrolidine alkaloids does not appear to be simple. Thus, 1,4- dideoxy- 1,4- imino- D- mannito1 (14), related to swainsonine (8), inhibits mannosidases ${ }^{19}$ but 1,4- dideoxy- 1,4- imino- D- glucitol (15) and galactitol (16) are not inhibitors ${ }^{20}$. The imino mannitol (1) and imino arabinitol (2) inhibit glucosidases 3,21 . (3), lacking a C2 hydroxyl, is only a very poor inhibitor. (Fig 4).

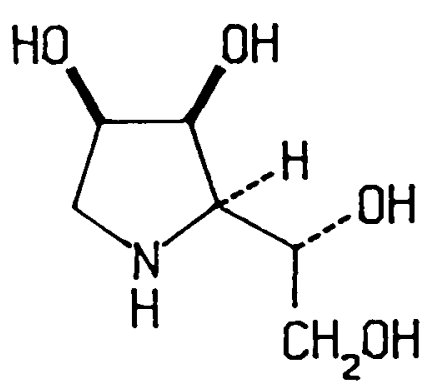

(14)

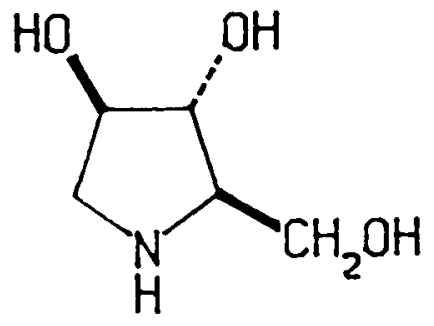

(2)<smiles>OCC(O)C1NCC(O)C1O</smiles>

(15)

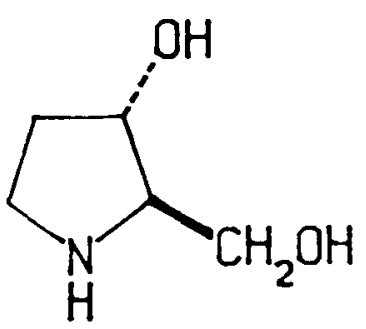

(3)<smiles>OCC(O)C1NCC(O)C1O</smiles>

(16)<smiles>OCC1NC(CO)C(O)C1O</smiles>

(1) 
Current theories on the mode of glycosidase action and mechanism of inhibition.

The active site of the enzyme contains an acidic group which initially protonates the glycoside (general acid catalysis) ${ }^{22}$. Kinetic studies suggest a 2 step mechanism ${ }^{23}$ - initial formation of a glycosyl - enzyme complex and then fragmentation of the glycoside to produce an oxonium ion stabilised electrostatically by the carboxylate group.

The hydroxylated piperidines can block this pathway as, when protonated by the acidic group in the active site, they form positive ions which resemble glycosyl cations ${ }^{24}$. The more basic nitrogen has a greater affinity for the active site than the substrate and so the enzyme action is blocked. In cases where the effect of $\mathrm{pH}$ has been studied it has been found that increasing the $\mathrm{pH}$ up to 7 increases the inhibition ${ }^{25}$. This has been interpreted as showing that it is the unprotonated amines which are the inhibitors of the hydrolysis and supports the above hypothesis.

Until recently it was accepted that the hydrolysis of glycosides proceeded by the equivalent of acid catalysed cleavage of the exocyclic C-O bond, which leads to a pyranose cation (17) (route 1, Fig 5) and that the protonated form of the amine in the active site (18) acted by mimicking this cation.

However, as pointed out, it has generally been found that the hydroxylated piperidines are highly specific in the enzymes they inhibit, yet the stereochemical arrangements in (17) and (18) are quite different which is inconsistent with this observation. The chemical similarity between the two cations (17) and (18) is also tentative.

An alternative pathway (route 2, Fig 5) has recently been proposed involving endocyclic $\mathrm{C}-0$ cleavage ${ }^{26}$. In this pathway the protonated amines (18) have geometry which closely resembles the transition state of the hydrolysis. This correlates with the high specificity shown by the inhibitors. 
<smiles>[R9]C1OC(CO)C(O)C(O)C1O</smiles>

(18)

\section{FIG 5}

A recent molecular dynamics simulation ${ }^{27}$ suggested that endocyclic bond cleavage may be energetically favoured.

There is no conclusive evidence that the hydrolysis of glycosides catalysed by any of the enzymes inhibited by the polyhydroxylated piperidines generally proceeds by fragmentation of one acetal bond or the other. It may be that one or other mechanism (or both) occur depending on the conditions. 


\section{Synthetic Strategy}

The results in this thesis are divided into 5 chapters which illustrate different general strategies towards the synthesis of the polyhydroxylated nitrogen heterocycles from carbohydrates.

Since all the molecules are structurally related to sugars and contain 3 or 4 contiguous chiral centres with hydroxyl groups, monosaccharides are the obvious starting materials for their synthesis. The advantage of using sugars is that all the chirality is already present and the starting materials are cheap and readily available. The main disadvantage is the need for protection / deprotection stages which must be efficient to make the routes viable.

\section{1) Synthesis from Hexoses (Chapters 1 - 3)}

A piperidine ring may be constructed from a hexose by joining either $\mathrm{Cl}$ to C5 or C2 to C6 through a nitrogen bridge. The latter approach is illustrated in chapter 1 where nucleophilic displacement by azide ion at C2 in a Dglucose derivative with subsequent cyclisation onto C6 leads to the synthesis of the highly divergent bicyclic amine (1.10), which is used to synthesise several polyhydroxylated piperidines. (Fig 6).

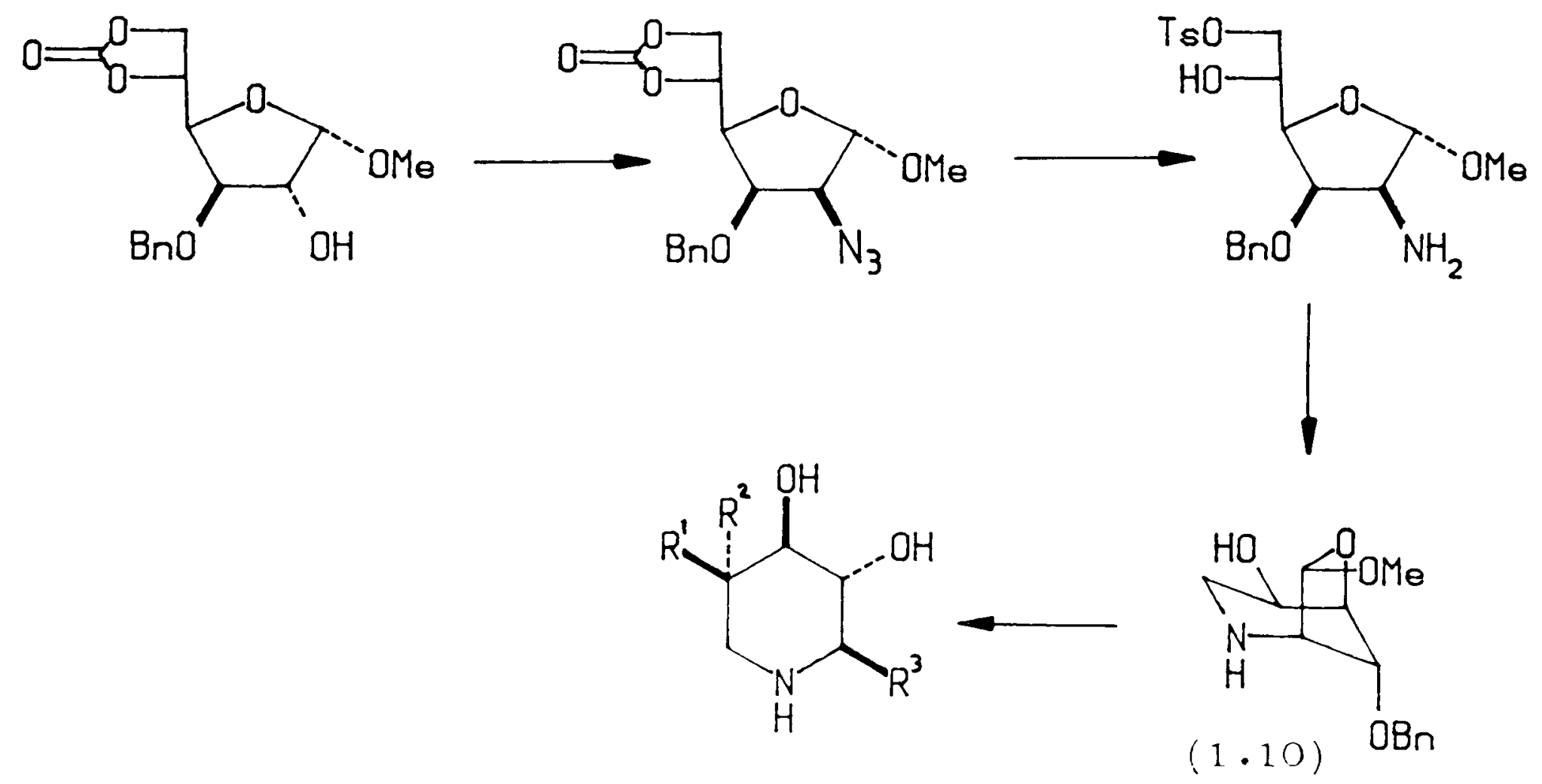


A pyrrolidine ring may be constructed in 3 ways :-

a) Introduction of a nitrogen bridge between $\mathrm{C} 2$ and $\mathrm{C} 5$ :

This approach is illustrated in the synthesis of 2,5- dideoxy- 2,5- iminoD- mannitol (1 and 1.8) in chapter 1. (Fig 7).

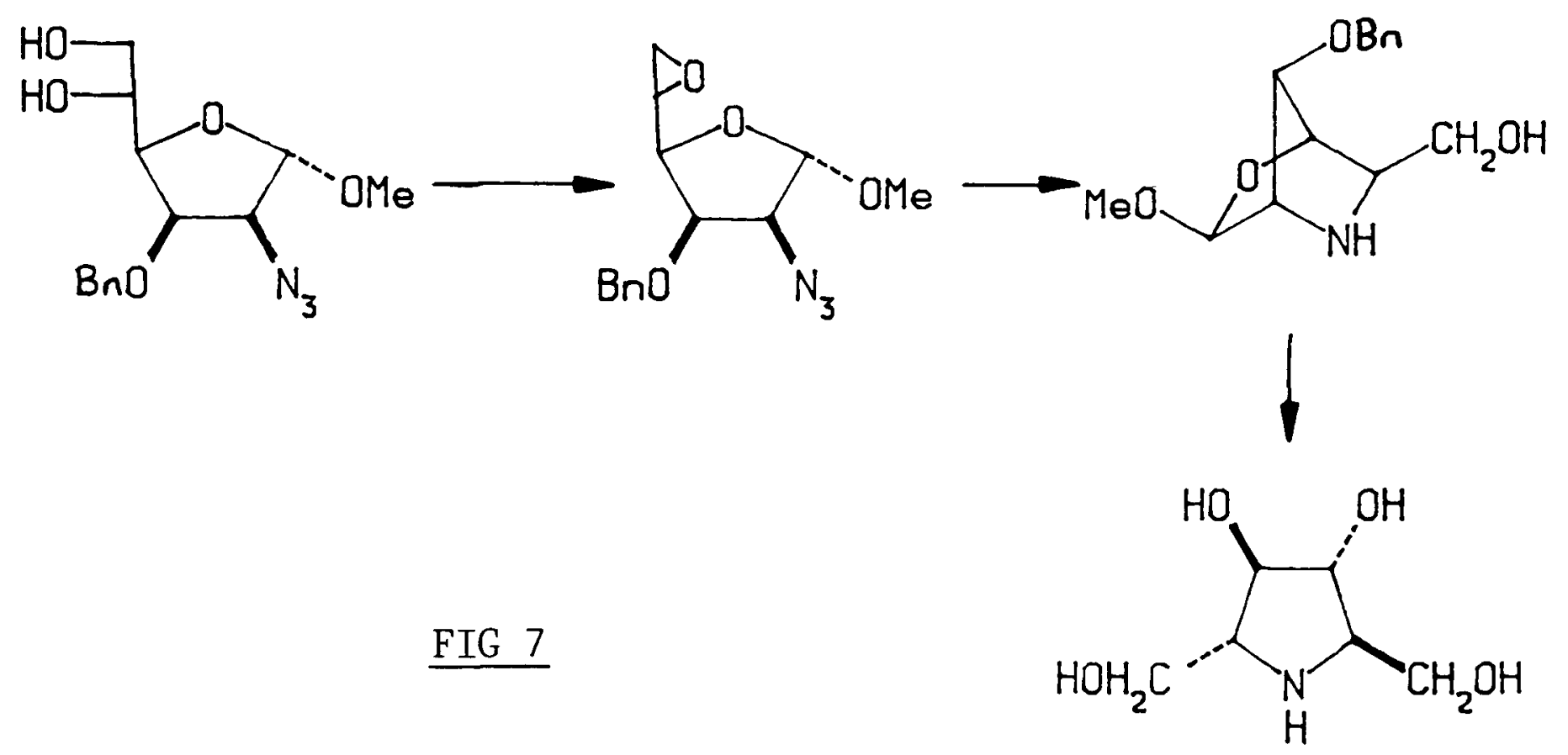

(1)

b) Introduction of a nitrogen bridge between C3 and C6:

This strategy is illustrated in chapter 2, where the highly divergent intermediate (2.13) is synthesised from D- glucose via initial displacement at C3 by azide ion and subsequent cyclisation onto C6. (Fig 8).
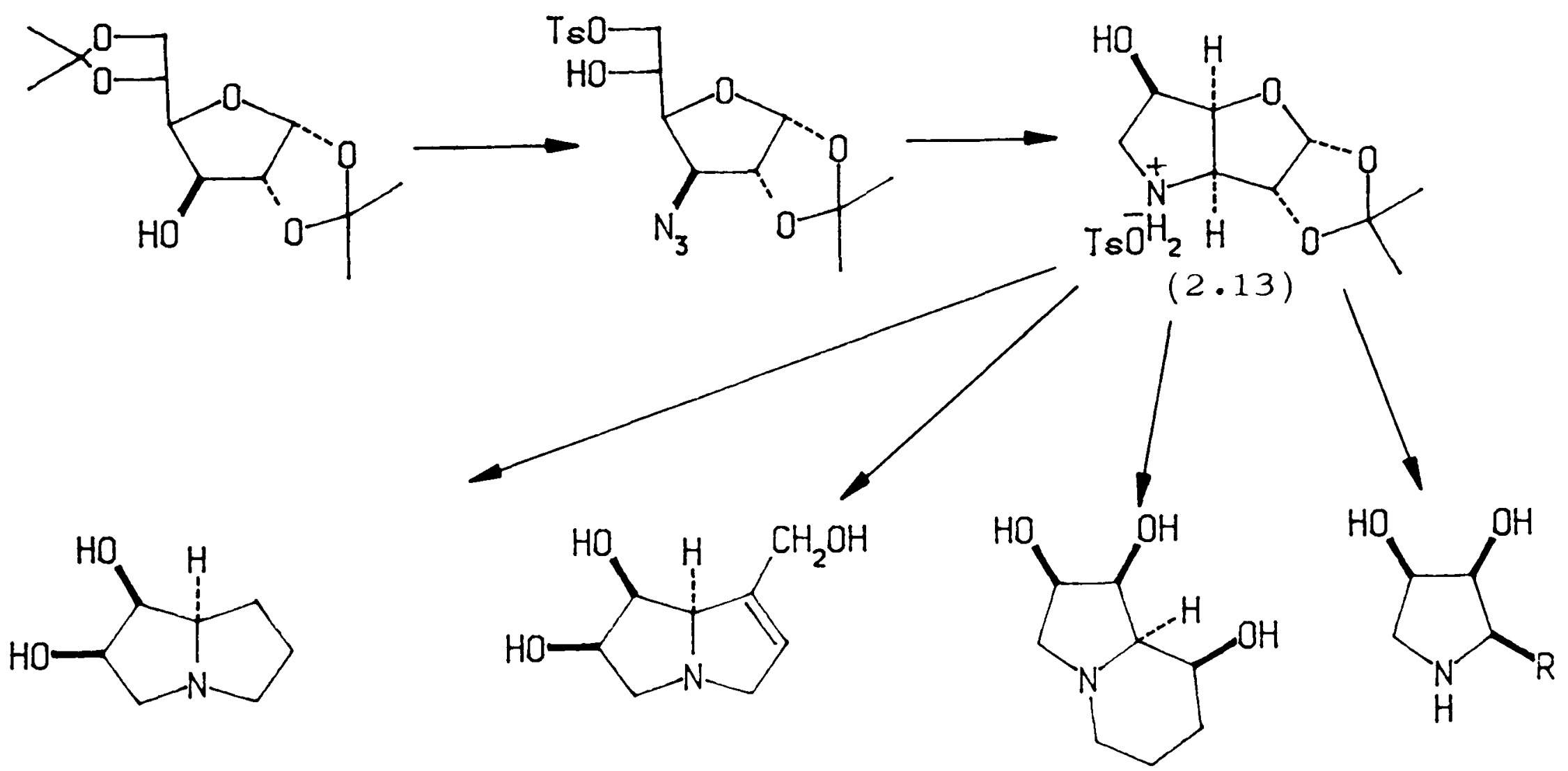
Elaboration of (2.13) into polyhydroxylated pyrrolidines and indolizines is described and approaches to a further class of natural products, the pyrrolizidine alcohols is discussed.

c) Introduction of a nitrogen bridge between $\mathrm{Cl}$ and $\mathrm{C} 4$ :

In chapter 3, the key intermediate (3.3) (prepared from $\underline{D}$ - mannose via an azide displacement at $\mathrm{C} 4$ and subsequent reductive amination onto $\mathrm{C} 1$ ) is converted into the imino 1yxitol (3.1). Approaches to the pyrrolizidine alcohol crotanecine are also described. (Fig 9).

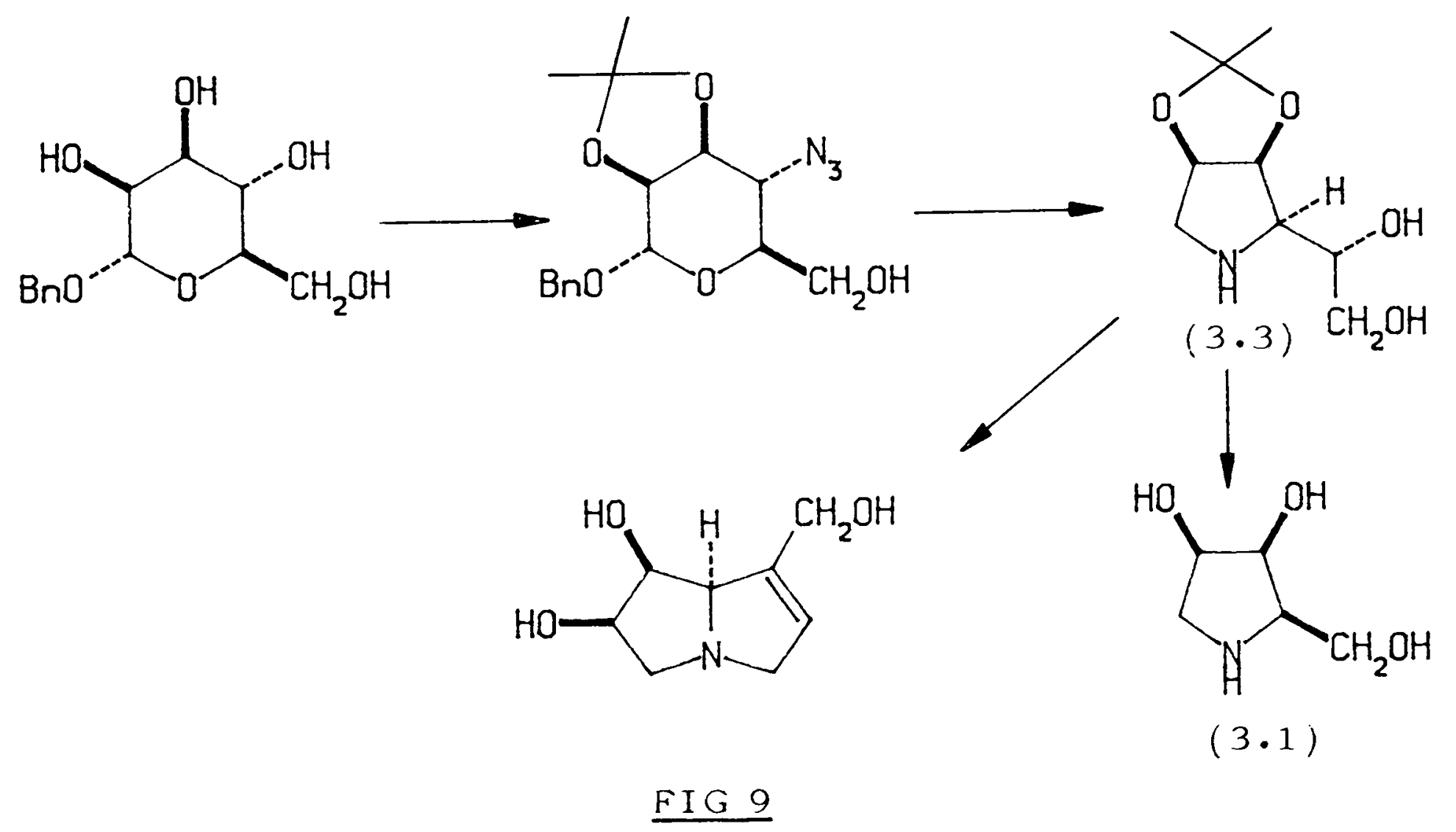

2) Synthesis from Pentoses (Chapter 4 and 5).

Pyrrolidine rings can be synthesised from pentoses by introducing a nitrogen bridge between $\mathrm{C} 1$ and $\mathrm{C} 4$ or $\mathrm{C} 2$ and $\mathrm{C} 5$. Both routes are exemplified in chapter 4 where both enantiomers of 1,4-dideoxy-1,4- imino- arabinitol are prepared from D- xylose. (Fig 10). 
$\mathrm{TsO}$

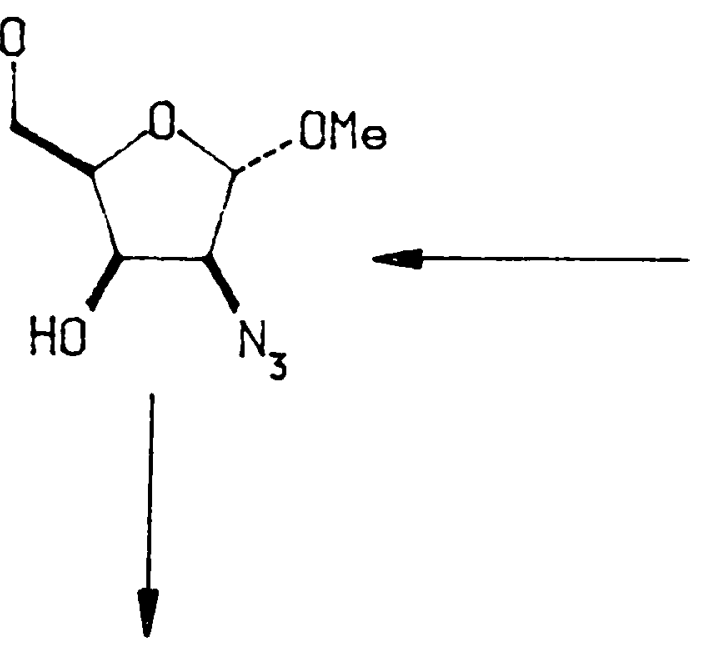<smiles>CC1(C)OCC2OC([O-])C(O)C2O1</smiles>

$\mathrm{OH}$

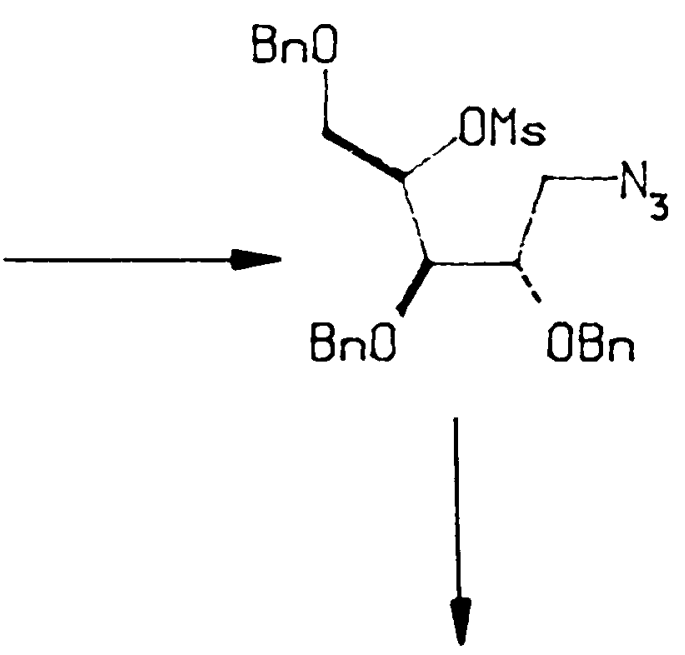

$\sum_{\mathrm{H}^{\prime} \mathrm{CH}_{2} \mathrm{OH}}^{\mathrm{OH}}$

$\underline{F I G \quad 10}$

Chapter 5 illustrates the use of sugar lactones in the synthesis of amino acids. Since the $\mathrm{Cl}$ position in the sugar lactone is already at the same oxidation level as the acid group in the amino acid, the problem of having to perform an oxidation during the synthesis, which can be troublesome, is avoided. In addition, nucleophilic displacement $a$ to a carbonyl group is more facile than $a$ to the anomeric position and introduction of the nitrogen is therefore easier. The synthesis of ( $2 R, 3 S, 4 R)-3,4-$ dihydroxyproline (5.1) in which the stereochemistry at the C2 position of ribonolactone is unexpectedly retained in a nucleophilic displacement, is described. (Fig 11).

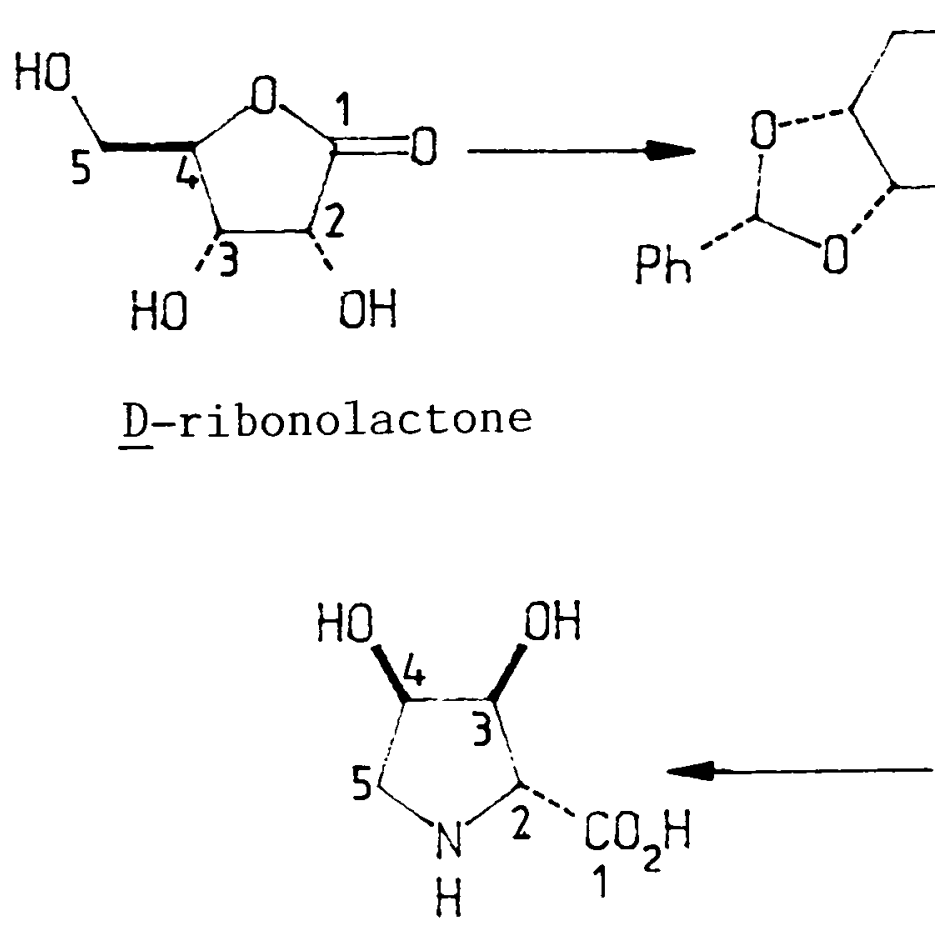

$(5.1)$

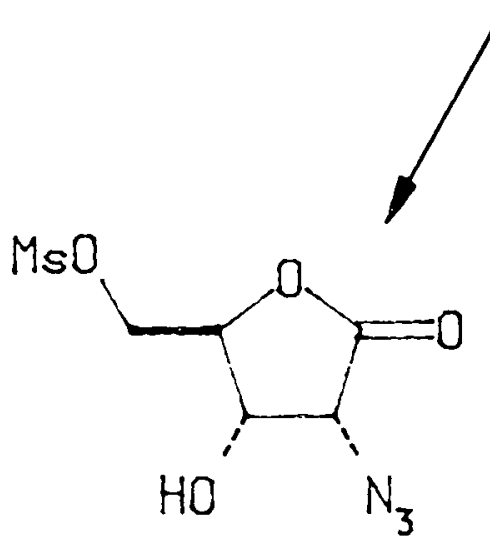




\section{REFERENCES}

1. S.V.Evans, L.E.Fellows, T.K.M.Shing and G.W.J.Fleet, Phytochemistry., 1985, $\underline{24}, 1953$.

2. L.E.Fellows in'New Scientist' 15th August 1985. No 1469.p 40.

3. L.E.Fellows, S.V.Evans, R.J.Nash and E.A.Bell in 'Natural Resistance of Plants to Pests and Diseases' eds. M.B.Green and P.A.Hedin, American Chemical Society Symposium Series 296, pp 72-78 (1986).

4. D.D.Schmidt, W.Frommer, L.Muller and E.Truscheit, Naturwissenschaften., 1979, $\underline{66}, 584$.

5. R.Saul, J.J.Ghidoni, R.J.Molyneux and A.D.Elbein, Proc.Natn.Acad.Sci.U.S.A., 1985, 82, 93.

6. H.P.Krause, U.Keup, G.Thomas and W.Puls, Metabolism., 1982, 31 , 710.

7. R.Stuart-Gray and J.M.Olefsky, Metabolism., 1982, 31, 88.

8. U.Fuhrmann, E.Bause and H.Ploegh, Biochim.Biophys.Acta., 1985, 825, 95.

9. A.D.E1bein, Crit.Rev.Biochem., 1984, 16, 21.

10. I.C.diBello, P.Dorling, L.E.Fellows and B.Winchester, FEBS.Lett., 1984, 176,61 .

11. M.Hino, O.Nakayama, Y.Tsurumi, K.Adachi,T.Shibata, H.Terano, M.Kohsaka, H.Aoki and H.Imanaka, J.Antibiotics., 1985, 38, 926.

12. M.Hino, O.Nakayama, Y.Tsurumi, K.Adachi, T.Shibata, H.Terano, M.Kohsaka H.Aoki and H.Imanaka, J.Antibiotics., 1985, 38, 936.

13. T.Niwa, S.Inouye, T.Tsuruoka, Y.Koaze and T.Niida, Agric.Biol.Chem., 1970, 34, 966; H.Hettkamp, G.Legler and E.Bause, Eur.J.Biochem., 1984, 142, 85. 14. A.D.E1bein, G.Legler, A.Tlutsy, W.McDowe1l and R.Schwarz, Arch.Biochem. Biophys., 1984, 235, 579 .

15. G.W.J.Fleet, A.N.Shaw, S.V.Evans and L.E.Fellows, J.Chem.Soc.Chem.Commun., 1985,841 .

16.M.Koyama and S.Sakamura, Agric.Biol.Chem., 1974, 38, 1111.

17. K-R.Roeser and G.Legler, Biochem.Biophys.Acta., 1981, 657, 321. 
18. R.Saul, J.P.Chambers, R.J.Molyneux and A.D.Elbein, Arch.Biochem.Biophys., $1983,221,593$.

19. G.W.J.Fleet, P.W.Smith, S.V.Evans and L.E.Fellows, J.Chem.Soc.Chem.Commun., 1984,1240 .

20. G.W.J.Fleet, J.C.Son and S.Peturssen unpublished results.

21. R.J.Nash, E.A.Bell and J.M.Williams, Phytochemistry., 1985, 24, 1620.

22. B.Capon, Chem.Rev., 1969, 69, 407.

23. J.DePrycker and C.K.DeBruyne, Carbohydr.Res., 1975, 43, 175.

24. H-Y.Lai and B.Axelrod, Biochem.Biophys.Res.Commun., 1973, 54, 463;

P.Lalegene, G.Legler and J.M.Yon, Biochimie., 1982, 64, 977; P.R.Dorling,

C.R.Huxtable and S.M.Colegate, Biochem.J., 1980, 191, 649.

25. R.Saul, R.J.Molyneux and A.D.E1bein, Arch.Biochem.Biophys., 1984, 230, 668.

P.J.Card and W.D.Hitz, J.Org.Chem., 1985, 50, 891.

26. G.W.J.Fleet, Tetrahedron.Lett., 1985, 26, 5073.

27. C.B.Post and M.Karplus, J.Amer.Chem.Soc., 1986, 108, 1317. 
1. APPROACHES TO THE SYNTHESIS OF POLYHYDROXYLATED NITROGEN HETEROCYCLES

FROM D-GLUCOSE PART I: INTRODUCTION OF NITROGEN AT C2

\section{INTRODUCTION}

This chapter describes the synthesis from D-glucose of the polyhydroxylated piperidines (1.1) to (1.7) and the pyrrolidine (1.8) (fig. 1.1).<smiles>[R]C1NCC2([R])OC1C(O)C2[R]</smiles>

$(1 \cdot 1)-(1 \cdot 7)$<smiles>OCC1NC(CO)C(O)C1O</smiles>

$(1.8)$<smiles>OCC1NC(O)C(O)C(O)C1O</smiles>

$(1 \cdot 9)$ $\begin{array}{cllll}\frac{\text { Compound }}{(1.1)} & \frac{\mathrm{R}^{1}}{\mathrm{OH}} & \frac{\mathrm{R}^{2}}{\mathrm{H}} & \frac{\mathrm{R}^{3}}{\mathrm{CH}_{2} \mathrm{OH}} \\ (1.2) & \mathrm{H} & \mathrm{H} & \mathrm{CH}_{2} \mathrm{OH}\end{array}$

(1.3) $\mathrm{OH} \quad \mathrm{H} \quad \mathrm{CO}_{2} \mathrm{H}$

$(1.4) \quad \mathrm{H} \quad \mathrm{OH} \quad \mathrm{CH}_{2} \mathrm{OH}$

(1.5) $\mathrm{H} \quad \mathrm{OH} \quad \mathrm{CO}_{2} \mathrm{H}$

(1.6) $\mathrm{NHAC} \quad \mathrm{H} \quad \mathrm{CH}_{2} \mathrm{OH}$

(1.7) $\mathrm{H} \quad \mathrm{NHAc} \mathrm{CH}_{2} \mathrm{OH}$<smiles>O=C(O)C1NCC(O)C(O)C1O</smiles>

$(1 \cdot 3)$

(1.1)<smiles>OC[C@H]1NCCC(O)[C@@H]1O</smiles>

$(1.2)$<smiles>[CH]N[C@@H]1CN[C@H](CO)[C@H](O)[C@H]1O</smiles>

$(1.6)$<smiles>OCC1NCC(O)C(O)C1O</smiles>

(1.4) $\underline{\text { FIG } 1.1}$

(1.5)

$\underline{\text { EIG } 1.1}$<smiles>O=C(O)C1NCC(O)C(O)C1O</smiles><smiles>CNC1CN[C@H](CO)C(O)C1O</smiles>

$(1.7)$<smiles>OCC1NC(CO)C(O)C1O</smiles> 
Occurrence \& Biological Action of the natural products.

The piperidines (1.1), (1.2), (1.4) and (1.5) and the pyrrolidine (1.8) all occur in nature.

Deoxymannojirimycin (1,5 dideoxy-1,5-imino-D-mannito1) (1.1) was first isolated as the hydrochloride salt from the tropical legumes lonchocarpus $\underline{\text { sericeus }}$ and lonchocarpus costaricensis. It was identified by spectroscopic methods ${ }^{1}$ and the absolute configuration determined by the benzoate chirality $\operatorname{method}^{2}$. Deoxymannojirimycin (1.1) inhibits $a$ and $\beta$ mannosidase ${ }^{3,4}$.

Fagomine (1,2,5-trideoxy-1,5-imino-D-arabino hexitol) (1.2) was isolated in $1974^{5}$ from fagopyrum esculentem Moench and the structure and relative stereochemistry were determined by spectroscopic methods. Fagomine (1.2) also occurs as an aglycone, 4--- $(\beta-\underline{D}-g l u c o p y r a n o s y 1)$ - fagomine isolated from the legume xanthocersis zambesiaca ${ }^{6}$. Fagomine (1.2) is a substantially less potent inhibitor of glycosidases than deoxymannojirimycin $(1.1)^{6}$, but showed some inhibition against a range of disaccharidases ${ }^{7}$.

Deoxynojirimycin (1,5-dideoxy-1,5-imino-D-glucitol)(1.4) is produced together with nojirimycin (5 deoxy-1,5-imino-D-glucose) (1.9) by several streptomyces ${ }^{8}$ and by many strains of the genus Bacillus ${ }^{9}$. It has been isolated from the plant morus (moraceae) ${ }^{10}$. The structure and relative stereochemistry were determined by spectroscopic studies and the absolute configuration confirmed by a synthesis from $\underline{D}$-glucose ${ }^{8}$. Deoxynojirimycin (1.4) was prepared from nojirimycin (1.9) by reduction.

Nojirimycin is a potent inhibitor of many glucosidases 9,11 . Deoxynojirimycin (1.4) is a less effective inhibitor of $\beta$ glucosidase (emulsion) than nojirimycin (1.9), but a more effective inhibitor of $a$-glucosidase (intestinal maltase and $a$-gluco amylase) and also inhibits a microbial trehalase ${ }^{12}$ as well as 
several other disaccharidases. 6

(2S, 3R, 4R, 5S) 3,4,5 Trihydroxypipecolic acid (1.5) (gluco- configuration) was isolated from the seeds of Baphia racemosa ${ }^{13}$. The structure and relative stereochemistry were determined spectroscopically and the absolute configuration confirmed by synthesis ${ }^{14,15}$. (1.5) is a glucuronidase (human liver) and iduronidase inhibitor ${ }^{13,16}$ but does not inhibit glucosidase or mannosidase.

2,5- Dideoxy- 2,5- imino- D- mannitol (2R,5R-Dihydroxymethy 1-3R,4R-dihydroxypyrrolidine) (1.8) was initially isolated from the leaves of the tropical legume Derris elliptica ${ }^{17}$ and later detected in the seeds of the closely related lonchicarpus sericeus $^{18}$. (1.8) is a potent inhibitor of viral glycoprotein processing glucosidase $\mathrm{I}^{19}$, yeast $\boldsymbol{a}$-glucosidase, almond emulsin $\beta$-glucosidase, trehalase, invertase and xylosidase ${ }^{18}$.

\section{Previous synthetic work}

a) Deoxymannojirimycin (1.1) : There are several reported syntheses of deoxymannojirimycin $(1.1)^{20-23}$.

In one synthesis an azido nitration of methyl 3,4-di-0-acety1-2,6-anhydro-5deoxy-D-1yxo-hex-5-enoate (1) and subsequent treatment with sodium acetate in glacial acetic acid gave $6 \%$ yield of the manno- isomer (2), which was elaborated to deoxymannojirimycin (1.1) (Scheme 1.1) ${ }^{20}$.

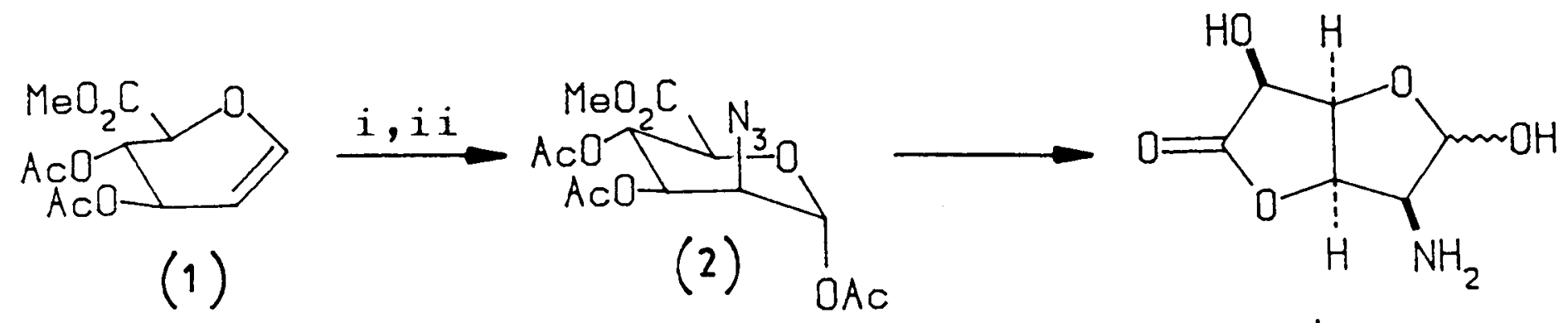

i) Ceric ammonium nitrate, then $\mathrm{NaN}_{3}$

ii) $\mathrm{ACO}^{-} / \mathrm{AcOH}$

i.i ) $\mathrm{NaBH}_{4}, \mathrm{E} \mathrm{tOH}$

i.v) $\mathrm{H}_{2}$

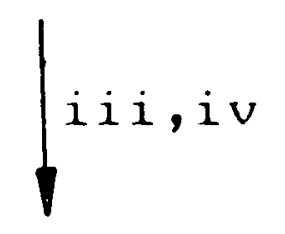

$(1 \cdot 1)$

SCHEME 1.1 
Two syntheses from D-mannose have been reported 22,23 . Both involved introduction of nitrogen between $\mathrm{C} 1$ and $\mathrm{C} 5$ with a double inversion at $\mathrm{C} 5$ (Scheme 1.2).
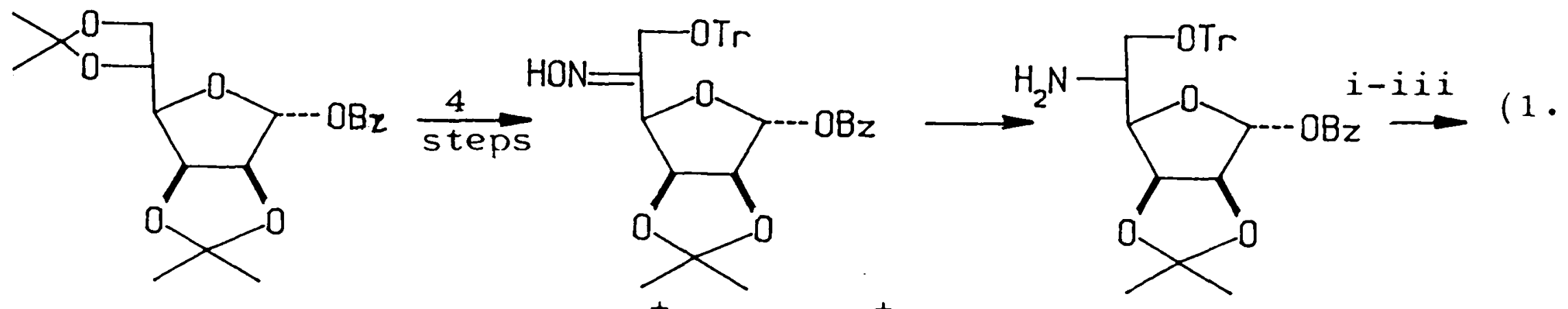

i) MeONa ii) $\mathrm{H}_{2}$, $\mathrm{Pd}$ iii) $\mathrm{H}_{3} \mathrm{O}^{+}$iv) $\mathrm{Bu}_{4} \mathrm{~N}^{+} \mathrm{F}^{-}$.

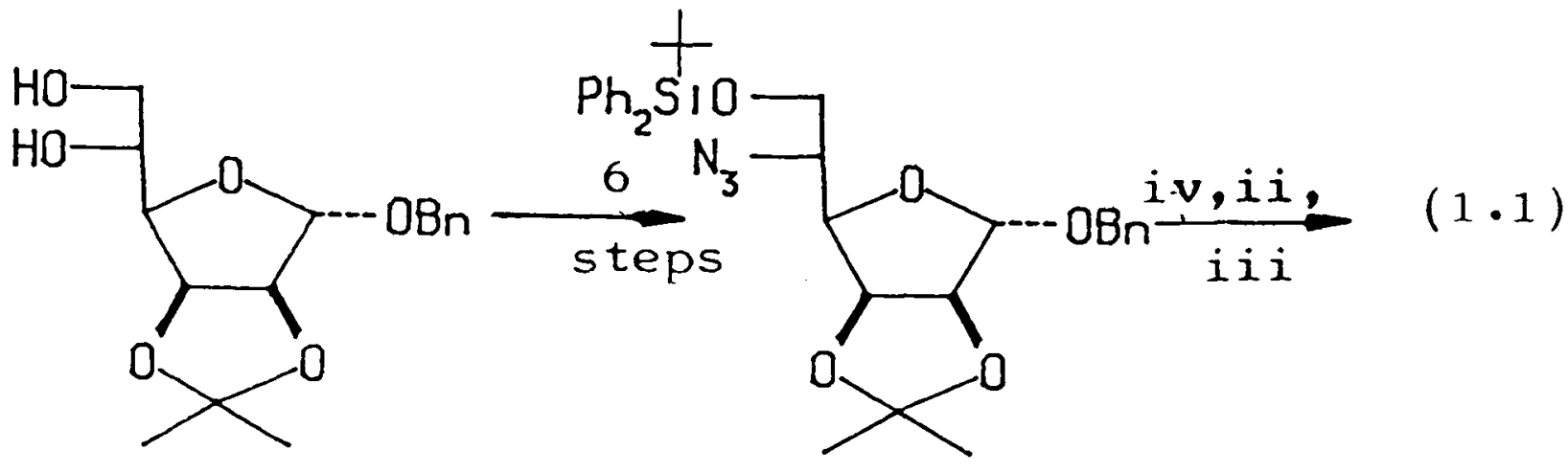

\section{SCHEME 1.2}

A synthesis from D-glucose ${ }^{23}$ involved introduction of nitrogen at C6 with subsequent displacement of a leaving group at C2 (Scheme 1.3).

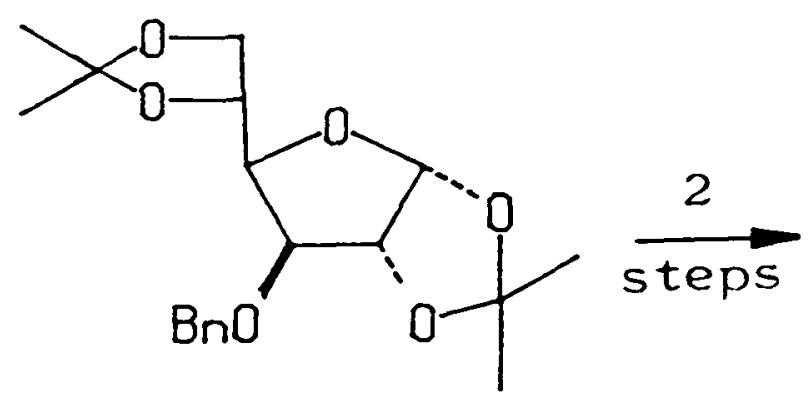<smiles>CO[C@@H]1O[C@H]2COC(c3ccccc3)OC2C(Cc2ccccc2)[C@H]1O</smiles><smiles>CC(C)CC1C(O)C(O)OC(CO)C1Cc1ccccc1</smiles>

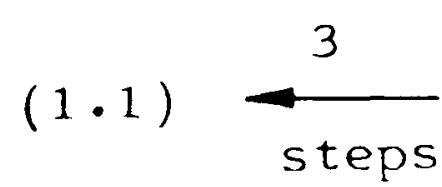<smiles>OC1OC2CN1C(O)C(Br)C2Br</smiles>

i) $\mathrm{LiAlH}_{4}, \mathrm{AlCl}_{3}, \mathrm{Et}_{2} \mathrm{O}$ ii) $\left(\mathrm{CF}_{3} \mathrm{SO}_{2}\right)_{2} \mathrm{O}$ iii) $\mathrm{NH}_{3}$ iv) $\mathrm{PhCH}_{2} \mathrm{OCOCl}$ SCHEME 1.3 
A short synthesis from D-mannose involving a selective enzymic oxidation at C5 and a subsequent reductive amination has been described ${ }^{21}$. This route was also used to prepare deoxynojirimycin (1.4) on a gram scale.

b) Fagomine (1.2): There are no reported syntheses of fagomine.

c) Deoxynojirimycin (1.4): Was first synthesised from $\underline{L}-$ sorbose in $1967^{24}$, via an intramolecular reductive amination between the ketone at $\mathrm{C} 2$ and azide, previously introduced at $\mathrm{C6}$.

A more recent synthesis involved a 1,3 dipolar addition of a nitrone to a furan (Scheme 1.4) 27 .
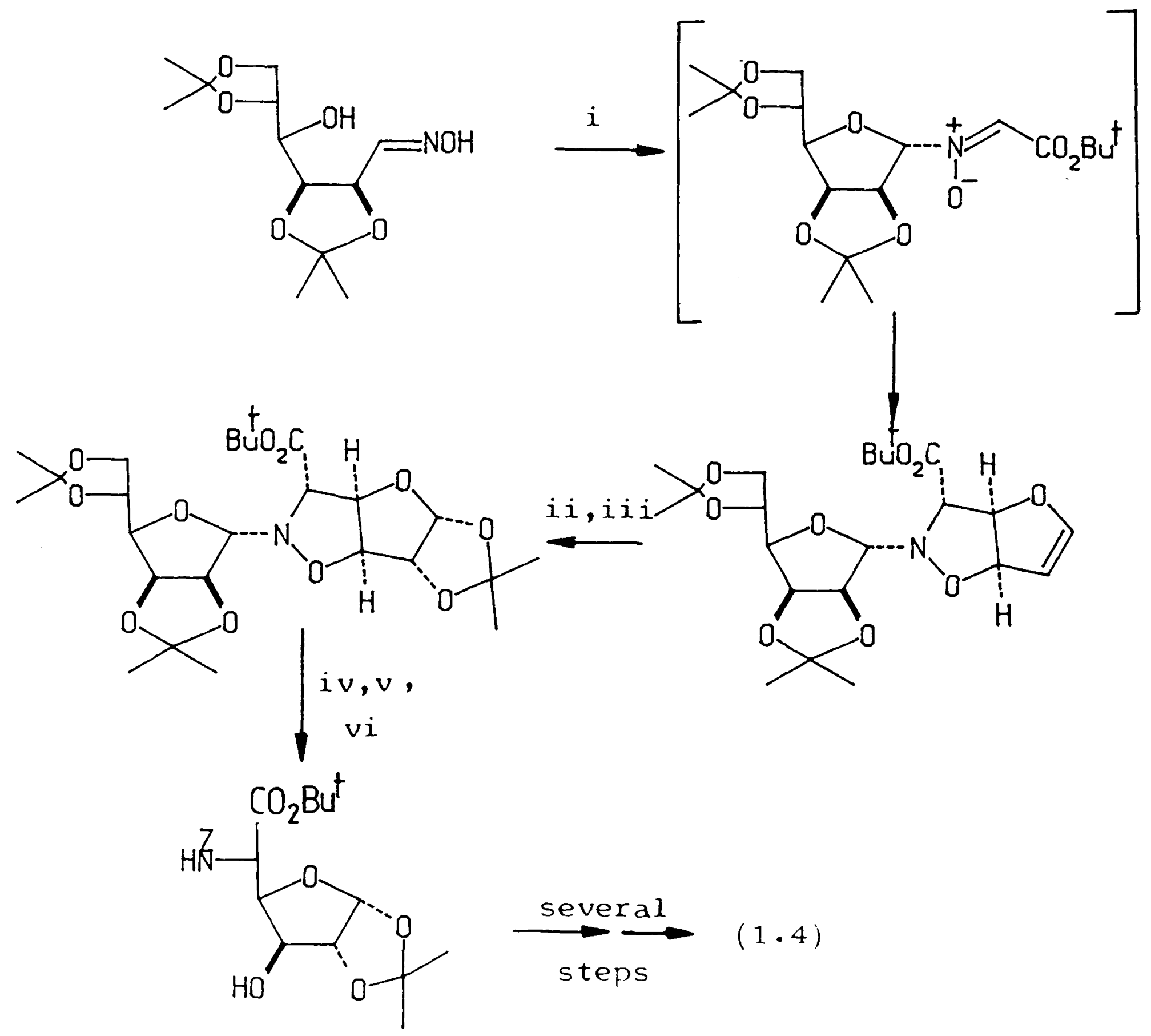

i) Furan $+\mathrm{OHC}-\mathrm{COOBu} \mathrm{C}^{\mathrm{t}}$ ii) $\mathrm{OSO}_{4}$ iii) ile $\left.2 \mathrm{CO} / \mathrm{H}^{+} \mathrm{iv}\right) \mathrm{H}_{2}$ v) $\left.\mathrm{H}_{3} \mathrm{O}^{+} \mathrm{vi}\right) \mathrm{PhCH}_{2} \mathrm{OCOCl}$ 
Three syntheses from D-glucose have been reported $8,25,26$. All involve connection between $\mathrm{C} 1$ and $\mathrm{C5}$ via a nitrogen atom with a double inversion at $\mathrm{C} 5$.

d) $(2 S, 3 R, 4 R, 5 S)-3,4,5$-Trihydroxypipecolic acid (1.5) was synthesised

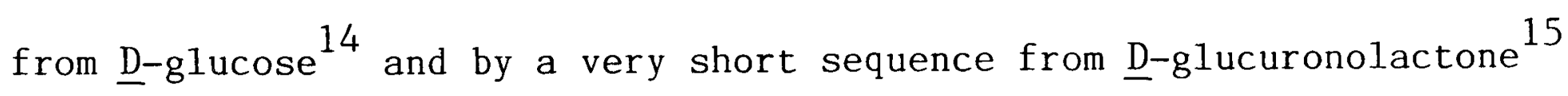
(Scheme 1.5).
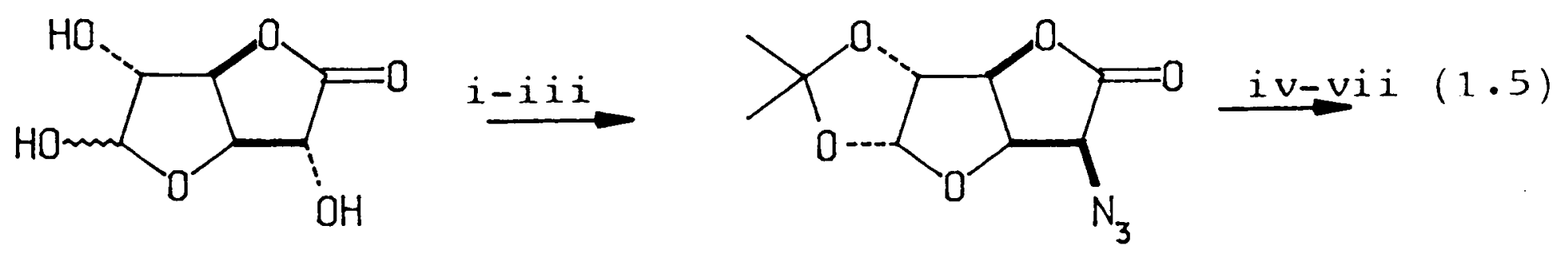

i) $\mathrm{Me}_{2} \mathrm{CO}, \mathrm{H}^{+}$ii) $\left(\mathrm{CF}_{3} \mathrm{SO}_{2}\right)_{2} \mathrm{O}$ iii) $\mathrm{NaN}_{3}$ iv) $\left.\mathrm{H}_{2}, \mathrm{Pd} \mathrm{v}\right) \mathrm{PhCH}_{2} \mathrm{OCOCl}$ vi) aq TFA vii) $\mathrm{H}_{2}$, $\mathrm{Pd}$

\section{SCHEME 1.5}

e) 2,5-Dideoxy-2,5-imino-D-mannito1 (1.8): Was synthesised from $\underline{\text { L-sorbose }}{ }^{28}$ (Scheme 1.6).

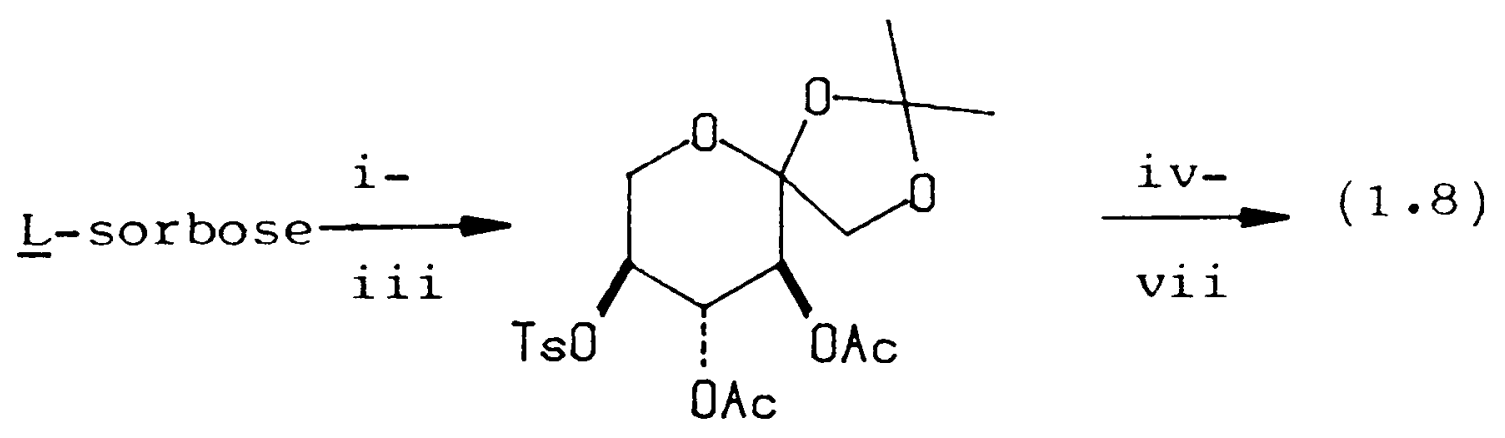

i) $\left.\left.\left(\mathrm{CH}_{3}\right)_{2} \mathrm{C}\left(\mathrm{OCH}_{3}\right)_{2} / \mathrm{H}^{+} \mathrm{ii}\right) \mathrm{TsCl} \mathrm{iii}\right) \mathrm{Ac}_{2} \mathrm{O}$ iv) LiN 3 v) NaOMe vi) $\mathrm{H}_{3} \mathrm{O}^{+}$vii) $\mathrm{H}_{2}$, catalyst.

\section{SCHEME 1.6}

The selective tosylation proceeded in only $39 \%$ yield ${ }^{29}$, with the desired product crystallising from the reaction mixture. The reductive amination produced (1.8) as a single diastereoisomer. From this route, it was possible to prepare (1.8) in gram quantities. 
RESULTS AND DISCUSSION

Retrosynthetic Analysis

The piperidines $(1.1)-(1.7)$ were all constructed by initial introduction of nitrogen at the $\mathrm{C} 2$ position in $\underline{\mathrm{D}}-\mathrm{glucose}$, with inversion of configuration, and subsequent cyclisation through nitrogen onto C6. The bicyclic protected amine (1.10) was a common intermediate in all the syntheses and this was derived from the azido mannose (1.11), prepared from 1,2; 5,6 di---isopropylidene-D-glucofuranose in 7 steps. (Scheme 1.7).

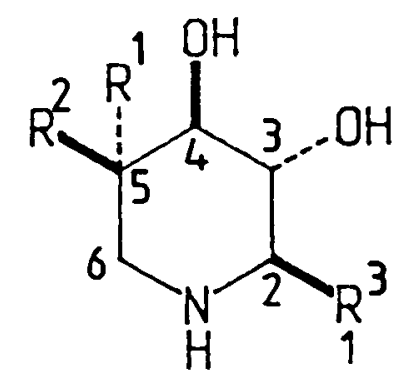

$(1.1)-(1.7)$

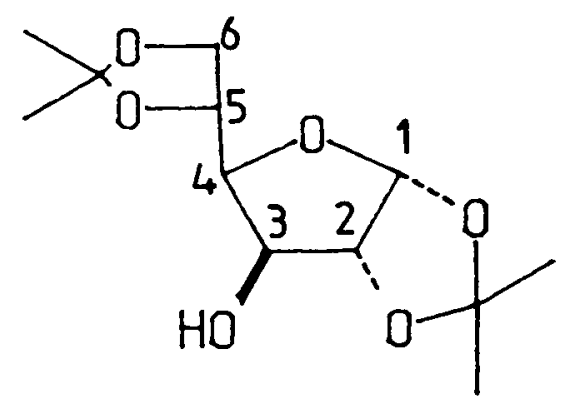

Diacetone glucose<smiles>[R]C1([R])CNC(C=O)C(O)C1O</smiles>
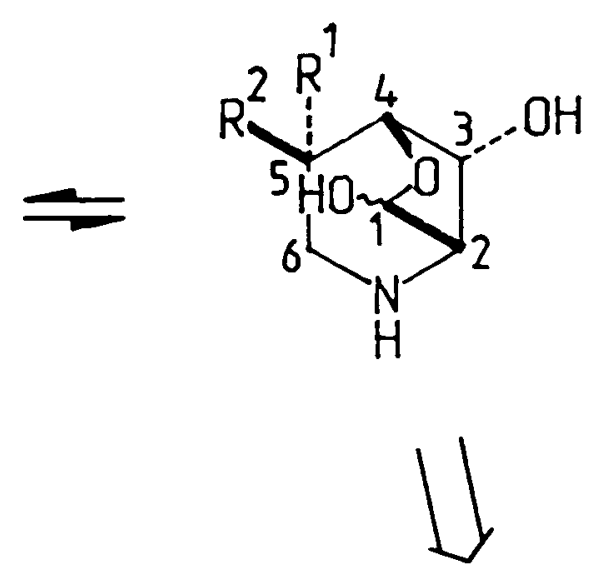

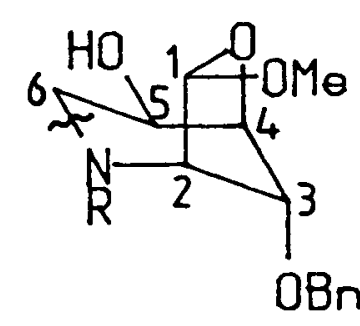

$(1 \cdot 11)$
$(1 \cdot 10)$

a: $\mathrm{R}=\mathrm{PhCH}_{2} \mathrm{OCO}$

$b: R=t B u O C O$ 
The pyrrolidine (1.8) required cyclisation by nucleophilic nitrogen derived from the azide at $\mathrm{C} 2$ in (1.11), onto C5 with overall retention of configuration. This was accomplished by two inversions. Initially the epoxide (1.12) was produced and then this was inverted again at C5 by nucleophilic attack by nitrogen (Scheme 1.8).<smiles>OCC1NC(CO)C(O)C1O</smiles>

$(1.8)$

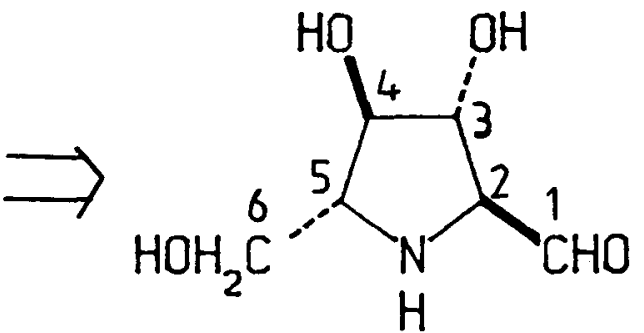

$\mathrm{H}$<smiles>C=CCC1NC2OC(O)C1C2O</smiles><smiles>C=CCC</smiles><smiles>COC1OC(CO)C(O)C1[N]</smiles>

$(1 \cdot 11)$<smiles>C=CC</smiles>

Bno

$(1 \cdot 12)$

SCHEME 1.8<smiles></smiles>

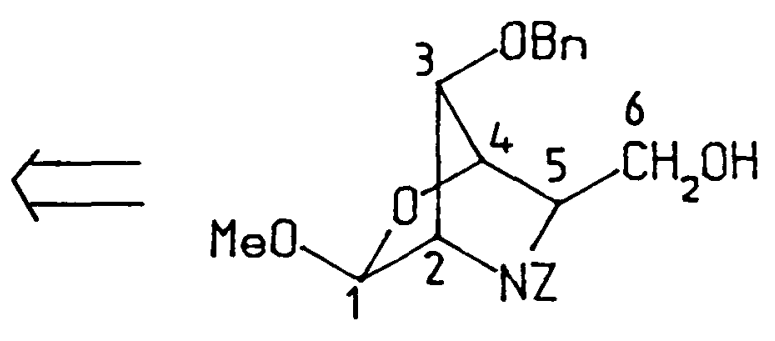

\section{Synthesis}

i) Preparation of the bicyclic intermediates: Methyl (N-benzyloxycarbonyl and $\underline{N}$-t-butyloxycarbony $1-3-\underline{0}$-benzyl-2,6-dideoxy-2,6-imino)- $a$ - $\underline{D}$-mannofuranoside $(1.10 \mathrm{a})$ and $(1.10 \mathrm{~b})$.

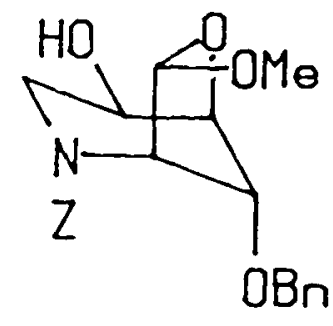

(1.10a)

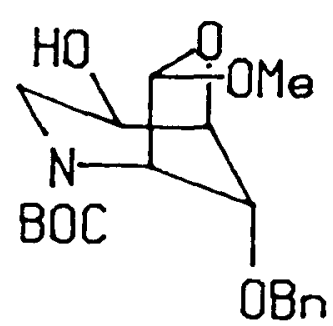

$(1.10 b)$ 
a) Introduction of nitrogen at the C2 position of D-glucose.

The initial requirement was the synthesis of a D-glucose derivative with only the $\mathrm{C} 2$ hydroxy 1 group free. This was accomplished in 4 steps from the readily available diacetone glucose (1.13).

The C3 hydroxyl group of diacetone glucose (1.13) was protected as the benzyl ether (1.14) by treatment with benzyl bromide and sodium hydride in refluxing THF. The 5,6 - isopropylidene acetal was selectively cleaved in methanol/ water containing hydrochloric acid, and the resulting diol (1.15) protected as the carbonate $(1.16)$ by treatment with dimethyl carbonate and sodium methoxide 30 (Scheme 1.9).

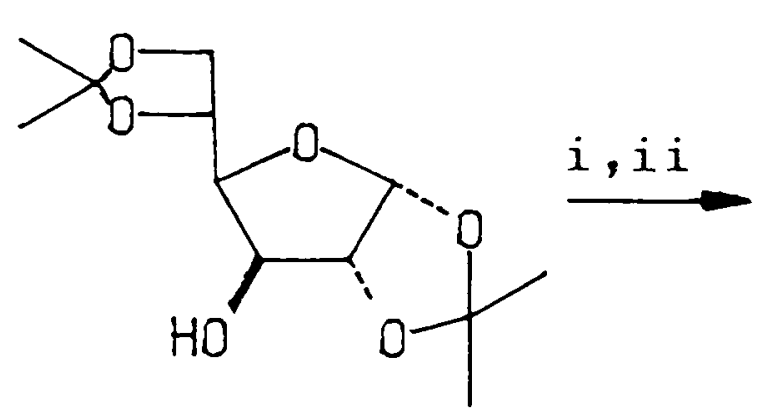

$(1 \cdot 13)$

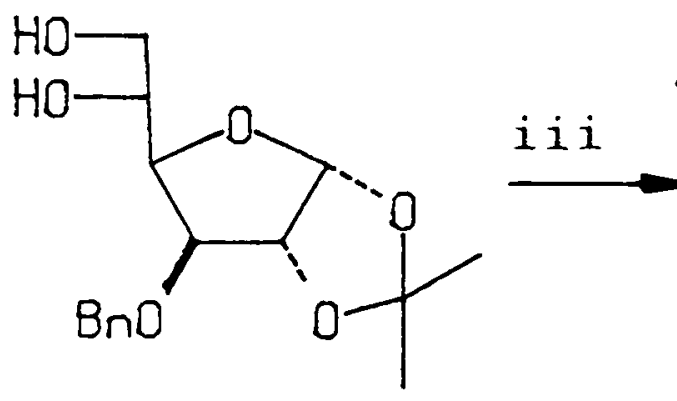

$(1.15)$

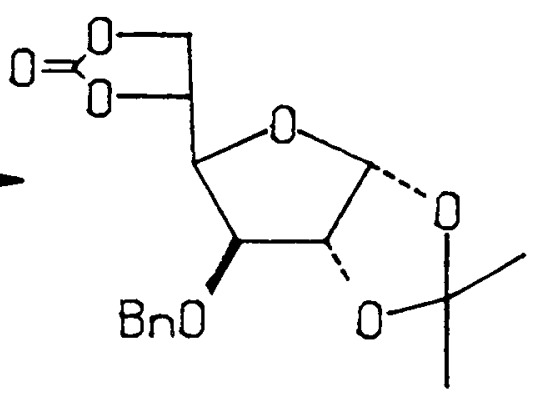

$(1 \cdot 16)$

i) $\mathrm{PhCH}_{2} \mathrm{Br}, \mathrm{NaH}$, THF ii) aq $\mathrm{AcOH}$ iii) ( $\left.\mathrm{MeO}\right)_{2} \mathrm{CO}$, NaOMe, heat

\section{SCHEME 1.9}

Dimethyl carbonate is a much milder reagent than phosgene for this transformation and this makes the reaction reversible. For large scale preparations of (1.16) it was necessary to remove the methanol produced in the reaction by distillation, to displace the equilibrium over to the carbonate. The crystalline carbonate (1.16), identical to the literature compound, was prepared in $80 \%$ yield on $50 \mathrm{~g}$ scale from (1.13) without any purification of the intermediates. 
The carbonate group of (1.16) was rapidly removed on treatment with a trace of sodium methoxide in methanol.

The carbonate (1.16) is a powerful synthetic intermediate since it provides access to any of the hydroxyl groups in D-glucose. The C2 hydroxyl group was freed by methanolysis of (1.16) with a range of acids. The reaction gave a mixture of methyl $\alpha(1.17 \mathrm{a})$ and $\beta$ (1.17b) glucosides. (Scheme 1.10)

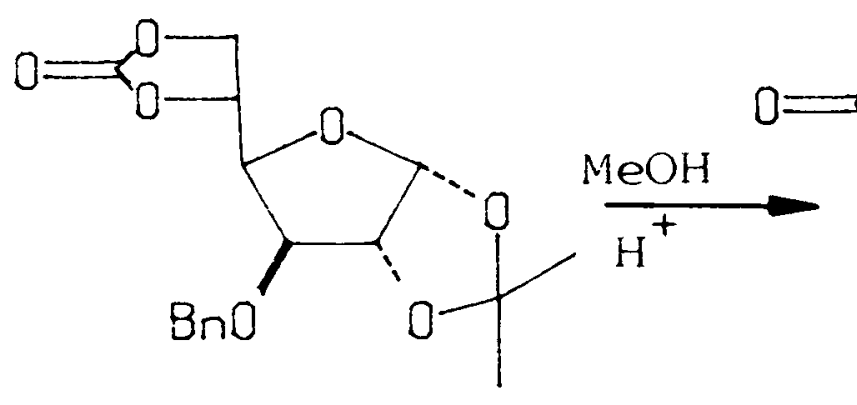

$(1.16)$

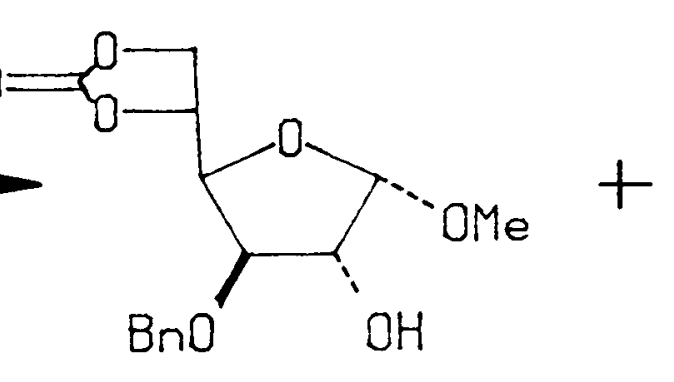

$(1.17 \mathrm{a})$

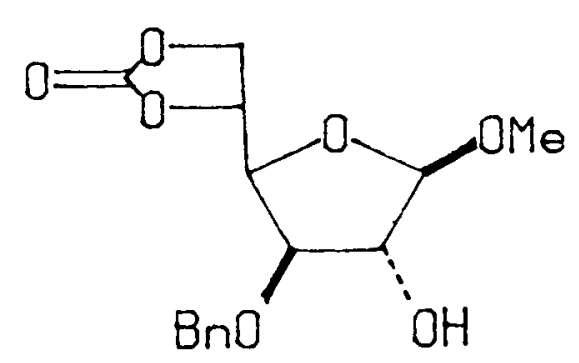

$(1.17 \mathrm{~b})$

\section{SCHEME 1.10}

The $\alpha / \beta$ ratio depended on the acid used. Due to subsequent difficulties in the displacement of a leaving group at $\mathrm{C} 2$ in the $\beta$ series (see below), a method was sought which maximised the yield of the $a$ alcohol (1.17a). With Dowex $50 \mathrm{~W}-\mathrm{XH}$ acidic ion exchange resin in methanol at reflux, a ratio of around $2 \beta$ to $1 \alpha$ was obtained (92\% yield). The anomers were separated, with difficulty on a large scale, using flash chromatography. Further $\alpha$ anomer was obtained by refluxing the isolated $\beta$ anomer with the acid resin in methanol, thereby reforming the equilibrium mixture. In this way the $a$ anomer was prepared in $10 \mathrm{~g}$ quantities.

When a mixture of $50 \%$ trifluoroacetic acid in methanol at room temperature was used, the ratio was about $4 \alpha$ to $1 \beta$, but the major product of the reaction was the lactol; 3-0-benzyl - D-glucofuranose-5,6-carbonate (30 $\mathrm{g}$ of (1.16) produced $7 \mathrm{~g}$ of pure $\alpha$ anomer (1.17a), but also $20 \mathrm{~g}$ of the lactol). 
Nucleophilic displacements in sugars have until recently often proved troublesome, particularly at the $\mathrm{C} 2$ position. This has been explained in terms of the dipole moments and steric factors affecting the ease of formation of the transition state ${ }^{31}$. The use of trifluoromethanesulphonate as a leaving group, has considerably reduced this problem ${ }^{32}$. For example, the mesylate of methyl 4,6-0-benzylidene-3-0-methyl-a-D-glucopyranoside failed to give any displacement with nucleophiles ${ }^{33}$, but the trifluoromethanesulphonate of methy1-4,6-0-benzylidene-3-ㅁ-benzoy1-a-D-glucopyranoside was displaced cleanly by several nucleophiles ${ }^{34}$.

Both the $\alpha$ and $\beta$ anomers (1.17a and $b$ ) formed stable triflates (1.18) on treatment with trifluoromethanesulphonic anhydride in dichloromethane containing pyridine. The $a$ triflate is a syrup, whereas the $\beta$-triflate is highly crystalline. Displacement of the $\mathbb{a - t r i f l a t e}$ with sodium azide in DMF was very slow at room temperature, but after $24 \mathrm{~h}$ at $50^{\circ} \mathrm{C}$ complete conversion to the azide (1.19a) was accomplished, on multigram scale. Displacement of the $\beta$-triflate (1.18b) proved much more difficult, presumably due to the increased steric hinderance to the approaching nucleophile. Treatment with sodium azide at room temperature gave no reaction, and at $50^{\circ} \mathrm{C}$ the triflate reacted only very slowly, giving several products. At $100^{\circ} \mathrm{C}$ complete decomposition of the triflate occurred. Tetrabutylammonium azide $^{35}$ in DMF at room temperature effected conversion to the azide over several days on a small scale, but substantial amounts of triflate remained and several unidentified minor products were produced. (Scheme 1.11) 

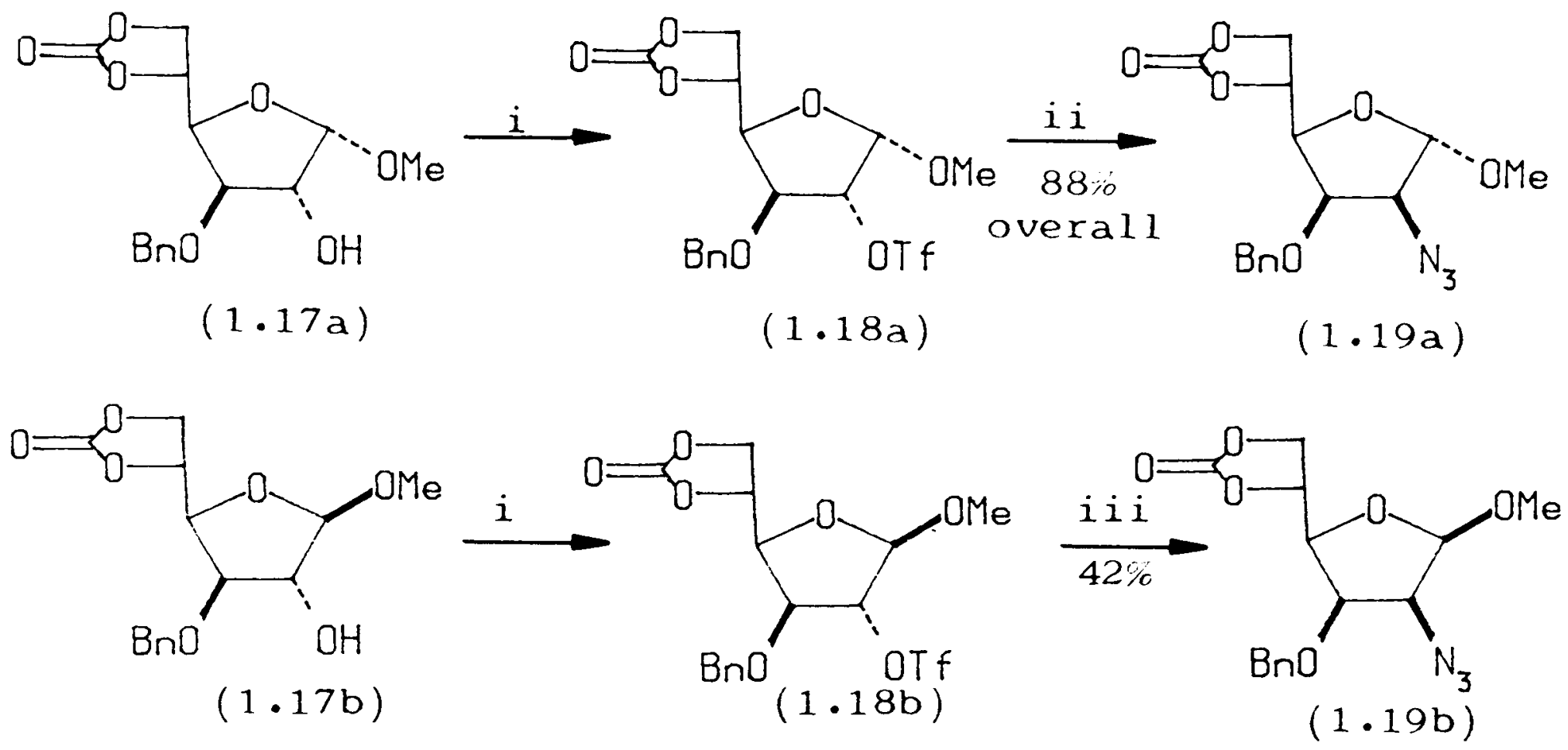

i) $\left(\mathrm{CF}_{3} \mathrm{SO}_{2}\right)_{2} \mathrm{O}$, py ii) $\mathrm{NaN}_{3}, 50^{\circ}, 48 \mathrm{~h}$ iii) $\mathrm{Bu}_{4} \mathrm{NN}_{3}, \mathrm{rt}, 10 \mathrm{~d}$.

\section{SCHEME 1.11}

Attempts to perform the displacement without separating (1.17) or (1.18) resulted in isolation of a low yield of the $\alpha$-azide (1.19a) contaminated with impurities from the $\beta$-series (this was also wasteful of the relatively expensive triflic anhydride). For this reason, the separation of the $a$ and $\beta$ anomers was necessary. The separation was most readily accomplished at the alcohol stage (1.17) and was more difficult with the triflates (1.18).

A further attempt to overcome the $\beta$ displacement problem was by formation of a lactone at $\mathrm{C} 1$. $\mathrm{C} 2$ would then be $\alpha$ - to a carbonyl group and displacement should be more facile.

Hydrolysis of the acetonide group in (1.16) and oxidation of the resulting lacto 1 with bromine in aqueous dioxane containing barium carbonate ${ }^{36}$, gave the lactone (1.20) (58\%) (Scheme 1.12). 


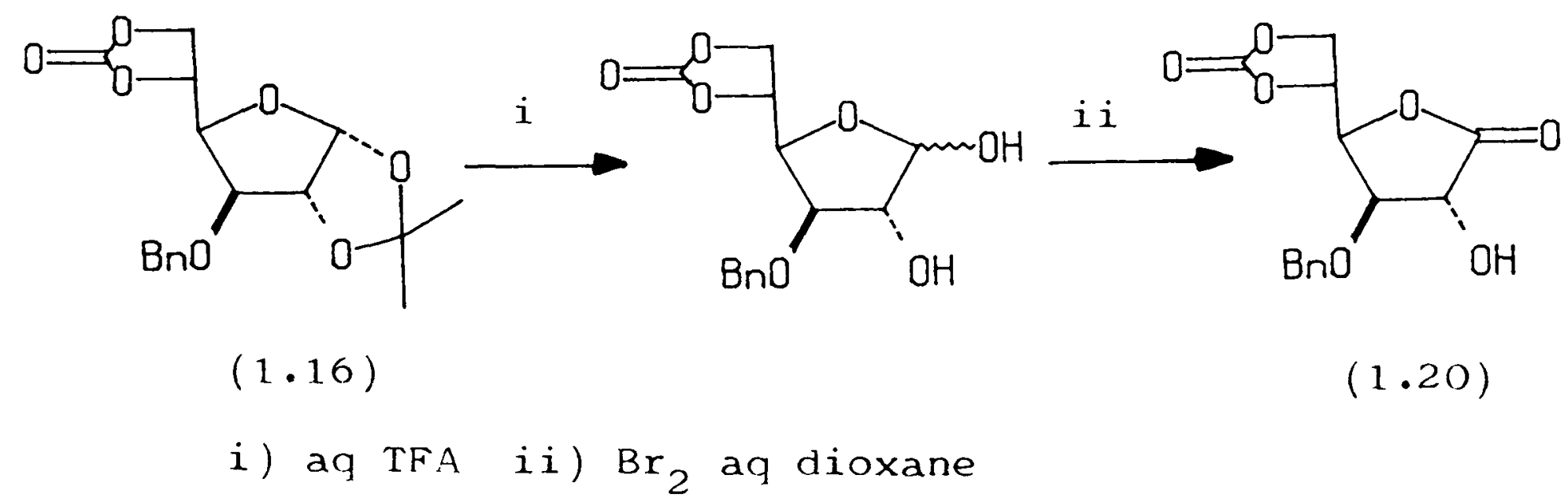

\section{SCHEME 1.12}

The problem with the lactone (1.20) was that the carbonate protecting group could not be selectively removed in the presence of the lactone. Treatment with a trace of sodium methoxide in methanol, gave several unidentified products. This route was not investigated further.

A11 subsequent compounds were produced via the pure $a$-alcohol ( $1.17 \mathrm{a})$. The $\beta$ anomer (1.17b) was re-equilibrated several times in order to prepare substantial quantities of $(1.17 \mathrm{a})$.

Removal of the carbonate group in (1.19a) was accomplished using a trace of sodium methoxide in methanol at room temperature, to give the diol (1.11). In a subsequent experiment the pure $a$ alcohol (1.17a) was converted in 3 steps to the diol (1.11) in $75 \%$ overall yield on multigram scale without purification of the intermediates. The diol was purified by flash chromatography and recrystallised from ethyl acetate/hexane.

\section{b) Cyclisation}

Selective tosylation of the diol (1.11) at the primary hydroxyl position with 1.1 equivalents of freshly recrystallised p-toluenesulphonyl chloride (benzene/40:60 petroleum ether) in pyridine, gave the tosylate (1.21) in 95\% yield at $0^{\circ} \mathrm{C}$. At room temperature, the selectivity was reduced and some di-tosylation occurred. 
Reduction of the azide group of (1.21) with hydrogen and palladium black in ethanol proceeded cleanly in several hours (depending on the catalyst used and the scale of reaction). The cyclisation was accomplished by heating a solution of crude amine in ethano 1 to $50^{\circ} \mathrm{C}$ overnight in the presence of a trace of sodium acetate. Without this buffer, the cyclisation proceeded much more slowly. The bicyclic amine (1.22) could be isolated cleanly either as the benzyl-oxycarbony 1 (Z) derivative (1.10a), (65\% from 1.21), by treatment with benzyl chloroformate in ethyl acetate with saturated aqueous sodium bicarbonate ${ }^{37}$, or the t-butyloxycarbonyl (BOC) derivative (1.10b) (76\% from 1.21 ) by treatment with di-tert-butyldicarbonate in pyridine (Scheme 1.13).

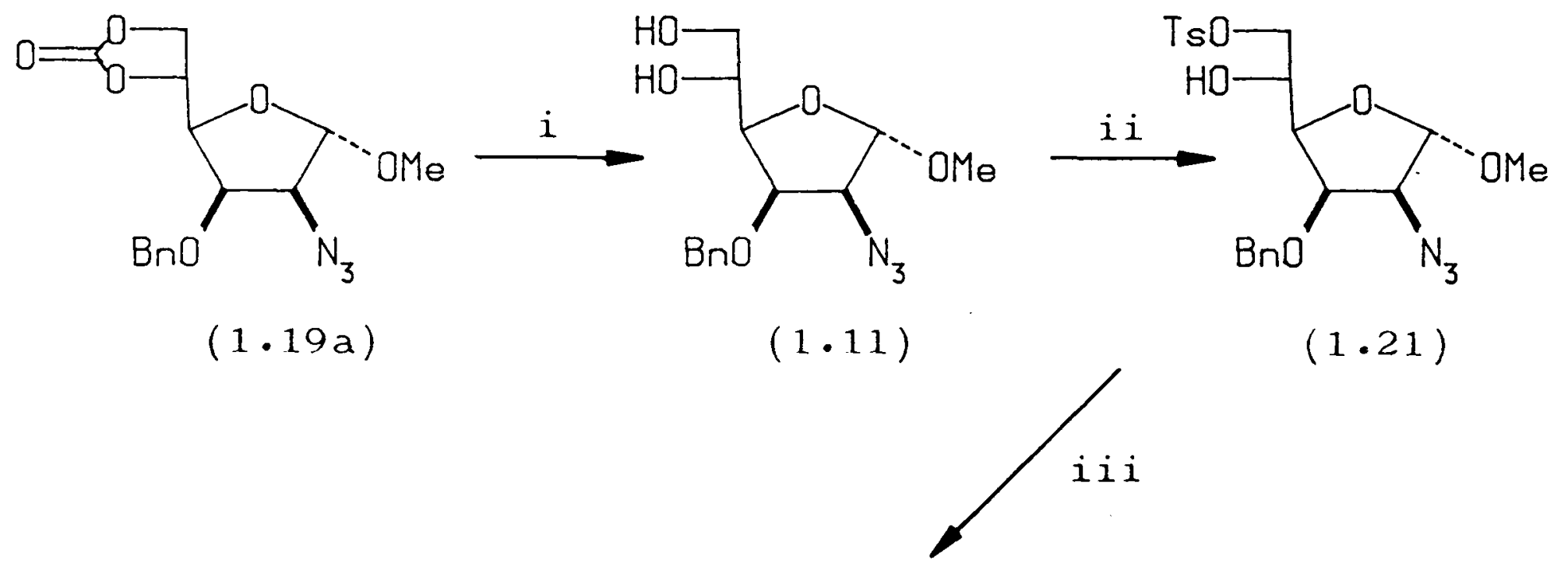

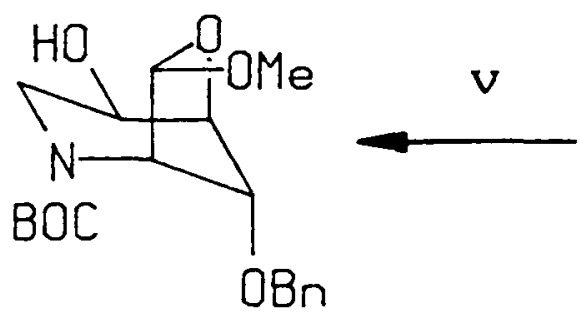

$(1 \cdot 10 \mathrm{Ob})$

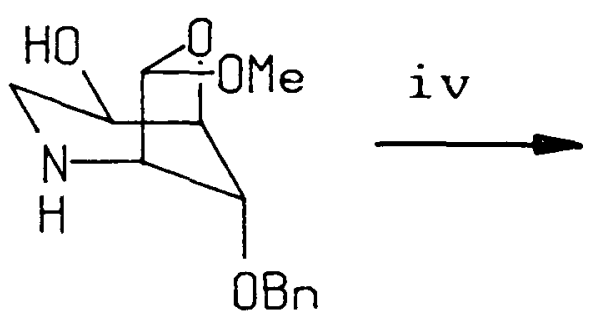

$(1.22)$

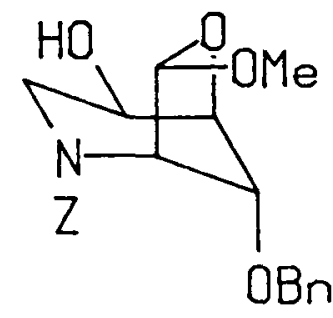

$(1 \cdot 10 \mathrm{a})$

i) $\mathrm{NaOMe}$, $\mathrm{MeOH}$ ii) $\mathrm{TsCl}$, py, $\mathrm{O}^{\circ} \mathrm{C}$ iii) $\mathrm{H}_{2}$, $\mathrm{Pd}$ black, EtOH, then $\mathrm{NaOAC}$, EtOH, heat iv) $\mathrm{PhCH}_{2} \mathrm{OCOCl} v$ ) (tBuOCO$)_{2} \mathrm{O}$, py. 
The proton NMR of these and all subsequent compounds containing the $\mathrm{Z}$ or BOC protecting groups were substantially broadened and very difficult to assign due to the presence of rotamers.

\section{ii) Synthesis of the piperidine alkaloids $(1.1)-(1.7)$}

a) Deoxymannojirimycin (1.1)

The stereochemistry about the piperidine ring in the bicyclic acetals (1.10a and $1.10 \mathrm{~b})$ is the same as in deoxymannojirimycin (1.1). Hydrolysis of the acetal group in (1.10a) and subsequent reduction with sodium borohydride afforded the triol (1.23) (81\%). The benzyl and $Z$ protecting groups were removed by hydrogenolysis with palladium hydroxide in ethanol, to give crude deoxymannojirimycin (Scheme 1.14). Flash chromatography was generally unsuitable for purification of these highly polar compounds and ion-exchange

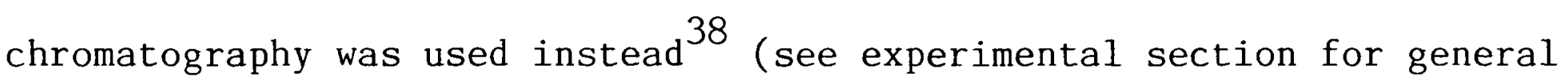
procedures). The synthetic deoxymannojirimycin (1.1) was obtained as a solid in $68 \%$ yield after ion exchange. Generally these compounds were difficult to crystallise as free bases with hygroscopic gums being more usually obtained. In such cases, the hydrochloride salts were prepared which were generally much more crystalline and less hygroscopic.

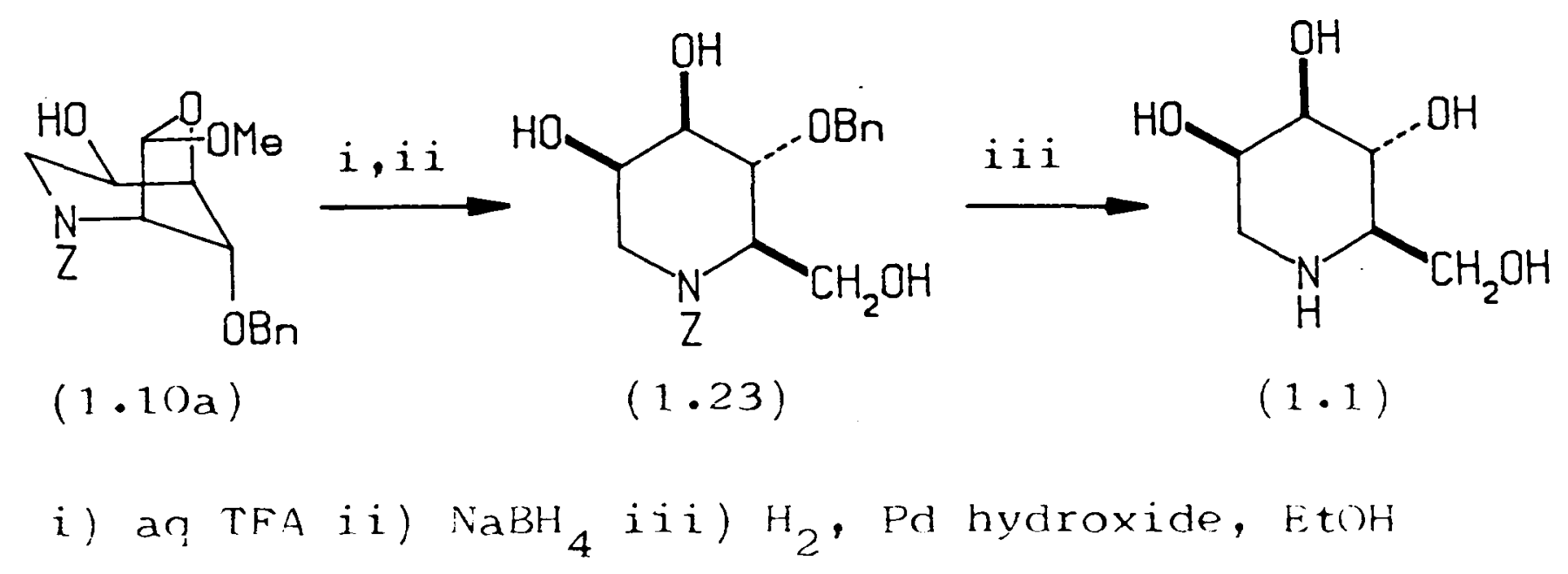


The synthetic deoxymannojirimycin was identical (nmr, mass spectrum, optical rotation and melting point) to the natural product.

\section{b) Fagomine (1.2)}

Synthesis of fagomine (1.2) required deoxygenation of the alcohol at the C5 position in (1.10a), and then an identical sequence to the last 3 steps in the synthesis of $(1.1)$.

The deoxygenation was attempted using both nucleophilic displacement by hydride and free radical methods.

Esterification with trifluoromethanesulphonic anhydride and subsequent treatment with the nucleophilic hydridedonor lithium triethylborohydride 39 gave only a low yield (16\%) of the deoxygenated material (1.24) directly. There was, however, substantial loss of the carbamate protecting group and the yield was greatly increased when the crude mixture was treated with benzyl chloroformate under the usual conditions (78\%)

An attempt to effect elimination from the triflate by treatment with DBU in chloroform at $50^{\circ} \mathrm{C}$ gave only recovered triflate. More vigorous conditions resulted in decomposition of material.

The Barton reaction ${ }^{40}$ is the usual way for performing radical deoxygenations. However, this method has been reported to give benzyl ether ${ }^{41}$, unknown ${ }^{42}$ and starting materia1 ${ }^{40,41}$ biproducts.

A modified procedure 43 involves the use of thionocarbonates and their radical induced fragmentation.

The alcohol (1.10a) was treated with phenylchlorothionocarbonate (1.2 equivalents) and DMAP ( 4 equivalents) in acetonitrile at room temperature to give the thionocarbonate (1.25) (91\%). Treatment with tributyltin hydride 44 in 
toluene in the presence of $\mathrm{AIBN}^{45}$ at $75^{\circ} \mathrm{C}$, gave a mixture of products. The deoxygenated material (1.24) was obtained contaminated with tin residues which could not be removed at this stage. (Scheme 1.15)

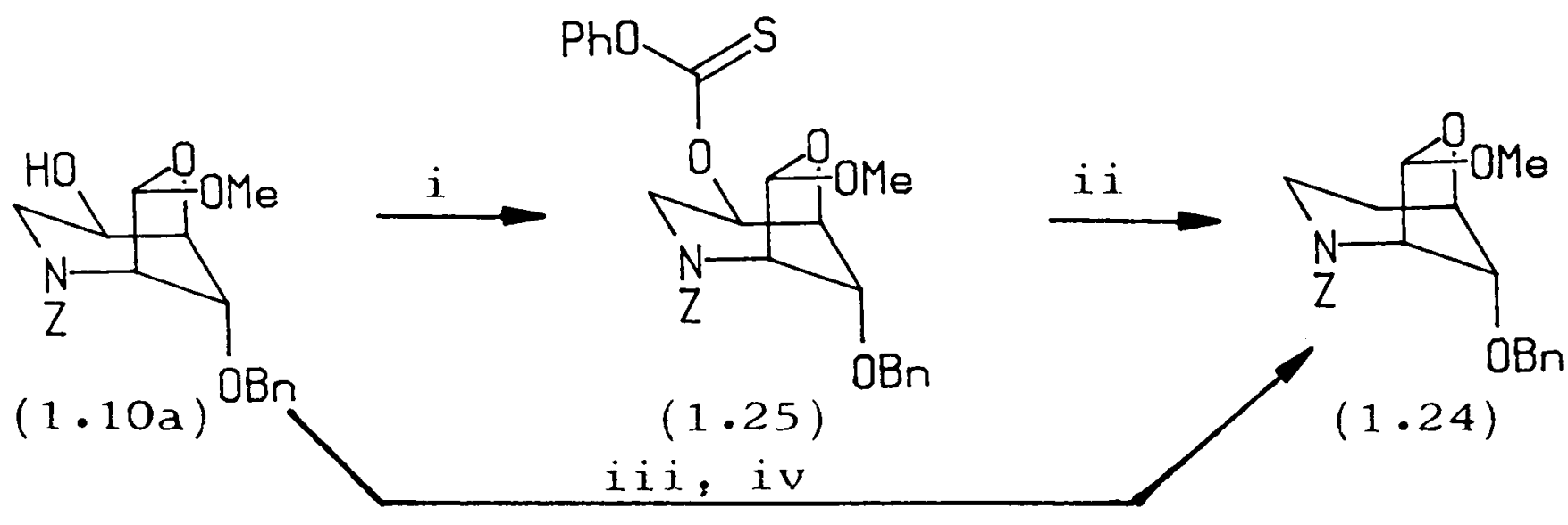

i) PTC-Cl, DNAP, MeCN, i i) Bu $3 \mathrm{SnH}, 4 \mathrm{IBN}$, PhMe, heat iii) $\left(\mathrm{CF}_{3} \mathrm{SO}_{2}\right)_{2}^{\mathrm{O}}$ iv) LiBHEt 3 then $\mathrm{PhCH}_{2} \mathrm{OCOCl}$.

\section{SCHEME 1.15}

Hydrolysis and reduction of the tin contaminated acetal, gave the diol (1.26) (23\% from 1.10a). Hydrolysis and reduction of the product from the super hydride reaction, gave 1.26 in $58 \%$ yield.

Hydrogenolysis of (1.26) and purification by ion exchange chromatography, gave fagomine (1.2) (74\%) (Scheme 1.16). Excessive reaction times in the hydrogenolysis with ethanol as solvent were avoided since a mixture of fagomine with the N-ethyl compound was produced. The synthetic fagomine was identical ( $\mathrm{nmr}$, mass spectrum, optical rotation and melting point) with the natural product.

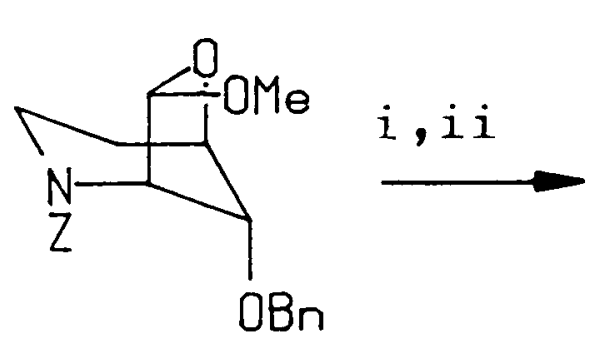

$(1.24)$<smiles>[Z]N1CCC(O)C(OCc2ccccc2)C1CO</smiles>

$(1.26)$<smiles>OCC1NCCC(O)C1O</smiles>

$(1.2)$

i) aq TFA ii) $\mathrm{NaBH}_{4}$ iii) $\mathrm{H}_{2}, \mathrm{Pd}$ 


\section{c) Deoxynojirimycin}

Synthesis of deoxynojirimycin (1.4) required inversion of configuration of the hydroxyl group at C-5 in (1.10) (which becomes $\mathrm{C} 2$ in the target molecule when the acetal is opened). Oxidation of $1.10 \mathrm{a}$ and $\mathrm{b}$ with pyridinium chlorochromate and powdered molecular sieve ${ }^{46}$ and subsequent reduction of the resulting ketones with sodium borohydride at $0^{\circ} \mathrm{C}$, gave exclusive reduction from one face and produced the inverted alcohols (1.27a andb) (Scheme 1.17) ( $78 \%$ and $74 \%$ respectively).

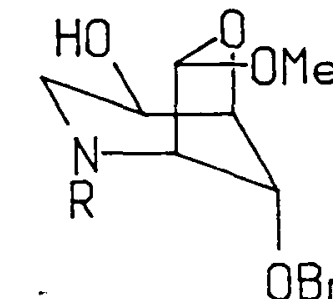

$$
\begin{aligned}
(1.10 \mathrm{a} & \mathrm{R}=7 \\
\mathrm{~b} & \mathrm{R}=\mathrm{BOC})
\end{aligned}
$$

i) Pyridinium chlorochromate

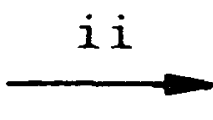

ii) $\mathrm{NaBH}_{4}$

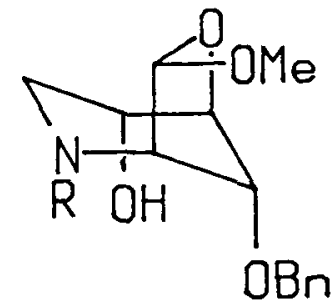

$$
\begin{aligned}
(1.27 \exists & R=Z \\
b & R=B O C)
\end{aligned}
$$

\section{SCHEME 1.17}

Hydrolysis and reduction of 1.27 a proceeded as before to the protected imino glucitol (1.28) (65\%) which was hydrogenolysed with palladium black in acetic acid (quantitative). (The use of ethanol gave predominantly the N-ethyl derivative). Purification by ion exchange chromatography gave deoxynojirimycin (1,5-dideoxy-1,5-imino-D-glucitol) (1.4) identical (nmr, mass spectrum) with the natural compound (Scheme 1.18).

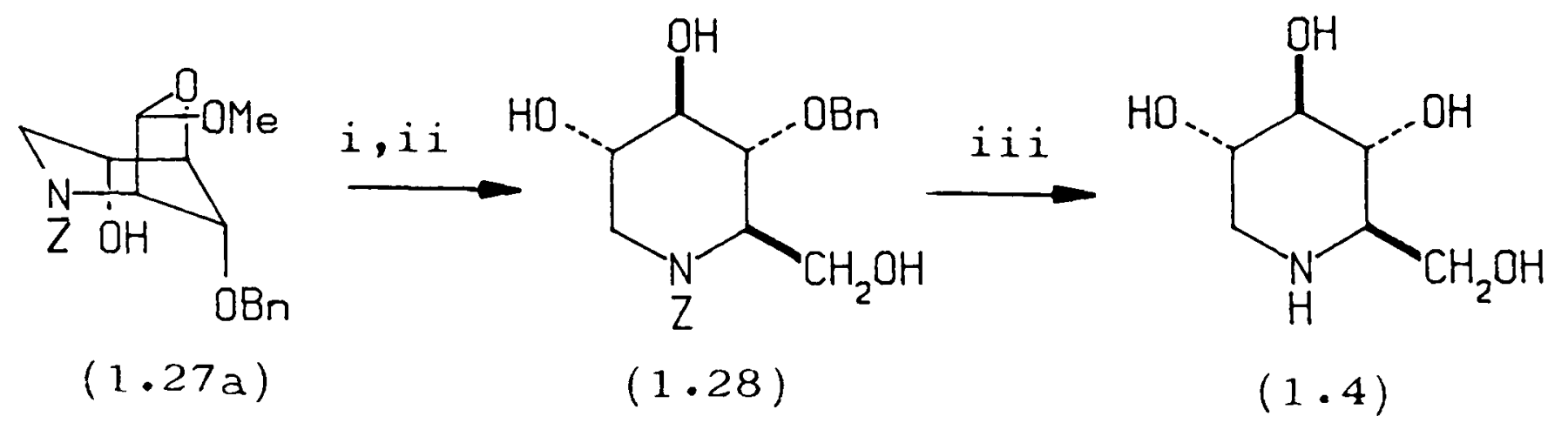

i) aq TFA ii) $\mathrm{NaBH}_{4}$ iii) $\mathrm{H}_{2}$, Pd black, AcOH.

SCHEME 1.18 
Hydrolysis of the methyl acetal in (1.27b) resulted in simultaneous removal of the BOC protecting group and consequent difficulties in isolating the intermediates in a pure form. However, it was possible to obtain (1.4) by this route.

Generally, this inability to hydrolyse the acetal without removing the Nprotecting group was the major drawback in all syntheses starting from the BOC alcohol (1.27b).

d) The Trihydroxypipecolic acids (1.3) and (1.5).

The manno (1.3) and gluco (1.5) isomers were prepared from (1.10a) and (1.27a) respectively. Initial hydrolysis of the methyl acetal and subsequent bromine water oxidation of the resulting lactols in aqueous dioxane with barium carbonate buffer ${ }^{36}$, produced the lactones (1.29) and (1.30), which were hydrogenolysed in aqueous acetic acid to give the amino acids (Scheme 1.19).

The yield of the oxidation was very low in the gluco-series. This is presumably because the lactol produced on acid hydrolysis possesses four axial substituents about the piperidine ring and so it opens to the free aldehyde to enable all the substituents to become equatorial.

Oxidation of the hydrated aldehyde to the corresponding acid may occur, but the acid could not be isolated by flash chromatography, although a highly polar product was observed on t.l.c.

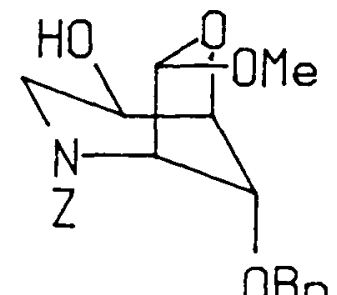

(1.10a)

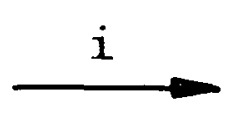

$\mathrm{OBn}$

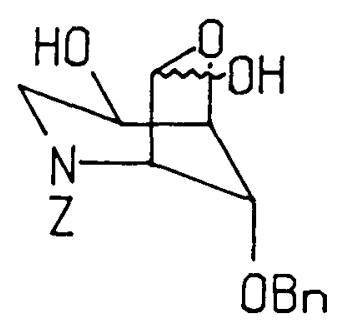

OBn
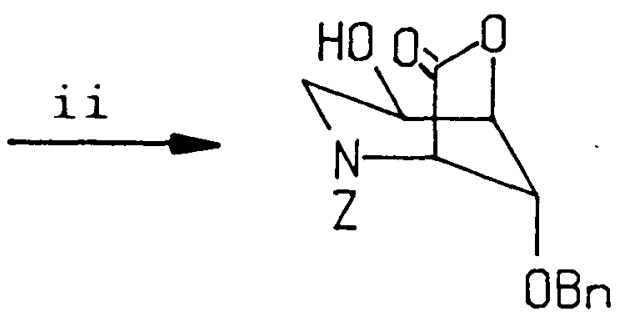

(1.29) 

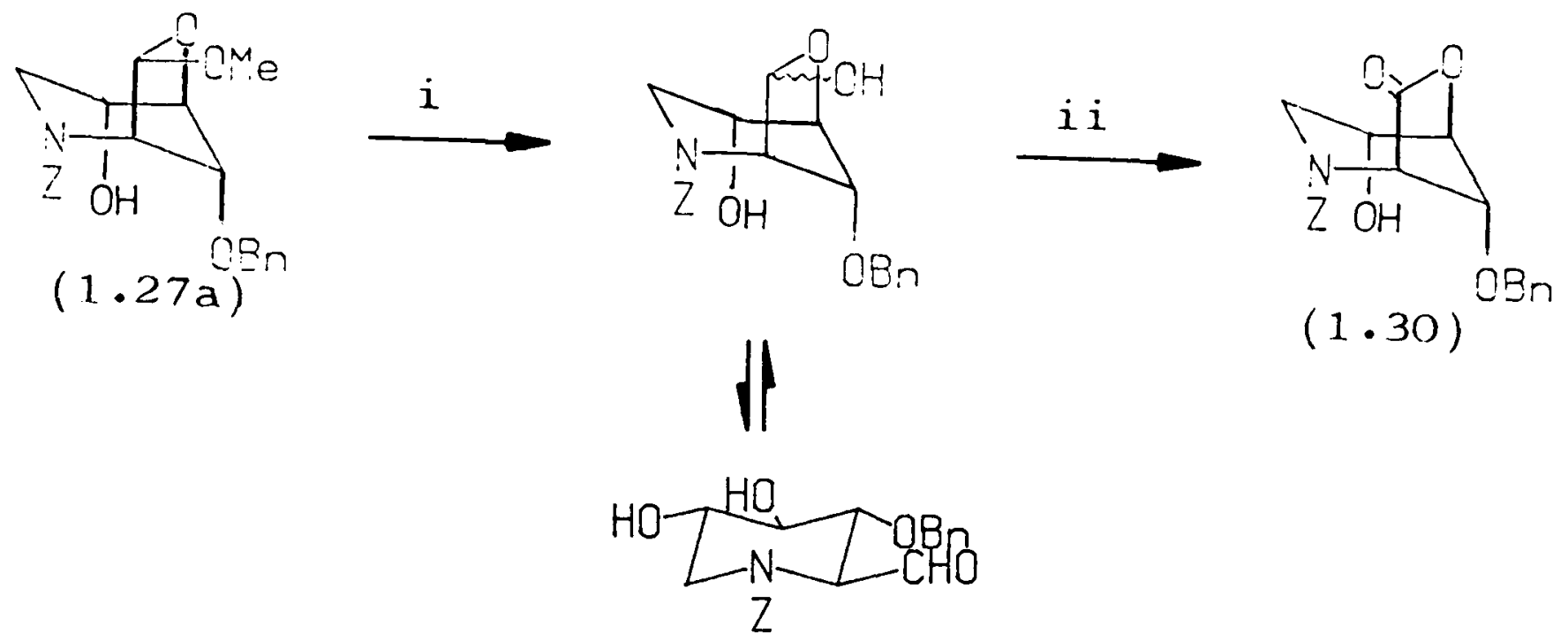

$(1.29)$

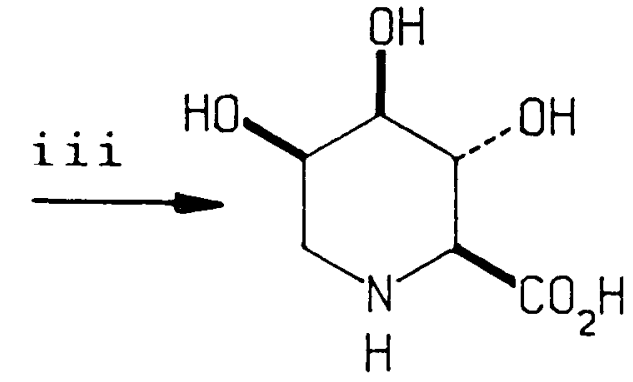

$(1 \cdot 3)$<smiles>O=C(O)C1NCC(O)C(O)C1O</smiles>

$(1.5)$

i) aq $\mathrm{TFA}$ ii) $\mathrm{Br}_{2}$, aq dioxane, $\mathrm{BaCO}_{3}$ iii) $\mathrm{H}_{2}$, $\mathrm{Pd}$, aq $\mathrm{AcOH}$ SCHEME 1.19

Although the lactone (1.29) has been drawn as the bicyclo $[3,2,1$, system, it could actually be the $[2,2,2]$ lactone shown below:-<smiles>O=C1OC2NC1C(Cc1ccccc1)C2O</smiles>

Such a possibility does not exist for the epimeric system (1.30).

The synthetic amino acid (1.5) was identical ( $\mathrm{mmr}$, mass spectrum, melting point) to the natural product.

e) The N-Acetyl glucosamine and mannosamine analogues (1.7) and (1.6). A number of glycosidase enzymes have been found to be elevated in malignancy and associated with tumour cell invasion and degradation of basement membrane components. Elevations of serum $\beta$-N-acetyl-glucosaminidase and 
$\beta$-glucuronidase have been found to occur most commonly, and these enzymes have been shown to be secreted into the extracellular medium by many different tumour cell types in vitro. It is, therefore, of considerable interest to develop inhibitors against these enzymes ${ }^{47,48}$.

On the basis of the structure of the known inhibitors and the enzymes they inhibit, it was anticipated that 2-Acetamido-1,5-imino-1,2,5-trideoxy-Dglucitol would be a potential $\beta$-N-acetylglucosaminidase inhibitor and its synthesis was undertaken.

The synthesis of the gluco-isomer (1.7) required introduction of nitrogen at the C5 position of 1.10 a with inversion of configuration.

The benzyloxycarbonyl protected amine (1.10a) was esterified with trifluoromethanesulphonic anhydride in dichloromethane containing pyridine and the resulting triflate treated with sodium azide in $\mathrm{DMF}$ at $60^{\circ} \mathrm{C}$ for $24 \mathrm{~h}$ to give, as the major isolated product, the azide (1.31a) in which the configuration at $\mathrm{C}-5$ had been inverted in the displacement (36\%), together with the epimeric azide (1.32a) (23\%) (Scheme 1.20). (This was deduced from spectra of the target molecules derived from the respective azides - see below).

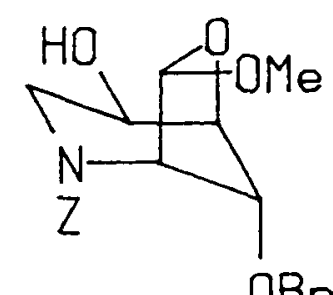

$(1 \cdot 10 \mathrm{a})$

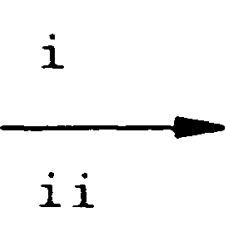

Bn

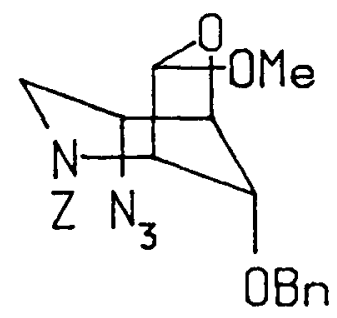

$(1.31 \mathrm{a})$

major

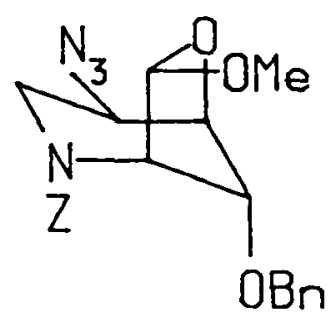

$(1.32 a)$

minor
i) $\left(\mathrm{CF}_{3} \mathrm{SO}_{2}\right)_{2} \mathrm{O}, \mathrm{py}$
ii) $\mathrm{NaN}_{3}, \mathrm{DMF}, 60^{\circ} \mathrm{C}$.

\section{SCHEME 1.20}

Treatment of (1.31a) with sodium hydrogen telluride 49 selectively reduced the azide in the presence of the benzyloxycarbonyl group (this could not be 
accomplished by hydrogenolysis) and acetylation with acetic anhydride in pyridine, gave the amide (1.33) (92\%). Hydrolysis of the furanoside (1.33) with aqueous trifluoroacetic acid, and sodium borohydride reduction of the resulting lactol, gave (1.34) (80\%). Removal of the protecting groups in (1.34) by hydrogenolysis with palladium black in acetic acid, gave the $\mathrm{N}$ - acetylglucosamine analogue (1.7) (92\%, 25\% from 1.10a).(scheme 1.21).

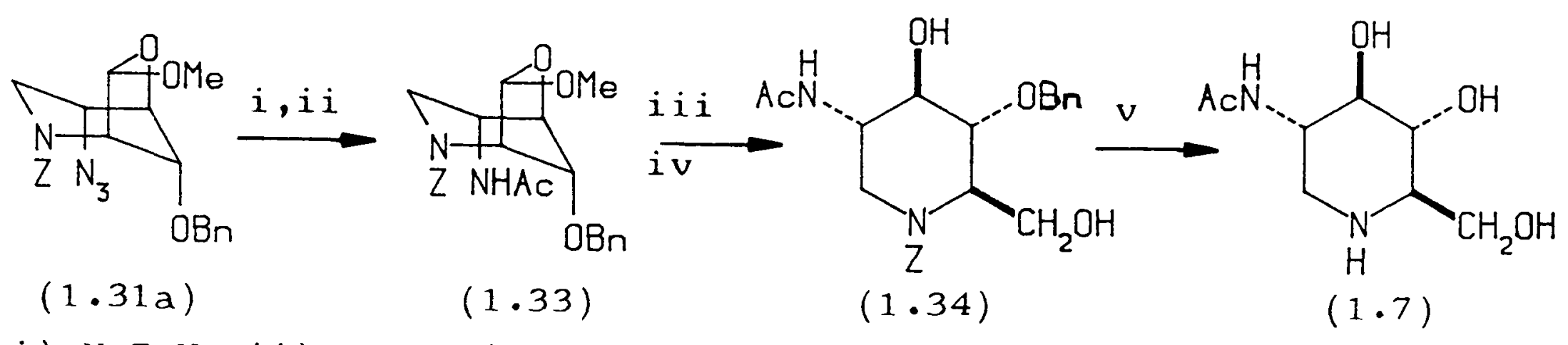

i) $\mathrm{NaTeH}$ ii) $\mathrm{Ac}_{2} \mathrm{O}$ iii) aq TFA iv) $\mathrm{NaBH}_{4}$ v) $\mathrm{H}_{2}$, Pd black.

SCHEME 1.21

When the minor azide (1.32a) was subjected to the same sequence of reactions (1.6) was produced ( $53 \%$ from 1.32 a without isolation of the intermediates).

The t-butyloxycarbonyl protected amine (1.10b) was converted to the corresponding triflate and treated with sodium azide in DMF at $70^{\circ} \mathrm{C}$ for $48 \mathrm{~h}$.

Two azides were again produced. The major product (1.32b) (42\%) in which the stereochemistry at $\mathrm{C}-5$ had been retained in the displacement, and the minor product (1.31b) (15\%) in which $\mathrm{C}-5$ had been inverted (Scheme 1.22).

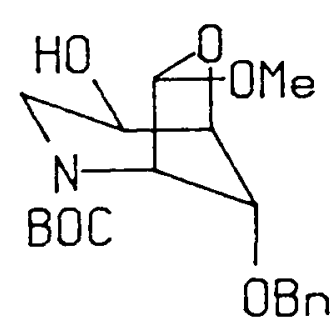

$(1 \cdot 1 \mathrm{Ob})$

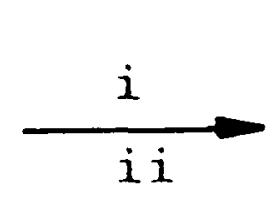

Bn

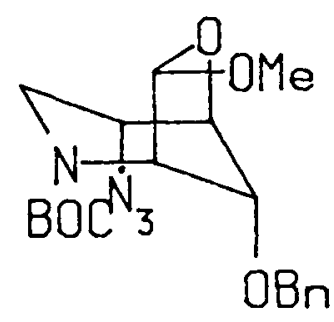

$(1.31 \mathrm{~b})$ minor

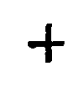

i) $\left(\mathrm{CF}_{3} \mathrm{SO}_{2}\right)_{2} \mathrm{O}$ ii) $\mathrm{NaN}_{3}, \mathrm{DMF}, 70^{\circ} \mathrm{C}$

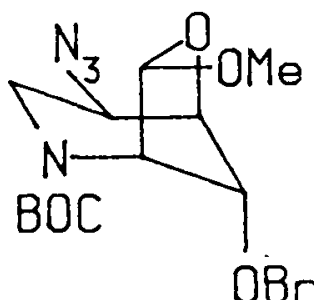

$(1.32 b)$ major 
Hydrogenation of the azide (1.32b) with palladium black in ethanol and acetylation with acetic anhydride in pyridine gave the amide (1.35) (83\%). Hydrolysis of (1.35) caused simultaneous removal of the BOC protecting group and hydrolysis of the furanoside to the corresponding lactol. Reduction with sodium borohydride gave (1.36) which on hydrogenation in acetic acid with palladium black, gave the $\mathrm{N}$ - acetylmannosamine analogue (1.6) (52\% from 1.35$)$ (Scheme 1.23 )

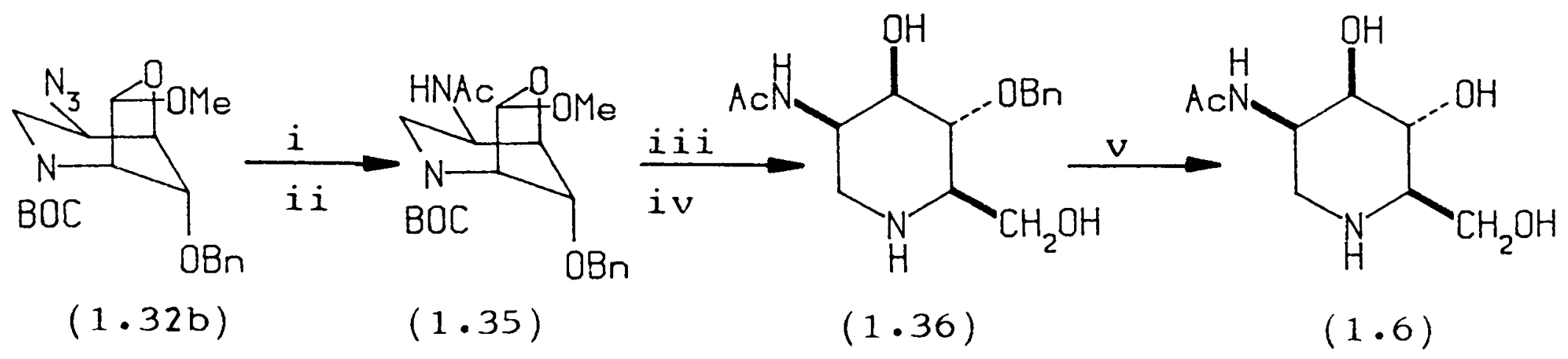

i) $\mathrm{H}_{2}, \mathrm{Pd}, \mathrm{EtOH}$ ii) $\mathrm{Ac}_{2} \mathrm{O}$ iii) aq TFA iv) $\mathrm{NaBH}_{4}$ v) $\mathrm{H}_{2}, \mathrm{Pd}, \mathrm{AcOH}$ SCHEME 1.23

The retention of configuration observed in the displacement reactions is probably due to neighbouring group participation by $\mathrm{BOC}$ and $\mathrm{Z}$. The incoming nucleophile is considerably hindered by the axial $\underline{0}-$ benzyl group, (A recent study on the series epimeric at $\mathrm{C} 3$ i.e. OBn equatorial has shown the displacement at $\mathrm{C} 5$ to be very easy ${ }^{51}$ ) and so the rate of direct displacement is slow.

Neighbouring group participation by $\mathrm{BOC}$ and $\mathrm{Z}$ protected amines in nucleophilic displacements has been observed before ${ }^{50}$. An explanation of the greater degree of retention of configuration in the BOC series is that BOC is a much more effective neighbouring group than $Z$. This may arise due to the greater $(+I)$ inductive effect of the $\underline{t}$-butyl group in comparison to the benzyl group. 
An attempt to avoid the displacement problem and produce the gluco- isomer cleanly was made by reductive amination. The alcohol at C5 in (1.10a) was oxidised with pyridinium chlorochromate as before, but treatment with ammonia and sodium cyanoborohydride failed to give any amine containing products.

The appearance of the three protons on the carbon atoms $\mathrm{Cl}$ and $\mathrm{C} 5$, adjacent to nitrogen, in the ${ }^{1} \mathrm{H}$ NMR spectra of the $\underline{N}$ - acetylglucosamine analogue (1.7) was identical to that of the corresponding protons in deoxynojirimycin (1.4). A different characteristic pattern for the corresponding protons in the $\underline{N}-$ acetylmannosamine analogue (1.6) and in deoxymannojirimycin (1.1) was also observed. The coupling constants between the $\mathrm{H} 1$ and $\mathrm{H} 2$ protons were informative in deducing the stereochemistry at $\mathrm{C} 2$. In the compounds with the gluco- configuration, (1.4) and (1.7), one large coupling and one small coupling was observed, indicating that the $\mathrm{H} 2$ proton must be axial; in the manno- isomers, (1.1) and (1.6), both $\mathrm{J}$ values were small, indicating that $\mathrm{H} 2$ was equatorial (Table 1.1). 
TABLE 1.1

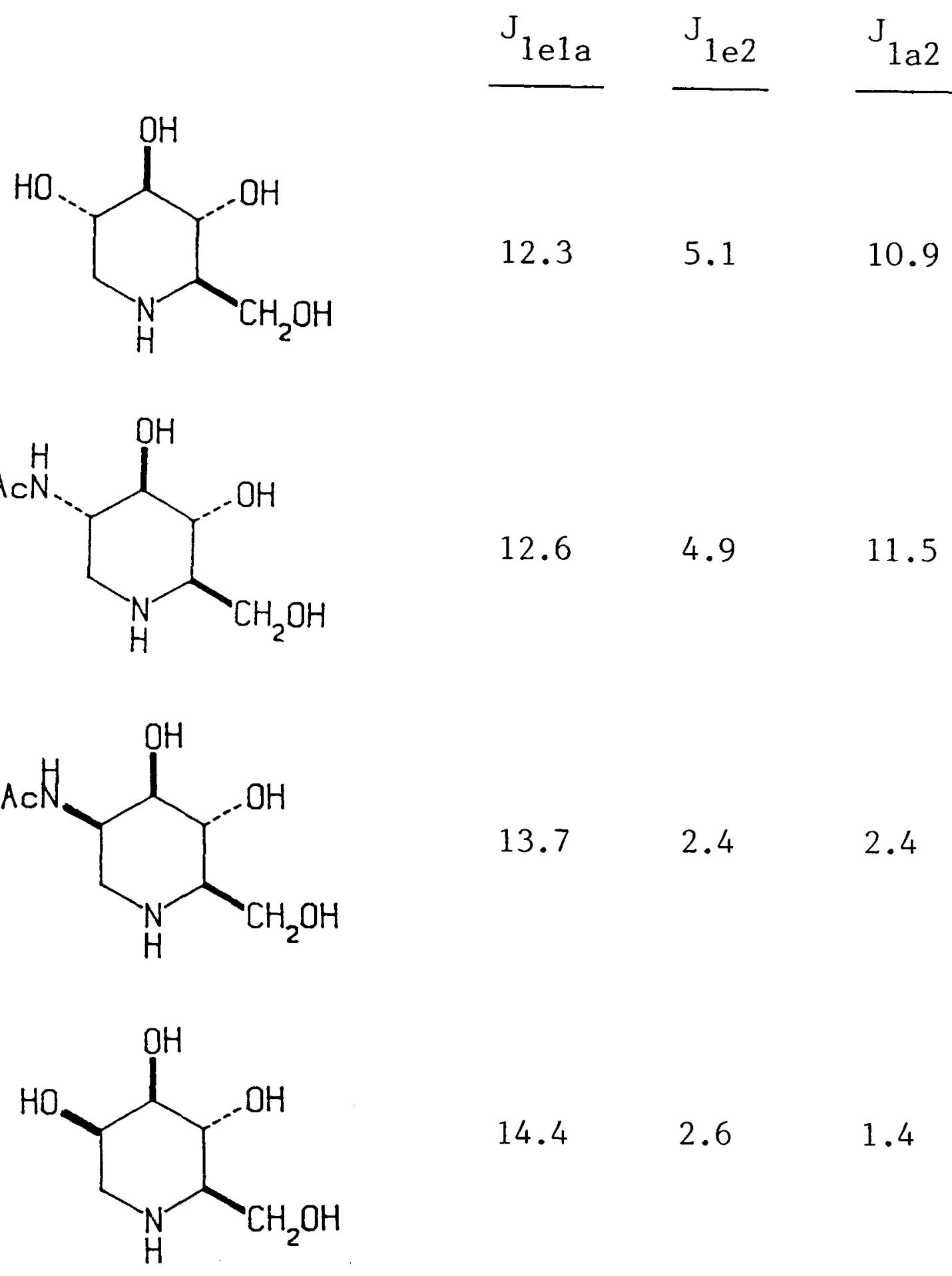

It was through comparison of these spectra that the stereochemical assignment for the nucleophilic displacement was made.

The inhibitory actions of (1.6) and (1.7) on the hydrolysis of the corresponding p-nitrophenyl glycopyranosides catalysed by a range of glycosidases were determined 52,53 .

The $\mathrm{N}$-acetyl glucosamine analogue (1.7) was a potent competitive inhibitor of $\beta$-N-acetylglucosaminidases from Jack Bean ( $50 \%$ inhibition at $3.4 \times 10^{-7} \mathrm{M}$, 
$\mathrm{K}_{\mathrm{I}} 2.3 \times 10^{-7} \mathrm{M}$ ) bovine kidney (50\% inhibition $7.5 \times 10^{-6} \mathrm{M}, \mathrm{K}_{\mathrm{I}} 6.0 \times 10^{-7} \mathrm{M}$ ) and human placenta ( $50 \%$ inhibition $6 \times 10^{-6} \mathrm{M}, \mathrm{K}_{\mathrm{I}} 9.0 \times 10^{-7} \mathrm{M}$ ). Weaker inhibition of the bond and aglycon specific N-acetyl glucosaminidase from streptococcus pneumoniae $^{54}$ was observed (50\% inhibition $3.2 \times 10^{-4} \mathrm{M}$ ) while no inhibition of Aspergillus niger N-acetylglucosaminidase was found. The glucosamine analogue (1.7) did not inhibit the catalytic action of any of the other glycosidases examined at $3 \times 10^{-4} \mathrm{M}$. The mannosamine analogue (1.6) showed no significant inhibition of the glycosidase activity of any of the enzymes.

iii) Synthesis of the pyrrolidine alkaloid 2,5-dideoxy-2,5-imino-Dmannito1 (1.8)

The diol (1.11) was selectively esterified at the primary hydroxyl group with 1.1 equivalents of benzoyl chloride in pyridine at $0^{\circ} \mathrm{C}$ to afford the ester (1.37) (81\%). Mesylation of (1.37) with an excess of methanesulphonyl chloride in pyridine, gave the mesylate (1.38) (94\%). Treatment of (1.38) with sodium methoxide in $\mathrm{DMF}$ at $50^{\circ} \mathrm{C}$ effected rapid removal of the benzoyl ester to give the alcohol (1.39) which slowly cyclised to the epoxide (1.12) (82\%) inverting the configuration at C5 (Scheme 1.24). 


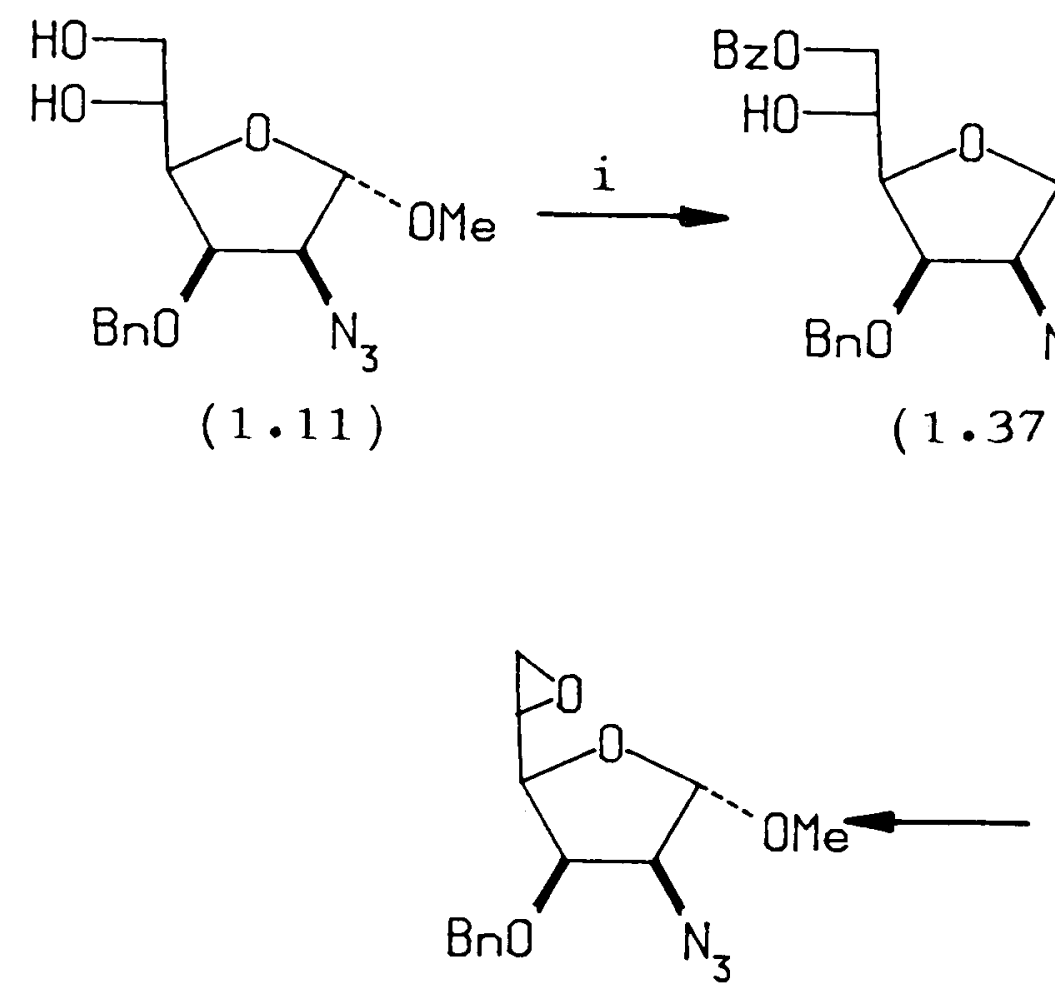

(1.12)

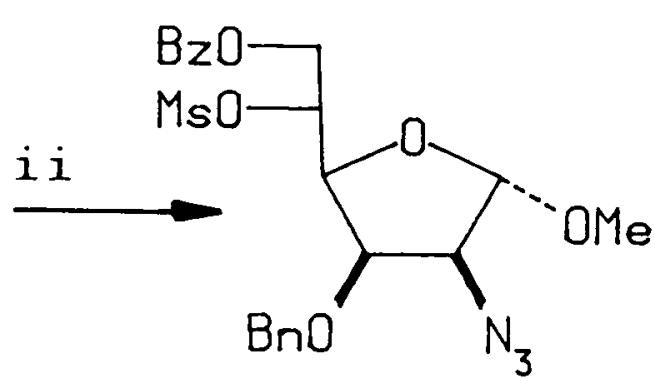

(1.38)

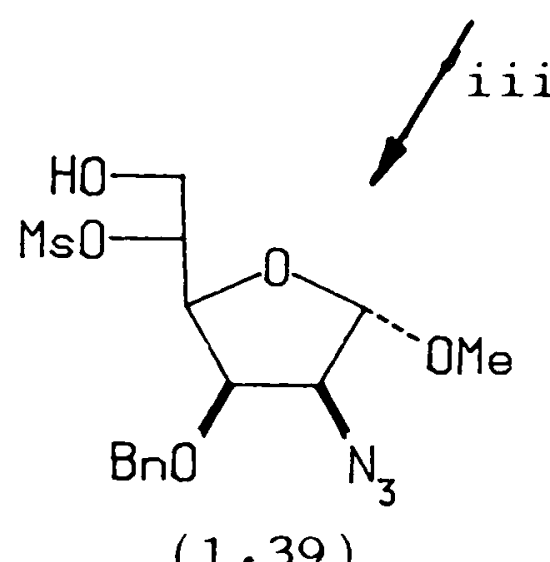

i) $\mathrm{BzCl}, \mathrm{py}, \mathrm{O}^{\mathrm{O}} \mathrm{C}$, ii) $\mathrm{MsCl}$, py, $\mathrm{rt}$ iii) NaOMe, $\mathrm{DMF}, 50^{\circ} \mathrm{C}$. SCHEME 1.24

The cyclisation did not proceed in methanol and prolonged times in DMF led to a slow disappearance of the epoxide and appearance of a new product, presumably due to nucleophilic attack at $\mathrm{C6}$ by methoxide.

Hydrogenolysis of the azide (1.12) with palladium black in ethanol, led to two products, which were isolated and separated as the N-benzyloxycarbonyl derivatives by subsequent treatment with benzyl chloroformate.

The major product corresponded to the cyclised amine produced by a 5-exo-tet ring opening of the epoxide 55 (1.40) (43\%). A similar example involving the formation of a carbocycle has been reported 56 . The minor product was initially believed to be the 7-endo-tet product, but inspection of the nmr showed a doublet at $1.2 \delta$ integrating as $3 \mathrm{H}$. The mass spectrum (DCI, $\left.\mathrm{NH}_{3}\right)$ gave peaks at 419 and 402 .

The structure proposed is (1.41) in which the epoxide has been reduced before the cyclisation could occur (Scheme 1.25). 
<smiles>[CH]C1OC(C2CO2)C([Hg])C1[Hg]C(=O)c1ccccc1</smiles>

$(1.12)$

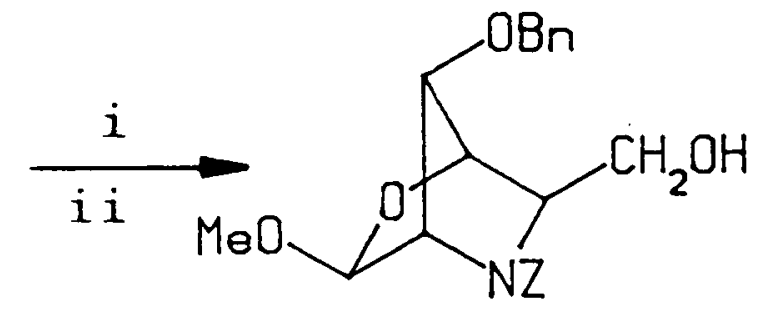

(1.40)

major

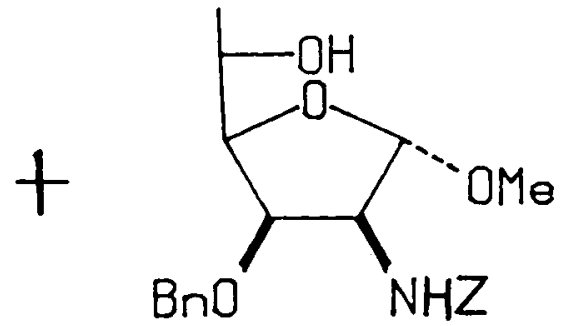

(1.41) minor

i) $\mathrm{H}_{2}, \mathrm{Pd}$ black, $\mathrm{EtOH}$ ii) $\mathrm{PhCH}_{2} \mathrm{OCOCl}$

SCHEME 1.25

This reduction of the epoxide by hydrogenolysis has been observed in a similar system $^{57}$.

Elaboration of (1.40) into the target molecule proceeded through the usual sequence. Hydrolysis with aqueous trifluoroacetic acid and sodium borohydride reduction of the lactol, gave the triol (1.42) (73\%), which on hydrogenolysis with palladium black in acetic acid, gave the pyrrolidine (1.8) as the acetate salt. Neutralisation and purification by ion exchange chromatography, gave the free base, identical (nmr, mass spectrum, optical rotation) to the natural product ${ }^{58}$. (Scheme 1.26$)$.

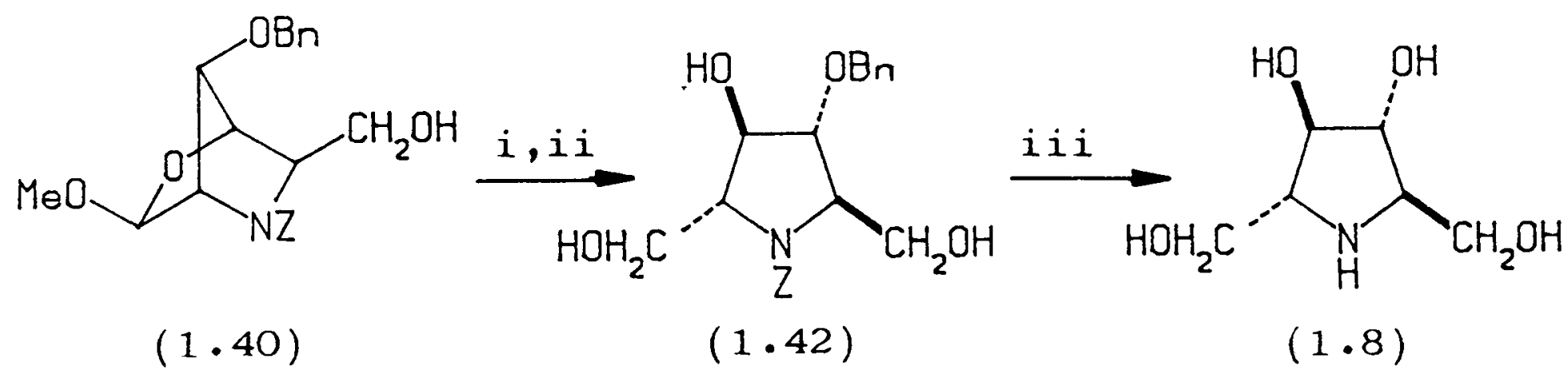

i) aq TFA ii) $\mathrm{NaBH}_{4}$ iii) $\mathrm{H}_{2}$, Pd black, AcOH. 
$\underline{\text { SYNTHETIC }}$
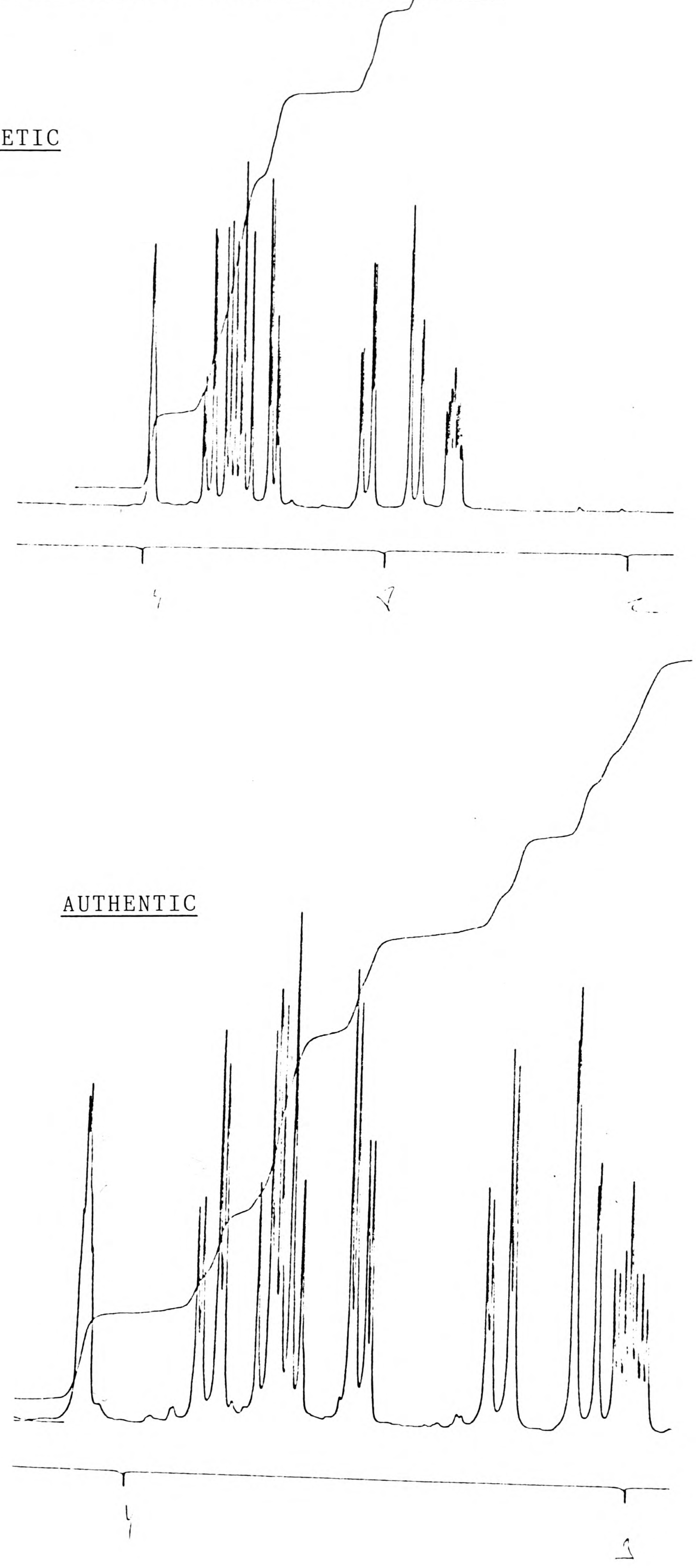


$$
\text { How }
$$


$-46-$

FIG $1.4:{ }^{1}$ H NMR OF DEOXYNOJIRIMYCIN (1.4) (hydrochloride salts)

$\underline{\text { SYNTHETIC }}$
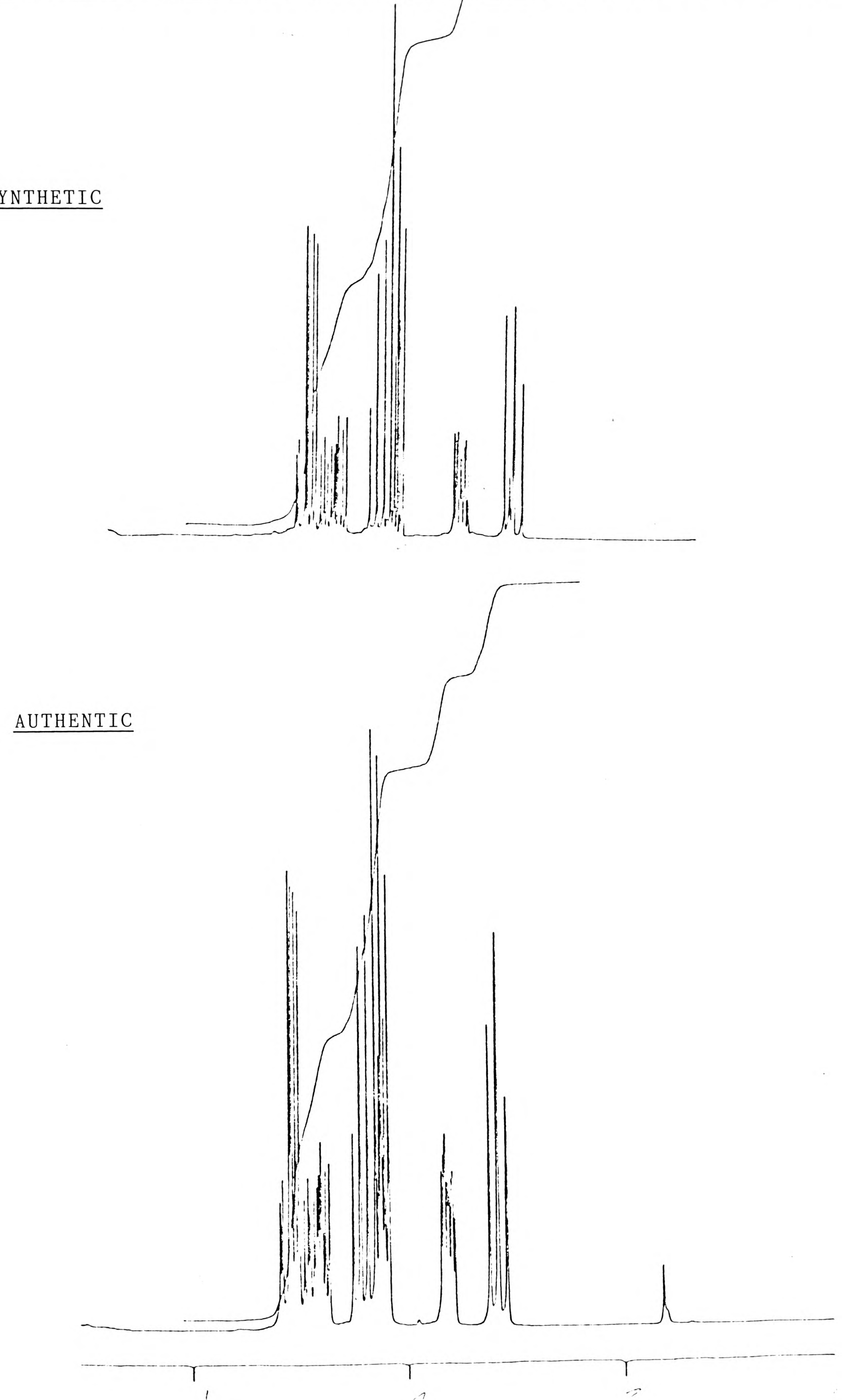
FIG $1.6:{ }^{1}$ H NMR OF THE TRIHYDROXYPIPECOLIC ACID $(1.5)$ iv
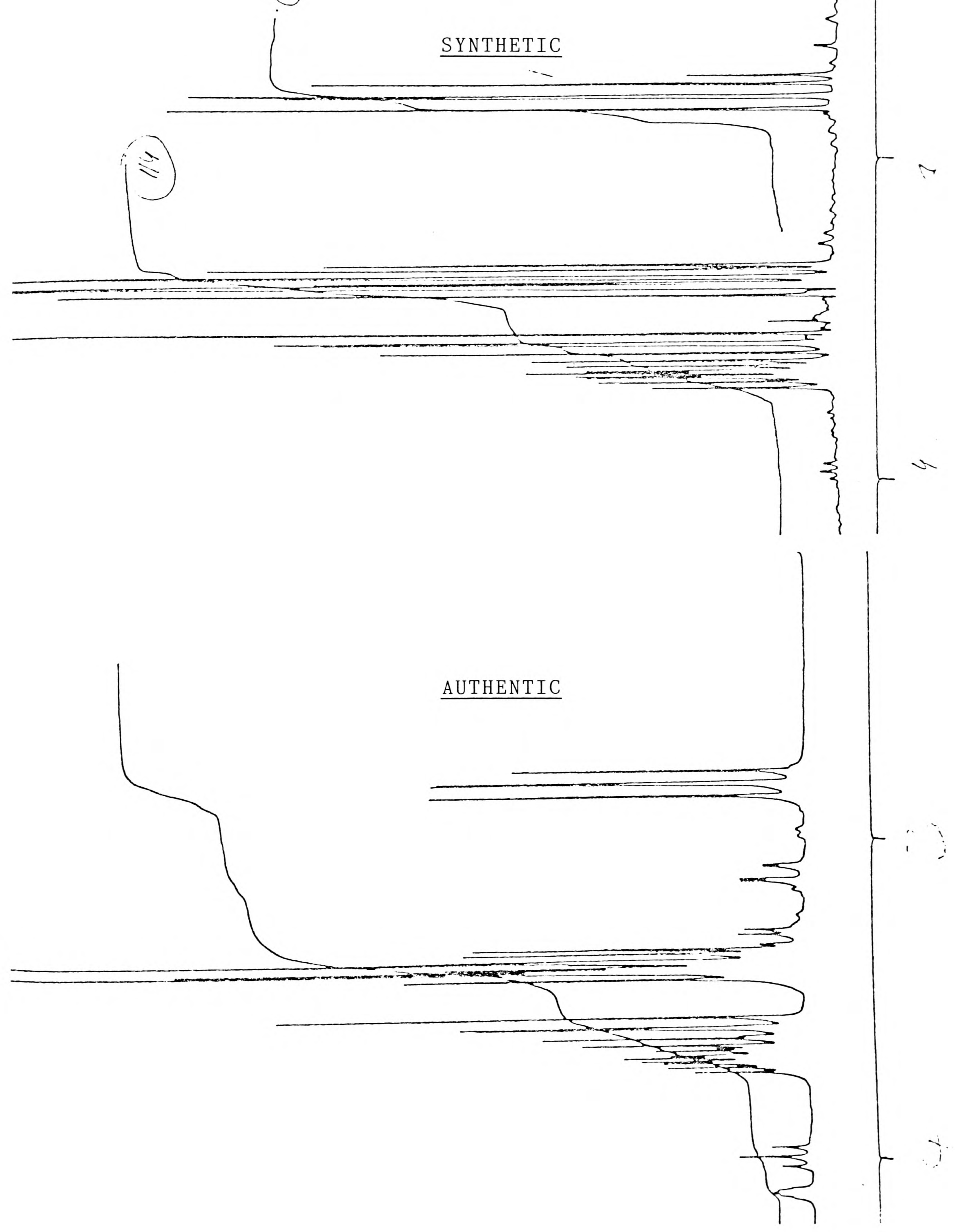
$-49-$

FIG $1.7:{ }^{1}$ H NMR OF THE N-ACETYL GLUCO AND MANNOSAMINE ANALOGUES $(1.7)$ and $(1.6)$

MANNO ANALOGUE $(1.6)$

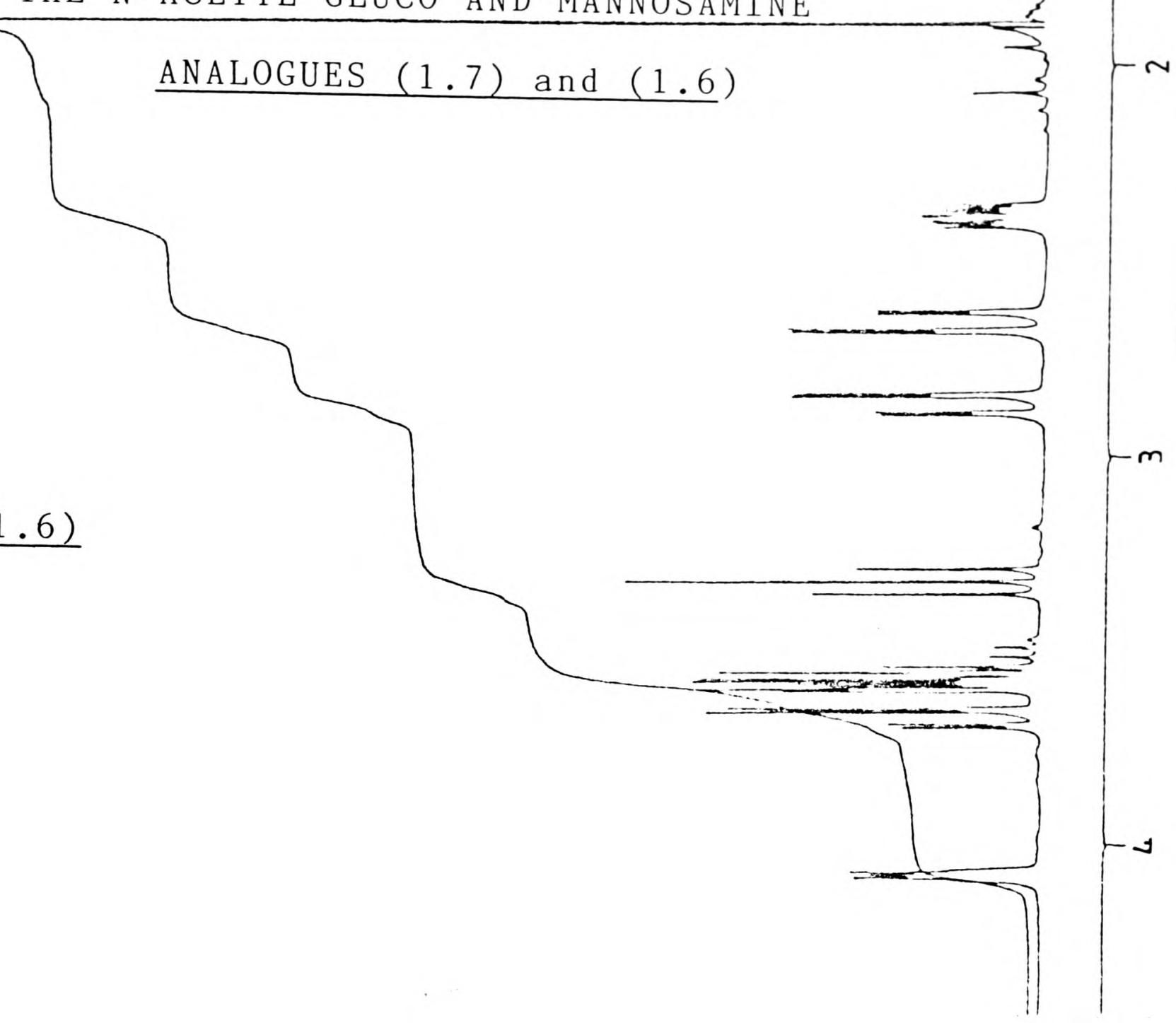

$\underline{\text { GLUCO ANALOGUE }(1.7)}$

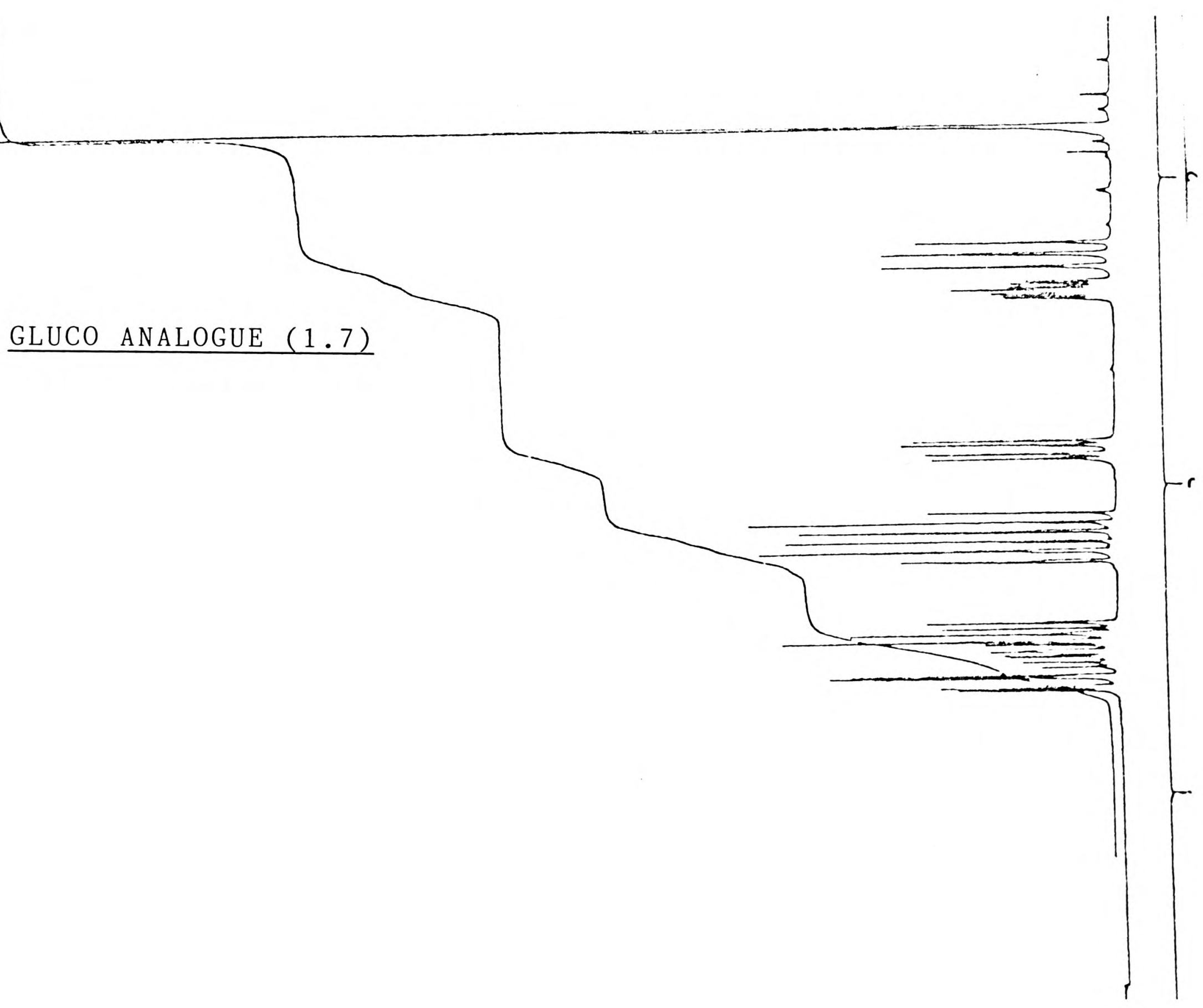




$$
-50-
$$

FIG $1.8:{ }^{1}{ }_{H}$ NMR SPECTRUM OF SYNTHETIC $(1.8)$
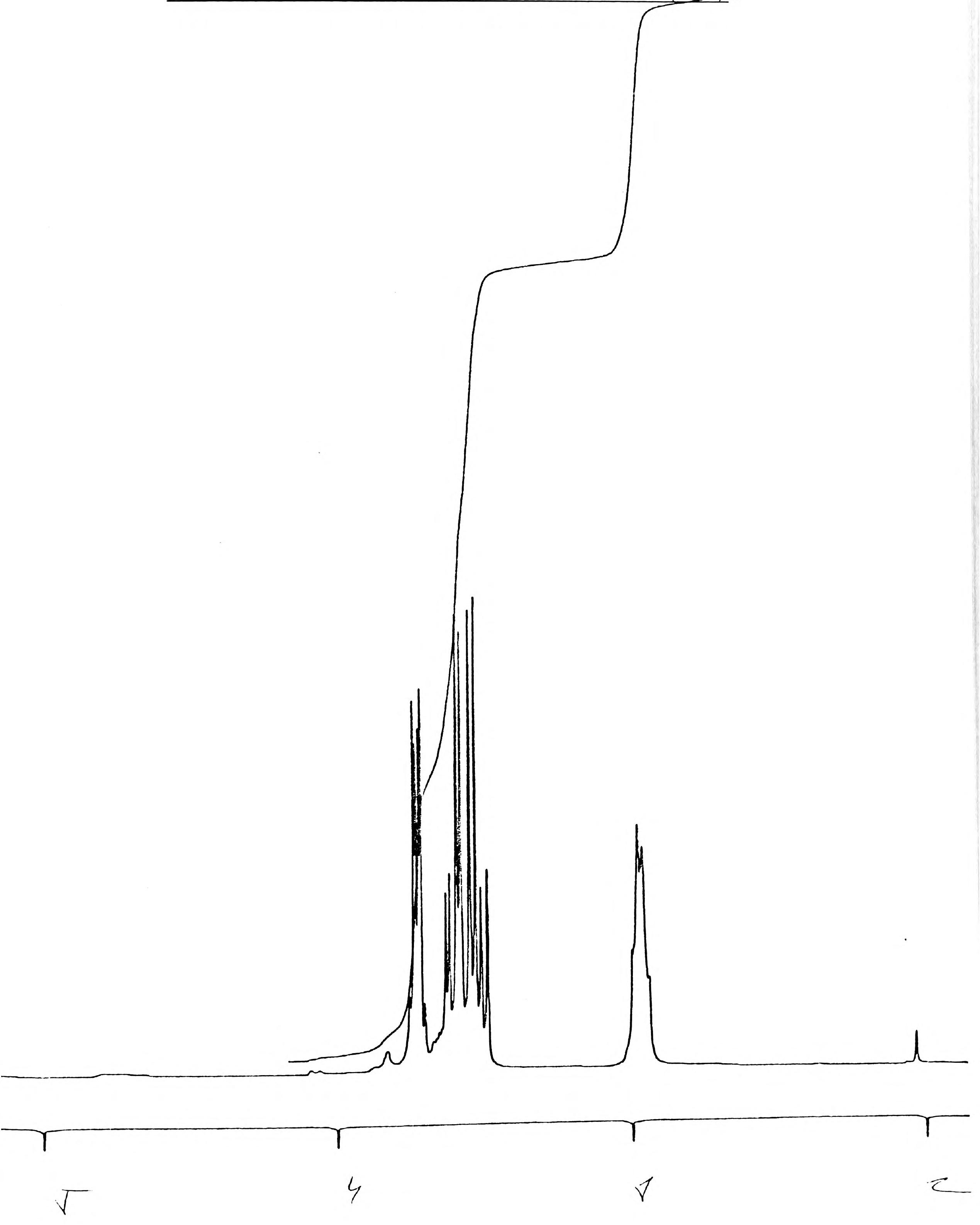


\section{EXPERIMENTAL SECTION}

\section{Genera1 Directions}

Proton nuclear magnetic resonance $\left({ }^{1} \mathrm{H}\right.$ NMR) spectra were recorded on a Bruker WH $300(300 \mathrm{MHz})$ spectrometer. All chemical shifts are reported on the $\delta$ scale using residual solvent as internal standard. Deuteriochloroform was used as solvent unless otherwise stated.

Carbon nuclear magnetic resonance $\left({ }^{13} \mathrm{C}\right.$ NMR $)$ spectra were recorded on a Bruker AM 250 spectrometer (at $62.9 \mathrm{MHz}$ ) using residual solvent as internal standard. Deuteriochloroform was used as solvent unless stated. For ${ }^{13} \mathrm{C}$ NMR samples in $\mathrm{D}_{2} \mathrm{O}$, dioxane was added as reference ( $\delta$ 67.6).

Infra red (IR) spectra were recorded on Perkin-Elmer 297, 310 or Pye-Unicam SP3-200 spectrophotometers. Infra red spectra of syrups were normally run as thin films, and solids as solutions in chloroform, unless stated. Routine mass spectra were recorded on a VG micromass 30F spectrometer using the desorption chemical ionisation $\left(\mathrm{DCI}, \mathrm{NH}_{3}\right.$ ) technique unless stated. Electron impact (EI), chemical ionisation (CI) and field desorption (FD) techniques are indicated when used.

Optical rotations were measured on a Perkin-E1mer 241 polarimeter. Concentrations are given in $\mathrm{g} / 100 \mathrm{~m} 1$.

Melting points were recorded on a Koffler block. Microanalyses were performed by the microanalytical services of the University of Manchester and the Dyson Perrins laboratory.

T.1.c was carried out on glass plates coated with silica gel Blend 41 (comprising of a mixture of $80 \%$ silica gel $\mathrm{HF}_{254}$ and $20 \%$ silica gel $\mathrm{G}$ ) or on aluminium sheets pre-coated with Merck silica gel $60 \mathrm{~F}_{254^{\circ}}$ Plates were developed using either: $5 \% \mathrm{w} / \mathrm{v}$ dodeca-molybdophosphoric acid in ethanol; $5 \% \mathrm{v} / \mathrm{v}$ conc 
sulphuric acid in methanol or $5 \% \mathrm{w} / \mathrm{v}$ ninhydrin in ethanol.

Flash chromatography ${ }^{59}$ was carried out using Merck Kieselgel 60, 230-400 mesh.

Dry column chromatography ${ }^{60}$ was carried out using Merck Kieselgel $60 \mathrm{H}$. Solvents were dried according to standard methods ${ }^{61}$.

Al1 evaporations were conducted under reduced pressure and drying of solutions was achieved using anhydrous sodium sulphate.

3- $\underline{0}-$ Benzyl- 1,2;5,6- di- 0 - isopropylidene- $a$ - D- glucofuranose (1.14) Diacetone glucose (1.13) (Aldrich, $26 \mathrm{~g}, 0.1 \mathrm{~mol}$ ) in dry THF (240 ml) was added dropwise with cooling and stirring to a suspension of sodium hydride ( $50 \%$ dispersion in oil, washed with hexane, $5.28 \mathrm{~g}, 1.1$ equivs) in THF (30 m1). Benzy1 bromide ( $13 \mathrm{ml}, 1.1$ equivs) and tetrabutylammonium iodide $(0.6 \mathrm{~g})$ were then added and the mixture refluxed for $45 \mathrm{~min}$. The solution was cooled, filtered through celite and concentrated to a yellow syrup $(39.5 \mathrm{~g})$ which was used directly in the hydrolysis. Purification of a small quantity of material afforded the title compound (1.14) as a clear syrup. $1_{\mathrm{H} \text { NMR }}(60 \mathrm{MHz}) \delta 7.1(5 \mathrm{H}, \mathrm{m}, \mathrm{ArH}) ; 5.6(1 \mathrm{H}, \mathrm{d}, \mathrm{H}-1) ; 4.0$ $(8 \mathrm{H}, \mathrm{m}) ; 1.4-1.2\left(12 \mathrm{H}, 4 \mathrm{~s}, \mathrm{CH}_{3} \mathrm{C}\right)$.

3- - Benzy1- 1,2- -- isopropylidene- $a$ - D- glucofuranose (1.15) The crude diacetonide (1.14) (39.5 g) was dissolved in a solution of concentrated hydrochloric acid $(1.1 \mathrm{ml})$ and water $(20 \mathrm{~m} 1)$ in methanol $(200 \mathrm{~m} 1)$ and stirred at room temperature. After $20 \mathrm{~h}, \mathrm{t} .1 . \mathrm{c}$ (ether : hexane, 2 : 1) showed no starting material $\left(R_{f} 0.9\right)$ and one product $\left(R_{f} 0.2\right)$. The solution was neutralised with ammonia solution (SG 0.88) and concentrated to a syrup 
which was dissolved in ethyl acetate $(200 \mathrm{~m} 1)$ and washed with water $(2 \mathrm{x}$ $200 \mathrm{ml})$. Evaporation of the solvent and purification by dry column chromatography (ethyl acetate : hexane) afforded the title compound (1.15) (27.3 $\mathrm{g}$, $88 \%$ from $(1.13)$ ) as a clear syrup. $[a]_{D}^{20}-50.8^{\circ}\left(\underline{c}, 1.24, \mathrm{CHCl}_{3}\right)\left(1\right.$ it $^{62}[a]_{\mathrm{D}}^{20}$ $\left.-46.4^{\circ}\left(\underline{c}, 4.98, \mathrm{CHCl}_{3}\right)\right) . v_{\max } 3500(\mathrm{br}), 1075,1020 \mathrm{~cm}^{-1} \cdot 1_{\mathrm{H} \text { NMR } \delta 7.3-7.2}$ $(5 \mathrm{H}, \mathrm{m}, \mathrm{ArH}) ; 5.95(1 \mathrm{H}, \mathrm{d}, \mathrm{H}-1) ; 4.75\left(2 \mathrm{H}, \mathrm{ABq}, \mathrm{PhCH}_{2}\right) ; 4.74(1 \mathrm{H}, \mathrm{d}, \mathrm{H}-2)$; $4.1-3.7\left(5 \mathrm{H}, \mathrm{m}, \mathrm{H}-3,4,5,6,6^{\prime}\right) ; 3.05(2 \mathrm{H}, \mathrm{br} \mathrm{s}, \mathrm{OH}) ; 1.5,1.3\left(6 \mathrm{H}, 2 \mathrm{~s}, \mathrm{CH}_{3} \mathrm{C}\right)$. 3---Benzy1- 1,2- $\underline{0}-$ isopropylidene- $a-\underline{D}-$ glucofuranose- 5,6- carbonate $(1.16)^{30}$ The diol (1.15) (5.5 g, $17.7 \mathrm{mmol})$ was dissolved in dimethyl carbonate (50 $\mathrm{m} 1$ ) and refluxed for $12 \mathrm{~h}$ with sodium methoxide $(1 \mathrm{~g}, 18.5 \mathrm{mmol})$. The solution was washed with water $(50 \mathrm{ml})$ and concentrated to a syrup which was crystal1ised spontaneously on addition of ether to give the title compound (1.16) as colourless crystals $(5.3 \mathrm{~g}, 89 \%)$. m.p $119-120^{\circ} \mathrm{C}\left(1 \mathrm{it}^{30} 119-120.5^{\circ} \mathrm{C}\right)$. $[a]_{D}^{20}-52.2^{\circ}\left(\underline{c}, 1.15, \mathrm{CHCl}_{3}\right)\left(1 \mathrm{it}^{30}[a]_{\mathrm{D}}^{20}-53.0^{\circ}\left(\underline{c}, 3.7, \mathrm{CHCl}_{3}\right)\right) \cdot v_{\max }$ $1810 \mathrm{~cm}^{-1}$. $1_{\mathrm{H} \text { NMR }} \delta 7.5-7.3(5 \mathrm{H}, \mathrm{m}, \mathrm{ArH}) ; 5.97\left(1 \mathrm{H}, \mathrm{d}, \mathrm{H}-1, \mathrm{~J}_{12} 3.6 \mathrm{~Hz}\right) ; 4.88$ $(1 \mathrm{H}, \mathrm{ddd}, \mathrm{H}-5) ; 4.64(1 \mathrm{H}, \mathrm{d}, \mathrm{H}-2) ; 4.57(1 \mathrm{H}, \mathrm{dd}, \mathrm{H}-4) ; 4.58\left(2 \mathrm{H}, \mathrm{ABq}, \mathrm{PhCH}_{2}\right)$; $4.47\left(3 \mathrm{H}, \mathrm{m}, \mathrm{H}-3,6,6^{\prime}\right) ; 1.50,1.34\left(6 \mathrm{H}, 2 \mathrm{~s}, \mathrm{CH}_{3} \mathrm{C}\right) . \underline{\mathrm{m} / \mathrm{z}}: 354\left(\mathrm{M}+\mathrm{NH}_{4}^{+}, 100 \%\right)$. In a separate experiment the carbonate was prepared directly from diacetone glucose without purification of any of the intermediates. Diacetone glucose (1.13) (52 g, $0.2 \mathrm{~mol})$ was converted into crude (1.15) as described above. The crude syrup was dissolved in dimethyl carbonate (400 m1) and refluxed for $3 \mathrm{~h}$ with sodium methoxide $(10 \mathrm{~g})$. The reflux condenser was replaced with a still head and the heating continued until the temperature of the distillate had reached $90^{\circ} \mathrm{C}$ (this was approximately $2 \mathrm{~h}$ ). It was necessary to periodically add further dimethyl carbonate to maintain the 
volume of solvent. At this time t.1.c showed complete conversion to carbonate (1.16) had been achieved and the same work up procedure described previously was employed, affording the carbonate $(54.06 \mathrm{~g}, 80 \%)$ as colourless crystals.

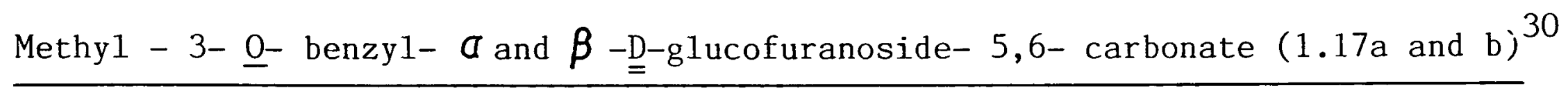

Acetonide (1.16) (8.95 g, $26.6 \mathrm{mmol})$ was dissolved in methanol (150 ml) containing acid resin (Dowex 50W- XH; $16 \mathrm{~g}$ ) and the suspension refluxed for $12 \mathrm{~h}$. The solution was filtered and concentrated to a syrup. Purification by flash chromatography (eluant ether : hexane, 1:1) gave three fractions. The first, pure $\alpha$ anomer (1.17a) (1.68 g), then a mixture of anomers $(2.18 \mathrm{~g})$ and finally pure $\beta$ anomer (1.17b) (4.3 g, total yield $8.16 \mathrm{~g}, 99 \%)$ all colourless syrups. $a$ anomer $(1.17 \mathrm{a})[a]_{\mathrm{D}}^{20}+88.6^{\circ}(\underline{c} 1.3, \mathrm{MeOH})\left(1 \mathrm{it}{ }^{30}\right.$ $\left.[a]_{\mathrm{D}}^{20}+93.3^{\circ}(\underline{c} 2.7, \mathrm{MeOH})\right) . v_{\max }: 3500(\mathrm{br}), 1805,1790 \mathrm{~cm}^{-1} \cdot{ }_{\mathrm{H}} \mathrm{NMR} \delta$ $7.5-7.3(5 \mathrm{H}, \mathrm{m}, \mathrm{ArH}) ; 5.06\left(1 \mathrm{H}, \mathrm{d}, \mathrm{H}-1, \mathrm{~J}_{12} 4.5 \mathrm{~Hz}\right) ; 4.87(1 \mathrm{H}$, ddd, H-5); $4.61\left(2 \mathrm{H}, \mathrm{ABq}, \mathrm{PhCH}_{2}\right) ; 4.58(1 \mathrm{H}, \mathrm{dd}, \mathrm{H}-4) ; 4.43\left(2 \mathrm{H}, \mathrm{m}, \mathrm{H}-6,6^{\prime}\right) ; 4.20(1 \mathrm{H}$, $\mathrm{dd}, \mathrm{H}-2) ; 4.07(1 \mathrm{H}, \mathrm{dd}, \mathrm{H}-3) ; 3.50\left(3 \mathrm{H}, \mathrm{s}, \mathrm{CH}_{3} \mathrm{O}\right) ; 2.81(1 \mathrm{H}, \mathrm{d}, \mathrm{OH}) . \underline{\mathrm{m} / \mathrm{z}}$ : $328\left(\mathrm{M}+\mathrm{NH}_{4}^{+}, 100 \%\right) \cdot \beta$ anomer $(1.17 \mathrm{~b})[a]_{\mathrm{D}}^{20}-40.1^{\circ}$ (c 3.4, MeOH) (1it ${ }^{30}$ $\left.-61^{\circ}(\underline{c} 3.3, \mathrm{MeOH})\right) .1_{\mathrm{H}} \operatorname{NMR} \delta 7.5-7.3(5 \mathrm{H}, \mathrm{m}, \mathrm{ArH}) ; 4.93(1 \mathrm{H}, \mathrm{s}, \mathrm{H}-1)$; $4.82(1 \mathrm{H}, \mathrm{ddd}, \mathrm{H}-5) ; 4.75(1 \mathrm{H}, \mathrm{d}, \mathrm{H}-3) ; 4.69(1 \mathrm{H}, \mathrm{d}, \mathrm{H}-4) ; 4.52(2 \mathrm{H}, \mathrm{ABq}$, $\left.\mathrm{PhCH}_{2}\right) ; 4.32\left(2 \mathrm{H}, \mathrm{m}, \mathrm{H}-6,6^{\prime}\right) ; 4.00(1 \mathrm{H}, \mathrm{d}, \mathrm{H}-2) ; 3.41\left(3 \mathrm{H}, \mathrm{s}, \mathrm{CH}_{3} \mathrm{O}\right) ; 3.25$ $(1 \mathrm{H}$, br $\mathrm{s}, \mathrm{OH}) . \underline{\mathrm{m} / \mathrm{z}}: 328\left(\mathrm{M}+\mathrm{NH}_{4}^{+}, 100 \%\right)$.

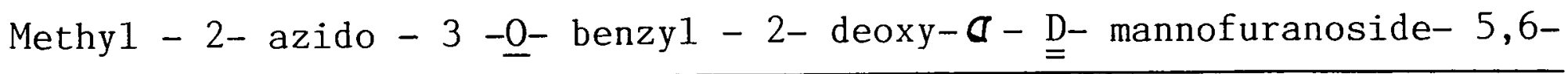
carbonate $(1.19 a)$

Trifluoromethanesulphonic anhydride $(2.06 \mathrm{ml}, 1.2$ equivs) was added dropwise 
with stirring at $-30^{\circ} \mathrm{C}$ under an atmosphere of nitrogen to a solution of the pure $a$ anomer (1.17a) (3.16 g, $10.2 \mathrm{mmol})$ in dry dichloromethane (20 ml) containing pyridine $(1.65 \mathrm{ml}, 2$ equivs). After $15 \mathrm{~min}$ the solution was washed with water $(2 \times 20 \mathrm{ml})$ and saturated aqueous sodium bicarbonate solution $(20 \mathrm{ml})$ and concentrated to a pale yellow syrup, methy1- 3- 0 - benzyl- 2-

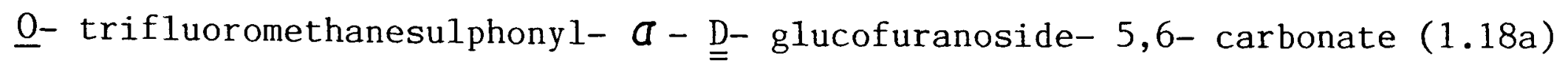
Purification of a small quantity by flash chromatography (ether : hexane, 2 : 1) afforded the triflate $(1.18 \mathrm{a})$ as a colourless syrup. $[a]_{D}^{20}+70.5^{\circ}$ $\left(\underline{c}, 0.24, \mathrm{CHCl}_{3}\right) \cdot v_{\max } 1805 \mathrm{~cm}^{-1} \cdot{ }^{1} \mathrm{H} \operatorname{NMR} \delta 7.4-7.2(5 \mathrm{H}, \mathrm{m}, \operatorname{ArH}) ; 5.19(1 \mathrm{H}$, $\left.\mathrm{d}, \mathrm{H}-1, \mathrm{~J}_{12} 4.3 \mathrm{~Hz}\right) ; 5.02(1 \mathrm{H}, \mathrm{t}, \mathrm{H}-2) ; 4.86(1 \mathrm{H}, \mathrm{ddd}, \mathrm{H}-5) ; 4.56(1 \mathrm{H}, \mathrm{dd}, \mathrm{H}-4)$; $4.57\left(2 \mathrm{H}, \mathrm{ABq}, \mathrm{PhCH}_{2}\right) ; 4.46\left(3 \mathrm{H}, \mathrm{m}, \mathrm{H}-3,6,6^{\prime}\right) ; 3.46\left(3 \mathrm{H}, \mathrm{s}, \mathrm{CH}_{3} \mathrm{O}\right) . \mathrm{m} / \mathrm{z}:$ $460\left(\mathrm{M}+\mathrm{NH}_{4}^{+}, 100 \%\right)$.

The crude syrup was dissolved in dry DMF $(20 \mathrm{ml})$ and stirred at $50^{\circ} \mathrm{C}$ for $24 \mathrm{~h}$ with sodium azide $(2.2 \mathrm{~g}, 3$ equivs) when $t .1 . c$ (ether : hexane, $3: 1$ ) showed no triflate $\left(R_{f} 0.5\right)$ and one product $\left(R_{f} 0.4\right)$. The solvent was removed and the resulting syrup dissolved in chloroform $(50 \mathrm{ml})$. The chloroform was washed with water $(3 \times 50 \mathrm{ml})$, dried and evaporated to give a pale yellow syrup which was purified by flash chromatography (ether : hexane, 2 : 1), affording pure azide $(1.19 \mathrm{a})(3.02 \mathrm{~g}, 88 \%)$ as a colourless syrup. $[\sigma]_{D}^{20}$ $+56.2^{\circ}\left(\underline{c} 0.49, \mathrm{CHCl}_{3}\right) \cdot v_{\max } 2110,1800 \mathrm{~cm}^{-1} \cdot{ }^{1} \mathrm{H} \mathrm{NMR} \delta 7.41-7.31(5 \mathrm{H}, \mathrm{m}$, $\mathrm{ArH}) ; 4.97\left(1 \mathrm{H}, \mathrm{d}, \mathrm{H}-1, \mathrm{~J}_{12} 1.5 \mathrm{~Hz}\right) ; 4.86(1 \mathrm{H}, \mathrm{ddd}, \mathrm{H}-5) ; 4.75-4.37(6 \mathrm{H}, \mathrm{m}$, $\left.\mathrm{PhCH}_{2}, \mathrm{H}-3,4,6,6^{\prime}\right) ; 3.94(1 \mathrm{H}, \mathrm{dd}, \mathrm{H}-2) ; 3.36\left(3 \mathrm{H}, \mathrm{s}, \mathrm{CH}_{3} \mathrm{O}\right) . \underline{\mathrm{m} / \mathrm{z}}(\mathrm{FD}):$ $336\left(\mathrm{M}+\mathrm{H}^{+}\right) ; 307\left(\mathrm{M}^{+}-\mathrm{N}_{2}\right)$. Found $\mathrm{C}, 53.5 ; \mathrm{H}, 5.15 ; \mathrm{N}, 12.2 \cdot \mathrm{C}_{15^{\mathrm{H}}} 17^{\mathrm{N}} \mathrm{O}_{6}$ requires $\mathrm{C}, 53.7 ; \mathrm{H}, 5.1 ; \mathrm{N}, 12.5$.

Methy1-2- azido- 3- $\underline{0}-$ benzyl- 2- deoxy- $\boldsymbol{\alpha}-\underline{\underline{D}}-$ mannofuranoside (1.11) Azido carbonate $(1.19 \mathrm{a})(3 \mathrm{~g}, 9.0 \mathrm{mmol})$ was dissolved in methanol $(15 \mathrm{ml})$ 
containing a trace of sodium methoxide and the solution left at room temperature for $6 \mathrm{~h}$. The solvent was removed and the resulting crude syrup partitioned between chloroform $(50 \mathrm{ml})$ and water $(50 \mathrm{~m} 1)$. The chloroform layer was dried and evaporated to a crude solid which was purified by flash chromatography (ether : hexane, $4: 1)$ to afford the diol (1.11) (2.23 g, $80 \%$ ) as colourless crystals. m.p 88-90 (from ethyl acetate /hexane). $[a]_{\mathrm{D}}^{20}+69.6^{\circ}(\underline{c} 0.79, \mathrm{MeOH}) . v_{\max } 2100 \mathrm{~cm}^{-1} \cdot{ }^{1} \mathrm{H} \mathrm{NMR} 7.43-7.35$ (5H, m, ArH); $4.94\left(1 \mathrm{H}, \mathrm{d}, \mathrm{H}-1, \mathrm{~J}_{12} 1.6 \mathrm{~Hz}\right) ; 4.70\left(2 \mathrm{H}, \mathrm{ABq}, \mathrm{PhCH}_{2}\right) ; 4.55(1 \mathrm{H}, \mathrm{t}, \mathrm{H}-3) ; 4.07$ $(2 \mathrm{H}, \mathrm{m}, \mathrm{H}-4,5) ; 3.84(1 \mathrm{H}, \mathrm{dd}, \mathrm{H}-2) ; 3.76\left(2 \mathrm{H}, \mathrm{m}, \mathrm{H}-6,6^{\prime}\right) ; 3.36(3 \mathrm{H}, \mathrm{s}$, $\left.\mathrm{CH}_{3} \mathrm{O}\right) ; 3.00\left(1 \mathrm{H}\right.$, br d, OH); $2.17(1 \mathrm{H}$, br s, OH $) . \underline{\mathrm{m} / \mathrm{z}}(\mathrm{FD}): 310\left(\mathrm{M}+\mathrm{H}^{+}\right)$. Found $\mathrm{C}, 53.9 ; \mathrm{H}, 5.9 ; \mathrm{N}, 13.1 . \mathrm{C}_{14} \mathrm{H}_{19} \mathrm{~N}_{3} \mathrm{O}_{5}$ requires $\mathrm{C}, 54.4 ; \mathrm{H}, 6.15 ; \mathrm{N}, 13.6$.

\section{Tetrabutylammonium azide}

A solution of tetrabutylammonium hydroxide $(0.04 \mathrm{~mol})$ in water $(20 \mathrm{~m} 1)$ was treated with sodium azide $(5.2 \mathrm{~g}, 0.08 \mathrm{~mol})$ in water $(10 \mathrm{~m} 1)$ and the title compound extracted twice with dichloromethane $(20 \mathrm{~m} 1)$. Evaporation and co-distillation with toluene afforded the azide $(8.5 \mathrm{~g})$ as a highly hygroscopic solid which must be stored in a desiccator.

Methy1- 2- azido- 3- $\underline{0}-$ benzy1- $2-$ deoxy $-\beta-\underline{\text { D- mannofuranoside- }}$

5,6 - carbonate $(1.19 b)$.

Methyl 3- $\underline{0}-$ benzy1- 2- $\underline{0}-$ trifluoromethanesulphonyl- $\beta$ - $\underline{\underline{D}}-$ glucofuranoside 5,6 - carbonate (1.18b) was prepared by an identical procedure to that for making the $a$ triflate $(1.18 \mathrm{a}) . v_{\max } 1705 \mathrm{~cm}^{-1} \cdot 1_{\mathrm{H}} \mathrm{NMR} \delta 7.4-7.2(5 \mathrm{H}, \mathrm{m}$, $\mathrm{ArH}) ; 5.09(2 \mathrm{H}, \mathrm{s}, \mathrm{H}-1,2) ; 4.75(1 \mathrm{H}, \mathrm{ddd}, \mathrm{H}-5) ; 4.52\left(2 \mathrm{H}, \mathrm{ABq}, \mathrm{PhCH}_{2}\right)$; $4.57(1 \mathrm{H}, \mathrm{dd}, \mathrm{H}-4) ; 4.35\left(2 \mathrm{H}, \mathrm{m}, \mathrm{H}-6,6^{\prime}\right) ; 4.21(1 \mathrm{H}, \mathrm{d}, \mathrm{H}-3) ; 3.41(3 \mathrm{H}, \mathrm{s}$, $\left.\mathrm{CH}_{3} \mathrm{O}\right) .{ }^{13} \mathrm{C}$ NMR $\delta 56.50\left(q, \mathrm{CH}_{3} \mathrm{O}\right) ; 66.25\left(\mathrm{t}, \mathrm{PhCH}_{2}\right) ; 72.88(\mathrm{t}, \mathrm{C}-6) ; 74.65$ (d), $80.20(\mathrm{~d}, \mathrm{C}-3,4) ; 81.92(\mathrm{~d}, \mathrm{C}-5) ; 88.70(\mathrm{~d}, \mathrm{C}-2) ; 107.11(\mathrm{~d}, \mathrm{C}-1)$; 
$119\left(\mathrm{q}, \mathrm{CF}_{3}\right) ; 128.05,128.76,128.84,135.63(\mathrm{ArC}) ; 155\left(\underline{\mathrm{CO}}_{3}\right) \cdot \underline{\mathrm{m} / \mathrm{z}}: 460$ $\left(\mathrm{M}+\mathrm{NH}_{4}^{+}\right)$.

The $\beta$ triflate $(1.18 \mathrm{~b})(0.13 \mathrm{~g}, 0.268 \mathrm{mmol})$ was dissolved in DMF $(5 \mathrm{ml})$ and stirred at room temperature with tetrabutylammonium azide $(0.21 \mathrm{~g}$, excess $)$. After $10 \mathrm{~d}$ two major products were observed on t.1.c (ether : hexane, $1: 1$, $\mathrm{R}_{\mathrm{f}} 0.4$ and 0.3 ) and the DMF was removed. Purification by flash chromatography (ether : hexane, $1: 1)$ gave unreacted triflate (1.18b) (51 mg) together with a small amount of the title compound (1.19b) (38 $\mathrm{mg}, 42 \%)$ as a syrup and other minor impurities which were not easily separated. $V_{\max } 2110,1805 \mathrm{~cm}^{-1}$ $1_{\mathrm{H} \operatorname{NMR}} \delta 7.4-7.3(5 \mathrm{H}, \mathrm{m}, \mathrm{ArH}) ; 4.96\left(1 \mathrm{H}, \mathrm{d}, \mathrm{H}-1, \mathrm{~J}_{12} 1.5 \mathrm{~Hz}\right) ; 4.84(1 \mathrm{H}$, ddd, $\mathrm{H}-5) ; 4.68(1 \mathrm{H}, \mathrm{dd}, \mathrm{H}-6) ; 4.61\left(2 \mathrm{H}, \mathrm{ABq}, \mathrm{PhCH}_{2}\right) ; 4.48(2 \mathrm{H}, \mathrm{m}, \mathrm{H}-3,4) ; 4.40$ $\left(1 \mathrm{H}, \mathrm{t}, \mathrm{H}-6^{\prime}\right) ; 3.94\left(1 \mathrm{H}, \mathrm{dd}, \mathrm{H}-2, \mathrm{~J}_{23} 5.0 \mathrm{~Hz}\right) ; 3.36\left(3 \mathrm{H}, \mathrm{s}, \mathrm{CH}_{3} \mathrm{O}\right) . \mathrm{m} / \mathrm{z}:$ $336\left(\mathrm{M}+\mathrm{H}^{+}\right)$.

3- $\underline{\theta}-$ benzyl- D- glucurono- 1,4- lactone- 5,6- carbonate (1.20) Acetonide (1.16) (2 g, $5.96 \mathrm{mmol})$ was dissolved in trifluoroacetic acid : water $(3: 2)(10 \mathrm{ml})$ and heated at $50^{\circ} \mathrm{C}$ for $1 \mathrm{~h}$. The solvent was evaporated and the residue dissolved in dioxane : water ( 2 : 1$)$ (18 $\mathrm{m} 1)$. The solution was cooled to $0^{\circ} \mathrm{C}$ and barium carbonate $(3.4 \mathrm{~g}, 3$ equivs) added. Bromine (0.46 ml, 1.5 equivs) was added dropwise, with stirring, in the dark and the solution was stirred at room temperature for $12 \mathrm{~h}$. Excess bromine was destroyed by dropwise addition of aqueous sodium thiosulphate solution (1 M) and the sulphur removed by centrifugation. The clear solution was diluted with ethyl acetate $(30 \mathrm{~m} 1)$ and the phases separated. The aqueous phase was extracted with ethyl acetate $(2 \times 20 \mathrm{~m} 1)$. The organic extracts were combined dried and evaporated to a syrup which was purified by flash chromatography (ether : hexane, $4: 1$ ) to afford the highly crystalline title compound 
(1.20) $(0.98 \mathrm{~g}, 56 \%)$ m.p $133-134^{\circ} \mathrm{C} . \quad[a]_{\mathrm{D}}^{20}+28.5^{\circ}$ (c 0.53 , EtOAc).

$v_{\max }\left(\right.$ nujol) $3300(\mathrm{br}), 1810,1780.1_{\mathrm{H}} \operatorname{NMR} \delta 7.4-7.3(5 \mathrm{H}, \mathrm{m}, \operatorname{ArH}) ; 5.02$ $(1 \mathrm{H}, \mathrm{m}, \mathrm{H}-5) ; 4.86\left(1 \mathrm{H}, \mathrm{dd}, \mathrm{H}-3, \mathrm{~J}_{23} 6.4 \mathrm{~Hz}, \mathrm{~J}_{34} 3.1 \mathrm{~Hz}\right) ; 4.69\left(2 \mathrm{H}, \mathrm{ABq}, \mathrm{PhCH}_{2}\right)$; $4.59(1 \mathrm{H}, \mathrm{m}, \mathrm{H}-4) ; 4.51(1 \mathrm{H}, \mathrm{t}, \mathrm{H}-6) ; 4.43\left(1 \mathrm{H}, \mathrm{dd}, \mathrm{H}-6^{\prime}\right) ; 4.43(1 \mathrm{H}, \mathrm{d}, \mathrm{H}-2)$; $3.50(1 \mathrm{H}$, br $\mathrm{s}, \mathrm{OH}) .{ }^{13} \mathrm{C} \mathrm{NMR} 65.37\left(\mathrm{t}, \mathrm{PhCH}_{2}\right) ; 70.90(\mathrm{~d}, \mathrm{C}-5) ; 71.75(\mathrm{t}$, C-6); 74.99, 78.25, 80.19 (3d, C-2, 3, 4); 127.74, 127.95, 128.51, 137.39 $(\mathrm{ArC}) ; 154.42(\mathrm{~s}, \mathrm{C}-1) ; 174.23\left(\mathrm{~s}, \underline{\mathrm{CO}}_{3}\right) \cdot \underline{\mathrm{m} / \mathrm{z}}: 312\left(\mathrm{M}+\mathrm{NH}_{4}^{+}, 100 \%\right)$. Found $\mathrm{C}, 56.92 ; \mathrm{H}, 4.84 . \mathrm{C}_{14} \mathrm{H}_{14} \mathrm{O}_{7}$ requires $\mathrm{C}, 57.14 ; \mathrm{H}, 4.76$.

Methy1- 2- azido- 3- $\underline{0}-$ benzyl- 2- deoxy- 6- $\underline{0}-\underline{p}$ toluenesulphony1- $\alpha-\underline{D}-$ mannofuranoside (1.21)

Azido diol (1.11) (4.20 g, $13.6 \mathrm{mmol})$ was dissolved in dry pyridine (50 m1) and stirred at $0^{\circ} \mathrm{C}$ with freshly recrystallised $\mathrm{p}$ toluenesulphony 1 chloride (2.84 $\mathrm{g}, 1.1$ equivs) for $12 \mathrm{~h}$. The solution was concentrated, diluted with dichloromethane $(100 \mathrm{ml})$ and washed successively with hydrochloric acid (2M aq, $100 \mathrm{~m} 1)$, water $(100 \mathrm{~m} 1)$ and saturated aqueous sodium bicarbonate solution $(100 \mathrm{~m} 1)$. The dichloromethane was then dried and evaporated to give a colourless syrup which was purified by flash chromatography (ether : hexane, $1: 1)$ affording the title compound $(1.21)(5.95 \mathrm{~g}, 95 \%)$ as a colourless syrup. $[a]_{D}^{20}+21.6^{\circ}\left(\underline{c} 0.76, \mathrm{CHCl}_{3}\right) \cdot v_{\max } 3550(\mathrm{br}), 2110$,

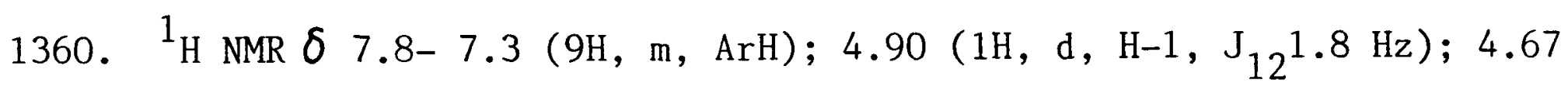
$\left(2 \mathrm{H}, \mathrm{ABq}, \mathrm{PhCH}_{2}\right) ; 4.51(1 \mathrm{H}, \mathrm{t}, \mathrm{H}-3) ; 4.27(1 \mathrm{H}, \mathrm{m}, \mathrm{H}-5) ; 4.16(2 \mathrm{H}, \mathrm{m}, \mathrm{H}-6$, $\left.6^{\prime}\right) ; 4.06(1 \mathrm{H}, \mathrm{dd}, \mathrm{H}-4) ; 3.80(1 \mathrm{H}, \mathrm{dd}, \mathrm{H}-2) ; 3.32\left(3 \mathrm{H}, \mathrm{s}, \mathrm{CH}_{3} \mathrm{O}\right) ; 2.88(1 \mathrm{H}$, br d, OH $) ; 2.44\left(3 \mathrm{H}, \mathrm{s}, \mathrm{CH}_{3} \mathrm{Ar}\right) . \underline{\mathrm{m} / \mathrm{z}}(\mathrm{FD}): 464\left(\mathrm{M}+\mathrm{H}^{+}\right)$. 
Methyl (N- benzyloxycarbony1-3- $\underline{0}-$ benzy1-2,6-dideoxy-2,6- imino) $a-$

D- mannofuranoside $(1.10 \mathrm{a})$

Azido tosylate $(1.21)(3.5 \mathrm{~g}, 7.6 \mathrm{mmol})$ was dissolved in ethanol (25 $\mathrm{ml})$ and stirred under hydrogen with palladium black $(0.2 \mathrm{~g})$ at atmospheric pressure and room temperature. After $12 \mathrm{~h}$ the solution was filtered and sodium acetate $(0.1 \mathrm{~g})$ added. The mixture was then heated at $50^{\circ} \mathrm{C}$ under nitrogen for a further $12 \mathrm{~h}$ to accomplish the cyclisation. Evaporation of the solvent and extraction into chloroform gave an off white solid, the free amine (1.22) which was not purified $\left({ }^{1} \mathrm{H}\right.$ NMR $\delta 7.8-7.3$ (5H, m, ArH); $4.99(1 \mathrm{H}, \mathrm{s}, \mathrm{H}-1) ; 4.60\left(2 \mathrm{H}, \mathrm{s}, \mathrm{PhCH}_{2}\right) ; 4.35-4.22(4 \mathrm{H}, \mathrm{m}, \mathrm{H}-3,5, \mathrm{OH}, \mathrm{NH})$; $3.91(1 \mathrm{H}, \mathrm{dd}, \mathrm{H}-4) ; 3.41\left(3 \mathrm{H}, \mathrm{s}, \mathrm{CH}_{3} \mathrm{O}\right) ; 3.18\left(2 \mathrm{H}, \mathrm{m}, \mathrm{H}-2,6^{\prime}\right) ; 2.58(1 \mathrm{H}$, dd, H-6), but dissolved in ether : saturated aqueous sodium bicarbonate solution $(5: 2)(35 \mathrm{~m} 1)$ and treated with benzyl chloroformate $(1.6 \mathrm{~m} 1$, 1.5 equivs) and vigorously stirred at room temperature for $2 \mathrm{~h}$ to ensure mixing of the two phases. The layers were then separated and the aqueous layer washed with ether $(2 \times 20 \mathrm{ml})$. The organic extracts were combined, dried and evaporated to a syrup. Purification by flash chromatography (ethyl acetate : hexane, $1: 3$ ) afforded the title compound (1.10a) $(1.95 \mathrm{~g}, 65 \%)$ as a colourless syrup. $[a]_{\mathrm{D}}^{20}+22.6^{\circ}\left(\underline{c} 0.46, \mathrm{CHCl}_{3}\right)$. $v_{\max } 3450(\mathrm{br}), 1685 \mathrm{~cm}^{-1} \cdot 1_{\mathrm{H}} \operatorname{NMR} \delta 7.4-7.2(10 \mathrm{H}, \mathrm{m}, \mathrm{ArH}) ; 5.11(2 \mathrm{H}, \mathrm{d}$, $\left.\mathrm{PhCH}_{2}\right) ; 4.98(1 \mathrm{H}, \mathrm{s}, \mathrm{H}-1) ; 4.77-4.08(7 \mathrm{H}, \mathrm{m}) ; 3.41\left(3 \mathrm{H}, \mathrm{d}, \mathrm{CH}_{3} 0\right) ; 2.85$ $(1 \mathrm{H}, \mathrm{m}, \mathrm{H}-6) ; 2.00(1 \mathrm{H}$, br s, OH $) . \underline{\mathrm{m} / \mathrm{z}}: 400\left(\mathrm{M}+\mathrm{H}^{+}\right), 356,204,91(100 \%)$. Found $\mathrm{C}, 65.9 ; \mathrm{H}, 6.6 ; \mathrm{N}, 3.6 . \mathrm{C}_{22} \mathrm{H}_{25} \mathrm{NO}_{6}$ requires $\mathrm{C}, 66.2 ; \mathrm{H}, 6.3 ; \mathrm{N}, 3.5$. 
Methy1 (N- -butyloxycarbony1- 3- -- benzy1- 2,6- dideoxy- 2,6- imino )- $a-$

$\underline{\underline{D}-\text { mannofuranoside }(1.10 \mathrm{~b})}$

Azido tosylate $(1.21)(3 \mathrm{~g}, 6.5 \mathrm{mmol})$ was reduced and cyclised exactly as described above. The crude amine was dissolved in pyridine $(15 \mathrm{ml})$ and treated with di-tert-butyl-dicarbonate ( $1.6 \mathrm{~g}, 1.1$ equivs) at room temperature. After $30 \mathrm{~min}$ the pyridine was removed and the resulting syrup was purified by flash chromatography (ethyl acetate : hexane, $1: 2$ ) to yield the title compound (1.10b) (1.81 g, 76\%) as a colourless syrup which crystallised. m.p $103^{\circ} \mathrm{C} . \quad[\mathrm{a}]_{\mathrm{D}}^{20}+17.7^{\circ}\left(\underline{c}, 0.38, \mathrm{CHCl}_{3}\right) \cdot v_{\max } 3430$ (br), 1685, 1420,

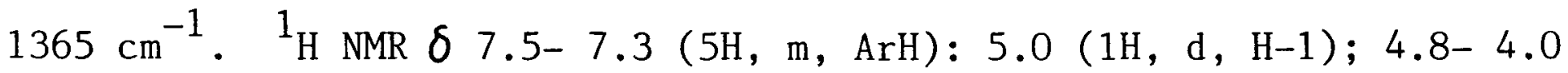
$(7 \mathrm{H}, \mathrm{m}) ; 3.4\left(3 \mathrm{H}, \mathrm{s}, \mathrm{CH}_{3} \mathrm{O}\right) ; 2.9(1 \mathrm{H}, \mathrm{m}, \mathrm{H}-6) ; 2.0(1 \mathrm{H}, \mathrm{br} \mathrm{s}, \mathrm{OH}) ; 1.4,1.35$ $(9 \mathrm{H}, \mathrm{d}, \mathrm{tBu}) . \underline{\mathrm{m} / \mathrm{z}}: 383\left(\mathrm{M}+\mathrm{NH}_{4}^{+}\right) ; 366\left(\mathrm{M}+\mathrm{H}^{+}\right), 327\left(\mathrm{M}+\mathrm{NH}_{4}^{+}\right.$- butene, $100 \%$ ). Found $\mathrm{C}, 62.7 ; \mathrm{H}, 7.7 ; \mathrm{N}, 3.6 . \mathrm{C}_{19} \mathrm{H}_{27} \mathrm{NO}_{6}$ requires $\mathrm{C}, 62.5 ; \mathrm{H}, 7.4$; $\mathrm{N}, 3.8$.

N- benzyloxycarbony1- 4- $\underline{0}-$ benzy1- 1,5- dideoxy- 1,5- imino- D- mannitol (1.23)

Bicyclic acetal (1.10a) (98 mg, $0.25 \mathrm{mmol}$ ) was dissolved in $50 \%$ aqueous trifluoroacetic acid and stirred at room temperature for $10 \mathrm{~min}$. The solvent was removed and the resulting syrup dissolved in ethanol $(2 \mathrm{~m} 1)$. A solution of sodium borohydride $(20 \mathrm{mg}, 0.5 \mathrm{mmol})$ in water $(0.5 \mathrm{ml})$ was added, with stirring, at $0^{\circ} \mathrm{C}$ and the mixture was slowly allowed to warm to room temperature over $30 \mathrm{~min}$. The unreacted sodium borohydride was destroyed by the addition of excess ammonium chloride and the solvent removed. The solid residue was suspended in chloroform $(10 \mathrm{~m} 1)$, filtered and the chloroform was dried and evaporated to a syrup which was purified by flash chromatography ( $5 \%$ methanol in chloroform) to afford the title compound (1.23) 
$(77 \mathrm{mg}, 81 \%) . \mathrm{m} \cdot \mathrm{p} 138-140^{\circ} \mathrm{C} .[a]_{\mathrm{D}}^{20}-22.3^{\circ}$ (c, $\left.0.3, \mathrm{MeOH}\right) . v_{\max } 3300,1675 \mathrm{~cm}^{-1}$. ${ }^{1} \mathrm{H} \mathrm{NMR} \delta 7.4-7.3(10 \mathrm{H}, \mathrm{m}, \mathrm{ArH}) ; 5.2-3.8(9 \mathrm{H}, \mathrm{m}) ; 3.3-3.2(3 \mathrm{H}, \mathrm{m}, \mathrm{H}-1,4$, $\left.4^{\prime}\right) ; 2.9(3 \mathrm{H}$, br s, OH $) . \underline{\mathrm{m} / \mathrm{z}}: 297\left(\mathrm{M}+\mathrm{NH}_{4}^{+}-\mathrm{PhCH}_{2} \mathrm{OH}\right) ; 280\left(\mathrm{M}+\mathrm{H}^{+}-\mathrm{PhCH}_{2} \mathrm{OH}\right.$, $100 \%$ ). Analysis - decomposed to a mixture with the oxazolidine.

Deoxymannojirimycin [1,5- dideoxy- 1,5- imino- D- mannitol] (1.1)

Protected mannitol (1.23) (66 mg, $0.17 \mathrm{mmol}$ ) was dissolved in ethanol ( $1 \mathrm{~m} 1$ ) and hydrogenated with $10 \%$ palladium hydroxide on charcoal catalyst (10 mg). The $\mathrm{Z}$ group was removed in a few minutes, but the removal of the benzyl ether was only complete after $36 \mathrm{~h}$. The catalyst was filtered and the solvent removed to give a brown syrup which was purified by ion exchange chromatography (procedure 1 below) to afford the title compound (1.1) as an amorphous solid. $(19 \mathrm{mg}, 68 \%) . \quad \mathrm{m} \cdot \mathrm{p} 185-187^{\circ} \mathrm{C} . \quad\left(1 \mathrm{it}{ }^{23} 186^{\circ} \mathrm{C}\right) \cdot[\mathrm{a}]_{\mathrm{D}}^{20}-27.1^{\circ}\left(\underline{c}, 0.14, \mathrm{H}_{2} \mathrm{O}\right)$ $\left(1 \mathrm{it}^{23}[\mathrm{a}]_{\mathrm{D}}^{20}-34.0^{\circ}(\underline{c}, 0.3, \mathrm{MeOH})\right) .1_{\mathrm{H} \text { NMR }}\left(\mathrm{D}_{2} \mathrm{O}\right) \delta$ a) free base $: 3.81(1 \mathrm{H}$, $\mathrm{m}, \mathrm{H}-2) ; 3.58\left(2 \mathrm{H}, \mathrm{d}, \mathrm{H}-6,6^{\prime}\right) ; 3.39(2 \mathrm{H}, \mathrm{m}, \mathrm{H}-3,4) ; 2.81\left(1 \mathrm{H}, \mathrm{dd}, \mathrm{H}-1, \mathrm{~J}_{11}\right.$ ' $\left.14.4 \mathrm{~Hz}, \mathrm{~J}_{12} 2.6 \mathrm{~Hz}\right) ; 2.57\left(1 \mathrm{H}, \mathrm{dd}, \mathrm{H}-1^{\prime}, \mathrm{J}_{1}{ }^{\prime} 1.4 \mathrm{~Hz}\right) ; 2.29(1 \mathrm{H}, \mathrm{m}, \mathrm{H}-5)$. b) hydrochloride salt : $3.97(1 \mathrm{H}, \mathrm{m}, \mathrm{H}-2) ; 3.72\left(1 \mathrm{H}, \mathrm{dd}, \mathrm{H}-6, \mathrm{~J}_{66}, 12.3 \mathrm{~Hz}, \mathrm{~J}_{56}\right.$ $3.2 \mathrm{~Hz}) ; 3.62\left(1 \mathrm{H}, \mathrm{dd}, \mathrm{H}-6^{\prime}\right) ; 3.58(1 \mathrm{H}, \mathrm{t}, \mathrm{H}-4) ; 3.45\left(1 \mathrm{H}, \mathrm{dd}, \mathrm{H}-3, \mathrm{~J}_{34} 9.5 \mathrm{~Hz}\right.$, $\left.\mathrm{J}_{23} 3.0 \mathrm{~Hz}\right) ; 3.07\left(1 \mathrm{H}, \mathrm{dd}, \mathrm{H}-1, \mathrm{~J}_{11}, 13.9 \mathrm{~Hz}, \mathrm{~J}_{12} 2.9 \mathrm{~Hz}\right) ; 2.87\left(1 \mathrm{H}, \mathrm{dd}, \mathrm{H}-1\right.$ ', J ${ }_{1}^{\prime} 2$ $1.3 \mathrm{~Hz}) ; 2.72(1 \mathrm{H}, \mathrm{m}, \mathrm{H}-5) . \underline{\mathrm{m} / \mathrm{z}}: 164\left(\mathrm{M}+\mathrm{H}^{+}, 100 \%\right), 132\left(\mathrm{M}+\mathrm{H}^{+}-\mathrm{MeOH}\right) ; 110$.

General Procedures For Ion Exchange Chromatography. Acid resins : Sigma CG 120 (fine mesh) $\mathrm{Na}^{+}$form Aldrich 50X 8-100

Basic resin : Sigma CG $400 \mathrm{Cl}^{-}$form 


\section{i) Preparation of resins}

Acidic resins were supplied in the sodium form and were used in the $\mathrm{H}^{+}$form.

The resin was converted into the $\mathrm{H}^{+}$form by suspending in hydrochloric acid (2M, aq) for at least $1 \mathrm{~h}$ before use.

Basic resins were supplied in the chloride form and used in the $\mathrm{OH}^{-}$form. The resin was converted into the $\mathrm{OH}^{-}$form by suspending in sodium hydroxide solution (2M, aq) for at least $1 \mathrm{~h}$ before use.

\section{ii) Preparation of columns}

The amount of resin used depended on the scale of the purification. Generally a pasteur pipette containing $5 \mathrm{~cm}$ depth of resin was sufficient resin for up to $0.5 \mathrm{~g}$.

The resin was transferred to the column as a slurry in either hydrochloric acid or sodium hydroxide solution. The column was then thoroughly washed with distilled water until the eluant was neutral (as judged by universal indicator paper). The column was then ready for use.

\section{iii) Running the column}

a) With Acid resin (general procedure 1).

The compound to be purified was dissolved in distilled water and loaded onto the resin surface carefully so that disturbance was minimal. The column was then washed with at least three column volumes of distilled water, to ensure that all unwanted inorganics were removed. The compound binds to the resin and the $\mathrm{pH}$ of the initial fractions obtained from the column was acidic. The eluant was then changed to aqueous ammonia solution. Generally $0.5 \mathrm{M}$ solution was sufficient to displace any amine, but occasionally stronger solutions were required. For amino acids, the eluant used was aqueous pyridine (generally $1 \mathrm{M}$ solution) as strong ammonia solutions can cause some racemisation. Fractions were usually of about $3-5 \mathrm{ml}$. 
The fractions containing the desired material were freeze dried as the amines became discoloured very easily when warmed. Occasionally decolourising charcoal was needed to remove impurities. The purified amines were most easily stored as their hydrochloride salts.

ii) With Basic Resin (general procedure 2)

Generally the basic resin afforded a clean way of producing the free base, from a salt contaminated with inorganics. It was also a good way of removing many coloured impurities which were not absorbed by the acidic columns.

The compound was loaded in the same way as in procedure 1, but this time the compound did not bind to the resin and was collected immediately in the first fractions.

Methy1 (N- benzyloxycarbony1- 3- $\underline{0}-$ benzyl- 2,6- dideoxy- 2,6- imino- 5- $\underline{0}-$

(phenyloxy)thiocarbony 1$) a-\underline{\underline{D}}$ - mannofuranoside (1.25)

The alcohol (1.10a) (0.27 g, $0.68 \mathrm{mmol})$ and 4-dimethylaminopyridine (0.22 $\mathrm{g}$, 4. equivs) were dissolved in dry acetonitrile $(3 \mathrm{ml})$, and stirred at room temperature, under nitrogen, with phenyl chlorothionocarbonate $(0.08 \mathrm{ml}$, 1.2 equivs) for $24 \mathrm{~h}$. The solution was washed with water $(5 \mathrm{~m} 1)$, dried and evaporated to a syrup which was purified by flash chromatography (ether : hexane, $1: 3)$ to afford the title compound (1.25) (0.34 $\mathrm{g}, 91 \%)$ as a syrup. $[a]_{\mathrm{D}}^{20}+34.7^{\circ}\left(\underline{c}, 0.57, \mathrm{CHCl}_{3}\right) \cdot v_{\max } 1700 \mathrm{~cm}^{-1} \cdot 1_{\mathrm{H} \mathrm{NMR}} \delta 7.4-7.1(15 \mathrm{H}, \mathrm{m}$, $\mathrm{ArH}) ; 5.68(1 \mathrm{H}, \mathrm{m}, \mathrm{H}-5) ; 5.08(1 \mathrm{H}, \mathrm{s}, \mathrm{H}-1) ; 5.20-4.30(8 \mathrm{H}, \mathrm{m}) ; 3.43(3 \mathrm{H}$, d, $\left.\mathrm{CH}_{3} \mathrm{O}\right) ; 3.23\left(1 \mathrm{H}, \mathrm{m}, \mathrm{H}-6^{\prime}\right)$. $\underline{\mathrm{m} / \mathrm{z}}: 536\left(\mathrm{M}+\mathrm{H}^{+}\right) ; 91(100 \%)$. 
Methyl (N- benzyloxycarbony $1-3-\underline{0}-$ benzyl- 2,5,6- trideoxy- 2,6- imino)

$a-\underline{\underline{D}}-$ mannofuranoside $(1.24)$

i) Barton deoxygenation.

A solution of the thiocarbonate $(1.25)(0.183 \mathrm{~g}, 0.33 \mathrm{mmol})$ in dry toluene (5 ml) with AIBN ( $10.8 \mathrm{mg}, 0.2$ equivs) was degassed with nitrogen (20 min) and then treated with tri-n-buty 1 tin hydride $(0.13 \mathrm{~m} 1,1.5$ equivs $)$. The solution was heated at $75^{\circ} \mathrm{C}$ for $24 \mathrm{~h}$. The mixture was cooled, washed with water (5 m1), dried and evaporated to a syrup which was purified by flash chromatography (ether : hexane, $1: 4$ ) yielding the deoxygenated material (1.24) (96 mg, 76\%) contaminated with tin residues. $v_{\max } 1700 \mathrm{~cm}^{-1} \cdot 1_{\mathrm{H}} \mathrm{NMR} \delta 7.4-$ $7.2(10 \mathrm{H}, \mathrm{m}, \mathrm{ArH}) ; 5.15(1 \mathrm{H}, \mathrm{s}, \mathrm{H}-1) ; 5.1-4.0(6 \mathrm{H}, \mathrm{m}) ; 3.3\left(3 \mathrm{H}, \mathrm{d}, \mathrm{CH}_{3} \mathrm{O}\right)$; $3.1\left(1 \mathrm{H}, \mathrm{m}, \mathrm{H}-6^{\prime}\right) ; 2.1-1.4(4 \mathrm{H}, \mathrm{m}) . \underline{\mathrm{m} / \mathrm{z}}: 384\left(\mathrm{M}+\mathrm{H}^{+}\right), 250\left(\mathrm{M}+\mathrm{NH}_{4}^{+}-\right.$ $\left.\mathrm{CO}_{2}-\mathrm{PhCH}_{2} \mathrm{O}, 100 \%\right)$.

ii) Nucleophilic displacement by hydride

Alcohol (1.10a) (151 mg, $0.378 \mathrm{mmol}$ ) was dissolved in dry dichloromethane ( $5 \mathrm{~m} 1$ ) containing pyridine $\left(0.06 \mathrm{ml}, 2\right.$ equivs) and stirred at $-30^{\circ} \mathrm{C}$ under nitrogen with trifluoromethanesulphonic anhydride ( $0.076 \mathrm{ml}, 1.1$ equivs). After $1 \mathrm{~h}$ the solution was washed with water $(5 \mathrm{~m} 1)$, dried and evaporated to a syrup, which was dissolved in THF $(5 \mathrm{ml})$ and stirred at room temperature under nitrogen with lithium triethyl borohydride (1M solution in THF, $0.76 \mathrm{~m} 1$ ). After $6 \mathrm{~h}$, t.1.c (ether : hexane, $1: 1)$ showed loss of the triflate $\left(\mathrm{R}_{\mathrm{f}} 0.9\right)$ and appearance of the deoxygenated material $\left(R_{f} 0.5\right)$. Evaporation of the solvent and purification by flash chromatography (ether : hexane, 1 : 2) afforded the title compound $(1.24)(23 \mathrm{mg}, 16 \%)$ as a syrup. $[a]_{D}^{20}+39.5^{\circ}$ $\left(\underline{c}, 0.41, \mathrm{CHCl}_{3}\right)$.

In a separate experiment the alcohol (1.10a) (0.15 g, $0.38 \mathrm{mmol})$ was treated as described above and the crude product from the superhydride reduction 
was dissolved in ethyl acetate : saturated aqueous sodium bicarbonate ( 5 : $2,10 \mathrm{~m} 1)$. An excess of benzyl chloroformate was added and the solution stirred vigorously for $30 \mathrm{~min}$. The layers were separated and purification of the organic extracts by flash chromatography (as above) gave the title compound (1.24) $(0.112 \mathrm{~g}, 78 \%)$ as a mobile oil.

$\underline{N}-$ benzyloxycarbony1- 4- $\underline{0}-$ benzy1- 1,5- imino- 1,2,5- trideoxy- D-

arabino- hexito1 (1.26)

Deoxygenated bicyclic acetal contaminated with tin residues ( $88 \mathrm{mg}, 0.25$ mmol) was dissolved in $70 \%$ aqueous trifluoroacetic acid $(3 \mathrm{ml})$. After $45 \mathrm{~min}$ the solvent was removed and the crude syrup dissolved in ethanol $(5 \mathrm{~m} 1)$. Sodium borohydride $(10 \mathrm{mg})$ was added and the mixture stirred at room temp for $2 \mathrm{~h}$. The solvent was removed and the residue partitioned between water and chloroform. The chloroform was evaporated to a syrup which was purified by flash chromatography (ethyl acetate : hexane, $1: 2$ ) to give the title compound $(1.26)(28 \mathrm{mg}, 33 \%)$ as a syrup. $[a]_{D}^{20}-46.1^{\circ}\left(\underline{c}, 0.17, \mathrm{CHCl}_{3}\right)$. $v_{\max } 3400,1670 \mathrm{~cm}^{-1} \cdot 1_{\mathrm{H} \operatorname{NMR}} \delta 7.4-7.3(10 \mathrm{H}, \mathrm{m}, \mathrm{ArH}) ; 5.1\left(2 \mathrm{H}, \mathrm{s}, \mathrm{PhCH}_{2}\right)$; $4.8\left(2 \mathrm{H}, \mathrm{ABq}, \mathrm{PhCH}_{2}\right) ; 4.3(1 \mathrm{H}, \mathrm{br} \mathrm{m}, \mathrm{H}-3) ; 4.0-3.5(6 \mathrm{H}, \mathrm{m}) ; 2.9(1 \mathrm{H}, \mathrm{br} \mathrm{s}$, $\mathrm{OH}) ; 2.1(1 \mathrm{H}, \mathrm{m}, \mathrm{H}-2) ; 1.5(1 \mathrm{H}, \mathrm{br} \mathrm{s}, \mathrm{OH}) ; 1.4\left(1 \mathrm{H}, \mathrm{dd}, \mathrm{H}-2^{\prime}\right) . \underline{\mathrm{m} / \mathrm{z}}$ : $372\left(\mathrm{M}+\mathrm{H}^{+}\right) ; 328\left(\mathrm{M}+\mathrm{H}^{+}-\mathrm{CO}_{2}\right) ; 264(100 \%)$. Hydrolysis and reduction of the superhydride product ( 1.24 ) (99 mg, $0.28 \mathrm{mmol}$ ) as described above gave (1.26) (55 mg, 81\%) as a syrup.

Fagomine [1,2,5- trideoxy- 1,5- imino- D- arabino- hexitol] (1.2)

Protected fagomine $(1.26)(25 \mathrm{mg}, 0.067 \mathrm{mmol})$ was dissolved in ethanol (5 m1) and stirred under hydrogen with $10 \%$ palladium hydroxide on charcoal ( $5 \mathrm{mg}$ ) at 
atmospheric pressure. After $12 \mathrm{~h}$ the catalyst was filtered and the solvent evaporated. Purification by ion exchange chromatography (procedure 1) afforded fagomine $(1.2)(7.3 \mathrm{mg}, 74 \%)$ as the free base. m.p $178-182^{\circ} \mathrm{C} .\left(1 \mathrm{it}^{6}\right.$ $\left.180-184^{\circ} \mathrm{C}\right) . \quad[a]_{\mathrm{D}}^{20}+21.6^{\circ}\left(\underline{c}, 0.37, \mathrm{H}_{2} \mathrm{O}\right)\left(1 \mathrm{it}{ }^{6}[a]_{\mathrm{D}}^{20}+24.7^{\circ}\left(\underline{c}, 0.4, \mathrm{H}_{2} \mathrm{O}\right)\right)$. ${ }^{1} \mathrm{H} \mathrm{NMR}\left(\mathrm{D}_{2} 0\right) \delta 3.68\left(1 \mathrm{H}, \mathrm{dd}, \mathrm{H}-6, \mathrm{~J}_{66}, 11.6 \mathrm{~Hz}, \mathrm{~J}_{56} 2.9 \mathrm{~Hz}\right) ; 3.46\left(1 \mathrm{H}, \mathrm{dd}, \mathrm{H}-6^{\prime}\right.$, $\left.\mathrm{J}_{56}, 6.6 \mathrm{~Hz}\right) ; 3.37(1 \mathrm{H}, \mathrm{m}, \mathrm{H}-3) ; 2.99(1 \mathrm{H}, \mathrm{t}, \mathrm{H}-4) ; 2.83\left(1 \mathrm{H}, \mathrm{ddd}, \mathrm{H}-1, \mathrm{~J}_{11}\right.$ ' $12.8 \mathrm{~Hz}) ; 2.45\left(1 \mathrm{H}, \mathrm{ddd}, \mathrm{H}-1^{\prime}\right) ; 2.4(1 \mathrm{H}, \mathrm{m}, \mathrm{H}-5) ; 1.81(1 \mathrm{H}, \mathrm{ddd}, \mathrm{H}-2) ; 1.28$ $\left(1 \mathrm{H}, \mathrm{ddd}, \mathrm{H}-2^{\prime}\right) . \underline{\mathrm{m} / \mathrm{z}}: 148\left(\mathrm{M}+\mathrm{NH}_{4}^{+}, 100 \%\right), 130,116$.

Methyl (N- benzyloxycarbony1-3- $\underline{0}-$ benzyl- 2,6- dideoxy- 2,6- imino ) $\beta$ -

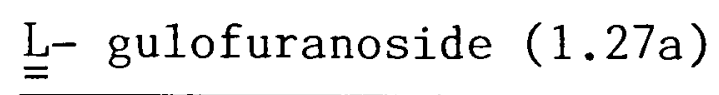

Alcohol (1.10a) ( $815 \mathrm{mg}, 2.04 \mathrm{mmol}$ ) was dissolved in dry dichloromethane $(8 \mathrm{ml})$ and stirred at room temperature with pyridinium chlorochromate $(1.1 \mathrm{~g}$, 2.5 equivs) and powdered molecular sieve $(1 \mathrm{~g})$. After $2 \mathrm{~h}$, the solution was diluted with ether $(10 \mathrm{ml})$ and filtered through a silica plug (eluted with ether). The ether was then evaporated to give a colourless syrup which was dissolved in ethanol ( $10 \mathrm{ml})$. Sodium borohydride ( $75 \mathrm{mg}, 1$ molar equiv) was added at $0^{\circ} \mathrm{C}$ and the reaction maintained at this temperature for $1 \mathrm{~h}$. Ammonium chloride ( $1 \mathrm{~g}$, excess) was added and the solvent removed. The residue was partitioned between chloroform $(20 \mathrm{ml})$ and water $(20 \mathrm{ml})$. The chloroform layer was dried and evaporated to a syrup which was purified by flash chromatography (ethyl acetate : hexane, $1: 3$ ) to give the title compound (1.27a) $(633 \mathrm{mg}, 78 \%)$ as a colourless syrup. $[a]_{D}^{20}+6.1^{\circ}(\underline{c}, 0.96$,

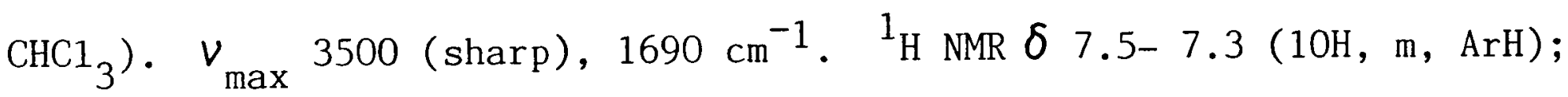
$7.1(1 \mathrm{H}, \mathrm{brd}, \mathrm{OH}) ; 5.21\left(2 \mathrm{H}, \mathrm{ABq}, \mathrm{PhCH}_{2}\right) ; 5.01(1 \mathrm{H}, \mathrm{s}, \mathrm{H}-1) ; 4.67(2 \mathrm{H}, \mathrm{ABq}$, $\left.\mathrm{PhCH}_{2}\right) ; 4.90-3.51(6 \mathrm{H}, \mathrm{m}) ; 3.39,3.38\left(3 \mathrm{H}, 2 \mathrm{~s}, \mathrm{CH}_{3} \mathrm{O}\right) \cdot \underline{\mathrm{m} / \mathrm{z}}\left(\mathrm{CI}, \mathrm{NH}_{3}\right): 417$ 
$\left(\mathrm{M}+\mathrm{NH}_{4}^{+}\right), 400\left(\mathrm{M}+\mathrm{H}^{+}, 100 \%\right)$. Found $\mathrm{C}, 66.41 ; \mathrm{H}, 6.45 ; \mathrm{N}, 3.32$.

$\mathrm{C}_{22} \mathrm{H}_{25}{ }^{\mathrm{NO}} 6$ requires $\mathrm{C}, 66.17 ; \mathrm{H}, 6.27 ; \mathrm{N}, 3.51$.

Methy1 (N- ㄴ-butyloxycarbonyl-3- $\underline{0}-$ benzy1- 2,6- dideoxy- 2,6- imino) $\beta-$

$\underline{\underline{L}-\text { gulofuranoside }(1.27 \mathrm{~b})}$

Alcohol (1.10b) was dissolved in dry dichloromethane $(12 \mathrm{ml})$ and stirred at room temperature with pyridinium chlorochromate $(0.79 \mathrm{~g}, 3$ equivs) and powdered molecular sieve $(0.8 \mathrm{~g})$. After $1 \mathrm{~h}$ the mixture was diluted with ether $(10 \mathrm{ml})$ and filtered through a silica plug. The solvent was removed to give a clear syrup, which was dissolved in ethanol (10 ml). The solution was cooled to $0^{\circ} \mathrm{C}$ and sodium borohydride ( $76 \mathrm{mg}, 1.5$ molar equivs) added. After $1 \mathrm{~h}$ ammonium chloride $(0.5 \mathrm{~g})$ was added, the solvent was removed and the residue partitioned between chloroform $(25 \mathrm{~m} 1)$ and water $(25 \mathrm{~m} 1)$. The organic layer was dried and evaporated to a syrup which was purified by flash chromatography (ether : hexane, $1: 2$ ) to afford the title compound $(1.27 \mathrm{~b})(0.37 \mathrm{~g}, 74 \%)$ as a syrup. $[a]_{\mathrm{D}}^{20}+9.7^{\circ}\left(\underline{c}, 0.3, \mathrm{CHC1}_{3}\right) \cdot v_{\max } 3500$, $1685 \mathrm{~cm}^{-1}$. ${ }^{1} \mathrm{H}$ NMR $\delta 7.5-7.3(5 \mathrm{H}, \mathrm{m}, \mathrm{ArH}) ; 5.0(1 \mathrm{H}, \mathrm{s}, \mathrm{H}-1) ; 4.9-3.4$ $(9 \mathrm{H}, \mathrm{m}) ; 3.3\left(3 \mathrm{H}, \mathrm{s}, \mathrm{CH}_{3} \mathrm{O}\right) ; 1.5(9 \mathrm{H}, \mathrm{s}, \mathrm{tBu}) . \underline{\mathrm{m} / \mathrm{z}}: 366\left(\mathrm{M}+\mathrm{H}^{+}\right) ; 310$ $\left(\mathrm{M}+\mathrm{H}^{+}\right.$-butene $) ; 266(100 \%)$. Found $\mathrm{C}, 61.9 ; \mathrm{H}, 7.8 ; \mathrm{N}, 3.6 . \mathrm{C}_{19} \mathrm{H}_{27}{ }^{\mathrm{NO}} 6$ requires $\mathrm{C}, 62.4 ; \mathrm{H}, 7.4 ; \mathrm{N}, 3.8$.

$\underline{N}-$ benzyloxycarbony $1-4-\underline{0}-$ benzy1- 1,5- dideoxy- 1,5- imino- D- glucitol (1.28) Inverted $\mathrm{Z}$ acetal (1.27a) (0.12 $\mathrm{g}, 0.31 \mathrm{mmol})$ was dissolved in $50 \%$ aqueous trifluoroacetic acid $(5 \mathrm{ml})$ and left at room temperature for $30 \mathrm{~min}$. The solvent was removed and the lactol dissolved in aqueous ethanol (1:4) (5 m1). Sodium borohydride was added and the solution stirred at room temperature for 
15 min. The solvent was evaporated and the residue taken up into ethyl acetate $(10 \mathrm{ml})$ and filtered. Evaporation and purification by flash chromatography ( $5 \%$ methanol in chloroform) gave the title compound ( 1.28 ) (79 $\mathrm{mg}, 65 \%$ ) as a syrup. $[a]_{\mathrm{D}}^{20}-16.8^{\circ}(\underline{c}, 0.15, \mathrm{MeOH}) \cdot v_{\max } 3400,1675 \mathrm{~cm}^{-1}$. $1_{\mathrm{H} \mathrm{NMR}} \delta 7.3-7.1(10 \mathrm{H}, \mathrm{m}, \mathrm{ArH}) ; 4.7-4.4\left(4 \mathrm{H}, \mathrm{m}, \mathrm{PhCH}_{2}\right) ; 4.3-3.1(11 \mathrm{H}, \mathrm{m})$. $\underline{\mathrm{m} / \mathrm{z}}\left(\mathrm{CI}, \mathrm{NH}_{3}\right): 388\left(\mathrm{M}+\mathrm{H}^{+}\right) ; 280\left(\mathrm{M}+\mathrm{H}^{+}-\mathrm{PhCH}_{2} \mathrm{OH}\right)$.

Deoxynojirimycin, [1,5- dideoxy- 1,5- imino- D- glucitol] (1.4)

Protected glucitol (1.28) (75 mg, $0.19 \mathrm{mmol}$ ) was dissolved in glacial acetic acid ( $5 \mathrm{~m} 1)$ and hydrogenated with palladium black (10 mg). After $48 \mathrm{~h}$, the catalyst was filtered and the solvent evaporated. Purification by ion exchange chromatography (procedure 1 and 2) gave the free amine (1.4) (30 mg, quant) which was crystallised as the hydrochloride salt. m.p $203^{\circ} \mathrm{C}\left(1\right.$ it $^{8}$ $\left.206^{\circ} \mathrm{C}\right) .[a]_{\mathrm{D}}^{20}+31^{\circ}\left(\underline{c}, 0.28, \mathrm{H}_{2} \mathrm{O}\right)\left(1 \mathrm{it}^{8}[\mathrm{a}]_{\mathrm{D}}^{20}+47^{\circ}\left(\mathrm{H}_{2} \mathrm{O}\right)\right) \cdot{ }^{1} \mathrm{H} \operatorname{NMR}\left(\mathrm{D}_{2} \mathrm{O}\right) \delta$ a) free base $3.66\left(1 \mathrm{H}, \mathrm{dd}, \mathrm{H}-6, \mathrm{~J}_{66}, 11.8 \mathrm{~Hz}, \mathrm{~J}_{56} 3.0 \mathrm{~Hz}\right) ; 3.47(1 \mathrm{H}$, dd, $\left.\mathrm{H}-6^{\prime}, \mathrm{J}_{56}, 6.2 \mathrm{~Hz}\right) ; 3.34(1 \mathrm{H}, \mathrm{ddd}, \mathrm{H}-2) ; 3.16(1 \mathrm{H}, \mathrm{t}) ; 3.08(1 \mathrm{H}, \mathrm{t}, \mathrm{H}-3,4)$;

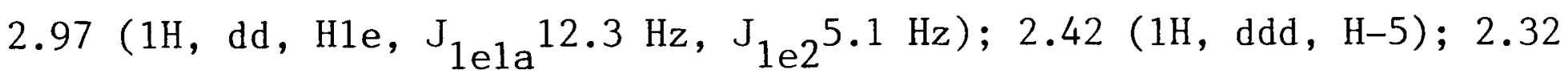
$\left(1 \mathrm{H}, \mathrm{dd}, \mathrm{H}-1 \mathrm{a}, \mathrm{J}_{1 \mathrm{a} 2} 10.9 \mathrm{~Hz}\right)$. b) hydrochloride salt $3.9(1 \mathrm{H}$, dd, $\mathrm{H}-6) ; 3.8$ $\left(1 \mathrm{H}, \mathrm{dd}, \mathrm{H}-6^{\prime}\right) ; 3.7$ (1H, ddd, H-2); 3.4 (3H, m, H-1e, 3, 4); $3.05(1 \mathrm{H}$, ddd, $\mathrm{H}-5) ; 2.9(1 \mathrm{H}, \mathrm{dd}, \mathrm{H}-1 \mathrm{a}) . \underline{\mathrm{m} / \mathrm{z}}\left(\mathrm{CI}, \mathrm{NH}_{3}\right): 164\left(\mathrm{M}+\mathrm{H}^{+}, 100 \%\right)$.

$\underline{N}-$ benzyloxycarbony $1-3-\underline{0}-$ benzyl- 2,6- dideoxy- 2,6- imino- D- mannurono$1,4-$ lactone (1.29)

Acetal (1.10a) ( $0.1 \mathrm{~g}, 0.25 \mathrm{mmol})$ was dissolved in $50 \%$ aqueous trifluoroacetic acid $(3 \mathrm{ml})$ at room temperature. After $15 \mathrm{~min}$ the solvent was removed and the crude syrup dissolved in dioxane : water (3:1) (4 ml), containing 
barium carbonate $\left(0.12 \mathrm{~g}, 3\right.$ equivs). The suspension was cooled to $0^{\circ} \mathrm{C}$ and bromine ( $0.016 \mathrm{ml}, 1.25$ equivs) added dropwise in the dark. The solution was slowly allowed to warm to room temperature and stirred for $24 \mathrm{~h}$. Excess bromine was destroyed by dropwise addition of sodium thiosulphate solution (1M, aq) until no red colour was visible. The precipitated sulphur was removed by centrifugation and the resulting clear solution diluted with ethyl acetate $(10 \mathrm{~m} 1)$. The phases were separated and the aqueous phase was extracted with further ethyl acetate $(2 \times 10 \mathrm{ml})$. The organic extracts were combined, dried and evaporated to a syrup which was purified by flash chromatography (ethy 1 acetate : hexane, $1: 1$ ) to afford the lactone (1.29) (89 mg, 93\%), a syrup. [a] ${ }_{D}^{20}-72.3^{\circ}\left(\underline{c}, 0.24, \mathrm{CHCl}_{3}\right) \cdot v_{\max } 3400(\mathrm{br}), 1770$, $1700 \mathrm{~cm}^{-1} .{ }_{\mathrm{H} \text { NMR }}^{1} 7.4-7.3(10 \mathrm{H}, \mathrm{m}, \mathrm{ArH}) ; 5.1-4.5(7 \mathrm{H}, \mathrm{m}) ; 3.9-3.7$ $\left(3 \mathrm{H}, \mathrm{m}, \mathrm{H}-2,6,6^{\prime}\right) ; 3.2(1 \mathrm{H}$, br s, OH $) . \underline{\mathrm{m} / \mathrm{z}}: 401\left(\mathrm{M}+\mathrm{NH}_{4}^{+}\right), 340,250$. Found $\mathrm{C}, 65.98 ; \mathrm{H}, 5.73 ; \mathrm{N}, 3.42 . \mathrm{C}_{21} \mathrm{H}_{21} \mathrm{NO}_{6}$ requires $\mathrm{C}, 65.80 ; \mathrm{H}, 5.48$; $\mathrm{N}, 3.66$.

$\underline{N}-$ benzyloxycarbony $1-3-\underline{0}-$ benzy1- 2,6- dideoxy- 2,6- imino- L- gulono$1,4-$ lactone $(1.30)$

Was prepared in exactly the same way as (1.29) above, using the inverted bicyclic acetal (1.27a) (82 mg, $0.21 \mathrm{mmol})$. Purification by flash chromatography (ethyl acetate : hexane, $1: 1$ ) gave unreacted lactol (15 mg, 19\%) and the title compound (1.30) (15 mg, 19\%) together with baseline products. $(1.30): v_{\max } 1790,1700 \mathrm{~cm}^{-1} \cdot 1_{\mathrm{H} N M R} \delta 7.4(10 \mathrm{H}, \mathrm{m}, \mathrm{ArH}) ; 5.3-3.5(11 \mathrm{H}, \mathrm{m})$; $\underline{\mathrm{m} / \mathrm{z}}: 401\left(\mathrm{M}+\mathrm{NH}_{4}^{+}, 100 \%\right) ; 340$.

$(2 S, 3 R, 4 R, 5 R), 3,4,5$ Trihydroxy-pipecolic acid (1.3) Bicyclic lactone (1.29) (62 $\mathrm{mg}, 0.16 \mathrm{mmol}$ ) was dissolved in acetic acid : 
water $(2: 1)(2 \mathrm{ml})$ and hydrogenated with palladium black $(8 \mathrm{mg})$. After $48 \mathrm{~h}$ the catalyst was filtered and the solvent evaporated. Purification by ion exchange chromatography (procedure 1, elute with aq pyridine) gave the title compound (1.3) (28 mg, quantitative) a hygroscopic syrup. $[a]_{D}^{20}-13.8^{\circ}$ $\left(\underline{c}, 0.21, H_{2} 0\right) . v_{\max } 3500-3300,1730,1620(w) .1_{H} \operatorname{NMR}\left(D_{2} 0\right) \delta 4.00$ $(1 \mathrm{H}, \mathrm{dt}, \mathrm{H}-5) ; 3.84(1 \mathrm{H}, \mathrm{t}, \mathrm{H}-3) ; 3.54\left(1 \mathrm{H}, \mathrm{dd}, \mathrm{H}-4, \mathrm{~J}_{34} 8.9 \mathrm{~Hz}, \mathrm{~J}_{45} 3.1 \mathrm{~Hz}\right)$; $3.21\left(1 \mathrm{H}, \mathrm{d}, \mathrm{H}-2, \mathrm{~J}_{23} 9.2 \mathrm{~Hz}\right) ; 3.15\left(1 \mathrm{H}, \mathrm{dd}, \mathrm{H}-6, \mathrm{~J}_{66}, 13.6 \mathrm{~Hz}, \mathrm{~J}_{56} 4.0 \mathrm{~Hz}\right)$; $2.93\left(1 \mathrm{H}, \mathrm{dd}, \mathrm{H}-6^{\prime}, \mathrm{J}_{56^{\prime}}, 2.0 \mathrm{~Hz}\right) . \underline{\mathrm{m} / \mathrm{z}}: 178\left(\mathrm{M}+\mathrm{H}^{+}, 100 \%\right), 160,132,124$.

$(2 S, 3 R, 4 R, 5 S) 3,4,5-$ trihydroxy-pipecolic acid (1.5)

Lactone (1.30) (9 mg, $0.023 \mathrm{mmol}$ ) was hydrogenated in 50\% aqueous acetic acid ( $1 \mathrm{ml}$ ) with palladium black $(5 \mathrm{mg})$. After $24 \mathrm{~h}$, the catalyst was filtered and the solvent removed. Purification by ion exchange chromatography (procedure 1) gave the acid $(3 \mathrm{mg}, 72 \%)$ m.p $222-226^{\circ} \mathrm{C} .\left(1 \mathrm{it}^{15} 228-230^{\circ} \mathrm{C}\right.$ ). $1_{\mathrm{H} \text { NMR }}\left(\mathrm{D}_{2} \mathrm{O}\right) \delta 3.7(1 \mathrm{H}, \mathrm{ddd}, \mathrm{H}-5) ; 3.55(1 \mathrm{H}, \mathrm{dd}, \mathrm{H}-3) ; 3.3(3 \mathrm{H}, \mathrm{m}, \mathrm{H}-2$, $4,6 e) ; 2.9(1 \mathrm{H}, \mathrm{dd}, \mathrm{H}-6 \mathrm{a}) . \underline{\mathrm{m} / \mathrm{z}}: 178\left(\mathrm{M}+\mathrm{H}^{+}\right) ; 124(100 \%)$.

Methy1 (N- benzyloxycarbony1- 5- azido- 3- $0-$ benzy1- 2,6- imino- 2,5,6- trideoxy ) $a$ - D- mannofuranoside (1.32a) and Methyl (N- benzyloxycarbonyl- 5-

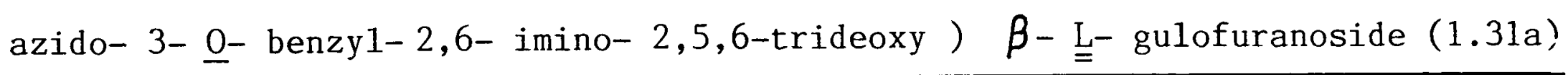

The alcohol (1.10a) (1.6 g, $4.01 \mathrm{mmol})$ was dissolved in dichloromethane containing pyridine $(0.68 \mathrm{ml}, 2$ equivs $)$ and stirred at $-30^{\circ} \mathrm{C}$ under nitrogen, with trifluoromethanesulphonic anhydride $(0.94 \mathrm{~m} 1,1.4$ equivs $)$. After $30 \mathrm{~min}$ the solution was washed with water $(20 \mathrm{ml})$ and evaporated to a syrup containing the crude triflate. This was not isolated but dissolved in DMF 
$(20 \mathrm{~m} 1)$ and stirred at $60^{\circ} \mathrm{C}$ with sodium azide $(0.3 \mathrm{~g}, 1.15$ equivs). After $24 \mathrm{~h}$ the solvent was removed and the residue partitioned between chloroform (25 $\mathrm{m} 1$ ) and water $(25 \mathrm{~m} 1)$. The organic layer was dried and evaporated. Purification by flash chromatography (ether : hexane, $1: 4$ ) gave three products. The first was the azide with retention of configuration : methy1 ( $N$ - benzyloxycarbony $1-5$ - azido- 3- 0- benzyl-2,6- imino- 2,5,6trideoxy- ) $a-D$ - mannofuranoside (1.32a) $(0.39 \mathrm{~g}, 23 \%)$ a syrup. $v_{\max }$ $2100,1700 \mathrm{~cm}^{-1} .1_{\mathrm{H} \operatorname{NMR}} \delta 7.4-7.3(10 \mathrm{H}, \mathrm{m}, \mathrm{ArH}) ; 5.2-3.5(11 \mathrm{H}, \mathrm{m}) ; 3.4$ $\left(3 \mathrm{H}, \mathrm{s}, \mathrm{CH}_{3} \mathrm{O}\right) . \underline{\mathrm{m} / \mathrm{z}}(\mathrm{FD}): 424\left(\mathrm{M}^{+}\right)$. The second product was eliminated material (170 mg, 11\%). $v_{\max } 1700(\mathrm{~s}), 1630(\mathrm{w}) \mathrm{cm}^{-1} \cdot 1_{\mathrm{H} \text { NMR }} \delta 7.4-7.3$ $(10 \mathrm{H}, \mathrm{m}, \mathrm{ArH}) ; 7.1,6.9(2 \mathrm{H}, 2 \mathrm{~d}, \mathrm{H}-5,6) ; 5.1-4.1(8 \mathrm{H}, \mathrm{m}) ; 3.3\left(3 \mathrm{H}, 2 \mathrm{~s}, \mathrm{CH}_{3} \mathrm{O}\right)$. $\underline{\mathrm{m} / \mathrm{z}}: 382\left(\mathrm{M}+\mathrm{H}^{+}, 100 \%\right), 338$. The third product eluted was the inverted azide : methy1 (N- benzyloxycarbony1- 5- azido- 3- 0- benzy1-2,6- imino- 2,5,6trideoxy- ) $\beta$ - L- gulofuranoside $(1.31 \mathrm{a})(0.60 \mathrm{~g}, 36 \%)$, a syrup. $[a]_{D}^{20}+5.9^{\circ}$ $\left(\underline{c}, 0.68, \mathrm{CHCl}_{3}\right) \cdot v_{\max } 2105,1700,1450,1420 \mathrm{~cm}^{-1} \cdot 1_{\mathrm{H} N \mathrm{NMR}} \delta .37-7.29$ $(10 \mathrm{H}, \mathrm{m}, \mathrm{ArH}) ; 5.2-3.8(9 \mathrm{H}, \mathrm{m}) ; 4.88,4.82(1 \mathrm{H}, 2 \mathrm{~s}, \mathrm{H}-1) ; 3.74,3.65(1 \mathrm{H}$, $2 \mathrm{~m}, \mathrm{H}-5) ; 3.37,3.32\left(3 \mathrm{H}, 2 \mathrm{~s}, \mathrm{CH}_{3} \mathrm{O}\right) \cdot \underline{\mathrm{m} / \mathrm{z}}: 442\left(\mathrm{M}+\mathrm{NH}_{4}^{+}\right) ; 397(100 \%)$. Found $\mathrm{C}, 61.97 ; \mathrm{H}, 5.60 ; \mathrm{N} 12.97 . \mathrm{C}_{22} \mathrm{H}_{24} \mathrm{~N}_{4} \mathrm{O}_{5}$ requires $\mathrm{C}, 62.26 ; \mathrm{H}, 5.66$; $\mathrm{N}, 13.21$.

Methy1 (N- benzyloxycarbony1- 5- acetamido- 3- 0 - benzy1- 2,6- imino- 2,5,6trideoxy - ) $\beta$ - L- gulofuranoside (1.33)

Powdered tellurium ( $309 \mathrm{mg}, 2.5$ equivs) and sodium borohydride ( $217 \mathrm{mg}$, 6 equivs) were refluxed in ethanol $(20 \mathrm{~m} 1)$ under nitrogen until all the tellurium dissolved and the solution became cherry red in appearance $(2 \mathrm{~h})$. The solution was cooled to room temperature and the azide (1.31a) (415 mg, 
$0.98 \mathrm{mmol})$ in ether $(20 \mathrm{ml})$ injected slowly. The solution immediately lost its colour and tellurium was precipitated with evolution of nitrogen. After 10 min the vessel was opened to the atmosphere to destroy excess reagent and then the solution was filtered through celite. The solvent was evaporated and the crude amine dissolved in pyridine $(8 \mathrm{ml})$. Acetic anhydride $(0.46 \mathrm{ml}$, 5 equivs) was added and the solution stirred at room temperature for $2 \mathrm{~h}$. The solvent was evaporated and purification by flash chromatography (ethyl acetate : hexane, $3: 1$ ) afforded the title compound (1.33) (395 mg, 92\%), a syrup. $[a]_{\mathrm{D}}^{20}+88.0^{\circ}\left(\underline{c}, 0.41, \mathrm{CHCl}_{3}\right) \cdot v_{\max } 3410$ (sharp), 1700, 1680,

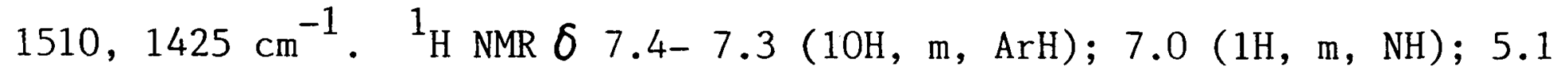
$\left(2 \mathrm{H}, \mathrm{ABq}, \mathrm{PhCH}_{2}\right) ; 5.05(1 \mathrm{H}, \mathrm{s}, \mathrm{H}-1) ; 4.7\left(2 \mathrm{H}, \mathrm{ABq}, \mathrm{PhCH}_{2}\right) ; 5.1-3.7(6 \mathrm{H}, \mathrm{m})$; $3.4\left(3 \mathrm{H}, \mathrm{s}, \mathrm{CH}_{3} \mathrm{O}\right) ; 1.8\left(3 \mathrm{H}, \mathrm{s}, \mathrm{CH}_{3} \mathrm{CO}\right) . \underline{\mathrm{m} / \mathrm{z}}: 441\left(\mathrm{M}+\mathrm{H}^{+}, 100 \%\right)$. Found $\mathrm{C}, 65.41 ; \mathrm{H}, 6.37 ; \mathrm{N}, 6.42 . \mathrm{C}_{24} \mathrm{H}_{28} \mathrm{~N}_{2} \mathrm{O}_{6}$ requires $\mathrm{C}, 65.45 ; \mathrm{H}, 6.36 ; \mathrm{N}, 6.36$.

$\underline{N}-$ benzyloxycarbony $1-2$ - acetamido- 4- $\underline{0}-$ benzy1- 1,5- imino- 1,2,5- trideoxy - D- glucitol $(1.34)$

Acetal (1.33) (0.39 $\mathrm{g}, 0.89 \mathrm{mmol})$ was dissolved in $50 \%$ aqueous trifluoroacetic acid $(4 \mathrm{~m} 1)$ and stirred at room temperature for $15 \mathrm{~min}$. The solvent was removed and the resulting syrup dissolved in ethanol ( $4 \mathrm{~m} 1)$. A solution of sodium borohydride ( $33 \mathrm{mg}, 1$ molar equiv) in water $(1 \mathrm{~m} 1)$ was added and the mixture stirred at room temperature until effervescence ceased (10 min). Ammonium chloride $(0.5 \mathrm{~g})$ was added, the solvent evaporated and the residue extracted into ethyl acetate $(3 \times 20 \mathrm{~m} 1)$. The ethyl acetate was filtered, dried and evaporated to a syrup which was purified by flash chromatography ( $2 \%$ ethanol in ethyl acetate) to afford the title compound (1.34) (306 mg, $80 \%$ ) as a syrup. $[a]_{\mathrm{D}}^{20}+9.6^{\circ}\left(\underline{c}, 0.23, \mathrm{CHCl}_{3}\right) \cdot v_{\max } 3400(\mathrm{br}), 1670,1530 \mathrm{~cm}^{-1}$. 
$1_{\mathrm{H} \mathrm{NMR}} \delta 7.5-7.4(10 \mathrm{H}, \mathrm{m}, \mathrm{ArH}) ; 6.8(1 \mathrm{H}, \mathrm{br} \mathrm{d}, \mathrm{NH}) ; 5.2-3.6(12 \mathrm{H}, \mathrm{m})$; $2.9(2 \mathrm{H}$, br s, OH $) ; 1.4\left(3 \mathrm{H}, \mathrm{s}, \mathrm{CH}_{3} \mathrm{CO}\right) . \underline{\mathrm{m} / \mathrm{z}}: 429\left(\mathrm{M}+\mathrm{H}^{+}\right) ; 338\left(\mathrm{M}+\mathrm{NH}_{4}^{+}{ }_{-}\right.$ $\left.\mathrm{PhCH}_{2} \mathrm{OH}\right) ; 321\left(\mathrm{M}+\mathrm{H}^{+}-\mathrm{PhCH}_{2} \mathrm{OH}\right)$. Found $\mathrm{C}, 64.2, \mathrm{H}, 6.7 ; \mathrm{N}, 5.9$. $\mathrm{C}_{23} \mathrm{H}_{28} \mathrm{~N}_{2} \mathrm{O}_{6}$ requires $\mathrm{C}, 64.5 ; \mathrm{H}, 6.5 ; \mathrm{N}, 6.5$.

2- Acetamido- 1,5- imino- 1,2,5- trideoxy- D- glucitol (1.7)

Protected imino glucitol (1.34) (305 $\mathrm{mg}, 0.71 \mathrm{mmol}$ ) was dissolved in acetic acid $(5 \mathrm{ml})$ and stirred under hydrogen with palladium black ( $40 \mathrm{mg}$ ). After $24 \mathrm{~h}$, the catalyst was filtered and the solvent evaporated. Purification of the residue by ion exchange chromatography (procedure 1 and 2 ) gave the imino glucitol (1.7) (145 mg, quantitative) as a colourless solid. m.p 227-228 ${ }^{\circ} \mathrm{C}$ (decomp). $[a]_{\mathrm{D}}^{20}+35.0^{\circ}\left(\underline{c}, 0.3, \mathrm{H}_{2} \mathrm{O}\right) \cdot v_{\max }(\mathrm{KBr}) 3400$ (br), 3280 (sharp), 1640, $1560 \mathrm{~cm}^{-1} .1_{\mathrm{H} \text { NMR }}\left(\mathrm{D}_{2} 0\right) \delta 3.64\left(1 \mathrm{H}, \mathrm{dd}, \mathrm{H}-6, \mathrm{~J}_{66}, 11.7 \mathrm{~Hz}, \mathrm{~J}_{56} 3.0 \mathrm{~Hz}\right) ; 3.55(1 \mathrm{H}$, $\mathrm{dt}, \mathrm{H}-2) ; 3.47\left(1 \mathrm{H}, \mathrm{dd}, \mathrm{H}-6^{\prime}, \mathrm{J}_{56}, 6.0 \mathrm{~Hz}\right) ; 3.21(1 \mathrm{H}, \mathrm{t}) ; 3.12(1 \mathrm{H}, \mathrm{t}, \mathrm{H}-3,4)$; $2.88\left(1 \mathrm{H}, \mathrm{dd}, \mathrm{H}-1 \mathrm{e}, \mathrm{J}_{1 \mathrm{e} 1 \mathrm{a}} 12.6 \mathrm{~Hz}, \mathrm{~J}_{1 \mathrm{e} 2} 4.9 \mathrm{~Hz}\right) ; 2.37\left(1 \mathrm{H}, \mathrm{ddd}, \mathrm{H}-5, \mathrm{~J}_{45} 9.3 \mathrm{~Hz}\right)$; $2.25\left(1 \mathrm{H}, \mathrm{dd}, \mathrm{H}-\mathrm{la}, \mathrm{J}_{1 \mathrm{a} 2} 11.5 \mathrm{~Hz}\right) ; 1.82\left(3 \mathrm{H}, \mathrm{s}, \mathrm{CH}_{3} \mathrm{CO}\right) \cdot{ }^{13} \mathrm{C} \mathrm{NMR}\left(\mathrm{D}_{2} \mathrm{O}\right) \delta 22.77$ $\left(\mathrm{q}, \mathrm{CH}_{3}\right) ; 47.64(\mathrm{t}, \mathrm{C}-1) ; 52.88(\mathrm{~d}, \mathrm{C}-5) ; 61.15(\mathrm{~d}, \mathrm{C}-2) ; 61.95(\mathrm{t}, \mathrm{C}-6) ; 72.68$ (d), $76.54(\mathrm{~d}, \mathrm{C}-3,4) ; 170\left(\mathrm{~s}, \mathrm{CH}_{3} \mathrm{CO}\right) \cdot \underline{\mathrm{m} / \mathrm{z}}: 205\left(\mathrm{M}+\mathrm{H}^{+}, 100 \%\right), 145$. Found $\mathrm{C}, 47.14 ; \mathrm{H}, 8.01 ; \mathrm{N}, 13.41 . \mathrm{C}_{8} \mathrm{H}_{16} \mathrm{~N}_{2} \mathrm{O}_{4}$ requires $\mathrm{C}, 47.06 ; \mathrm{H}, 7.84 ; \mathrm{N}, 13.73$.

Methyl (N- $\underline{t}-b u t y 1 o x y c a r b o n y 1-5-$ azido- 3- $\underline{0}-$ benzyl- 2,6- imino- 2,5,6- trideoxy ) $a-\underline{D}-$ mannofuranoside $(1.32 b)$ and methyl (N- $\underline{t}$-butyloxycarbonyl- 5azido- 3- $\underline{0}-$ benzy1-2,6- imino- 2,5,6- trideoxy ) $\beta$ - L- gulofuranoside (1.31b) Alcohol (1.10b) (0.38 g, $1.04 \mathrm{mmol})$ was dissolved in dry dichloromethane $(10 \mathrm{ml})$ containing pyridine $\left(0.17 \mathrm{ml}, 2\right.$ equivs) and stirred at $-30^{\circ} \mathrm{C}$ under nitrogen with trifluoromethanesulphonic anhydride $(0.22 \mathrm{~m} 1,1.2$ equivs $)$. 
After $30 \mathrm{~min}$ the solution was washed with water $(10 \mathrm{~m} 1)$ and concentrated to a syrup, the triflate $\left({ }^{1} \mathrm{H}\right.$ NMR $\delta 7.4-7.3(5 \mathrm{H}, \mathrm{m}, \mathrm{ArH}) ; 5.2(1 \mathrm{H}, \mathrm{m}, \mathrm{H}-5)$; $5.0(1 \mathrm{H}, \mathrm{s}, \mathrm{H}-1) ; 4.6\left(2 \mathrm{H}, \mathrm{ABq}, \mathrm{PhCH}_{2}\right) ; 4.9-4.3(4 \mathrm{H}, \mathrm{m}) ; 3.3\left(3 \mathrm{H}, \mathrm{s}, \mathrm{CH}_{3} \mathrm{O}\right)$; $3.1\left(1 \mathrm{H}, \mathrm{s}, \mathrm{H}-6^{\prime}\right) ; 1.5(9 \mathrm{H}, \mathrm{s}, \mathrm{tBu})$. ) which was not isolated, but dissolved in $\mathrm{DMF}(10 \mathrm{~m} 1)$ and stirred at $70^{\circ} \mathrm{C}$ with sodium azide $(0.1 \mathrm{~g}, 1.5$ equivs $)$. After $48 \mathrm{~h}$, the solvent was removed and the residue partitioned between chloroform $(20 \mathrm{~m} 1)$ and water $(20 \mathrm{~m} 1)$. The chloroform layer was dried and evaporated to a syrup. Purification by flash chromatography (ether : hexane, $1: 4)$ gave three products. The first, the azide with retention of configuration : methy1 ( $\mathrm{N}-\mathrm{t}$-butyloxycarbony $1-5$ - azido- 3-0- benzy1-2,6imino- 2,5,6-trideoxy- $a-D$-mannofuranoside (1.32b) (172 mg, 42\%), a syrup. $[a]_{D}^{20}+44.7^{\circ}\left(\underline{c}, 1.33, \mathrm{CHCl}_{3}\right) \cdot v_{\max } 2095,1695 \mathrm{~cm}^{-1} \cdot{ }_{\mathrm{H} \mathrm{NMR}} \delta 7.4-7.3$ $(5 \mathrm{H}, \mathrm{m}, \mathrm{ArH}) ; 5.0(1 \mathrm{H}, \mathrm{d}, \mathrm{H}-1) ; 4.9-4.3(6 \mathrm{H}, \mathrm{m}) ; 3.9(1 \mathrm{H}, \mathrm{m}, \mathrm{H}-5) ; 3.4(3 \mathrm{H}, \mathrm{s}$, $\left.\mathrm{CH}_{3} \mathrm{O}\right) ; 3.0(1 \mathrm{H}, \mathrm{m}, \mathrm{H}-6) ; 1.5(9 \mathrm{H}, \mathrm{d}, \mathrm{tBu}) . \underline{\mathrm{m} / \mathrm{z}}: 408\left(\mathrm{M}+\mathrm{NH}_{4}^{+}\right) ; 391\left(\mathrm{M}+\mathrm{H}^{+}\right.$, $100 \%$ ). The second, the eliminated product ( $35 \mathrm{mg}, 10 \%$ ), and the third the inverted azide : methyl ( $\mathrm{N}$ - t-butyloxycarbony1- 5-azido- 3-0-benzy1-

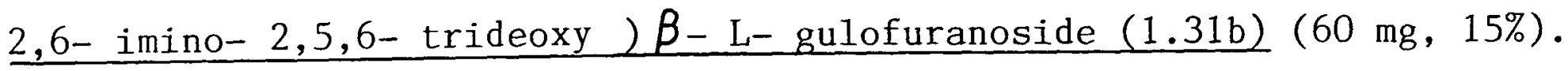
$v_{\max } 2110,1690 \mathrm{~cm}^{-1} \cdot 1_{\mathrm{H}} \operatorname{NMR} \delta 7.4-7.3(5 \mathrm{H}, \mathrm{m}, \mathrm{ArH}) ; 4.9-4.2(6 \mathrm{H}, \mathrm{m}) ; 3.4$ $\left(3 \mathrm{H}, \mathrm{s}, \mathrm{CH}_{3} \mathrm{O}\right) ; 3.3-3.2(3 \mathrm{H}, \mathrm{m}) ; 1.5(9 \mathrm{H}, \mathrm{d}, \mathrm{tBu}) \cdot \underline{\mathrm{m} / \mathrm{z}}: 363\left(\mathrm{M}+\mathrm{H}^{+}-\mathrm{N}_{2}\right)$, $356\left(\mathrm{M}+\mathrm{NH}_{4}^{+}\right.$- butene); $248(100 \%)$.

Methyl (N- t-butyloxycarbony1- 5- acetamido- 3- $\underline{0}-$ benzyl-2,6- imino- 2,5,6trideoxy ) $a-\underline{=}-$ mannofuranoside (1.35)

Azide (1.32b) (178 mg, $0.46 \mathrm{mmol}$ ) was hydrogenated at atmospheric pressure with palladium black (20 mg) in ethanol $(5 \mathrm{~m} 1$ ). After $90 \mathrm{~min}$ t.1.c (ethyl acetate : hexane, $1: 1)$ showed no azide $\left(R_{f} 0.7\right)$ and one product, the amine 
$\left(R_{f}\right.$ 0.0). The catalyst was filtered and the solvent removed. The resulting syrup was dissolved in pyridine $(2 \mathrm{ml})$ and stirred at room temperature with acetic anhydride $(0.1 \mathrm{ml}, 2.3$ equivs). After $2 \mathrm{~h}$ the solvent was evaporated and the residue purified by flash chromatography (ethyl acetate : hexane, 2 : 1) affording the amide $(1.35)(180 \mathrm{mg}, 96 \%) . \mathrm{m} \cdot \mathrm{p} 109-110^{\circ} \mathrm{C} .[a]_{\mathrm{D}}^{20}+15.9^{\circ}$ $\left(\underline{c}, 1.07, \mathrm{CHCl}_{3}\right) . v_{\max } 3400(\mathrm{br}), 1690,1650,1540 \mathrm{~cm}^{-1} \cdot 1_{\mathrm{H} \mathrm{NMR}} \delta 7.4-$ $7.3(5 \mathrm{H}, \mathrm{m}, \mathrm{ArH}) ; 5.7(1 \mathrm{H}, \mathrm{br} \mathrm{s}, \mathrm{NH}) ; 4.95(1 \mathrm{H}, \mathrm{s}, \mathrm{H}-1) ; 4.9-4.2(7 \mathrm{H} . \mathrm{m}) ; 3.4$ $\left(3 \mathrm{H}, \mathrm{s}, \mathrm{CH}_{3} \mathrm{O}\right) ; 2.8(1 \mathrm{H}, \mathrm{m}, \mathrm{H}-6) ; 2.0\left(3 \mathrm{H}, \mathrm{s}, \mathrm{CH}_{3} \mathrm{CO}\right) ; 1.5(9 \mathrm{H}, \mathrm{d}, \mathrm{tBu}) . \underline{\mathrm{m} / \mathrm{z}}$ : $351\left(\mathrm{M}+\mathrm{H}^{+}\right.$- butene, 100\%), 307. Found $\mathrm{C}, 61.7 ; \mathrm{H}, 7.6 ; \mathrm{N}, 6.54 . \mathrm{C}_{21} \mathrm{H}_{30} \mathrm{~N}_{2} \mathrm{O}_{6}$ requires $\mathrm{C}, 62.07 ; \mathrm{H}, 7.39 ; \mathrm{N}, 6.90$.

2- Acetamido- 4- $\underline{0}-$ benzy1- 1,5- imino- 1,2,5- trideoxy- D- mannitol (1.36) Acetal (1.35) (58 mg, $0.14 \mathrm{mmol}$ ) was dissolved in $50 \%$ aqueous trifluoroacetic acid $(2 \mathrm{~m} 1)$. After 5 min the solvent was removed and the crude syrup dissolved in ethanol $(2 \mathrm{~m} 1)$. A solution of sodium borohydride (14 $\mathrm{mg}, 0.38 \mathrm{mmol}$ ) in water $(0.5 \mathrm{~m} 1)$ was added at $0^{\circ} \mathrm{C}$ and the solution was stirred until effervescence ceased $(15 \mathrm{~min})$. Ammonium chloride $(0.1 \mathrm{~g})$ was added, the solvent was removed and the residue taken up into $50 \%$ ethanol in chloroform (10 mI) and filtered. The solvent was removed and purification by flash chromatography (ethanol : chloroform, $1: 1$ ) gave the title compound (1.36) (40 mg, 97\%) as a brown syrup. $[a]_{D}^{20}+11.0^{\circ}(\underline{c}, 0.37, \mathrm{MeOH}) .1_{\mathrm{H} N M R}\left(\mathrm{D}_{2} 0\right)$ $\delta 7.4-7.3(5 \mathrm{H}, \mathrm{m}, \mathrm{ArH}) ; 4.7\left(2 \mathrm{H}, \mathrm{m}, \mathrm{PhCH}_{2}\right) ; 4.3-3.8(5 \mathrm{H}, \mathrm{m}) ; 3.3-3.1$ $\left(3 \mathrm{H}, \mathrm{m}, \mathrm{H}-1,1^{\prime}, 5\right) ; 2.0\left(3 \mathrm{H}, \mathrm{s}, \mathrm{CH}_{3} \mathrm{CO}\right) . \underline{\mathrm{m} / \mathrm{z}}: 295\left(\mathrm{M}+\mathrm{H}^{+}\right)+$higher mass impurities. 
2- Acetamido- 1,5- imino- 1,2,5- trideoxy- D- mannitol (1.6)

Benzyl ether (1.36) (32 mg, $0.11 \mathrm{mmol}$ ) was hydrogenated in ethanol $(10 \mathrm{ml})$ with palladium hydroxide on charcoal (10\%, $10 \mathrm{mg}$ ). After $24 \mathrm{~h}$ the catalyst was filtered and the solvent evaporated. The crude syrup which resulted was purified by ion exchange chromatography (procedure 1 and 2) producing the title compound $(1.6)\left(22 \mathrm{mg}\right.$, quantitative). m.p $203-207^{\circ} \mathrm{C} .[a]_{\mathrm{D}}^{20}-53.3^{\circ}$ $\left(\underline{c}, 0.12, \mathrm{H}_{2} 0\right) \cdot v_{\max }(\mathrm{KBr}) 3450,3350,3300,3150(\mathrm{br}), 1660,1550 \mathrm{~cm}^{-1} \cdot 1_{\mathrm{H} \mathrm{NMR}}$ $\left(\mathrm{D}_{2} \mathrm{O}\right) \delta 4.05\left(1 \mathrm{H}, \mathrm{dt}, \mathrm{H}-2, \mathrm{~J}_{12}, \mathrm{~J}_{1} \cdot 2.4 \mathrm{~Hz}, \mathrm{~J}_{23} 4.7 \mathrm{~Hz}\right) ; 3.64$ (1H, dd, H-6, $\left.\mathrm{J}_{66^{\prime}} 11.7 \mathrm{~Hz}, \mathrm{~J}_{56} 3.0 \mathrm{~Hz}\right) ; 3.55\left(1 \mathrm{H}, \mathrm{dd}, \mathrm{H}-3, \mathrm{~J}_{34} 9.7 \mathrm{~Hz}\right) ; 3.54\left(1 \mathrm{H}, \mathrm{dd}, \mathrm{H}-6^{\prime}\right.$, $\left.\mathrm{J}_{56}, 5.9 \mathrm{~Hz}\right) ; 3.29(1 \mathrm{H}, \mathrm{t}, \mathrm{H}-4) ; 2.84\left(1 \mathrm{H}, \mathrm{dd}, \mathrm{H}-1, \mathrm{~J}_{11}, 13.7 \mathrm{~Hz}\right) ; 2.63(1 \mathrm{H}, \mathrm{dd}$, $\left.\mathrm{H}-1^{\prime}\right) ; 2.36(1 \mathrm{H}$, ddd, $\mathrm{H}-5) ; 1.9\left(3 \mathrm{H}, \mathrm{s}, \mathrm{CH}_{3} \mathrm{CO}\right) .{ }^{13} \mathrm{C} \operatorname{NMR}\left(\mathrm{D}_{2} \mathrm{O}\right) \delta 22.08\left(\mathrm{q}, \mathrm{CH}_{3} \mathrm{CO}\right)$ $46.52(t, C-1) ; 50.54(d, C-5) ; 60.74(d, C-2) ; 61.01(t, C-6) ; 68.70,73.03$ $(2 \mathrm{~d}, \mathrm{C}-3,4) ; 174.65\left(\mathrm{~s}, \mathrm{CH}_{3} \mathrm{CO}\right) . \underline{\mathrm{m} / \mathrm{z}}: 217$ (impurity), $205\left(\mathrm{M}+\mathrm{H}^{+}, 100 \%\right)$. Found $\mathrm{C}, 47.2 ; \mathrm{H}, 8.13 ; \mathrm{N}, 13.03 . \mathrm{C}_{8} \mathrm{H}_{16} \mathrm{~N}_{2} \mathrm{O}_{4}$ requires $\mathrm{C} 47.06 ; \mathrm{H} 7.84 ; \mathrm{N} 13.73$.

Methy1- 2- azido- 6- $\underline{0}-$ benzoyl- 3- $\underline{0}-$ benzyl- 2- deoxy- $a-$ D- mannofuranoside (1.37)

Benzoyl chloride $(0.31 \mathrm{~m} 1,1.1$ equivs) was added dropwise, with stirring, to a solution of the azido diol (1.11) (0.76 g, 2.43 mmol) in pyridine ( $7 \mathrm{ml})$. The solution was slowly allowed to warm to room temperature and stirred for $4 \mathrm{~h}$. The mixture was then diluted with dichloromethane $(50 \mathrm{ml})$ and washed successively with hydrochloric acid ( $2 \mathrm{M}$ aq, $2 \times 25 \mathrm{~m} 1)$, water $(50 \mathrm{~m} 1)$ and saturated aqueous sodium bicarbonate solution ( $50 \mathrm{ml})$, dried and evaporated to a syrup which was purified by flash chromatography (ether : hexane, $1: 1$ ) to afford the title compound $(1.37)(0.82 \mathrm{~g}, 81 \%)$ as a colourless syrup which crystallised. m.p $73-74^{\circ} \mathrm{C} .[a]_{\mathrm{D}}^{20}+20.7^{\circ}\left(\mathrm{c}, 0.45, \mathrm{CHCl}_{3}\right) \cdot v_{\max } 2110$, $1725,1360,1270,1180 \mathrm{~cm}^{-1} \cdot 1_{\mathrm{H} \mathrm{NMR}} \delta 8.1-7.3(10 \mathrm{H}, \mathrm{m}, \mathrm{ArH}) ; 4.98(1 \mathrm{H}, \mathrm{s}$, 
$\left.\mathrm{H}-1, \mathrm{~J}_{12} 1.8 \mathrm{~Hz}\right) ; 4.73\left(2 \mathrm{H}, \mathrm{ABq}, \mathrm{PhCH}_{2}\right) ; 4.63\left(1 \mathrm{H}, \mathrm{dd}, \mathrm{H}-6, \mathrm{~J}_{66}, 11.6 \mathrm{~Hz}\right)$; $4.58(1 \mathrm{H}, \mathrm{t}, \mathrm{H}-3) ; 4.44\left(1 \mathrm{H}, \mathrm{dd}, \mathrm{H}-6^{\prime}\right) ; 4.33(1 \mathrm{H}, \mathrm{m}, \mathrm{H}-5) ; 4.16(1 \mathrm{H}, \mathrm{dd}$, $\mathrm{H}-4) ; 3.85(1 \mathrm{H}, \mathrm{dd}, \mathrm{H}-2) ; 3.35\left(3 \mathrm{H}, \mathrm{s}, \mathrm{CH}_{3} \mathrm{O}\right) ; 3.00(1 \mathrm{H}, \mathrm{br} \mathrm{s}, \mathrm{OH}) . \underline{\mathrm{m} / \mathrm{z}}(\mathrm{FD}):$ $414\left(\mathrm{M}+\mathrm{H}^{+}\right)$. Found $\mathrm{C}, 61.5 ; \mathrm{H}, 5.8 ; \mathrm{N}, 9.5 . \mathrm{C}_{21} \mathrm{H}_{23} \mathrm{~N}_{3} \mathrm{O}_{6}$ requires $\mathrm{C}, 61.0$; $\mathrm{H}, 5.6 ; \mathrm{N}, 10.1$.

Methy1- 2- azido- 6- $\underline{0}-$ benzoy1- 3- $\underline{0}-$ benzy1- 2- deoxy- 5- $\underline{0}-$ methanesulphonyl$a-\underline{\underline{D}}-$ mannofuranoside $(1.38)$

Alcohol (1.37) (0.815 g, $1.97 \mathrm{mmol})$ was dissolved in pyridine $(5 \mathrm{~m} 1)$ and stirred at room temperature with methanesulphonyl chloride $(0.19 \mathrm{ml}, 1.5$ equivs). After $4 \mathrm{~h}$ the solution was diluted with dichloromethane (50 $\mathrm{m} 1)$ and washed with hydrochloric acid ( $2 \mathrm{M} \mathrm{aq}, 50 \mathrm{~m} 1)$, water $(50 \mathrm{~m} 1)$ and saturated aqueous sodium bicarbonate solution $(50 \mathrm{ml})$. The organic layer was dried and evaporated to a syrup which was purified by flash chromatography (ether : hexane, $1: 1$ ) affording the title compound (1.38) (0.914 $\mathrm{g}, 94 \%)$ as a clear syrup. $[\sigma]_{\mathrm{D}}^{20}+43.2^{\circ}\left(\underline{\mathrm{c}}, 0.75, \mathrm{CHCl}_{3}\right) . v_{\max } 2110,1720,1360,1270 \mathrm{~cm}^{-1}$. $1_{\mathrm{H} \mathrm{NMR}} \delta 8.1-7.3(10 \mathrm{H}, \mathrm{m}, \mathrm{ArH}) ; 5.37(1 \mathrm{H}, \mathrm{m}, \mathrm{H}-5) ; 5.00\left(1 \mathrm{H}, \mathrm{d}, \mathrm{H}-1, \mathrm{~J}_{12}\right.$ $2.4 \mathrm{~Hz}) ; 4.87\left(1 \mathrm{H}, \mathrm{dd}, \mathrm{H}-6, \mathrm{~J}_{66}, 12.7 \mathrm{~Hz}\right) ; 4.75\left(2 \mathrm{H}, \mathrm{ABq}, \mathrm{PhCH}_{2}\right) ; 4.62(1 \mathrm{H}$, $\left.\mathrm{dd}, \mathrm{H}-6^{\prime}\right) ; 4.47(2 \mathrm{H}, \mathrm{m}, \mathrm{H}-2,3) ; 3.87(1 \mathrm{H}, \mathrm{dd}, \mathrm{H}-2) ; 3.37\left(3 \mathrm{H}, \mathrm{s}, \mathrm{CH}_{3} \mathrm{O}\right)$; $2.98\left(3 \mathrm{H}, \mathrm{s}, \mathrm{CH}_{3} \mathrm{~S}\right) \cdot \underline{\mathrm{m} / \mathrm{z}}(\mathrm{FD}): 492\left(\mathrm{M}+\mathrm{H}^{+}\right) ; 477\left(\mathrm{M}+\mathrm{H}^{+}-\mathrm{Me}\right)$. Found $\mathrm{C}, 53.3 ; \mathrm{H}, 5.1 ; \mathrm{N}, 8.5 . \mathrm{C}_{22} \mathrm{H}_{25} \mathrm{~N}_{3} \mathrm{O}_{8} \mathrm{~S}$ requires $\mathrm{C}, 53.77 ; \mathrm{H}, 5.09 ; \mathrm{N}, 8.55$.

Methy1- 5,6- anhydro- 2- azido- 3- $\underline{0}-$ benzy1- 2- deoxy- $\beta$ - L- gulofuranoside (1.12)

The ester mesylate $(1.38)(0.498 \mathrm{~g}, 1.01 \mathrm{mmol})$ was dissolved in dry DMF ( $7 \mathrm{ml})$ and heated at $50^{\circ} \mathrm{C}$ with sodium methoxide $(0.11 \mathrm{~g}, 2$ equivs). After 5 min t.1.c (ether : hexane, $1: 1$ ) showed complete loss of starting material 
$\left(R_{f} 0.5\right)$ and one product $\left(R_{f} 0.1\right):$ methy1-2-azido-3-0- benzyl-2-deoxy5- 0 - methanesulphony1- $a$ - D- mannofuranoside $(1.39)\left({ }^{1} \mathrm{H}\right.$ NMR $\delta$ 7.5- 7.3 $(5 \mathrm{H}, \mathrm{m}, \mathrm{ArH}) ; 5.02(1 \mathrm{H}, \mathrm{m}, \mathrm{H}-5) ; 4.96\left(1 \mathrm{H}, \mathrm{d}, \mathrm{H}-1, \mathrm{~J} 12^{2.4} \mathrm{~Hz}\right) ; 4.70(2 \mathrm{H}, \mathrm{ABq}$, $\left.\mathrm{PhCH}_{2}\right) ; 4.42(2 \mathrm{H}, \mathrm{m}, \mathrm{H}-3,4) ; 4.12\left(1 \mathrm{H}, \mathrm{dd}, \mathrm{H}-6, \mathrm{~J}_{66}, 12.8 \mathrm{~Hz}\right) ; 3.94(1 \mathrm{H}, \mathrm{dd}$, $\left.\mathrm{H}-6^{\prime}\right) ; 3.86(1 \mathrm{H}, \mathrm{dd}, \mathrm{H}-2) ; 3.37\left(3 \mathrm{H}, \mathrm{s}, \mathrm{CH}_{3} \mathrm{O}\right) ; 3.03\left(3 \mathrm{H}, \mathrm{s}, \mathrm{CH}_{3} \mathrm{~S}\right) ; 2.17(1 \mathrm{H}$, br $s, \mathrm{OH})$. ). Heating for a further $3 \mathrm{~h}$ resulted in the formation of a second product $\left(R_{f} 0.7\right)$ and loss of the initial alcohol. The solvent was removed and the mixture partitioned between water $(20 \mathrm{ml})$ and chloroform $(20 \mathrm{ml})$. The organic layer was dried and evaporated to a syrup which was purified by flash chromatography (ether : hexane, $1: 2$ ) affording the title compound (1.12) (254 mg, 82\%) as a colourless syrup. $[a]_{D}^{20}+19.5^{\circ}$ (c, 0.58 , $\left.\mathrm{CHCl}_{3}\right) \cdot v_{\max } 2110 \mathrm{~cm}^{-1} \cdot 1_{\mathrm{H} N M R} \delta 7.5-7.3(5 \mathrm{H}, \mathrm{m}, \mathrm{ArH}) ; 4.98(1 \mathrm{H}, \mathrm{d}, \mathrm{H}-1$, $\left.\mathrm{J}_{12} 1.2 \mathrm{~Hz}\right) ; 4.65\left(2 \mathrm{H}, \mathrm{ABq}, \mathrm{PhCH}_{2}\right) ; 4.47(1 \mathrm{H}, \mathrm{dd}, \mathrm{H}-3) ; 3.88(1 \mathrm{H}, \mathrm{dd}, \mathrm{H}-2)$; $3.69(1 \mathrm{H}, \mathrm{t}, \mathrm{H}-4) ; 3.36\left(3 \mathrm{H}, \mathrm{s}, \mathrm{CH}_{3} \mathrm{O}\right) ; 3.33(1 \mathrm{H}, \mathrm{m}, \mathrm{H}-5) ; 2.84(1 \mathrm{H}, \mathrm{t}, \mathrm{H}-6)$; $2.51\left(1 \mathrm{H}, \mathrm{dd}, \mathrm{H}-6^{\prime}\right) . \underline{\mathrm{m} / \mathrm{z}}(\mathrm{FD}): 292\left(\mathrm{M}+\mathrm{H}^{+}\right), 263\left(\mathrm{M}+\mathrm{H}^{+}-\mathrm{N}_{2}\right)$.

$\operatorname{Methy1}(\underline{\mathbb{N}}-$ benzyloxycarbony1- 3- $\underline{0}-$ benzy1-2,5- dideoxy - 2,5- imino ) $a-$

$\underline{\underline{D}-\text { mannofuranoside }(1.40)}$

Azido epoxide (1.12) (254 mg, $0.87 \mathrm{mmol}$ ) was dissolved in ethanol (10 m1) and hydrogenated at atmospheric pressure with palladium black (30 mg). After $1 \mathrm{~h}$ all the azide had been reduced and the catalyst was filtered. The solution was then heated at $50^{\circ} \mathrm{C}$ for $5 \mathrm{~h}$. The solvent was removed and the crude product dissolved in ether : saturated sodium bicarbonate solution (5 : 2) (15 ml) and vigorously stirred with benzyl chloroformate $(0.25 \mathrm{~m} 1$, 2 equivs) at room temperature for $2 \mathrm{~h}$. The two layers were separated and the aqueous phase washed with ether $(2 \times 10 \mathrm{ml})$. The organic extracts were combined, dried and evaporated to a syrup which was purified by flash 
chromatography (ether : hexane, $1: 1$ ) affording two products. The first : methy1-2- benzyloxycarbonylamino- 3- 0 - benzy1- 2,6- dideoxy- $\beta$ - L- gulofuranoside (1.41) (84 mg, 24\%), a syrup. ${ }^{1} \mathrm{H}$ NMR $\delta 7.4-7.3$ (10H, m, ArH); $6.0(1 \mathrm{H}$, br d, $\mathrm{NH}) ; 5.1\left(2 \mathrm{H}, \mathrm{ABq}, \mathrm{PhCH}_{2}\right) ; 4.9(1 \mathrm{H}, \mathrm{s}, \mathrm{H}-1) ; 4.5(2 \mathrm{H}, \mathrm{ABq}$, $\left.\mathrm{PhCH}_{2}\right) ; 4.6(1 \mathrm{H}, \mathrm{m}, \mathrm{H}-3) ; 4.4(1 \mathrm{H}, \mathrm{m}, \mathrm{H}-4) ; 4.1(1 \mathrm{H}, \mathrm{br} \mathrm{m}, \mathrm{H}-5) ; 3.95(1 \mathrm{H}$, $\mathrm{dd}, \mathrm{H}-2) ; 3.3\left(3 \mathrm{H}, \mathrm{s}, \mathrm{CH}_{3} \mathrm{O}\right) ; 2.6(1 \mathrm{H}$, br s, OH $) ; 1.2\left(3 \mathrm{H}, \mathrm{d}, \mathrm{CH}_{3}\right) . \underline{\mathrm{m} / \mathrm{z}}:$ $419\left(\mathrm{M}+\mathrm{NH}_{4}^{+}\right), 402\left(\mathrm{M}+\mathrm{H}^{+}\right), 370\left(\mathrm{M}+\mathrm{H}^{+}-\mathrm{OMe}\right)$. and the lower, the title compound $(1.40)(149 \mathrm{mg}, 43 \%)$ a syrup. $[a]_{\mathrm{D}}^{20}+10.6^{\circ}\left(\underline{c}, 0.52, \mathrm{CHC1}_{3}\right)$.

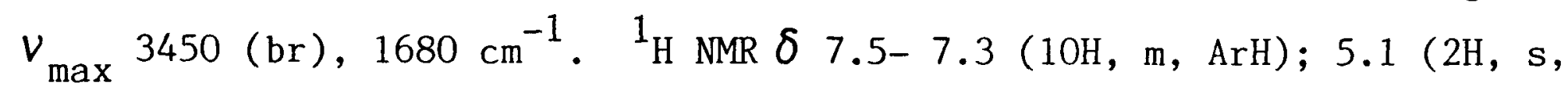
$\left.\mathrm{PhCH}_{2}\right) ; 4.8(1 \mathrm{H}, \mathrm{s}, \mathrm{H}-1) ; 4.8-4.2(5 \mathrm{H}, \mathrm{m}) ; 4.1(1 \mathrm{H}, \mathrm{dd}, \mathrm{H}-3) ; 3.9(2 \mathrm{H}, \mathrm{m}$, $\left.\mathrm{H}-6,6^{\prime}\right) ; 3.3\left(3 \mathrm{H}, \mathrm{s}, \mathrm{CH}_{3} \mathrm{O}\right) ; 1.8(1 \mathrm{H}, \mathrm{br} \mathrm{s}, \mathrm{OH}) . \underline{\mathrm{m} / \mathrm{z}}: 400\left(\mathrm{M}+\mathrm{H}^{+}, 100 \%\right)$, 356,306 . Found $\mathrm{C}, 66.10 ; \mathrm{H}, 6.60 ; \mathrm{N}, 4.02 . \mathrm{C}_{22} \mathrm{H}_{25} \mathrm{NO}_{6}$ requires $\mathrm{C}, 66.17$; $\mathrm{H}, 6.27 ; \mathrm{N}, 3.51$.

N- benzyloxycarbony1-3- $\underline{0}-$ benzy1- 2,5- dideoxy- 2,5- imino- D- mannitol (1.42)

Bicyclic acetal (1.40) (24 mg, $0.06 \mathrm{mmol})$ was dissolved in $50 \%$ aqueous trifluoroacetic acid $(1 \mathrm{~m} 1)$ and stirred at room temperature for $15 \mathrm{~min}$. The solvent was removed and the resulting syrup dissolved in ethanol ( $2 \mathrm{~m} 1)$. Sodium borohydride (10 $\mathrm{mg}$, excess) in water $(1 \mathrm{~m} 1)$ was added, and the solution stirred at room temperature until effervescence ceased (10 min). The reaction was quenched by the addition of excess ammonium chloride, the solvent was removed and the residue partitioned between chloroform $(10 \mathrm{~m} 1)$ and water (10 $\mathrm{m} 1$ ). The chloroform layer was dried and evaporated to a syrup, which was purified by flash chromatography (ethyl acetate : hexane, $2: 1$ ), to afford the title compound $(1.42)(17 \mathrm{mg}, 73 \%)$ as a syrup. $\nu_{\max } 3500-3300,1680 \mathrm{~cm}^{-1}$. ${ }^{1}$ H NMR $\delta 7.35-7.3(10 \mathrm{H}, \mathrm{m}, \mathrm{ArH}) ; 4.65\left(2 \mathrm{H}, \mathrm{ABq}, \mathrm{PhCH}_{2}\right) ; 5.1-4.0(10 \mathrm{H}, \mathrm{m})$; $3.9-3.7(2 \mathrm{H}, \mathrm{m}, \mathrm{H}-2,5) ; 2.1(1 \mathrm{H}$, br s, OH $)$. 
2,5- Dideoxy- 2,5- imino- D- mannitol (1.8)

Protected pyrrolidine (1.42) (29.6 mg, $0.076 \mathrm{mmol})$ was dissolved in glacial acetic acid( $5 \mathrm{ml})$ and stirred under hydrogen with palladium black $(5 \mathrm{mg})$. After $13 \mathrm{~h}$ the solvent was removed and the catalyst filtered, affording the title compound as the acetate salt $\left({ }^{1} \mathrm{H}\right.$ NMR $\delta 3.9(2 \mathrm{H}, \mathrm{dt}, \mathrm{H}-3,4) ; 3.8,3.7$ $\left.\left(4 \mathrm{H}, 2 \mathrm{dd}, \mathrm{H}-1,1^{\prime}, 6,6^{\prime}\right) ; 3.4(2 \mathrm{H}, \mathrm{m}, \mathrm{H}-2,5) ; 1.9\left(3 \mathrm{H}, \mathrm{s}, \mathrm{CH}_{3} \mathrm{COO}\right).\right)$. Purification by ion exchange chromatography (procedure 1) gave the title compound (1.8) as the free base $(9.1 \mathrm{mg}, 70 \%)$, which was a highly hygroscopic gum. $[a]_{\mathrm{D}}^{20}+53.8^{\circ}\left(\underline{\mathrm{c}}, 0.32 \mathrm{H}_{2} 0\right)\left(1 \mathrm{it}^{17}[a]_{\mathrm{D}}^{20}+56.4^{\circ}\left(\underline{c}, 7, \mathrm{H}_{2} 0\right) .{ }_{\mathrm{H} \mathrm{NMR}}\right.$ $\left(\mathrm{D}_{2} \mathrm{O}\right) \delta 3.9(2 \mathrm{H}, \mathrm{dt}, \mathrm{H}-3,4) ; 3.6,3.5\left(4 \mathrm{H}, 2 \mathrm{dd}, \mathrm{H}-1,1^{\prime}, 6,6^{\prime}\right) ; 3.0(2 \mathrm{H}, \mathrm{m}$, $\mathrm{H}-2,5) . \underline{\mathrm{m} / \mathrm{z}}: 164\left(\mathrm{M}+\mathrm{H}^{+}, 100 \%\right), 132$. 


\section{SUMMARY}

The highly divergent intermediates methyl (N- benzyloxycarbonyl and $\underline{N}$ - $\underline{-}$-butyloxycarbony1-3- $\underline{0}-$ benzy1-2,6- dideoxy-2,6- imino)- $a$ - D-mannofuranoside (1.10a and b) were synthesised from diacetone glucose in 10 steps and converted to a series of polyhydroxylated piperidines (1.1)- (1.7). In addition, the pyrrolidine alkaloid (1.8) was prepared from the azido diol (1.11).<smiles>CC1(C)OCC(C2OC3OC(C)(C)OC3C2O)O1</smiles>

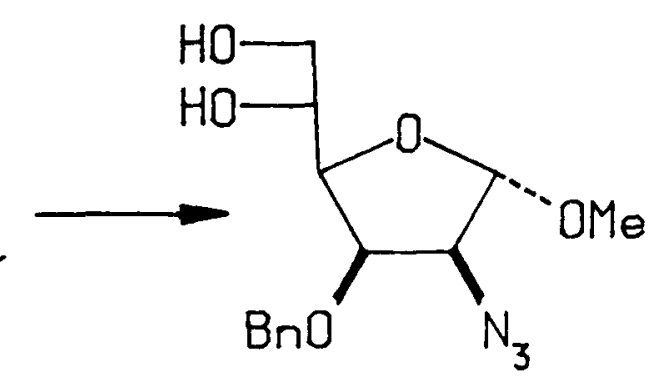

(1.11)

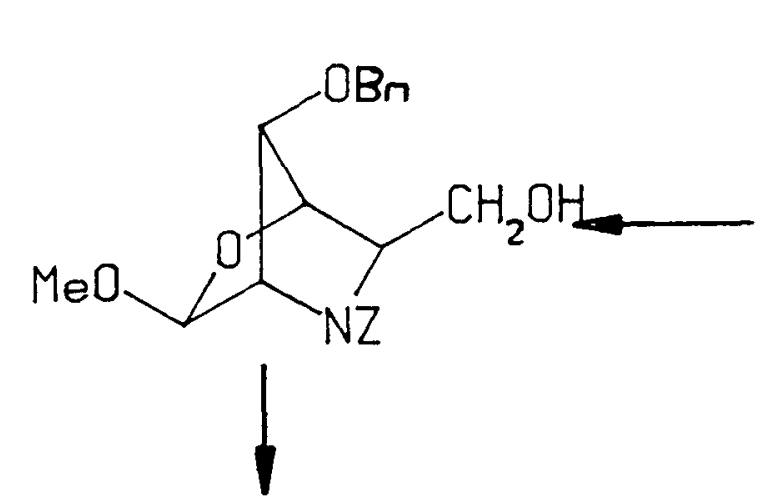<smiles>OCC1NC(CO)C(O)C1O</smiles>

$\mathrm{H}$<smiles>[CH2]C1OC(C2CO2)C(O)C1[Hg]</smiles><smiles>OCC1NCC(O)C(O)C1O</smiles>

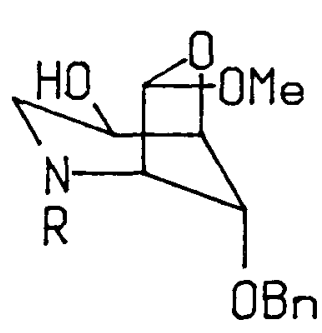<smiles>OCC1NCCC(O)C1O</smiles>

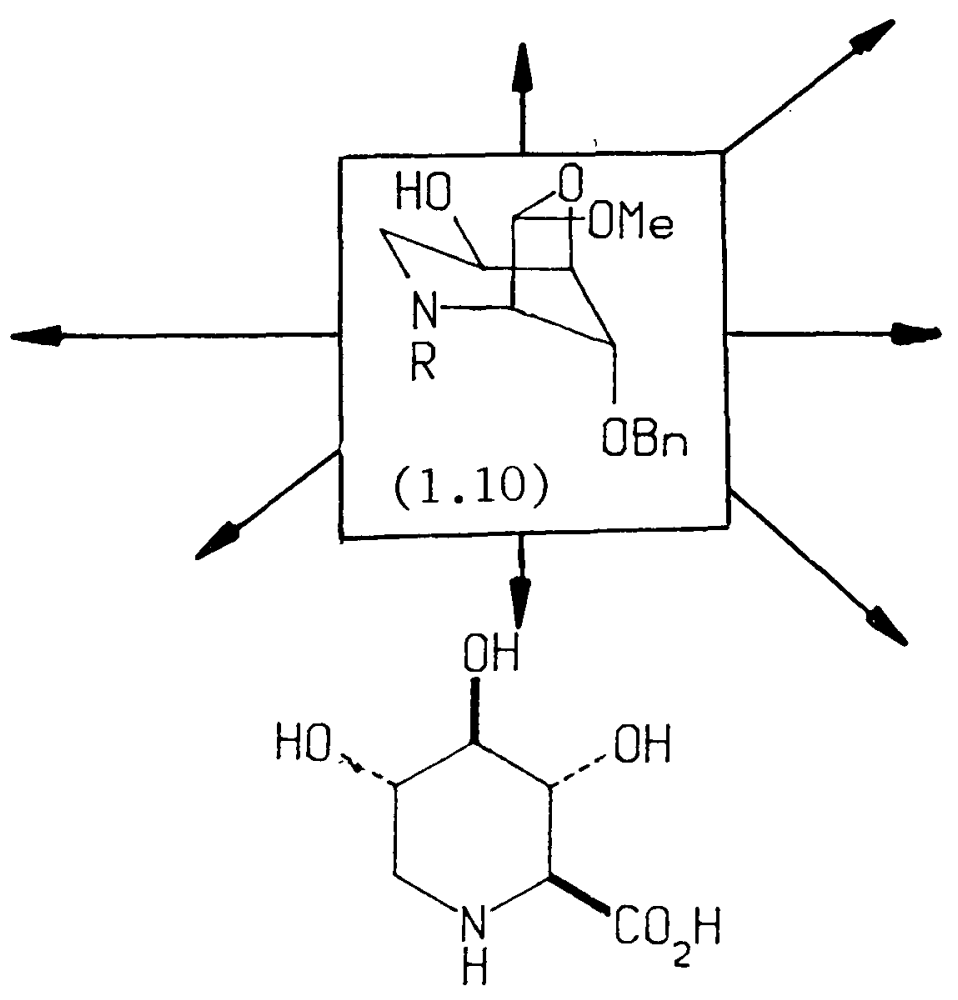<smiles>O=C(O)C1NCC(O)C(O)C1O</smiles><smiles>OCC1NC[C@H](CO)C(O)[C@H]1O</smiles><smiles>OC[C@H]1NC[C@@H](O)[C@H](O)[C@H]1O</smiles> 


\section{CHAPTER 1 REFERENCES}

1. L.E. Fellows, E.A. Be11, D.G. Lynn, F. Pilkiewicz, I. Miura and

K. Nakanish. J. Chem.Soc. Chem. Commun., 1979,977

2. M. Koreeda, N. Harada \& K. Nakanish, J. Chem. Soc. Chem. Commun., 1969,548: N. Harada, H. Sato and K. Nakanish, Ibid 1970,1691: N. Harada and K. Nakanish, Acc.Chem. Res. 1972, ㅁ, 257

3. U. Fuhrmann, E. Bause, G. Legler and H. Ploegh, Nature 1984, 307, 755.

4. G. Legler and E. Julich, Carbohydr. Res. 1984, 128, 61

5. M. Koyama and S. Sakamura. Agric. Biol. Chem. 1974, 38, 1111.

6. L.E. Fellows, A.R. Hayman, S.V.Evans, T.K.M. Shing, A.E. Derome and G.W.J. Fleet, Tetrahedron Lett 1985, 26, 1465.

7. A.M. Schofield, L.E. Fellows, R.J. Nash and G.W.J. Fleet, Life Sciences $1986, \underline{39}, 645$.

8. S. Inouye, T. Tsuruoka, T. Ito and T. Niida, Tetrahedron 1968, 24, 2125.

9. D.D. Schmidt, W. Frommer, L. Muller and E. Truscheit Naturwissenschaften $1979, \underline{66}, 585$

10. M. Yagi, T. Kuono, Y. Aoyagi and H. Murai, Nippon Nogei Kagu Kaishi $1976, \underline{50}, 570$ (Chem. Abs $\underline{86}, 167851$ )

11. T. Niwa, S. Inouye, T. Tsuruoka, Y. Koaze and T. Niida, Agric. Biol. Chem. 1970, 34, 966; E.T. Reese, F.W. Parish \& E. Ettlinger, Carbohydr. Res. $1971, \underline{18}, 381$.

12. S. Murao and S. Miyata, Agric. Biol. Chem. 1980, 44, 219.

13. K.S. Manning, D.G. Lynn, J.Shabanowitz, L.E. Fellows, M. Singh and B.D. Schrire, J. Chem. Soc.Chem. Commun 1985, 127.

14. R.C. Bernotas and B. Ganem, Tetrahedron Lett 1985, 26, 4981.

15. P. Bashyal, H.F. Chow and G.W.J. Fleet, Tetrahedron Lett 1986, 27, 3205.

16. I.C. diBe1lo, P. Dorling, L. Fellows and B. Winchester, FEBS Lett, 1984, $\underline{176}, 61$. 
17. A. Walter, G. Dardene, M. Marlier and J. Casimir, Phytochem 1976, $\underline{25}, 747$.

18. L.E. Fellows, S.V. Evans, R.J. Nash and E.A. Bell in Natura1

Resistance of plants to pests and diseases, eds M.B. Green and P.A. Hedin, ACS Symposium series 296, p 72-78 (1986). S.V. Evans and L.E. Fellows, Phytochemistry, 1986 in press

19. A.D. Elbein, M. Mitche11, L.E. Fellows and S.V. Evans, J. Biol.Chem. $1984, \underline{259}, 12409$.

20. K. Leontein, B. Lindberg and J. Lonngren. Acta Chem. Scand Ser B $1982, \underline{36}, 515$.

21. G. Kinast and M. Schede1, Angew Chem. Int.Ed. Eng1.1981, 20, 805.

22. G. Legler and E. Julich, Carbohydr. Res. 1984, $128,61$.

23. G.W.J. Fleet, M.J. Gough and T.K.M. Shing, Tetrahedron Lett 1984, 25, 4029.

24. H. Paulsen, I. Sangster and K. Heyns, Chem. Ber. 1967, 100, 802.

25. H. Saeki and E. Ohki, Chem. Pharm. Bu11, 1968, 16, 2477.

26. R.C. Bernotas and B. Ganem, Tetrahedron Lett, 1984, 25, 161.

27. A. Vasella and R. Voeffray, Helv. Chim. Acta., 1982, 65, 1134.

28. P.J. Card and W.D. Hitz, J. Org. Chem., 1985, 50, 891.

29. M. Chmielewski and R.L. Whistler, J. Org. Chem., 1975, 40, 639.

30. V.D. Gusev, T.K. Mitrofanova and R.P. Evstigneeva, Khim. Prir. Soedin 1972, 8, 8; H. Saeki, T. Iwashige and E. Ohki, Chem. Pharm. Bull, 1968, $\underline{16}, 1040$.

31. A.C. Richardson, Carbohydr. Res. 1969, 10, 395.

32. For example, V.K. Iyer, J.P. Horwitz, J. Org. Chem. 1982, 47, 644;

T.J. Tewson, M.J. Welch, M.E. Raichle, J. Nucl. Med., 1979, 19, 1339;

T.J. Tewson, J. Org. Chem. 1983, 48, 3507; G.W.J. Fleet and T.K.M.Shing, J. Chem. Soc. Chem. Commun. 1983, 849; R.D. Howe1ls \& J.D. McCown, 
Chem. Rev., 1977, 77, 69; P.J. Story, M. Hanack and L.R. Subramanian, Synthesis 1982,85 .

33. M. Miljkovic, M. Gligorijevic and D. Glisin, J. Org. Chem., 1974, 39, 3223 .

34. Y. Ishido and N. Sakairi, Carbohydr. Res., 1981, 97, 151.

35. A. Brandstrom, B. Lamm and I. Palmertz, Acta Chem. Scand., 1974, 288,699.

36. H.S. Isbe11 'Methods in carbohydrate chemistry' vol. II (Academic Press) p13, 1963.

37. E. Babad and D. Ben-Ishai, J. Heterocycl. Chem. 1969, ㅁ, 235.

38. I am indebted to L.E. Fellows, S.V. Evans and R.J. Nash for their considerable technical assistance with this technique.

39. H.C. Brown and S. Krishnamurthy, J. Amer. Chem. Soc. 1973, 95, 1669.

40. W. Hartwig, Tetrahedron, 1983, 39, 2609, DHR Barton and S.W. McCrombie, J. Chem. Soc. Perkin I. 1975, 1574. D.H.R. Barton and W.B. Motherwell, Pure App1. Chem. 1981, 53, 15.

41. E.M. Acton, R.N. Goerner, H.S. Uh, K.J. Ryan, D.W. Henry, C.E. Cass and G.A. LePage, J. Med. Chem. 1979, 22, 518.

42. J.S. Brimacombe, A.S. Mengech and M.S. Saeed, Carbohydr. Res. 1979, 75, C5.

43. M.J. Robbins, J.S. Wilson and F. Hansske, J.Amer. Chem. Soc. 1983, 105, 4059.

44. H.G. Kuivila, Synthesis, $1970,499$.

45. H.G. Kuivila and L.W. Menapace, J. Org. Chem., 1963, 28, 2165.

46. G. Piancate1li, A. Scettri and M. D'Auria, Synthesis, 1982, 245.

47. R.J. Bernacki, M.J. Niedbala and W. Korytnyk, Cancer Metastatis Rev. $1985,4,81$.

48. R. Csusk and B.I. Glanzer, J. Chem. Soc. Chem. Commun., 1986, 343.

49. H. Suzuki and K. Takoaka, Chem. Lett, 1984, 1733

50. J.K. Thottathil and J.L. Moniot, Tetrahedron Lett 1986, 27, 151. 
51. G.W.J. Fleet and C.J. Murphy, unpublished results.

52. G.W.J. Fleet, P.W. Smith, R.J. Nash, L.E. Fellows, R.B. Parekh and T.W. Rademacher, Chem. Lett, 1986, 1051.

53. All biological tests described in this thesis were performed by L.E. Fellows et.al., Jodrell Laboratory, Royal Botanic Gardens, Kew, or at the Biochemistry Department, Oxford University.

54. K. Yamashita, T. Ohkura, H. Yoshima and A. Kobata, Biochem. Biophys.

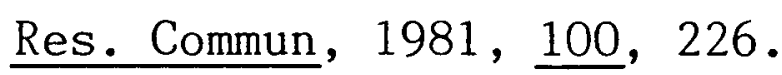

55. J.E. Baldwin, J. Chem. Soc. Chem. Commun. 1976, 734.

56. H. Ohrui and H. Kuzuhara, Agric. Biol. Chem. 1980, 44, 907.

57. G.W.J. Fleet, C.J. Matthews, H.F. Chow - unpublished results.

58. I am grateful to Dr. L.E. Fellows for providing authentic samples of all natural products in this chapter.

59. W.C. Still, M. Kahn and A. Mitra, J. Org. Chem., 1978, 43, 2923.

60. L.M. Harwood, Aldrichimica Acta, 1985, 18, 25.

61. D.D. Perrin, W.L.F. Armarego and R.D. Perrin 'Purification of Laboratory chemicals', Pergammon, 1966.

62. A.S. Meyer and T. Reichstein, Helv. Chim. Acta, 1946, 29, 156. 


\section{APPROACHES TO THE SYNTHESIS OF POLYHYDROXYLATED NITROGEN HETEROCYCLES}

FROM D- GLUCOSE PART II. INTRODUCTION OF NITROGEN AT C3.

\section{INTRODUCTION}

This chapter describes the synthesis of:-

i) The pyrrolidine alkaloids: 1,4-dideoxy-1,4-imino-L-gulitol (2.1), 1,4-dideoxy-1,4-imino-D-1yxitol (2.2) and 2S, 3S, 4R dihydroxyproline (2.3).

ii) The indolizijne alkaloid ( $1 S, 2 R, 8 S, 8 a R)-1,2,8$ - trihydroxyoctahydroindolizine (2.4).

iii) The pyrrolizidine alcohol (1S, 2R, 8R)-1,2- dihydroxy pyrrolizidine (2.5) and approaches to the synthesis of crotanecine (2.6) (fig 2.1).<smiles>OCC(O)C1NCC(O)C1O</smiles>

$(2 \cdot 1)$

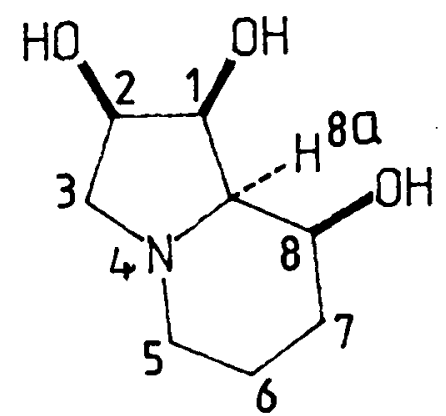

$(2.4)$<smiles>OC[C@H]1NCC(O)C1O</smiles>

$(2 \cdot 2)$

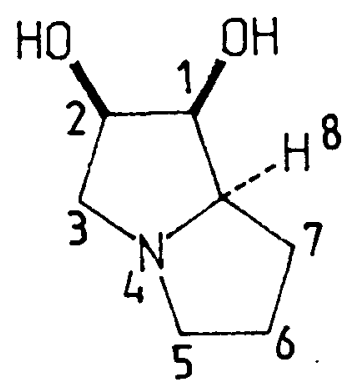

$(2.5)$<smiles>O=C(O)C1NCC(O)C1O</smiles>

$(2 \cdot 3)$

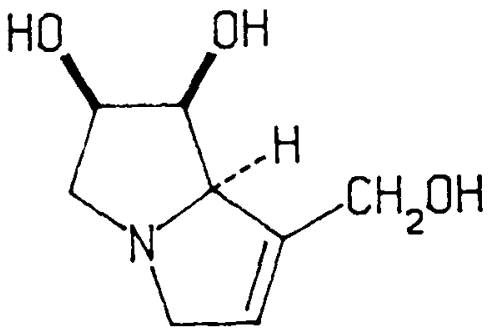

$(2.6)$

\section{FIG 2.1}

For convenience and clarity in discussion and NMR assignments, all compounds with the indolizjine skeleton are numbered according to the system used for (2.4) in fig 2.1. Likewise all pyrrolizidine intermediates containing the same diol unit are numbered in exactly the same way as (2.5) in fig 2.1 . 
Occurrence, biological action and previous syntheses.

i) The pyrrolidine alkaloids (2.1) and (2.2) are both natural product analogues synthesised as potential g1ycosidase inhibitors. The natura1 product 1,4-dideoxy-1,4-imino-D-arabinitol (2.7 and 4.1), epimeric with (2.2) at $\mathrm{C} 3$ is a potent glucosidase inhibitor (chapter 4) and the synthetic 1,4-dideoxy-1,4-imino-D-mannitol (2.8), epimeric with (2.1) at C5 is a potent mannosidase inhibitor ${ }^{1,2}$.

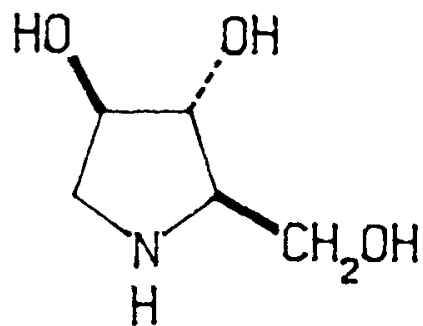

$(2.7)$

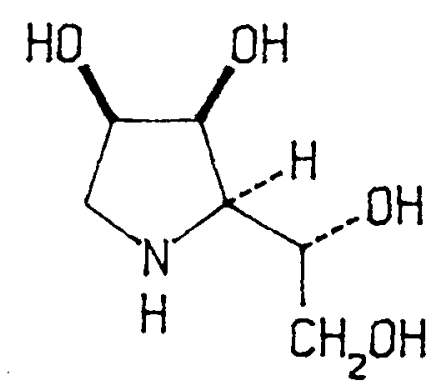

$(2.8)$

ii) The Dihydroxy proline (2.3) was made in order to confirm the stereochemistry of the dihydroxy-proline synthesised in chapter 5. (2.3) is not a naturally occurring compound, but some dihydroxy prolines are known in nature (chapter 5).

iii) The indolizidine alkaloid (2.4) was synthesised as a potential glycosidase inhibitor. There are 2 naturally occurring indolizidine alkaloids which are known to be potent glycosidase inhibitors. Castanospermine (2.9) inhibits $\alpha$ and $\beta$ glucosidases ${ }^{3}$ and swainsonine $(2.10)^{4}$, which is epimeric with (2.4) at $\mathrm{C} 8$, is a potent mannosidase inhibitor ${ }^{5}$.<smiles>OC1CCN2C[C@H](O)C(O)[C@H](O)[C@H]12</smiles>

$(2 \cdot 9)$<smiles>OC1CCCN2C[C@@H](O)[C@H](O)[C@H]12</smiles>

$(2 \cdot 10)$ 
The syntheses of swainsonine ${ }^{6}$ and its epimers ${ }^{7}$ have received considerable recent attention with several of the syntheses starting from carbohydrates.

(2.4) has been synthesised from $\underline{D}-g l u c o s e{ }^{7}$, but in a very low overall yield (Scheme 2.1).

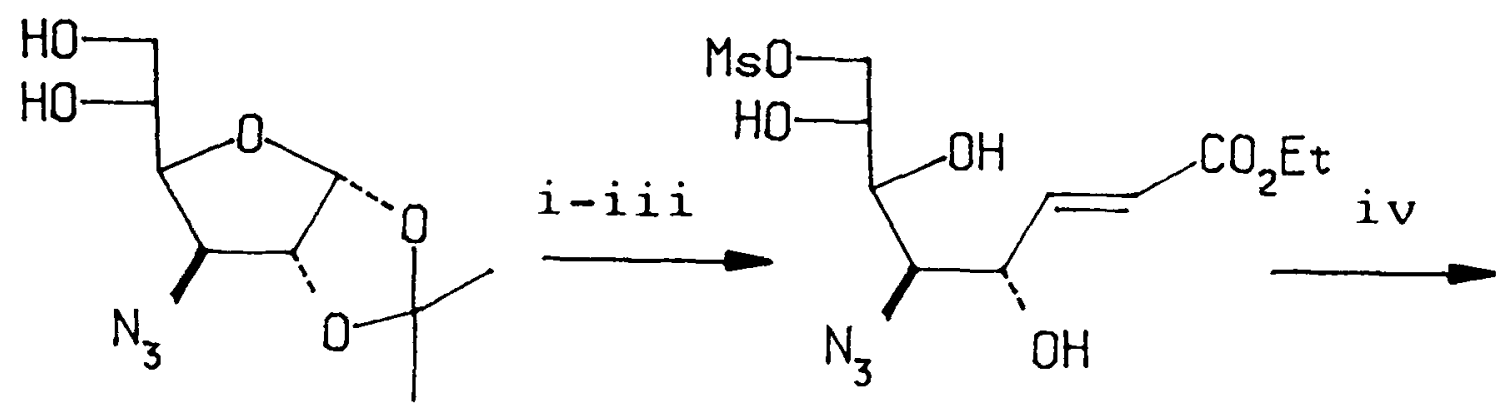

i) $\mathrm{MSCl}$ ii) aq TFA iii) $\mathrm{Ph}_{3} \mathrm{PCHCO}_{2} \mathrm{Et}$ ( $8 \%$ yield)

iv) $\mathrm{H}_{2}, \mathrm{Pd}$, $\mathrm{MeOH}(36 \%$ yield) v) TBDMS-Cl

vi) $\mathrm{H}_{3} \mathrm{~B}$ SMe 2 vii) $\mathrm{H}_{3} \mathrm{O}^{+}$(8\% yield)

\section{SCHEME 2.1}<smiles>O=C1CC[C@@H](O)[C@H]2[C@H](O)[C@H](O)CN12</smiles>

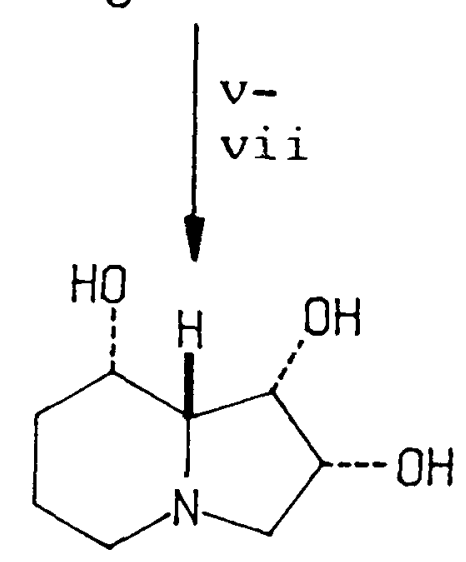

$(2.4)$

iv) The pyrrolizidine alcohols (2.5) and(2.6)

The diol (2.5) is a new pyrrolizidine alcohol but crotanecine (2.6) is a natural product obtained by alkaline hydrolysis of two pyrrolizidine alkaloids.

The pyrrolizidine alkaloids are a large and important group of natural products which have been isolated from a variety of plant sources (compositae, boraginaceae, 1eguminosae). They are usually composed of two moieties - a pyrrolizidine alcohol and a carboxylic (usually hydroxy) acid, which are combined by an ester linkage ${ }^{8}$. The pyrrolizidine alcohol portion is derived in vivo from two molecules of ornithine (2.11) (Scheme 2.2). 


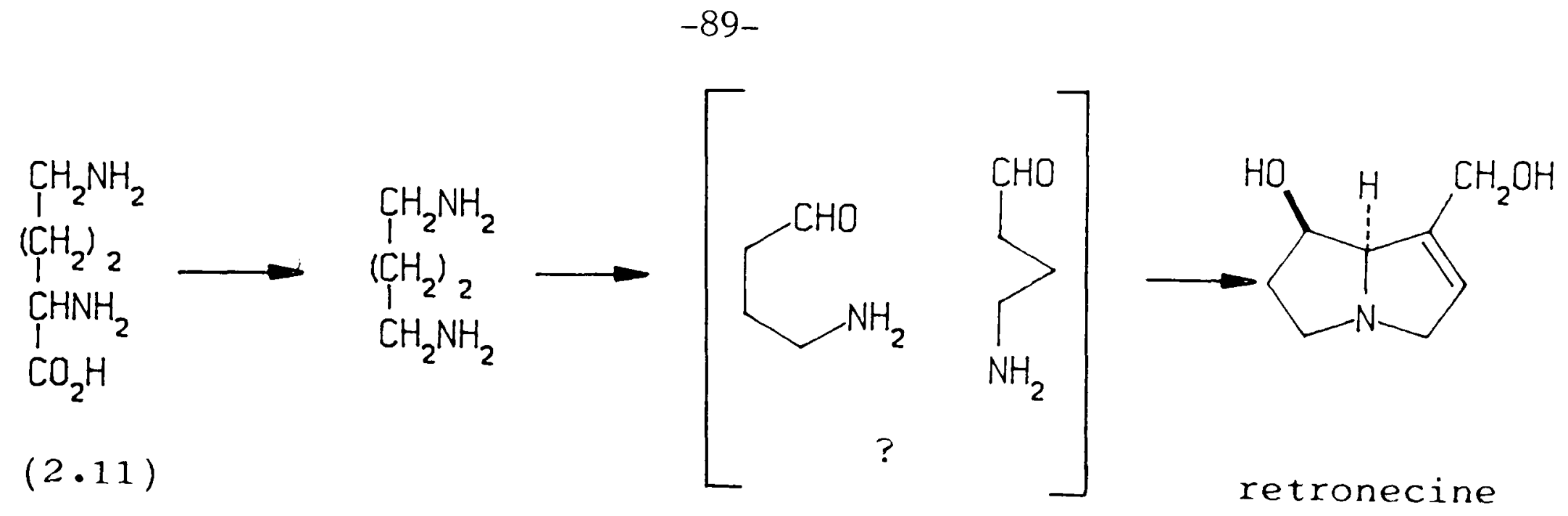

SCHEME 2.2

Evidence for this has been obtained by feeding ${ }^{14} \mathrm{C}$ labelled ornithine to several plants and isolating labelled pyrrolizidines ${ }^{9}$.

The naturally occurring pyrrolizidine alcohols are illustrated in fig. 2.2.

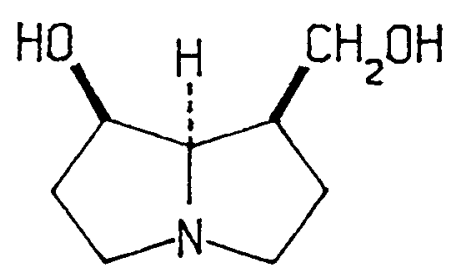

platynecine

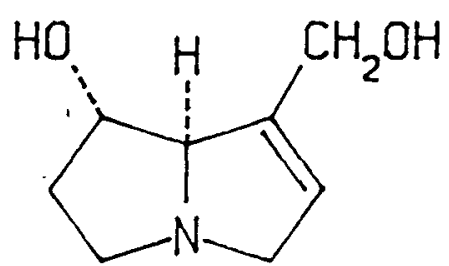

heliotridine

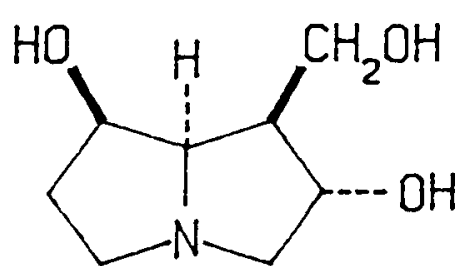

rosmarinecine

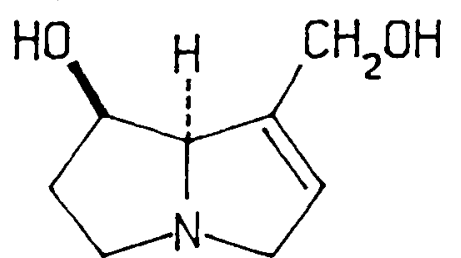

retronecine

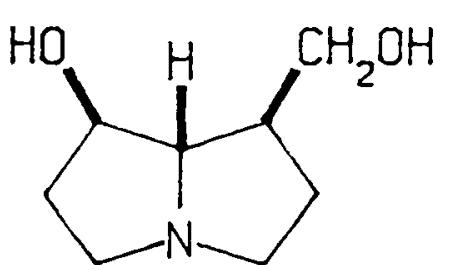

hastanecine

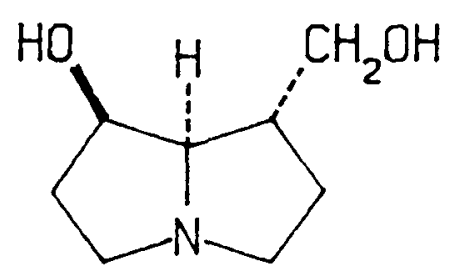

turneforcidine

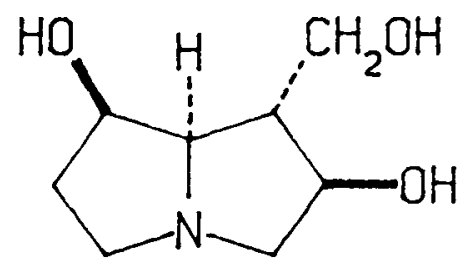

croalbinecine

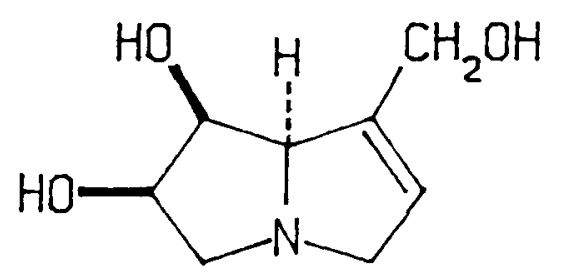

crotanecine

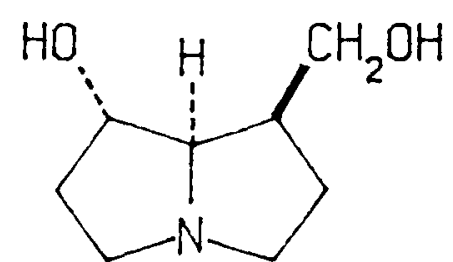

dihydroxy heliotridine

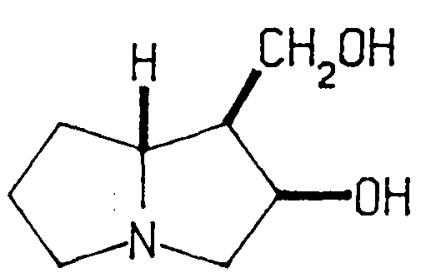

macronecine

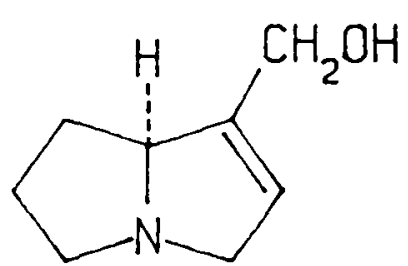

supinidine 
Recently, a new pyrrolizidine alkaloid uspallatine containing a pyrrolizidine alcohol (2.12), epimeric with crotanecine, has been isolated from senecio uspallatensis $^{10}$.

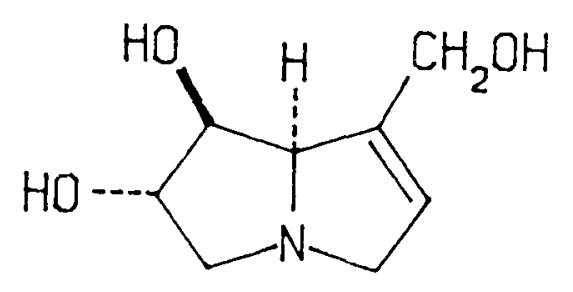

$$
(2 \cdot 12)
$$

The antitumour activity of the pyrrolizidine alkaloids has been recognised for about 20 years $^{11}$ and consequent1y there has been considerable interest in the synthesis of the corresponding pyrrolizidine alcohols. Many different methods for constructing the pyrrolizidine nucleus have been successful ${ }^{12}$. The presence of several contiguous chiral centres makes the use of carbohydrates inviting. However the problem is to introduce the carbon branching. In a recent synthesis of (-) - rosmarinecine from D-glucosamine, this was overcome by a skeletal rearrangement early in the synthesis (Scheme 2.3$)^{13}$. 


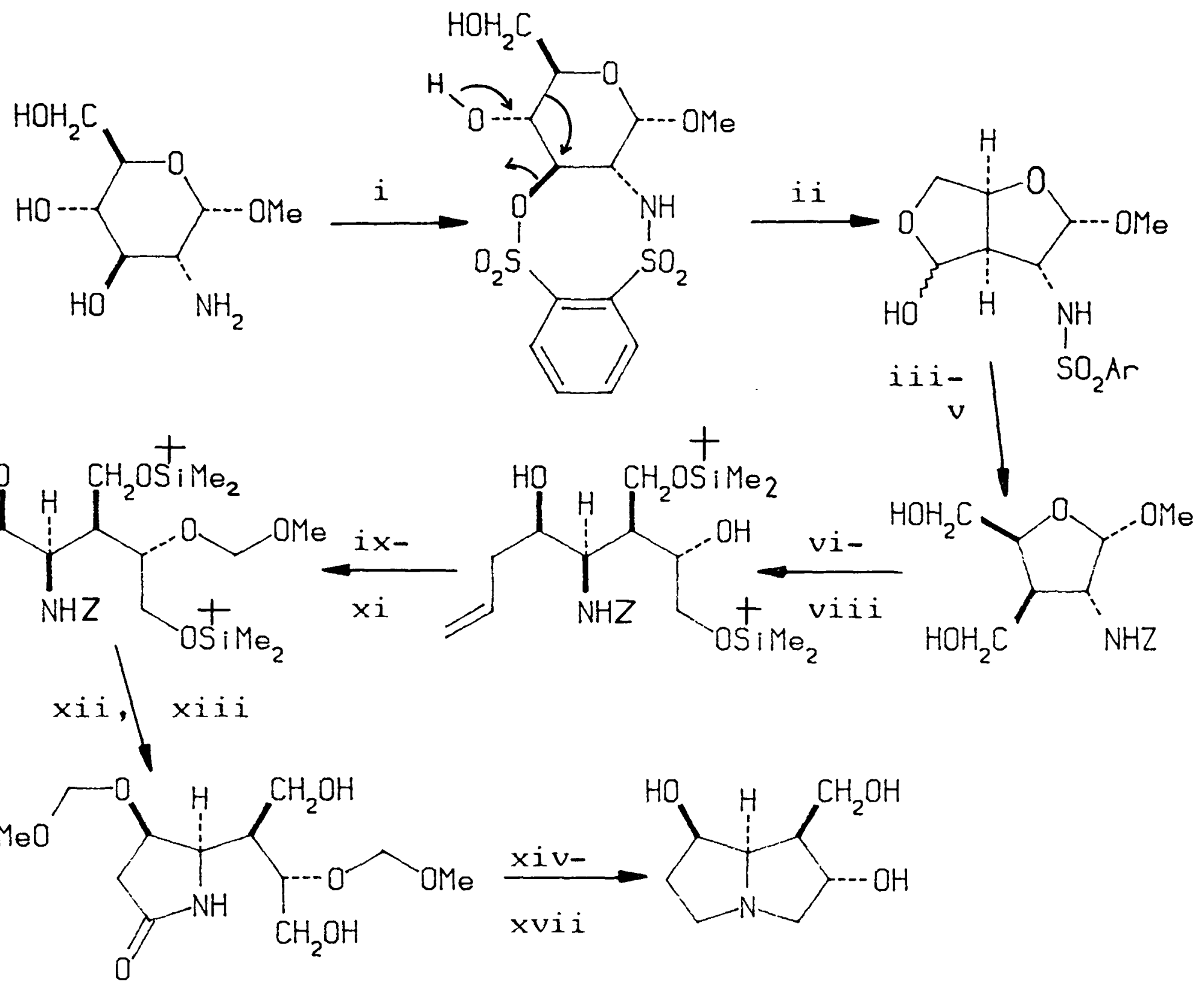

i) o- $\left.-\mathrm{C}_{6} \mathrm{H}_{4}\left(\mathrm{SO}_{2} \mathrm{Cl}\right)_{2} \mathrm{ii}\right) \mathrm{NaOMe} 82 \%$ iii) Li, $\left.\mathrm{NH}_{3} \mathrm{iv}\right) \mathrm{Z}-\mathrm{Cl}$ v) $\mathrm{NaBH}_{4}$ vi) $\mathrm{H}_{3} \mathrm{O}^{-1}$ vii) TBDMS-Cl viii) $\mathrm{CH}_{2}=\mathrm{CH} . \mathrm{CH}_{2} \mathrm{MgBr}$ ix) $\mathrm{NaIO}_{4}, \mathrm{KMnO}_{4}, \mathrm{OH}^{-} \times \mathrm{CH}_{2} \mathrm{~N}_{2}$ xi) $\left.\left.\left.\mathrm{MeO} \cdot \mathrm{CH}_{2} \cdot \mathrm{Cl} \times \mathrm{ii}\right) \mathrm{H}_{2} \times \mathrm{iii}\right) \mathrm{F}^{-} \times \mathrm{iv}\right) \mathrm{MeO} \cdot \mathrm{CH}_{2} \cdot \mathrm{Cl}$, then separate xv) $\left.\mathrm{MsCl} \times \mathrm{xi}) \mathrm{BH}_{3} \cdot \mathrm{Me}_{2} \mathrm{~S} \times \mathrm{xii}\right) \mathrm{H}_{3} \mathrm{O}^{+}$

\section{SCHEME 2.3}

The problem of introducing the carbon branch is not as acute in the dehydro series and retronecine was recently synthesised in a long sequence from D-glucose ${ }^{14}$ (Scheme 2.4). 

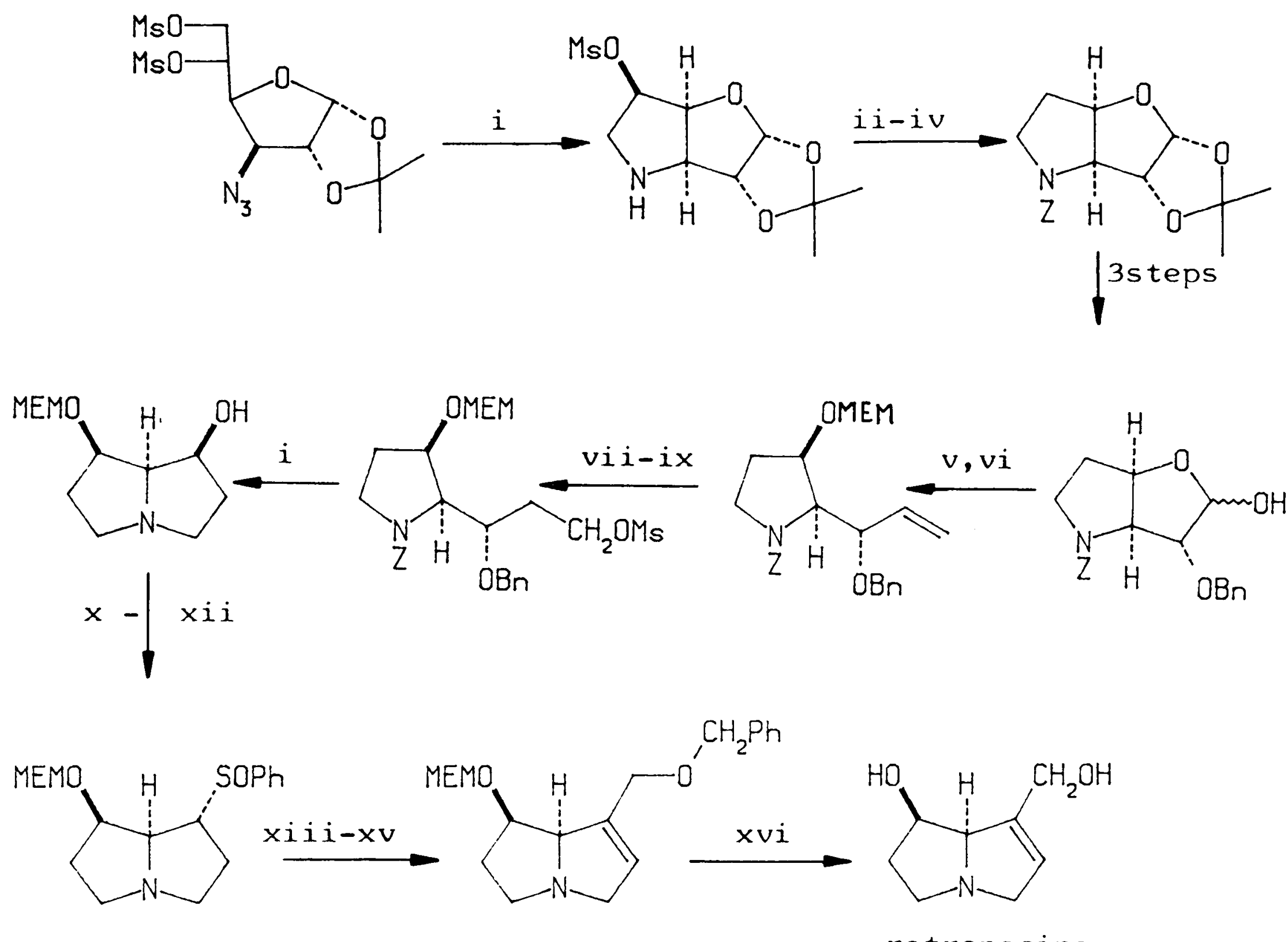

i) $\left.\mathrm{H}_{2} \mathrm{ii}\right) \mathrm{Z}-\mathrm{Cl}$ iii) $\mathrm{Cl}^{-}$iv) $\mathrm{Bu}_{3} \mathrm{SnH}$, initiator v) $\mathrm{Ph}_{3} \mathrm{P}=\mathrm{CH}_{2}$ vi) MEM-Cl vii) $9 \mathrm{BBN}$ viii) $\mathrm{H}_{2} \mathrm{O}_{2}$, $\mathrm{OH}^{-} \mathrm{ix}, \mathrm{x}$ ) $\mathrm{MsCl} \times \mathrm{i}$ ) PhSNa xii) MCPBA xiii) LDA xiv) BOM-Cl xv) heat xvi) $\mathrm{H}_{3} \mathrm{O}^{+}$.

\section{SCHEME 2.4}

Crotanecine (2.6) was obtained in 1965 by alkaline hydrolysis of the pyrrolizidine alkaloids madurensine (isolated from crotalaria madurensis and c.agatiflora) and anacrotine (isolated from seed of c.agyroides) ${ }^{15}$. The structure and relative configuration were deduced by spectroscopic methods and recently confirmed by X-ray analysis ${ }^{16}$. The absolute configuration has been established by synthesis from 2S,4R-4-hydroxyproline ${ }^{17}$, although only a very small amount of crotanecine was prepared (Scheme 2.5). 


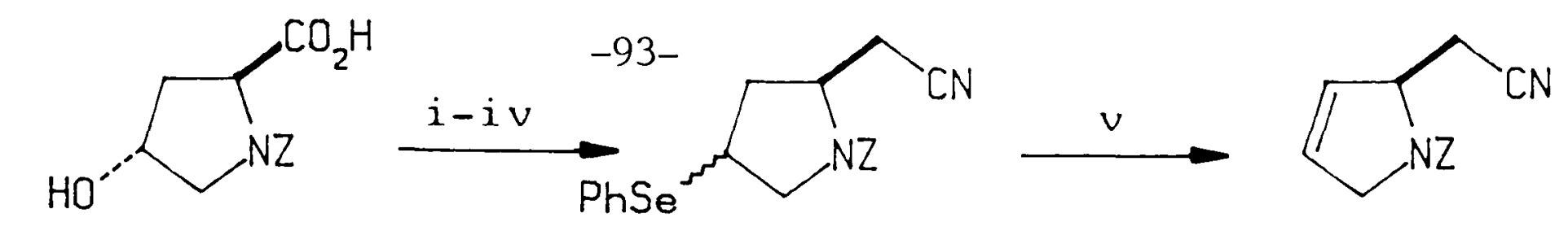

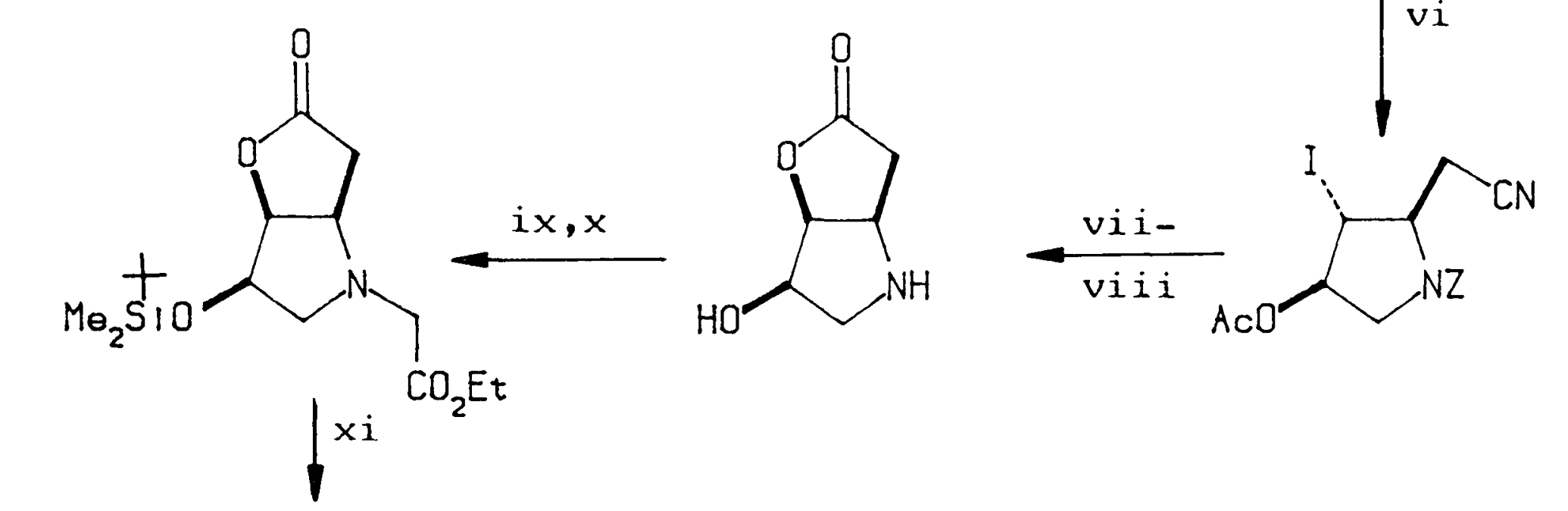

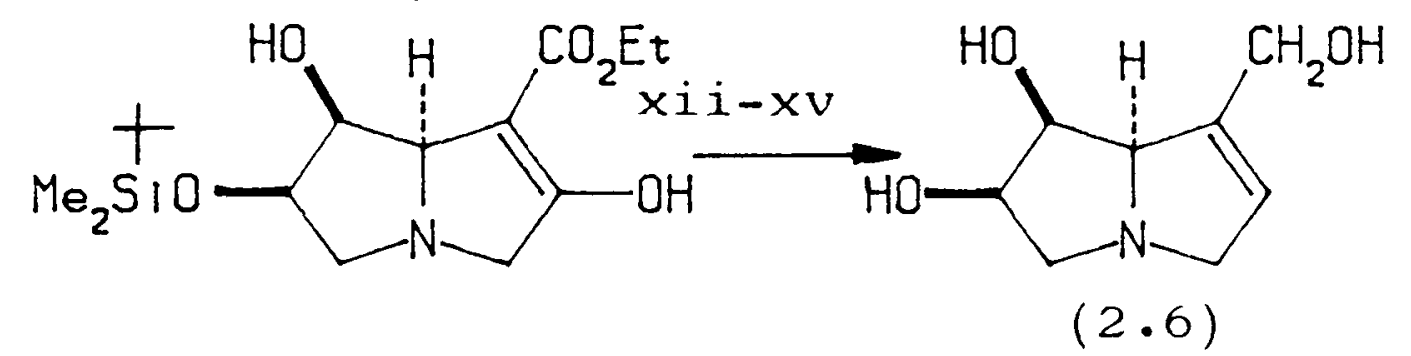

i) BMS ii) TsCl iii) $\mathrm{CN}^{-}$iv) PhSeNa v) $\mathrm{H}_{2} \mathrm{O}_{2}$, heat vi) $\mathrm{NIS}$, $\mathrm{AcOH}$, heat vii) aq $\mathrm{ACOH}$ viii) $\mathrm{MeOH}, \mathrm{HCl} i x) \mathrm{BrCH}_{2} \mathrm{CO}_{2} \mathrm{Et} \times$ ) TBDMS-Cl $x i)$ KOEt, toluene, $\left.\left.\left.0^{\circ}-\mathrm{rt} \times \mathrm{ii}\right) \mathrm{NaBH}_{3} \mathrm{CN} \times \mathrm{iii}\right) \mathrm{Ac}_{2} \mathrm{O} \times \mathrm{iv}\right) \mathrm{F}^{-}$then $\mathrm{Ac}_{2} \mathrm{O}$ $x V)$ DIBAL.

\section{SCHEME 2.5}

A similar strategy was employed by the same authors in a synthesis of croalbinecine, platynecine and retronecine. ${ }^{18}$

\section{RESULTS AND DISCUSSION}

\section{Retrosynthetic analysis}

The compounds $(2.1)-(2.6)$ can all be retrosynthetically derived from the key intermediate (2.13) (Scheme 2.6).

The carbon skeleton and stereochemistry in (2.13) is the same as in the imino gulitol (2.1). Cleavage of the $\mathrm{Cl}-2$ bond of (2.13) gives rise to the pyrrolidines (2.2) and (2.3). 
$-94-$

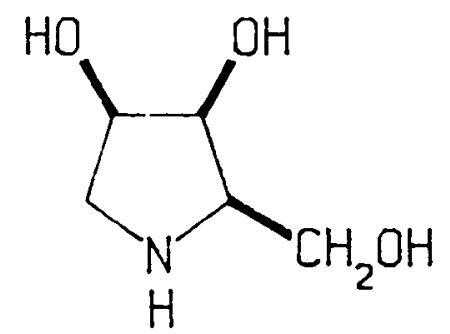

$(2.2)$

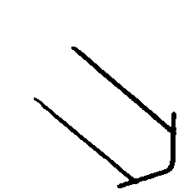

HO

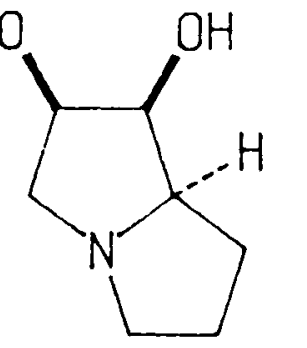

(2.5)
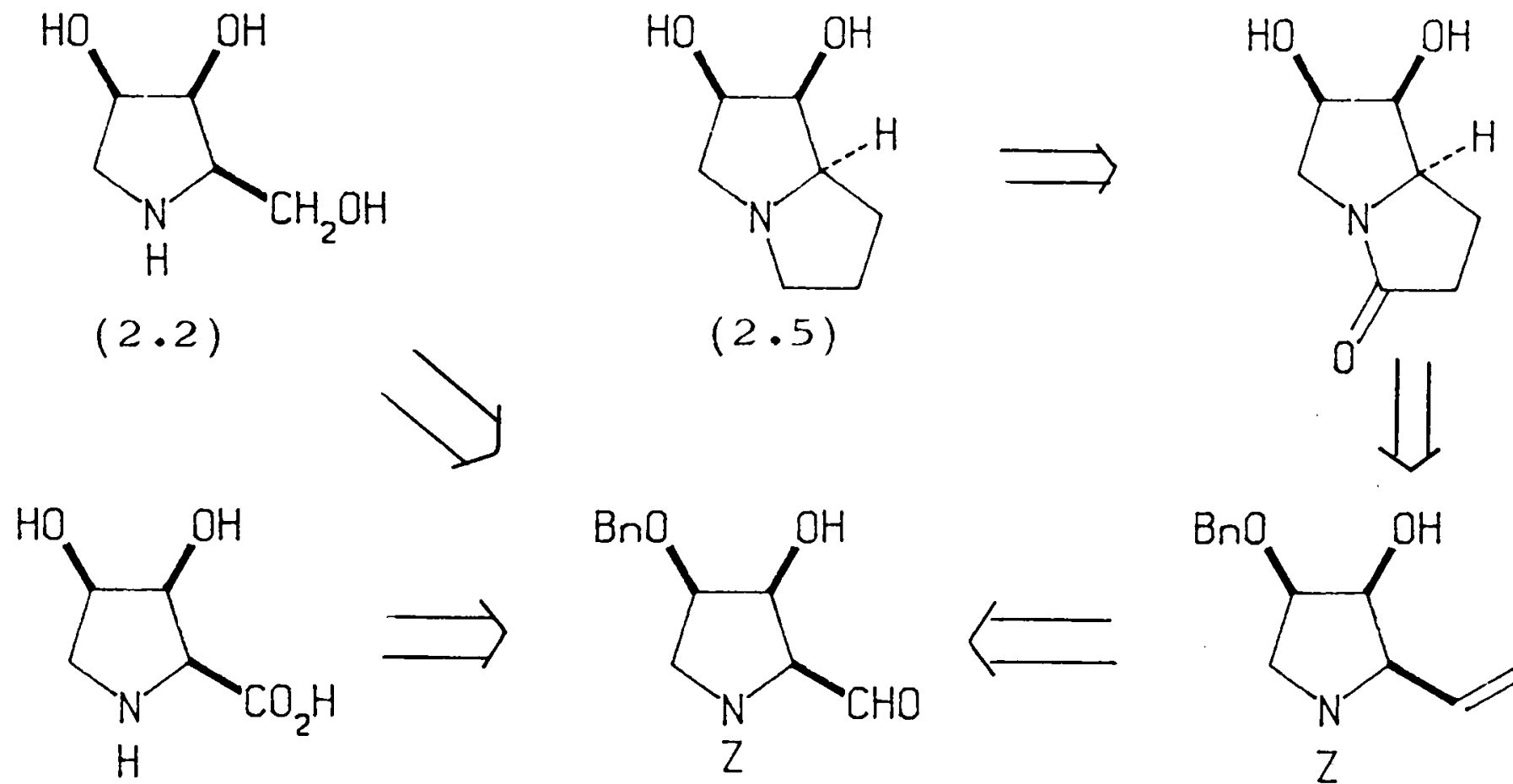<smiles>C=CCC</smiles>

(2.3)
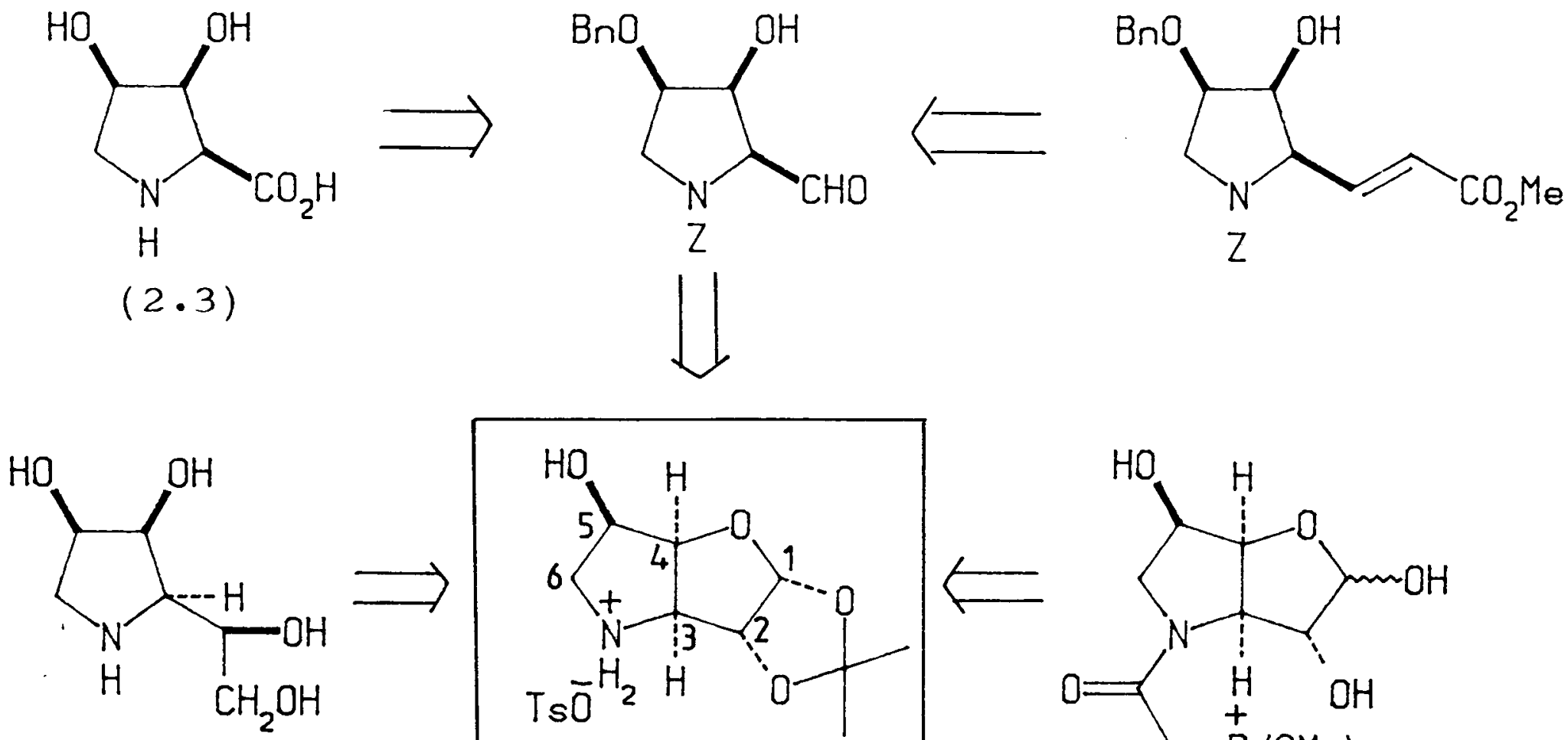

$(2 \cdot 1)$
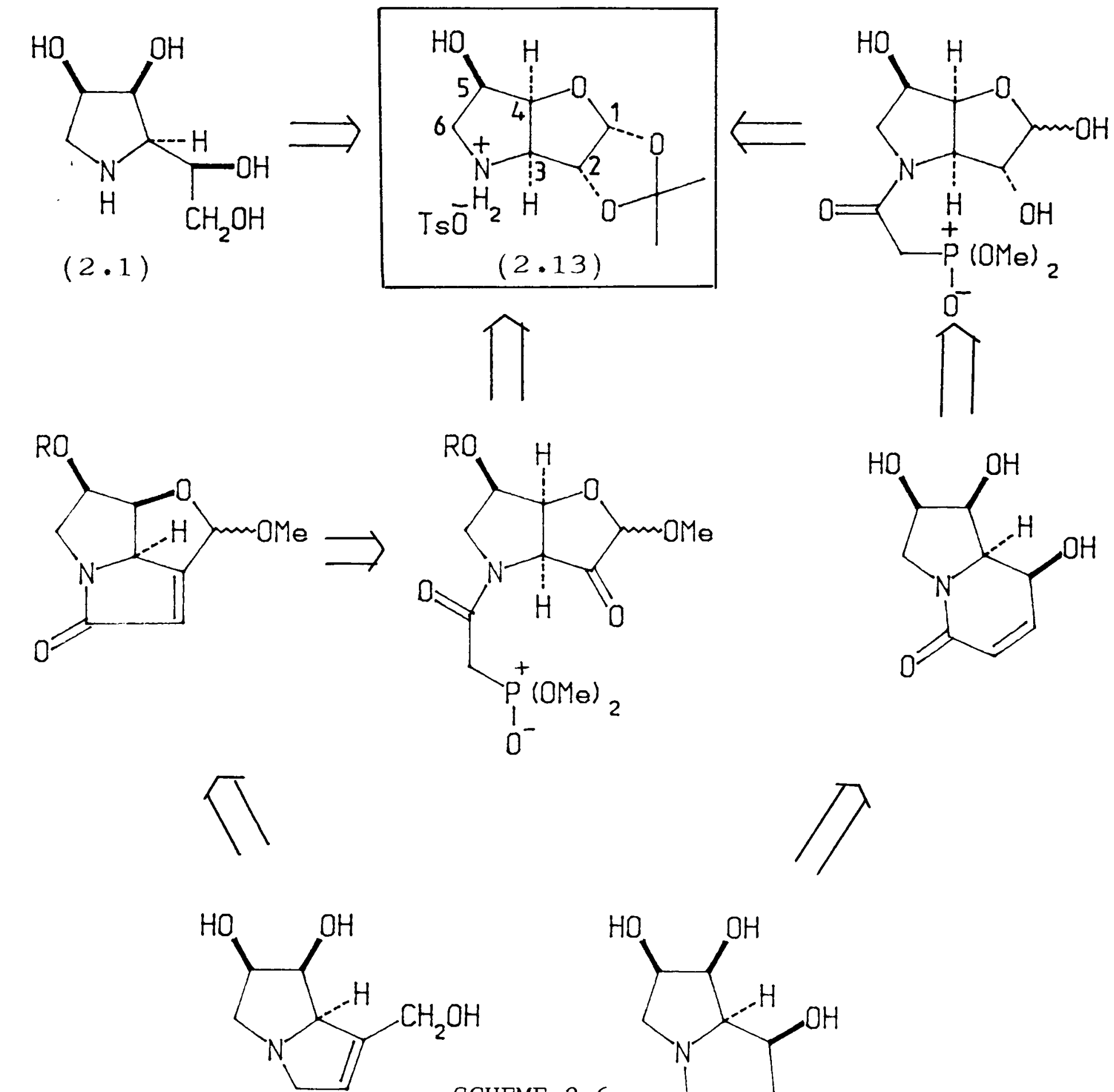

SCHEME 2.6

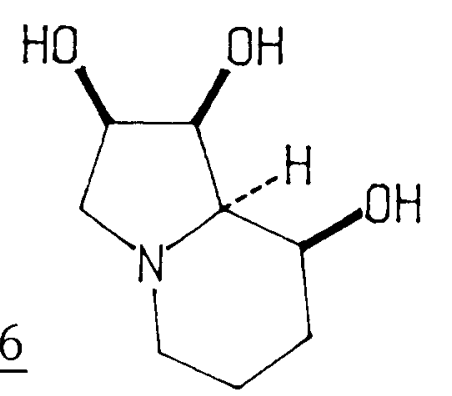

$(2 \cdot 6)$

$(2.4)$ 
Introduction of a 2 carbon fragment on the nitrogen in (2.13) followed by intramolecular cyclisation onto $\mathrm{Cl}$ produces the indolizine skeleton and similarly cyclisation onto $\mathrm{C} 2$ produces the pyrrolizidine framework.

Alternatively, the $\mathrm{C}-\mathrm{C}$ bond could be made first. A 2 carbon chain extension from C2 followed by intramolecular cyclisation onto nitrogen leads to the pyrrolizidine (2.5).

The key intermediate (2.13) was derived from D- glucose by initial introduction of nitrogen at $\mathrm{C} 3$ with overall retention of configuration and subsequent intramolecular cyclisation onto C6 (Scheme 2.7). This strategy for the synthesis of 3,6- dideoxy-3,6- imino glucosides has been investigated previously ${ }^{14,19,20}$.

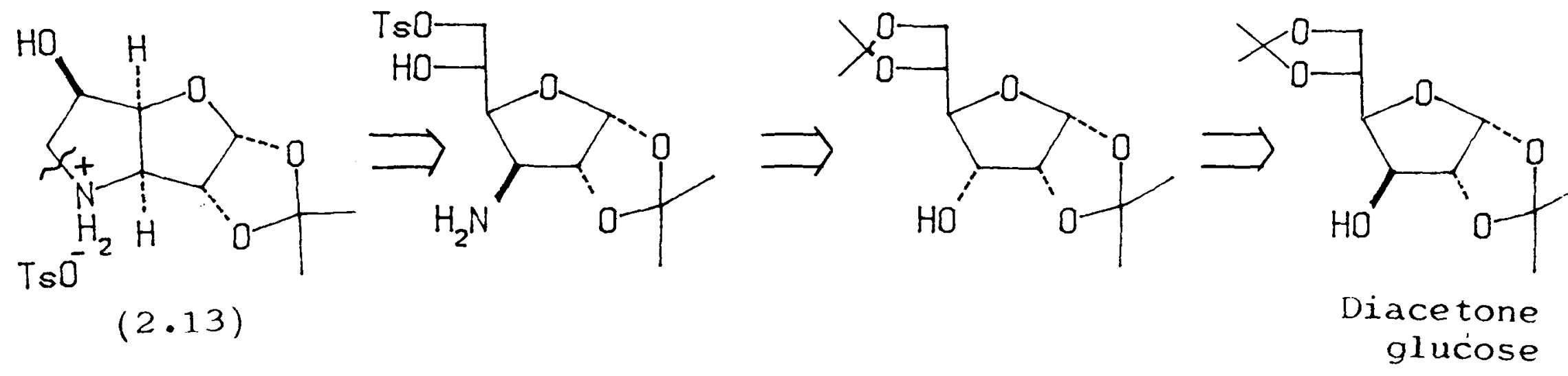

SCHEME 2.7

\section{The syntheses}

i) Preparation of the tosylate salt of 3,6- dideoxy- 3,6- imino- 1,2-0isopropylidene Q- D- glucofuranose (2.13)

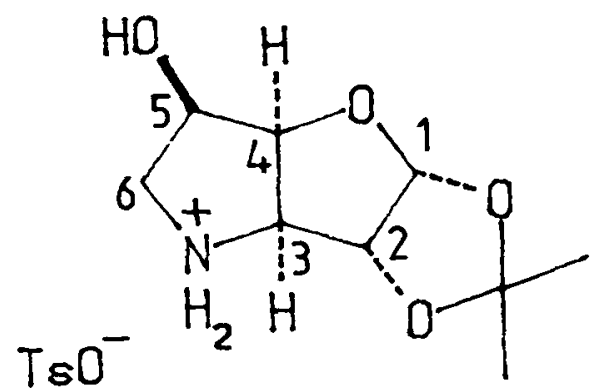

$(2.13)$<smiles>OC(O)C1OC(O)C(O)C1O</smiles>

D-glucofuranose 
The initial requirement was a $D$ - glucose derivative with only the C3 hydroxyl group unprotected. The cheap and readily available diacetone glucose fulfilled this requirement. Oxidation of diacetone glucose by pyridinium chlorochromate with powdered molecular sieve in dichloromethane, and subsequent reduction with sodium borohydride at $0^{\circ} \mathrm{C}$, effected complete inversion to the allo isomer $(2.14)(84 \%)^{21}$ due to approach of the hydride from the least hindered face. Esterification with trifluoromethanesulphonic anhydride and subsequent displacement with sodium azide in $\mathrm{DMF}$ at $50^{\circ} \mathrm{C}$ afforded the azido acetonide (2.15) in 92\%. This is an improved yield to the literature method ${ }^{22}$, where displacement of a tosylate was used, which required much more vigorous conditions.

The 5,6 isopropylidene group of (2.15) was selectively removed with acetic acid / water / methanol to afford the crystalline diol (2.16) identical to the 1 iterature compound ${ }^{20}$ (quantitative, $77 \%$ from diacetone glucose) (Scheme 2.8).

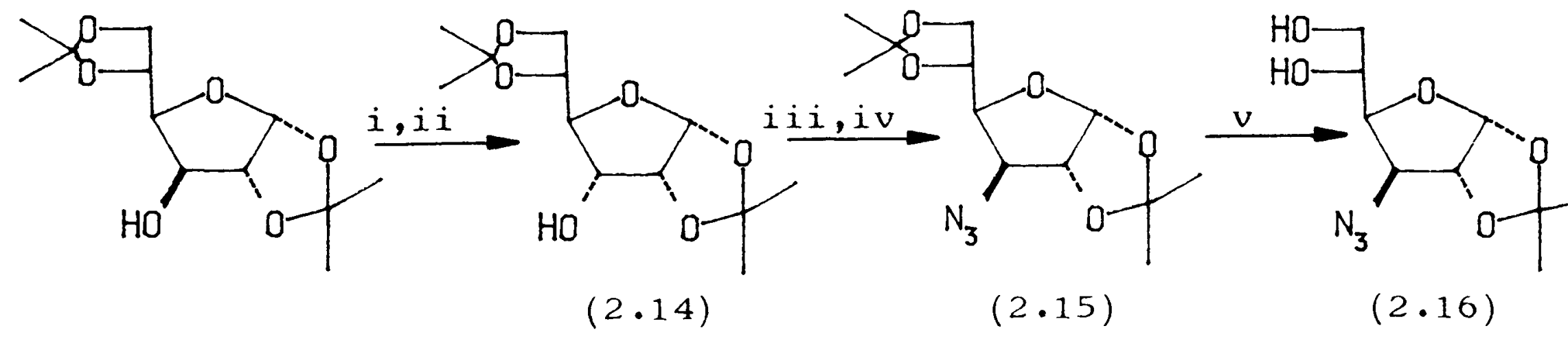

i) $\mathrm{PCC}$, powdered mol sieve, $\mathrm{CH}_{2} \mathrm{Cl}_{2}$ ii) $\mathrm{NaBH}_{4}$, EtOH iii) $\left(\mathrm{CF}_{3} \mathrm{SO}_{2}\right)_{2} \mathrm{O}$ iv) $\left.\mathrm{NaN}_{3}, \mathrm{DMF}, 50^{\circ} \mathrm{v}\right) \mathrm{MeOH}, \mathrm{ACOH}, \mathrm{H}_{2} \mathrm{O}$.

\section{SCHEME 2.8}

Selective tosylation of the primary hydroxyl with 1.1 equivalents of recrystallised $\mathrm{p}$-toluenesulphonyl chloride in pyridine at $-10^{\circ} \mathrm{C}$ proceeded to the tosylate (2.17) in $89 \%$ yield. The tosylate (2.17) was hydrogenolysed 
in ethanol with palladium black and after several minutes the tosylate salt (2.13) was seen to slowly crystallise from the solution. The reaction time depended on the catalyst and the scale, but complete reduction was always achieved within $24 \mathrm{~h}$. The salt was redissolved by addition of water to enable the catalyst to be removed by filtration. When the solvent was subsequently evaporated, the salt was readily crystallised by the addition of ethanol to the residue and recrystallised from hot ethanol. In this way the salt (2.13) could be prepared in $77 \%$ yield from the tosylate (2.17) on multigram scale (53\% from diacetone glucose) (Scheme 2.9).

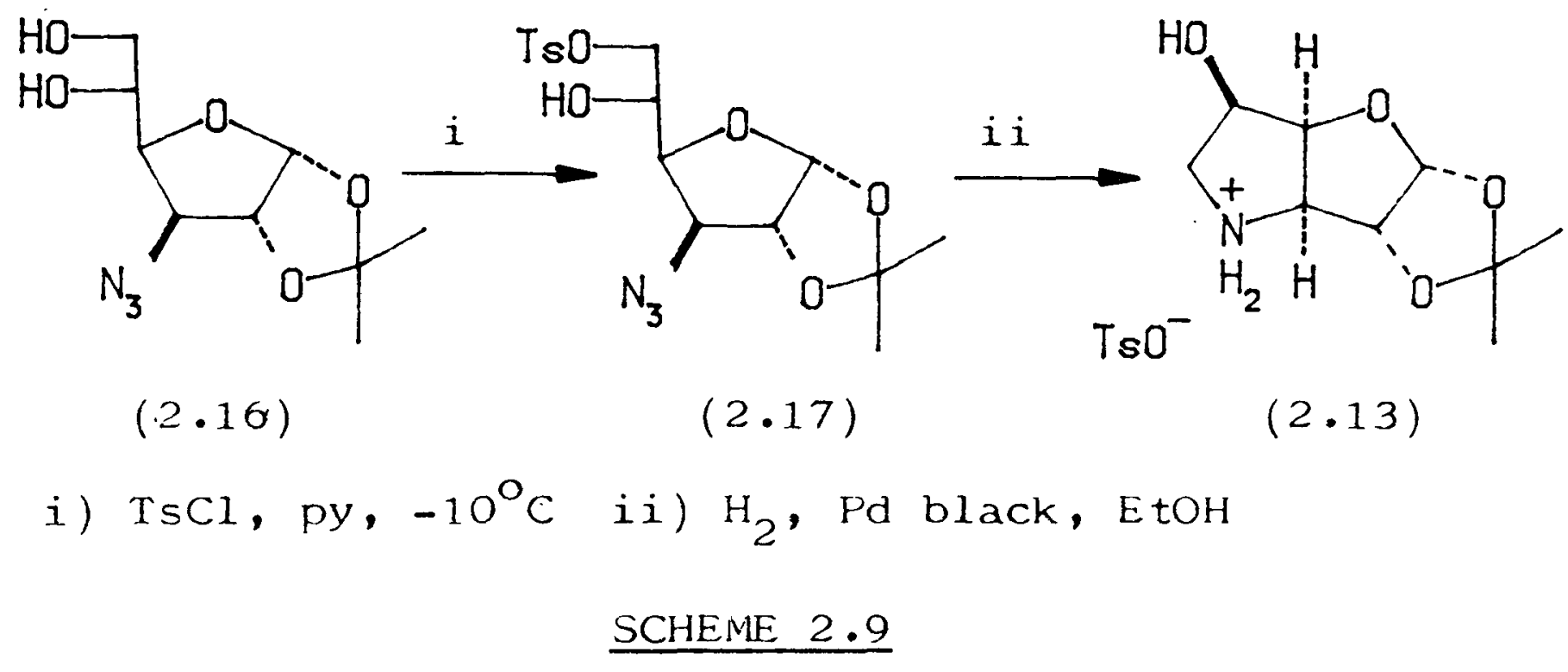

In subsequent experiments none of the intermediates (2.14) - (2.17) were purified by flash or dry column chromatography. However, it was essential that the crude diol (2.16) from the hydrolysis reaction was washed with aqueous sodium bicarbonate solution to remove all traces of acetic acid. In one experiment, where traces of acetic acid were not removed the yield of the tosylate was reduced and an unwanted biproduct, from displacement of the tosylate by acetate, was produced. 
ii) Synthesis of the pyrrolidines (2.1) - (2.3).<smiles>OC[C@H](O)[C@H]1NCC(O)C1O</smiles>

$(2 \cdot 1)$

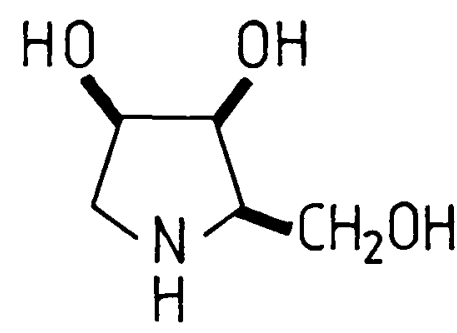

$(2.2)$

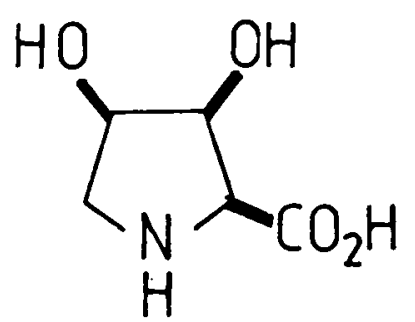

$(2 \cdot 3)$

\section{a) 1,4- dideoxy- 1,4- imino- L- gulito1 (2.1)}

Hydrolysis of the salt (2.13) with aqueous trifluoroacetic acid and subsequent sodium borohydride reduction to give the imino gulitol (2.1) directly proved troublesome. The initial hydrolysis of the acetal proceeded cleanly to the lactol (2.18). The reaction could be monitored by NMR (60 MHz, Perkin Elmer $\mathrm{R} 24$ ) if TFA / $\mathrm{D}_{2} \mathrm{O}$ was used, by observing the disappearance of the two singlets due to the isopropylidene protons $(\delta 1.5,1.3)$ and appearance of the singlet for acetone $(\delta 2.1)$. When the hydrolysis was complete (about $1 \mathrm{~h}$ in $50 \%$ aqueous $\mathrm{TFA}$ at $50^{\circ} \mathrm{C}$ ) the solvent was removed under reduced pressure to give a colourless syrup, but traces of TFA always remained, and the $\mathrm{pH}$ of the solution was consequently always about 1 . The sodium borohydride reduction of this residue in aqueous ethanol was very difficult to monitor due to the polarity of the compounds making t.1.c examination impossible, and the similarity of the spectra of starting material and product made NMR difficult. The sodium borohydride was rapidly consumed in the acidic medium and a large excess was usually required. This meant difficulties in isolating the product, and the best method for this proved to be peracetylation of the residue with acetic anhydride in pyridine. However, this proceeded in only moderate yieldand meant that 2 further steps were required to produce (2.1), namely de- - acetylation, accomplished using sodium methoxide in methanol, 
and de- $\underline{N}$ - acetylation, which required reflux in hydrochloric acid (0.1M, aq). Although (2.1) could be prepared this way it was unsatisfactory.

If the residue from the hydrolysis reaction was neutralised with dilute aqueous sodium hydroxide, then the borohydride reduction could be achieved without having to use a large excess of the reagent, and further, it was possible to purify the product of the borohydride reduction by loading the crude reaction mixture directly onto an acid ion exchange resin column and subsequently eluting with aqueous ammonia. In this way the imino gulitol (2.1) was available from the salt (2.13) directly in $76 \%$ yield. (2.1) was readily crystallised as the hydrochloride salt. (Scheme 2.10).

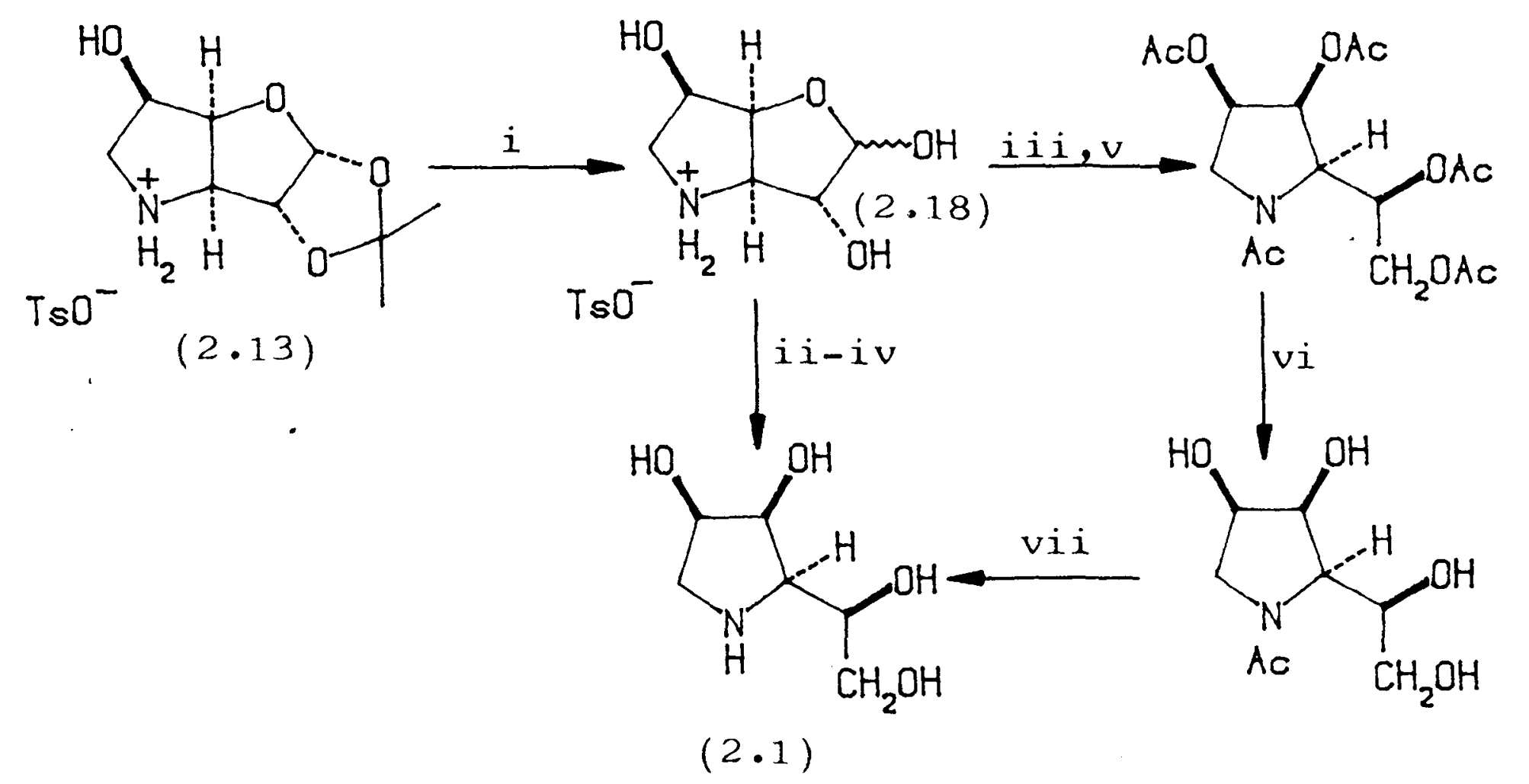

i) aq TFA, $50^{\circ}, 1 \mathrm{~h}$ ii) neutralise $\mathrm{iii)} \mathrm{NaBH}_{4}$ iv)ion exchange chromatography $v$ ) $\mathrm{Ac}_{2} \mathrm{O}$, py vi) $\mathrm{NaOMe}$, MeOH vii) $0.1 \mathrm{M} \mathrm{HCl}$, reflux 
Preliminary experiments testing (2.1) against a range of glycosidases showed no significant inhibition of any of the systems examined ${ }^{23}$.

b) 1,4-Dideoxy- 1,4- imino-D-1yxitol (2.2) and 2S, 3S, 4R dihydroxyproline $\underline{(2.3)}$

The salt (2.13) was protected on nitrogen as the benzyl carbamate (2.19) by treatment with benzyl chloroformate under the usual conditions (95\%). Hydrolysis of the acetal group of (2.19) and subsequent oxidative cleavage with sodium periodate proceeded only in moderate yield. Isolation problems were encountered after subsequent oxidation or reduction of the periodate product due to the polarity of the compounds. This problem was overcome by initially protecting the free hydroxyl group at C5. Treatment of (2.19) with benzyl bromide and sodium hydride gave the benzyl ether (2.20) (84\%). Hydrolysis of (2.20) with $50 \%$ aqueous trifluoroacetic acid gave the lactol (2.21) (96\%), then treatment of (2.21) with sodium periodate in aqueous ethanol produced the aldehyde (2.22). This compound was not purified, but used directly in the next step of the sequence. Reduction of the aldehyde of (2.22) with sodium borohydride in ethanol also resulted in hydrolysis of the formate ester to produce the diol (2.23) (84\%). Hydrogenolysis of (2.23) with palladium black in acetic acid removed both protecting groups. Purification by ion exchange chromatography (procedure 1 and 2 , chapter 1 ) gave the imino lyxitol (2.2) which formed a highly crystalline hydrochloride salt (67\%). (Scheme 2.11). 


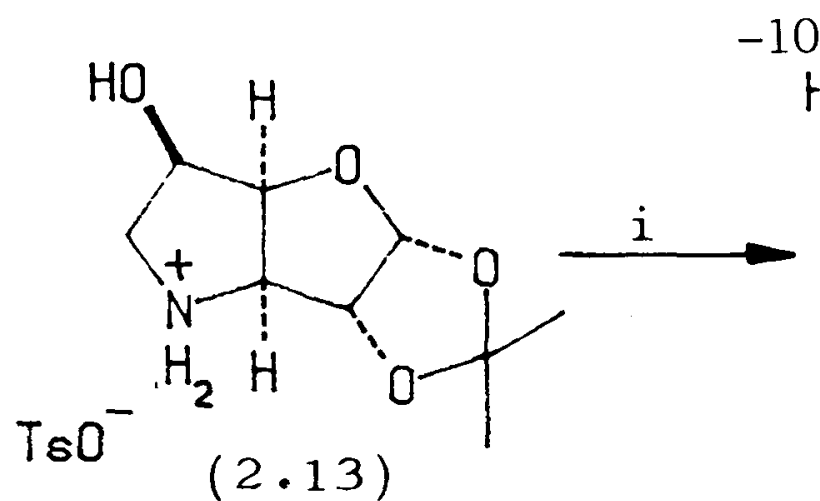

$(2.13)$

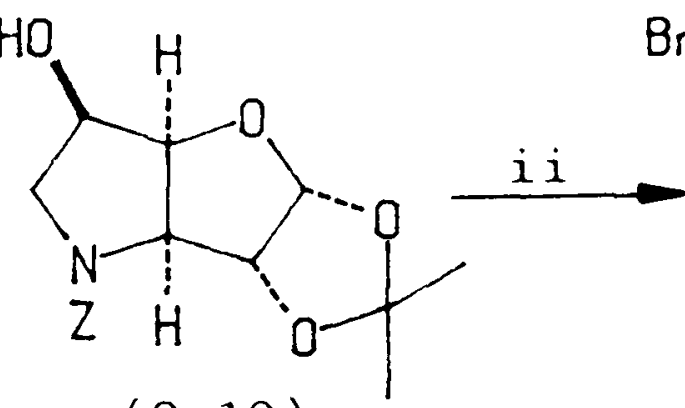

$(2.19)$

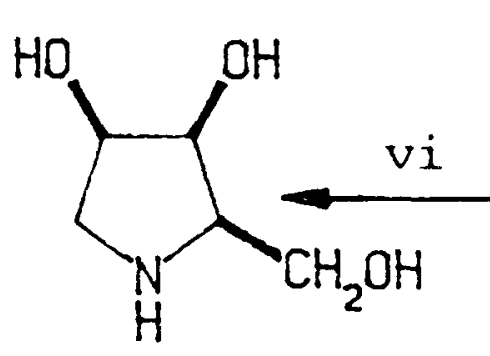

$(2.2)$

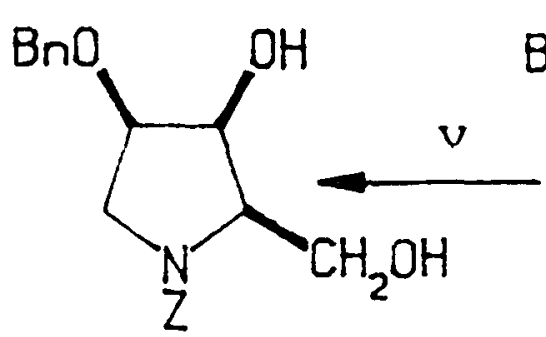

$(2.23)$

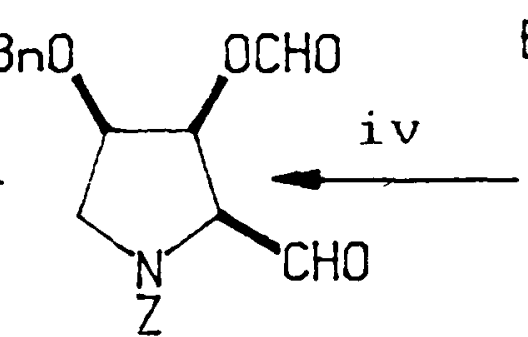

$(2.22)$

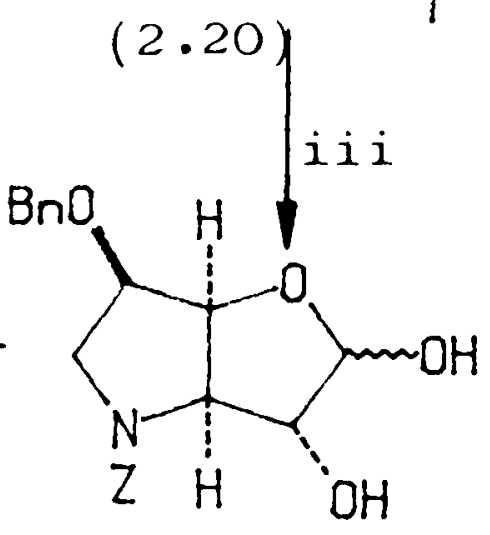

$(2.21)$

i) $\mathrm{PhCH}_{2} \mathrm{O} \cdot \mathrm{COCl}$ ii) $\mathrm{BnBr}, \mathrm{NaH}$, THF iii) aq TFA, rt iv) $\mathrm{NaIO}_{4}$, aq EtOH v) $\mathrm{NaBH}_{4}$ vi) $\mathrm{H}_{2}$, Pd black, AcOH.

\section{SCHEiVE $2 \cdot 11$}

Oxidation of the aldehyde (2.22) to the corresponding acid (2.24) proved to be more difficult. Several methods were tried. Bromine water oxidation gave no reaction. Heating with silver (I) oxide ${ }^{24}$ produced a silver mirror, but the yield was always very low with mainly unreacted aldehyde recovered (even after prolonged reaction times). The use of ruthenium (III) chloride trihydrate 25 or ruthenium dioxide hydrate ${ }^{26}$ in the periodate oxidation of (2.21) (which produce ruthenium tetroxide in situ) resulted in the formation of several unidentifiable products and the acid (2.24) was not isolated.

The most successful oxidation tried was with sodium chlorite in aqueous t-butanol at about $\mathrm{pH} 3$ in the presence of an alkene which acts as a scavenger of $\mathrm{HOCl}^{27}$. The reaction appeared to proceed cleanly to the acid as judged by t.1.c, but considerable difficulties were encountered in isolating the acid in a pure form. Eventually the best solution found was to partition the crude reaction mixture between water and ethyl acetate and hydrogenolyse the crude organic extract with palladium black in acetic acid without any purification. The deprotected material (2.3) could then be isolated pure 
by ion exchange chromatography (acid resin, elute with aqueous pyridine). The amino acid (2.3) was obtained in $36 \%$ yield from the lactol (2.21) using this route and as expected (2.3) was spectroscopically different to the epimeric dihydroxyproline synthesised in chapter 5 (Scheme 2.12).

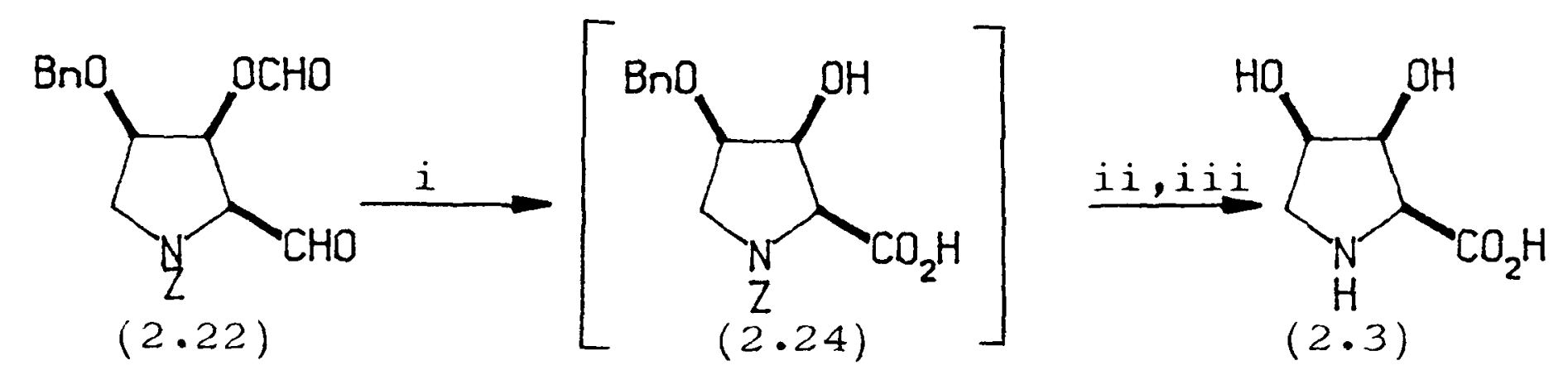

i) $\mathrm{NaClO}_{2}, \mathrm{tBuOH}$, cyclohexene, $\left.\mathrm{rt.ii}\right) \mathrm{H}_{2}$ iii) ion exchange SCHEME 2.12

Preliminary evaluation of 1,4- dideoxy- 1,4- imino- D- 1yxito1 (2.2) as a glycosidase inhibitor has been carried out ${ }^{28}$. The imino 1yxitol. (2.2) only moderately inhibits $a$ - mannosidase activity ( $50 \%$ inhibition at $1.4 \times 10^{-5} \mathrm{M}$ ), but has found to be a very potent, competitive inhibitor of $a$ - galactosidase (ex- green coffee beans) $\left(\mathrm{K}_{\mathrm{m}} 8.3 \times 10^{-4}\right)$ with $50 \%$ inhibition at $2 \times 10^{-7} \mathrm{M}$. Only weak inhibition of $\beta$-galactosidase (Aspergillus niger) was observed. The derivative of the imino ly xitol (2.25) has recently been synthesised ${ }^{29}$, but showed much weaker inhibition against a range of glycosidases.

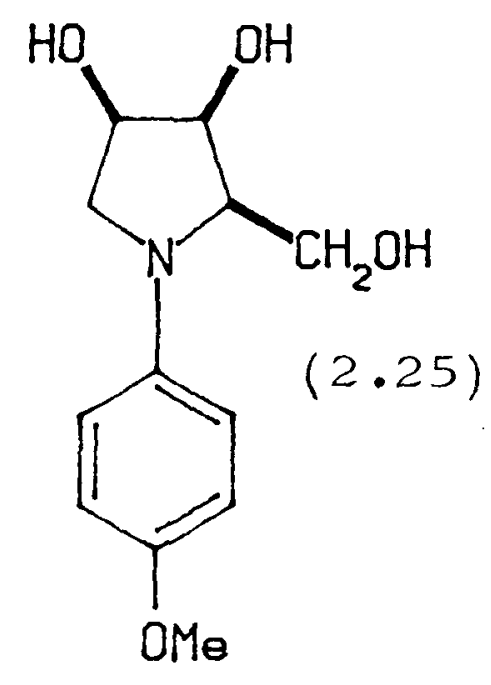


iii) Synthesis of the indolizidne (2.4)

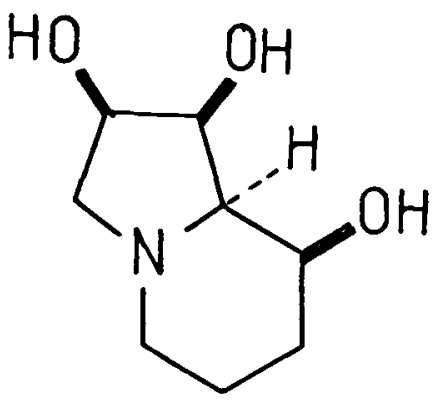

$(2.4)$

The strategy for this synthesis was to couple dimethoxyphosphiny 1 acetic acid to the salt (2.13) and then form the 6 membered ring by an intramolecular Wadsworth - Emmans reaction ${ }^{30}$ of the phosphonate onto C1. The alternative route from an intermediate with the 5 membered ring already made, namely to form the $\mathrm{C}-\mathrm{C}$ bond first and then cyclise onto nitrogen was used in a synthesis of swainsonine $(2.10)^{31}$.

Dimethoxyphosphinylacetic acid $\left.(\mathrm{MeO})_{2} \mathrm{PO}^{\mathrm{C}} \mathrm{CH}_{2} \mathrm{CO}_{2} \mathrm{H}\right)$ was prepared as an oil from trimethyl phosphonoacetate by alkaline hydrolysis using the literature procedure $^{32}$. Coupling of this acid with the salt (2.13) was achieved using DCC $^{33}$. The salt was first neutralised with an excess of triethylamine in DMF and then added dropwise to a solution of the acid and DCC in DMF at $0^{\circ} \mathrm{C}$. The reaction was complete in a few hours and proceeded to the amide (2.26) in high yield (87\%). When 1 - HOBT was used ${ }^{34}$, the yield was lower and the product obtained was not easily separated from the HOBT.

Hydrolysis of the isopropylidene group of (2.26) proceeded in $1 \mathrm{~h}$ in aqueous trifluoroacetic acid at $50^{\circ} \mathrm{C}$ to the lactol (2.27) (quantitative) which is set up for the cyclisation. (Scheme 2.13). 


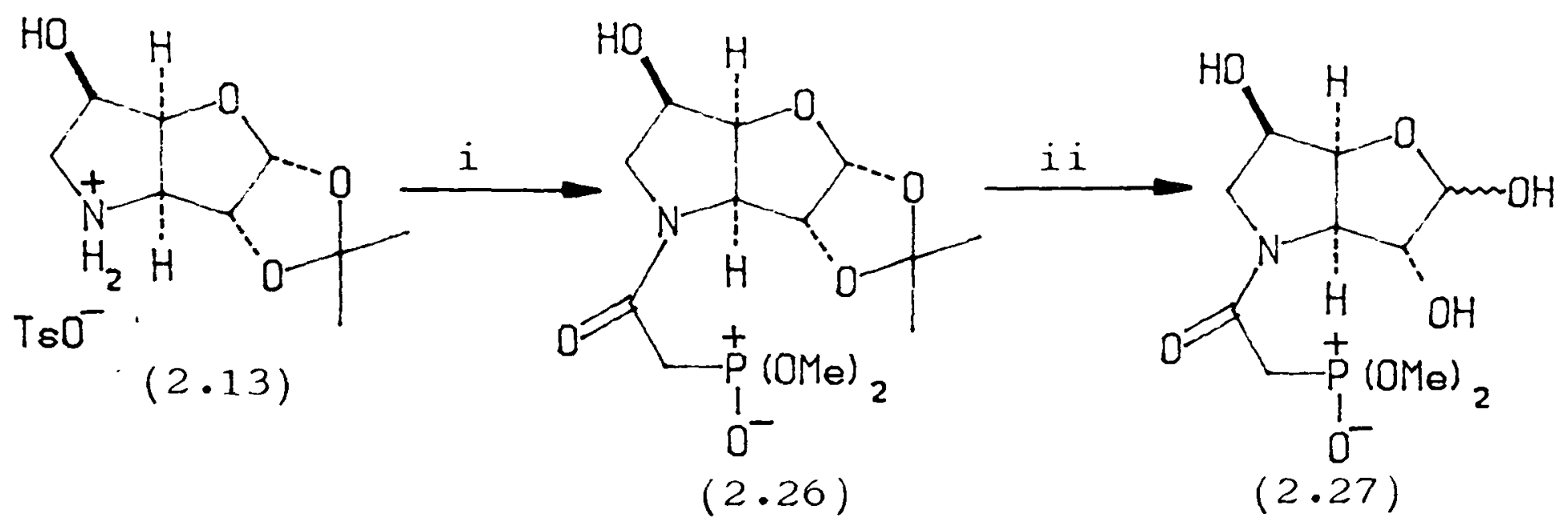

i) $\mathrm{DCC},(\mathrm{MeO}){ }_{2} \mathrm{PO} \cdot \mathrm{CH}_{2} \mathrm{COOH}, \mathrm{DMF}$ ii) aq TFA

\section{SCHEME 2.13}

Treatment of the phosphonate lactol (2.27) with 1 equivalent of 18 crown 6 and 3 equivalents of potassium carbonate in DMF at $70^{\circ} \mathrm{C}^{35}$ effected slow cyclisation to the unsaturated amide (2.28). No reaction was observed in the absence of the 18 crown 6 . (Scheme 2.14).
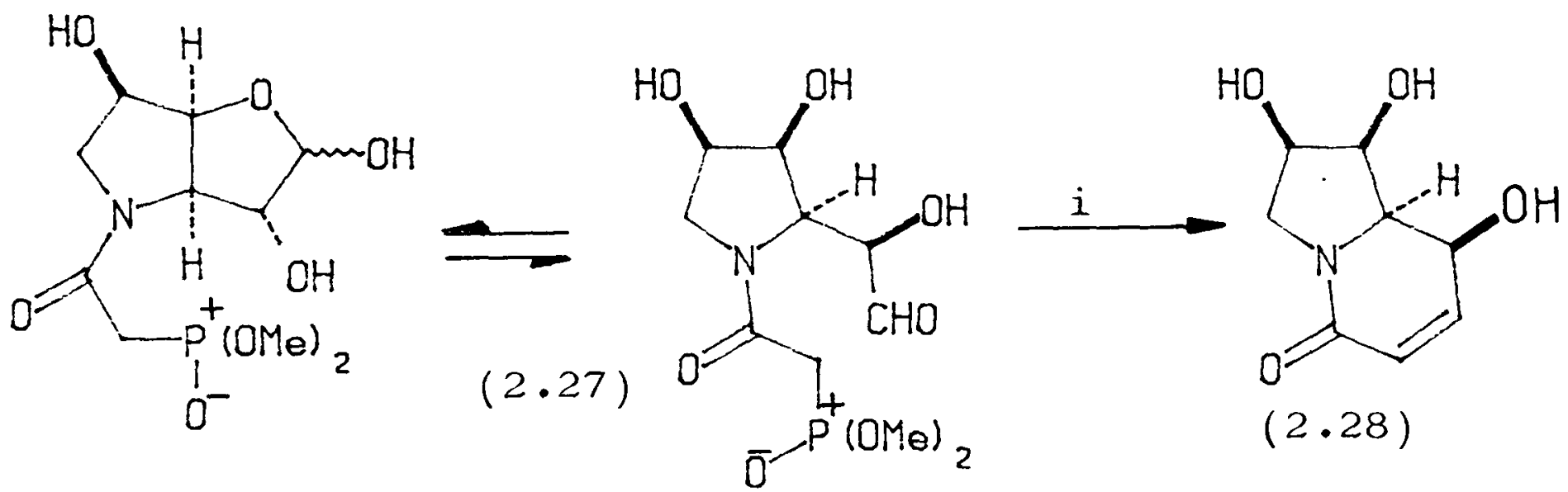

i) $\mathrm{K}_{2} \mathrm{CO}_{3}, 18-\mathrm{C}-6, \mathrm{DMF}, 70^{\circ}, 12 \mathrm{~h}$.

\section{SCHEME 2.14}

The reaction was very difficult to monitor by t.l.c since both starting material and product had very similar $R_{f}$ values $(0.3$ in $20 \%$ methanol in chloroform). The product was, however, strongly u.v active on t.1.c and the starting material inactive, so it was possible to observe product development. After several experiments it was established that the reaction 
was complete after $12 \mathrm{~h}$ and the product was isolated by flash chromatography. However, examination of the chromatographed (2.28) by NMR and mass spectroscopy revealed that it was contaminated with 18 crown 6 . The 18 crown 6 could not be removed by further chromatography and so the unsaturated amide (2.28) was used crude in the next step.

Hydrogenation with palladium black in ethanol caused reduction of the double bond to give the saturated amide (2.29). Again, both starting material and product had identical $R_{f}$ values, but since the product was $u \cdot v$ inactive on t.l.c, the reaction was easily monitored. Purification by flash chromatography gave the saturated amide (2.29) still contaminated with 18 crown 6 . Attempts to produce the target molecule (2.4) directly from the amide (2.29) by reduction with lithium aluminium hydride gave only very low isolated yields. Presumably the hydroxyl groups in (2.4) become complexed to the aluminium. Instead of the direct reduction a 3 step procedure, similar to that reported in a synthesis of swainsonine 31 , was used. The 3 hydroxyl groups were initially protected by acetylation, the amide then selectively reduced, followed by deacetylation to give the target molecule.

The triol amide (2.29) contaminated with 18 crown 6 was acetylated with acetic anhydride in pyridine to give the pure triacetate (2.30) (47\% from the lactol (2.27) ). After several hours at room temperature the acetylation only produced a mixture of diacetates, and the third acetyl group could only be introduced at elevated temperatures $\left(50^{\circ} \mathrm{C}\right.$ for $\left.2 \mathrm{~h}\right)$. (Scheme 2.15). 


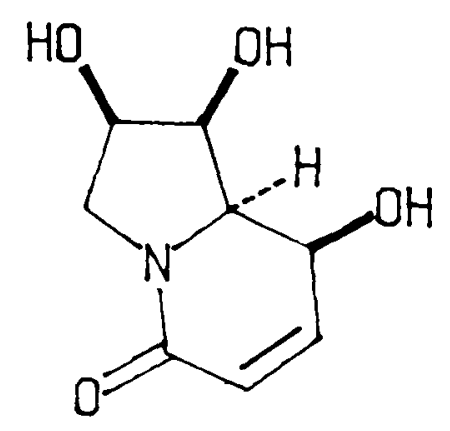

$(2.28)$

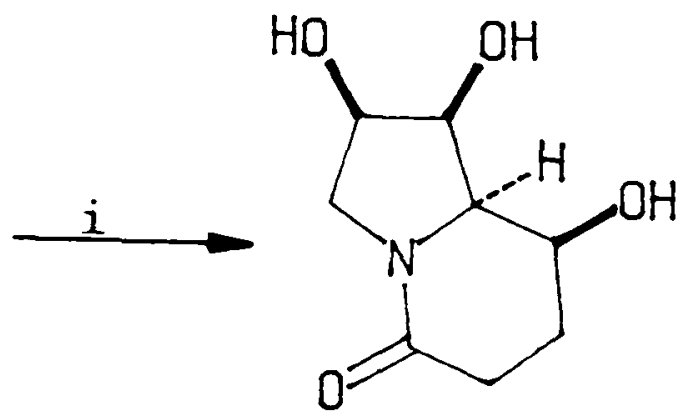

$(2.29)$

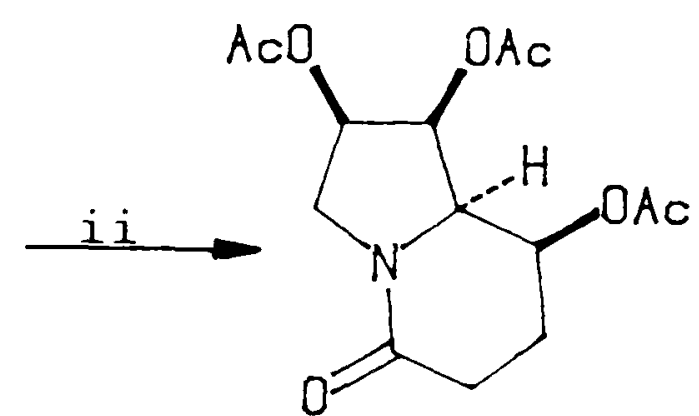

$(2.30)$

i) $\mathrm{H}_{2}, \mathrm{Pd}$ black, EtOH $1 \mathrm{~h}$. ii) $\mathrm{Ac}_{2} \mathrm{O}, \mathrm{py}, 50^{\circ} \mathrm{C}, 2 \mathrm{~h}$.

\section{$\underline{\text { SCHEME } 2.15}$}

Reduction of the amide (2.30) using borane-dimethyl sulphide complex ${ }^{36}$ produced a single product which had a higher $R_{f}$ value than the amide starting material. Isolation of the product by flash chromatography and subsequent spectroscopic examination $\left({ }^{11} \mathrm{~B}\right.$ NMR, broad signal at $-8.6 \mathrm{ppm}$, infra red $V 2380$ and $1500 \mathrm{~cm}^{-1}$ ( $\mathrm{BH}$ and $\mathrm{BN}$ stretching), and microanalysis) revealed that this was the borane adduct of the amine (2.31) (70\%). Generally, BMS reduction of tertiary amides produce the corresponding borane adduct 37 . The borane adduct was stable at $0^{\circ} \mathrm{C}$ but slowly decomposed to the amine when stored at room temperature.

The acetyl groups of (2.31) were removed by treatment with sodium methoxide in methanol. Two acetyl groups were rapid1y removed, but the third required heating to $50^{\circ} \mathrm{C}$ for $2 \mathrm{~h}$. The $\underline{\mathrm{N}}$ - borane complex was destroyed by treating the deacetylated material with aqueous trifluoroacetic acid. Purification by ion exchange chromatography gave the indolizine (2.4) (80\%). (Scheme 2.16). The spectroscopic data of the indolizjine triol (2.4) and the amide triol (2.29) were different to those reported in the only other previous synthesis published $^{7}$, but in agreement with the data quoted in a recently submitted paper ${ }^{41}$. 
<smiles>COC1CN2C(=O)CCC(OC)C2C1OC</smiles>

$(2.30)$

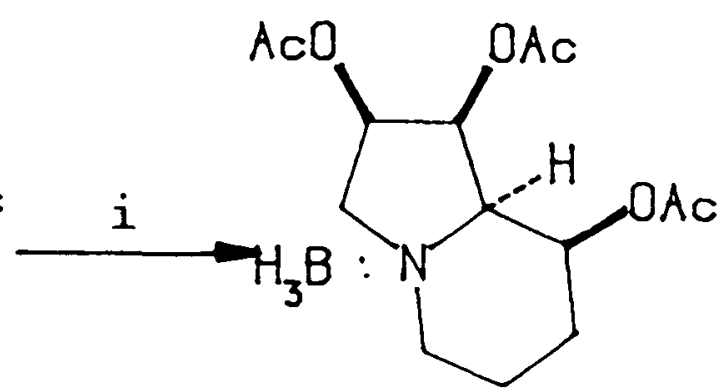

$(2.31)$

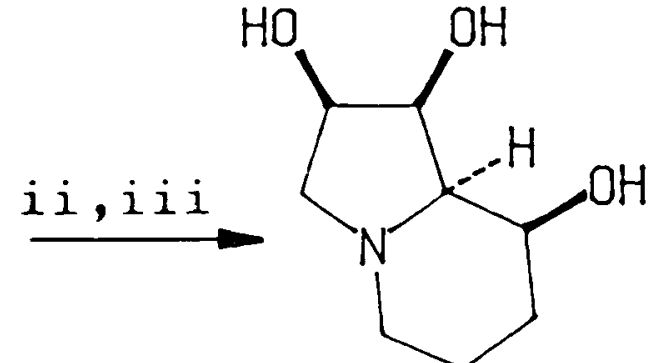

$(2.4)$

i) $\mathrm{BH}_{3} \cdot \mathrm{Me}_{2} \mathrm{~S}$, THF, rt ii) NaOMe, MeOH, $50^{\circ}$ iii)aq TFA SCHEME 2.16

\section{iv) Synthesis of the pyrrolizidine alcohol (2.5)}

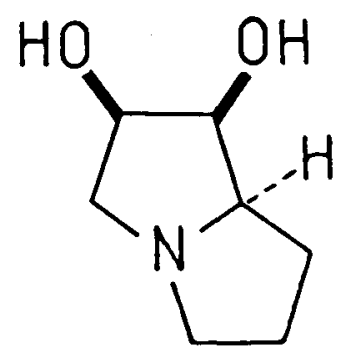

$(2.5)$

The pyrrolizidine alcohol was synthesised from the aldehyde (2.22) (Scheme 2.11) by an initial 2 carbon chain extension, and subsequent cyclisation onto the nitrogen.

The lactol (2.21) was oxidatively cleaved with sodium periodate to the aldehyde (2.22) as described previously. The crude aldehyde was dissolved in benzene and heated at reflux with 3 equivalents of carbomethoxymethylene triphenylphosphorane to produce the trans alkene (2.32) (74\%) (Scheme 2.17).

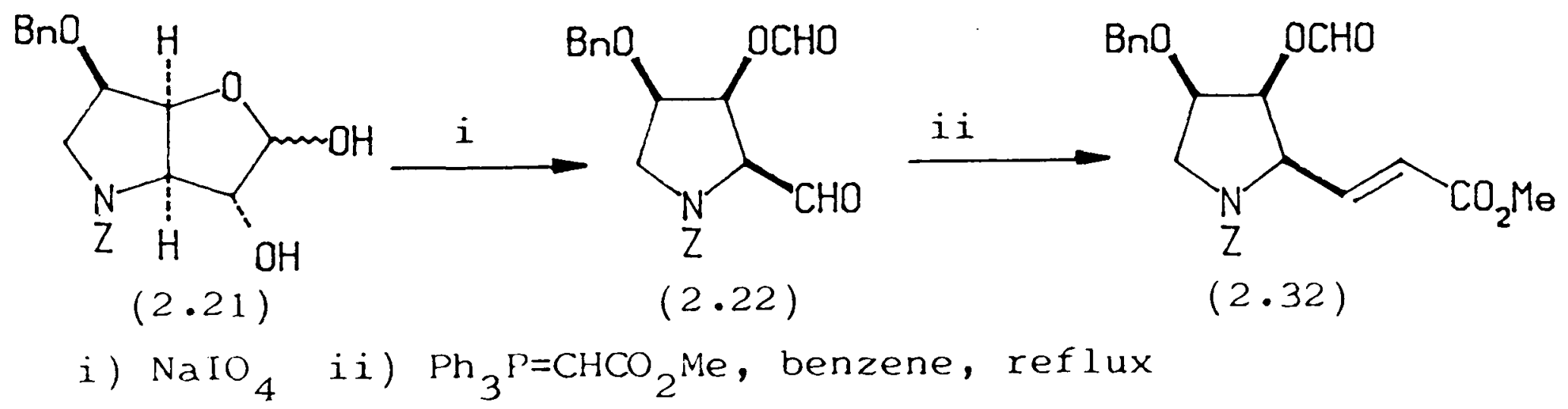

\section{SCHEME 2.17}


Wittig reaction with formylmethylenetriphenylphosphorane gave only low yields of the corresponding aldehyde.

Hydrogenation of the unsaturated ester (2.32) gave a complex mixture of products, from which only a very low yield of the cyclised amide (2.33), which still contained the benzyl ether, was obtained. If, however, the formate group was initially removed by treating the ester (2.32) with a trace of sodium methoxide in methanol ( $85 \%$ yield, instantaneous reaction), then the alcohol (2.34) was produced. Hydrogenation of (2.34) in the presence of palladium black in ethanol, initially gave several products, but after $48 \mathrm{~h}$ only 2 major products remained. When these products were isolated, they were found to be the benzylated cyclised amide (2.33) (14\%) and the cyclised amide diol (2.35) (50\%). (Scheme 2.18).
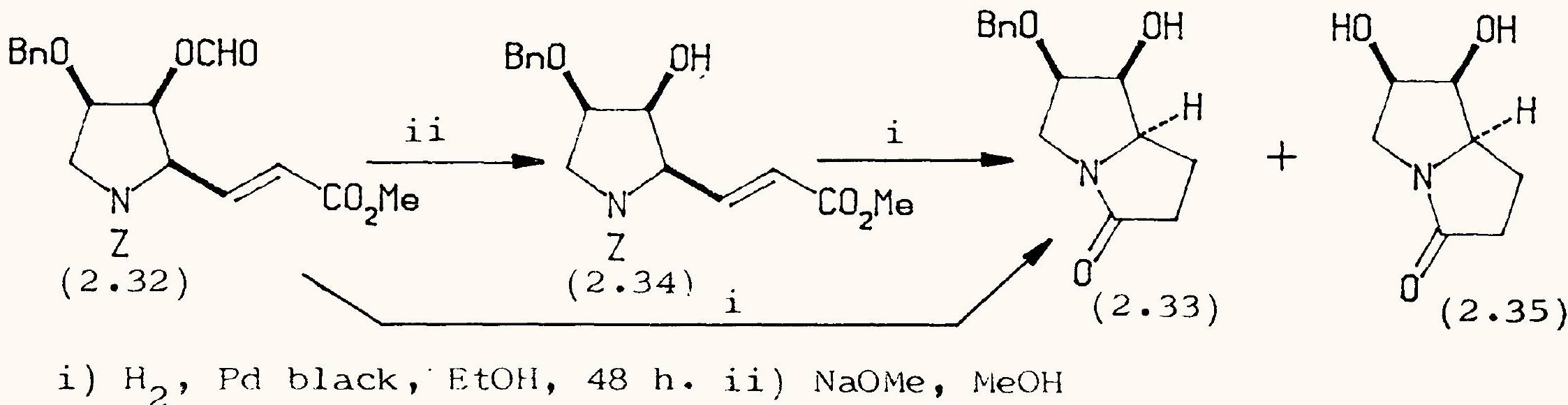

\section{SCHEME 2.18}

The diol (2.35) was converted to the acetonide (2.36) by treatment with a mixture of acetone and 2, 2 dimethoxypropane in the presence of $10( \pm)$-camphorsulphonic acid (quantitative). Reduction of the amide group of (2.36) was achieved by two different methods. With borane- dimethyl sulphide complex a product with a higher $\mathrm{R}_{\mathrm{f}}$ than (2.36) was produced, namely the borane adduct (2.37) (70\%). With lithium aluminium hydride a product with a much lower $R_{f}$ than the amide (2.36) was obtained, namely the free amine 
(2.38) (43\%). The borane method had the advantage that the product was much easier to isolate than the product from the lithium aluminium hydride reduction. Consequently the yield in the latter reaction was low.

Both (2.37) and (2.38) gave the pyrrolizidine diol (2.5) on treatment with aqueous trifluoroacetic acid at $50^{\circ} \mathrm{C}$ (quantitative). (Scheme 2.19).

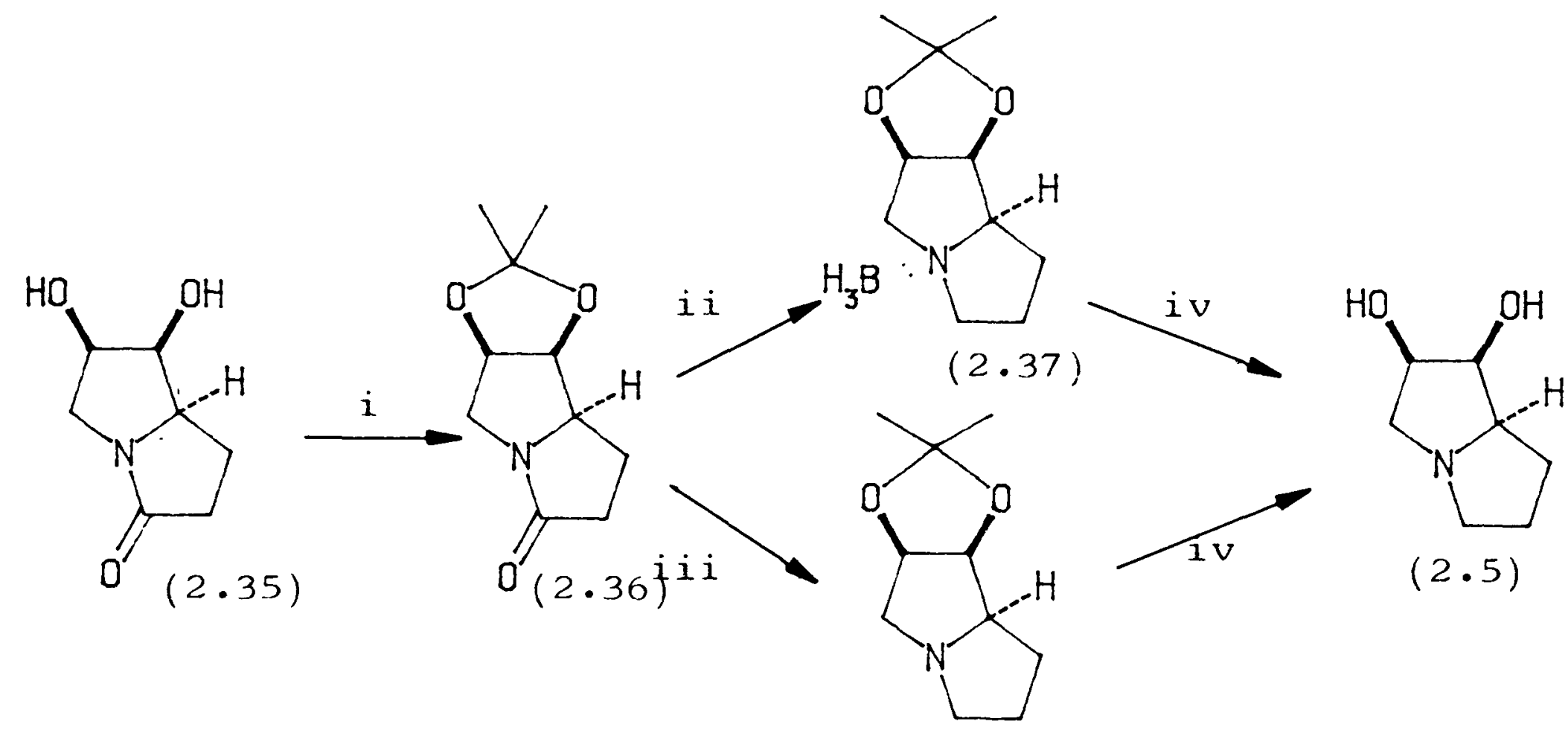

$(2 \cdot 38)$

i) $\mathrm{Me}_{2} \mathrm{C}(\mathrm{OMe})_{2}, \mathrm{Me}_{2} \mathrm{CO}, \mathrm{H}^{+}$ii) $\mathrm{BH}_{3} \cdot \mathrm{Me}_{2} \mathrm{~S}$ iii) $\mathrm{LiAlH}_{4}$ iv) aq TFA SCHEME 2.19

v) Approaches to the synthesis of crotanecine (2.6)

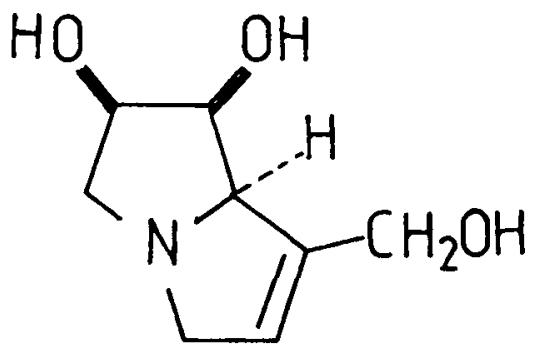

$(2.6)$ 
Synthesis of crotanecine from (2.13) requires introduction of a 2 carbon fragment between the nitrogen atom and C2 (fig 2.3).

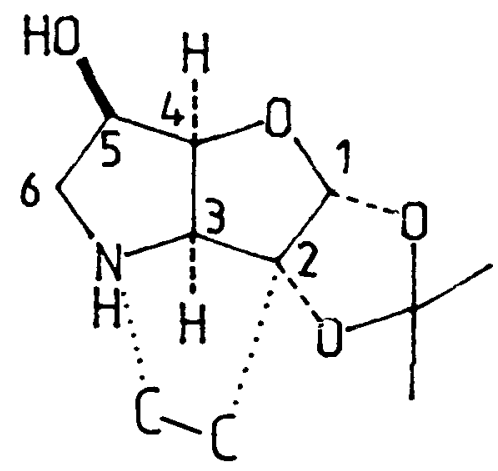

\section{FIG 2.3}

Two general approaches can be envisaged, namely formation of the $\mathrm{C}-\mathrm{C}$ bond first, followed by intramolecular cyclisation onto nitrogen (c.f synthesis of (2.5) ) or formation of the $\mathrm{C}-\mathrm{N}$ bond first followed by intramolecular cyclisation onto C2 (c.f synthesis of (2.4) with similar cyclisation onto C1). Both strategies were investigated.

\section{a) Formation of the $\mathrm{C}-\mathrm{C}$ bond first}

The salt (2.13) was converted to the fully protected (2.20) as described before (Scheme 2.11). Methanolysis of the acetonide group of (2.20) gave an unequal mixture of anomers of (2.39) (94\%). Generally the mixture was not separated but oxidised by pyridinium chlorochromate with powdered molecular sieve to the ketone (2.40) (56\%) (Scheme 2.20).

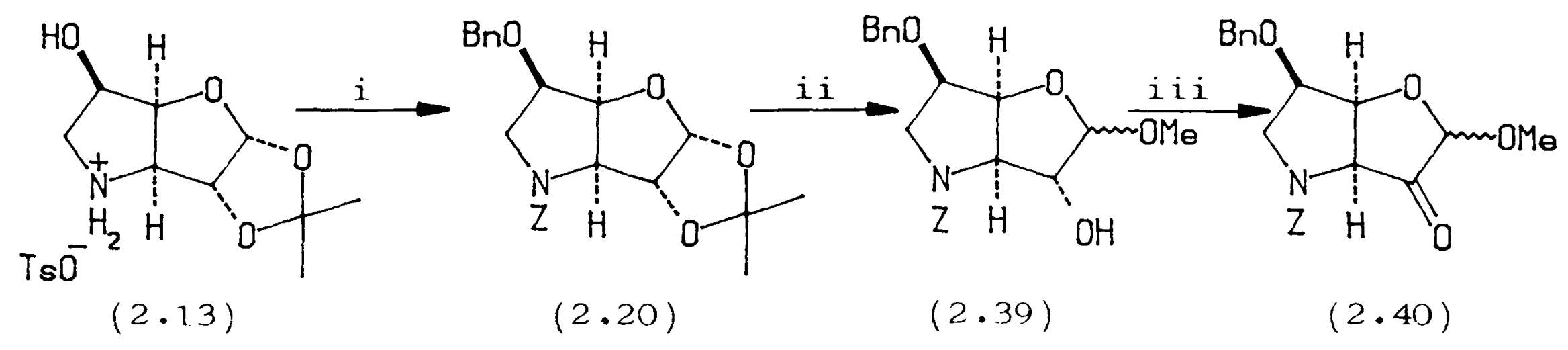

i) see scheme 2.11 ii) $\mathrm{MeOH} / \mathrm{H}^{+}$iii) PCC, powdered mol sieve. 
Two other protecting groups for the hydroxyl at C5 were tried. t-Butyldimethyl silyloxy was completely removed during the methanolysis, whilst $\underline{t}$-butyldiphenylsily $1^{38}$ gave only poor yields. The ketone (2.40) did not react cleanly under Reformatsky conditions, but gave a clean Wittig reaction with carbomethoxymethylenetriphenylphosphorane, to give a mixture of unsaturated esters (2.41) (92\%). Preliminary attempts at hydrogenolysis of the mixture of esters (2.41) gave several unidentified products and none of the cyclised material (2.42) was isolated. This reaction requires further investigation. (Scheme 2.21).

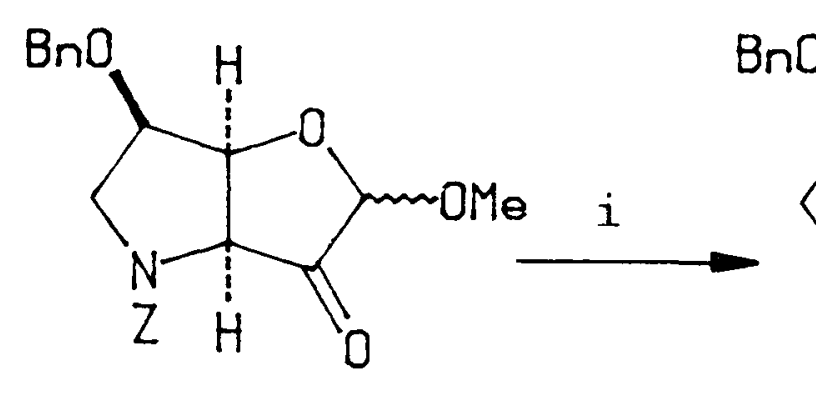

$(2.40)$
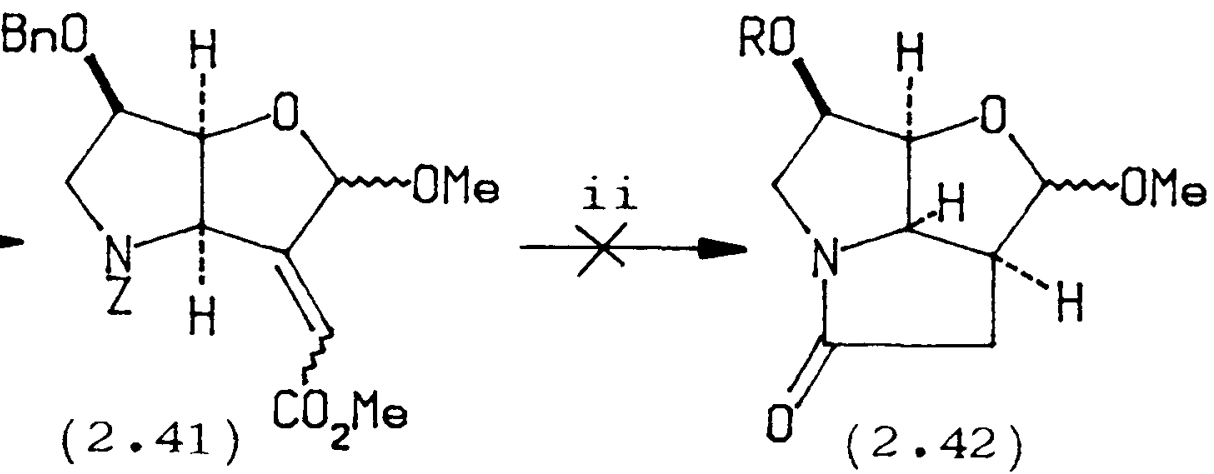

i) $\mathrm{Ph}_{3} \mathrm{P}=\mathrm{CHCO}_{2} \mathrm{Me}, \mathrm{PhH}$, reflux ii) $\mathrm{H}_{2}$, Pd black, EtOH

\section{SCHEME 2.21}

\section{b) Formation of the $\mathrm{C}-\mathrm{N}$ bond first}

\section{1 . Without opening the acetal ring}

The salt (2.13) was coupled with either dimethoxy or diethoxyphosphinyl acetic acid as described above ( $87 \%$ and $85 \%$ respectively). The next problem was to introduce a protecting group on the $\mathrm{C} 5$ hydroxyl which was neither acid nor base labile. Silyl groups appeared to be the most suitable, but $\underline{t}$-buty1dimethylsilyl was completely removed in alcohol and acid. Using t-butyldiphenylsilyl protection, however, reasonable yields of the desired methanolysis (2.44) (35\%) and ethanolysis (2.46) (82\%) products were obtained. (Scheme 2.22). 


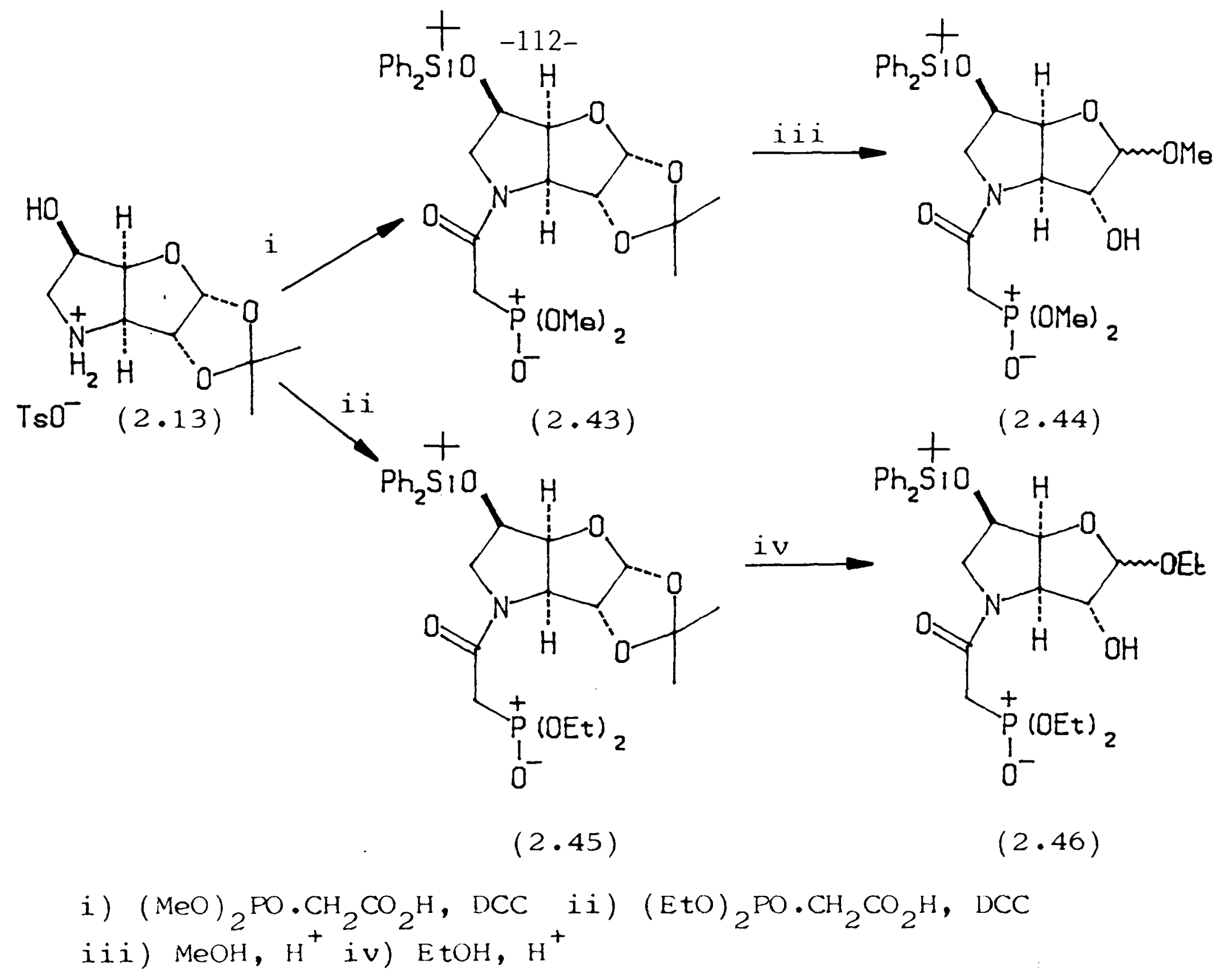

\section{SCHEME 2.22}

Oxidation of $(2.44)$ and $(2.46)$ proved difficult. Neither pyridinium chlorochromate nor the Swern ${ }^{39}$ reaction gave the desired ketone, but a catalytic quantity of ruthenium dioxide hydrate with sodium periodate gave the hydrated ketones ( $89 \%$ ethyl series, $60 \%$ methyl series).

Attempts at the intramolecular cyclisation of the phosphonate ketones proved generally unsuccessful. Usually very polar unidentifiable products were obtained. However, the tricyclic saturated amide (2.48) did appear to be produced in very low yield (8\%) in two separate experiments from the hydrated ketone (2.47) using potassium carbonate and 18 crown 6 in toluene (NMR spectrum reproduced in fig 2.4 ). (Scheme 2.23 ). 
-113-

FIG $2.4{ }^{1}$ H NMR SPECTRUM OF $(2.48)$

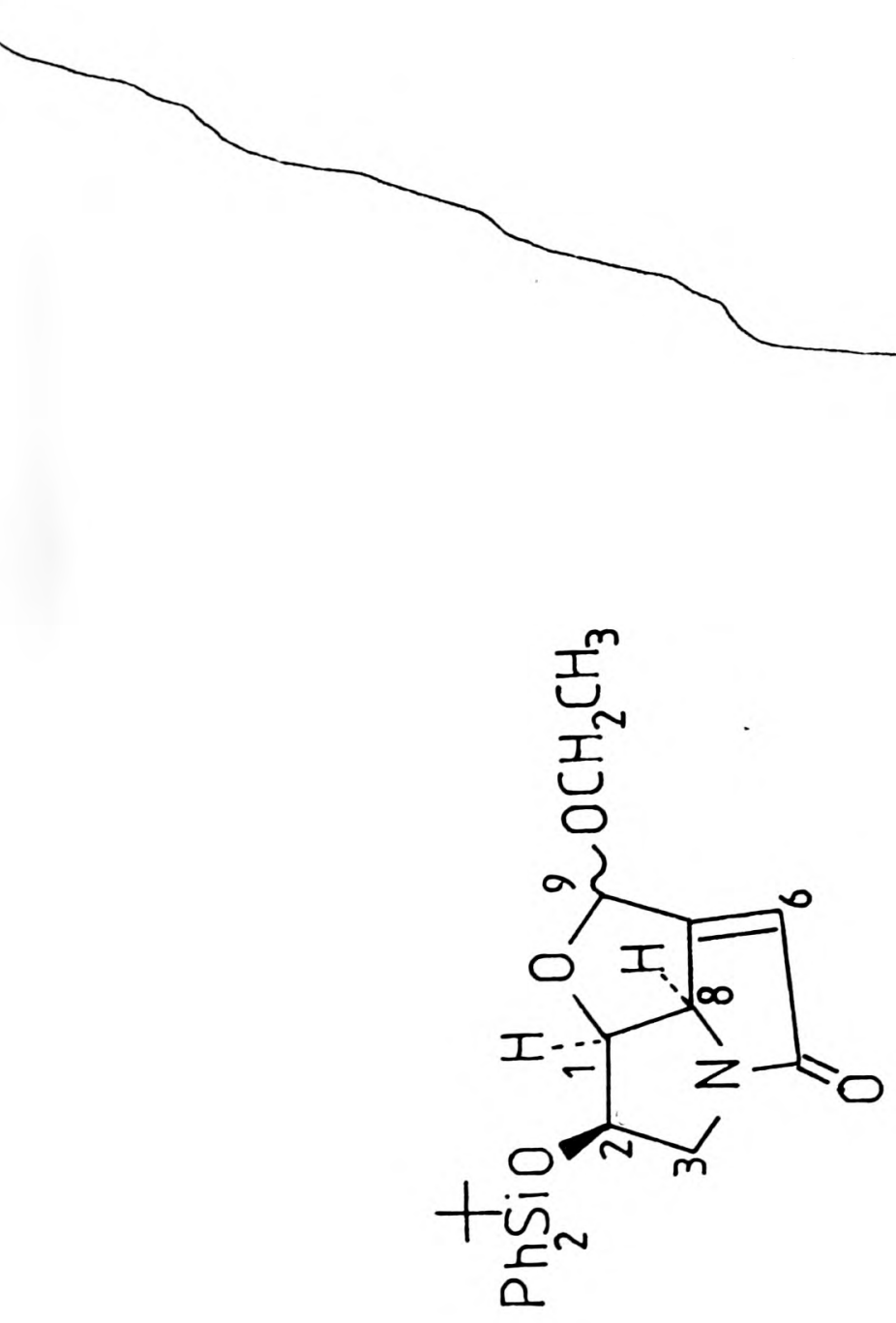




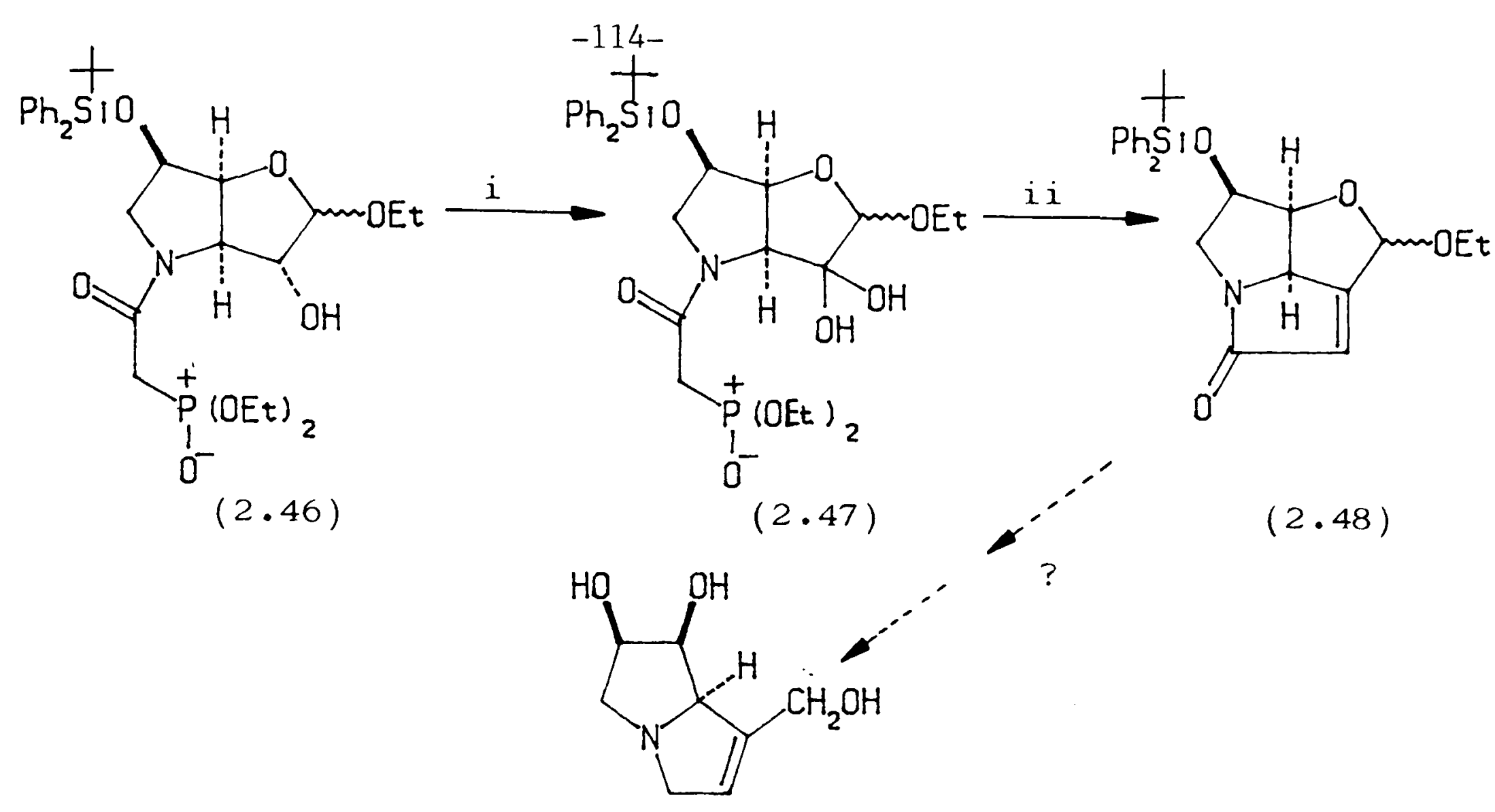

$(2.6)$

i) $\mathrm{RuO}_{2}, \mathrm{NaIO}_{4}^{\prime}$ ii) $\mathrm{K}_{2} \mathrm{CO}_{3}, 18-\mathrm{C}-6$, $\mathrm{PhMe}, 50^{\circ}$

\section{SCHEME 2.23}

Unfortunately this product was only ever produced in very small quantities and the reaction was not optimised. Other conditions tried gave no cyclised products

This reaction requires further investigation; if optimised it could lead to crotanecine in a further 3 steps.

The use of other protecting groups for the C5 hydroxyl was investigated. Benzyl and phenylcarbamy $1^{40}$ were tried. The methanolysis products (2.49) and (2.50) were isolated, but these compounds could not be oxidised cleanly under any of the standard conditions.

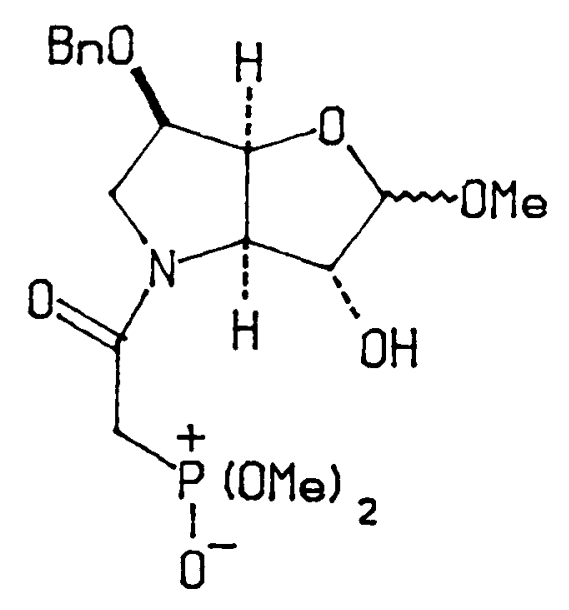

$(2.49)$<smiles>O=C(Nc1ccccc1)C1CN(C(=O)C[P+]([O-])O[Na])C2CO[C@@H](O)C(O)[C@H]12</smiles>

$(2.50)$ 


\section{With initial opening of the acetal ring}

Initial opening of the acetal ring in (2.13) as before, using aqueous trifluoroacetic acid and subsequent sodium borohydride reduction gave the imino gulitol (2.1) (Scheme 2.10). Attempts to functionalise (2.1) proved difficult. Protection of the nitrogen by treatment with benzyl chloroformate under the usual conditions and attempted silylation of the primary hydroxyl group failed due to the low solubility of (2.1) in any organic solvent. Acetonation with acetone and 2,2 dimethoxypropane gave only a modest yield of the diacetonide (2.51) (31\%). Once again the problem here was that under the acidic conditions of the reaction the already very insoluble amine was protonated. It then precipitated as the salt from the solution. The diacetonide (2.51) did couple with dimethoxyphosphinylacetic acid in the presence of DCC to give (2.52) (69\%), but subsequent hydrolysis of the 5,6 acetonide of (2.52) did not occur with great selectivity. Unreacted diacetonide (2.52) (39\%), the desired product (2.53) (44\%) and the fully deprotected (2.54) (11\%) were all obtained using the very mild conditions of acetic acid / water / methanol, $1: 1: 1$ at room temperature. (Scheme 2.24). 
$-116-$

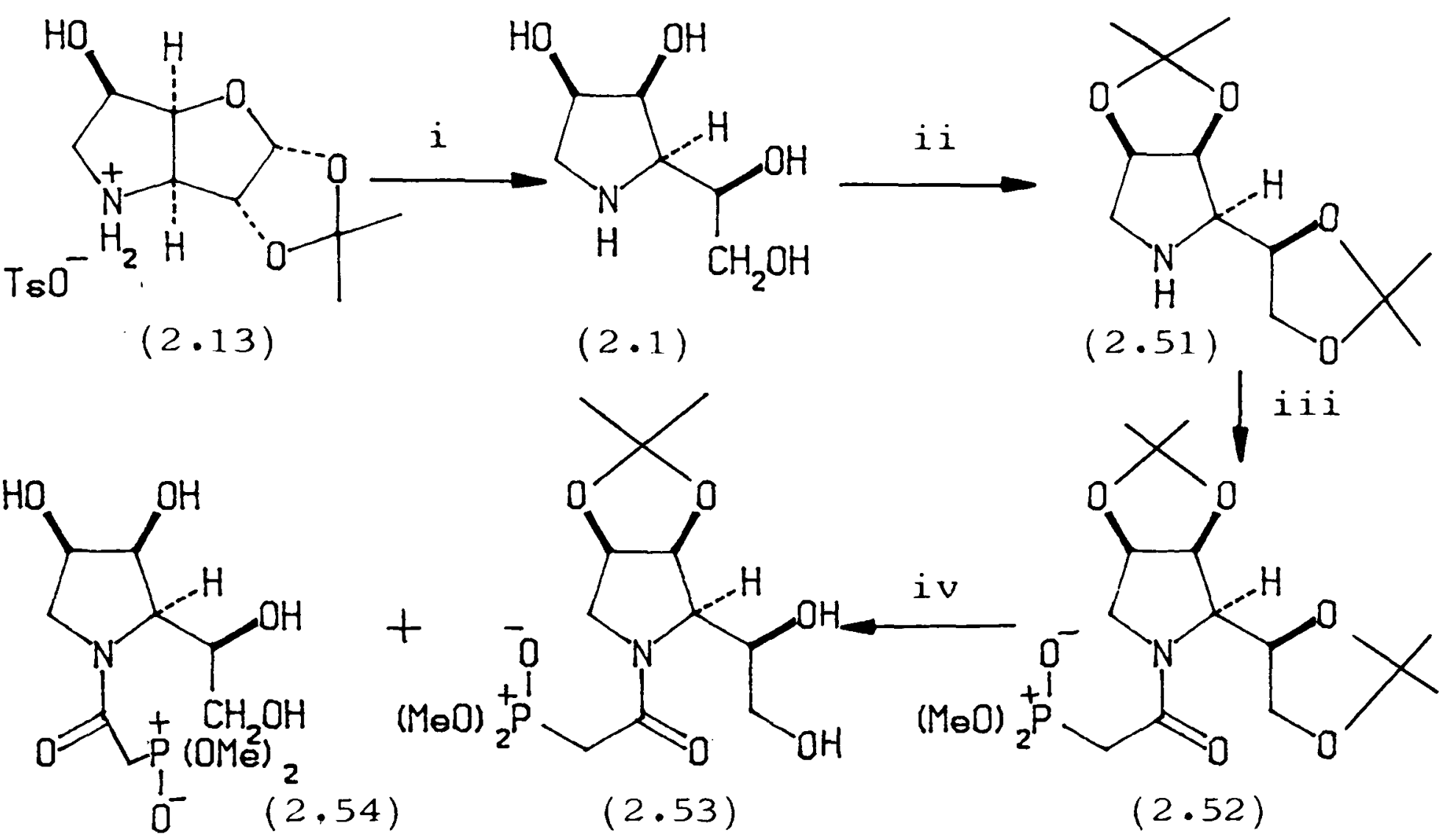

i) scheme $\left.2.10 \mathrm{ii}) \mathrm{Me}_{2} \mathrm{C}(\mathrm{OMe})_{2}, \mathrm{H}^{+} \mathrm{iii}\right)(\mathrm{MeO})_{2} \mathrm{PO} \cdot \mathrm{CH}_{2} \mathrm{CO}_{2} \mathrm{H}, \mathrm{DCC}$ iv) $\mathrm{MeOH}, \mathrm{ACOH}, \mathrm{H}_{2} \mathrm{O}$.

\section{SCHEME 2.24}

Elaboration of (2.53) was not pursued since the route was already very inefficient. However, a similar approach to the synthesis of crotanecine from an analogous intermediate derived from $\underline{D}$ - mannose is described in chapter 3 .

\section{EXPREIMENTAL SECTION}

For general directions see chapter 1 . 
$\underline{\text { FIG } 2.5}{ }^{1}$ H NMR SPECTRUM OF (2.1) (hydrochloride salt)

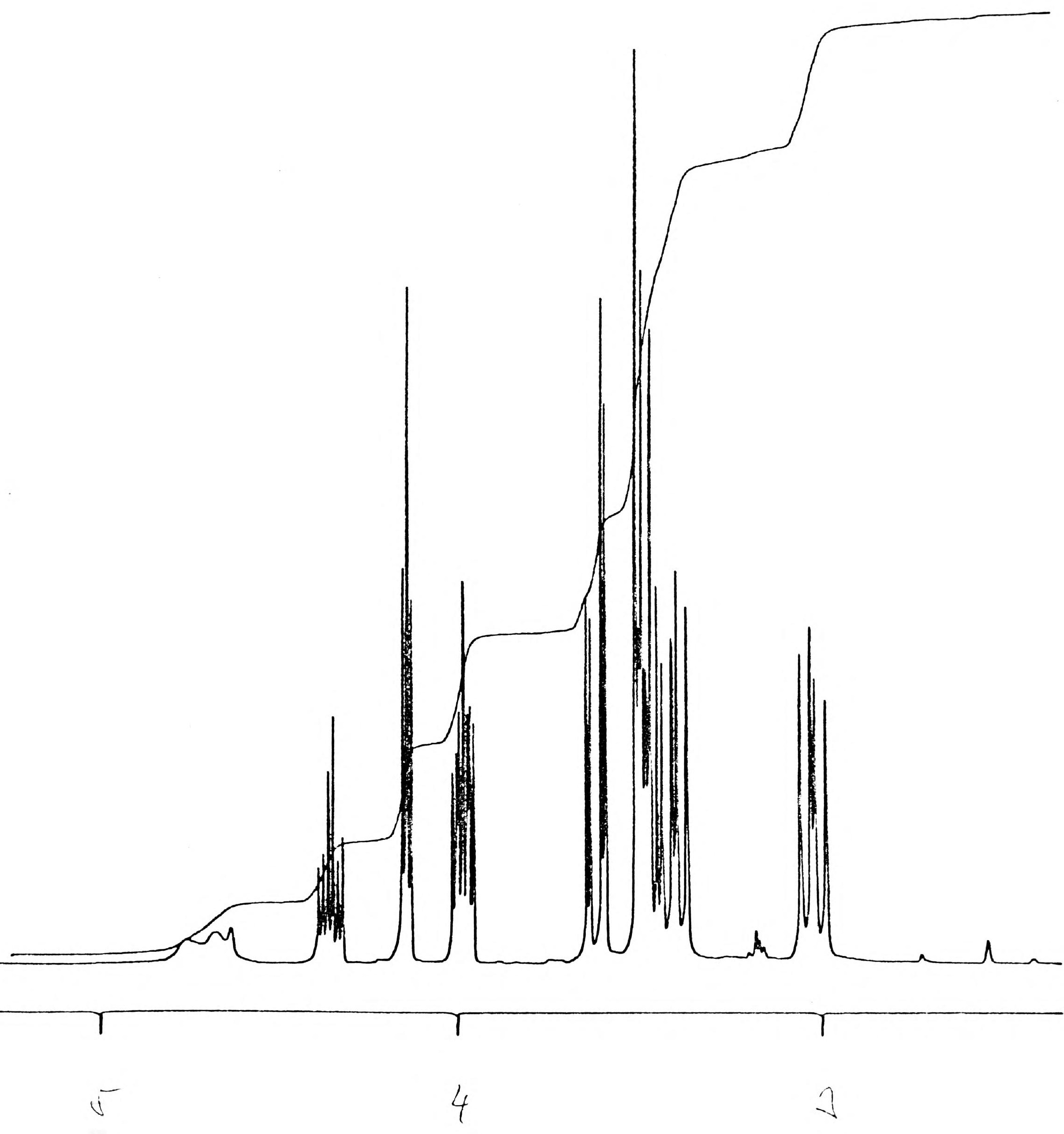


$\underline{\text { FIG } 2.6 \quad 1_{\text {H }} \text { NMR SPECTRUM OF (2.2) (hydrochloride salt) }}$

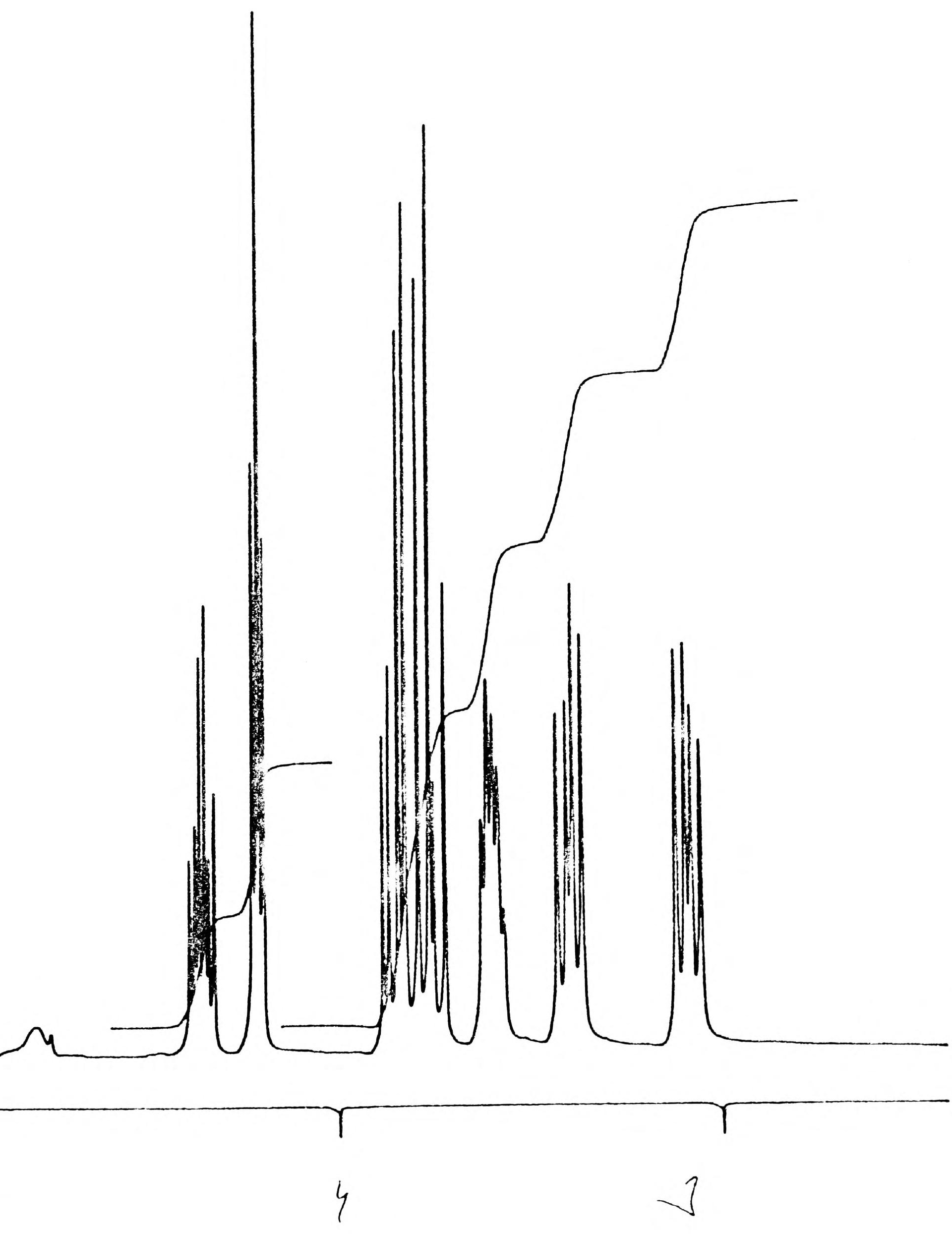


$-119-$

$\begin{array}{lllllll}\text { FIG } & 2.7 & 1_{H} & \text { NMR } & \text { SPECTRUM OF } & (2.4) & \text { (free base) }\end{array}$

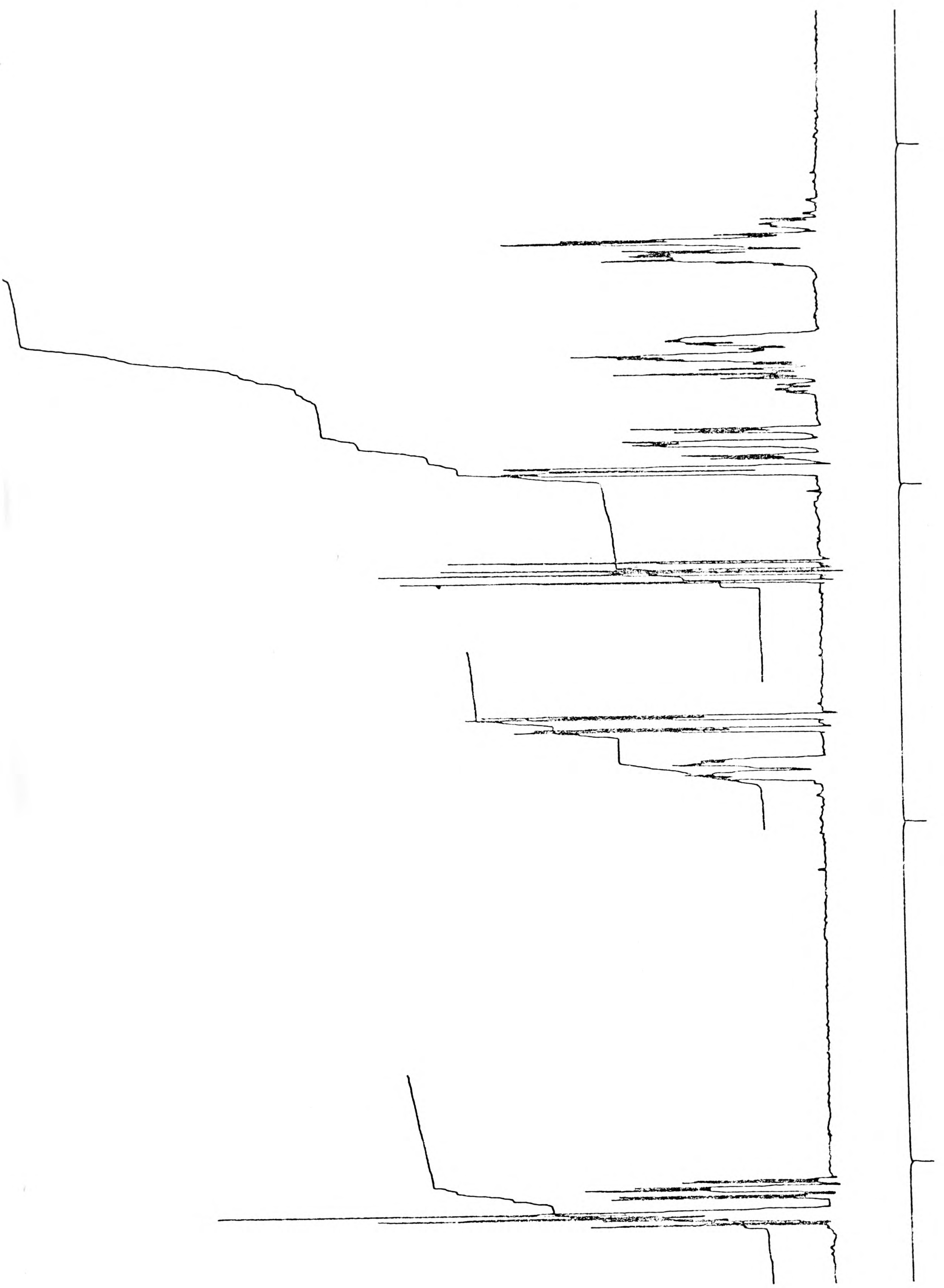


$\underline{\text { FIG } 2.8{ }^{1} \text { H NMR SPECTRUM OF }(2.5)}$ (trifluoroacetate salt)
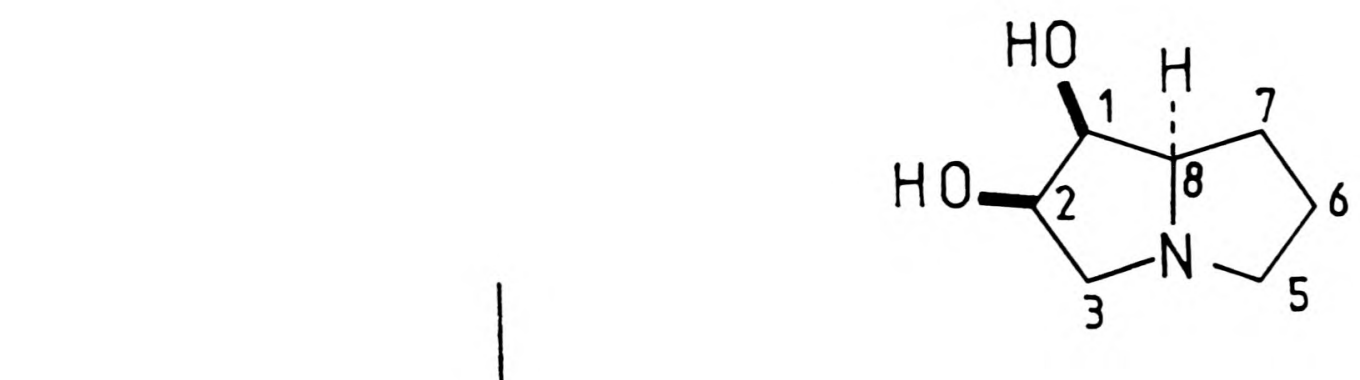
$\underline{\text { FIG }} 2.9$ DOUBLE IRRADIATION EX PERIMENTS ON $(2.5)^{\circ}$
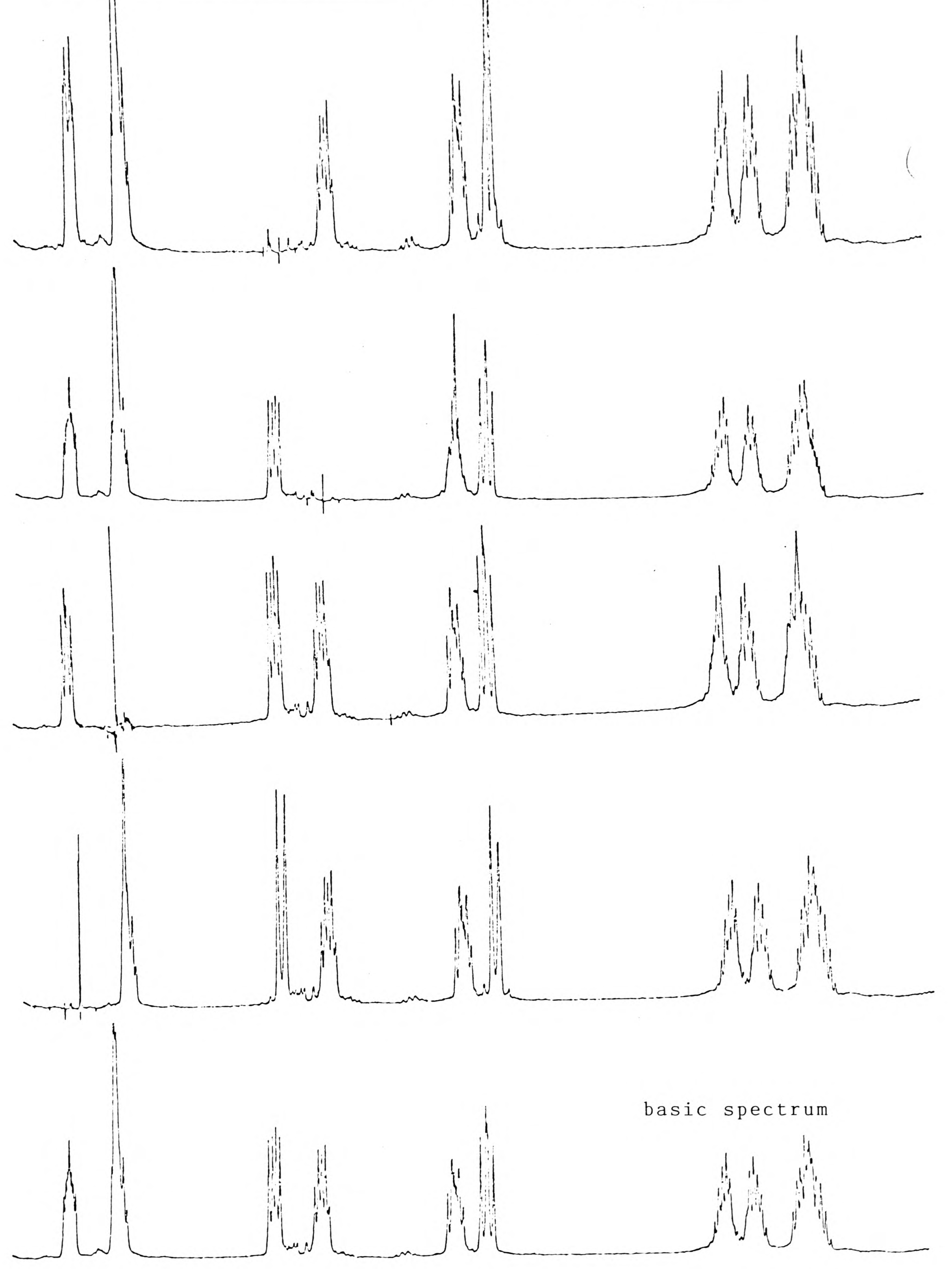

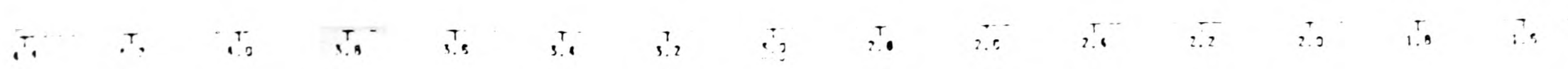


1,$2 ; 5,6-\mathrm{Di}-\underline{0}-$ isopropylidene- $a-\underline{\underline{D}-\text { allofuranose (2.14) }}$

Pyridinium chlorochromate $(25.8 \mathrm{~g}, 0.12 \mathrm{~mol})$ and powdered molecular sieve $(30 \mathrm{~g})$ were added to diacetone glucose $(15.67 \mathrm{~g}, 0.06 \mathrm{~mol})$ in dry dichloromethane $(100 \mathrm{ml})$ and the mixture was stirred at room temperature for $3 \mathrm{~h}$. The suspension was diluted with ether $(100 \mathrm{ml})$, triturated and filtered through a silica plug (elute with ether). The resulting colourless solution was concentrated, affording the crude ketone which was not isolated, but dissolved in a mixture of ethanol $(90 \mathrm{~m} 1)$ and water $(10 \mathrm{~m} 1)$ and cooled to $0^{\circ} \mathrm{C}$. Sodium borohydride ( $6 \mathrm{~g}, 0.16 \mathrm{~mol})$ was added and the solution stirred for $1 \mathrm{~h}$. Addition of an excess of ammonium chloride destroyed unreacted borohydride and the resulting solution was concentrated. The crude material was dissolved in chloroform $(200 \mathrm{ml})$ and washed with water $(2 \times 100 \mathrm{~m} 1)$, dried and concentrated affording the alcohol $(2.14)(12.37 \mathrm{~g}, 84 \%)$ as a colourless solid. m.p $72-74^{\circ} \mathrm{C}\left(1 \mathrm{it}^{21} 77-78^{\circ} \mathrm{C}\right) \cdot[a]_{\mathrm{D}}^{20}+35.3^{\circ}\left(\mathrm{c}, 1.0, \mathrm{CHCl}_{3}\right)\left(1 \mathrm{it}{ }^{21}[a]_{\mathrm{D}}^{20}+34^{\circ}\right.$ $\left.\left(\underline{c}, 0.4, \mathrm{H}_{2} \mathrm{O}\right)\right) .{ }^{1} \mathrm{H}$ NMR $\delta 5.85(1 \mathrm{H}, \mathrm{d}, \mathrm{H}-1) ; 4.65(1 \mathrm{H}, \mathrm{dd}, \mathrm{H}-2) ; 4.35(1 \mathrm{H}, \mathrm{m}$, $\mathrm{H}-5) ; 4.05\left(3 \mathrm{H}, \mathrm{m}, \mathrm{H}-4,6,6^{\prime}\right) ; 3.85(1 \mathrm{H}, \mathrm{dd}, \mathrm{H}-3) ; 2.65(1 \mathrm{H}, \mathrm{br} \mathrm{d}, \mathrm{OH}) ; 1.60$, $1.50,1.40,1.39\left(12 \mathrm{H}, 4 \mathrm{~s}, \mathrm{CH}_{3} \mathrm{C}\right)$.

3- Azido- 3- deoxy- 1,2- $\underline{0}-$ isopropylidene- $a$ - $\underline{\underline{D}}-$ glucofuranose (2.16)

Diacetone allose (2.14) (11.04 g, $42.5 \mathrm{mmol})$ was dissolved in dry dichloromethane (150 m1) containing pyridine $(6.9 \mathrm{~m} 1,2$ equivs) and the solution cooled to $-30^{\circ} \mathrm{C}$ under an atmosphere of nitrogen. Trifluoromethanesulphonic anhydride ( $14.38 \mathrm{~g}, 1.2$ equivs) was added dropwise over $10 \mathrm{~min}$ and the suspension stirred for a further $30 \mathrm{~min}$. Methanol $(5 \mathrm{ml})$ was added, and the solution allowed to warm to room temperature. The solution was washed with water $(2 \times 100 \mathrm{~m} 1)$, dried and evaporated to a pale yellow syrup containing the triflate which was used directly without purification. 
The triflate was dissolved in dry DMF (100 ml) and stirred at $50^{\circ} \mathrm{C}$ for $8 \mathrm{~h}$ with sodium azide ( $5.5 \mathrm{~g}, 2$ equivs). The DMF was evaporated and the residue partitioned between chloroform $(100 \mathrm{ml})$ and water $(100 \mathrm{ml})$. The organic layer was dried and concentrated to a syrup containing 3- azido- 3- deoxy1,$2 ; 5,6 \mathrm{di}-\underline{0}-$ isopropylidene $a_{-}-\mathrm{D}-$ glucofuranose $(2.15)(11.12 \mathrm{~g}, 92 \%)$. A small quantity was purified by flash chromatography to give a colourless oil. $[a]_{\mathrm{D}}^{20}-41.8^{\circ}\left(\underline{c}, 4.3, \mathrm{CHCl}_{3}\right)\left(1 \mathrm{it}^{22}[a]_{\mathrm{D}}^{20}-41.5^{\circ}\left(\underline{c}, 2.0, \mathrm{CHCl}_{3}\right)\right) \cdot v_{\max } 2120$ $\mathrm{cm}^{-1} .1_{\mathrm{H} \mathrm{NMR}} \delta 5.90(1 \mathrm{H}, \mathrm{d}, \mathrm{H}-1) ; 4.60(1 \mathrm{H}, \mathrm{d}, \mathrm{H}-2) ; 4.25(1 \mathrm{H}, \mathrm{m}, \mathrm{H}-5)$; $4.15\left(2 \mathrm{H}, \mathrm{m}, \mathrm{H}-6,6^{\prime}\right) ; 3.95(1 \mathrm{H}, \mathrm{dd}, \mathrm{H}-4) ; 1.50,1.45,1.35,1.30(12 \mathrm{H}, 4 \mathrm{~s}$, $\left.\mathrm{CH}_{3} \mathrm{C}\right) . \underline{\mathrm{m} / \mathrm{z}}: 286\left(\mathrm{M}+\mathrm{H}^{+}\right)$. The crude diacetonide (2.15) was dissolved in methanol : acetic acid : water $(50 \mathrm{ml}, 40 \mathrm{ml}, 60 \mathrm{ml})$ and heated at $50^{\circ} \mathrm{C}$ for $12 \mathrm{~h}$. The solvent was removed and the resulting product filtered through a silica plug (eluted. with ether) affording the title compound (2.16) (9.55 g, quantitative) as a colourless syrup which crystallised. m.p $86-87^{\circ} \mathrm{C}\left(1 \mathrm{it}^{20}\right.$ $\left.84-85^{\circ} \mathrm{C}\right) . \quad[a]_{\mathrm{D}}^{20}-32.3^{\circ}\left(\underline{c}, 0.95, \mathrm{CHCl}_{3}\right)\left(\operatorname{lit}^{20}[a]_{\mathrm{D}}^{20}-30^{\circ}\left(\underline{c}, 1.0, \mathrm{CHCl}_{3}\right)\right.$. $V_{\max } 3540-3320,2100 \mathrm{~cm}^{-1} \cdot 1_{\mathrm{H}} \mathrm{NMR} \delta 5.90(1 \mathrm{H}, \mathrm{d}, \mathrm{H}-1) ; 4.65(1 \mathrm{H}, \mathrm{d}, \mathrm{H}-2)$; 4.25- $3.75\left(5 \mathrm{H}, \mathrm{m}, \mathrm{H}-3,4,5,6,6^{\prime}\right) ; 2.65(1 \mathrm{H}, \mathrm{br} \mathrm{d}, \mathrm{OH}) ; 2.20(1 \mathrm{H}, \mathrm{br} \mathrm{s}$, $\mathrm{OH}) ; 1.55,1.40\left(6 \mathrm{H}, 2 \mathrm{~s}, \mathrm{CH}_{3} \mathrm{C}\right) \cdot \underline{\mathrm{m} / \mathrm{z}}: 263\left(\mathrm{M}+\mathrm{NH}_{4}^{+}\right), 220(100 \%) \cdot$ Found $\mathrm{C}, 44.5 ; \mathrm{H}, 6.4 ; \mathrm{N}, 17.0 . \mathrm{C}_{9} \mathrm{H}_{15} \mathrm{~N}_{3} \mathrm{O}_{5}$ requires $\mathrm{C}, 44.1 ; \mathrm{H}, 6.1 ; \mathrm{N}, 17.1$.

3- Azido- 3- deoxy- 1,2- $\underline{0}-$ isopropylidene- 6- $\underline{0}-$ p-toluenesulphony1- $a-$

$\underline{\underline{D}-\text { glucofuranose }(2.17)}$

Azido diol (2.16) (5.09 g, $20.8 \mathrm{mmol})$ was dissolved in dry pyridine ( $80 \mathrm{ml})$ and $\mathrm{p}$-toluenesulphonyl chloride $(4.16 \mathrm{~g}, 21.8 \mathrm{mmol})$ was added, with stirring, at $-10^{\circ} \mathrm{C}$. The solution was kept at this temperature for $24 \mathrm{~h}$. The bulk of the pyridine was removed and the solution diluted with dichloro- 
methane $(100 \mathrm{~m} 1)$ and washed successively with hydrochloric acid (2M, aq, 100 $\mathrm{m} 1$ ), water ( $2 \times 100 \mathrm{~m} 1)$ and saturated aqueous sodium bicarbonate solution $(100 \mathrm{~m} 1)$. The organic layer was dried, and evaporated to a syrup which was filtered through a silica plug (eluted with ether) affording the title compound $(2.17)(7.42 \mathrm{~g}, 89 \%)$ as a syrup. $[a]_{\mathrm{D}}^{20}-9.0^{\circ}\left(\underline{\mathrm{c}}, 4.7, \mathrm{CHCl}_{3}\right)$. $V_{\max } 3600,2120,1360,1180 \mathrm{~cm}^{-1} \cdot 1_{\mathrm{H} \text { NMR }} \delta 7.80,7.30(4 \mathrm{H}, 2 \mathrm{~d}, \mathrm{ArH}) ; 5.80$ $(1 \mathrm{H}, \mathrm{d}, \mathrm{H}-1) ; 4.60(1 \mathrm{H}, \mathrm{d}, \mathrm{H}-2) ; 4.30-4.00\left(5 \mathrm{H}, \mathrm{m}, \mathrm{H}-3,4,5,6,6^{\prime}\right)$; $3.1(1 \mathrm{H}$, br s, OH $) ; 2.45\left(3 \mathrm{H}, \mathrm{s}, \mathrm{ArCH}_{3}\right) ; 1.40,1.30\left(6 \mathrm{H}, 2 \mathrm{~s}, \mathrm{CH}_{3} \mathrm{C}\right) . \underline{\mathrm{m} / \mathrm{z}}:$ $417\left(\mathrm{M}+\mathrm{NH}_{4}^{+}\right)$. Found $\mathrm{C}, 48.47 ; \mathrm{H}, 5.28 ; \mathrm{N}, 10.38 . \mathrm{C}_{16} \mathrm{H}_{21} \mathrm{~N}_{3} \mathrm{O}_{7} \mathrm{~S}$ requires $\mathrm{C}, 48.12 ; \mathrm{H}, 5.26 ; \mathrm{N}, 10.53$.

3,6- Dideoxy- 3,6- imino- 1,2- $\underline{0}-$ isopropylidene- $a-\underline{\underline{D}}-$ glucofuranose tosylate salt $(2.13)$

The tosylate $(2.17)(7.42 \mathrm{~g}, 18.6 \mathrm{mmol})$ was dissolved in ethanol ( $80 \mathrm{ml})$ and hydrogenated with palladium black $(0.28 \mathrm{~g})$. After a few minutes the title compound was seen to commence crystallisation from the solution. After $24 \mathrm{~h}$ the crystallised material was re-dissolved by addition of water (100 ml) and the catalyst removed by filtration. The solvent was evaporated and the title compound (2.13) recrystallised directly by the addition of ethanol as white needles $\left(5.31 \mathrm{~g}, 77 \%, 53 \%\right.$ from diacetone glucose). m.p $187-188^{\circ} \mathrm{C}$. $[a]_{D}^{20}+28.1^{\circ}\left(\underline{c}, 0.83, \mathrm{H}_{2} \mathrm{O}\right) .{ }^{1} \mathrm{H} \operatorname{NMR}\left(\mathrm{D}_{2} \mathrm{O}\right) \delta 7.5,7.2(4 \mathrm{H}, 2 \mathrm{~d}, \operatorname{ArH}) ; 6.0$ $\left(1 \mathrm{H}, \mathrm{d}, \mathrm{H}-1, \mathrm{~J}_{12} 3.8 \mathrm{~Hz}\right) ; 4.97(1 \mathrm{H}, \mathrm{d}, \mathrm{H}-2) ; 4.81(1 \mathrm{H}, \mathrm{t}, \mathrm{H}-4) ; 4.37$ (1H, ddd, $\mathrm{H}-5) ; 4.18\left(1 \mathrm{H}, \mathrm{d}, \mathrm{H}-3, \mathrm{~J}_{34} 3.9 \mathrm{~Hz}\right) ; 3.35\left(1 \mathrm{H}, \mathrm{dd}, \mathrm{H}-6, \mathrm{~J}_{66}, 11.7 \mathrm{~Hz}, \mathrm{~J}_{56} 6.6 \mathrm{~Hz}\right)$; $3.03\left(1 \mathrm{H}, \mathrm{dd}, \mathrm{H}-6^{\prime}, \mathrm{J}_{56^{\prime}} 8.5 \mathrm{~Hz}\right) ; 2.23\left(3 \mathrm{H}, \mathrm{s}, \mathrm{ArCH}_{3}\right) ; 1.37,1.22\left(6 \mathrm{H}, 2 \mathrm{~s}, \mathrm{CH}_{3} \mathrm{C}\right)$. ${ }^{13} \mathrm{C}$ NMR $\left(\mathrm{D}_{2} \mathrm{O}\right) \delta 20.26\left(\mathrm{q}, \mathrm{CH}_{3} \mathrm{Ar}\right) ; 25.46,25.81\left(2 \mathrm{q}, \underline{\mathrm{CH}}_{3} \mathrm{C}\right) ; 47.83(\mathrm{t}, \mathrm{C}-6)$; $65.21(\mathrm{~d}, \mathrm{C}-3) ; 69.21(\mathrm{~d}, \mathrm{C}-5) ; 81.74,82.56(2 \mathrm{~d}, \mathrm{C}-2,4) ; 106.29(\mathrm{~d}, \mathrm{C}-1)$; $113.96\left(\mathrm{~s}, \mathrm{CH}_{3} \mathrm{C}\right) ; 125.20$ (d), 129.29 (d), 139.35 (s), 142.29 (s) (ArC). 
$\underline{\mathrm{m} / \mathrm{z}}\left(\mathrm{FAB}, \mathrm{Ar}^{+}\right): 202\left(\mathrm{M}+\mathrm{H}^{+}, 100 \%\right)$. Found $\mathrm{C}, 51.4 ; \mathrm{H}, 6.2 ; \mathrm{N}, 3.7$. $\mathrm{C}_{16}{ }_{23}{ }^{\mathrm{NO}} 6{ }_{6} \mathrm{~S}$ requires $\mathrm{C}, 51.5 ; \mathrm{H}, 6.2 ; \mathrm{N}, 3.8$.

1,4- Dideoxy- 1,4- imino- L- gulitol hydrochloride (2.1)

Tosylate salt (2.13) (0.2 $\mathrm{g}, 0.54 \mathrm{mmol})$ was dissolved in $50 \%$ aqueous trifluoroacetic acid $(4 \mathrm{ml})$ and warmed to $50^{\circ} \mathrm{C}$ for $1 \mathrm{~h}$. [The reaction could be monitored by NMR if $\mathrm{D}_{2} \mathrm{O}$ was used by observing the disappearance of the two isopropylidene singlets $(\delta 1.5,1.3)$ and appearance of the singlet of acetone ( 62.05$)$ ]. The solvent was removed and several co-distillations with toluene ensured removal of virtually all traces of TFA. The resulting syrup was dissolved in $50 \%$ aqueous ethanol, neutralised with sodium hydroxide solution (2M, aq) and then treated with sodium borohydride (25 mg, excess). After 15 min the reaction was quenched with ammonium chloride and the reaction mixture concentrated to a volume of $2 \mathrm{ml}$. This solution was loaded directly onto an acid ion exchange column (Dowex 50W-XH) (acid form). The inorganic impurities were washed away with distilled water and then the amine was eluted from the column with aqueous ammonia solution ( 0.5 molar). After freeze drying the free amine was obtained $(69 \mathrm{mg}, 76 \%)$ as a syrup. Acidification with dilute aqueous hydrochloric acid and freeze drying gave the crystalline hydrochloride salt, which was much easier to handle than the free amine. m.p $170-173^{\circ} \mathrm{C} . \quad[a]_{\mathrm{D}}^{20}+7.1^{\circ}\left(\underline{c}, 0.48, \mathrm{H}_{2} \mathrm{O}\right) . v_{\max }(\mathrm{KBr}) 3392,2961,2741$, $2579,2497,2424,2364,2041,1910,1601,1478,1450,1397,1377,1288,1231 \mathrm{~cm}^{-1}$. $1_{\mathrm{H} \text { NMR }}\left(\mathrm{D}_{2} \mathrm{O}\right) \delta 4.35\left(1 \mathrm{H}, \mathrm{dt}, \mathrm{H}-2, \mathrm{~J}_{23} 4.0 \mathrm{~Hz}, \mathrm{~J}_{12} 8.3 \mathrm{~Hz}\right) ; 4.13(1 \mathrm{H}, \mathrm{t}, \mathrm{H}-3)$; $3.98(1 \mathrm{H}, \mathrm{m}, \mathrm{H}-5) ; 3.62\left(1 \mathrm{H}, \mathrm{dd}, \mathrm{H}-6, \mathrm{~J}_{66}, 12.2 \mathrm{~Hz}\right) ; 3.45\left(3 \mathrm{H}, \mathrm{m}, \mathrm{H}-1,4,6^{\prime}\right)$; $3.01\left(1 \mathrm{H}, \mathrm{dd}, \mathrm{H}-1^{\prime}, \mathrm{J}_{11}, 12.0 \mathrm{~Hz}\right) .{ }^{13} \mathrm{C}\left(\mathrm{D}_{2} 0\right) \delta 47.48(\mathrm{t}, \mathrm{C}-1) ; 63.97$ ( $\mathrm{t}$ and d, $\mathrm{C}-4, \mathrm{C}-6) ; 69.07,70.68,71.32,(3 \mathrm{~d}, \mathrm{C}-2,3,5) . \underline{\mathrm{m} / \mathrm{z}}: 164\left(\mathrm{M}+\mathrm{H}^{+}, 100 \%\right)$. Found $\mathrm{C}, 35.99 ; \mathrm{H}, 7.07 ; \mathrm{N}, 6.66 . \mathrm{C}_{6} \mathrm{H}_{14} \mathrm{NO}_{4} \mathrm{Cl}$ requires $\mathrm{C}, 36.09 ; \mathrm{H}, 7.02$; 
$\mathrm{N}, 7.02$.

N- benzyloxycarbonyl- 3,6- dideoxy- 3,6- imino- 1,2- $\underline{0}-$ isopropylidene- $a$ -

$\underline{\underline{D}-\text { glucofuranose }(2.19)}$

Benzyl chloroformate $(2 \mathrm{ml}, 8.94 \mathrm{mmol})$ was added to a vigorously stirred suspension of the salt (2.13) ( $2 \mathrm{~g}, 5.36 \mathrm{mmol})$ partitioned between ether $(30 \mathrm{~m} 1)$ and saturated aqueous sodium bicarbonate solution $(12 \mathrm{ml})$ at $0^{\circ} \mathrm{C}$. After $1 \mathrm{~h}$ the two layers were separated and the organic layer dried and concentrated to a syrup. Purification by flash chromatography (ethyl acetate : hexane, $1: 1$ ) afforded the $\underline{\mathrm{N}}$ protected product $(2.19)(1.7 \mathrm{~g}, 95 \%)$ as a colourless syrup. $[a]_{D}^{20}-28.2^{\circ}\left(\underline{c}, 0.44, \mathrm{CHCl}_{3}\right) . v_{\max } 3500-3300,1700 \mathrm{~cm}^{-1}$. $1_{\mathrm{H} \text { NMR }} \delta 7.45-7.30(5 \mathrm{H}, \mathrm{m}, \mathrm{ArH}) ; 5.87\left(1 \mathrm{H}, \mathrm{d}, \mathrm{H}-1, \mathrm{~J}_{12} 3.3 \mathrm{~Hz}\right) ; 5.13-4.31$ $(5 \mathrm{H}, \mathrm{m}) ; 4.1,3.94,3.05\left(3 \mathrm{H}, \mathrm{m}, \mathrm{H}-3,6,6^{\prime}\right) ; 2.5(1 \mathrm{H}, \mathrm{br} \mathrm{s}, \mathrm{OH}) ; 1.52,1.33$ $\left(6 \mathrm{H}, 2 \mathrm{~s}, \mathrm{CH}_{3} \mathrm{C}\right) \cdot \underline{\mathrm{m} / \mathrm{z}}: 353\left(\mathrm{M}+\mathrm{NH}_{4}^{+}, 100 \%\right), 336$. Found $\mathrm{C}, 60.9 ; \mathrm{H}, 6.7$; $\mathrm{N}, 4.3 . \mathrm{C}_{17} \mathrm{H}_{21} \mathrm{NO}_{6}$ requires $\mathrm{C}, 60.9 ; \mathrm{H}, 6.3 ; \mathrm{N}, 4.2$.

$\underline{N}-$ benzyloxycarbony $1-5-\underline{0}-$ benzy $1-3,6-$ dideoxy- 3,6- imino- $1,2-\underline{0}-$ isopropylidene- $a-\underline{\underline{D}}-$ glucofuranose $(2.20)$

The $\mathrm{Z}$ protected amine $(2.19)(1.7 \mathrm{~g}, 5.1 \mathrm{mmol})$ in dry THF (10 ml) was added to a stirred suspension of sodium hydride ( $50 \%$ dispersion in oil, prewashed with hexane, $0.25 \mathrm{~g}, 1.1$ equivs $)$ in $\mathrm{THF}(10 \mathrm{ml})$ at $0^{\circ} \mathrm{C}$. Benzy 1 bromide $(0.66 \mathrm{ml}, 5.5 \mathrm{mmol})$ and tetra-butylammonium iodide $(0.2 \mathrm{~g})$ were added to the resulting suspension and the whole refluxed for $1 \mathrm{~h}$.

The solvent was removed and the residue partitioned between chloroform (50 $\mathrm{m} 1$ ) and water $(50 \mathrm{~m} 1)$. The organic layer was dried and concentrated to a syrup. Purification by flash chromatography (ethyl acetate : hexane, 1 : 3) gave the 
title compound $(2.20)(1.82 \mathrm{~g}, 84 \%)$ as a clear syrup. $[a]_{D}^{20}-25.2^{\circ}(\underline{c}, 0.79$, $\left.\mathrm{CHCl}_{3}\right) \cdot v_{\max } 1680 \mathrm{~cm}^{-1} \cdot 1_{\mathrm{H} N M R} \delta 7.3-7.2(10 \mathrm{H}, \mathrm{m}, \mathrm{ArH}) ; 5.95(1 \mathrm{H}, \mathrm{d}, \mathrm{H}-1)$; $5.15-4.1(7 \mathrm{H}, \mathrm{m}) ; 3.9-3.15\left(3 \mathrm{H}, \mathrm{m}, \mathrm{H}-3,6,6^{\prime}\right) ; 1.45,1.25\left(6 \mathrm{H}, 2 \mathrm{~s}, \mathrm{CH}_{3} \mathrm{C}\right)$. $\underline{\mathrm{m} / \mathrm{z}}: 443\left(\mathrm{M}+\mathrm{NH}_{4}^{+}\right), 426,368(100 \%)$. Found $\mathrm{C}, 68.2 ; \mathrm{H}, 6.4 ; \mathrm{N}, 3.5$. $\mathrm{C}_{24} \mathrm{H}_{27}{ }^{\mathrm{NO}} 6$ requires $\mathrm{C}, 67.8 ; \mathrm{H}, 6.4 ; \mathrm{N}, 3.3$.

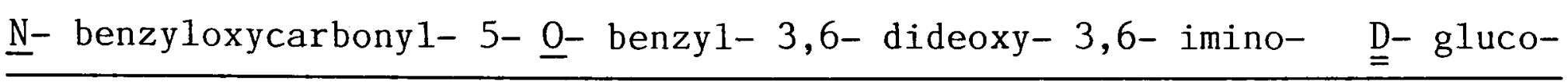
furanose $\quad(2.21)$

Acetonide (2.20) (1.82 $\mathrm{g}, 4.28 \mathrm{mmol})$ was dissolved in $50 \%$ aqueous trifluoroacetic acid $(10 \mathrm{~m} 1)$ and kept at room temperature for $4 \mathrm{~h}$. The solvent was removed and the residue purified by flash chromatography (ethyl acetate : hexane, $1: 1)$ to afford the lactol $(2.21)(1.58 \mathrm{~g}, 96 \%)$ as a hygroscopic syrup. $[a]_{D}^{20}-16.7^{\circ}\left(\underline{c}, 0.76, \mathrm{CHCl}_{3}\right) \cdot v_{\max } 3500-3300,1680 \mathrm{~cm}^{-1} \cdot 1_{\mathrm{H} \mathrm{NMR}} \delta$ 7.4- $7.25(10 \mathrm{H}, \mathrm{m}, \mathrm{ArH}) ; 5.55-4.1(8 \mathrm{H}, \mathrm{m}) ; 3.9,3.8,3.3\left(3 \mathrm{H}, \mathrm{m}, \mathrm{H}-3,6,6^{\prime}\right)$. $\underline{\mathrm{m} / \mathrm{z}}: 403\left(\mathrm{M}+\mathrm{NH}_{4}^{+}\right), 386,368,91(100 \%)$. Found $\mathrm{C}, 65.1 ; \mathrm{H}, 6.0 ; \mathrm{N}, 3.65$. $\mathrm{C}_{21} \mathrm{H}_{23}{ }^{\mathrm{NO}} 6$ requires $\mathrm{C}, 65.4 ; \mathrm{H}, 6.0 ; \mathrm{N}, 3.64$.

$\underline{N}-$ benzyloxycarbony1- 2- $\underline{0}-$ benzy1- 1,4- dideoxy- 1,4- imino- D- lyxitol (2.23) Lactol (2.21) (1.4 g, $3.64 \mathrm{mmol})$ was dissolved in $50 \%$ aqueous ethanol (25 $\mathrm{m} 1)$ and stirred at room temperature for $1 \mathrm{~h}$ with sodium periodate $(0.86 \mathrm{~g}, 1.1$ equivs). Sodium borohydride ( $75 \mathrm{mg}, 0.5$ molar equivs) was added and the stirring continued for $15 \mathrm{~min}$. Excess ammonium chloride was added to consume unreacted borohydride and the mixture concentrated to a syrup, which was partitioned between chloroform $(50 \mathrm{~m} 1)$ and water $(50 \mathrm{ml})$. The organic layer was dried and evaporated to a syrup. Purification by flash chromatography (ethyl acetate : hexane, $1: 1$ ) gave the title compound (2.23) as a clear $\operatorname{syrup}(1.09 \mathrm{~g}, 84 \%) \cdot[a]_{D}^{20}-50.5^{\circ}\left(\underline{c}, 0.37, \mathrm{CHC1}_{3}\right) \cdot v_{\max } 3420-3300,1680 \mathrm{~cm}^{-1}$ 


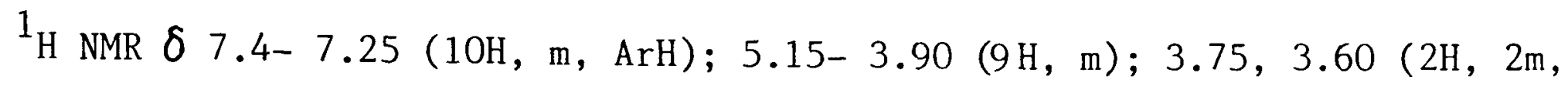
$\left.\mathrm{H}-1,1^{\prime}\right) . \underline{\mathrm{m} / \mathrm{z}}: 358\left(\mathrm{M}+\mathrm{H}^{+}\right)$. Analysis- decomposed to a mixture with the oxazolidine.

1,4- Dideoxy- 1,4- imino- D- 1yxitol hydrochloride (2.2).

Protected 1yxitol (2.23) (1.09 g, $3.05 \mathrm{mmol})$ was dissolved in glacial acetic acid $(10 \mathrm{ml})$ and hydrogenated with palladium black $(0.1 \mathrm{~g})$ for $24 \mathrm{~h}$. The catalyst was filtered and the solvent removed. Purification by ion exchange chromatography (procedure 1 and 2, chapter 1) afforded the lyxitol (2.2) as the free base which was crystallised as the hydrochloride salt by titration to $\mathrm{pH} 4$ with dilute hydrochloric acid (2M) and subsequent freeze drying of the resulting solution $(0.34 \mathrm{~g}, 66 \%)$ m.p $159-161^{\circ} \mathrm{C} .[a]_{\mathrm{D}}^{20}+19.8^{\circ}(\underline{\mathrm{c}}, 0.45$, $\left.\mathrm{H}_{2} \mathrm{O}\right) .{ }^{1} \mathrm{H}$ NMR $\left(\mathrm{D}_{2} \mathrm{O}\right) \delta 4.31\left(1 \mathrm{H}, \mathrm{dt}, \mathrm{H}-2, \mathrm{~J}_{23} 4.1 \mathrm{~Hz}\right) ; 4.17\left(1 \mathrm{H}, \mathrm{t}, \mathrm{H}-3, \mathrm{~J}_{34}\right.$ $4.1 \mathrm{~Hz}) ; 3.81\left(1 \mathrm{H}, \mathrm{dd}, \mathrm{H}-5, \mathrm{~J}_{45^{5}} .0 \mathrm{~Hz}\right) ; 3.72\left(1 \mathrm{H}, \mathrm{dd}, \mathrm{H}-5^{\prime}, \mathrm{J}_{55}, 12.1 \mathrm{~Hz}, \mathrm{~J}_{45}\right.$ ' $8.4 \mathrm{~Hz}) ; 3.56(1 \mathrm{H}, \mathrm{m}, \mathrm{H}-4) ; 3.36\left(1 \mathrm{H}, \mathrm{dd}, \mathrm{H}-1, \mathrm{~J}_{12} 7.3 \mathrm{~Hz}\right) ; 3.03\left(1 \mathrm{H}, \mathrm{dd}, \mathrm{H}-1^{\prime}\right.$, $\left.\mathrm{J}_{11}, 12.2 \mathrm{~Hz}, \mathrm{~J}_{1} \cdot 27.3 \mathrm{~Hz}\right) \cdot{ }^{13} \mathrm{C} \operatorname{NMR}\left(\mathrm{D}_{2} 0\right) \delta 70.70,70.55(2 \mathrm{~d}, \mathrm{C}-2,3) ; 63.22$ $(\mathrm{d}, \mathrm{C}-4) ; 58.38(\mathrm{t}, \mathrm{C}-5) ; 47.87(\mathrm{t}, \mathrm{C}-1) . \underline{\mathrm{m} / \mathrm{z}}: 134\left(\mathrm{M}+\mathrm{H}^{+}, 100 \%\right), 102$. Found $\mathrm{C}, 35.4 ; \mathrm{H}, 7.1 ; \mathrm{N}, 8.0 ; \mathrm{Cl}, 20.7 . \mathrm{C}_{5} \mathrm{H}_{12} \mathrm{NO}_{3} \mathrm{Cl}$ requires $\mathrm{C}, 35.4 ; \mathrm{H}, 7.1$; $\mathrm{N}, 8.26 ; \mathrm{Cl}, 20.9$. 
(2S, 3S, 4R)- 3,4- Dihydroxyproline (2.3)

Lacto1 (2.21) (572 mg, $1.49 \mathrm{mmol}$ ) was dissolved in ethanol : water ( $3: 1$, $32 \mathrm{~m} 1$ ) and stirred at room temperature with sodium periodate ( $1.24 \mathrm{~g}, 5.8$ mmol). After $2 \mathrm{~h}$, the solution was filtered and concentrated and the residue partitioned between water $(10 \mathrm{~m} 1)$ and chloroform $(10 \mathrm{~m} 1)$. The chloroform layer was dried and concentrated to a syrup.

The crude syrup was dissolved in t-butyl alcohol (20 m1) containing cyclohexene $(1.4 \mathrm{ml}, 13.8 \mathrm{mmol})$. A solution of sodium chlorite $(1.3 \mathrm{~g}, 14.4 \mathrm{mmol})$ and potassium dihydrophosphate $(1.4 \mathrm{~g}, 10.3 \mathrm{mmol})$ in water ( $7 \mathrm{ml}$ ) was added with vigorous stirring and the solution turned yellow. After $12 \mathrm{~h}$ the colour had disappeared and the solvent was removed. The residue was partitioned between water $(5 \mathrm{ml})$ and ethyl acetate $(20 \mathrm{ml})$ and the organic extract dried and concentrated to a syrup.

The crude syrup was dissolved in glacial acetic acid (10 m1) and stirred under hydrogen with palladium black (50 mg) for $24 \mathrm{~h}$. The catalyst was removed by filtration and the solvent evaporated. Purification of the residue by ion exchange chromatography (procedure 1, elute with aqueous pyridine) afforded the amino acid (2.3) ( $79 \mathrm{mg}, 36 \%$ over 3 steps) as a white crystalline solid which was recrystallised from aqueous acetone. m.p decomp above $220^{\circ} \mathrm{C}$. $[a]_{D}^{20}-56.8^{\circ}\left(\underline{c}, 0.16, H_{2} 0\right) . v_{\max }(\mathrm{KBr}) 3460,3160,3080,2980,2940,1625$, $1420 \mathrm{~cm}^{-1} \cdot 1_{\mathrm{H} \mathrm{NMR}}\left(\mathrm{D}_{2} \mathrm{O}\right) \delta 4.29(2 \mathrm{H}, \mathrm{m}, \mathrm{H}-3,4) ; 3.96\left(1 \mathrm{H}, \mathrm{d}, \mathrm{H}-2, \mathrm{~J}_{23} 3.9 \mathrm{~Hz}\right)$; $3.35\left(1 \mathrm{H}, \mathrm{dd}, \mathrm{H}-5, \mathrm{~J}_{45} 7.5 \mathrm{~Hz}\right) ; 3.07\left(1 \mathrm{H}, \mathrm{dd}, \mathrm{H}-5^{\prime}, \mathrm{J}_{55}, 11.4 \mathrm{~Hz}, \mathrm{~J}_{45}, 8.8 \mathrm{~Hz}\right)$. ${ }^{13} \mathrm{C}$ NMR $\left(\mathrm{D}_{2} 0\right) \delta 47.62(\mathrm{t}, \mathrm{C}-5) ; 65.36(\mathrm{~d}, \mathrm{C}-2) ; 71.36,71.65(2 \mathrm{~d}, \mathrm{C}-3,4)$; $171.20(\mathrm{~s}, \mathrm{C}-1) . \underline{\mathrm{m} / \mathrm{z}}: 165\left(\mathrm{M}+\mathrm{NH}_{4}^{+}\right), 148\left(\mathrm{M}+\mathrm{H}^{+}, 100 \%\right), 102,84,68$. Found $\mathrm{C}, 40.78 ; \mathrm{H}, 6.67 ; \mathrm{N}, 9.52 . \mathrm{C}_{5} \mathrm{H}_{9} \mathrm{NO}_{4}$ requires $\mathrm{C}, 40.82 ; \mathrm{H}, 6.12$; $\mathrm{N}, 9.71$. 


\section{Dimethoxyphosphinylacetic acid}

A solution of potassium hydroxide $(0.76 \mathrm{~g})$ in methanol $(5 \mathrm{ml})$ was added to a solution of trimethylphosphonoacetate $(2.2 \mathrm{ml}, 13.6 \mathrm{mmol})$ in methanol $(5 \mathrm{ml})$. The mixture was heated to $50^{\circ} \mathrm{C}$ for $2 \mathrm{~h}$. The solvent was evaporated and the residue suspended in acetone $(5 \mathrm{ml})$ and cooled to $0^{\circ} \mathrm{C}$. A saturated solution of hydrogen chloride in ether $(5 \mathrm{ml})$ was added with vigorous stirring until the solution was neutral. The solution was filtered and concentrated to afford the title compound $(2.19 \mathrm{~g}, 96 \%)$ as an oil. $1_{\mathrm{H} \text { NMR }}(60 \mathrm{MHz}) \delta$ $10.1\left(1 \mathrm{H}\right.$, br s, $\left.\mathrm{CO}_{2} \underline{\mathrm{H}}\right) ; 3.5,3.3\left(6 \mathrm{H}, 2 \mathrm{~s}, \mathrm{CH}_{3} \mathrm{O}\right) ; 2.8\left(2 \mathrm{H}, \mathrm{d}, \mathrm{CH}_{2}\right)$.

N- Dimethoxyphosphinylacety1- 3,6- dideoxy- 3,6- imino- 1,2- $\underline{0}$ - isopropylidene-

$a-\stackrel{D}{=}-$ glucofuranose $(2.26)$

A solution of the tosylate salt $(2.13)(2 \mathrm{~g}, 5.36 \mathrm{mmol})$ in DMF (10 ml) was neutralised with triethylamine $(1.12 \mathrm{ml}, 1.5$ equivs) and added to a solution of dimethoxyphosphinylacetic acid ( $1.35 \mathrm{~g}, 1.5$ equivs) and $\mathrm{N}^{\prime} \mathrm{N}^{\prime}$ dicyclohexy1carbodiimide (DCC) $\left(1.66 \mathrm{~g}, 1.5\right.$ equivs) in DMF (10 ml) at $0^{\circ} \mathrm{C}$. The solution was allowed to warm to room temperature and stirred for $8 \mathrm{~h}$. The dicyclohexyl urea (DCU) produced in the reaction was removed by filtration and the solution concentrated to a syrup. Purification by flash chromatography ( $10 \%$ ethanol in chloroform) gave the title compound $(2.26)(1.63 \mathrm{~g}, 87 \%$ ). $\mathrm{m} \cdot \mathrm{p} 123-124^{\circ} \mathrm{C} . \quad[a]_{\mathrm{D}}^{20}-40.6^{\circ}$ (c, $\left.0.34, \mathrm{MeOH}\right) . v_{\max } 3400(\mathrm{br}), 1640 \mathrm{~cm}^{-1}$. ${ }^{1}{ }_{\mathrm{H} N M R} \delta 5.9(1 \mathrm{H}, \mathrm{d}, \mathrm{H}-1) ; 4.9-3.1(7 \mathrm{H}, \mathrm{m}) ; 3.8\left(6 \mathrm{H}, 2 \mathrm{~m}, \mathrm{CH}_{3} \mathrm{O}\right) ; 3.0(2 \mathrm{H}, \mathrm{d}$, $\left.\mathrm{CH}_{2} \mathrm{P}\right) ; 1.5,1.3\left(6 \mathrm{H}, 2 \mathrm{~s}, \mathrm{CH}_{3} \mathrm{C}\right) . \underline{\mathrm{m} / \mathrm{z}}: 369\left(\mathrm{M}+\mathrm{NH}_{4}^{+}\right), 308(100 \%)$. Found $\mathrm{C}, 44.6 ; \mathrm{H}, 6.5 ; \mathrm{N}, 3.8 ; \mathrm{P}, 8.6 . \mathrm{C}_{13} \mathrm{H}_{22}{ }^{\mathrm{NO}} 8 \mathrm{P}^{\mathrm{P}}$ requires $\mathrm{C}, 44.4 ; \mathrm{H}, 6.3$; $\mathrm{N}, 4.0 ; \mathrm{P}, 8.8$. 
N- Dimethoxyphosphinylacetyl-3,6- dideoxy- 3,6- imino- D- glucose (2.27)

Acetonide (2.26) ( $1 \mathrm{~g}, 2.8 \mathrm{mmol})$ was dissolved in $50 \%$ aqueous trifluoroacetic acid $(10 \mathrm{ml})$ and stirred at $50^{\circ} \mathrm{C}$ for $1 \mathrm{~h}$. The solvent was removed and purification by flash chromatography (20\% methanol in chloroform) gave the title compound $(2.27)\left(0.88 \mathrm{~g}\right.$, quantitative), as a glass. $[\sigma]_{\mathrm{D}}^{20}-49.1^{\circ}$ $(\underline{c}, 0.4, \mathrm{EtOH}) . v_{\max } 3500-3200,1630 \mathrm{~cm}^{-1} \cdot 1_{\mathrm{H}} \mathrm{NMR}\left(\mathrm{D}_{2} \mathrm{O}\right) \delta 5.2(1 \mathrm{H}, \mathrm{m}, \mathrm{H}-1)$; $4.2-3.2(6 \mathrm{H}, \mathrm{m}) ; 3.6\left(6 \mathrm{H}, 2 \mathrm{~m}, \mathrm{CH}_{3} \mathrm{O}\right) ; 3.1\left(2 \mathrm{H}, \mathrm{d}, \mathrm{CH}_{2} \mathrm{P}\right) . \underline{\mathrm{m} / \mathrm{z}}: 312\left(\mathrm{M}+\mathrm{H}^{+}\right)$ and higher mass impurities.

(1S, 2R, 8S, 8aR)- 1,2,8 tri- $\underline{0}-$ acety1- 5- oxo- octahydroindolizine (2.30) Lactol (2.27) $(0.55 \mathrm{~g}, 1.78 \mathrm{mmol})$ was stirred at $70^{\circ} \mathrm{C}$ for $12 \mathrm{~h}$ with potassium carbonate $(0.74 \mathrm{~g}, 3$ equivs $)$ and $18-$ crown $-6(0.47 \mathrm{~g}, 1$ equiv) in DMF (12 m1). The solution was cooled, filtered through celite, concentrated and purified by flash chromatography (20\% methanol in chloroform) to give the cyclised unsaturated amide $(2.28)$ contaminated with $18-$ crown- $6 . \quad\left[v_{\max } 3400(\mathrm{br})\right.$, $1660,1590 \mathrm{~cm}^{-1}$. ${ }^{1} \mathrm{H} \operatorname{NMR}\left(\mathrm{D}_{2} 0\right) \delta 6.68\left(1 \mathrm{H}, \mathrm{dd}, \mathrm{H}-7, \mathrm{~J}_{67} 9.8 \mathrm{~Hz}, \mathrm{~J}_{78} 6.0 \mathrm{~Hz}\right)$; $5.90(1 \mathrm{H}, \mathrm{d}, \mathrm{H}-6) ; 4.49\left(1 \mathrm{H}, \mathrm{dd}, \mathrm{H}-1, \mathrm{~J}_{12} 4.0 \mathrm{~Hz}\right) ; 4.43\left(1 \mathrm{H}, \mathrm{dd}, \mathrm{H}-8, \mathrm{~J}_{88 \mathrm{a}} 3.5\right.$ $\mathrm{Hz}) ; 4.20\left(1 \mathrm{H}, \mathrm{dt}, \mathrm{H}-2, \mathrm{~J}_{23} 6.9 \mathrm{~Hz}\right) ; 3.75(1 \mathrm{H}, \mathrm{m}, \mathrm{H}-8 \mathrm{a}) ; 3.64$ (1H, ddd, H-3,

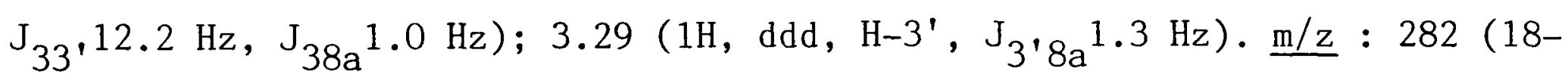
crown- $\left.\left.6+\mathrm{NH}_{4}^{+}, 100 \%\right), 186\left(\mathrm{M}+\mathrm{H}^{+}\right)\right]$.

The crude unsaturated amide was dissolved in ethanol $(8 \mathrm{ml})$ and hydrogenated in the presence of palladium black $(40 \mathrm{mg})$. The progress of the reaction was monitored by the disappearance of u.v activity on t.1.c as the saturated and unsaturated amides had identical $R_{f}$ values $(0.25$ in $20 \%$ methanol in chloroform). After $1 \mathrm{~h}$, no starting material remained. The catalyst was removed by filtration and the solvent evaporated. Purification by flash chromatography (20\% methanol in chloroform) gave the saturated amide (1S, 2R, 
8S, 8aR)- 1,2,8- trihydroxy- 5- oxo- octahydroindolizine (2.29) contaminated with 18 crown 6. [A pure sample of (2.29) was prepared by deacetylation of (2.30) using sodium methoxide in methanol at $50^{\circ} \mathrm{C} .[\mathrm{f} G]_{\mathrm{D}}^{20}-2.0^{\circ}(\underline{c}, 0.66, \mathrm{MeOH})$ $\left(1 \mathrm{it}^{7}[a]_{\mathrm{D}}^{25}+44^{\circ}(\mathrm{MeOH})\right) .{ }_{\mathrm{H} \text { NMR }}\left(\mathrm{D}_{2} \mathrm{O}\right) \delta 3.72(1 \mathrm{H}, \mathrm{dt}, \mathrm{H}-8) ; 3.68(1 \mathrm{H}, \mathrm{t}, \mathrm{H}-1)$; $3.56(1 \mathrm{H}, \mathrm{dt}, \mathrm{H}-2) ; 3.00(1 \mathrm{H}, \mathrm{m}, \mathrm{H}-8 \mathrm{a}) ; 2.92\left(1 \mathrm{H}, \mathrm{dd}, \mathrm{H}-3, \mathrm{~J}_{33}, 12.0 \mathrm{~Hz}\right) ; 2.59$ $\left(1 \mathrm{H}, \mathrm{ddd}, \mathrm{H}-3^{\prime}\right) ; 1.63\left(2 \mathrm{H}, \mathrm{m}, \mathrm{H}-6,6^{\prime}\right) ; 1.2\left(2 \mathrm{H}, \mathrm{m}, \mathrm{H}-7,7^{\prime}\right) . \underline{\mathrm{m} / \mathrm{z}}: 188\left(\mathrm{M}+\mathrm{H}^{+}\right.$, 100\%). Found $\mathrm{C}, 51.33 ; \mathrm{H}, 7.15 ; \mathrm{N}, 7.89 . \mathrm{C}_{8} \mathrm{H}_{13} \mathrm{NO}_{4}$ requires $\mathrm{C}, 51.34 ; \mathrm{H}, 6.95$; $\mathrm{N}, 7.49$.$] .$

The crude saturated amide was dissolved in pyridine ( $2 \mathrm{~m} 1$ ) containing acetic anhydride $(1 \mathrm{~m} 1)$. The solution was heated to $50^{\circ} \mathrm{C}$ for $4 \mathrm{~h}$, when t.l.c (ethyl acetate : acetone, $3: 1$ ) showed a single product $\left(\mathrm{R}_{\mathrm{f}} 0.3\right)$. The solvent was removed and purification by flash chromatography (ethyl acetate : acetone, $3: 1)$ gave the title compound, the triacetate $(2.30)(0.26 \mathrm{~g}, 47 \%)$. m.p $127-128^{\circ} \mathrm{C}\left(1 \mathrm{it}{ }^{41} 126-127^{\circ} \mathrm{C}\right) .[a]_{\mathrm{D}}^{20}-17.2^{\circ}\left(\mathrm{c}, 0.25, \mathrm{CHCl}_{3}\right)\left(1 \mathrm{it}^{41}[\sigma]_{\mathrm{D}}^{21}-21.8^{\circ}\right.$ $\left.\left(\underline{c}, 0.9, \mathrm{CHCl}_{3}\right)\right) \cdot v_{\max } 1740,1640,1235 \mathrm{~cm}^{-1} \cdot{ }_{\mathrm{H} N M R} \delta .56(1 \mathrm{H}, \mathrm{t}, \mathrm{H}-1) ; 5.39$ $(1 \mathrm{H}, \mathrm{dt}, \mathrm{H}-8) ; 5.30(1 \mathrm{H}, \mathrm{dt}, \mathrm{H}-2) ; 3.98(1 \mathrm{H}, \mathrm{dd}, \mathrm{H}-8 \mathrm{a}) ; 3.82(1 \mathrm{H}, \mathrm{dd}, \mathrm{H}-3) ; 3.71$ $\left(1 \mathrm{H}, \mathrm{dd}, \mathrm{H}-3^{\prime}\right) ; 2.32\left(2 \mathrm{H}, \mathrm{m}, \mathrm{H}-6,6^{\prime}\right) ; 2.01\left(2 \mathrm{H}, \mathrm{m}, \mathrm{H}-7,7^{\prime}\right) ; 2.08,2.07,2.05$ $\left(9 \mathrm{H}, 3 \mathrm{~s}, \mathrm{CH}_{3} \mathrm{CO}\right) .{ }^{13} \mathrm{C}$ NMR $\delta 20.50(2 \mathrm{q}), 21.04\left(\mathrm{q}, \mathrm{CH}_{3} \mathrm{CO}\right) ; 26.24(\mathrm{t}, \mathrm{C}-7) ; 27.04$ $(t, C-6) ; 46.78(t, C-3) ; 60.00(d, C-8 a) ; 64.70,69.06,71.60(t, C-1,2,8)$; $168.02(\mathrm{~s}, \mathrm{C}-5) ; 169.61(\mathrm{~s}), 169.73\left(2 \mathrm{~s}, \mathrm{CH}_{3} \mathrm{CO}\right) \cdot \underline{\mathrm{m} / \mathrm{z}}\left(\mathrm{ACE}, \mathrm{NH}_{3}\right) ; 314\left(\mathrm{M}+\mathrm{H}^{+}\right.$, $100 \%$ ). Found $\mathrm{C}, 53.52 ; \mathrm{H}, 6.13 ; \mathrm{N}, 4.27 . \mathrm{C}_{14} \mathrm{H}_{19} \mathrm{NO}_{7}$ requires $\mathrm{C}, 53.67 ; \mathrm{H}, 6.07$; N, 4.47 .

$(1 S, 2 R, 8 S, 8 a R)-1,2,8-$ tri- $\underline{0}-$ acetyl- octahydroindolizine borane adduct (2.31)

Amide (2.30) (0.18 g, $0.58 \mathrm{mmol})$ was dissolved in dry THF (15 ml) and borane methyl sulphide complex $(0.3 \mathrm{~m} 1)$ added at room temperature under a stream of dry nitrogen. After $1 \mathrm{~h}$, the reaction was carefully quenched with water (10 $\mathrm{m} 1$ ) and extracted with chloroform $(3 \times 20 \mathrm{~m} 1)$. The organic extracts were combined, 
dried and evaporated. Purification by flash chromatography (ethyl acetate : hexane, 2 : 3) gave the title compound (2.31) (0.12 g, 70\%). m.p 131-135 ${ }^{\circ} \mathrm{C}$. $[a]_{\mathrm{D}}^{20}-22.3^{\circ}\left(\underline{c}, 0.22, \mathrm{CHCl}_{3}\right) . v_{\max } 2380,1735,1500 \mathrm{~cm}^{-1} \cdot 1_{\mathrm{H}} \mathrm{NMR} \delta 5.85(1 \mathrm{H}$, $\mathrm{t}, \mathrm{H}-1) ; 5.58(1 \mathrm{H}, \mathrm{dt}, \mathrm{H}-2) ; 5.32(1 \mathrm{H}, \mathrm{m}, \mathrm{H}-8) ; 3.72(1 \mathrm{H}, \mathrm{dd}, \mathrm{H}-8 \mathrm{a}) ; 3.60(1 \mathrm{H}$, $\mathrm{dd}, \mathrm{H}-3) ; 3.35\left(1 \mathrm{H}, \mathrm{dd}, \mathrm{H}-3^{\prime}\right) ; 3.22(2 \mathrm{H}, \mathrm{m}, \mathrm{H}-5) ; 2.05\left(9 \mathrm{H}, 3 \mathrm{~s}, \mathrm{CH}_{3} \mathrm{CO}\right) ; 1.9-$ $1.7\left(4 \mathrm{H}, \mathrm{m}, \mathrm{H}-6,6^{\prime}, 7,7^{\prime}\right) .{ }^{13} \mathrm{C} \operatorname{NMR} \delta 17.22(\mathrm{t}, \mathrm{C}-6) ; 20.42(2 \mathrm{q}), 21.05(\mathrm{q}$, $\left.\underline{\mathrm{CH}}_{3} \mathrm{CO}\right) ; 26.30(\mathrm{t}, \mathrm{C}-7) ; 56.83(\mathrm{t}), 63.91(\mathrm{t}, \mathrm{C}-3,5) ; 65.43(\mathrm{~d}, \mathrm{C}-8 \mathrm{a}) ; 66.32$ (d), 68.91 (d), 70.30 (d) $(\mathrm{C}-1,2,8) ; 168.77(\mathrm{~s}) ; 169.29\left(2 \mathrm{~s}, \mathrm{CH}_{3} \mathrm{CO}\right) .{ }^{11}{ }_{\mathrm{B} \mathrm{NMR}}$ $\delta-8.6(\mathrm{br} \mathrm{s}) . \underline{\mathrm{m} / \mathrm{z}}\left(\mathrm{CI}, \mathrm{NH}_{3}\right): 300\left(\mathrm{M}+\mathrm{H}^{+}-\mathrm{BH}_{3}\right), 273,231$ (100\%). Found $\mathrm{C}, 53.71 ; \mathrm{H}, 7.88 ; \mathrm{N}, 4.75 . \mathrm{C}_{14} \mathrm{H}_{21} \mathrm{NO}_{6} \cdot \mathrm{BH}_{3}$ requires $\mathrm{C}, 53.67 ; \mathrm{H}, 7.67 ; \mathrm{N}, 4.48$.

$(1 \mathrm{~S}, 2 \mathrm{R}, 8 \mathrm{~S}, 8 \mathrm{aR})-1,2,8$ - trihydroxyoctahydroindolizine (2.4)

Triacetate (2.31) (50 mg, $0.16 \mathrm{mmol}$ ) was dissolved in methanol (5 m1) and stirred at $50^{\circ} \mathrm{C}$ for $2 \mathrm{~h}$ with a trace of sodium methoxide. The solution was evaporated to dryness and the residue dissolved in $50 \%$ aqueous trifluoroacetic acid $(2 \mathrm{~m} 1)$. After 5 min the solvent was evaporated. Subsequent purification of the residue by ion exchange chromatography (procedure 1 and 2) and removal of the solvent by freeze drying gave the indolizine (2.4) (22 $\mathrm{mg}, 80 \%$ ) as a white foam. $[a]_{D}^{20}-25.0^{\circ}(\underline{c}, 0.1, \mathrm{MeOH})\left(1 i t^{41}[\sigma]_{D}^{21}-24.8^{\circ}(\underline{c}, 0.67, \mathrm{MeOH})\right.$, $\left.1 \mathrm{it}^{7}[a]_{\mathrm{D}}^{21}-3.43^{\circ}(\underline{c}, 0.9, \mathrm{MeOH})\right) .{ }_{\mathrm{H}} \mathrm{NMR}\left(\mathrm{D}_{2} 0\right) \delta 4.1(2 \mathrm{H}, \mathrm{m}, \mathrm{H}-1,2) ; 4.05$ $(1 \mathrm{H}, \mathrm{dt}, \mathrm{H}-8) ; 2.9(1 \mathrm{H}, \mathrm{dt}, \mathrm{H}-5) ; 2.8(1 \mathrm{H}, \mathrm{dd}, \mathrm{H}-3) ; 2.3\left(1 \mathrm{H}, \mathrm{dd}, \mathrm{H}-3^{\prime}\right) ; 1.95$ $(1 \mathrm{H}, \mathrm{dd}, \mathrm{H}-8 \mathrm{a}) ; 1.9\left(1 \mathrm{H}, \mathrm{dt}, \mathrm{H}-5^{\prime}\right) ; 1.7-1.3\left(4 \mathrm{H}, \mathrm{m}, \mathrm{H}-6,6^{\prime}, 7,7^{\prime}\right) .{ }^{13} \mathrm{C}$ NMR $\left(d^{4} \mathrm{MeOH}\right) \delta 20.6(t, C-7) ; 32.0(t, C-6) ; 54.2,62.8(2 t, C-3,5) ; 67.5(d$, $\mathrm{C}-8 \mathrm{a}) ; 69.3,69.9,74.2(3 \mathrm{~d}, \mathrm{C}-1,2,8) .{ }^{13} \mathrm{C}$ NMR (hydrochloride salt) $\left(\mathrm{d}^{4} \mathrm{MeOH}\right)$ $\delta 19.02,30.35,53.88,59.54,65.60,69.53,70.05,72.89$. (1it spectrum ${ }^{41}$ $20.68,32.08,54.27,62.98,67.53,69.40,69.96,74.29$. 1it spectrum ${ }^{7} 17.9,24.5$, $44.4,61.5,64.3,72.2,75.2,82.1$ (both $\left.\mathrm{d}^{4} \mathrm{MeOH}\right) . \underline{\mathrm{m} / \mathrm{z}}: 174\left(\mathrm{M}+\mathrm{H}^{+}, 100 \%\right)$, $155,113,96$. 
Methyl E- (N- benzyloxycarbony1- 2- $\underline{0}-$ benzy1- 3- $\underline{0}-$ formy 1- 1,4- imino-

1,4,5,6- tetradeoxy- D- 1yxo-heptafuranosid)- uro- 5- enoate (2.32)

Lactol (2.21) (0.49 $\mathrm{g}, 1.27 \mathrm{mmol})$ was dissolved in ethanol : water, $3: 1$ $(50 \mathrm{ml})$ and stirred at room temperature with sodium periodate $(0.82 \mathrm{~g}, 3$ equivs). After $1 \mathrm{~h}$ the solution was filtered and the solvent evaporated. The residue was partitioned between chloroform $(50 \mathrm{ml})$ and water $(50 \mathrm{ml})$. The chloroform layer was dried and evaporated to a syrup, the aldehyde (2.22) ( ${ }^{1} \mathrm{H}$ NMR $\delta 9.54$, $9.47\left(1 \mathrm{H}, 2 \mathrm{~d}, \mathrm{CHO}, \mathrm{J}_{45} 2.4 \mathrm{~Hz}\right) ; 8.08(1 \mathrm{H}, 2 \mathrm{~s}, \mathrm{OCHO}) ; 7.38-7.28(10 \mathrm{H}, \mathrm{m}, \mathrm{ArH})$; $5.64,5.54(1 \mathrm{H}, 2 \mathrm{dd}, \mathrm{H}-3) ; 5.1-4.5\left(4 \mathrm{H}, \mathrm{m}, \mathrm{PhCH}_{2} \mathrm{x} 2\right) ; 4.3(1 \mathrm{H}, \mathrm{dt}, \mathrm{H}-2)$; $4.1(1 \mathrm{H}, \mathrm{m}, \mathrm{H}-4) ; 3.9(2 \mathrm{H}, \mathrm{m}, \mathrm{H}-1)$ ) which was dissolved in benzene $(25 \mathrm{~m} 1)$. Carbomethoxymethylene triphenylphosphorane $(0.86 \mathrm{~g}, 3$ equivs $)$ was added and the mixture refluxed for $4 \mathrm{~h}$.

The solution was cooled, washed with water $(50 \mathrm{ml})$, dried and evaporated to a syrup which was purified by flash chromatography (ether : hexane, 2 : 1) to afford the title compound $(2.32)(0.42 \mathrm{~g}, 74 \%)$ as a clear syrup. $[a]_{D}^{20}+14^{\circ}$ $\left(\underline{c}, 0.3, \mathrm{CHCl}_{3}\right) \cdot v_{\max } 1720(\mathrm{br}), 1660(\mathrm{w}), 1410,1340 \mathrm{~cm}^{-1} \cdot 1_{\mathrm{H}} \mathrm{NMR} \delta 8.1$ $(1 \mathrm{H}$, br s, OCHO) ; 7.5- $7.3(10 \mathrm{H}, \mathrm{m}, \mathrm{ArH}) ; 7.0(1 \mathrm{H}, \mathrm{m}, \mathrm{H}-5) ; 5.9(1 \mathrm{H}, 2 \mathrm{~d}, \mathrm{H}-6)$; $5.4(1 \mathrm{H}, \mathrm{m}, \mathrm{H}-3) ; 5.1\left(2 \mathrm{H}, \mathrm{ABq}, \mathrm{PhCH}_{2}\right) ; 4.7\left(3 \mathrm{H}, \mathrm{m}, \mathrm{PhCH}_{2}, \mathrm{H}-2\right) ; 4.1(1 \mathrm{H}, \mathrm{dd}$, $\mathrm{H}-4) ; 3.9-3.7\left(2 \mathrm{H}, \mathrm{m}, \mathrm{H}-1,1^{\prime}\right) ; 3.8\left(3 \mathrm{H}, \mathrm{s}, \mathrm{CH}_{3} 0\right) .{ }^{13} \mathrm{C} \mathrm{NMR} \delta 49.09$ (t, $\left.\mathrm{C}-1\right)$; $51.41\left(\mathrm{q}, \mathrm{CH}_{3}\right) ; 58.82\left(\right.$ br d, C-4); 67.26, $72.19\left(2 \mathrm{t}, \mathrm{PhCH}_{2}\right) ; 72.85(2 \mathrm{~d}), 75.39$ $(2 \mathrm{~d}, \mathrm{C}-2,3) ; 123.79(\mathrm{~d}, \mathrm{C}-5) ; 127.4-137.1(\mathrm{ArC}) ; 142.93(2 \mathrm{br} d, \mathrm{C}-6) ; 154.52$ $(\mathrm{s}, \underline{\mathrm{CON}}) ; 159.49(\mathrm{~d}, \underline{\mathrm{OCHO}}) ; 165.99(\mathrm{~s}, \underline{\mathrm{CO}} 2 \mathrm{Me}) . \underline{\mathrm{m} / \mathrm{z}}: 457\left(\mathrm{M}+\mathrm{NH}_{4}^{+}\right), 440$, $91(100 \%)$. Found $\mathrm{C}, 65.36 ; \mathrm{H}, 5.76 ; \mathrm{N}, 2.97 . \mathrm{C}_{24} \mathrm{H}_{25} \mathrm{NO}_{7}$ requires $\mathrm{C}, 65.60$; $\mathrm{H}, 5.69 ; \mathrm{N}, 3.19$. 
Methy1- E- (N- benzyloxycarbony1- 2- $\underline{0}-$ benzy1- 1,4- imino- 1,4,5,6-

tetradeoxy - D- 1yxo-heptafuranosid)- uro- 5- enoate (2.34)

Formate ester (2.32) (0.11 g, $0.25 \mathrm{mmol})$ was dissolved in methanol $(3 \mathrm{ml})$ containing a trace of sodium methoxide. The solvent was immediately removed and purification by flash chromatography (ethyl acetate : hexane, 1 : 1), gave the title compound (2.34) (87 $\mathrm{mg}, 85 \%$ ) as a syrup. ${ }^{1} \mathrm{H}$ NMR $\delta 7.5-7.3$ $(10 \mathrm{H}, \mathrm{m}, \mathrm{ArH}) ; 6.95(1 \mathrm{H}, \mathrm{m}, \mathrm{H}-5) ; 5.97\left(1 \mathrm{H}, 2 \mathrm{~d}, \mathrm{H}-6, \mathrm{~J}_{56} 15.8 \mathrm{~Hz}\right) ; 5.10(2 \mathrm{H}, \mathrm{m}$, $\left.\mathrm{PhCH}_{2}\right) ; 4.72(2 \mathrm{H}, \mathrm{m}, \mathrm{H}-2,3) ; 4.52\left(2 \mathrm{H}, \mathrm{m}, \mathrm{PhCH}_{2}\right) ; 4.07(1 \mathrm{H}, \mathrm{m}, \mathrm{H}-4) ; 3.74$ $\left(3 \mathrm{H}, \mathrm{s}, \mathrm{CH}_{3}\right) ; 2.64\left(2 \mathrm{H}, \mathrm{m}, \mathrm{H}-1,1^{\prime}\right) ; 2.69(1 \mathrm{H}, \mathrm{OH})$.

In a separate experiment, the alcohol (2.34) was prepared directly from the lacto1 (2.21) without isolating the formate ester (2.32). From the lactol (2.21) (1.36 $\mathrm{g}, 3.5 \mathrm{mmol})$, the alcohol (2.34) (1.17 $\mathrm{g}, 81 \%)$ was prepared in 3 steps.

$(1 \mathrm{~S}, 2 \mathrm{R}, 8 \mathrm{R})$ 1,2 dihydroxy-5- oxo- pyrrolizidine (2.35)

The unsaturated ester $(2.34)(1.1 \mathrm{~g}, 2.7 \mathrm{mmol})$ was dissolved in ethanol (40 m1) and stirred under hydrogen with palladium black $(0.2 \mathrm{~g})$ at atmospheric pressure. After $48 \mathrm{~h}, \mathrm{t.1.c}$ ( $10 \%$ methanol in chloroform) showed disappearance of starting material $\left(R_{f} 1\right)$ and two products. The major product $\left(R_{f} 0.2\right)$ was subsequently found to be the title compound (2.35) and the minor product $\left(R_{f} 0.7\right)$ was the cyclised material with the $\underline{0}$ benzyl group still present (2.33). The catalyst was removed by filtration and the solvent evaporated. Purification of the residue by flash chromatography ( $10 \%$ methanol in chloroform) initially gave the benzylated material (2.33) (96 mg, 14\%) ( ${ }^{1} \mathrm{H}$ NMR $\delta 7.4-7.3$ $(5 \mathrm{H}, \mathrm{m}, \mathrm{ArH}) ; 4.7\left(2 \mathrm{H}, \mathrm{ABq}, \mathrm{PhCH}_{2}\right) ; 4.3(1 \mathrm{H}, \mathrm{dt}, \mathrm{H}-2) ; 4.0(1 \mathrm{H}, \mathrm{t}, \mathrm{H}-1) ; 3.9$ $(1 \mathrm{H}, \mathrm{m}, \mathrm{H}-8) ; 3.5(1 \mathrm{H}, \mathrm{dd}, \mathrm{H}-3) ; 3.3\left(1 \mathrm{H}, \mathrm{dd}, \mathrm{H}-3^{\prime}\right) ; 2.5\left(2 \mathrm{H}, \mathrm{m}, \mathrm{H}-6,6^{\prime}\right)$; $\left.2.1\left(2 \mathrm{H}, \mathrm{m}, \mathrm{H}-7,7^{\prime}\right).\right)$ together with the title compound (2.35) (0.21 g, 50\%). m.p $160-162^{\circ} \mathrm{C} . \quad[a]_{\mathrm{D}}^{20}-31.3^{\circ}(\underline{c}, 0.2, \mathrm{MeOH}) . v_{\max }(\mathrm{nujol}) 3400(\mathrm{br}), 1625 \mathrm{~cm}^{-1}$. 
${ }^{1} \mathrm{H} \mathrm{NMR}\left(\mathrm{D}_{2} \mathrm{O}\right) \delta 3.91(1 \mathrm{H}, \mathrm{dt}, \mathrm{H}-8) ; 4.4(1 \mathrm{H}, \mathrm{dt}, \mathrm{H}-2) ; 3.8(1 \mathrm{H}, \mathrm{t}, \mathrm{H}-1) ; 3.3$ $(1 \mathrm{H}, \mathrm{ddd}, \mathrm{H}-3) ; 2.9\left(1 \mathrm{H}, \mathrm{dd}, \mathrm{H}-3^{\prime}\right) ; 2.4(1 \mathrm{H}, \mathrm{m}, \mathrm{H}-6) ; 2.1\left(1 \mathrm{H}, \mathrm{H}-6^{\prime}\right) ; 1.9$ $\left(2 \mathrm{H}, \mathrm{m}, \mathrm{H}-7,7^{\prime}\right) . \underline{\mathrm{m} / \mathrm{z}}$ (in beam $\left.\mathrm{EI}\right): 157\left(\mathrm{M}^{+}\right), 139,114,97(100 \%)$. Found $\mathrm{C}, 53.41 ; \mathrm{H}, 7.00 ; \mathrm{N}, 8.64 . \mathrm{C}_{7} \mathrm{H}_{11} \mathrm{NO}_{3}$ requires $\mathrm{C}, 53.50 ; \mathrm{H}, 7.01 ; \mathrm{N}$, 8.92 .

(1S, 2R, 8R)- 1,2- $\underline{0}-$ isopropylidene- 5- oxo- pyrrolizidine (2.36)

Diol (2.35) (97 mg, $0.62 \mathrm{mmol}$ ) was suspended in acetone ( $3 \mathrm{~m} 1$ ) and 2,2 dimethoxypropane $(3 \mathrm{ml})$ containing a trace of $10( \pm)$ - camphorsulphonic acid such that the $\mathrm{pH}$ of the mixture was about $3-4$. The diol slowly dissolved as the reaction proceeded and after $3 \mathrm{~h}$ the clear solution was neutralised with ammonia solution (SG 0.88 ). The solvent was evaporated and the residue partitioned between water $(5 \mathrm{ml})$ and ethyl acetate $(5 \mathrm{~m} 1)$. The organic layer was dried and evaporated. Purification of the residue by flash chromatography (1\% ethanol in ethyl acetate) gave the title compound (2.36) $\left(0.12 \mathrm{~g}\right.$, quantitative). m.p $75^{\circ} \mathrm{C} .[\mathrm{a}]_{\mathrm{D}}^{20}+28.8^{\circ}\left(\underline{c}, 0.32, \mathrm{CHCl}_{3}\right) \cdot v_{\max }$ $\left.1680 \mathrm{~cm}^{-1}\right) .1_{\mathrm{H} \text { NMR }} \delta 4.81(1 \mathrm{H}, \mathrm{t}, \mathrm{H}-2) ; 4.52(1 \mathrm{H}, \mathrm{dd}, \mathrm{H}-1) ; 3.96(1 \mathrm{H}, \mathrm{d}, \mathrm{H}-3)$; $3.78\left(1 \mathrm{H}, \mathrm{m}, \mathrm{H}-8, \mathrm{~J}_{18^{4}} .1 \mathrm{~Hz}\right) ; 2.95\left(1 \mathrm{H}, \mathrm{ddd}, \mathrm{H}-3^{\prime}, \mathrm{J}_{33^{\prime}} 13.2 \mathrm{~Hz}\right) ; 2.55(2 \mathrm{H}$, $\left.\mathrm{m}, \mathrm{H}-6,6^{\prime}\right) ; 2.22\left(2 \mathrm{H}, \mathrm{m}, \mathrm{H}-7,7^{\prime}\right) ; 1.40,1.30\left(6 \mathrm{H}, 2 \mathrm{~s}, \mathrm{CH}_{3} \mathrm{C}\right) . \mathrm{m} / \mathrm{z}$ (in beam EI) : $197\left(\mathrm{M}^{+}\right), 182,139,110,82,62,45(100 \%)$. Found $\mathrm{C}, 60.85 ; \mathrm{H}, 7.79$; $\mathrm{N}, 7.14 . \mathrm{C}_{10} \mathrm{H}_{15} \mathrm{NO}_{3}$ requires $\mathrm{C}, 60.91 ; \mathrm{H}, 7.61 ; \mathrm{N}, 7.11$. (1S, 2R, 8R) 1,2- 0 - isopropylidene- pyrrolizidine borane adduct (2.37). The amide (2.36) (96 mg, $0.49 \mathrm{mmol}$ ) was dissolved in dry THF ( $5 \mathrm{ml}$ ) and stirred at room temperature under nitrogen with borane methyl sulphide complex $(0.2 \mathrm{~m} 1)$. After $2 \mathrm{~h}$ the reaction was cautiously quenched with water $(10 \mathrm{ml})$ and diluted with chloroform $(25 \mathrm{ml})$. The aqueous phase was 
extracted with further chloroform $(3 \times 10 \mathrm{ml})$ and the organic extracts were combined, dried and concentrated. Purification by flash chromatography ( athyl acetate : hexane, $1: 4$ ) gave the title compound (2.37) (81 mg, 90\%). $[a]_{\mathrm{D}}^{20}-15.4^{\circ}\left(\underline{\mathrm{c}}, 0.28, \mathrm{CHCl}_{3}\right) .1_{\mathrm{H}} \operatorname{NMR} \delta 4.9(1 \mathrm{H}, \mathrm{m}, \mathrm{H}-2) ; 4,8(1 \mathrm{H}, \mathrm{dd}, \mathrm{H}-1)$; $3.6-3.2\left(5 \mathrm{H}, \mathrm{m}, \mathrm{H}-3,3^{\prime}, 5,5^{\prime}, 8\right) ; 2.2-2.0\left(4 \mathrm{H}, \mathrm{m}, \mathrm{H}-6,6^{\prime}, 7,7^{\prime}\right)$; $1.5,1.3\left(6 \mathrm{H}, 2 \mathrm{~s}, \mathrm{CH}_{3} \mathrm{C}\right) \cdot \underline{\mathrm{m} / \mathrm{z}}: 183\left(\mathrm{M}+\mathrm{H}^{+}\right)$

(1S, 2R, 8R) 1,2- Dihydroxy pyrrolizidine hydrochloride (2.5)

Acetonide (2.37) (61 mg, $0.31 \mathrm{mmol}$ ) was heated to $50^{\circ} \mathrm{C}$ in $50 \%$ aqueous trifluoroacetic acid $(4 \mathrm{ml})$ for $12 \mathrm{~h}$. Evaporation of the solvent and purification by ion exchange chromatography (procedure 1) gave the title compound as the free base, which was neutralised with hydrochloric acid and freeze dried to give the hydrochloride salt (55 mg, quantitative) as a hygroscopic gum. $[\sigma]_{\mathrm{D}}^{20} 0$ (c, $\left.0.1, \mathrm{H}_{2} \mathrm{O}\right) .1_{\mathrm{H} N M R}(\operatorname{salt})\left(\mathrm{D}_{2} \mathrm{O}\right) \delta 3.97(1 \mathrm{H}$, ddd, $\mathrm{H}-2) ; 3.82(2 \mathrm{H}, \mathrm{m}, \mathrm{H}-1,8) ; 3.30\left(1 \mathrm{H}, \mathrm{dd}, \mathrm{H}-3, \mathrm{~J}_{33}, 11.6 \mathrm{~Hz}, \mathrm{~J}_{23} 6.3 \mathrm{~Hz}\right)$; $3.15(1 \mathrm{H}, \mathrm{m}, \mathrm{H}-5) ; 2.71\left(1 \mathrm{H}, \mathrm{m}, \mathrm{H}-5^{\prime}\right) ; 2.61\left(1 \mathrm{H}, \mathrm{dd}, \mathrm{H}-3^{\prime}, \mathrm{J}_{23}{ }^{\prime} 9.4 \mathrm{~Hz}\right)$; $1.77(2 \mathrm{H}, \mathrm{m}) ; 1.56\left(2 \mathrm{H}, \mathrm{m}, \mathrm{H}-6,6^{\prime}, 7,7^{\prime}\right) . \underline{\mathrm{m} / \mathrm{z}}\left(\mathrm{ACE}, \mathrm{NH}_{3}\right): 183$ (impurity, 2.37), $143\left(\mathrm{M}+\mathrm{H}^{+}\right)$.

Methy1 (- benzyloxycarbony1- 5- $0-$ benzyl- 3,6- dideoxy- 3,6- imino-)

$a$ and $\beta-\underline{\underline{D}}-$ glucofuranosides $(2.39)$

Acetonide (2.20) (0.96 g, 2.26 mmol) was dissolved in methanol (20 ml) and refluxed for $48 \mathrm{~h}$ with Dowex $50 \mathrm{~W}-\mathrm{XH}$ acid resin $(1.3 \mathrm{~g})$. The resin was removed by filtration and the solution concentrated to a syrup. Purification by flash chromatography (ethyl acetate : hexane, $1: 2$ ) gave 2 fractions. The upper $(0.64 \mathrm{~g}, 71 \%)$ a pure anomer and the lower $(0.21 \mathrm{~g}, 23 \%)$ 
a mixture of anomers. ${ }^{1} \mathrm{H}$ NMR (upper) $\delta 7.38-7.29(10 \mathrm{H}, \mathrm{m}, \operatorname{ArH}) ; 5.15(1 \mathrm{H}, \mathrm{s}$, $\mathrm{H}-1) ; 5.13\left(2 \mathrm{H}, \mathrm{ABq}, \mathrm{PhCH}_{2}\right): 4.9\left(2 \mathrm{H}, \mathrm{ABq}, \mathrm{PhCH}_{2}\right) ; 4.8(1 \mathrm{H}, \mathrm{t}) ; 4.6(1 \mathrm{H}, \mathrm{t}$, $\mathrm{H}-3,4) ; 4.15(1 \mathrm{H}, \mathrm{dd}, \mathrm{H}-2) ; 3.95(1 \mathrm{H}, \mathrm{m}, \mathrm{H}-5) ; 3.90(1 \mathrm{H}, \mathrm{dd}, \mathrm{H}-6) ; 3.42$ $\left(3 \mathrm{H}, \mathrm{s}, \mathrm{CH}_{3} \mathrm{O}\right) ; 3.31\left(1 \mathrm{H}, \mathrm{dd}, \mathrm{H}-6^{\prime}\right) ; 3.10(1 \mathrm{H}, \mathrm{br} \mathrm{s}, \mathrm{OH})$. $\mathrm{m} / \mathrm{z}$ (on mixture) : $400\left(\mathrm{M}+\mathrm{H}^{+}\right), 368,266,91(100 \%)$.

$8 \beta$ - Benzyloxy- 6- benzyloxycarbony1-3- methoxy- (1aH, 5aH)-6- aza- 2-

oxa- 4- oxo- bicyclo $[3,3,0]$ octane hydrate $(2.40)$

Pyridinium chlorochromate $(0.29 \mathrm{~g}, 3$ equivs) and powdered molecular sieve $(0.3 \mathrm{~g})$ were added to a solution of the alcohol (2.39)(anomer mixture) (0.17 $\mathrm{g}$, $0.43 \mathrm{mmol})$ in dry dichloromethane $(5 \mathrm{ml})$ at room temperature. After $8 \mathrm{~h}$ the solution was diluted with ether $(10 \mathrm{ml})$, filtered through celite, concentrated and purified by flash chromatography (ether : hexane, $7: 1$ ), to give the title compound $(2.40)(0.1 \mathrm{~g}, 56 \%)$ as a syrup. $V_{\max } 3400(\mathrm{br})$, $1680 \mathrm{~cm}^{-1} .{ }_{\mathrm{H} \text { NMR }}^{1}$ 7.4- $7.3(10 \mathrm{H}, \mathrm{m}, \mathrm{ArH}) ; 5.1\left(2 \mathrm{H}, \mathrm{ABq}, \mathrm{PhCH}_{2}\right) ; 4.9(1 \mathrm{H}, \mathrm{m}$, $\mathrm{H}-6) ; 4.8(1 \mathrm{H}, \mathrm{s}, \mathrm{H}-3) ; 4.7\left(2 \mathrm{H}, \mathrm{ABq}, \mathrm{PhCH}_{2}\right) ; 4.3(1 \mathrm{H}, \mathrm{d}, \mathrm{H}-5) ; 3.9(2 \mathrm{H}, \mathrm{m})$; $3.5\left(3 \mathrm{H}, \mathrm{s}, \mathrm{CH}_{3} \mathrm{O}\right) ; 3.4\left(1 \mathrm{H}, \mathrm{t}, \mathrm{H}-7^{\prime}\right) . \underline{\mathrm{m} / \mathrm{z}}: 398\left(\mathrm{M}+\mathrm{H}^{+}-\mathrm{H}_{2} \mathrm{O}\right), 354,91(100 \%)$.

$\underline{Z}$ and $\underline{E}$ 4- Carbomethoxymethylene- $8 \beta$ - benzyloxy- 6- benzyloxycarbony $1-3-$ methoxy- $\left(1 a \mathrm{H}, 5 a_{\mathrm{H}}\right)-6-$ aza- $2-$ oxa- bicyclo $[3,3,0]$ octane hydrate $(2.41)$ Hydrated ketone $(2.40)(75 \mathrm{mg}, 0.19 \mathrm{mmol})$ was refluxed in benzene $(5 \mathrm{ml})$ with carbomethoxymethylene triphenylphosphorane ( $0.19 \mathrm{~g}, 3$ equivs). After $4 \mathrm{~h}$ the solvent was removed and purification by flash chromatography (ethyl acetate : hexane, $1: 4$ ) gave a mixture of unsaturated esters (2.41) (79 $\mathrm{mg}, 92 \%$ ) as a syrup. $V_{\max } 1720,1700 \mathrm{~cm}^{-1} \cdot 1_{\mathrm{H} N M R} \delta 7.3(10 \mathrm{H}, \mathrm{m}, \operatorname{ArH}) ; 6.5(1 \mathrm{H}, \mathrm{s}, \mathrm{H}-3)$; $6.0(1 \mathrm{H}, \mathrm{m}$, olefinic $\mathrm{H}) ; 5.1\left(2 \mathrm{H}, \mathrm{ABq}, \mathrm{PhCH}_{2}\right) ; 5.1-3.6(7 \mathrm{H}, \mathrm{m}) ; 3.8(3 \mathrm{H}, \mathrm{d}$, 
$\left.\mathrm{CH}_{3} \mathrm{O}_{2} \mathrm{C}\right) ; 3.6\left(3 \mathrm{H}, \mathrm{d}, \mathrm{CH}_{3} \mathrm{O}\right) . \underline{\mathrm{m} / \mathrm{z}}: 471\left(\mathrm{M}+\mathrm{NH}_{4}^{+}\right) ; 439(100 \%), 422$.

\section{Diethoxyphosphinylacetic acid}

A solution of potassium hydroxide $(0.38 \mathrm{~g})$ in ethanol : water $(3: 1)(1.6 \mathrm{ml})$ was added to triethylphosphonoacetate $(1.5 \mathrm{~g}, 6.2 \mathrm{mmol})$ at room temperature. After $1 \mathrm{~h}$, the solvent was evaporated and the residue dissolved in hydrochloric acid (2M aq, $5 \mathrm{ml})$ and extracted with chloroform $(3 \times 10 \mathrm{ml})$. The chloroform was dried and evaporated to give the title compound $(1.27 \mathrm{~g}, 90 \%)$ an oil. $1_{\mathrm{H} \text { NMR }} \delta 10.76\left(1 \mathrm{H}\right.$, br s, $\left.\mathrm{CO}_{2} \underline{\mathrm{H}}\right) ; 4.01\left(4 \mathrm{H}, \mathrm{m}, \mathrm{CH}_{3} \mathrm{CH}_{2}\right) ; 2.83\left(2 \mathrm{H}, \mathrm{d}, \underline{\mathrm{CH}}_{2} \mathrm{P}\right)$; $1.15\left(6 \mathrm{H}, \mathrm{t}, \mathrm{CH}_{3} \mathrm{CH}_{2}\right)$.

N- Diethoxyphosphinylacety1- 3,6- dideoxy- 3,6- imino- 1,2- ㅇ- isopropy1idene- $\sigma_{-}$D- glucofuranose

The salt (2.13) $(0.41 \mathrm{~g}, 1.1 \mathrm{mmol})$ was neutralised with TEA $(0.15 \mathrm{ml}$, 1 equiv) in DMF ( $5 \mathrm{~m} 1)$ and added to a solution of diethoxyphosphinylacetic acid $(0.23 \mathrm{~g}$, 1.1 equivs), 1 - hydroxybenzotriazole $(0.17 \mathrm{~g}, 1.1$ equivs) and N,N'- dicyclohexylcarbodiimide $(0.26 \mathrm{~g}, 1.1$ equivs $)$ in DMF $(5 \mathrm{~m} 1)$ at $0^{\circ} \mathrm{C}$. The solution was slowly allowed to warm to room temperature and stirred for $8 \mathrm{~h}$. The mixture was filtered and concentrated to a syrup which was purified by flash chromatography ( $7 \%$ ethanol in chloroform) to afford the title compound $(0.39 \mathrm{~g}$, 94\%). $1_{\mathrm{H} \text { NMR } \delta 5.87}(1 \mathrm{H}, \mathrm{d}, \mathrm{H}-1) ; 4.81(2 \mathrm{H}, \mathrm{m}, \mathrm{H}-3,4) ; 4.49(1 \mathrm{H}, \mathrm{m}, \mathrm{H}-2)$; $4.1(5 \mathrm{H}, \mathrm{m}) ; 4.03(1 \mathrm{H}, \mathrm{dd}, \mathrm{H}-6) ; 3.32\left(1 \mathrm{H}, \mathrm{t}, \mathrm{H}-6^{\prime}\right) ; 2.98\left(2 \mathrm{H}, \mathrm{d}, \mathrm{CH}_{2} \mathrm{P}\right) ; 2.5$ $(1 \mathrm{H}$, br d, OH $) ; 1.53,1.35\left(6 \mathrm{H}, 2 \mathrm{~s}, \mathrm{CH}_{3} \mathrm{C}\right) ; 1.33\left(6 \mathrm{H}, 2 \mathrm{t}, \mathrm{CH}_{3} \mathrm{CH}_{2}\right)$.

$\underline{N}-$ Diethoxyphosphinylacety $1-5-\underline{0}-\underline{t}$-butyldiphenylsilyl- 3,6-dideoxy- 3,6imino- 1,2- $\underline{0}-$ isopropylidene- $a-\underline{D}-$ glucofuranose $(2.45)$ 
under nitrogen, to a solution of the alcohol (N-Diethoxyphosphinylacety13,6- dideoxy- 3,6- imino- 1,2- $\underline{0}$ - isopropylidene $\sigma \underline{D}$ - glucofuranose) (0.28 g, $0.74 \mathrm{mmol})$ in dry $\operatorname{DMF}(10 \mathrm{ml})$ containing imidazole $(0.12 \mathrm{~g}, 2.4$ equivs $)$. After $12 \mathrm{~h}$, the solvent was removed and the residue partitioned between chloroform $(10 \mathrm{~m} 1)$ and water $(10 \mathrm{~m} 1)$. The chloroform layer was dried and evaporated. Purification of the residue by flash chromatography (ethy 1 acetate) gave the title compound $(2.45)(0.38 \mathrm{~g}, 85 \%)$ a syrup. ${ }^{1}$ H NMR $\delta$ $7.8-7.4(10 \mathrm{H}, \mathrm{m}, \mathrm{ArH}) ; 5.9(1 \mathrm{H}, \mathrm{d}, \mathrm{H}-1) ; 4.8(1 \mathrm{H}, \mathrm{c}, \mathrm{H}-2) ; 4.5(1 \mathrm{H}, \mathrm{t}, \mathrm{H}-4)$; $4.1(6 \mathrm{H}, \mathrm{m}) ; 3.5(1 \mathrm{H}, \mathrm{dd}, \mathrm{H}-6) ; 3.45\left(1 \mathrm{H}, \mathrm{t}, \mathrm{H}-5^{\prime}\right) ; 2.9\left(2 \mathrm{H}, \mathrm{d}, \mathrm{CH}_{2} \mathrm{P}\right) ; 1.4$, $1.2\left(6 \mathrm{H}, 2 \mathrm{~s}, \mathrm{CH}_{3} \mathrm{C}\right) ; 1.1\left(6 \mathrm{H}, 2 \mathrm{t}, \mathrm{CH}_{3} \mathrm{CH}_{2}\right) ; 1.05(9 \mathrm{H}, \mathrm{s}, \mathrm{tBu}) . \underline{\mathrm{m} / \mathrm{z}}: 618$ $\left(\mathrm{M}+\mathrm{H}^{+}\right), 560,502(100 \%)$.

Ethyl (N- Diethoxyphosphinylacety1- 5- $\underline{0}-\underline{t}$-butyldiphenylsilyl- 3,6- dideoxy3,6- imino ) $\alpha$ and $\beta$ - D- glucofuranoside (2.46)

Acetonide (2.45) (91 mg, $0.15 \mathrm{mmol}$ ) was stirred at room temperature in a solution of hydrogen chloride $(1 \% \mathrm{w} / \mathrm{w})$ in ethanol (5 m1). After $24 \mathrm{~h}$, the solution was neutralised with ammonia solution (SG 0.88), evaporated to a syrup and the residue taken up in ethy 1 acetate $(3 \times 10 \mathrm{~m} 1)$. The ethyl acetate was dried, filtered and evaporated. Purification of the residue by flash chromatography (5\% ethanol in ethyl acetate) gave the title compound (2.46) (74 mg, 82\%). $v_{\max } 3350(\mathrm{br}), 1640 \mathrm{~cm}^{-1} \cdot 1_{\mathrm{H} \mathrm{NMR}} \delta 7.8-7.4(10 \mathrm{H}, \mathrm{m}$, $\mathrm{ArH}) ; 5.1(1 \mathrm{H}, \mathrm{s}, \mathrm{H}-1) ; 4.6(1 \mathrm{H}, \mathrm{t}, \mathrm{H}-4) ; 4.1(9 \mathrm{H}, \mathrm{m}) ; 3.6\left(2 \mathrm{H}, \mathrm{m}, \mathrm{H}-6,6^{\prime}\right)$; $2.9\left(2 \mathrm{H}, \mathrm{dd}, \mathrm{CH}_{2} \mathrm{P}\right) ; 2.0(1 \mathrm{H}, \mathrm{br} \mathrm{s}, \mathrm{OH}) ; 1.2\left(9 \mathrm{H}, 3 \mathrm{t}, \mathrm{CH}_{3} \mathrm{CH}_{2}\right) ; 1.05(9 \mathrm{H}, \mathrm{s}$, tBu). $\underline{m} / \mathrm{z}: 606\left(\mathrm{M}+\mathrm{H}^{+}, 100 \%\right), 548$. 
N- Dimethoxyphosphinylacety1-5- -ㅡㄴ-butyldiphenylsilyl- 3,6- dideoxy- 3,6-

imino- 1,2- $\underline{0}$ - isopropylidene- $\sigma$ - D- glucofuranose (2.43)

Alcohol (2.26) (126 mg, $0.36 \mathrm{mmol}$ ) was dissolved in DMF (2 ml) containing imidazole (56 mg, 2.3 equivs) and t-butylchlorodiphenylsilane $(0.11 \mathrm{ml}, 1.2$ equivs) added dropwise under nitrogen. After $24 \mathrm{~h}$, the solvent was removed and the residue partitioned between chloroform $(10 \mathrm{ml})$ and water $(10 \mathrm{~m} 1)$. The chloroform layer was dried and concentrated. Purification by flash chromatography (ethyl acetate) gave the title compound (2.43) (178 mg, 84\%) a syrup. ${ }^{1}$ H NMR $\delta 7.8-7.4(10 \mathrm{H}, \mathrm{m}, \operatorname{ArH}) ; 5.9(1 \mathrm{H}, \mathrm{d}, \mathrm{H}-1) ; 4.7(1 \mathrm{H}, \mathrm{d}, \mathrm{H}-2)$; $4.4(1 \mathrm{H}, \mathrm{t}, \mathrm{H}-4) ; 4.2(1 \mathrm{H}, \mathrm{d}, \mathrm{H}-3) ; 3.85(7 \mathrm{H}, \mathrm{m}, \mathrm{H}-5,2 \mathrm{x} \mathrm{OMe}) ; 3.5(2 \mathrm{H}, \mathrm{m}$, $\left.\mathrm{H}-6,6^{\prime}\right) ; 2.9\left(2 \mathrm{H}, \mathrm{dd}, \mathrm{CH}_{2} \mathrm{P}\right) ; 1.5,1.3\left(6 \mathrm{H}, 2 \mathrm{~s}, \mathrm{CH}_{3} \mathrm{C}\right) ; 1.05(9 \mathrm{H}, \mathrm{s}, \mathrm{tBu})$. $\underline{\mathrm{m} / \mathrm{z}}: 590\left(\mathrm{M}+\mathrm{H}^{+}\right), 532(100 \%)$.

Methy1 (N-Dimethoxyphosphinylacety1- 5- -ㅡㄴ t-butyldiphenylsily1- 3,6-

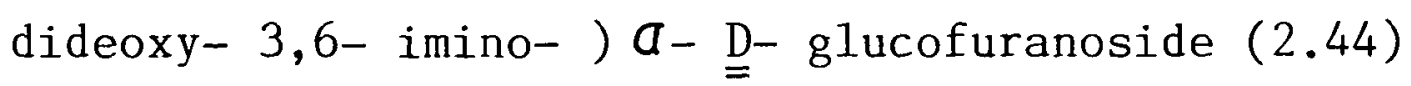

Acetonide (2.43) $(0.2 \mathrm{~g}, 0.34 \mathrm{mmol})$ was dissolved in methanol $(8 \mathrm{ml})$ containing acetyl chloride $(0.06 \mathrm{ml}$ ) (approx $0.5 \% \mathrm{w} / \mathrm{w} \mathrm{HCl}$ in $\mathrm{MeOH}$ ) and left at room temperature. After $24 \mathrm{~h}$ the solution was neutralised with ammonia solution (SG 0.88), evaporated and the residue taken up in ethyl acetate $(3 \times 10 \mathrm{ml})$. The ethyl acetate was filtered, dried and evaporated to a syrup. Purification by flash chromatography ( $1 \%$ ethanol in ethyl acetate) gave the title compound (2.44) (66 $\mathrm{mg}, 35 \%)$ together with the compound which had also lost the silyl group $(33 \mathrm{mg}, 30 \%) .(2.44):{ }^{1} \mathrm{H}$ NMR $\delta 7.8-7.4(10 \mathrm{H}, \mathrm{m}, \mathrm{ArH}) ; 5.00(1 \mathrm{H}, \mathrm{s}$, $\mathrm{H}-1) ; 4.58(1 \mathrm{H}, \mathrm{t}, \mathrm{H}-4) ; 4.2-3.5(14 \mathrm{H}, \mathrm{m}) ; 2.9\left(2 \mathrm{H}, \mathrm{dd}, \mathrm{CH}_{2} \mathrm{P}\right) ; 1.05(9 \mathrm{H}, \mathrm{s}$, $\mathrm{tBu}) ; 3.5\left(3 \mathrm{H}, \mathrm{s}, \mathrm{CH}_{3} \mathrm{O}\right) . \underline{\mathrm{m} / \mathrm{z}}: 564\left(\mathrm{M}+\mathrm{H}^{+}, 100 \%\right)$. 
$8 \beta$ - t-butyldiphenylsilyloxy- 6- dimethoxyphosphinylacety $1-3-a$ methoxy$\left(1 a \mathrm{H}, 5 a_{\mathrm{H}}\right)-6$ - aza- 2- oxa- 4- oxo- bicyclo $[3,3,0]$ octane hydrate

Was prepared in exactly the same way as the diethoxy derivative (2.47). Alcohol (2.44) (50 mg, $0.089 \mathrm{mmol}$ ) was treated with ruthenium dioxide hydrate ( $5 \mathrm{mg}$ ), sodium periodate ( $27 \mathrm{mg}, 1.4$ equivs) and potassium carbonate ( $4 \mathrm{mg}$ ) and yielded the title compound ( $31 \mathrm{mg}, 60 \%) . v_{\max } 3400(\mathrm{br}), 1640 \mathrm{~cm}^{-1}$.

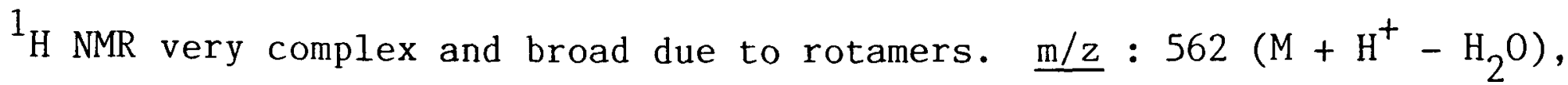
504.

$8 \beta$ - t-butyldiphenylsilyloxy- 6- diethoxyphosphinylacety $1-3-\alpha$ ethoxy$(1 \propto \mathrm{H}, 5 a \mathrm{H})-6-$ aza- 2- oxa- 4- oxo- bicyclo $[3,3,0]$ octane hydrate $(2.47)$ The alcohol (2.46) (0.22 $\mathrm{g}, 0.36 \mathrm{mmol})$ was dissolved in chloroform ( $2 \mathrm{ml})$ containing ruthenium dioxide hydrate $(20 \mathrm{mg}$, catalytic quantity). The solution was vigorously stirred and a solution of sodium periodate $(0.12 \mathrm{~g}, 1.5$ equivs) and potassium carbonate $(14 \mathrm{mg})$ in water $(2 \mathrm{ml})$ was added. The stirring was maintained so that the two layers were completely mixed and the solution became pale green. After $12 \mathrm{~h}$ the reaction was quenched by the addition of a few drops of propan- 2- ol and the green colour disappeared as the black ruthenium dioxide was re-precipitated. The 2 layers were separated and the aqueous phase extracted several times with chloroform. The organic extracts were combined, dried and evaporated. Purification of the residue by flash chromatography gave the hydrated ketone $(2.47)(0.2 \mathrm{~g}, 89 \%) . V_{\max } 3400(\mathrm{br})$,

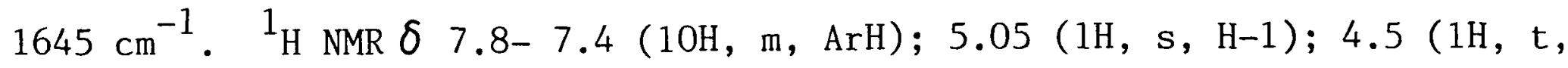
$\mathrm{H}-4): 4.3-3.9(8 \mathrm{H}, \mathrm{m}) ; 3.8(2 \mathrm{H}, \mathrm{m}, \mathrm{H}-6) ; 2.9\left(2 \mathrm{H}, \mathrm{dd}, \mathrm{CH}_{2} \mathrm{P}\right) ; 1.3(9 \mathrm{H}, \mathrm{m}$, $\left.\mathrm{CH}_{3} \mathrm{CH}_{2}\right) ; 1.05(9 \mathrm{H}, \mathrm{s}, \mathrm{tBu})$. 
Attempted cyclisation of (2.47)

The phosphonate ketone $(2.47)(0.16 \mathrm{~g}, 0.27 \mathrm{mmol})$ was dissolved in toluene (2 $\mathrm{ml}$ ) and stirred at room temperature with 18 crown 6 ( $79 \mathrm{mg}, 1.1$ equivs) and potassium carbonate $(0.11 \mathrm{~g}, 3$ equivs). After 5 mins t.1.c (ethy1 acetate) showed presence of a fast running product $\left(R_{f} 0.9\right)$ together with starting material $\left(R_{f} 0.1\right)$. After several hours the t.1.c remained the same and a similar result was found at elevated temperatures. The solution was filtered and evaporated. Purification of the residue by flash chromatography (ethyl acetate : hexane, $1: 10)$ gave a fast running product $(2.48)$ (10 mg, $8 \%$ if cyclised product), together with slower components (eluted with ethyl acetate). The slower components could not be identified spectroscopically.

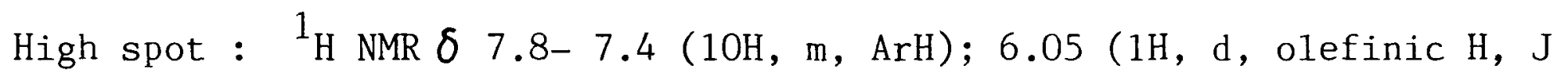
$12 \mathrm{~Hz}) ; 5.7(1 \mathrm{H}, \mathrm{s}, \mathrm{H}-1) ; 4.9(1 \mathrm{H}, \mathrm{dd}, \mathrm{H}-5): 4.6(1 \mathrm{H}, \mathrm{dd}, \mathrm{H}-4) ; 4.05(1 \mathrm{H}, \mathrm{dd}$, $\mathrm{H}-3) ; 3.9,3.7\left(2 \mathrm{H}, 2 \mathrm{~m}, \mathrm{CH}_{3} \mathrm{CH}_{2}\right) ; 3.8(1 \mathrm{H}, \mathrm{d}, \mathrm{H}-6) ; 3.1\left(1 \mathrm{H}, \mathrm{dd}, \mathrm{H}-1^{\prime}\right) ; 1.2$ $\left(3 \mathrm{H}, \mathrm{t}, \mathrm{CH}_{3}\right) ; 1.0(9 \mathrm{H}, \mathrm{s}, \mathrm{tBu})$. (the protons are numbered in the same way as in $(2.47))$.

Methy1 (N-Dimethoxyphosphinylacety1- 5- - phenylcarbamy 1- 3,6- dideoxy-

3,6- imino- ) $a-$ D- glucofuranoside (2.50)

Alcohol (2.26) (0.156 $\mathrm{g}, 0.44 \mathrm{mmo1})$ was dissolved in pyridine $(3 \mathrm{ml})$ and treated with pheny 1 isocyanate $(0.097 \mathrm{ml}, 2$ equivs $)$ at room temperature. After 30 mins the solution was diluted with ethyl acetate $(25 \mathrm{ml})$ and washed successively with hydrochloric acid (2M aq, $20 \mathrm{ml}$ ), water (20 $\mathrm{ml}$ ) and saturated aqueous sodium bicarbonate solution $(20 \mathrm{ml})$. The ethyl acetate was dried and evaporated. The residue was dissolved in methanol (3 $\mathrm{m} 1)$ containing acetyl chloride $(0.021 \mathrm{~m} 1)$ and heated to $50^{\circ} \mathrm{C}$. After 90 min the solution was 
neutralised with ammonia solution (SG 0.88), evaporated and partitioned between ethyl acetate $(20 \mathrm{ml})$ and water $(5 \mathrm{ml})$. The ethyl acetate was dried and evaporated. Purification of the residue by flash chromatography (10\% ethanol in ethyl acetate) gave the title compound (2.50) (0.128 g, 66\%). $1_{\mathrm{H} \mathrm{NMR}} \delta 7.5-7.0(6 \mathrm{H}, \mathrm{m}, \mathrm{ArH}, \mathrm{NH}) ; 5.1(2 \mathrm{H}, \mathrm{m}, \mathrm{H}-4,5) ; 5.0(1 \mathrm{H}, \mathrm{s}, \mathrm{H}-1)$; $4.5-3.5(5 \mathrm{H}, \mathrm{m}) ; 3.9\left(6 \mathrm{H}, 4 \mathrm{~s}, \mathrm{CH}_{3} \mathrm{OP}\right) ; 3.3\left(3 \mathrm{H}, \mathrm{s}, \mathrm{CH}_{3} \mathrm{O}\right) ; 3.0\left(2 \mathrm{H}, \mathrm{d}, \mathrm{CH}_{2} \mathrm{P}\right)$. $\underline{\mathrm{m} / \mathrm{z}}\left(\mathrm{ACE}, \mathrm{NH}_{3}\right): 445\left(\mathrm{M}+\mathrm{H}^{+}\right) ; 326,294(100 \%)$.

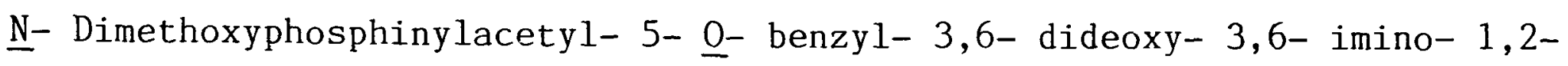

$\underline{\underline{0}-}$ isopropylidene- $a-\underline{D}-$ glucofuranose

$\mathrm{Z}$ protected amine $(2.20)(1.1 \mathrm{~g}, 2.6 \mathrm{mmol})$ was dissolved in ethanol $(20 \mathrm{ml})$ and hydrogenated in the presence of palladium black $(0.1 \mathrm{~g})$ at atmospheric pressure. After 30 min the catalyst was filtered and the solvent evaporated, to give the amine $(0.69 \mathrm{~g})$ which was used directly. The crude amine was dissolved in DMF (10 ml) and added to a solution of dimethoxyphosphinylacetic acid (0.8 g, 2 equivs) and DCC (0.98 g, 2 equivs) in DMF (10 $\mathrm{ml})$ at $0{ }^{\circ} \mathrm{C}$. The mixture was allowed to warm to room temperature and stirred for $6 \mathrm{~h}$. The solution was filtered and evaporated and the residue was purified by flash chromatography ( $2 \%$ ethanol in ethyl acetate) to afford the title compound $(0.97 \mathrm{~g}, 85 \%)$ as a syrup. $V_{\max } 1650,1430 \mathrm{~cm}^{-1} \cdot 1_{\mathrm{H}} \mathrm{NMR} \delta 7.5-7.3$ (5H, m, $\mathrm{ArH}) ; 5.9(1 \mathrm{H}, \mathrm{d}, \mathrm{H}-1) ; 4.9(1 \mathrm{H}, \mathrm{t}, \mathrm{H}-4) ; 4.8(1 \mathrm{H}, \mathrm{d}, \mathrm{H}-2) ; 4.6(2 \mathrm{H}, \mathrm{ABq}$, $\left.\mathrm{PhCH}_{2}\right) ; 4.3(1 \mathrm{H}, \mathrm{d}, \mathrm{H}-3) ; 4.0(1 \mathrm{H}, \mathrm{m}, \mathrm{H}-5) ; 3.9(1 \mathrm{H}, \mathrm{dd}, \mathrm{H}-6) ; 3.8(6 \mathrm{H}, 4 \mathrm{~s}$ $\left.\mathrm{CH}_{3} \mathrm{O}\right) ; 3.5\left(1 \mathrm{H}, \mathrm{t}, \mathrm{H}-6^{\prime}\right) ; 3.0\left(2 \mathrm{H}, \mathrm{m}, \mathrm{CH}_{2} \mathrm{P}\right) ; 1.5,1.3\left(6 \mathrm{H}, 2 \mathrm{~s}, \mathrm{CH}_{3} \mathrm{C}\right) . \underline{\mathrm{m} / \mathrm{z}}:$ $442\left(\mathrm{M}+\mathrm{H}^{+}\right) ; 384\left(\mathrm{M}+\mathrm{H}^{+}-\mathrm{Me}_{2} \mathrm{CO}, 100 \%\right)$. 
Methyl (N- Dimethoxyphosphinylacetyl- 5- $\underline{0}-$ benzyl- 3,6- dideoxy- 3,6- imino-)

$a-\stackrel{D}{=}-$ glucofuranoside $(2.49)$

Acetonide (prepared above) $(0.56 \mathrm{~g}, 1.27 \mathrm{mmol})$ was dissolved in methanol $(10 \mathrm{~m} 1)$ containing acety 1 chloride $(0.07 \mathrm{ml})$ and 1 eft at $50^{\circ} \mathrm{C}$. After $2.5 \mathrm{~h}$ the solution was neutralised with ammonia solution (SG 0.88) and evaporated to dryness. The residue was partitioned between ethyl acetate $(25 \mathrm{ml})$ and water $(10 \mathrm{~m} 1)$. The ethyl acetate was dried and evaporated. Purification of the residue by flash chromatography ( $8 \%$ ethanol in ethyl acetate) gave the title compound $(2.49)(0.4 \mathrm{~g}, 76 \%)$, a syrup. $v_{\max } 3400(\mathrm{br}), 1640,1440 \mathrm{~cm}^{-1}$. $1_{\mathrm{H} \mathrm{NMR}} \delta 7.5-7.3(5 \mathrm{H}, \mathrm{m}, \mathrm{ArH}) ; 5.0(1 \mathrm{H}, \mathrm{s}, \mathrm{H}-1) ; 4.6\left(2 \mathrm{H}, \mathrm{ABq}, \mathrm{PhCH}_{2}\right)$; $4.3(1 \mathrm{H}, \mathrm{d}, \mathrm{H}-3) ; 4.2(1 \mathrm{H}, \mathrm{s}, \mathrm{H}-2) ; 4.0(1 \mathrm{H}, \mathrm{m}, \mathrm{H}-5) ; 3.9(1 \mathrm{H}, \mathrm{dd}, \mathrm{H}-6) ; 3.8$ $(7 \mathrm{H}, \mathrm{m}) ; 3.5(1 \mathrm{H}, \mathrm{t}, \mathrm{H}-6) ; 3.4\left(3 \mathrm{H}, \mathrm{s}, \mathrm{CH}_{3} \mathrm{O}\right) ; 3.0\left(2 \mathrm{H}, \mathrm{dd}, \mathrm{CH}_{2} \mathrm{P}\right) . \mathrm{m} / \mathrm{z}: 416$ $\left(\mathrm{M}+\mathrm{H}^{+}, 100 \%\right), 384$.

1,4- Dideoxy- 1,4- imino- 2,3;5,6 di- $\underline{0}$ - isopropylidene- L- gulitol (2.51)

The salt (2.13) (0.35 $\mathrm{g}, 0.94 \mathrm{mmol})$ was converted to crude imino gulitol (1.1) as described previously. The crude amine was suspended in $50 \%$ acetone in 2,2 dimethoxypropane $(5 \mathrm{~m} 1)$ and $10( \pm)$ camphorsulphonic acid added to adjust the $\mathrm{pH}$ to about 3 . After $18 \mathrm{~h}$ the mixture was neutralised $\left(0.88 \mathrm{NH}_{3}\right)$, evaporated and the residue extracted into ethyl acetate $(5 \times 10 \mathrm{~m} 1)$. The ethyl acetate was dried and evaporated and the residue purified by flash chromatography (ethyl acetate) affording the title compound (2.51) (71 mg, 31\%), a syrup. ${ }^{1} \mathrm{H}$ NMR $\delta 4.68(1 \mathrm{H}, \mathrm{dd}, \mathrm{H}-2) ; 4.48(1 \mathrm{H}, \mathrm{dd}, \mathrm{H}-3) ; 4.23-3.71(3 \mathrm{H}, \mathrm{m}$, $\left.\mathrm{H}-5,6,6^{\prime}\right) ; 3.15\left(1 \mathrm{H}, \mathrm{d}, \mathrm{H}-1, \mathrm{~J}_{11}, 13.0 \mathrm{~Hz}\right) ; 2.71(1 \mathrm{H}, \mathrm{m}, \mathrm{H}-4) ; 2.67(1 \mathrm{H}, \mathrm{dd}$, $\left.\mathrm{H}-1^{\prime}\right) ; 2.49(1 \mathrm{H}$, br s, NH $) ; 1.44,1.43,1.37,1.27\left(12 \mathrm{H}, 4 \mathrm{~s}, \mathrm{CH}_{3} \mathrm{C}\right)$. 


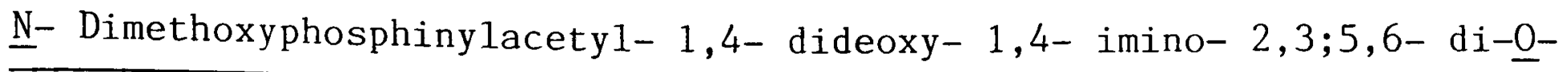

isopropylidene- L- gulitol (2.52)

Amine (2.51) (39 mg, $0.19 \mathrm{mmol}$ ) was dissolved in DMF ( $1 \mathrm{ml}$ ) and added to a solution of dimethoxyphosphinylacetic acid (34 mg, 1.1 equivs), 1- HOBT (26 $\mathrm{mg}, 1.1$ equivs) and DCC ( $46 \mathrm{mg}, 1.1$ equivs) in DMF ( $1 \mathrm{ml}$ ) at $0^{\circ} \mathrm{C}$.

After $12 \mathrm{~h}$ the solution was filtered and concentrated to a syrup. Purification by flash chromatography ( $5 \%$ ethanol in ethyl acetate) gave the title compound (2.52) (47 mg, 69\%), a syrup. $1_{\mathrm{H}} \mathrm{NMR} \delta 4.78(2 \mathrm{H}, \mathrm{m}, \mathrm{H}-2,3) ; 4.44-4.10$ $(4 \mathrm{H}, \mathrm{m}) ; 3.75\left(6 \mathrm{H}, 4 \mathrm{~s}, \mathrm{CH}_{3} \mathrm{O}\right) ; 3.68(1 \mathrm{H}, \mathrm{m}) ; 3.27(1 \mathrm{H}, \mathrm{br} \mathrm{d}) ; 2.93\left(2 \mathrm{H}, \mathrm{dd}, \mathrm{CH}_{2} \mathrm{P}\right)$; $1.47,1.42,1.30,1.29\left(12 \mathrm{H}, 4 \mathrm{~s}, \mathrm{CH}_{3} \mathrm{C}\right)$.

N-Dimethoxyphosphinylacety1- 1,4- dideoxy- 1,4- imino- 2,3- 0 - isopropylidene-

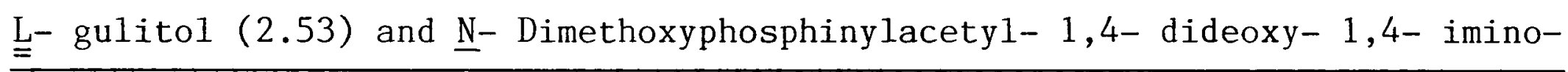
L- gulitol (2.54)

Diacetonide (2.52) ( $80 \mathrm{mg}, 0.2 \mathrm{mmol}$ ) was dissolved in acetic acid : water : methanol (1:1:1) (3 ml) at room temperature. After $16 \mathrm{~h} \mathrm{t.1.c} \mathrm{(10 \%} \mathrm{ethanol} \mathrm{in}$ ethyl acetate) showed that some starting material $\left(R_{f} 0.7\right)$ remained and 2 products had been produced $\left(R_{f} 0.4\right.$ and 0.05$)$. Evaporation of the solvent and purification by flash chromatography ( $10 \%$ ethanol in ethyl acetate) gave starting material (31 mg, 39\%), the monoacetonide $(2.53)(31 \mathrm{mg}, 44 \%)\left({ }_{\mathrm{H}} \mathrm{NMR} \delta\right.$ $4.88(1 \mathrm{H}, \mathrm{t}, \mathrm{H}-3) ; 4.77(1 \mathrm{H}, \mathrm{dd}, \mathrm{H}-2) ; 4.44(1 \mathrm{H}, \mathrm{t}, \mathrm{H}-6) ; 4.15(1 \mathrm{H}, \mathrm{m}, \mathrm{H}-5)$; $4.04\left(1 \mathrm{H}, \mathrm{dd}, \mathrm{H}-6^{\prime}\right) ; 3.84,3.83,3.80,3.79\left(6 \mathrm{H}, 4 \mathrm{~s}, \mathrm{CH}_{3} 0\right) ; 3.76-3.57(3 \mathrm{H}, \mathrm{m}$, $\left.\mathrm{H}-1,1^{\prime}, 4\right) ; 3.1\left(2 \mathrm{H}, \mathrm{m}, \mathrm{CH}_{2} \mathrm{P}\right) ; 1.54,1.36\left(6 \mathrm{H}, 2 \mathrm{~s}, \mathrm{CH}_{3} \mathrm{C}\right)$ ) and the fully deprotected material (2.54) (7 mg, 11\%). ${ }^{1} \mathrm{H} \operatorname{NMR}\left(\mathrm{D}_{2} \mathrm{O}\right) \delta 4.23(4 \mathrm{H}, \mathrm{m}) ; 3.97(1 \mathrm{H}$, ddd, $\mathrm{H}-5) ; 3.84(1 \mathrm{H}, \mathrm{dd}, \mathrm{H}-1) ; 3.65\left(6 \mathrm{H}, 4 \mathrm{~s}, \mathrm{CH}_{3} \mathrm{O}\right) ; 3.50\left(4 \mathrm{H}, \mathrm{m}, \mathrm{CH}_{2} \mathrm{P}, \mathrm{H}-1\right.$ ', 4$)$. 


\section{SUMMARY}

The highly divergent intermediate 3,6- dideoxy- 3,6- imino- 1,2- 0 - isopropylidene- $a$ - D- glucofuranose was prepared as the tosylate salt (2.13) in 7 steps from diacetone glucose. It was subsequently converted to the alkaloids (2.1) to (2.5). Several approaches to the pyrrolizidine (2.6) were also outlined.

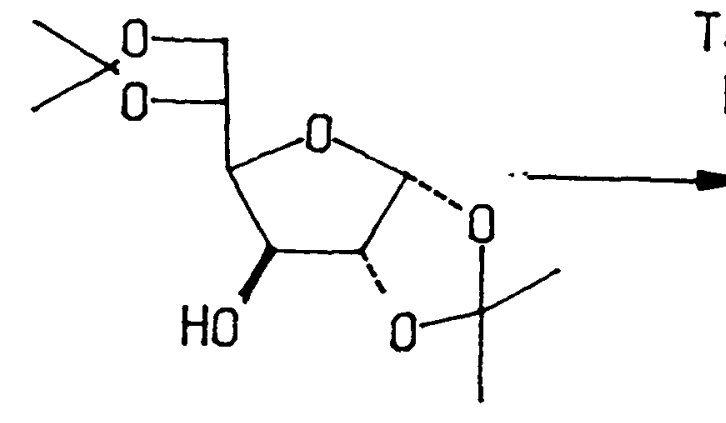

Diace tone glucose

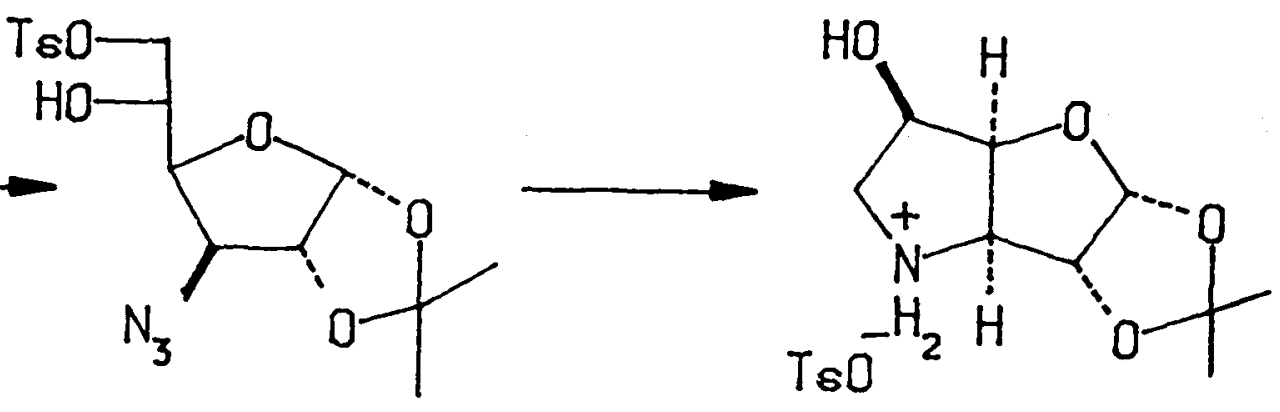

$(2 \cdot 13)$

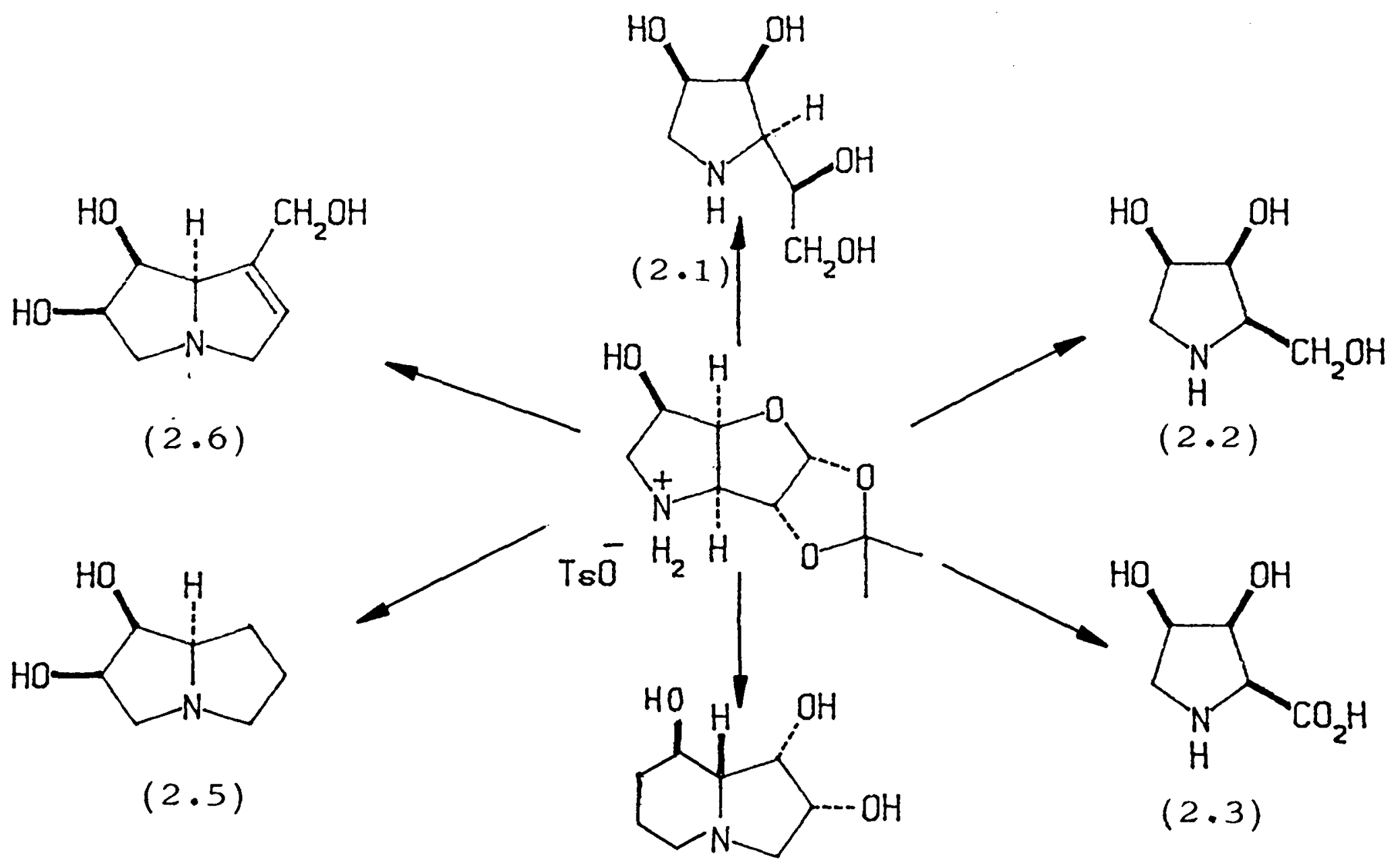

$(2.4)$ 


\section{REFERENCES}

1. G.W.J.Fleet, P.W.Smith, S.V.Evans and L.E.Fellows, J.Chem.Soc.Chem.Commun., $1984,1240$.

2. G.Palamarczyk, M.Mitche11, P.W.Smith, G.W.J.Fleet and A.D.Elbein, Arch. Biochem.Biophys., 1985, 243, 35.

3.R.Sau1, J.Chambers, R.J.Molyneux and A.D.Elbein, Arch.Biochem.Biophys., 1983, 221, 593; Y.T.Pan, H.Hori, R.Saul, B.A.Sanford, R.J.Molyneux and A.D.E1bein, Biochem., 1983, 22, 3973.

4. S.M.Colegate, P.R.Dorling and C.R.Huxtable, Aust.J.Chem., 1979, 32, 2257; S.J.Guenrich, H.P.diMari and H.P.Broquist, J.Amer.Chem.Soc., 1973, 95, 2055; D.Davies, P.Schwarz, T.Hernandez, M.Mitche11, B.Warnock and A.D.Elbein, Plant. Physio1., 1984, 76, 972 .

5. See for example : A.D.Elbein, Y.T.Pan, R.Solf and K.Vosbeck, J.Cell.Physiol., 1983, 115, 265; M.S.Kang and A.D.E1bein, J.Virol., 1983, 46, 60; D.R.P.Tulsiani and 0.Touster, Arch.Biochem.Biophys., 1983, 224, 594; V.A.Greenaway, S.Naish, W.Jessup and R.T.Dean, Biochem.Soc.Trans., 1982, 10, 533; K.Chatai, C.Jennings, B.Winchester and P.Dorling, J.Cel1.Biochem., 1983, 21, 107; V.A.Greenaway, W.Jessup, R.T.Dean and P.R.Dorling, Biochem.Biophys.Acta., 1983, 762, 569; U.Fuhrmann, E.Bause, G.Legler and H.Ploegh, Letters to Nature., 1984, 755; H.P.Broquist, Annu.Rev.Nutr., 1985, 5, 391, and references cited therein. 6. M.H.Ali, L.Hough and A.C.Richardson, J.Chem.Soc.Chem.Commun., 1984, 447; G.W.J.Fleet, M.J.Gough and P.W.Smith, Tetrahedron.Lett., 1984, 25, 1853; H.Setoi, H.Takeno and M.Hashimoto, J.Org.Chem., 1985, 50, 3948; M.H.Ali, L.Hough, and A.C.Richardson, Carbohydr.Res., 1985, 136, 225; T.Suami, K.Tadano and Y. Iimura, Carbohydr.Res., 1985, 136, 67; C.E.Adams, F.J.Walker and K.B.Sharpless, J.Crg.Chem., 1985, 50, 420 .

7. N.Yasuda, H.Tsutsumi and T.Takaya, Chem.Lett., 1985, 31. 
8. N.K.Kochetkov and A.M.Likhosherstov, Adv.Heterocycl.Chem., 1965, 5, 315 and references cited therein.

9. E.Nowacki and R.U.Byerrum, Life.Sci., 1962, 1, 157; C.A.Hughes, R.Letcher and F.L.Warrer!, J.Chem.Suc, 1964, 4974; W.Bottomley and T.A.Geissman, Phytochemistry., 1964, 3 , 357.

10. M.J.Pestchanker, M.S.Ascheri and O.S.Giordano, Phytochemistry., 1985, 24, 1622.

11. L.H.Zalkow, J.A.Glinski, L.T.Gelbaum, T.J.Fleischmann, L.S.McGowan arid M.M.Gordon, J.Med.Chem., 1985, 28, 687 and references cited therein.

12. For reviews see ref 8: and D.J.Robbins, Adv.Heterocyc1.Chem., 1979, 24, 247; D.J.Robbins, Nat.Prod.Reports., 1984, 1, 235 and ibid., 1985, 2, 213 and references cited therein. J.J.Tufarie1lo and K.Winzberg, Tetrahedron.Lett., $1986, \underline{27}, 1645$.

13. K.Tatsuta, H.Takahashi, Y.Amemiya and M.Kinoshita, J.Amer.Chem.Soc., 1983, 105,4096 .

14. Y.Nishimura, S.Kondo and H.Umezawa, J.Org.Chem., 1985, 50, 5210.

15. C.K.Atal, K.K.Kapur, C.J.Culvenor and L.W.Smith, Tetrahedron.Lett, 1966, 537.

16. J.F.Richardson and C.C.J.Culvenor, Acta.Crystallogr.Sect.C.Cryst.Struct. Commun., 1985, C41, 1475.

17. V.K.Yadav, H.Rueger and M.Benn, Heterocycles., 1984, 22, 2375.

18.H.Rueger and M.Benn, Heterocycles., 1983, 20, 1331.

19. W.M.ZuReckendorf, Chem.Ber., 1964, 97, 1275.

20. W.M.ZuReckendorf, Chem.Ber., 1968, 101, 3802.

21. J.D.Stevens in 'Methods in Carbohydrate Chemistry' Vol 6, p 123. (Academic press, 1972).

22. A.C.Richardson in 'Methods in Carbohydrate Chemistry' Vo1 6, p 218 (Academic press, 1972). 
23. L.E.Fellows and R.J.Nash, unpublished results.

24.K.G.A.Busch, J.W.Clark, L.B.Genung, E.F.Schroeder and W.L.Evans, J.Org.Chem., $1936,1,1$.

25. P.H.J.Carlsen, T.Katsuki, V.S.Maltin and K.B.Sharpless, J.Org.Chem., $1981, \underline{46}, 3937$.

26. D.C.Baker, D.Horton and C.G.Tindall Jr in 'Methods in Carbohydrate Chemistry' Vo1 7, p 4, (Academic press 1976).

27. B.O.Lindgren and T.Nilsson, Acta.Chem.Scand., 1973, 27, 888; G.A.Kraus and M.J.Taschner, J.Org.Chem., 1980, 45, 1175; B.S.Bal, W.E.Childers and H.W.Pinnick, Tetrahedron., 1981, 47, 2091; G.A.Kraus and B.Roth, J.Org.Chem., 1980, 45, 4825. 28. G.W.J.Fleet, S.J.Nicholas, P.W.Smith, S.V.Evans, L.E.Fellows and R.J.Nash, Tetrahedron.Lett., 1985, 26, 3127 .

29. P.DeShong, D.R.Sidler, D.A.Kell and N.N.Aronson Jr, Tetrahedron.Lett., $1985, \underline{26}, 3747$.

30. W.S.Wadsworth Jr, Organic Reactions., 1977, 25, 73.

31. M.H.Ali, L.Hough and A.C.Richardson, Carbohydr.Res., 1985, 136, 225.

32. R.A.Malevannaya, E.N.Tsvetkov and M.I.Kabachnik, Zhurnal.Obschei.Khimi., $1971, \underline{41}, 1426$.

33. W.A.Bonner and P.I.McNamee, J.Org.Chem., 1961, 26, 2554.

34. G.C.Windridge and E.C.Jorgensen, J.Amer.Chem.Soc., 1971, 93, 6318.

35. R.Baker and R.J.Sims, Synthesis., 1981, 117.

36. C.F.Lane, Aldrichimica.Acta., 1975, $\underline{8}, 20$.

37. H.C.Brown, Y.M.Choi and S.Narasimhan, J.Org.Chem., 1982, 47, 3153.

38. S.Hanessian and P.Lavalee, Can.J.Chem., 1975, 53, 2975.

39. R.E.Ireland and D.W.Norbeck, J.Org.Chem., 1985, 50, 2198.

40. K.L.Agarwal and H.G.Khorana, J.Amer.Chem.Soc., 1972, 94, 3578; H.0.Bouveng, Acta.Chem.Scand., $1961, \underline{15}, 87$.

41. Y.Iimura, Y.Hotta, K-i.Tadano and T.Suami paper submitted to Chem.Lett., Apri1 1985. 
3. SYNTHESIS OF 1,4-DIDEOXY-1,4-IMINO-D-LYXITOL \& APPROACHES TO THE SYNTHESIS OF PYRROLIZIDINE ALKALOIDS FROM D-MANNOSE.

INTRODUCTION

This chapter describes the synthesis of 1,4-Dideoxy-1,4-imino-D-1yxitol (3.1) and (2.2) and approaches to the synthesis of crotanecine (3.2) and (2.6) from D-mannose. The strategy employed is identical to an approach outlined in chapter 2 (p109).

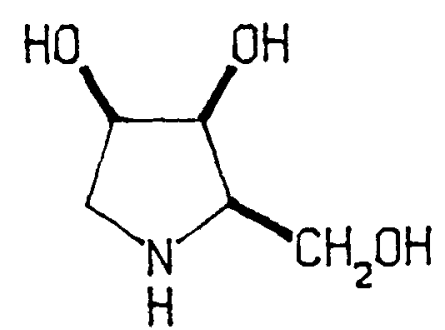

$(3.1)$

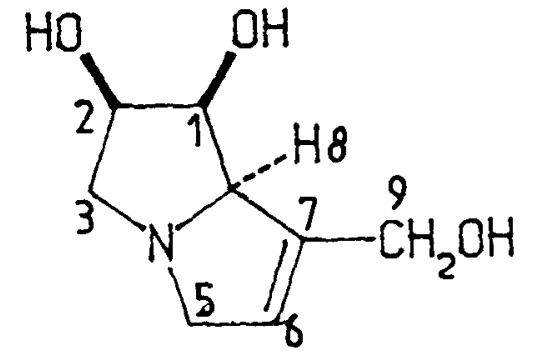

$(3.2)$

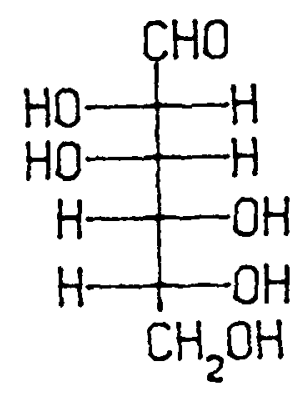

D-mannose

The occurrence and previous syntheses of crotanecine have been described ( p88).

D-mannose was converted into the key intermediate (3.3) in 9 steps by the sequence shown below (Scheme 3.1$)^{1}$. 


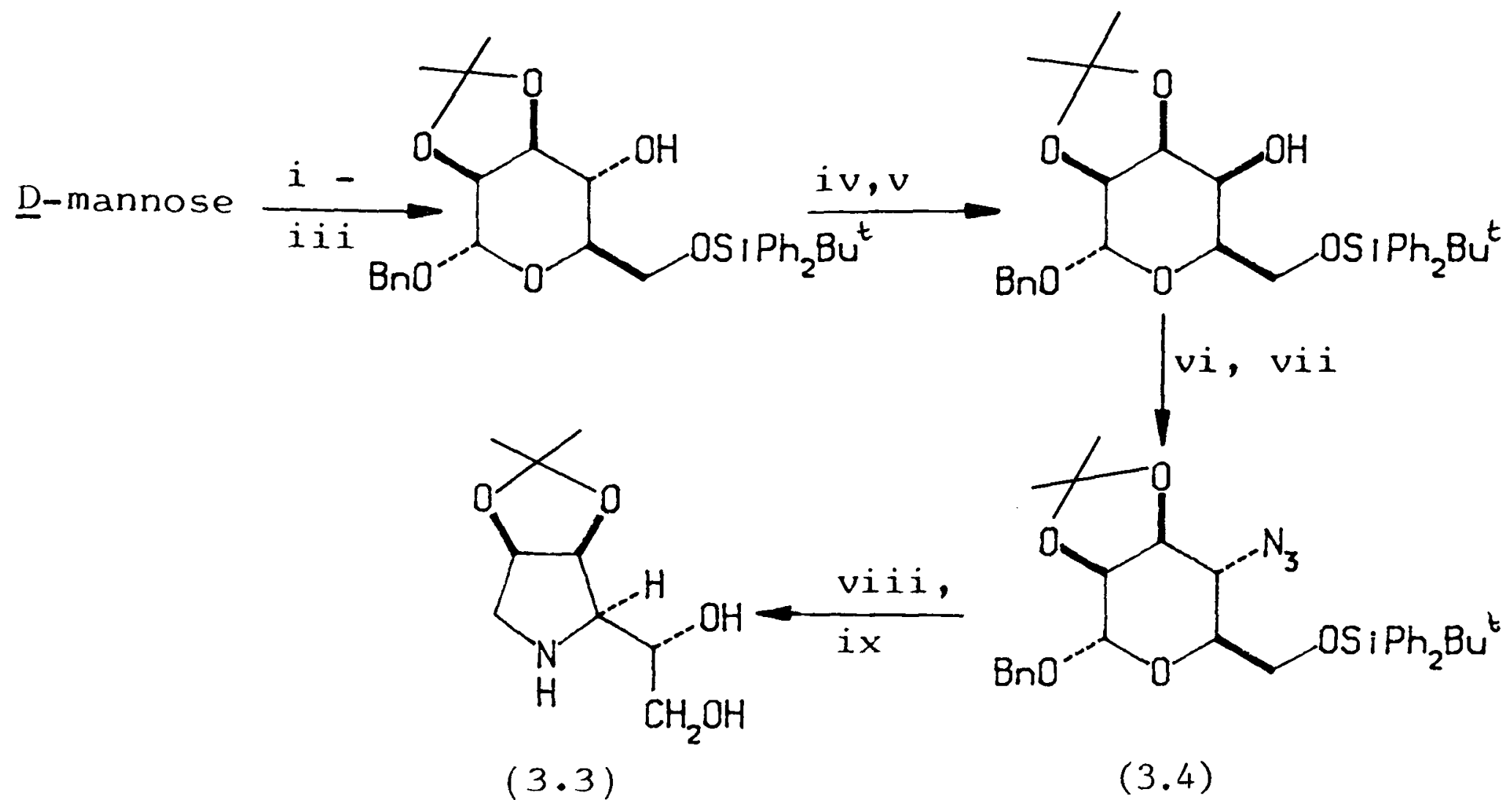

i) $\left.\mathrm{BnOH} / \mathrm{H}^{+} \mathrm{ii}\right) \mathrm{Ph}_{2} \mathrm{SiBu}{ }^{t} \mathrm{Cl}$ iii) $\mathrm{Me}_{2} \mathrm{C}(\mathrm{OMe})_{2} / \mathrm{H}^{+}$iv) $\mathrm{PCC}$

v) $\mathrm{NaBH}_{4}$ vi) $\left(\mathrm{CF}_{3} \mathrm{SO}_{2}\right)_{2} \mathrm{O}$ vii) $\left.\mathrm{NaN}_{3} \mathrm{viii}\right) \mathrm{Bu}_{4} \mathrm{~N}^{+} \mathrm{F}^{-}$ix) $\mathrm{H}_{2}$, cat.

\section{SCHEME 3.1}

The synthesis of 1,4-dideoxy-1,4-imino-D-mannitol (3.5) from (3.3) ${ }^{2}$ and swainsonine (3.6) from (3.4) have been reported ${ }^{1,3}$ previously.

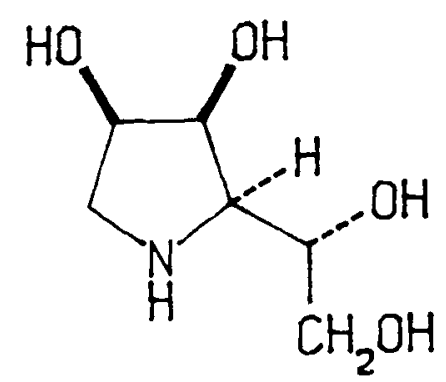

(3.5)

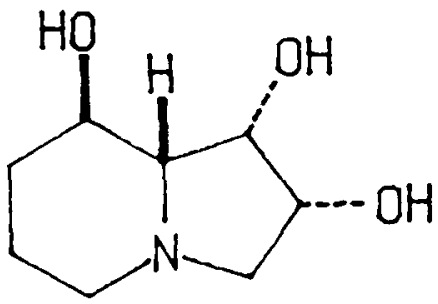

$(3.6)$ 


\section{RESULTS AND DISCUSSION}

\section{Synthesis of 1,4-Dideoxy-1,4-imino-D-1yxitol (3.1)}

The free amine of (3.3) was protected as the t-Butyl Carbamate (3.7) by treatment with di-tert-butyl dicarbonate in pyridine. The reaction proceeded only in a modest yield (47\%). Sodium periodate oxidation of the diol with subsequent sodium borohydride reduction, gave the lyxo alcohol (3.8) (78\%). The protecting groups were removed by hydrolysis using aqueous trifluoroacetic acid. The carbamate protecting group was rapidly removed followed by much slower removal of the acetal to give after purification by ion exchange chromatography the lyxitol (3.1) (68\%), identical in all respects to the compound synthesised in chapter 2 ( 998 ) (Scheme 3.2).

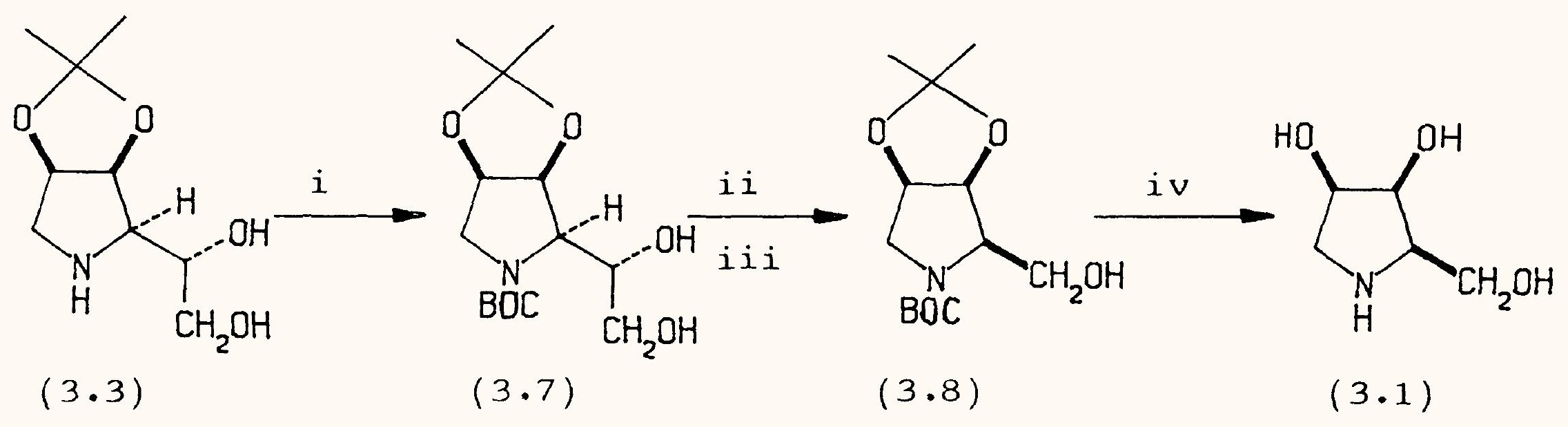

i) ( $(\mathrm{BuOCO})_{2} \mathrm{O}$ iị) $\mathrm{NaIO}_{4}$ iii) $\mathrm{NaBH}_{4}$ iv). aq TFA

SCHEME 3.2

Approaches to the Synthesis of $(t)$-Crotanecine (3.2)

Synthesis of crotanecine (3.2) from (3.3) requires formation of a $\mathrm{C}-\mathrm{N}$ bond and 2-C chain extension from $\mathrm{C}-5$ (Scheme 3.3).
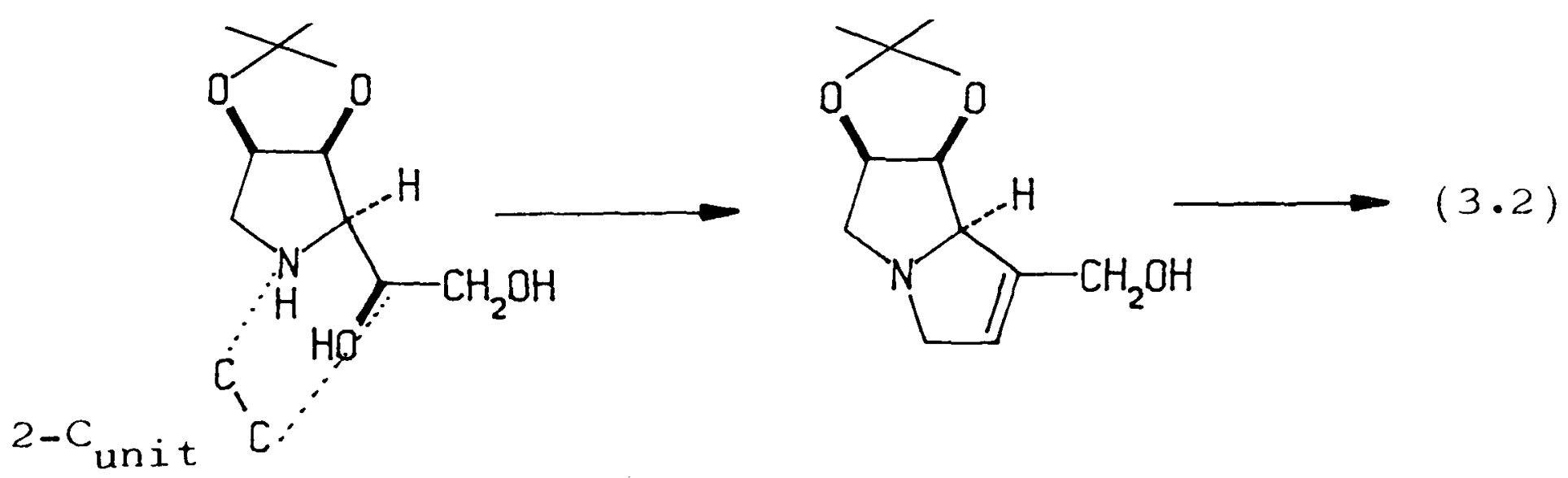
The formation of the $\mathrm{C}-\mathrm{N}$ bond and the $\mathrm{C}-\mathrm{C}$ bond could be performed in either order.

\section{i) Formation of the C-C bond first.}

The amine (3.3) was protected as the $Z$ derivative (3.9) by treatment with benzyl chloroformate, and the primary alcohol was protected as the t-butyldiphen.ylsily1 ether (3.10). Oxidation with pyridinum chlorochromate in the presence of molecular sieve in dichloromethane, gave the ketone (3.11)

(26\% from 3.3) (Scheme 3.4).

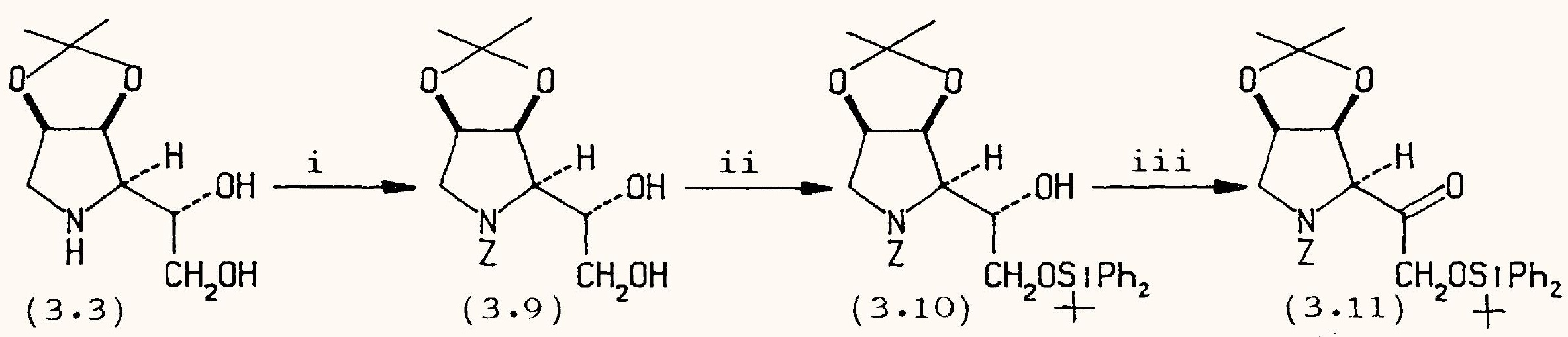

i) $\mathrm{PhCH}_{2} \mathrm{OCOCl}$ ii) $\mathrm{tBuPh}_{2} \mathrm{SiCl}$, imidazole iii) $\mathrm{pyH}^{+} \mathrm{CrO}_{3} \mathrm{Cl}^{-}$

\section{SCHEME 3.4}

Treatment of the ketone (3.11) with t-butyl bromoacetate and zinc in refluxing $\mathrm{THF}^{4}$ gave a low yield of the chain extended product (3.12), having formed an oxazolidine ring by elimation of benzyl alcohol (Scheme 3.5)

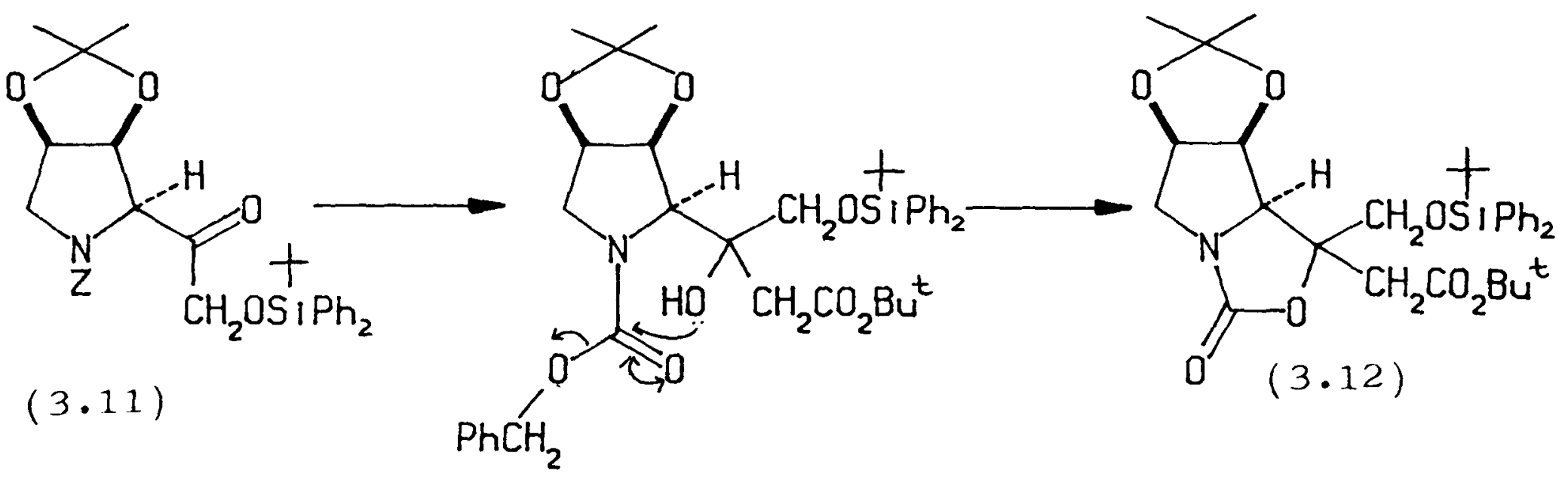

\section{SCHEME 3.5}


The product obtained was a single stereoisomer but the stereochemistry at C5 was not determined.

An attempt to form the $\mathrm{C}-\mathrm{C}$ and $\mathrm{C}-\mathrm{N}$ bonds simultaneously by initially removing the $Z$ group by hydrogenolysis and subsequently treating the amino ketone with sodium hydride and vinyl triphenyl phosphonium bromide $\left(\mathrm{CH}_{2}=\mathrm{CHPPh}_{3}+\mathrm{Br}^{-}\right)$, (Schweizers salt $\left.{ }^{5}\right)$. did not work.

\section{ii) Formation of the $\mathrm{C}-\mathrm{N}$ bond first: Wadsworth Emmans Approach.}

The primary alcohol of (3.3) was protected as the t-butyldiphenylsilyl ether (3.13) (52\%), and a DCC coupling with diethoxyphosphinyl acetic acid $^{6}$ in the presence of HOBT $^{7}$ gave the amide (3.14) (46\%) (Scheme 3.6)<smiles>COC1C(C)CNC1C(C)O</smiles>

$(3.3)$

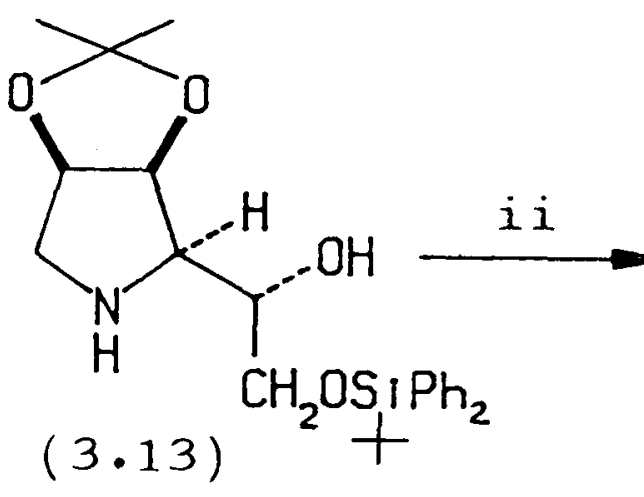

$(3.13)$

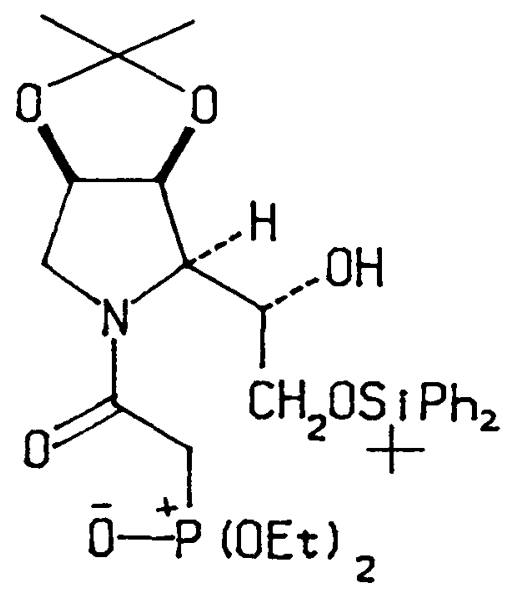

$(3.14)$

i) $\mathrm{tBuPh}_{2} \mathrm{SiCl}$, imidazole ii) (EtO) ${ }_{2} \mathrm{PO} \cdot \mathrm{CH}_{2} \mathrm{CO}_{2} \mathrm{H}, \mathrm{DCC}$

\section{SCHEME 3.6}

Oxidation proceeded smoothly with pyridinium chlorochromate to the ketone (3.15) but the cyclisation proved difficult. Treatment of the ketone (3.15) with potassium t-butoxide in THF gave a mixture of products. A low yield of a product with a mass 16 units too high was isolated (3.16). Closer inspection of the proton NMR and a $\mathrm{D}_{2} \mathrm{O}$ exchange experiment revealed that the bridgehead proton was missing and was replaced by $\mathrm{OH}$. (Scheme 3.7). 


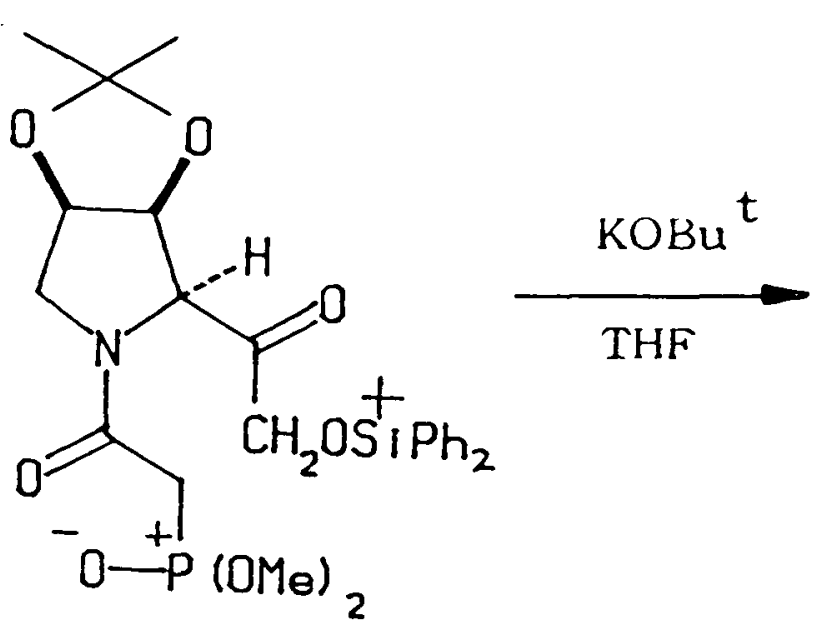

$(3.15)$

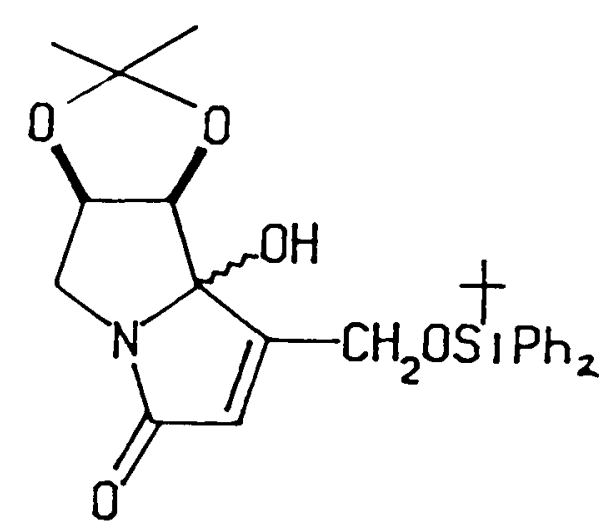

$(3.16)$

SCHEME 3.7

When the cyclisation was attempted using potassium carbonate and 18-crown-6 in toluene ${ }^{8}$, an improved yield of 2 isomeric products was obtained. The first ( $30 \%$ yield) had a very similar proton NMR spectrum to that of the potassium $\mathrm{t}$-butoxide cyclisation except that the $\mathrm{OH}$ proton was absent and a proton corresponding to the ring junction proton (H8) was present. The mass spectrum was consistent with the desired material. The second product (18\% yield) had a very different NMR spectrum, (still consistent with cyclised material) but gave the same molecular ion as the first. It was concluded that cyclisation under these conditions was resulting in epimerisation at the ring junction (Scheme 3.8). The identity of the 2 epimers was not established.

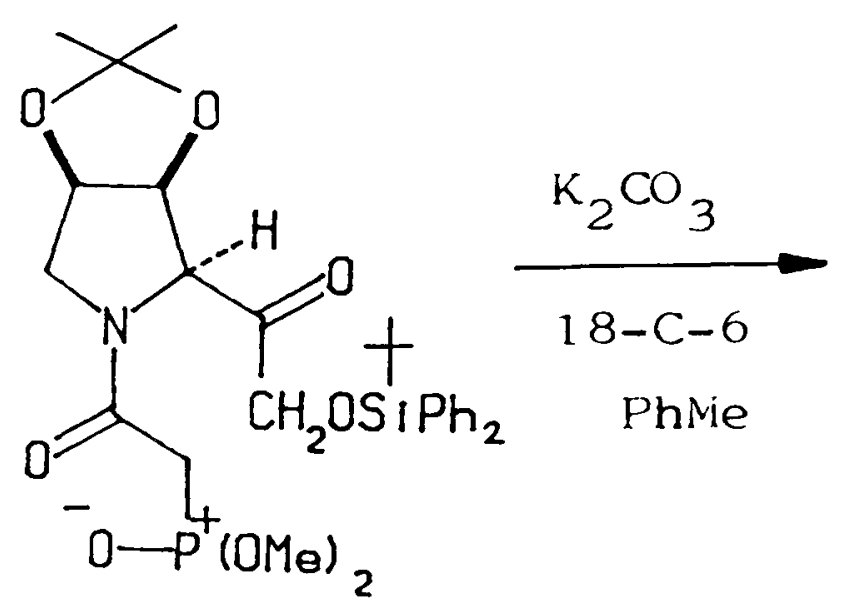

$(3.15)$

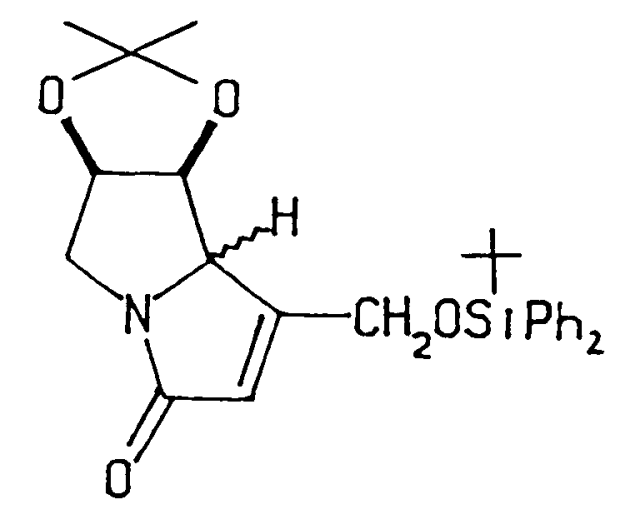

(3.17a and b)

SCHEME 3.8 
Further work is required in this area to optimise the conditions for the cyclisation.

The main problem with this route is that large quantities of (3.3) are not available, and also the protection of the amine in (3.3) always proceeded in only modest yields, despite trying a number of different conditions. 


\section{EXPERIMENTAL SECTION}

For general directions see chapter 1

N- t-butyloxycarbony1- 1,4- dideoxy- 1,4- imino- 2,3- $\underline{0}-$ isopropylidene-

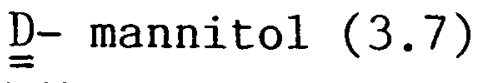

Amino diol (3.3) (0.2 g, $0.99 \mathrm{mmol})$ was dissolved in dry pyridine ( $5 \mathrm{~m} 1)$ and cooled to $0^{\circ} \mathrm{C}$. Di-tert-butyl dicarbonate $(0.28 \mathrm{~g}, 1.3 \mathrm{mmol})$ was added and the solution stirred for $3 \mathrm{~h}$. The mixture was diluted with dichloromethane $(25 \mathrm{ml})$ and washed successively with dilute hydrochloric acid (2M aq, $25 \mathrm{~m} 1)$, water $(25 \mathrm{~m} 1)$ and saturated aqueous sodium bicarbonate solution $(25 \mathrm{ml})$. The dichloromethane was dried and concentrated to a syrup which was purified by flash chromatography (ethyl acetate : hexane, $1: 1$ ) to give the title compound $(3.7)(0.14 \mathrm{~g}, 47 \%)$, a syrup. $[a]_{D}^{20}-44.5^{\circ}$ (c, 0.16 , $\left.\mathrm{CHCl}_{3}\right) \cdot v_{\max } 3450(\mathrm{br}), 1670 \mathrm{~cm}^{-1} \cdot 1_{\mathrm{H} \mathrm{NMR}} \delta 4.95(1 \mathrm{H}, \mathrm{t}, \mathrm{H}-3) ; 4.85(1 \mathrm{H}, \mathrm{m}$, $\mathrm{H}-2) ; 4.2-3.5(7 \mathrm{H}, \mathrm{m}) ; 3.2(1 \mathrm{H}, \mathrm{dd}, \mathrm{H}-1) ; 1.5,1.3\left(6 \mathrm{H}, 2 \mathrm{~s}, \mathrm{CH}_{3} \mathrm{CO}\right) ; 1.4$ $(9 \mathrm{H}, \mathrm{s}, \mathrm{tBu}) . \underline{\mathrm{m} / \mathrm{z}}: 304\left(\mathrm{M}+\mathrm{H}^{+}\right), 248,204(100 \%)$. Found $\mathrm{C}, 54.9 ; \mathrm{H}, 8.4$; $\mathrm{N}, 4.8 . \mathrm{C}_{14} \mathrm{H}_{25} \mathrm{NO}_{6}$ requires $\mathrm{C}, 55.4 ; \mathrm{H}, 8.3 ; \mathrm{N}, 4.6$.

N- -ㅡutyloxycarbony1- 1,4- dideoxy- 1,4- imino- 2,3- $\underline{0}-$ isopropylidene-

D- 1 yxitol (3.8)

The diol (3.7) ( $73 \mathrm{mg}, 0.24 \mathrm{mmol}$ ) was dissolved in $50 \%$ aqueous ethanol ( $7 \mathrm{~m} 1$ ) and stirred at room temperature with sodium periodate ( $63 \mathrm{mg}, 1.2$ equivs). After $15 \mathrm{~min}$ sodium borohydride ( $45 \mathrm{mg}, 5$ equivs) was added and stirring continued for a further $30 \mathrm{~min}$. The solution was filtered and evaporated and the residue partitioned between chloroform $(20 \mathrm{ml})$ and water $(20 \mathrm{~m} 1)$. The chloroform was dried and evaporated and the residue purified by flash 
chromatography (ethyl acetate : hexane, $3: 2$ ) to give the title compound (3.8) (51 mg, 78\%), a syrup. $[a]_{\mathrm{D}}^{20}-42.2^{\circ}\left(\underline{c}, 0.23, \mathrm{CHCl}_{3}\right) . v_{\max } 3400$ (br), $1680 \mathrm{~cm}^{-1} \cdot{ }^{1} \mathrm{H}$ NMR $\delta 4.9-3.5(8 \mathrm{H}$, br m$) ; 1.5,1.3\left(6 \mathrm{H}, 2 \mathrm{~s}, \mathrm{CH}_{3} \mathrm{CO}\right) ; 1.4(9 \mathrm{H}$, $\mathrm{s}, \mathrm{tBu}) . \underline{\mathrm{m} / \mathrm{z}}: 291\left(\mathrm{M}+\mathrm{NH}_{4}^{+}\right) ; 274\left(\mathrm{M}+\mathrm{H}^{+}\right), 218\left(\mathrm{M}+\mathrm{H}^{+}\right.$- butene, $\left.100 \%\right)$.

1,4- Dideoxy- 1,4- imino- D- 1yxitol (3.1) (and (2.2) )

Protected 1yxitol (3.8) (29 mg, $0.11 \mathrm{mmol}$ ) was dissolved in a mixture of $\mathrm{D}_{2} \mathrm{O}(0.5 \mathrm{~m} 1)$ and trifluoroacetic acid $(0.5 \mathrm{~m} 1)$ and left at room temperature. The progress of the reaction was monitored by NMR (60 MHz). After $12 \mathrm{~h}$ the solvent was removed and purification by ion exchange chromatography (procedure 1 and 2 ) gave the title compound (3.1 and 2.2) (10 mg, 68\%) as the free base $[\mathrm{G}]_{\mathrm{D}}^{20}-15.8^{\circ}\left(\mathrm{H}_{2} \mathrm{O}\right) . \mathrm{1}_{\mathrm{H} \text { NMR }}$ and $\underline{\mathrm{m} / \mathrm{z}}$ identical with the material synthesised in chapter 2.

6- $\underline{0}-\underline{\mathrm{t}}-$ butyldiphenylsilyl- 1,4- dideoxy- 1,4- imino- 2,3- $\underline{0}-$ isopropylidene-

D- mannitol (3.13)

Diol (3.3) (105 mg, $0.52 \mathrm{mmol}$ ) was dissolved in dry DMF (3 m1) containing imidazole ( $80 \mathrm{mg}, 2.2$ equivs) and stirred at room temperature with $\underline{t}$-butyl chlorodiphenylsilane $(0.15 \mathrm{ml}, 1.1$ equivs). After $8 \mathrm{~h}$, the solvent was evaporated and the residue partitioned between chloroform (10 $\mathrm{m} 1)$ and water $(10 \mathrm{~m} 1)$. The chloroform extract was dried and concentrated. Purification by flash chromatography (ethyl acetate) gave the title compound (3.13) (120 mg,

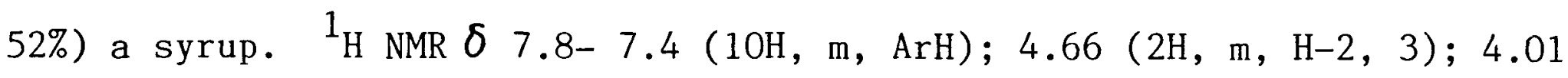
$(1 \mathrm{H}, \mathrm{m}, \mathrm{H}-5) ; 3.84\left(2 \mathrm{H}, \mathrm{m}, \mathrm{H}-6,6^{\prime}\right) ; 3.10\left(1 \mathrm{H}, \mathrm{d}, \mathrm{H}-1, \mathrm{~J}_{11}, 13.3 \mathrm{~Hz}\right) ; 2.74$ $(1 \mathrm{H}, \mathrm{dd}, \mathrm{H}-4) ; 2.60\left(1 \mathrm{H}, \mathrm{dd}, \mathrm{H}-1^{\prime}\right) ; 2.0(2 \mathrm{H}$, br s, OH, NH) $1.45,1.29$ $\left(6 \mathrm{H}, 2 \mathrm{~s}, \mathrm{CH}_{3}\right) ; 1.08(9 \mathrm{H}, \mathrm{s}, \mathrm{tBu}) . \underline{\mathrm{m} / \mathrm{z}}: 442\left(\mathrm{M}+\mathrm{H}^{+}, 100 \%\right)$. 
$\underline{N}$ - benzyloxycarbonyl- $1-\underline{0}-\underline{t}$-butyldiphenylsilyl- 3,6- dideoxy-3,6- imino-

2,3- $\underline{0}-$ isopropylidene- D- fructose (3.11)

Acetonide (3.13) (107 mg, $0.53 \mathrm{mmol}$ ) was dissolved in ether : saturated aqueous sodium bicarbonate solution $(5: 2,7 \mathrm{~m} 1)$ and stirred with benzy1 chloroformate $(0.21 \mathrm{ml}, 2$ equivs) at room temperature. After $3 \mathrm{~h}$, the layers were separated and the aqueous phase extracted with ethyl acetate $(5 \mathrm{~m} l)$. The organic extracts were combined, dried, filtered and evaporated. Purification of the residue by flash chromatography (ethyl acetate : hexane, 1 : 1) gave the $Z$ protected diol ( $80 \mathrm{mg}$ ), a syrup.

The $\mathrm{Z}$ protected diol was dissolved in DMF ( $3 \mathrm{ml})$ containing imidazole (37 $\mathrm{mg}, 2.2$ equivs) and treated with t-butylchlorodiphenylsilane $(0.069 \mathrm{~m} 1$, 1.1 equivs) at $0^{\circ} \mathrm{C}$ under nitrogen. After $48 \mathrm{~h}$ the solvent was removed and the residue partitioned between chloroform $(10 \mathrm{~m} 1)$ and water $(10 \mathrm{~m} 1)$. The chloroform was dried and evaporated to a syrup. Purification by flash chromatography (ethyl acetate : hexane, $1: 4$ ) gave $\mathbb{N}$ - benzyloxycarbonyl 6- $\underline{0}$ - t-butyldiphenylsilyl- 3,6- dideoxy- 3,6- imino- D- mannitol (86 mg), a syrup.

The syrup was dissolved in dry dichloromethane $(2 \mathrm{ml})$ and stirred at room temperature with pyridinium chlorochromate ( $97 \mathrm{mg}, 3$ equivs) and powdered molecular sieve $(90 \mathrm{mg})$. After $24 \mathrm{~h}$ the solution was diluted with ether ( $5 \mathrm{ml}$ ), filtered through celite, concentrated to a syrup and purified by flash chromatography (ethyl acetate : hexane, $1: 3$ ) to afford the title compound $(3.11)\left(80 \mathrm{mg}, 26 \%\right.$ over 3 steps) as a syrup. $v_{\max } 1740,1700 \mathrm{~cm}^{-1}$. $1_{\mathrm{H} \mathrm{NMR}} \delta 7.8-7.3(15 \mathrm{H}, \mathrm{m}, \mathrm{ArH}) ; 5.2(2 \mathrm{H}, \mathrm{m}, \mathrm{H}-4,5) ; 5.1\left(2 \mathrm{H}, \mathrm{m}, \mathrm{PhCH}_{2}\right)$; 4.9- $4.1\left(2 \mathrm{H}, \mathrm{m}, \mathrm{H}-1,1^{\prime}\right) ; 3.95-3.5\left(3 \mathrm{H}, \mathrm{m}, \mathrm{H}-3,6,6^{\prime}\right) ; 1.5,1.3(6 \mathrm{H}, 2 \mathrm{~s}$, 
$\left.\mathrm{CH}_{3} \mathrm{C}\right) ; 1.1(9 \mathrm{H}, \mathrm{s}, \mathrm{tBu}) . \underline{\mathrm{m} / \mathrm{z}}: 591\left(\mathrm{M}+\mathrm{NH}_{4}^{+}\right) ; 574\left(\mathrm{M}+\mathrm{H}^{+}\right) ; 196(100 \%)$.

Attempted Reformatsky reaction.on (3.11)

The ketone (3.11) (60 mg, $0.11 \mathrm{mmol})$ was dissolved in dry THF (2 ml) containing activated zinc (52 mg, $0.8 \mathrm{mmol})$. t-Butylbromoacetate was added slowly, with stirring, and the reaction was initiated by the addition of a trace of iodine. The mixture was then refluxed for $24 \mathrm{~h}$, when t.1.c (ether : hexane, $1: 1)$ showed complete loss of starting material $\left(R_{f} 0.45\right)$ and several products. The solution was cooled, diluted with ether $(10 \mathrm{ml})$, filtered through celite and washed with water $(10 \mathrm{ml})$. The organic layer was separated, dried and concentrated to a syrup. Purification by flash chromatography (ether : hexane, $1: 1)$ gave 1 major product $\left(R_{f} 0.5\right)$, the oxazolidine (3.12)

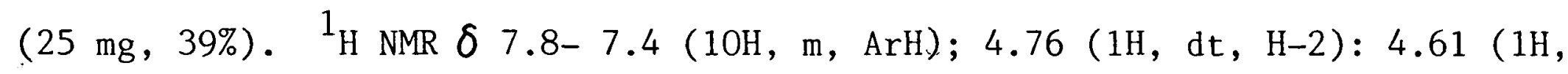
$\mathrm{dd}, \mathrm{H}-3) ; 4.29\left(2 \mathrm{H}, \mathrm{s}, \mathrm{CH}_{2} \mathrm{OSi}\right) ; 3.94(1 \mathrm{H}, \mathrm{d}, \mathrm{H}-4) ; 3.81(1 \mathrm{H}, \mathrm{d}, \mathrm{H}-1) ; 3.23$ $\left(1 \mathrm{H}, \mathrm{d}, \mathrm{CH}_{2} \mathrm{CO}_{2} \mathrm{Bu}^{\mathrm{t}}\right) ; 3.09\left(1 \mathrm{H}, \mathrm{dd}, \mathrm{H}-1^{\prime}\right) ; 2.75\left(1 \mathrm{H}, \mathrm{d}, \mathrm{CH}_{2} \mathrm{CO}_{2} \mathrm{Bu}^{\mathrm{t}}\right) ; 1.46(9 \mathrm{H}$, $\left.\mathrm{s}, \mathrm{tBuO}_{2} \mathrm{C}\right) ; 1.26,1.13\left(6 \mathrm{H}, 2 \mathrm{~s}, \mathrm{CH}_{3} \mathrm{C}\right) ; 1.07(9 \mathrm{H}, \mathrm{s}, \mathrm{tBuSi})$.

$\underline{N}-$ Diethoxyphosphinylacety1- 6- $\underline{0}-\underline{t}$-butyldiphenylsily1- 2,3- $\underline{0}-$ isopropy1idene- 1,4- dideoxy- 1,4- imino- D- mannitol (3.14)

Diethoxyphosphinyl acetic acid ( $33 \mathrm{mg}, 1.1$ equivs), 1- hydroxy benzotriazole (25 mg, 1.1 equivs) and $\mathrm{N}, \mathrm{N}^{\prime}$ dicyclohexylcarbodiimide (28 $\mathrm{mg}, 1.1$ equivs) were dissolved in dichloromethane $(2 \mathrm{ml})$ and the solution cooled to $0^{\circ} \mathrm{C}$. The amine (3.13) (73 $\mathrm{mg}, 0.17 \mathrm{mmol})$ in dichloromethane $(2 \mathrm{ml})$ was added dropwise and the solution stirred for $12 \mathrm{~h}$. The mixture was filtered and concentrated to a syrup. Purification by flash chromatography gave the title compound 
(3.14) (47 mg, 46\%) as a syrup. ${ }^{1} \mathrm{H}$ NMR $\delta 7.8-7.3(10 \mathrm{H}, \mathrm{m}, \mathrm{ArH}) ; 4.8-2.9$ $(15 \mathrm{H}, \mathrm{m}) ; 1.5,1.3\left(6 \mathrm{H}, 2 \mathrm{~s}, \mathrm{CH}_{3} \mathrm{C}\right) ; 1.4\left(6 \mathrm{H}, 2 \mathrm{t}, \mathrm{CH}_{3} \mathrm{CH}_{2}\right) ; 1.05(9 \mathrm{H}, \mathrm{s}, \mathrm{tBu})$. $\underline{\mathrm{m} / \mathrm{z}}: 620\left(\mathrm{M}+\mathrm{H}^{+}\right), 562,225(100 \%)$.

Oxidation then attempted cyclisation of (3.14)

\section{i) Cyclisation with potassium t-butoxide in THF}

Alcohol (3.14) (11.8 mg, $0.019 \mathrm{mmol})$ was dissolved in dry dichloromethane (2 $\mathrm{m} 1$ ) and stirred at room temperature with pyridinium chlorochromate (9 $\mathrm{mg}$, 2 equivs) and powdered molecular sieve (10 mg). After $12 \mathrm{~h}$ the reaction mixture was passed down a silica column (eluted with ethyl acetate) and the resulting colourless solution concentrated to a syrup, the crude ketone. The crude ketone was dissolved in dry THF and potassium t-butoxide $(2.2 \mathrm{mg}$, 1 equiv) was added, with stirring. The starting material reacted immediately and several products were observed on t.1.c (ethyl acetate). The solution was diluted with chloroform $(5 \mathrm{~m} 1)$ and washed with water $(5 \mathrm{ml})$. The organic layer was dried and evaporated. Purification of the residue by flash chromatography (ethyl acetate : hexane, $1: 2$ ) gave one major product $(1.7 \mathrm{mg})$. The ${ }^{1} \mathrm{H}$ NMR and $\underline{\mathrm{m} / \mathrm{z}}$ of the product were consistent with the structure (3.16) in which the cyclisation has occurred, but accompanied by oxidation at the bridgehead position. ${ }^{1} \mathrm{H}$ NMR $\delta 7.71-7.36(10 \mathrm{H}, \mathrm{m}, \mathrm{ArH})$; $6.07\left(1 \mathrm{H}, \mathrm{t}, \mathrm{H}-6, \mathrm{~J}_{69} 2.0 \mathrm{~Hz}\right) ; 4.93(1 \mathrm{H}, \mathrm{t}, \mathrm{H}-2) ; 4.63(1 \mathrm{H}, \mathrm{dd}, \mathrm{H}-9) ; 4.53$ $\left(1 \mathrm{H}, \mathrm{dd}, \mathrm{H}-9^{\prime}\right) ; 4.43(1 \mathrm{H}, \mathrm{d}, \mathrm{H}-1) ; 3.92(1 \mathrm{H}, \mathrm{d}, \mathrm{H}-3) ; 3.29\left(1 \mathrm{H}, \mathrm{dd}, \mathrm{H}-3^{\prime}\right.$, $\left.\mathrm{J}_{33}, 13.4 \mathrm{~Hz}\right) ; 2.24\left(1 \mathrm{H}\right.$, br $\mathrm{s}, \mathrm{OH}, \mathrm{D}_{2} \mathrm{O}$ exchanged $) ; 1.30,1.19\left(6 \mathrm{H}, 2 \mathrm{~s}, \mathrm{CH}_{3} \mathrm{C}\right)$; $1.08(9 \mathrm{H}, \mathrm{s}, \mathrm{tBu}) . \underline{\mathrm{m} / \mathrm{z}}: 480\left(\mathrm{M}+\mathrm{H}^{+}, 100 \%\right) ; 462\left(\mathrm{M}+\mathrm{H}^{+}-\mathrm{H}_{2} \mathrm{O}\right), 422,404,364$. 


\section{ii) Cyclisation with potassium carbonate and 18 - crown -6 .}

Alcohol (3.14) (30 mg, $0.048 \mathrm{mmol}$ ) was oxidised as described above to produce the ketone $(19 \mathrm{mg})$ which was slightly contaminated with chromium residues. The crude ketone was dissolved in toluene $(1 \mathrm{ml})$ and stirred at room temperature with $18-$ crown- 6 (15 mg, 2 equivs) and potassium carbonate ( $5 \mathrm{mg}, 1.2$ equivs). After $24 \mathrm{~h}$, the solution was washed with water and the organic layer was dried and evaporated. Purification of the residue by flash chromatography (ethyl acetate : hexane, $1: 2$ ) afforded 2 products. Inspection of the ${ }^{1} \mathrm{H}$ NMR of the products revealed that the 2 compounds were isomers of the desired cyclised material epimeric at the ring junction. isomer $1(6.7 \mathrm{mg}, 30 \%):{ }_{\mathrm{H} \text { NMR }} \delta 7.8-7.4(10 \mathrm{H}, \mathrm{m}, \mathrm{ArH}) ; 6.00(1 \mathrm{H}, \mathrm{t}, \mathrm{H}-6$, $\left.\mathrm{J}_{69^{1}} 1.7 \mathrm{~Hz}\right) ; 4.88(1 \mathrm{H}, \mathrm{dt}, \mathrm{H}-2) ; 4.55\left(2 \mathrm{H}, \mathrm{m}, \mathrm{H}-9,9^{\prime}\right) ; 4.15(2 \mathrm{H}, \mathrm{m}, \mathrm{H}-1,8)$; $4.12\left(1 \mathrm{H}, \mathrm{dd}, \mathrm{H}-3, \mathrm{~J}_{23} 6.7 \mathrm{~Hz}\right) ; 3.27\left(1 \mathrm{H}, \mathrm{dd}, \mathrm{H}-3^{\prime}, \mathrm{J}_{33}, 13.0 \mathrm{~Hz}, \mathrm{~J}_{23}, 3.4 \mathrm{~Hz}\right)$; $1.54,1.30\left(6 \mathrm{H}, 2 \mathrm{~s}, \mathrm{CH}_{3} \mathrm{C}\right) ; 1.09(9 \mathrm{H}, \mathrm{s}, \mathrm{tBu}) . \underline{\mathrm{m} / \mathrm{z}}: 464\left(\mathrm{M}+\mathrm{H}^{+}, 100 \%\right), 391$, 348, 225. isomer $2(4 \mathrm{mg}, 18 \%):{ }^{1} \mathrm{H} \mathrm{NMR} \delta 7.8-7.4(10 \mathrm{H}, \mathrm{m}, \operatorname{ArH}) ; 5.99(1 \mathrm{H}, \mathrm{t}$, $\mathrm{H}-6) ; 4.91\left(1 \mathrm{H}, \mathrm{t}, \mathrm{H}-2, \mathrm{~J}_{23} 4.7 \mathrm{~Hz}\right) ; 4.65(1 \mathrm{H}, \mathrm{t}, \mathrm{H}-1) ; 4.60(1 \mathrm{H}, \mathrm{dd}, \mathrm{H}-9)$; $4.50\left(1 \mathrm{H}, \mathrm{dd}, \mathrm{H}-9^{\prime}\right) ; 4.34(1 \mathrm{H}, \mathrm{d}, \mathrm{H}-8) ; 3.98(1 \mathrm{H}, \mathrm{d}, \mathrm{H}-3) ; 3.20\left(1 \mathrm{H}, \mathrm{dd}, \mathrm{H}-3^{\prime}\right.$, $\left.\mathrm{J}_{33}, 13.5 \mathrm{~Hz}, \mathrm{~J}_{23}, 4.6 \mathrm{~Hz}\right) ; 1.5,1.3\left(6 \mathrm{H}, 2 \mathrm{~s}, \mathrm{CH}_{3} \mathrm{C}\right) ; 1.1(9 \mathrm{H}, \mathrm{s}, \mathrm{tBu}) . \underline{\mathrm{m} / \mathrm{z}}:$ $464(100 \%), 406,348$. 


\section{SUMMARY}

The diol (3.3) which had previously been prepared in 9 steps from D- mannose was converted to the imino lyxitol (3.1) which was identical in all respects to (2.2). Approaches to the pyrrolizidine (3.2) from (3.3) were also discussed.

D-mannose

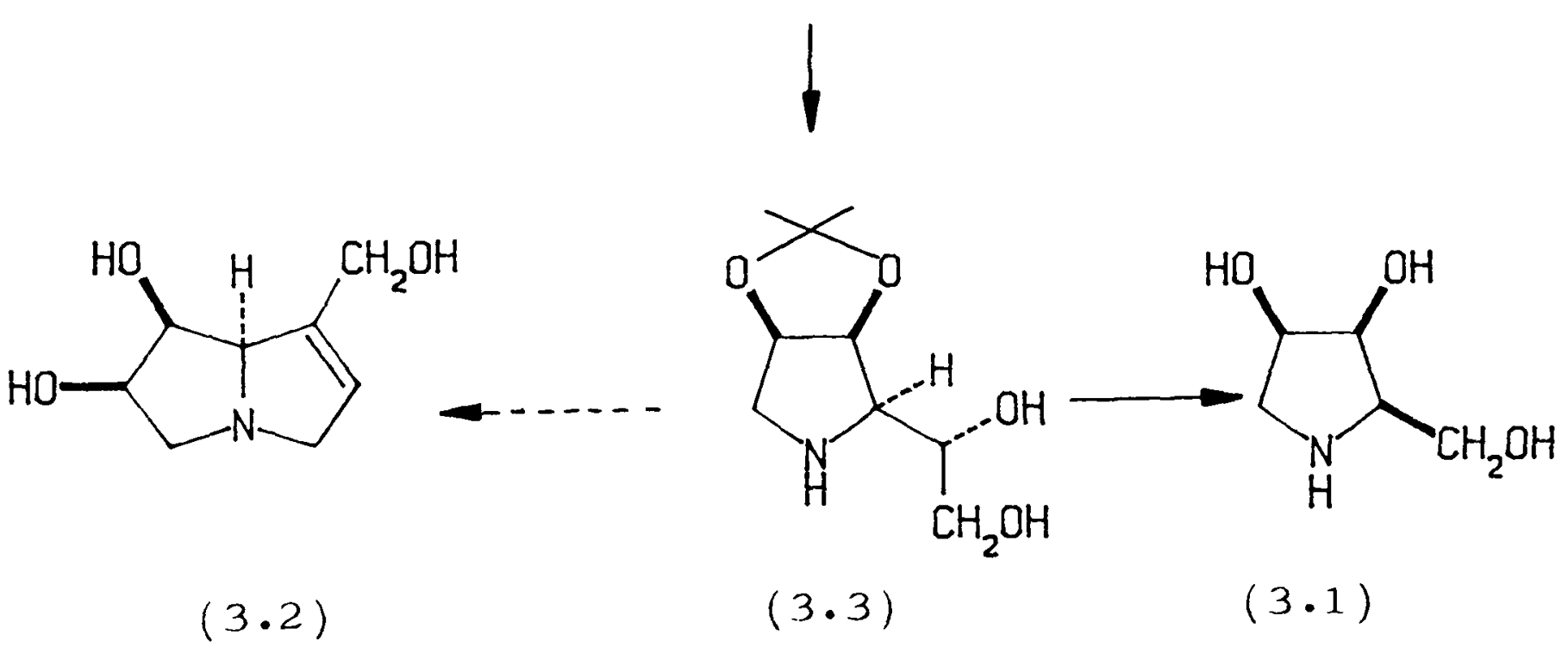

CHAPTER 3 SUMMARY 


\section{CHAPTER 3 REFERENCES.}

1. G.W.J. Fleet, M.J. Gough and P.W. Smith, Tetrahedron Lett, 1984, 25, 1853.

2. G.W.J. Fleet, P.W. Smith, S.V. Evans and L.E. Fellows, J. Chem. Soc. Commun. $1984,1240$.

3. N. Yasuda, H. Tsutsumi and T. Takaya, Chem. Lett, 1984, 1201.

4. R.L. Shriner, Org. Reactions, 1942, 1,1 .

M.W. Rathke, Org. Reactions, $1974, \underline{22}, 423$

5. E.E. Schweizer, J.Amer. Chem. Soc. 1964, 86, 2744; E.E. Schweizer and K.K. Light, Ibid, 1964, 86, 2963; E.E. Schweizer and G.J. O'Neill J. Org.Chem. 1965, 30, 2082; E.E. Schweizer and K.K. Light, ibid, 1966, 31, 870.

6. R.A. Malevannaya, E.N. Tsvetkov and M.I. Kabachnik, Zhurnal Obshchei. Khimii, $1971, \underline{41}, 1426$.

7. G.C. Windbridge and E.C. Jorgensen, J.Amer. Chem. Soc., 1971, 93, 6318.

8. R. Baker and R.J. Sims, Synthesis, 1981, 117 
4. THE SYNTHESIS OF BOTH ENANTIOMERS OF 1,4-DIDEOXY-1,4-IMINO-

\section{ARABINITOL FROM D-XYLOSE}

\section{INTRODUCTION}

This chapter describes the synthesis of the natural product 1,4-dideoxy1,4-imino-D-arabinitol (4.1) and its enantiomer (1,4-dideoxy-1,4-imino-Larabinito1) (4.2) from $\underline{D}-x y l o s e$.

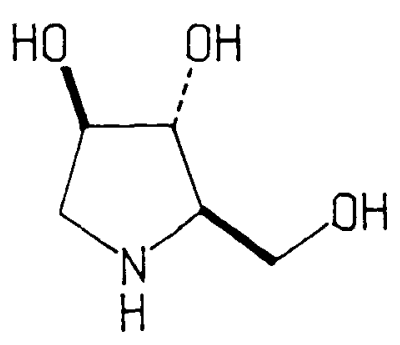

$(4 \cdot 1)$<smiles>OC[C@@H]1NCC(O)C1O</smiles>

$(4.2)$<smiles>O=C[C@H](O)[C@H](O)[C@H](O)CO</smiles>

D-Xylose

1,4-dideoxy-1,4-imino-D-arabinitol (4.1) occurs both in Arachniodes $\underline{\text { standishii }}^{1}$ and Angylocalyx boutiqueanus ${ }^{2}$ and has been shown to be a potent inhibitor of the hydrolysis of 4-nitrophenyl $a-\underline{D}-$ glucopyranoside catalysed by $a$-glucosidase (50\% inhibition at $\left.1.8 \times 10^{-7} \mathrm{M}\right)^{3}$.

\section{Previous Syntheses}

There are no published syntheses of the $\underline{D}$-isomer (4.1), but the synthesis of the $\underline{\mathrm{L}}$ enantiomer from methyl 2,3-di-0-benzoy1- $\beta$-L-Larabinopyranoside has been reported $^{4}$. (Scheme 4.1$)$.

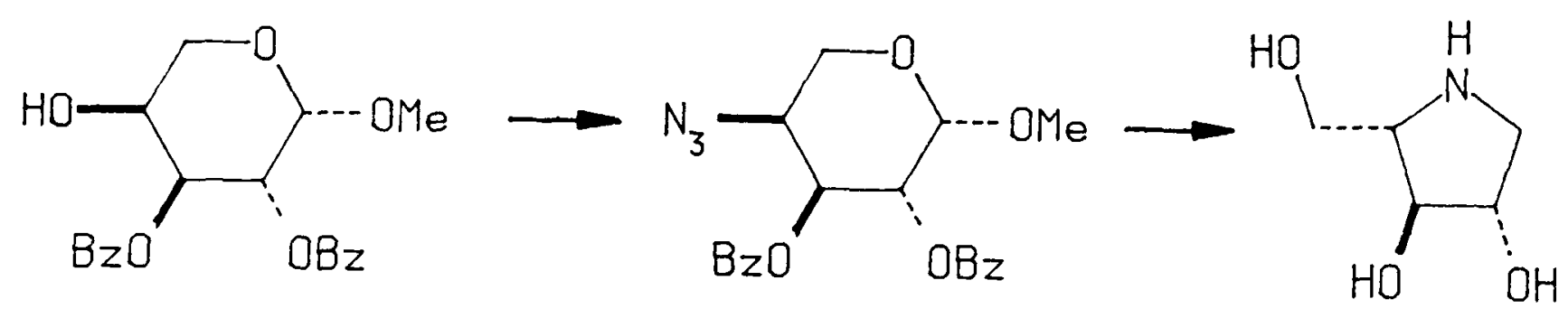

\section{SCHEME 4.1}

The double inversion and introduction of azide at C-4 was effected in two steps, by treating the alcohol with triphenylphosphine and 2,4,5 tribromoimidazole and then displacing the bromide produced with sodium azide. Removal of the protecting groups, acid hydrolysis and reductive amination 
of the azido lactol, produced the $\underline{L}$ enantiomer (4.2).

A recent synthesis of the $L$ enantiomer (4.2) from D-glucose, further confirms the structure ${ }^{8}$.

\section{RESULTS \& DISCUSSION}

\section{$\underline{\text { Retrosynthetic analysis }}$}
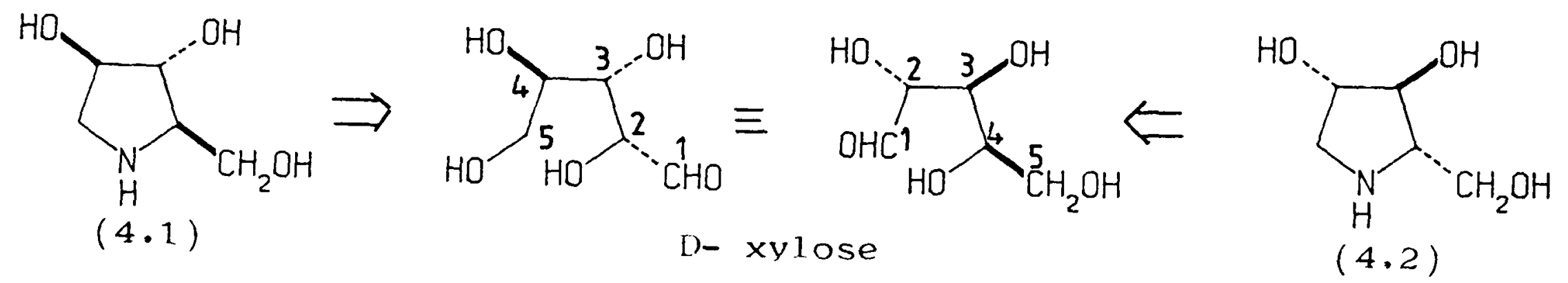

\section{SCHEME 4.2}

The synthesis of the $\underline{D}$ enantiomer (4.1) required introduction of nitrogen

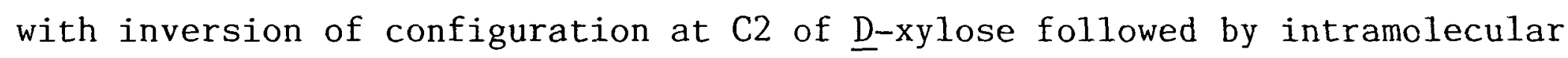
cyclisation onto $\mathrm{C5}$.

The synthesis of the $\underline{L}$ enantiomer (4.2) required a similar approach with introduction of nitrogen and intramolecular cyclisation between $\mathrm{C} 1$ and $\mathrm{C} 4$ of $\underline{D} x y$ lose, with inversion of configuration at $\mathrm{C} 4$. (Scheme 4.2).

\section{The Synthesis}

The synthesis of both enantiomers was accomplished from methy1-3,5-0isopropylidene- $a-\underline{D}$-xylofuranoside (4.3) which was prepared on multigram scale by kinetic methanolysis of D-xylose and acetonation, with acetone and anhydrous copper (II) sulphate (the method of Baker et $\underline{\text { al }}^{5}$. (Scheme 4.3)). This method gave a mixture of $\alpha$ and $\beta$ anomers in a ratio of about 1.5 : 1. (72\%). S1ightly improved ratios (about $3: 1$ ) were obtained when the acetonation was performed using a mixture of acetone and 2,2 dimethoxypropane, with 10-dl camphorsulphonic acid. Separation of the anomers by distillation 
using a Vigreux column, afforded the pure $\alpha$ anomer, but the $\beta$ anomer obtained was always slightly contaminated with $\alpha$, and since the $\beta$ anomer distilled at a higher temperature, material was often decomposed in trying to distil the last traces. A more efficient separation was achieved by flash chromatography (or dry column chromatography for large quantities) as the anomers were well resolved on $t .1 . c$.

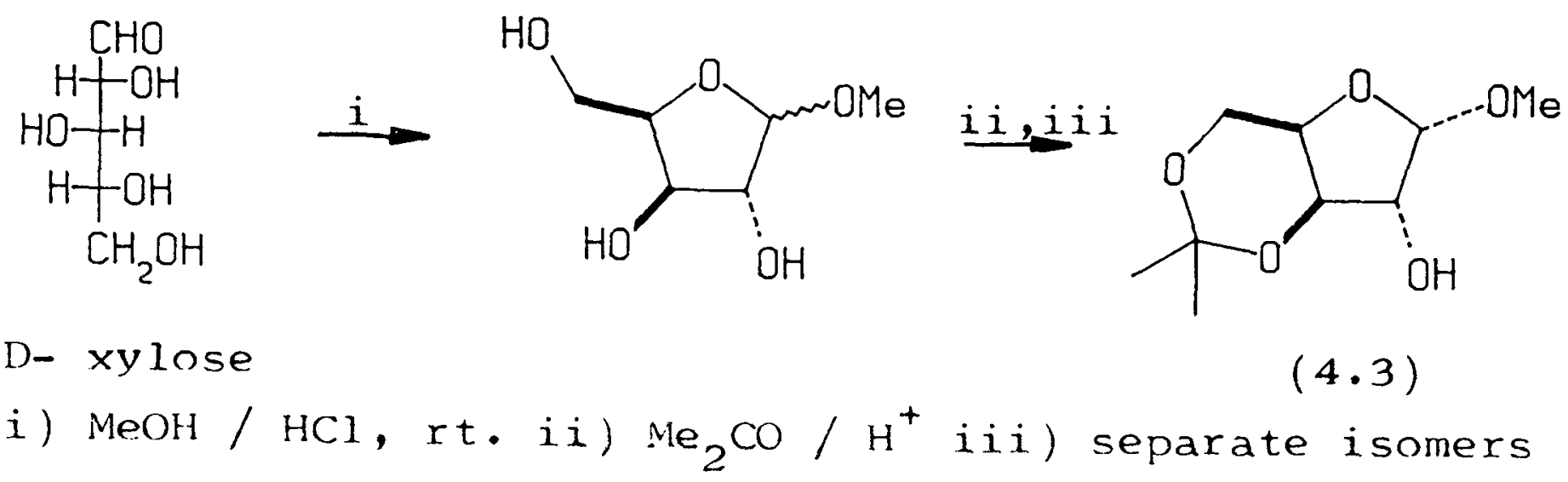

\section{SCHEME 4.3}

The $\beta$ anomer was not used further, but could have been employed in an identical manner to the $a$ anomer in the synthesis of the $\underline{L}$ enantiomer. The introduction of nitrogen at $\mathrm{C} 2$ in the $\beta$ anomer, was not attempted.

\section{1,4-Dideoxy-1,4-imino-D-arabinitol. (4.1)}

i) Introduction of azide with inversion at $\mathrm{C}-2$.

The free hydroxyl group in the $a$ anomer (4.3) was readily esterified with trifluoromethanesulphonic anhydride under the standard conditions, to give the triflate (4.4). Displacement with sodium azide in DMF proceeded very slow1y at $70^{\circ} \mathrm{C}$, but was complete in $12 \mathrm{~h}$ at $100^{\circ} \mathrm{C}$ producing the lyxo-azide (4.5) cleanly and in high overall yield (76\% from (4.3) on multigram scale) (Scheme 4.4). Both compounds are highly mobile oils and the azide could be obtained analytically pure by Kugelruhr distillation.

Attempts to displace the corresponding mesylate with sodium azide in DMF gave no azide containing product even under reflux. 


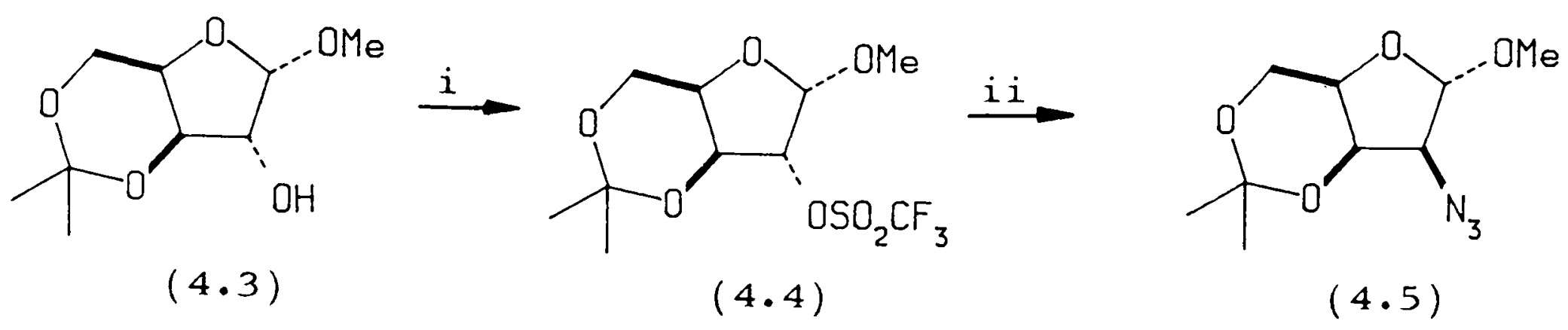

i) $\left(\mathrm{CF}_{3} \mathrm{SO}_{2}\right)_{2} \mathrm{O}, \mathrm{py}, \mathrm{CH}_{2} \mathrm{Cl}_{2}$ ii) $\mathrm{NaN}_{3}, \mathrm{DMF}, 100^{\circ}$.

SCHEME 4.4

\section{ii) Displacement of leaving group at C5}

The acetonide of the azide (4.5) was easily selectively hydrolysed using aqueous acetic acid at $50^{\circ}$ to give the diol (4.6) as a mobile oil (quantitative yield). Tosylation with 1.1 equivalents of freshly recrystallised p-toluenesulphonyl chloride cleanly gave the 5-tosylate (4.7). (74\%). Hydrogenolysis of the azide with palladium black in ethanol gave an amine which spontaneously cyclised. Attempts to isolate this bicyclic amine as the tosylate salt (4.8) by evaporation and recrystallisation, gave only very low yields. The sequence was made much more efficient by treating the crude mixture from the hydrogenolysis with benzyl chloroformate under the usual conditions and isolating the $\mathrm{Z}$ protected amine (4.9) (63\%) (Scheme 4.5). The bicyclic protected amine decomposed on storing at room temperature and was used immediately in the next step. 

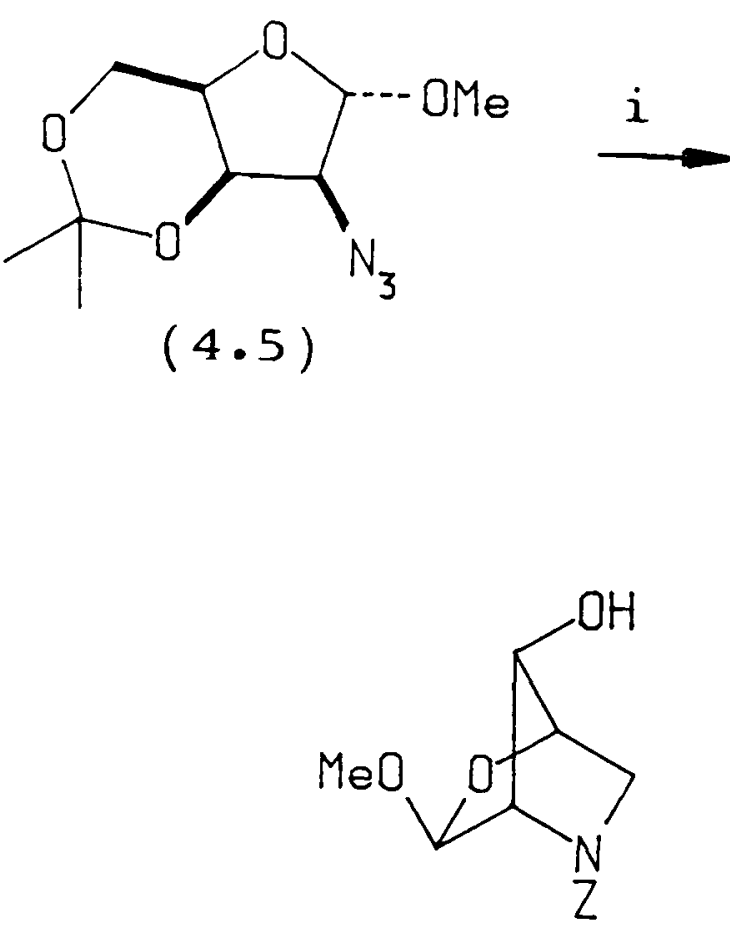

$(4.9)$
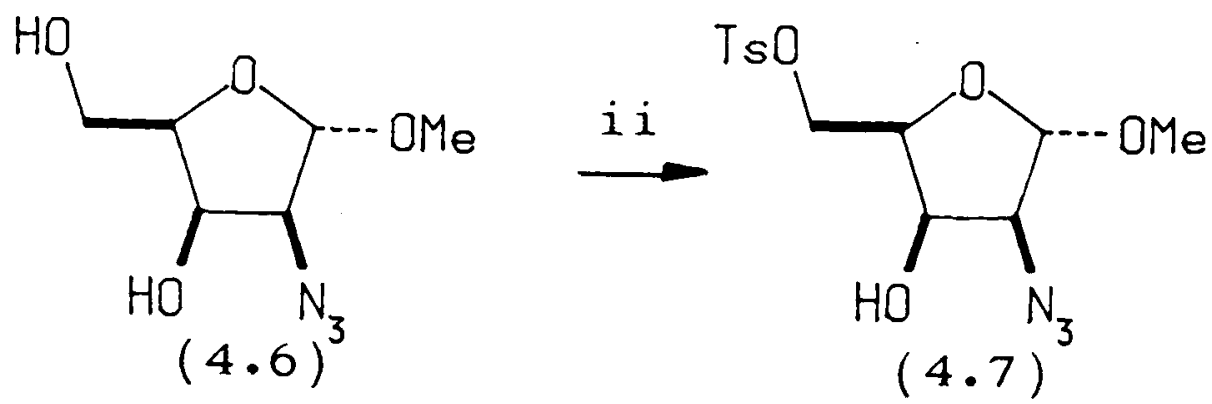

$(4.7)$

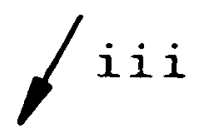

i) aq $\mathrm{AcOH}$ ii) $\mathrm{TsCl}$, py iii) $\mathrm{H}_{2}$, Pd black, EtOH iv) $\mathrm{PhCH}_{2} \mathrm{OCOCl}$

\section{SCHEME 4.5}

\section{iii) Removal of protecting groups}

Dissolution of the bicyclic protected amine (4.9) in aqueous trifluoroacetic acid, caused instantaneous hydrolysis of the acetal. Subsequent treatment with sodium borohydride in ethanol gave the target molecule protected only on nitrogen as the carbamate (4.10). Hydrogenolysis with palladium black in acetic acid, gave the amine (4.1) as a brown syrup. Purification by ion exchange chromatography and decolourising charcoal, failed to give the amine clean1y and it was necessary to use flash chromatography (10\% water in methano1). The free base was obtained as a colourless oil but crystallised as the hydrochloride salt (80\% from (4.9)) (Scheme 4.6).<smiles>[Z]N1CC2C(O)C(O)C1C2O</smiles>

$(4.9)$

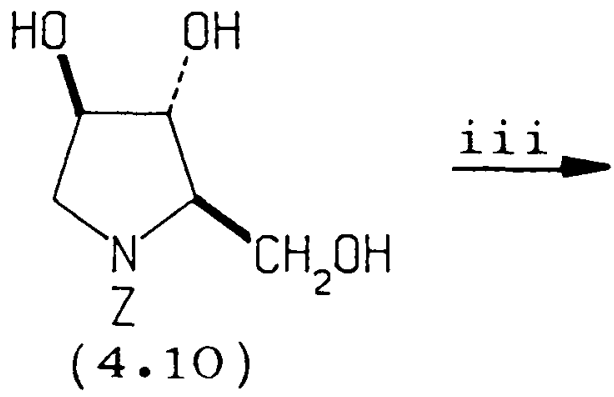

$(4 \cdot 10)$

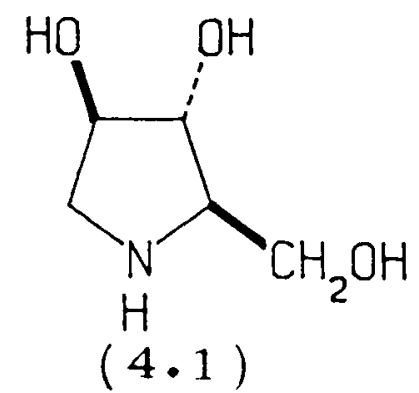

$(4 \cdot 1)$

i) aq TFA. ii) $\mathrm{NaBH}_{4}$, EtOH. iii) $\mathrm{H}_{2}$, Pd black, AcOH. SHCEME 4.6 
The material isolated was identical, in all respects, to the natural product isolated from Angylocalyx Boutiqueanus ${ }^{6}$.

1,4- Dideoxy- 1,4- imino- L-Arabinitol (4.2)

\section{i) Introduction of nitrogen}

The synthesis of the $\underline{L}-$ enantiomer (4.2) required an introduction of nitrogen between $\mathrm{C} 1$ and $\mathrm{C} 4$. Therefore, a derivative with the hydroxyl groups at C2, 3 and 5 protected, was required.

The acetonide group of methy $13,5-\underline{0}-$ isopropylidene- $a-\underline{D}-$ xylofuranoside (4.3) was removed in aqueous acetic acid to give the triol, methyl- $a_{-}$Dxylofuranoside (4.11). The free hydroxyl groups at C2, 3 and 5 were protected as benzyl ethers by treatment with an excess of benzyl bromide in the presence of silver (I) oxide in DMF. The tribenzylated xyloside (4.12) was produced in $54 \%$ yield from (4.3) on multigram scale.

The methyl glycoside of (4.12) was hydrolysed with aqueous trifluoroacetic acid and reduced with sodium borohydride in ethanol to give the diol (4.13) (76\%) which formed a dimesylate (4.14) on treatment with 2.5 equivalents of methanesulphonyl chloride in pyridine at $0^{\circ} \mathrm{C}(96 \%)$. Treatment of the dimesylate (4.14) with 1.1 equivalents of sodium azide in DMF at $50^{\circ} \mathrm{C}$, gave only displacement of the primary mesylate and produced the azido mesylate (4.15) (78\%) (Scheme 4.7). 


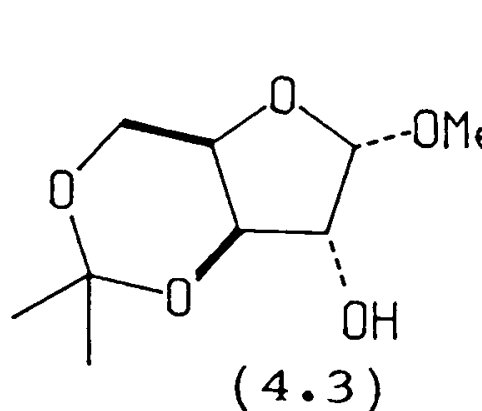

$(4.3)$

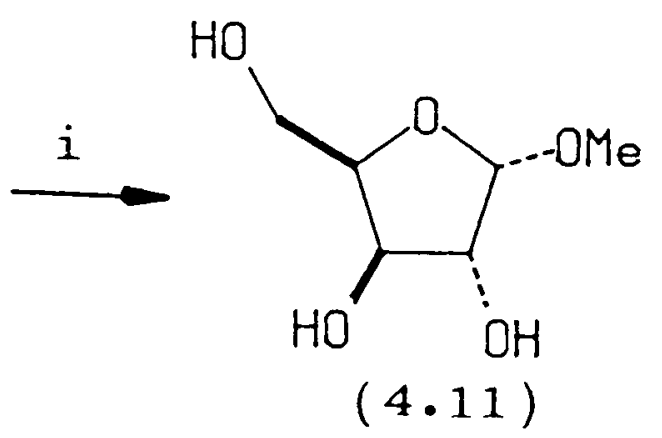

$(4.11)$

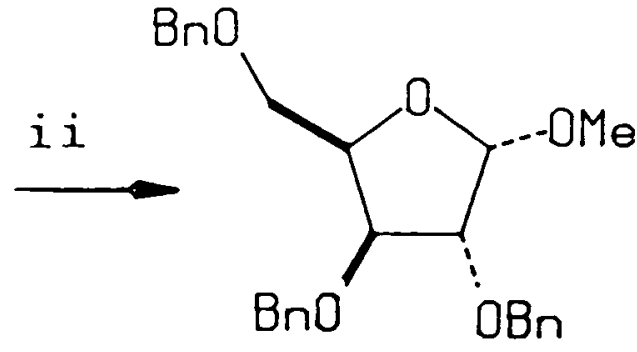

$(4 \cdot 12)$

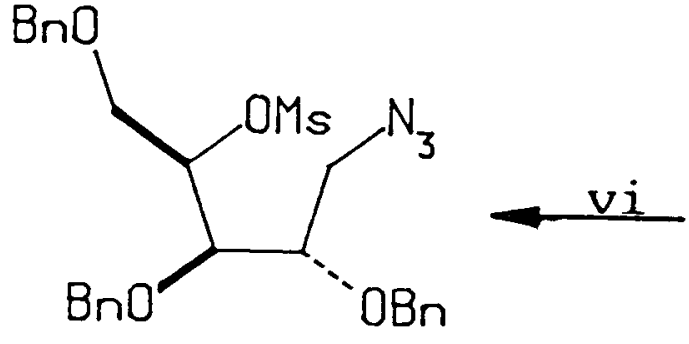

$(4.15)$

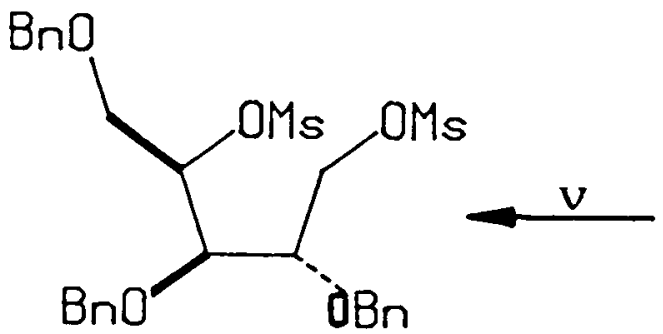

$(4.14)$ |iii,iv<smiles>OCC(Br)C(O)C(O)C(O)COBr</smiles>

$(4.13)$

i) aq $\mathrm{ACOH}$ ii) $\mathrm{PhCH}_{2} \mathrm{Br} / \mathrm{Ag}_{2} \mathrm{O}$ iii) aq TFA iv) $\mathrm{NaBH}_{4}, \mathrm{EtOH}$ v) $\mathrm{CH}_{3} \mathrm{SO}_{2} \mathrm{Cl}$, Dy, rt vi) $\mathrm{NaN}_{3}, \mathrm{DMF}, 50^{\circ} \mathrm{C}$

\section{SCHEME 4.7}

\section{ii) Cyclisation and removal of protecting groups}

The azido mesylate (4.15) was hydrogenated with palladium black in ethanol to effect reduction of the azide to the amine. The amine cyclised spontaneously since removal of solvent immediately after the azide disappeared and investigation by mass spectrometry showed only one product, $\underline{m} / \mathrm{z}\left(\mathrm{FAB}, \mathrm{Ar}^{+}\right)$ : $538\left(\mathrm{M}+\mathrm{H}^{+}\right)$, 494-the cyclised amine (4.16). Further hydrogenolysis in ethanol very slowly removed the benzyl protecting groups but inspection after several days, revealed that a mixture of desired product (4.2) and N-alkylated material (4.17) had been obtained. This problem was overcome by changing the solvent to glacial acetic acid after the initial reduction of the azide had taken place. In this way the $\underline{L}$ enantiomer (4.2) was produced cleanly in about $4 \mathrm{~d}$ at atmospheric pressure (Scheme 4.8). Purification by ion exchange chromatography and flash chromatography, gave the $\underline{L}$ enantiomer $(4.2)$ as a syrup which was readily crystallised as 
the hydrochloride salt (97\%). The $\underline{L}$ enantiomer was identical spectroscopically to the $\underline{D}$ enantiomer except in the sign of its optical rotation (fig 4.1-4.3). The biological properties of the $\underline{L}$ enantiomer were different to those of the $\underline{D}$ enantiomer.

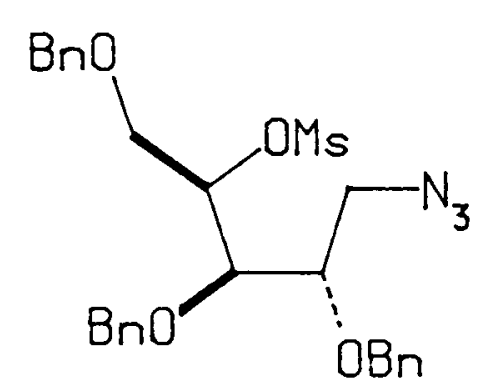

$(4.15)$

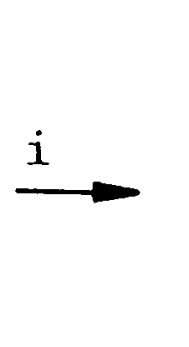

$\mathrm{BnO}$<smiles>OC1CNC(CBr)C1Cc1ccccc1</smiles>

(4.16)<smiles>[13CH3]</smiles><smiles>OCC1NCC(O)C1O</smiles>

ii) $\mathrm{H}_{2}$, Pd black, AcOH.

\section{SCHEME 4.8}

$*\left({ }^{1}\right.$ NMR $\delta 4.15(1 \mathrm{H}, \mathrm{m}, \mathrm{H}-2) ; 3.95(1 \mathrm{H}, \mathrm{m}, \mathrm{H}-3): 3.9(1 \mathrm{H}, \mathrm{dd}, \mathrm{H}-5) ; 3.8$ $\left(1 \mathrm{H}, \mathrm{dd}, \mathrm{H}-5^{\prime}\right) ; 3.45(1 \mathrm{H}, \mathrm{dd}, \mathrm{H}-1) ; 3.3\left(3 \mathrm{H}, \mathrm{m}, \mathrm{H}-4, \mathrm{CH}_{3} \mathrm{CH}_{2}\right) ; 3.1(1 \mathrm{H}, \mathrm{dd}$, $\left.\mathrm{H}-1) ; 1.1\left(3 \mathrm{H}, \mathrm{t}, \mathrm{CH}_{3} \mathrm{CH}_{2}\right).\right)$

Whereas the D- enantiomer caused 50\% inhibition of the hydrolysis of p-nitro-

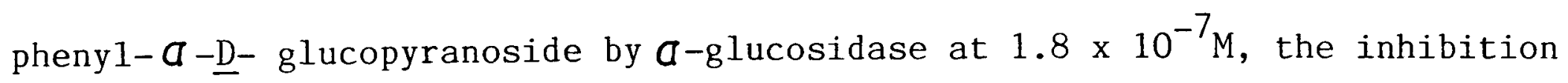
by the $\underline{L}-$ enantiomer was somewhat weaker ( $50 \%$ inhibition at $\left.1.0 \times 10^{-5} \mathrm{M}\right) .^{3}$ However, a recent study on the inhibition of a number of mouse gut disaccharidases has shown that the synthetic $\underline{L}$ enantiomer (4.2) is a more potent inhibitor than (4.1) of the hydrolysis of some natural substrate disaccharides. 7 For example, the concentrations required to cause $50 \%$ inhibition of the 
hydrolysis of the $6-\underline{0}-a$ - glucopyranosyl disaccharides isomaltose and palatinose for the synthetic $\underline{L}$ isomer were $6.6 \times 10^{-8}$ and $2.4 \times 10^{-7}$, in comparison to concentrations of $4.0 \times 10^{-6}$ and $1.3 \times 10^{-5} \mathrm{M}$ respectively for the naturally occurring $\underline{D}$ isomer (4.1). 
$-175-$

FIG $4.1:{ }^{1}$ H NMR OF AUTHENTIC AND SYNTHETIC (4.1) (FREE BASES)
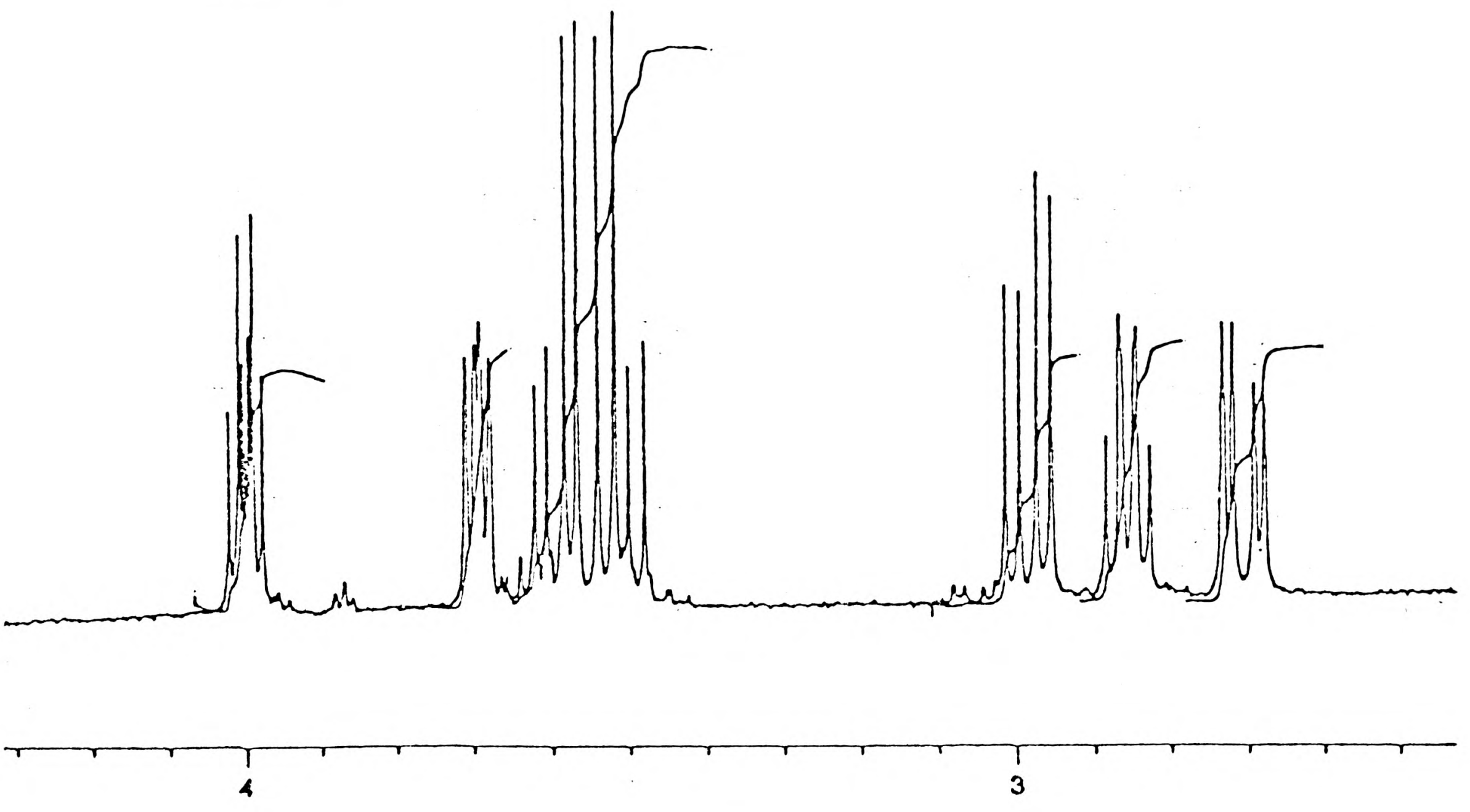

AUTHENTIC

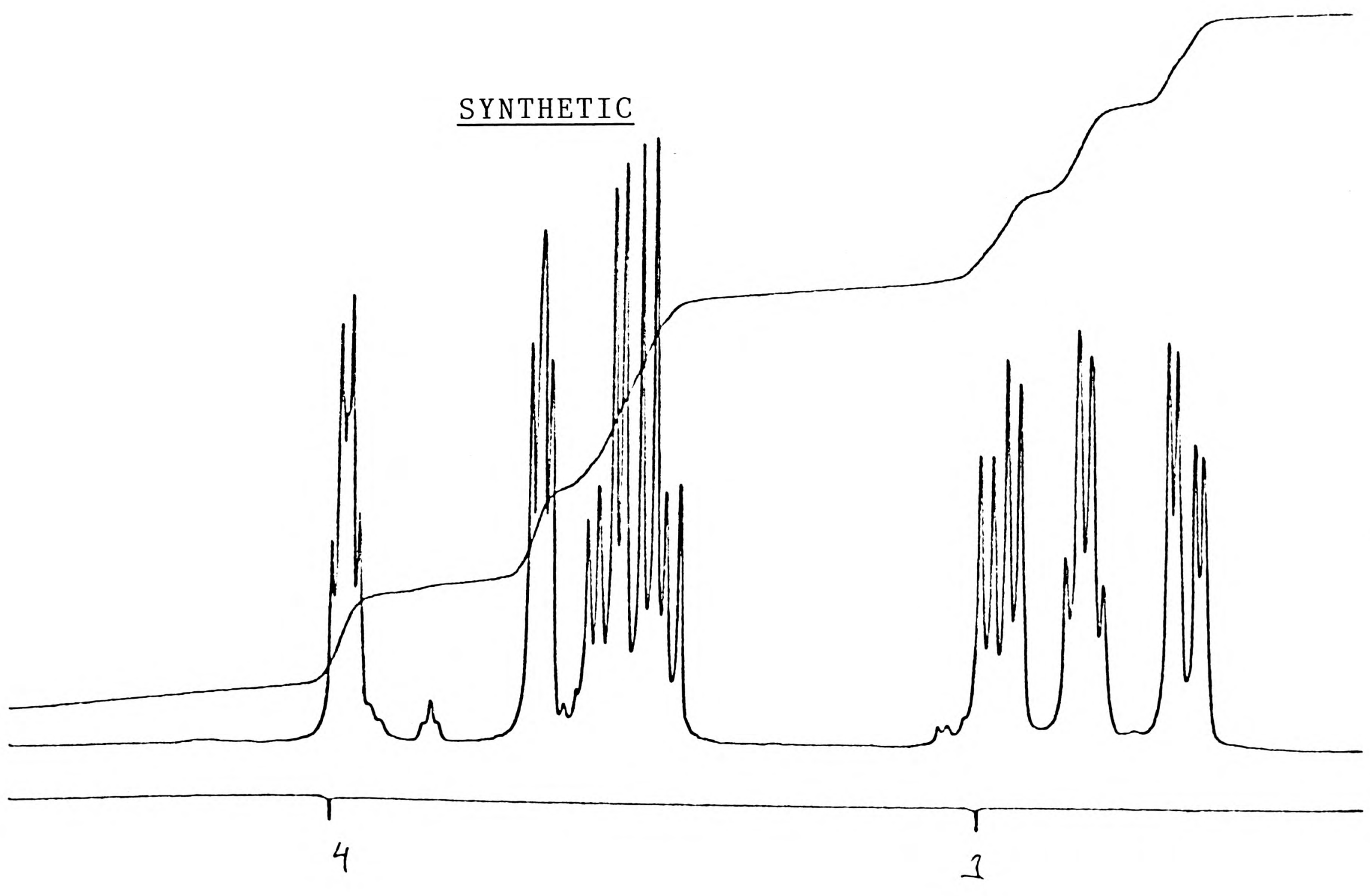


FIG 4.2: ${ }^{1}$ H NMR OF THE ENANTIOMERS (4.1) AND (4.2) (HYDROCHLORIDE SALTS)

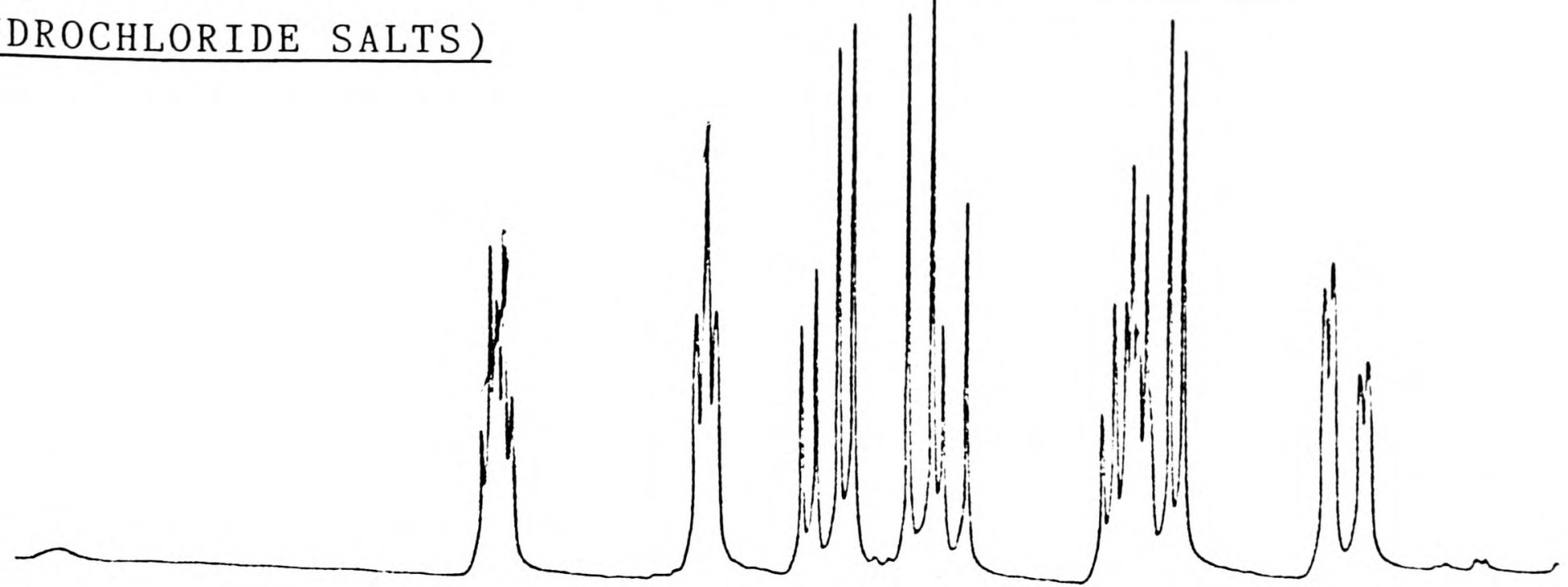

1,4-dideoxy-1,4- imino- D- arabinitol (4.1) 4 3

1,4- dideoxy-1,4- imino- L- arabinitol (4.2)

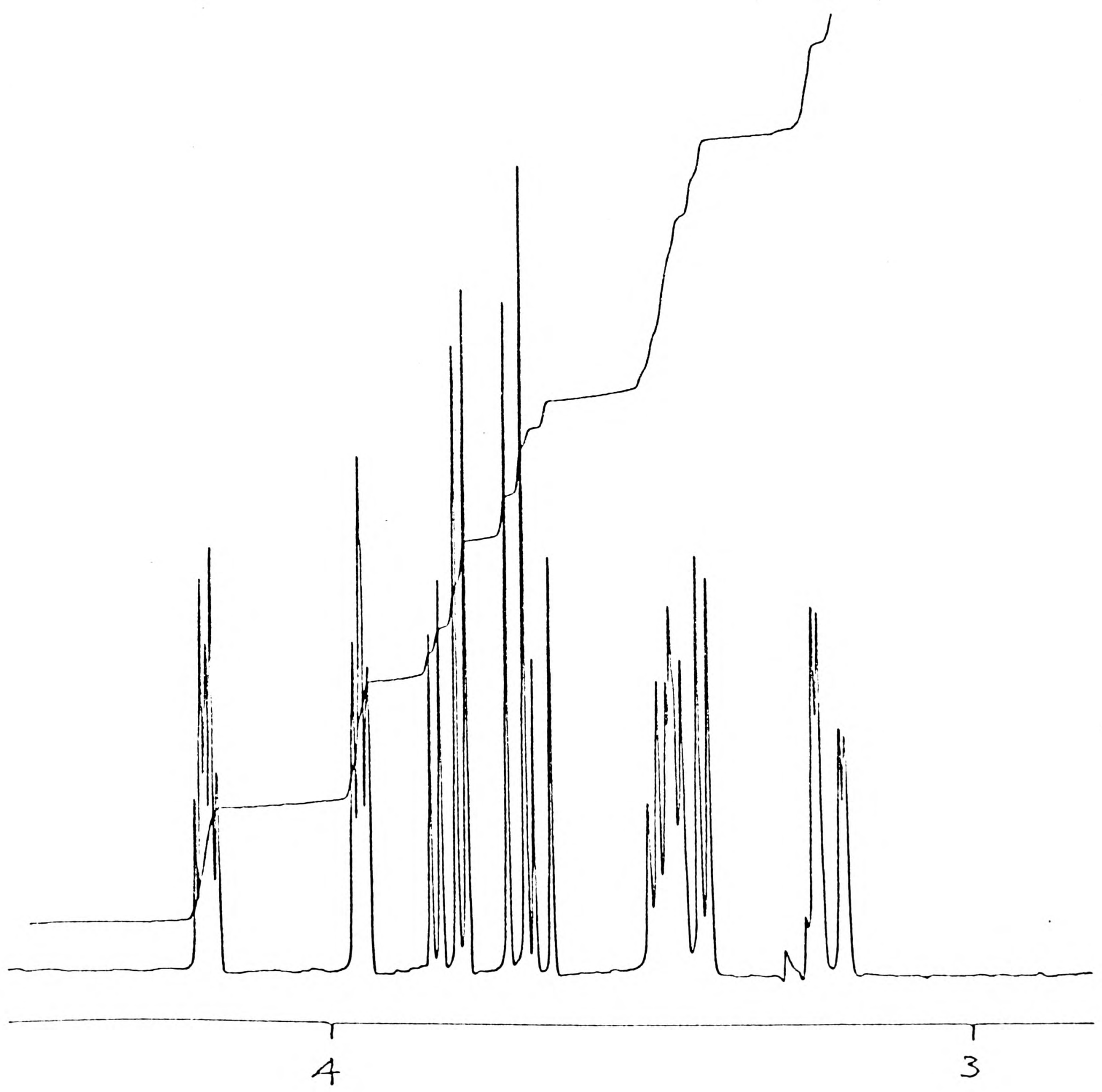


FIG 4.3 : MASS SPECTRA OF (4.1) AND (4.2) (salts)

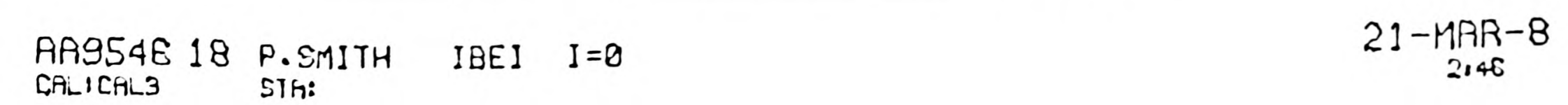
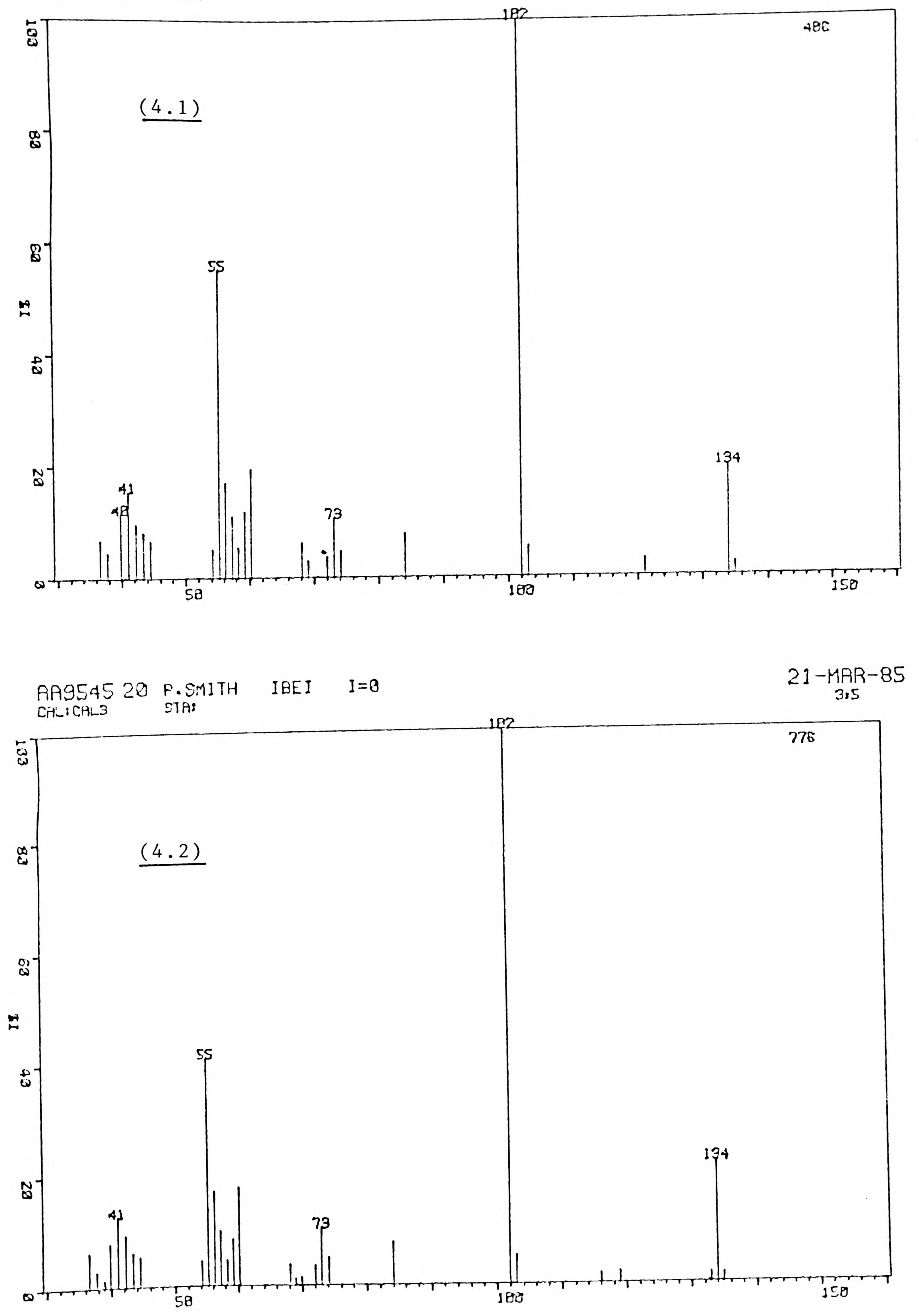


\section{EXPERIMENTAL SECTION.}

For general directions see chapter 1 .

Methyl 3, 5- $\underline{0}-$ isopropylidene- $\alpha-\underline{D}-$ xylofuranoside (4.3) and $\beta$ anomer

Acety1 chloride $(3.8 \mathrm{~m} 1)$ was added to methanol (500 $\mathrm{m} 1$ ) to produce an approximately $0.5 \%$ solution of hydrogen chloride. D- xylose ( $22 \mathrm{~g}, 0.147 \mathrm{mmol}$ ) was added in one portion, and the suspension stirred for $5 \mathrm{~h}$ at room temperature. The D- xylose had completely dissolved after about $1 \mathrm{~h}$. Silver carbonate $(12 \mathrm{~g})$ was added and the solution stirred for a further 30 mins before filtering through celite. The solution was concentrated to a syrup (maintaining water bath temperature below $40^{\circ} \mathrm{C}$ ) which was dissolved in acetone (250 $\left.\mathrm{ml}\right)$

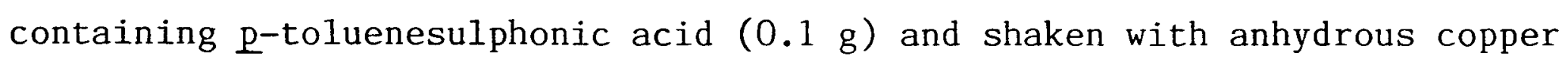
(II) sulphate $(40 \mathrm{~g})$ at room temperature for $24 \mathrm{~h}$. The mixture was filtered, neutralised with ammonia solution (SG 0.88) and evaporated to a clear syrup which was dissolved in chloroform $(200 \mathrm{ml})$ and washed with water $(200 \mathrm{ml})$. The chloroform layer was dried and evaporated to a syrup, a mixture of the two anomers $(21.53 \mathrm{~g}, 72 \%)$.

Distillation through a semi micro Vigreux column in vacuo gave two fractions : the first contained the pure $a$ anomer $(4.3)(7.75 \mathrm{~g})$. b.pt $85^{\circ} \mathrm{C}(0.1 \mathrm{~mm})$. $[a]_{D}^{20}+78^{\circ}\left(\underline{c}, 2.0, \mathrm{H}_{2} 0\right)\left(1 \mathrm{it}^{5}[\mathrm{a}]_{\mathrm{D}}^{20}+17.6^{\circ}\left(\mathrm{H}_{2} 0\right)\right) \cdot{ }_{\mathrm{H}} \operatorname{NMR} \delta 5.18(1 \mathrm{H}, \mathrm{d}$, $\left.\mathrm{H}-1, \mathrm{~J}_{12} 4.1 \mathrm{~Hz}\right) ; 4.2-3.9(5 \mathrm{H}, \mathrm{m}) ; 3.53\left(3 \mathrm{H}, \mathrm{s}, \mathrm{CH}_{3} 0\right) ; 2.98(1 \mathrm{H}, \mathrm{br} \mathrm{d}, \mathrm{OH})$; $1.41,1.36\left(6 \mathrm{H}, 2 \mathrm{~s}, \mathrm{CH}_{3} \mathrm{C}\right) .{ }^{13} \mathrm{C} \operatorname{NMR} \delta 19.32(\mathrm{q}), 28.37\left(\mathrm{q}, \underline{\mathrm{CH}}_{3} \mathrm{C}\right) ; 56.25(\mathrm{q}$, $\left.\mathrm{CH}_{3} \mathrm{O}\right) ; 60.36(\mathrm{t}, \mathrm{C}-5) ; 71.22,75.37,76.65(3 \mathrm{~d}, \mathrm{C}-2,3,4) ; 97.59\left(\mathrm{~s}, \mathrm{CH}_{3} \mathrm{C}\right)$; 103.15 (d, C-1). (1it $\left.{ }^{5} 19.6,28.5,56.3,60.5,71.3,75.5,76.8,97.7,103.4\right)$. $\underline{\mathrm{m} / \mathrm{z}}: 222\left(\mathrm{M}+\mathrm{NH}_{4}^{+}, 100 \%\right), 205,189,173$. Found $\mathrm{C}, 52.96 ; \mathrm{H}, 8.09 . \mathrm{C}_{9} \mathrm{H}_{16} \mathrm{O}_{5}$ requires $\mathrm{C}, 52.94 ; \mathrm{H}, 7.84$.

The second fraction contained a mixture of $\alpha$ and $\beta$ anomers $(9.21 \mathrm{~g}$ ) (b.pt $\left.90-110^{\circ} \mathrm{C}, 0.1 \mathrm{~mm}\right)$. A small amount of pure $\beta$ anomer was obtained by flash 
chromatography (ethyl acetate : hexane, $1: 3$ ). $[a]_{D}^{20}-60.6^{\circ}\left(\underline{c}, 1.21, \mathrm{H}_{2} 0\right)$ $\left(1 \mathrm{it}{ }^{5}[\mathrm{a}]_{\mathrm{D}}^{20}-64^{\circ}\left(\mathrm{H}_{2} \mathrm{O}\right)\right) \cdot{ }_{\mathrm{H}} \mathrm{NMR} \delta 4.86(1 \mathrm{H}, \mathrm{s}, \mathrm{H}-1) ; 4.25(1 \mathrm{H}, \mathrm{m}, \mathrm{H}-4)$; $4.17(1 \mathrm{H}, \mathrm{s}, \mathrm{H}-2) ; 4.13(1 \mathrm{H}, \mathrm{d}, \mathrm{H}-3) ; 3.96\left(1 \mathrm{H}, \mathrm{dd}, \mathrm{H}-5, \mathrm{~J} / 5^{4.0} \mathrm{~Hz}\right) ; 3.80$ $\left(1 \mathrm{H}, \mathrm{dd}, \mathrm{H}-5^{\prime}, \mathrm{J}_{45^{\prime}} 5.4 \mathrm{~Hz}\right) ; 3.40\left(3 \mathrm{H}, \mathrm{s}, \mathrm{CH}_{3} \mathrm{O}\right) ; 2.9(1 \mathrm{H}, \mathrm{br} \mathrm{s}, \mathrm{OH}) ; 1.38$, $1.35\left(6 \mathrm{H}, 2 \mathrm{~s}, \mathrm{CH}_{3} \mathrm{C}\right) \cdot{ }^{13} \mathrm{C} \operatorname{NMR} \delta 20.98(\mathrm{q}), 26.68\left(\mathrm{q}, \mathrm{CH}_{3} \mathrm{C}\right) ; 55.16\left(\mathrm{q}, \mathrm{CH}_{3} \mathrm{O}\right)$; $60.74(t, C-5) ; 74.65,75.23,80.22(3 \mathrm{~d}, \mathrm{C}-2,3,4) ; 98.33\left(\mathrm{~s}, \mathrm{CH}_{3} \mathrm{C}\right) ; 110.32$ $(\mathrm{d}, \mathrm{C}-1) . \underline{\mathrm{m} / \mathrm{z}}: 205$. Found $\mathrm{C}, 53.17 ; \mathrm{H}, 8.14 . \mathrm{C}_{9} \mathrm{H}_{16} \mathrm{O}_{5}$ requires $\mathrm{C}, 52.94$; $\mathrm{H}, 7.84$.

Methyl 2- azido- 2- deoxy- 3,5- $\underline{0}-$ isopropylidene- $\alpha$ - $\underline{\underline{D}}-1$ yxofuranoside (4.5) Alcohol (4.3) (6.57 g, $32.2 \mathrm{mmol})$ was dissolved in dichloromethane (100 m1) containing pyridine $\left(5.17 \mathrm{ml}, 2\right.$ equivs) and the solution cooled to $-30^{\circ} \mathrm{C}$ under nitrogen. Trifluoromethanesulphonic anhydride (10 g, 1.1 equivs) was added, with stirring, and the reaction mixture maintained at $-30^{\circ} \mathrm{C}$ for $30 \mathrm{~min}$. The solution was then allowed to warm to room temperature, washed with water $(100 \mathrm{~m} 1)$, and saturated aqueous sodium bicarbonate solution $(100 \mathrm{ml})$. The organic layer was dried and concentrated to afford a pale yellow syrup, a small amount of which was purified by flash chromatography (ethyl acetate : hexane, $1: 3)$ to give methy1 3,5-0- isopropylidene- 2-0-trifluoromethanesulphony1- $a-D$ - xylofuranoside (4.4), an oil. $[a]_{\mathrm{D}}^{20}+98.8^{\circ}$ (c, $\left.1.38, \mathrm{MeOH}\right)$. $1_{\mathrm{H} \text { NMR }} \delta 5.25\left(1 \mathrm{H}, \mathrm{d}, \mathrm{H}-1, \mathrm{~J}_{12} 4.3 \mathrm{~Hz}\right) ; 5.02(1 \mathrm{H}, \mathrm{dd}, \mathrm{H}-2) ; 4.45(1 \mathrm{H}, \mathrm{dd}, \mathrm{H}-3$, $\left.\mathrm{J}_{23} 1.8 \mathrm{~Hz}\right) ; 4.15\left(1 \mathrm{H}, \mathrm{q}, \mathrm{H}-4, \mathrm{~J}_{34} 3.8 \mathrm{~Hz}\right) ; 4.05\left(1 \mathrm{H}, \mathrm{dd}, \mathrm{H}-5, \mathrm{~J}_{45} 3.8 \mathrm{~Hz}\right) ; 3.90$ $\left(1 \mathrm{H}, \mathrm{dd}, \mathrm{H}-5^{\prime}, \mathrm{J}_{55}, 12.8 \mathrm{~Hz}, \mathrm{~J}_{45^{\prime}} 3.8 \mathrm{~Hz}\right) ; 3.51\left(3 \mathrm{H}, \mathrm{s}, \mathrm{CH}_{3} 0\right) ; 1.42,1.39(6 \mathrm{H}$, $\left.2 \mathrm{~s}, \mathrm{CH}_{3} \mathrm{C}\right) \cdot{ }^{13} \mathrm{C}$ NMR $\delta 20.51\left(\mathrm{q}, \underline{\mathrm{CH}}_{3} \mathrm{C}\right) ; 27.54\left(\mathrm{q}, \underline{\mathrm{CH}}_{3} \mathrm{C}\right) ; 56.39\left(\mathrm{q}, \mathrm{CH}_{3} \mathrm{O}\right) ; 59.86$ $(\mathrm{t}, \mathrm{C}-5) ; 70.90,73.36(2 \mathrm{~d}, \mathrm{C}-3,4) ; 88.23(\mathrm{~d}, \mathrm{C}-2) ; 98.96\left(\mathrm{~s}, \mathrm{CH}_{3} \mathrm{C}\right) ; 101.08$ $(\mathrm{d}, \mathrm{C}-1) ; 118.50\left(\mathrm{q}, \mathrm{CF}_{3}\right.$, not proton decoupled). $\underline{\mathrm{m} / \mathrm{z}}$ (in beam $\left.\mathrm{EI}\right): 321$ $\left(M-\mathrm{Me}^{+}, 20 \%\right)$. 
The remainder of the crude triflate (4.4) was dissolved in DMF ( $80 \mathrm{ml}$ ) and stirred with sodium azide $(6 \mathrm{~g}, 92.2 \mathrm{mmol})$ at $100^{\circ} \mathrm{C}$ for $18 \mathrm{~h}$ to give a clean conversion to the azide (4.5) as judged by t.1.c $\left(R_{f} 0.4\right.$, ethyl acetate : hexane, $1: 2$ ). The DMF was removed and the residue was partitioned between chloroform $(100 \mathrm{~m} 1)$ and water $(100 \mathrm{~m} 1)$. The organic layer was dried, and the solvent removed to give, after purification by flash chromatography (ethyl acetate : hexane, $1: 3)$ the azide $(4.5)(5.62 \mathrm{~g}, 76 \%)$, as an oil. $[a]_{D}^{20}$ $+128.0^{\circ}\left(\underline{c}, 0.97, \mathrm{CHCl}_{3}\right) . v_{\max } 2905,2100,1370 \mathrm{~cm}^{-1} \cdot 1_{\mathrm{H} \mathrm{NMR}} \delta 5.23(1 \mathrm{H}, \mathrm{d}$, $\left.\mathrm{H}-1, \mathrm{~J}_{12} 4.8 \mathrm{~Hz}\right) ; 4.45(1 \mathrm{H}, \mathrm{dd}, \mathrm{H}-3) ; 4.10-3.96\left(3 \mathrm{H}, \mathrm{m}, \mathrm{H}-4,5,5^{\prime}\right) ; 3.64$ $(1 \mathrm{H}, \mathrm{t}, \mathrm{H}-2) ; 3.49\left(3 \mathrm{H}, \mathrm{s}, \mathrm{CH}_{3} \mathrm{O}\right) ; 1.47\left(6 \mathrm{H}, \mathrm{s}, \mathrm{CH}_{3} \mathrm{C}\right) .{ }^{13} \mathrm{C} \operatorname{NMR} \delta 19.01$ (q, $\left.\underline{\mathrm{CH}}_{3} \mathrm{C}\right) ; 28.34\left(\mathrm{q}, \underline{\mathrm{CH}}_{3} \mathrm{C}\right) ; 56.33\left(\mathrm{q}, \mathrm{CH}_{3} \mathrm{O}\right) ; 60.41(\mathrm{t}, \mathrm{C}-5) ; 67.65(\mathrm{~d}, \mathrm{C}-2)$; $70.76,71.93(2 \mathrm{~d}, \mathrm{C}-3,4) ; 97.90\left(\mathrm{~s}, \mathrm{CH}_{3} \mathrm{C}\right) ; 106.66(\mathrm{~d}, \mathrm{C}-1) . \underline{\mathrm{m} / \mathrm{z}}: 247$ $\left(\mathrm{M}+\mathrm{NH}_{4}^{+}\right) ; 230,202(100 \%)$. Found $\mathrm{C} ; 47.4 ; \mathrm{H}, 6.6 ; \mathrm{N}, 18.3 . \mathrm{C}_{9} \mathrm{H}_{15} \mathrm{~N}_{3} \mathrm{O}_{4}$ requires $\mathrm{C}, 47.4 ; \mathrm{H}, 6.6 ; \mathrm{N}, 18.4$.

Methy1 2- azido- 2- deoxy- $a-\underline{D}$ - 1yxofuranoside (4.6)

The acetonide $(4.5)(1.74 \mathrm{~g}, 7.6 \mathrm{mmol})$ was dissolved in a mixture of water $(3 \mathrm{ml})$ and acetic acid $(7 \mathrm{ml})$, and the solution was warmed to $50^{\circ} \mathrm{C}$ for $1 \mathrm{~h}$. Evaporation of the solvent and purification by flash chromatography (ethyl acetate : hexane, $4: 1)$ gave the title compound $(4.6)(1.42 \mathrm{~g}, 99 \%)$, as a colourless oil. $[a]_{\mathrm{D}}^{20}+131.9^{\circ}\left(\underline{c}, 0.39, \mathrm{CHC1}_{3}\right) \cdot v_{\max } 3400(\mathrm{br}), 2110$, 1270,1100 and $1040 \mathrm{~cm}^{-1}$. ${ }^{1} \mathrm{H}$ NMR $\delta 4.93\left(1 \mathrm{H}, \mathrm{d}, \mathrm{H}-1, \mathrm{~J}_{12} 1.6 \mathrm{~Hz}\right) ; 4.69(1 \mathrm{H}$, $\mathrm{m}, \mathrm{H}-4) ; 4.17(1 \mathrm{H}, \mathrm{m}, \mathrm{H}-2) ; 3.95\left(3 \mathrm{H}, \mathrm{m}, \mathrm{H}-3,5,5^{\prime}\right) ; 3.42(1 \mathrm{H}, \mathrm{br} d, \mathrm{OH})$; $3.39\left(3 \mathrm{H}, \mathrm{s}, \mathrm{CH}_{3} \mathrm{O}\right) ; 2.37(1 \mathrm{H}, \mathrm{br} \mathrm{s}, \mathrm{OH}) .{ }^{13} \mathrm{C} \operatorname{NMR} \delta 55.44\left(\mathrm{q}, \mathrm{CH}_{3} \mathrm{O}\right) ; 61.15$ $(\mathrm{t}, \mathrm{C}-5) ; 67.60(\mathrm{~d}, \mathrm{C}-2) ; 73.06,78.47(2 \mathrm{~d}, \mathrm{C}-3,4) ; 105.71(\mathrm{~d}, \mathrm{C}-1) . \underline{\mathrm{m} / \mathrm{z}}$ : $207\left(\mathrm{M}+\mathrm{NH}_{4}^{+}, 100 \%\right), 190$. Found $\mathrm{C}, 38.07 ; \mathrm{H}, 6.04 ; \mathrm{N}, 22.15 . \mathrm{C}_{6} \mathrm{H}_{11} \mathrm{~N}_{3} \mathrm{O}_{4}$ requires $\mathrm{C}, 38.09 ; \mathrm{H}, 5.82 ; \mathrm{N}, 22.22$. 
Methy1 2- azido- 2- deoxy- 5- $\underline{0}-\underline{p}$-toluenesulphonyl- $a$ - D- 1yxofuranoside (4.7)

The diol (4.6) (3.8 $\mathrm{g}, 20.1 \mathrm{mmol})$ was dissolved in pyridine (70 $\mathrm{m} 1)$ and stirred at $0^{\circ} \mathrm{C}$ with $\mathrm{p}$-toluenesulphony 1 chloride $(4.03 \mathrm{~g}, 1.05$ equivs) for $12 \mathrm{~h}$. The bulk of the pyridine was removed and the residue dissolved in chloroform $(100 \mathrm{~m} 1)$. The resulting solution was washed successively with dilute aqueous hydrochloric acid (2M, $100 \mathrm{ml})$, water $(100 \mathrm{~m} 1)$ and saturated aqueous sodium bicarbonate solution (100 m1), dried and concentrated to a syrup which was purified by flash chromatography (ethyl acetate : hexane, $1: 2$ ) to give the title compound $(4.7)(5.09 \mathrm{~g}, 74 \%)$ as a colourless syrup. $[a]_{D}^{20}+67.2^{\circ}$ $\left(\underline{c}, 1.14, \mathrm{CHCl}_{3}\right) \cdot v_{\max } 3500(\mathrm{br}), 2110,1350,1170 \mathrm{~cm}^{-1} \cdot 1_{\mathrm{H}} \mathrm{NMR} \delta 7.81$ $(2 \mathrm{H}, \mathrm{d}, \mathrm{ArH}) ; 7.35(2 \mathrm{H}, \mathrm{d}, \mathrm{ArH}) ; 4.93(1 \mathrm{H}, \mathrm{d}, \mathrm{H}-1) ; 4.47-4.12(4 \mathrm{H}, \mathrm{m}, \mathrm{H}-3$, 4, 5, 5'); $3.89\left(1 \mathrm{H}, \mathrm{dd}, \mathrm{H}-2, \mathrm{~J}_{12} 3.1 \mathrm{~Hz}, \mathrm{~J}_{23} 5.0 \mathrm{~Hz}\right) ; 3.38\left(3 \mathrm{H}, \mathrm{s}, \mathrm{CH}_{3} \mathrm{O}\right)$; $2.46\left(3 \mathrm{H}, \mathrm{s}, \mathrm{CH}_{3} \mathrm{Ar}\right) ; 2.41(1 \mathrm{H}, \mathrm{d}, \mathrm{OH}) \cdot{ }^{13} \mathrm{C} \operatorname{NMR} \delta 21.61\left(\mathrm{q}, \mathrm{CH}_{3} \mathrm{Ar}\right) ; 55.95$ $\left(\mathrm{q}, \mathrm{CH}_{3} \mathrm{O}\right) ; 67.79(\mathrm{t}, \mathrm{C}-5) ; 68.09(\mathrm{~d}, \mathrm{C}-2) ; 71.47,77.48(2 \mathrm{~d}, \mathrm{C}-3,4) ; 106.43$ $(\mathrm{d}, \mathrm{C}-1) ; 128.02$ (d), 129.85(d), $132.72(\mathrm{~s})$ and $145.00(\mathrm{~s})(\mathrm{ArH}) . \underline{\mathrm{m} / \mathrm{z}}$ : $361\left(\mathrm{M}+\mathrm{NH}_{4}^{+}, 100 \%\right), 329,316$. Found $\mathrm{C}, 45.72 ; \mathrm{H}, 5.10 ; \mathrm{N}, 12.15$. $\mathrm{C}_{13} \mathrm{H}_{17} \mathrm{~N}_{3} \mathrm{O}_{6} \mathrm{~S}$ requires $\mathrm{C}, 45.48 ; \mathrm{H}, 4.96 ; \mathrm{N}, 12.24$.

Methy1 (N- benzyloxycarbony1- 2,5- dideoxy- 2,5- imino) $a-\underline{\underline{D}-1 y x o-}$

furanoside (4.9)

The tosylate $(4.7)(1.0 \mathrm{~g}, 2.9 \mathrm{mmol})$ was dissolved in ethanol (10 m1) and stirred at room temperature in a hydrogen atmosphere in the presence of palladium black $(0.1 \mathrm{~g})$ for $24 \mathrm{~h}$. The reaction mixture was filtered to remove the catalyst and concentrated to a brown syrup containing the tosylate salt $(4.8)\left({ }^{1} \mathrm{H}\right.$ NMR $\delta 7.6,7.3(4 \mathrm{H}, 2 \mathrm{~d}, \operatorname{ArH}) ; 4.95(1 \mathrm{H}, \mathrm{s}, \mathrm{H}-1) ; 4.7(1 \mathrm{H}, \mathrm{m})$; $4.5(1 \mathrm{H}, \mathrm{m}, \mathrm{H}-3,4) ; 3.95(1 \mathrm{H}, \mathrm{s}, \mathrm{H}-2) ; 3.4(1 \mathrm{H}, \mathrm{dd}, \mathrm{H}-5) ; 3.3\left(3 \mathrm{H}, \mathrm{s}, \mathrm{CH}_{3} \mathrm{O}\right)$ : $3.2\left(1 \mathrm{H}, \mathrm{d}, \mathrm{H}-5^{\prime}\right) ; 2.3\left(3 \mathrm{H}, \mathrm{s}, \mathrm{CH}_{3} \mathrm{Ar}\right) . \underline{\mathrm{m} / \mathrm{z}}: 146(100 \%+$ some higher mass impurities) ). The crude salt was partitioned between ethyl acetate $(10 \mathrm{ml})$ and aqueous sodium bicarbonate solution $(4 \mathrm{ml})$. The two layers were cooled 
to $0^{\circ} \mathrm{C}$ and benzyl chloroformate $(0.5 \mathrm{ml}$, excess) was added to the biphasic system which was vigorously stirred for $1 \mathrm{~h}$. The organic layer was separated, dried and evaporated to a brown syrup which was purified by flash chromatography (ethyl acetate : hexane, $1: 2$ ) affording the title compound (4.9) $(0.51 \mathrm{~g}, 63 \%)$ as an oil. $v_{\max } 3400(\mathrm{br}), 1690,1420,1355,1320,1255,1195$, $1090 \mathrm{~cm}^{-1}$. ${ }^{1} \mathrm{H} \mathrm{NMR} \delta 7.37-7.32(5 \mathrm{H}, \mathrm{m}, \mathrm{ArH}) ; 5.1-4.1(6 \mathrm{H}, \mathrm{m}) ; 3.6(1 \mathrm{H}, \mathrm{d}$, $\mathrm{H}-5) ; 3.3\left(3 \mathrm{H}, \mathrm{s}, \mathrm{CH}_{3} \mathrm{O}\right) ; 3.3\left(1 \mathrm{H}, \mathrm{m}, \mathrm{H}-5^{\prime}\right) ; 2.9(1 \mathrm{H}, \mathrm{s}, \mathrm{OH}) . \underline{\mathrm{m} / \mathrm{z}}: 280$ $\left(\mathrm{M}+\mathrm{H}^{+}, 100 \%\right), 236,158,91$.

N- benzyloxycarbony $1-1,4-$ dideoxy- 1,4- imino- D- arabinitol (4.10)

Freshly prepared bicyclic acetal (4.9) (1.99 g, $7.1 \mathrm{mmol}$ ) was dissolved in a mixture of trifluoroacetic acid $(16 \mathrm{ml})$ and water $(4 \mathrm{ml})$. After a clear solution had been obtained, the solvent was immediately evaporated and the residue dissolved in ethyl acetate $(25 \mathrm{ml})$. The ethyl acetate solution was carefully washed with saturated aqueous sodium bicarbonate solution ( $25 \mathrm{ml})$, dried and the solvent removed. The residue was dissolved in ethanol $(20 \mathrm{~m} 1)$ and a solution of sodium borohydride $(0.2 \mathrm{~g}, 0.75$ molar equivs $)$ in water (2 m1) was added at room temperature. After $15 \mathrm{~min}$, ammonium chloride $(0.2 \mathrm{~g})$ was added to quench excess sodium borohydride. When the effervescence ceased the ethanol was removed and the residue partitioned between water ( $30 \mathrm{~m} 1$ ) and ethyl acetate $(30 \mathrm{~m} 1)$. The aqueous layer was then extracted with further ethyl acetate $(4 \times 30 \mathrm{~m} 1)$ and the organic extracts were combined and dried. Evaporation of the solvent and purification of the residue by flash chromatography ( $2 \%$ ethanol in ethyl acetate) gave the title compound (4.10) $(1.54 \mathrm{~g}, 81 \%)$, a colourless syrup which slowly crystallised. m.p $128-129^{\circ} \mathrm{C}$. $[a]_{D}^{20}-29.7^{\circ}(\underline{c}, 0.3, \mathrm{MeOH}) . v_{\max } 3350(\mathrm{br}), 1680,1465,1435,1360,1210$, $1140 \mathrm{~cm}^{-1} \cdot{ }^{1} \mathrm{H}$ NMR $\left(\mathrm{D}_{2} \mathrm{O}\right) \delta 7.2(5 \mathrm{H}, \mathrm{m}, \mathrm{ArH}) ; 5.0(1 \mathrm{H}, \mathrm{m}) ; 4.8(5 \mathrm{H}, \mathrm{m}) ; 3.7$ 
$(2 \mathrm{H}, \mathrm{m}, \mathrm{H}-1) ; 3.1(1 \mathrm{H}, \mathrm{m}, \mathrm{H}-5) .{ }^{13} \mathrm{C} \mathrm{NMR}\left(\mathrm{D}_{2} \mathrm{O}\right) \delta 54.35,54.79(\mathrm{t}, \mathrm{C}-1)$; $61.64,61.82(t, \mathrm{C}-5) ; 68.08\left(\mathrm{t}, \mathrm{PhCH}_{2}\right) ; 68.27,68.55(\mathrm{~d}, \mathrm{C}-4) ; 75.61,76.15$; $78.72,79.39(\mathrm{~d}, \mathrm{C}-2,3) ; 128.85,128.98$ (d); $129.09,129.53$ (d), 137.95 (s); 157.18 (s) (ArC) (Two signals are observed for most carbons due to the existence of rotamers $) . \underline{\mathrm{m} / \mathrm{z}}: 268\left(\mathrm{M}+\mathrm{H}^{+}, 100 \%\right)$. Found $\mathrm{C}, 58.15 ; \mathrm{H}, 6.50 ; \mathrm{N}, 5.09$. $\mathrm{C}_{13} \mathrm{H}_{17} \mathrm{NO}_{5}$ requires $\mathrm{C}, 58.43 ; \mathrm{H}, 6.37 ; \mathrm{N}, 5.24$.

1,4- Dideoxy- 1,4- imino- D- arabinitol (4.1) and 1,4- dideoxy- 1,4- imino-

D- arabinitol hydrochloride

$\mathrm{Z}$ protected amine $(4.10)(1.54 \mathrm{~g}, 5.77 \mathrm{mmol})$ was dissolved in glacial acetic acid $(20 \mathrm{ml})$ and stirred in a hydrogen atmosphere in the presence of palladium black $(0.1 \mathrm{~g})$ for $30 \mathrm{~min}$. The catalyst was removed by filtration and the reaction mixture was concentrated to a brown syrup which was purified first by flash chromatography ( $10 \%$ water in methano1) and then by ion exchange chromatography (procedure 1 and 2) to give the free base (4.1), a colourless syrup. $[a]_{\mathrm{D}}^{20}+7.8^{\circ}\left(\underline{c}, 0.46, \mathrm{H}_{2} \mathrm{O}\right) .1_{\mathrm{H} N \mathrm{NMR}}\left(\mathrm{D}_{2} \mathrm{O}\right) \delta 4.03(1 \mathrm{H}, \mathrm{dt}, \mathrm{H}-2)$; $3.73(1 \mathrm{H}, \mathrm{t}, \mathrm{H}-3) ; 3.63\left(1 \mathrm{H}, \mathrm{dd}, \mathrm{H}-5, \mathrm{~J}_{45} 5.6 \mathrm{~Hz}\right) ; 3.55\left(1 \mathrm{H}, \mathrm{dd}, \mathrm{H}-5^{\prime}, \mathrm{J}_{55^{\prime}}\right.$ $\left.11.8 \mathrm{~Hz}, \mathrm{~J}_{4,5}, 6.8 \mathrm{~Hz}\right) ; 3.06\left(1 \mathrm{H}, \mathrm{dd}, \mathrm{H}-1, \mathrm{~J}_{12} 5.6 \mathrm{~Hz}\right) ; 2.97(1 \mathrm{H}, \mathrm{dt}, \mathrm{H}-4)$; $2.79\left(1 \mathrm{H}, \mathrm{dd}, \mathrm{H}-1^{\prime}, \mathrm{J}_{11}, 12.3 \mathrm{~Hz}, \mathrm{~J}_{1} \mathrm{2}^{3} .7 \mathrm{~Hz}\right) . \underline{\mathrm{m} / \mathrm{z}}: 134\left(\mathrm{M}+\mathrm{H}^{+}, 100 \%\right)$, $102\left(\mathrm{M}^{+}-\mathrm{CH}_{2} \mathrm{OH}\right)$. The ${ }_{\mathrm{H}} \mathrm{NMR}$ of synthetic (4.1) was identical to that of an authentic sample (fig 4.1). The free base (4.1) was dissolved in water $(5 \mathrm{~m} 1)$ and acidified to $\mathrm{pH} 4$ with dilute aqueous hydrochloric acid. The solution was freeze dried to give, after crystallisation from aqueous acetone, the hydrochloride salt of $(4.1)(0.78 \mathrm{~g}, 80 \%$ from $(4.10))$. m.p $113-115^{\circ} \mathrm{C}$ $\left(\operatorname{lit}^{1} 115^{\circ} \mathrm{C}\right) .[\mathrm{a}]_{\mathrm{D}}^{20}+39.7^{\circ}\left(\underline{c}, 0.53, \mathrm{H}_{2} \mathrm{O}\right) .{ }_{\mathrm{H} \mathrm{NMR}}\left(\mathrm{D}_{2} \mathrm{O}\right) \delta 4.19(1 \mathrm{H}, \mathrm{m}, \mathrm{H}-2)$; $3.95(1 \mathrm{H}, \mathrm{m}, \mathrm{H}-3) ; 3.81\left(1 \mathrm{H}, \mathrm{dd}, \mathrm{H}-5, \mathrm{~J}_{45^{4}} .7 \mathrm{~Hz}\right) ; 3.69\left(1 \mathrm{H}, \mathrm{dd}, \mathrm{H}-5^{\prime}, \mathrm{J}_{55}\right.$ ' 
$\left.12.2 \mathrm{~Hz}, \mathrm{~J}_{45}, 8.1 \mathrm{~Hz}\right) ; 3.46(2 \mathrm{H}, \mathrm{m}, \mathrm{H}-1,4) ; 3.21\left(1 \mathrm{H}, \mathrm{dd}, \mathrm{H}-1{ }^{\prime}, \mathrm{J}_{11}, 12.5 \mathrm{~Hz}\right.$, $\left.\mathrm{J}_{1} \cdot 2^{2.6 \mathrm{~Hz}}\right) \cdot{ }^{13} \mathrm{C} \operatorname{NMR}\left(\mathrm{D}_{2} 0\right) \delta 51.03(\mathrm{t}, \mathrm{C}-1) ; 59.93(\mathrm{t}, \mathrm{C}-5) ; 67.59(\mathrm{~d}, \mathrm{C}-4)$; $75.25,76.67(2 \mathrm{~d}, \mathrm{C}-2,3) . \underline{\mathrm{m} / \mathrm{z}}$ (in beam EI) : $134\left(\mathrm{M}+\mathrm{H}^{+}, 100 \%\right), 102,84$, 73, 55, 41 (fig 4.3).

Methyl $a-$ D- xylofuranoside (4.11)

Acetonide (4.3) (2 g, $9.8 \mathrm{mmol})$ was dissolved in acetic acid - water (2 : 1 , $30 \mathrm{~m} 1$ ) and left at room temperature for $12 \mathrm{~h}$. The solvent was removed and the resulting syrup purified by flash chromatography (5\% ethanol in ethyl acetate) to afford the title compound (4.11) (1.36 g, 85\%). m.p $82-83^{\circ} \mathrm{C}$ (1it $\left.{ }^{9} 85^{\circ} \mathrm{C}\right) .{ }^{1} \mathrm{H} \mathrm{NMR}\left(\mathrm{D}_{2} \mathrm{O}\right) \delta 4.85\left(1 \mathrm{H}, \mathrm{d}, \mathrm{H}-1, \mathrm{~J}_{12} 4.5 \mathrm{~Hz}\right) ; 4.09(2 \mathrm{H}, \mathrm{m}, \mathrm{H}-3,4)$; $4.00\left(1 \mathrm{H}, \mathrm{dd}, \mathrm{H}-2, \mathrm{~J}_{23} 5.2 \mathrm{~Hz}\right) ; 3.62\left(1 \mathrm{H}, \mathrm{dd}, \mathrm{H}-5, \mathrm{~J}_{45} 3.7 \mathrm{~Hz}, \mathrm{~J}_{55}, 12.2 \mathrm{~Hz}\right)$; $3.56\left(1 \mathrm{H}, \mathrm{dd}, \mathrm{H}-5^{\prime}, \mathrm{J}_{45^{\prime}}, 5.7 \mathrm{~Hz}\right) ; 3.29\left(3 \mathrm{H}, \mathrm{s}, \mathrm{CH}_{3} \mathrm{O}\right) \cdot{ }^{13} \mathrm{C} \mathrm{NMR}\left(\mathrm{D}_{2} \mathrm{O}\right) \delta 56.62$ $\left(\mathrm{q}, \mathrm{CH}_{3} \mathrm{O}\right) ; 61.45(\mathrm{t}, \mathrm{C}-5) ; 75.95,77.69,79.27(3 \mathrm{~d}, \mathrm{C}-2,3,4) ; 103.06(\mathrm{~d}, \mathrm{C}-1)$.

Methy1 2,3,5- tri- $\underline{0}-$ benzy1- $a-\underline{\underline{D}}-$ xylofuranoside (4.12)

Methyl $a$ - D- xylofuranoside (4.11) (1.36 g, $8.29 \mathrm{mmol})$ was dissolved in DMF (15 $\mathrm{m} 1)$ containing benzyl bromide $(6.7 \mathrm{ml}, 56 \mathrm{mmol})$ and silver(I) oxide (9.2 $\mathrm{g}$, $39.7 \mathrm{mmol}$ ). The reaction was stirred vigorously at room temperature in the dark for $24 \mathrm{~h}$. Addition of ether $(10 \mathrm{~m} 1)$ caused precipitation of the silver salts; the reaction mixture was then filtered through celite and concentrated to a syrup. Purification by flash chromatography (ether : hexane, $1: 4$ ) gave the title compound $(4.12)(2.26 \mathrm{~g}, 63 \%)$ as a syrup. $[a]_{D}^{20}+59^{\circ}(\underline{c}, 0.63$, $\left.\mathrm{CHCl}_{3}\right) .{ }^{1} \mathrm{H} \mathrm{NMR} \delta 7.4-7.2(15 \mathrm{H}, \mathrm{m}, \mathrm{ArH}) ; 4.81\left(1 \mathrm{H}, \mathrm{d}, \mathrm{H}-1, \mathrm{~J}_{12} 4.3 \mathrm{~Hz}\right) ; 4.58$ $\left(6 \mathrm{H}, \mathrm{m}, \mathrm{PhCH}_{2}\right) ; 4.40(1 \mathrm{H}, \mathrm{m}, \mathrm{H}-4) ; 4.32\left(1 \mathrm{H}, \mathrm{dd}, \mathrm{H}-3, \mathrm{~J}_{23} 5.9 \mathrm{~Hz}, \mathrm{~J}_{34}{ }^{7} .1 \mathrm{~Hz}\right)$; $4.02(1 \mathrm{H}, \mathrm{dd}, \mathrm{H}-2) ; 3.72\left(1 \mathrm{H}, \mathrm{dd}, \mathrm{H}-5, \mathrm{~J}_{45} 3.9 \mathrm{~Hz}, \mathrm{~J}_{55}, 10.6 \mathrm{~Hz}\right) ; 3.59(1 \mathrm{H}, \mathrm{dd}$, $\left.\mathrm{H}-5^{\prime}, \mathrm{J}_{45}, 6.1 \mathrm{~Hz}\right) ; 3.41\left(3 \mathrm{H}, \mathrm{s}, \mathrm{CH}_{3} \mathrm{O}\right) . \underline{\mathrm{m} / \mathrm{z}}: 452\left(\mathrm{M}+\mathrm{NH}_{4}^{+}\right)$. Found $\mathrm{C}, 74.83$; 
$\mathrm{H}, 7.00 . \mathrm{C}_{27} \mathrm{H}_{30} \mathrm{O}_{5}$ requires $\mathrm{C}, 74.65 ; \mathrm{H}, 6.91$.

2,3,5- Tri- $\underline{0}-$ benzyl- D- xylitol (4.13)

Acetal (4.12) (2.0 g, $4.6 \mathrm{mmol})$ was dissolved in $50 \%$ aqueous trifluoroacetic acid $(10 \mathrm{ml})$ and 1 eft at $50^{\circ} \mathrm{C}$ for $1 \mathrm{~h}$. The solvent was evaporated and the residue dissolved in chloroform $(10 \mathrm{ml})$ and washed with saturated aqueous sodium bicarbonate to remove the last traces of trifluoroacetic acid. The chloroform was removed and the resulting syrup dissolved in ethanol $(10 \mathrm{ml})$ and treated with sodium borohydride $(0.19 \mathrm{~g}, 5.1 \mathrm{mmol})$ at $0^{\circ} \mathrm{C}$ for $15 \mathrm{~min}$. The reaction was quenched with excess ammonium chloride. The ethanol was removed and the residue partitioned between water $(20 \mathrm{ml})$ and chloroform $(20 \mathrm{~m} 1)$. The organic layer was dried and evaporated to give a colourless syrup which was purified by flash chromatography (ether : hexane, 2 : 1) to yield the diol (4.13) $(1.48 \mathrm{~g}, 76 \%)$, an oil. $[\sigma]_{\mathrm{D}}^{20}-11.3^{\circ}\left(\underline{c}, 0.91, \mathrm{CHCl}_{3}\right)$. $v_{\max } 3550-3300 \mathrm{~cm}^{-1} \cdot 1_{\mathrm{H} \mathrm{NMR}} \delta 7.4-7.2(15 \mathrm{H}, \mathrm{m}, \mathrm{ArH}) ; 4.57\left(6 \mathrm{H}, \mathrm{m}, \mathrm{PhCH}_{2}\right)$; $4.07(1 \mathrm{H}, \mathrm{dt}, \mathrm{H}-4) ; 3.81\left(2 \mathrm{H}, \mathrm{m}, \mathrm{H}-1,1^{\prime}\right) ; 3.72(2 \mathrm{H}, \mathrm{m}, \mathrm{H}-2,3) ; 3.53(1 \mathrm{H}, \mathrm{dd}$, $\left.\mathrm{H}-5, \mathrm{~J}_{45} 6.4 \mathrm{~Hz}, \mathrm{~J}_{55}, 9.4 \mathrm{~Hz}\right) ; 3.44\left(1 \mathrm{H}, \mathrm{dd}, \mathrm{H}-5^{\prime}, \mathrm{J}_{45}, 6.3 \mathrm{~Hz}\right) ; 2.85(2 \mathrm{H}, \mathrm{br} \mathrm{s}$, OH). $\underline{\mathrm{m} / \mathrm{z}}: 440\left(\mathrm{M}+\mathrm{NH}_{4}^{+}\right), 91(100 \%)$. Found $\mathrm{C}, 73.97 ; \mathrm{H}, 7.32 . \mathrm{C}_{26} \mathrm{H}_{30} \mathrm{O}_{5}$ requires $\mathrm{C}, 73.93 ; \mathrm{H}, 7.11$.

1,4- Di- $\underline{0}-$ methanesulphony1- 2,3,5- tri- $\underline{0}-$ benzy1- D- xylitol (4.14)

Methanesulphony1 chloride $(0.64 \mathrm{ml}, 2.5$ equivs) was added, with stirring, to a solution of the diol (4.13) $(1.4 \mathrm{~g}, 3.3 \mathrm{mmol})$ in pyridine $(10 \mathrm{ml})$ at $0^{\circ} \mathrm{C}$. After $3 \mathrm{~h}$, the reaction mixture was diluted with dichloromethane (100 $\mathrm{m} 1)$ and washed successively with dilute aqueous hydrochloric acid (2M, 100m1), water $(100 \mathrm{~m} 1)$ and saturated aqueous sodium bicarbonate solution (100 m1). The dichloromethane solution was dried, the solvent removed and the residue 
purified by flash chromatography (ether : hexane, $2: 1$ ), to afford the title compound $(4.14)(1.84 \mathrm{~g}, 96 \%)$ as an oil. $[a]_{\mathrm{D}}^{20}+16^{\circ}\left(\underline{c}, 1.33, \mathrm{CHC1}_{3}\right)$. ${ }^{1} \mathrm{H} \mathrm{NMR} \delta 7.4-7.2(15 \mathrm{H}, \mathrm{m}, \mathrm{ArH}) ; 4.96(1 \mathrm{H}, \mathrm{m}, \mathrm{H}-4) ; 4.5(8 \mathrm{H}, \mathrm{m}) ; 3.87(2 \mathrm{H}, \mathrm{m}$, $\mathrm{H}-2,3) ; 3.62\left(2 \mathrm{H}, \mathrm{m}, \mathrm{H}-5,5^{\prime}\right) ; 3.00\left(3 \mathrm{H}, \mathrm{s}, \mathrm{CH}_{3} \mathrm{~S}\right) ; 2.92\left(3 \mathrm{H}, \mathrm{s}, \mathrm{CH}_{3} \mathrm{~S}\right)$. ${ }^{13} \mathrm{C}$ NMR $\delta 37.32\left(\mathrm{q}, \mathrm{CH}_{3} \mathrm{~S}\right) ; 38.59\left(\mathrm{q}, \mathrm{CH}_{3} \mathrm{~S}\right) ; 68.36,73.34,74.76,76.49,68.86$ (5t, C-1, 5, $\left.3 \times \mathrm{PhCH}_{2}\right) ; 75.94(\mathrm{~d}, \mathrm{C}-2,3) ; 80.15(\mathrm{~d}, \mathrm{C}-4) ; 127.90,127.99$, $128.10,128.21,128.52,137.08,137.17(\mathrm{ArC}) . \underline{\mathrm{m} / \mathrm{z}}: 596\left(\mathrm{M}+\mathrm{NH}_{4}^{+}\right), 91(100 \%)$. Found $\mathrm{C}, 58.33 ; \mathrm{H}, 6.07 . \mathrm{C}_{28} \mathrm{H}_{34} \mathrm{O}_{9} \mathrm{~S}_{2}$ requires $\mathrm{C}, 58.13 ; \mathrm{H}, 5.88$.

1- Azido- 1- deoxy- 4- $\underline{0}-$ methanesulphony1- 2,3,5- tri- $\underline{0}-$ benzy1- D- xylitol $(4.15)$

Dimesylate $(4.14)(1.64 \mathrm{~g}, 2.83 \mathrm{mmol})$ was dissolved in dry DMF $(10 \mathrm{ml})$ and stirred at $50^{\circ} \mathrm{C}$ with sodium azide $(0.2 \mathrm{~g}, 1.1$ equivs) for $12 \mathrm{~h}$. The solvent was removed and the residue partitioned between water ( $25 \mathrm{~m} 1$ ) and chloroform $(25 \mathrm{~m} 1)$. The chloroform layer was dried and the solvent removed; the residue was purified by flash chromatography (ether : hexane, $2: 3$ ) to yield the title compound $(4.15)(1.16 \mathrm{~g}, 78 \%)$, an oil. $[a]_{\mathrm{D}}^{20}+13.8^{\circ}\left(\underline{c}, 0.5, \mathrm{CHCl}_{3}\right)$. $v_{\max } 2100 \mathrm{~cm}^{-1} \cdot 1_{\mathrm{H} \mathrm{NMR}} \delta 7.4-7.2(15 \mathrm{H}, \mathrm{m}, \mathrm{ArH}): 4.87(1 \mathrm{H}, \mathrm{dt}, \mathrm{H}-4) ; 4.5$ $\left(6 \mathrm{H}, \mathrm{m}, \mathrm{PhCH}_{2}\right) ; 3.84(1 \mathrm{H}, \mathrm{t}, \mathrm{H}-3) ; 3.72(1 \mathrm{H}, \mathrm{q}, \mathrm{H}-2) ; 3.61\left(2 \mathrm{H}, \mathrm{m}, \mathrm{H}-5,5^{\prime}\right)$; $3.47\left(2 \mathrm{H}, \mathrm{m}, \mathrm{H}-1, \mathrm{l}^{\prime}\right) ; 2.88\left(3 \mathrm{H}, \mathrm{s}, \mathrm{CH}_{3} \mathrm{SO}_{2}\right) . \underline{\mathrm{m} / \mathrm{z}}: 543\left(\mathrm{M}+\mathrm{NH}_{4}^{+}, 100 \%\right)$. Found $\mathrm{C}, 61.43 ; \mathrm{H}, 6.17 ; \mathrm{N}, 7.78 . \mathrm{C}_{27} \mathrm{H}_{31} \mathrm{~N}_{3} \mathrm{O}_{6} \mathrm{~S}$ requires $\mathrm{C}, 61.71 ; \mathrm{H}, 5.90$; N, 8.00 .

1,4- Dideoxy- 1,4- imino- L- arabinitol (4.2)

The azido mesylate $(4.15)(0.96 \mathrm{~g}, 1.83 \mathrm{mmol})$ in ethanol $(15 \mathrm{~m} 1)$ was stirred under an atmosphere of hydrogen in the presence of palladium black (50 mg) at 
room temperature until all the starting material had disappeared (about 90 $\mathrm{min})$. The solvent was then changed to glacial acetic acid (15 $\mathrm{ml}$ ) and fresh catalyst added. The hydrogenation was continued until all the benzyl groups had been removed (about $4 \mathrm{~d}$ ). The catalyst was removed by filtration and the solvent evaporated. The residue was purified first by flash chromatography (10\% water in methano1) and then by ion exchange chromatography (procedure 1 and 2) to give a colourless syrup of the free base (4.2), which was dissolved in water $(5 \mathrm{~m} 1)$ and acidified to $\mathrm{pH} 4$ with dilute aqueous hydrochloric acid. The solution was then freeze dried to give the hydrochloride salt of (4.2) $\left(0.3 \mathrm{~g}, 97 \%\right.$ from (4.15)). m.p $109-110^{\circ} \mathrm{C}$ (from aqueous acetone). $[a]_{D}^{20}-34.6^{\circ}\left(\underline{c}, 0.37, \mathrm{H}_{2} \mathrm{O}\right)$. The NMR and mass spectra of the hydrochloride salt of (4.2) are superimposable on those of the hydrochloride salt of (4.1) (fig 4.2 and 4.3). 


\section{SUMMARY}

Methyl 3,5- 0 - isopropylidene- $a$ - $\underline{D}-$ xylofuranoside was elaborated in several steps to both enantiomers of 1,4- dideoxy-1,4- imino- arabinitol $(4.1)$ and (4.2).
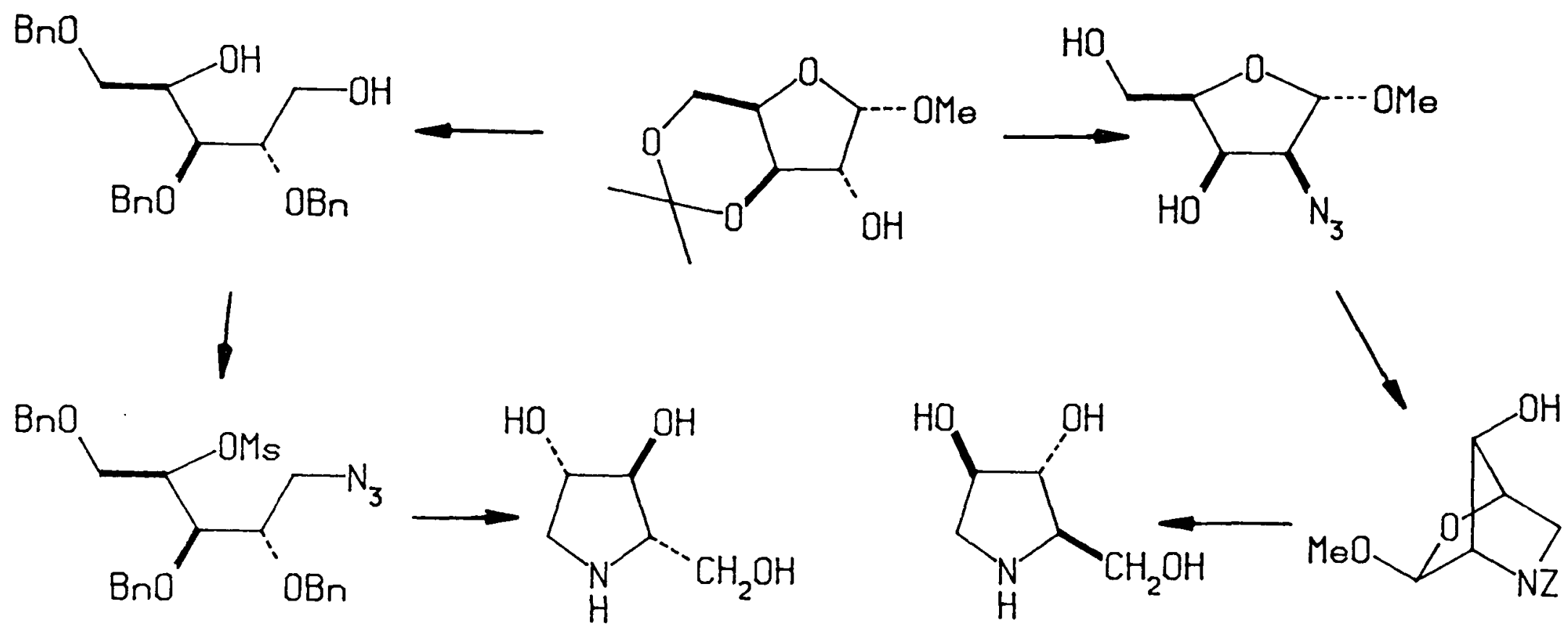

\section{CHAPTER 4 SUMMARY}

\section{REFERENCES}

1. J. Furukawa, S. Okuda, K. Saito and S.I Hatanaka, Phytochemistry, 1985, 24, 593. These authors incorrectly assigned the xylo- configuration to the compound on the basis of coupling constants. See ref 4 .

2. R.J. Nash, E.A Bell and J.M. Williams, Phytochemistry, 1985, 24, 1620 .

3. G.W.J. Fleet, S.J. Nicholas, P.W. Smith, S.V. Evans, L.E. Fellows and R.J. Nash, Tetrahedron. Lett, 1985, 26, 3127 .

4. D.W.C. Jones, R.J. Nash, E.A. Bell and J.M. Williams, Tetrahedron. Lett, $1985, \underline{26}, 3125$.

5. B.R. Baker, R.E. Schaub and J.H. Williams, J.Amer.Chem.Soc, 1955, 77, 7.

6. I am grateful to Dr L.E. Fellows for providing a sample of authentic material.

7. A.M. Schofield, L.E. Fellows, R.J. Nash and G.W.J. Fleet, Life Sciences, $1986, \underline{39}, 645$.

8. G.W.J. Fleet and S. Petursen unpublished results.

9. R.J. Ferrier, D. Prasad and A. Rudowski, J.Chem.Soc, 1965, 858. 
5. APPROACHES TO THE SYNTHESIS OF DIHYDROXYPROLINES FROM DERIVATIVES OF RIBOLACTONE

\section{INTRODUCTION}

This chapter describes the synthesis from D-ribonolactone of the amino acid (2R, 3S, 4R) - 3,4-Dihydroxyproline (5.1) and approaches to the epimer (2S, 3S, 4R) - 3,4-dihydroxyproline (5.2). An approach to the synthesis of (2S, 4S) - 4-hydroxyproline (5.29) is also discussed.

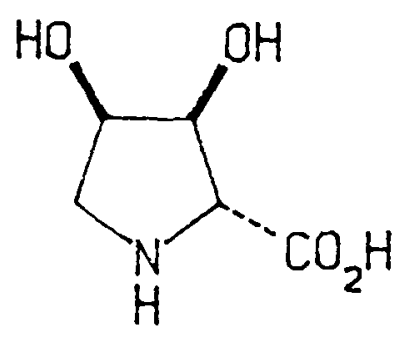

$(5 \cdot 1)$

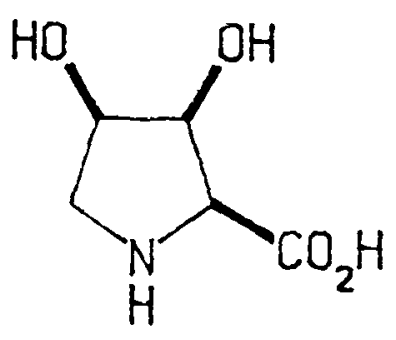

$(5.2)$

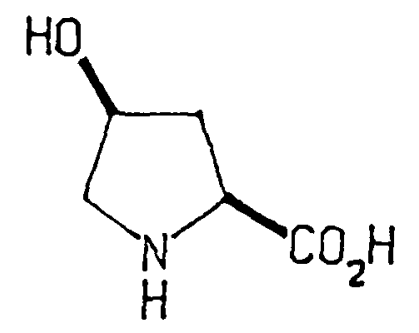

$(5.29)$<smiles>O=C1O[C@H](CO)[C@H](O)[C@H]1O</smiles><smiles>[CH-]</smiles><smiles>O=C1OCC(O)C(Br)C1O</smiles>

D-ribonolactone

Dihydroxy prolines in nature and previous synthetic work.

Two dihydroxy prolines have so far been found in nature (2S, 3R, 4R) 3,4-Dihydroxyproline(5.3) is a constituent amino acid of Virotoxin ${ }^{1}$ and (2S, 3S, 4S) - 3,4-dihydroxyproline (5.4) has been isolated from diatom cell walls ${ }^{2}$. 


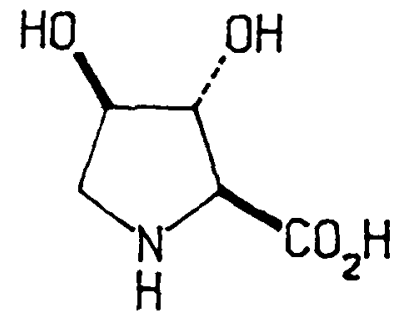

$(5 \cdot 3)$

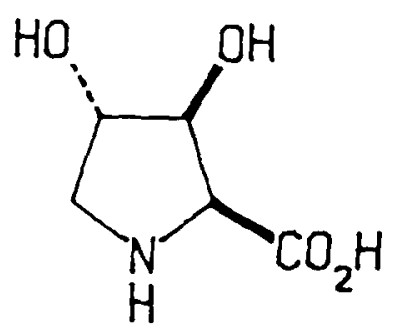

$(5.4)$

Both (5.3) and (5.4) have recently been synthesised from allyl glycine ${ }^{3}$ via a stereospecific halo- or mercuri- lactonisation in which the intermediate cation is stabilised by the C3 hydroxyl (Scheme 5.1).

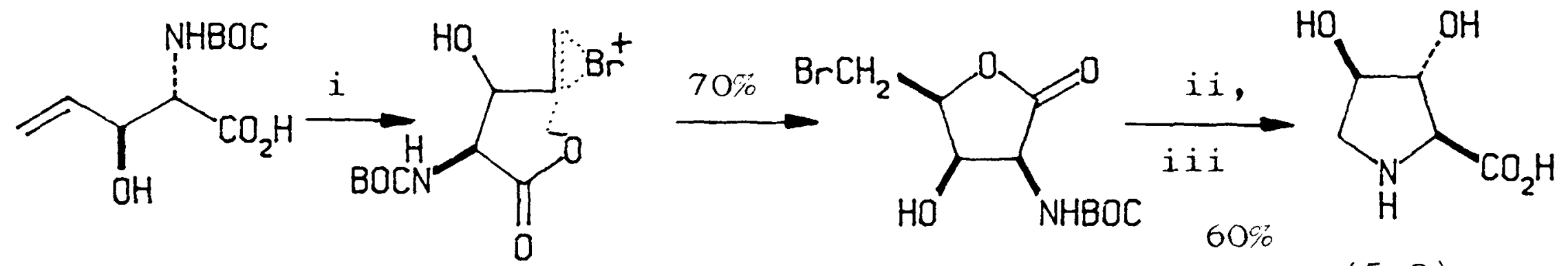

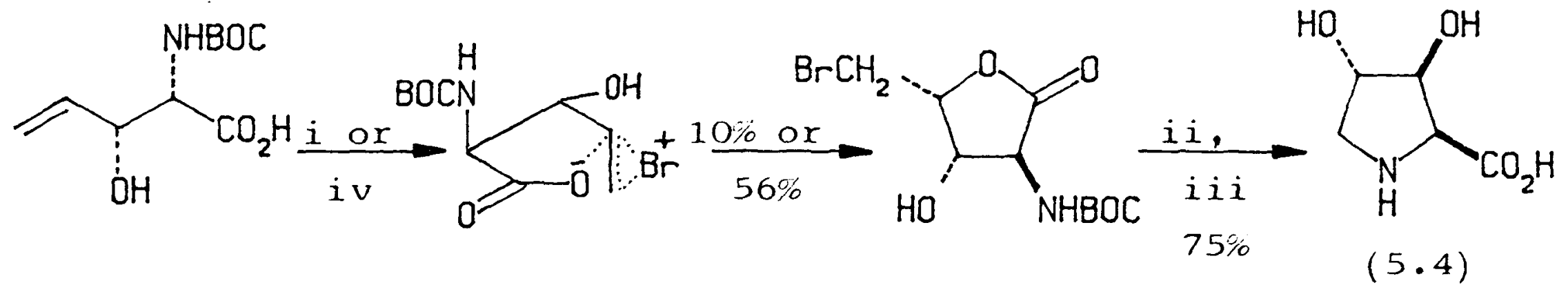

i) NBS ii) aq TFA iii) $\mathrm{NaOH}$ aq iv) $\mathrm{Hg}(\mathrm{OAC})_{2}$

\section{SCHEME 5.1}

A racemic synthesis of a mixture of (5.3) and (5.4) from 3,4- dehydroproline (5.5) via epoxidation and nucleophilic ring opening of the epoxide has also been reported ${ }^{4}$. 


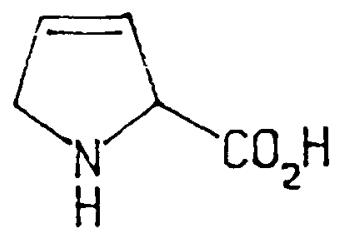

$(5.5)$

The same authors previously synthesised the isomers (5.1) and (5.2) in a racemic form from $(5.5)^{5}$. (Scheme 5.2).

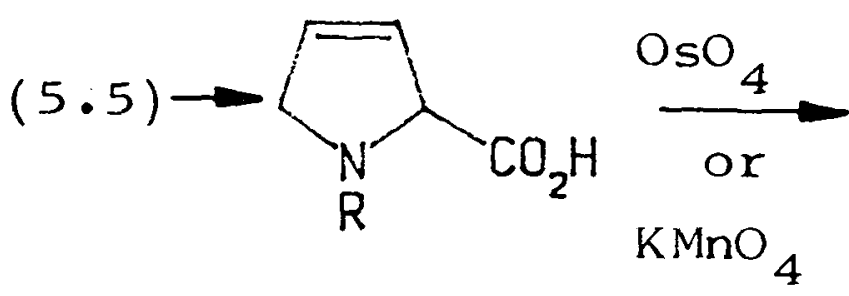<smiles>[R]N1CC(O)C(O)C1C(=O)O</smiles><smiles>CC(C)(C)C</smiles><smiles>[R]N1CC(O)C(O)C1C(=O)O</smiles>

SCHEME 5.2

\section{RESULTS AND DISCUSSION}

Retrosynthetic Analysis<smiles>O=C(O)C1NCCCCCCCCC1O</smiles>

$(5.2)$<smiles>O=C(O)C1NCC(O)C1O</smiles>

$(5.1)$<smiles>C1CCCCC1</smiles><smiles>[Y9]C=C(O)C(O)C(N)C(=O)O</smiles><smiles>[R]OC(=O)O</smiles><smiles>NC(C(=O)O)C(O)C(O)C(=O)O</smiles><smiles>C=CCC</smiles><smiles>CCCCCC(=O)OCC1OC(=O)C(N)C1O</smiles>

\section{SCHEME 5.3}

Formation of the nitrogen heterocycle required introduction of nitrogen functionality at $\mathrm{C} 2$ of $\underline{\mathrm{D}}$ - ribonolactone followed by an intramolecular nucleophilic displacement, by the nitrogen, of a leaving group at C5. If 
the nitrogen was introduced with retention of configuration at $\mathrm{C} 2$, then this would lead to the D- amino acid (5.1) and if inversion occurred, then the $\underline{L}$ - amino acid (5.2) would eventually be obtained. (Scheme 5.3).

Synthesis of the D- amino acid (2R, 3S, 4R)-3,4-Dihydroxyproline (5.1). Zinners lactone (5.6) was prepared as described ${ }^{6,7}$ by suspending D- ribonolactone in benzaldehyde containing concentrated hydrochloric acid and vigorously shaking the suspension for several hours. The structure initially assigned was the 1,4 lactone (5.7), but this was subsequently shown to be incorrect by X-ray analysis ${ }^{8}$.

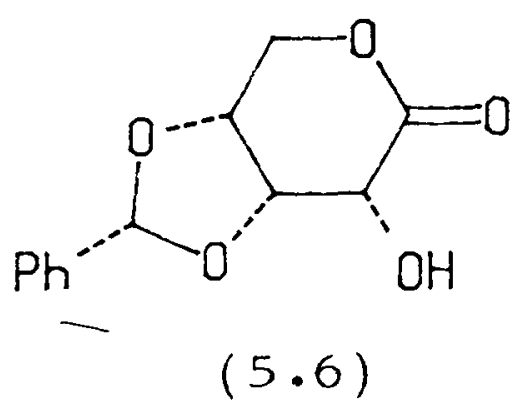

$(5.6)$<smiles>O=C1O[C@@H]2COC(c3ccccc3)O[C@H]2C1O</smiles>

$(5 \cdot 7)$

The lactone (5.6) is highly crystalline and was not readily soluble in any organic solvent. As a result of this, it could not be converted to the trifluoromethanesulphonate (5.8) in dichloromethane by the normal procedure, but instead, neat pyridine was used as solvent. The triflate (5.8) was recrystallised from ethanol and is very stable at room temperature.

Treatment of the triflate (5.8) with sodium azide in DMF at room temperature formed the azido lactone (5.9) as the only azide containing product (64\% from (5.6) on $10 \mathrm{~g}$ scale) in which the stereochemistry at C2 (established by X-ray crystallography, Fig 1.1 ) had been unexpectedly retained during the 
FIG 5.1: X - RAY CRYSTAL STRUCTURE OF 2- AZIDO- 3,4- $\underline{0}-$

BENZYLIDENE- 2- DEOXY-D-RIBONO-1,5- LACTONE (5.9).

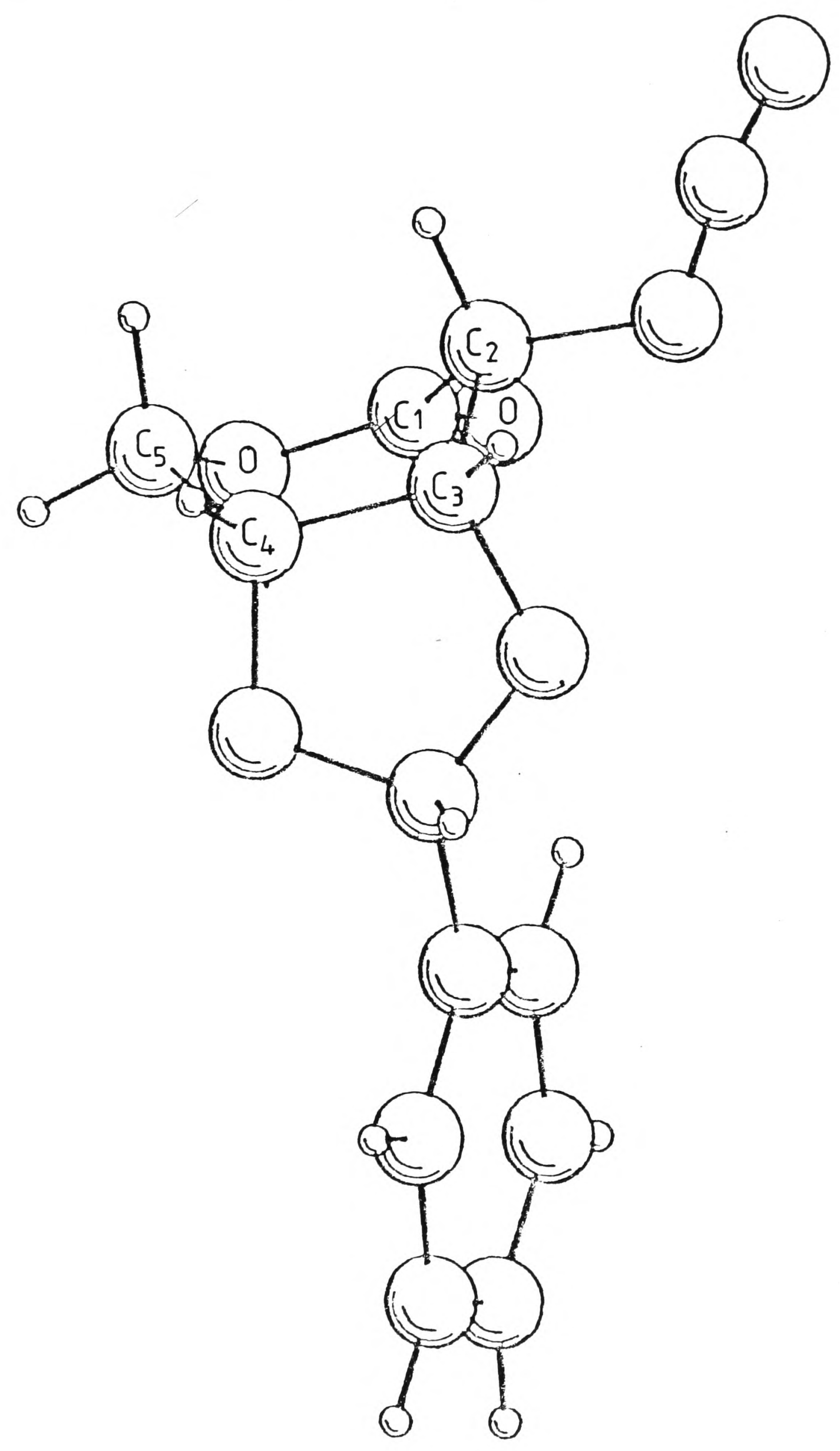


nucleophilic displacement (Scheme 5.4).

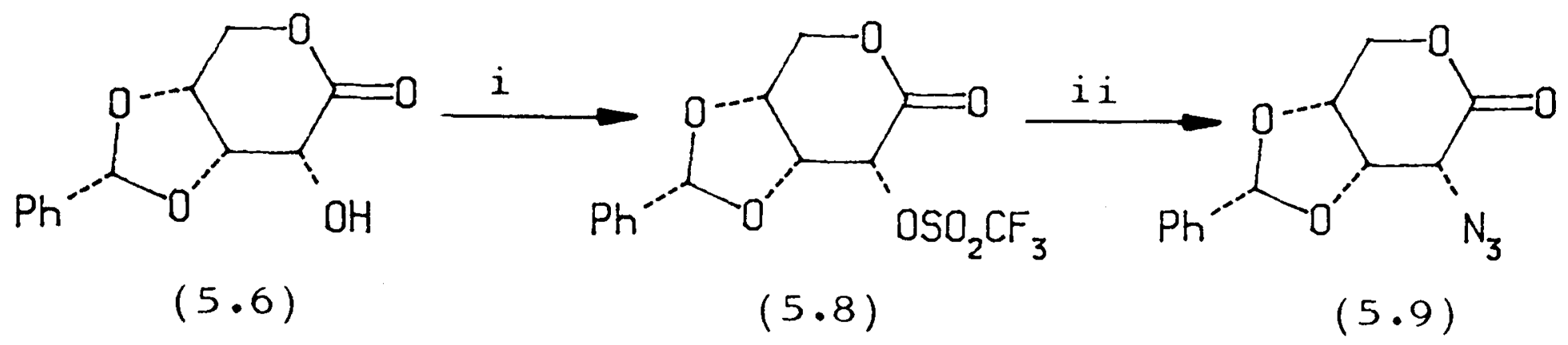

i) $\left(\mathrm{CF}_{3} \mathrm{SO}_{2}\right)_{2} \mathrm{O}$ in pyridine ii) $\mathrm{NaN}_{3}, \mathrm{DMF}, \mathrm{rt}, 1 \mathrm{~h}$

\section{SCHEME 5.4}

Since the coupling constants between the protons attached to $\mathrm{C} 2$ and $\mathrm{C} 3$ in the alcohol $(5.6),\left(\mathrm{J}_{23} 3.1 \mathrm{~Hz}\right)$, the azide $(5.9)\left(\mathrm{J}_{23} 3.3 \mathrm{~Hz}\right)$, the triflate $(5.8)$ $\left(\mathrm{J}_{23} 3.4 \mathrm{~Hz}\right)$ and the corresponding xanthate $\left(\mathrm{J}_{23} 2.9 \mathrm{~Hz}\right)^{7}$ are very similar, the triflate (5.8) also probably has the ribo configuration. All the other proton- proton coupling constants in the triflate (5.8) and the azide (5.9) are essentially the same, supporting the hypothesis that the two compounds have similar geometry.

The crystal structure of (5.9) (Fig 5.1) shows that the 1,3 dioxolane ring holds the lactone in a boat conformation, in which the azide occupies the bow - sprit position; the epimeric arabino azide would have the azide in the flagpole position in a boat conformation. An explanation of the observed retention is that the initially formed arabino azide equilibrates to the ribo azide (5.9) under the reaction conditions.

The corresponding mesylate of (5.6) gave no azide containing products on treatment with sodium azide in $\mathrm{DMF}^{9}$.

Hydrolysis of the benzylidene acetal in (5.9) with aqueous trifluoroacetic acid at $50^{\circ} \mathrm{C}$ also converted the 1,5 - to the $1,4-$ lactone (5.10) (94\%). The structure was again established by X-ray crystallography (fig 5.2). Selective 
FIG 5.2 : X-RAY CRYSTAL STRUCTURE OF 2- AZIDO- 2- DEOXY-

$\underline{\underline{D}-\mathrm{RIBONO}-1,4-\text { LACTONE }(5.10)}$

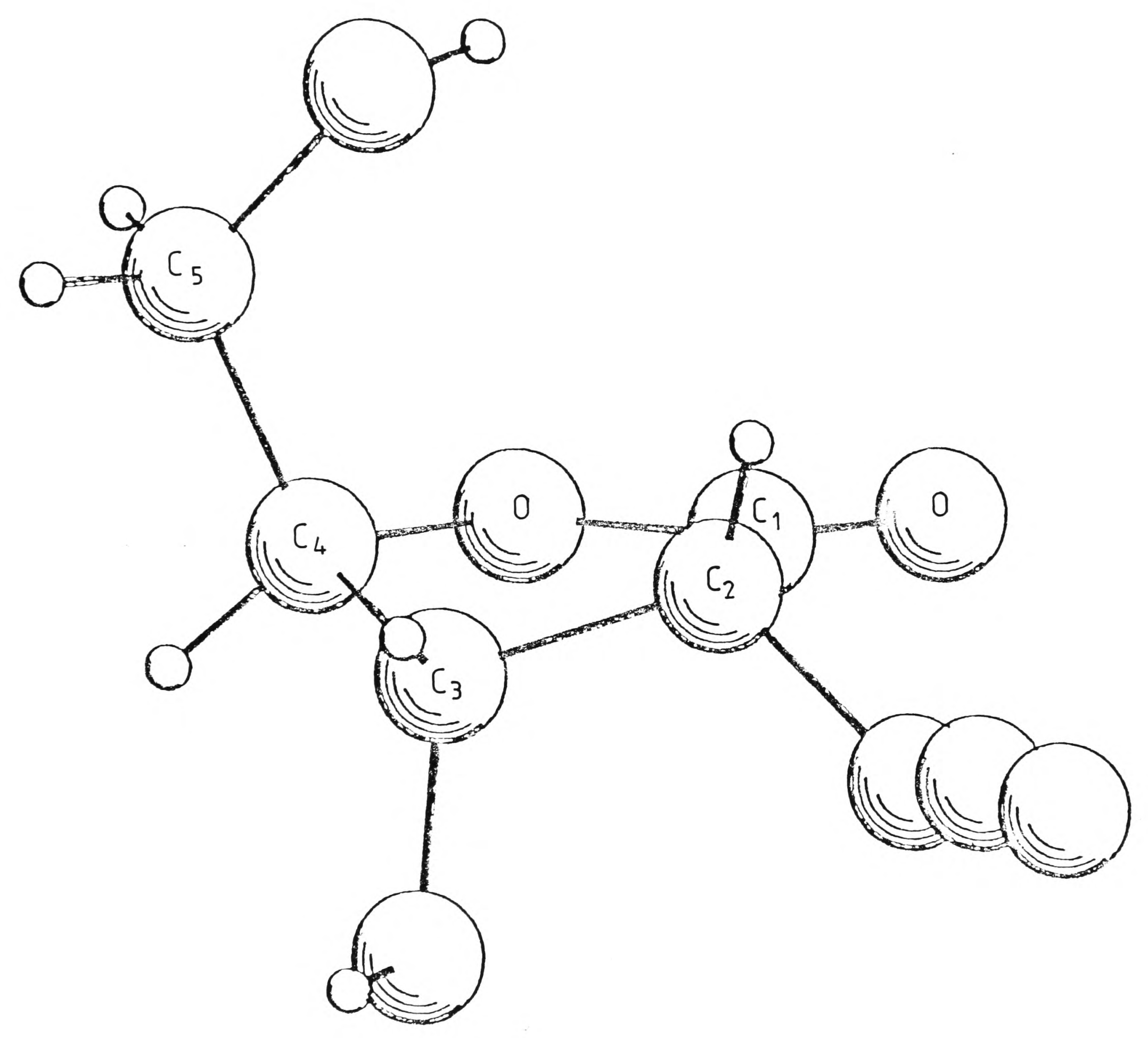


esterification of the primary hydroxyl group in the diol (5.10) with methanesulphonyl chloride in pyridine at $-20^{\circ} \mathrm{C}$ gave the mesylate (5.11) (71\%). (Scheme 5.5).

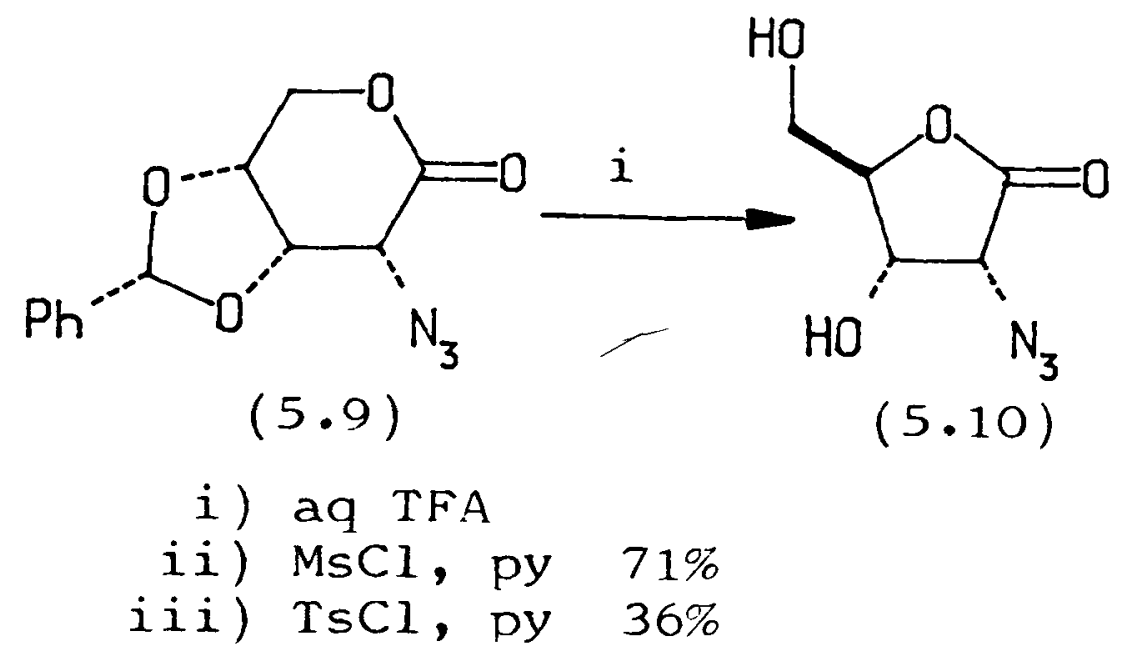

\section{$\underline{\text { SCHEME } 5.5}$}

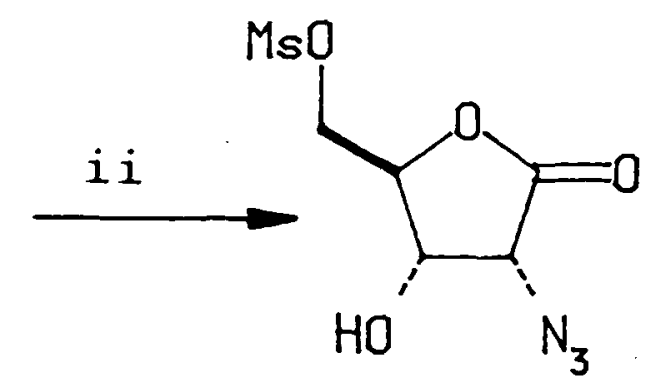

$(5.11)$

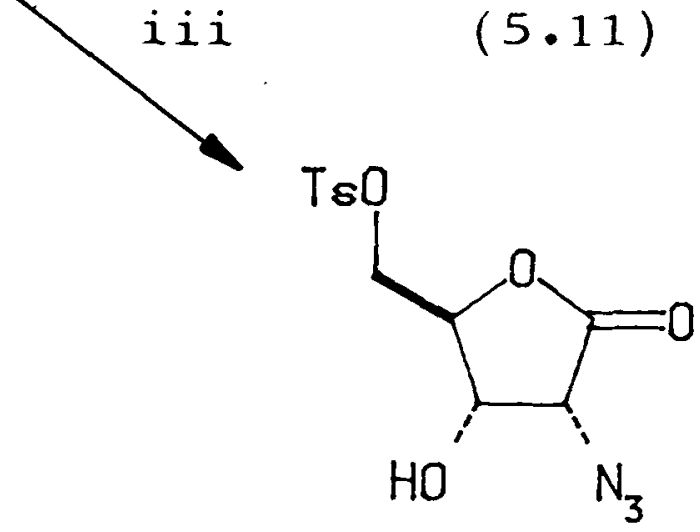

$(5.12)$

Formation of the corresponding 5- tosylate (5.12) proceeded in lower yield; a mixture of mono and di- tosylates, together with unreacted starting material was obtained.

The azide (5.9) could be converted by hydrogenolysis and subsequent treatment with benzyl chloroformate, to the $\mathrm{Z}$ protected amine (5.13), which underwent an analogous series of reactions (Scheme 5.6).<smiles>NC1C(=O)OCC2OC(c3ccccc3)OC21</smiles>

$(5.9)$

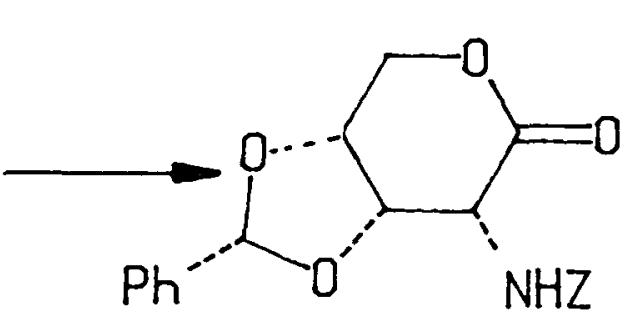

$(5 \cdot 13)$<smiles>[X]NC1C(=O)OC(CO)C1O</smiles>

$(5.14)$

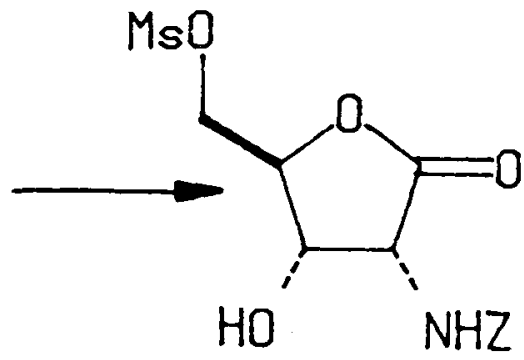

$(5.15)$

SCHEME 5.6 
Mesylation of the diol (5.14) gave a single mesylate product (5.15) and from this it was deduced that (5.14) was a 1,4-l lactone.

Generally, ${ }^{13} \mathrm{C}$ NMR may be used to establish the ring size in these compounds. Thus, the chemical shifts of $\mathrm{C} 3$ and $\mathrm{C} 4$ in all the 1,5- lactones are within the range 72.4 to 76.7 (Table 5.1), whereas in the $1,4-$ lactones, C3 is in the range 69.7 - 73.1 and $C 4$ resonates at much lower field (since C4 is now adjacent to a strongly electron withdrawing ester oxygen) in the range 84.6 88.5 (Table 5.2). In addition to this, the signal for $\mathrm{C} 5$ in the 1,5lactones is at a lower field than that for the 1,4- lactones without functionality at $\mathrm{C5}$. The carbonyl stretching frequencies are not reliable for establishing the size of the lactone ring in this class of compounds; very high carbonyl stretching frequencies (up to $1800 \mathrm{~cm}^{-1}$ ) have been observed for 1,5- lactones. This may indicate the lactone is in the boat conformation.

Table 5.1 : Infra - red and ${ }^{13} \mathrm{C}$ NMR data for 1,5- lactones.

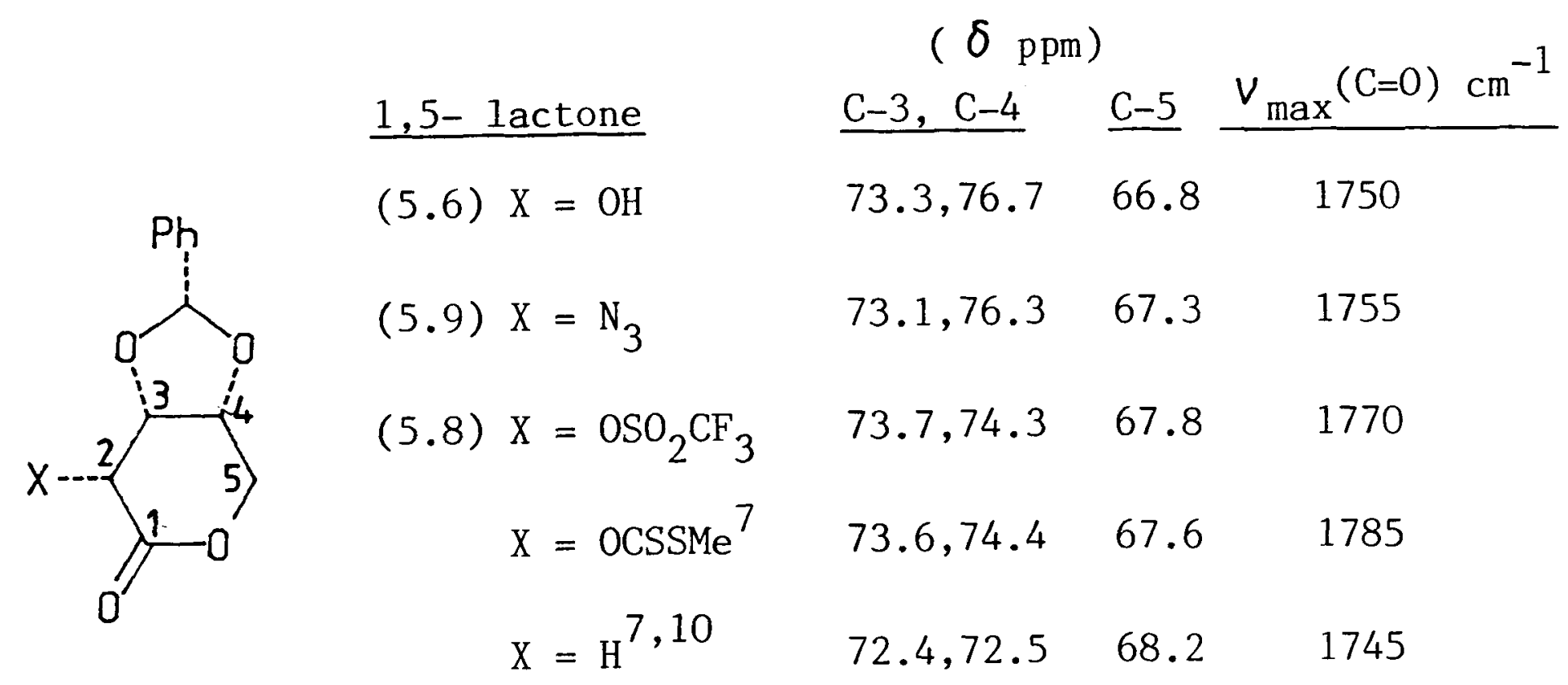


Table 5.2 : Infra red and ${ }^{13} \mathrm{C}$ NMR data for 1,4- 1actones.

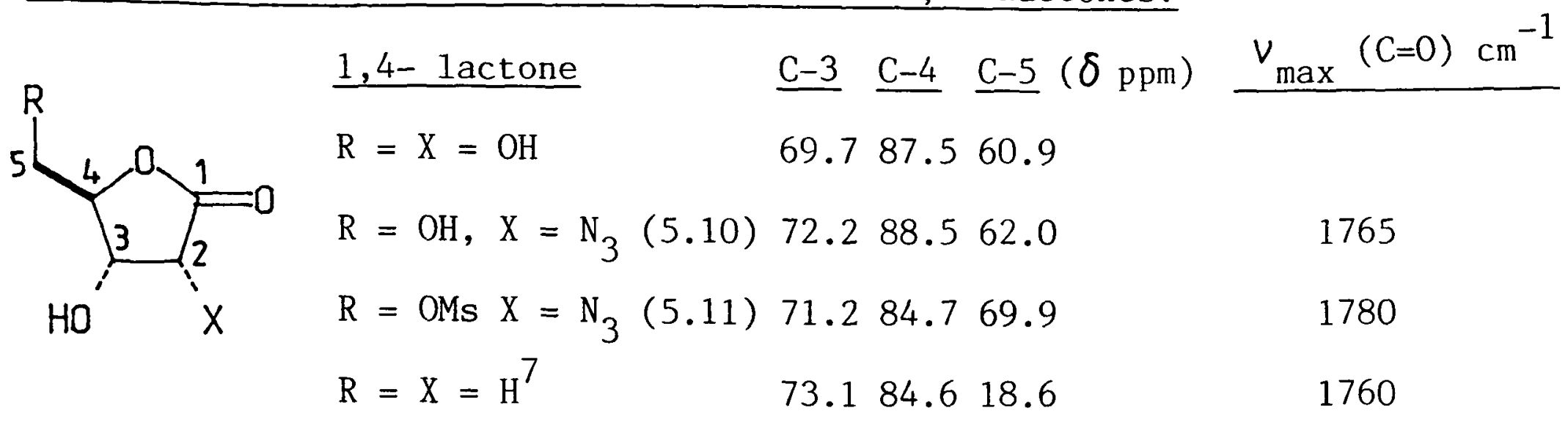

Hydrogenolysis of the azido mesylate (5.11) in the presence of palladium black in ethyl acetate, followed by treatment of the resulting amino lactone with aqueous sodium hydroxide gave, after purification by ion exchange chromatography (2R, 3S, 4R)-3,4- dihydroxyproline (5.1) (51\%) (20\% overall yield from D- ribonolactone) (Scheme 5.7).

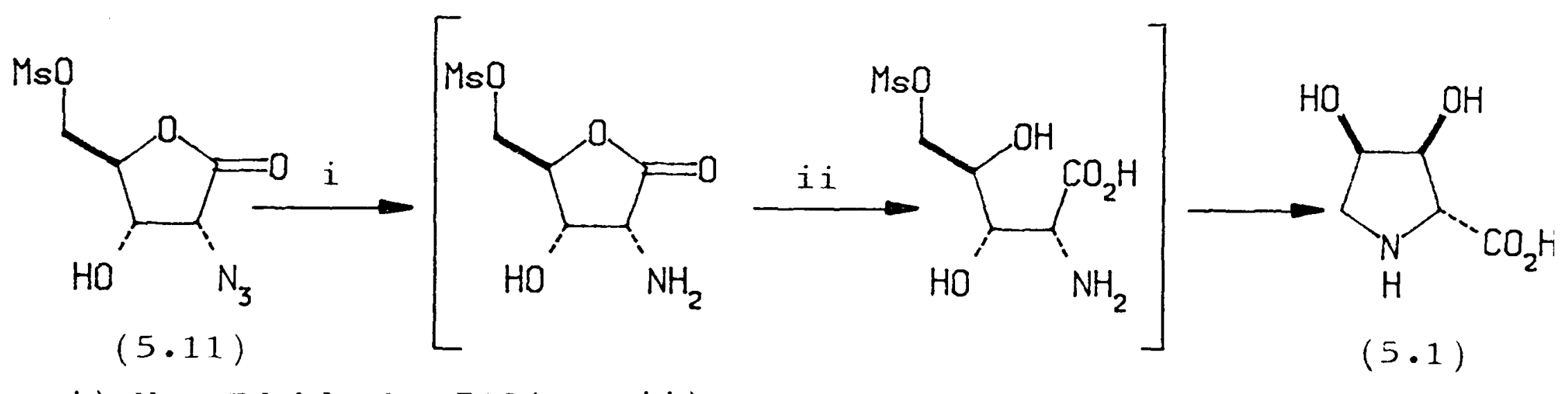

i) $\mathrm{H}_{2}, \mathrm{Pd}$ black, EtOAc ii) $\mathrm{NaOH}$ aq

\section{SCHEME 5.7}

The structure of the amino acid (5.1) was confirmed by chemical synthesis of the alternative epimer at the $C 2$ position ( $2 S, 3 S, 4 R)-3,4$ - dihydroxyproline (5.2 and 2.3) (chapter 2) and by $X$ - ray analysis of a sample recrystallised from aqueous acetone, which was found to be the hydrate (Fig 5.3).

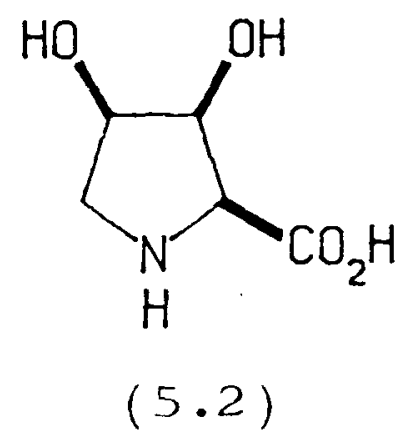


FIG 5.3 : X-RAY CRYSTAL STRUCTURE OF (2R, 3S, 4R) 3,4- DIHYDROXY

PROLINE (5.1)

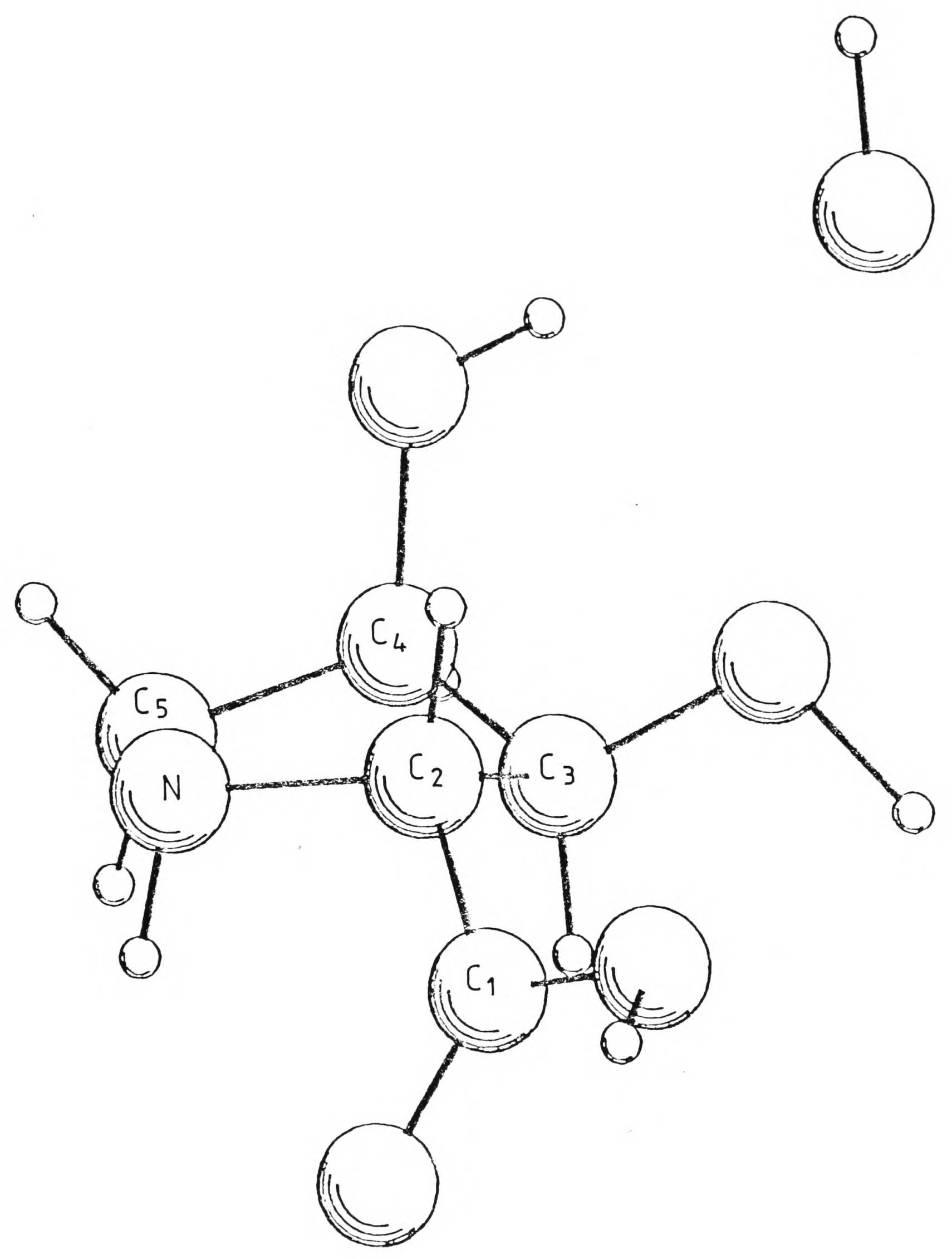


Approaches to the synthesis of (2S, 3S, 4R)-3,4-dihydroxyproline (5.2) from derivatives of D-ribonolactone.

The benzylidene acetal holds the lactone ring of (5.6) in the boat conformation 8 and ultimately leads to nucleophilic displacement at $\mathrm{C} 2$ occurring with retention of configuration. There are, in principle, two ways to overcome this problem (and obtain the expected inversion of configuration at $\mathrm{C} 2$ ) namelyto initially open the lactone ring and remove the constraint, or to make a ribonolactone derivative with different protecting groups. Both approaches were investigated.

\section{i) Ring opening of the lactone before displacement.}

Treatment of the azide (5.9) with hydrazine led to the ring opening of the lactone and formation of the acid hydrazide (5.16) (40\%, not optimised). Treatment of (5.9) with concentrated ammonia solution gave the ring opened amide (5.17) (Scheme 5.8).

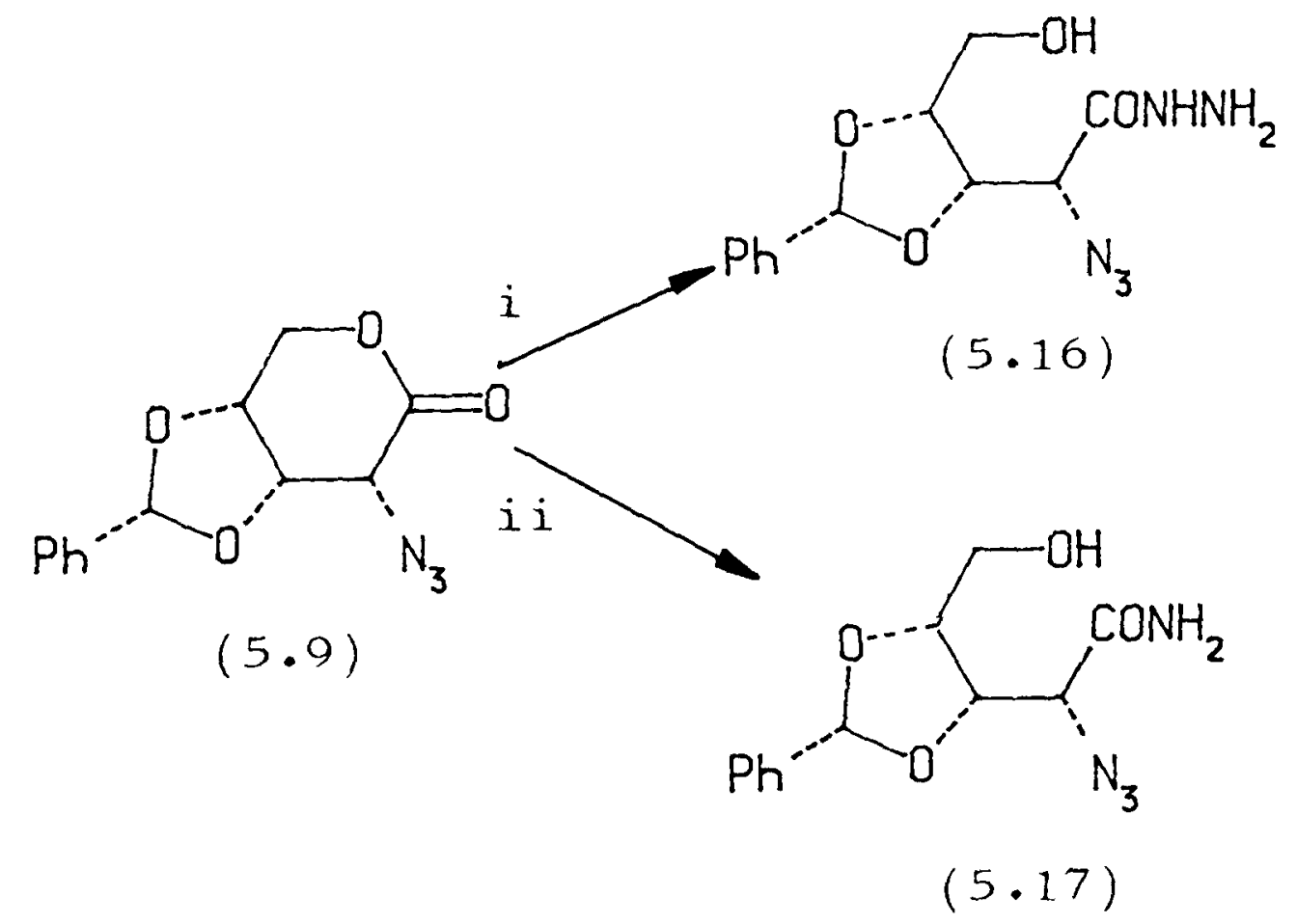

i) $\mathrm{H}_{2} \mathrm{NNH}_{2}$ ii) conc $\mathrm{NH}_{3}$ solution

SCHENE 5.8

It was therefore hoped that treatment of the triflate (5.8) with ammonia 
would effect both the ring opening and then displacement, with inversion of configuration, to give the amide (5.18). However, the major product isolated from the reaction was the furan derivative (5.19) (40\%, not optimised) and no (5.18) was detected. (scheme 5.9).

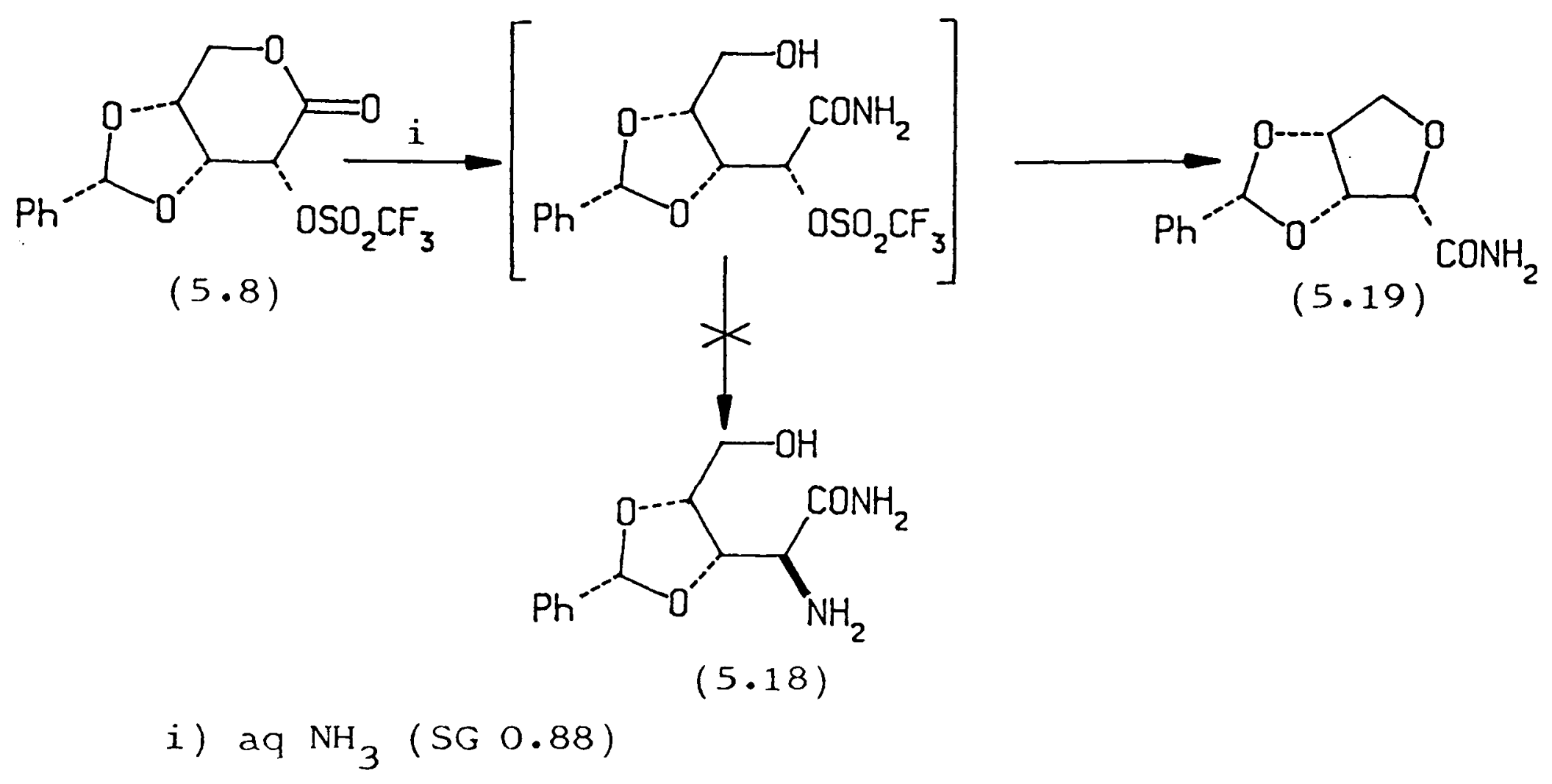

\section{SCHEME 5.9}

A third possibility, namely to open the lactone ring of the alcohol (5.6), then protect the primary hydroxyl group produced at C5, and finally carry out the displacement at $\mathrm{C} 2$ was not investigated.

\section{ii) Alternative protection of the hydroxyl groups.}

The 1,4- lactone (5.20) was prepared from diacetone allose ${ }^{11}$ (Scheme 5.10). The allofuranose was hydrolysed with acetic acid / water / methanol to selectively remove the 5,6- isopropylidene acetal. Cleavage of the 5,6- diol with sodium periodate and subsequent reduction with sodium borohydride produced $1,2-\underline{0}-$ isopropylidene $a-\underline{D}-$ ribofuranose ${ }^{12}$. The hydroxy1 groups at C3 and C5 


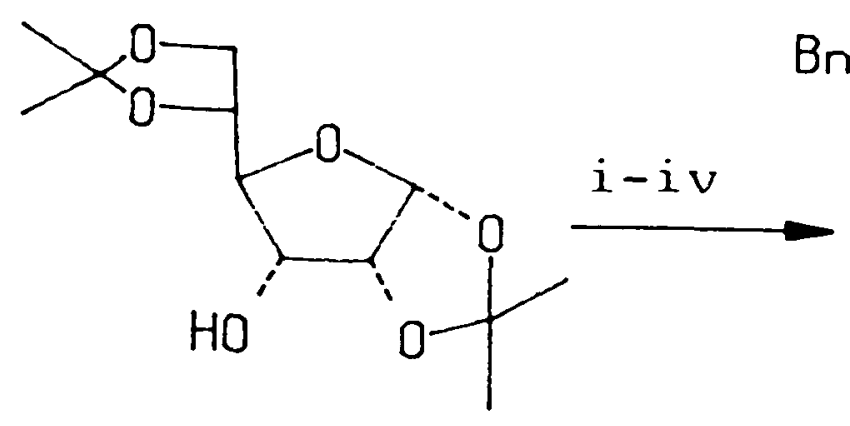

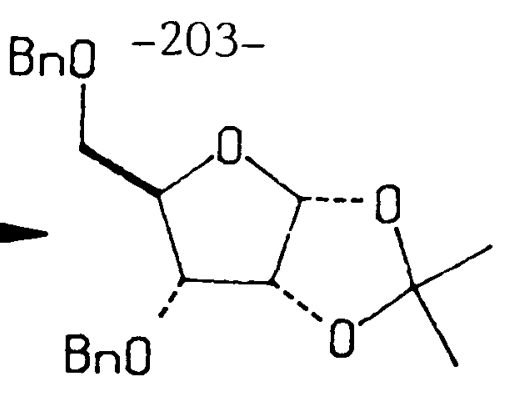

$(5.21)$

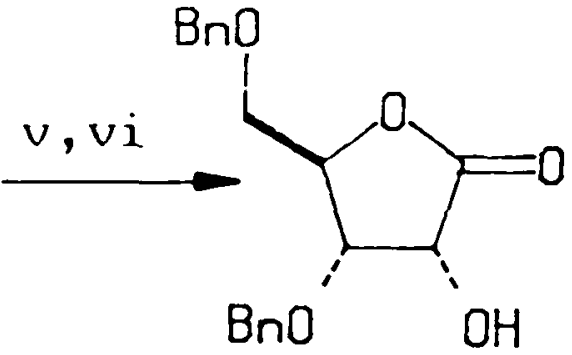

$(5.20)$

i) aq $\mathrm{ACOH}$ ii) $\mathrm{NaIO}_{4}$ iii) $\mathrm{NaBH}_{4}$ iv) $\mathrm{BnBr}, \mathrm{Ag}_{2} \mathrm{O} v$ ) aq TFA vi) $\mathrm{Br}_{2} \mathrm{aq}$.

\section{SCHEME 5.10}

were protected as benzyl ethers by treatment with benzyl bromide in the presence of silver (I) oxide in $\mathrm{DMF}^{13}$, to give 3,5- di-0- benzy1- 1,2- $\underline{0}$ - isopropylidene a -D- ribofuranose (5.21) (59\% from diacetone allose). Hydrolysis of the 1,2- acetal and bromine water oxidation (in the presence of barium carbonate) produced the lactone (5.20) (64\%).

The lactone (5.20) was readily converted to the corresponding triflate on treatment with trifluoromethanesulphonic anhydride under the usual conditions, but initial attempts to perform the displacement with sodium azide gave a complex mixture of products with only a very low yield of a clean azide containing product obtained. This reaction requires further investigation.

Approaches to the synthesis of (2S, 4S)- 4- hydroxyproline (5.29). Synthesis of the 4- hydroxyprolines required removal of oxygen from C3. At the outset of this work Zinner's lactone was believed to have the structure shown as $(5.7)^{7}$ and the proposed route to the 4 -hydroxyprolines was as shown in scheme 5.11 . 
<smiles>O=C1OC2COC(c3ccccc3)O[C]2C1O</smiles>

$\mathrm{HO}$

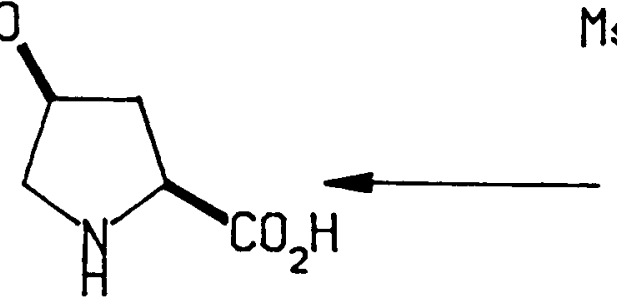

$(5.29)$
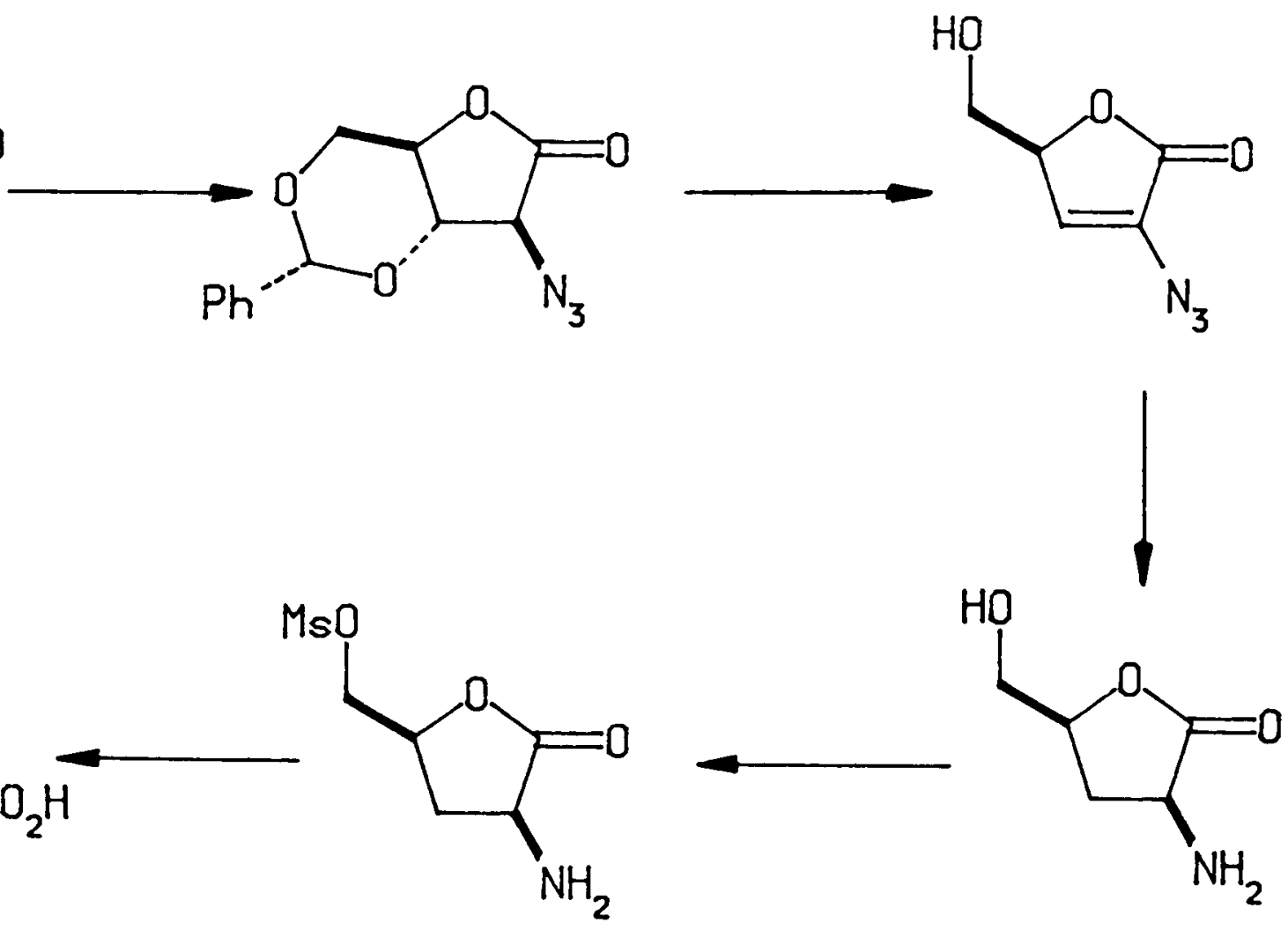

SCHEME 5.11

The subsequent difficulties experienced were easily understood when the structure of Zinner's lactone was corrected to (5.6).

Base catalysed elimination of the benzylidene acetal group of a range of protected nitrogen compounds gave only one product when non- nucleophilic bases, such as DBU or triethylamine, were used, but a mixture of products (presumably differing in ring size), which were inseparable by flash chromatography, was obtained when the base used was nucleophilic (e.g. sodium methoxide) (Scheme 5.12).<smiles>[X]C1=CC(O)COC1=O</smiles>

SCHEME 5.12

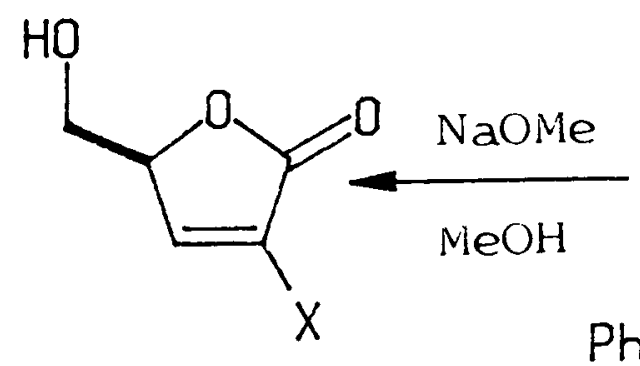

$\mathrm{Ph}^{\prime}$

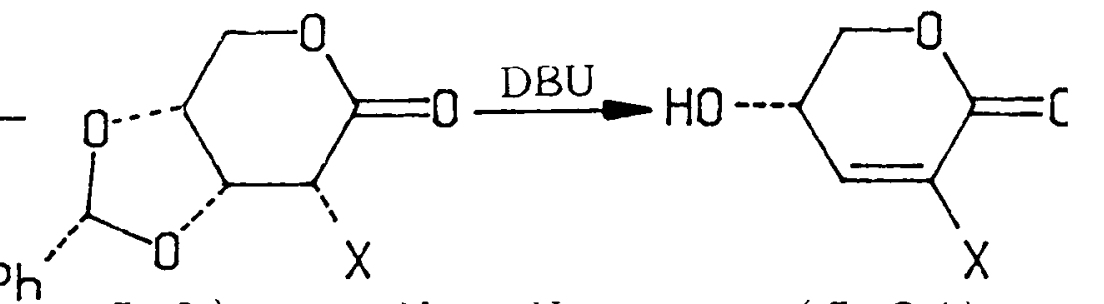

$(5.24)$

$(5.25)$

$(5.22) \quad X=\operatorname{NHCOCF}_{3}(5.26)$

$(5.23) \cdot x=$ NHAC $\quad(5.27)$ 
When the azido lactone (5.9) was used the reaction was instantaneous but the isolated yield of (5.24) was always low (44\%) and the solution rapidly darkened after only a few seconds. The $\mathrm{Z}$ derivative (5.13), however, gave much higher yields of the eliminated product (5.25)(68\%).

The main problem with the unsaturated lactones (5.24) and (5.25) was that when the $\mathrm{C}=\mathrm{C}$ bond was reduced by hydrogenation, the amine was deprotected. For this reason the amides (5.22) and (5.23) were prepared from (5.9) by reduction and acetylation with the corresponding acid anhydrides. These compounds underwent analogous elimination reactions with DBU, producing (5.26) and (5.27) respectively.

Reduction of the double bonds in the lactones (5.24-7) was only briefly investigated, and in no case wàs any high degree of stereoselectivity observed. This is where the 5 ring lactone series (scheme 5.11) should be considerably better. The synthesis of the 4- hydroxyprolines from D- glucurono- 3,6- lactone adopting this strategy is currently under investigation 14 (Scheme 5.13).

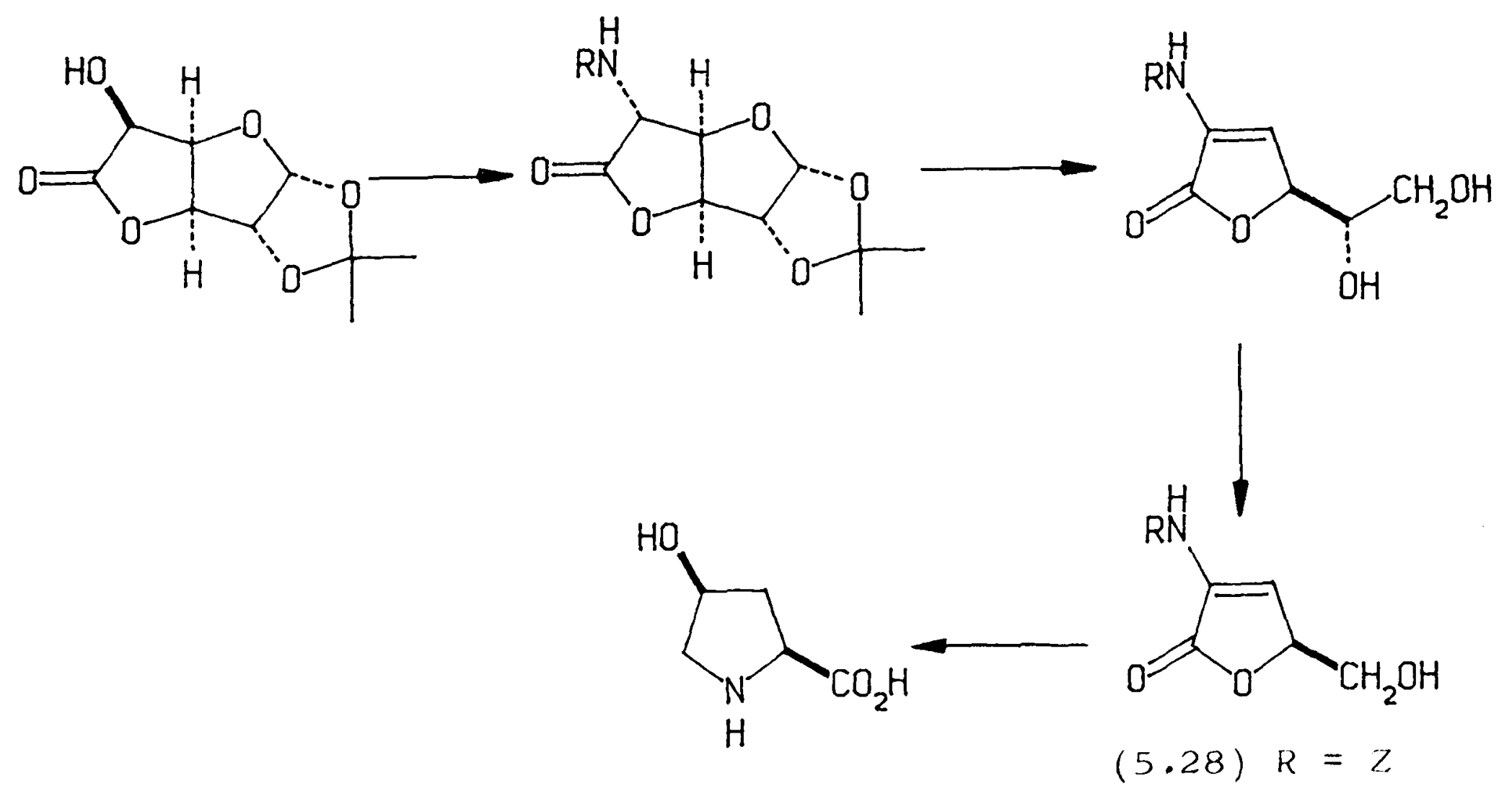


The NMR spectrum of (5.28) was identical with that of a minor product of the reaction of (5.13) with sodium methoxide in methanol. Any further advances in the ribonolactone approach must involve improving the efficiency of this transformation at the expense of the 1,5- lactones (5.24-7). 


\section{EXPERTMENTAL SECTION.}

For general directions see chapter 1 .

3,4- $\underline{0}-$ Benzylidene- D- Ribono- 1,5- lactone (5.6)

D- ribono- 1,4- lactone (20 g, $0.135 \mathrm{~mol})$ was dissolved in benzaldehyde $(200 \mathrm{~m} 1)$ and concentrated hydrochloric acid $(20 \mathrm{~m} 1)$ was added. The suspension was shaken vigorously at room temperature for $3 \mathrm{~h}$, the starting material dissolving in several minutes and the product subsequently slowly crystallising from the solution. The mixture was diluted with ether ( $250 \mathrm{ml})$ and the product collected by filtration. The crude product was washed sequentially with ether $(500 \mathrm{~m} 1)$, saturated aqueous sodium bicarbonate solution $(200 \mathrm{ml})$, water $(200 \mathrm{ml})$ and finally further ether $(500 \mathrm{ml})$ and desiccated over phosphorus pentoxide, affording the title compound (5.6) (28.33 g, 89\%) as a crystalline solid. A small amount could be recrystallised from hot ethyl acetate. m.p $233-234^{\circ} \mathrm{C}\left(1\right.$ it $\left.^{7} 233-235.5^{\circ} \mathrm{C}\right) .[a]_{D}^{20}-185.6^{\circ}$ (c, $\left.0.43, \mathrm{DMF}\right)$, $\left(1 \mathrm{it}^{7}[a]_{\mathrm{D}}^{20}-174.1^{\circ}\right.$ (c, 2.26, DMF). ${ }^{1} \mathrm{H} \operatorname{NMR}\left(\mathrm{d}^{6} \mathrm{DMSO}\right) \delta 7.4$ (5H, m, ArH); $5.8(1 \mathrm{H}, \mathrm{s}, \mathrm{PhCH}) ; 4.8-4.7(3 \mathrm{H}, \mathrm{m}, \mathrm{H}-2,3,4) ; 4.3(1 \mathrm{H}, \mathrm{d}, \mathrm{H}-5) ; 4.2(1 \mathrm{H}$, $\left.\mathrm{d}, \mathrm{H}-5^{\prime}\right) \cdot{ }^{13} \mathrm{C}$ NMR $\left(\mathrm{d}^{6}\right.$ DMSO $) \delta 66.8(\mathrm{t}, \mathrm{C}-5) ; 67.7(\mathrm{~d}, \mathrm{C}-2) ; 73.3,76.7$ $(2 \mathrm{~d}, \mathrm{C}-3,4) ; 102.6(\mathrm{~d}, \mathrm{PhCH}) ; 127.1,128.1,129.7,136.0,(\mathrm{ArC}), 171.6$ $(\mathrm{s}, \mathrm{C}-1)$. Found $\mathrm{C}, 60.76 ; \mathrm{H}, 5.08 . \mathrm{C}_{12} \mathrm{H}_{12} \mathrm{O}_{5}$ requires $\mathrm{C}, 61.02 ; \mathrm{H}, 5.08$. 3,4- $\underline{0}-(R)-$ Benzylidene- 2- $\underline{0}-$ trifluoromethanesulphonyl- D- ribono- 1,5lactone (5.8) and 2-Azido- 3,4- $\underline{0}-(\mathrm{R})$ - benzylidene- 2- deoxy- D- ribono1,5 - lactone (5.9)

Alcohol (5.6) (13.96 g, $59.1 \mathrm{mmol})$ was suspended in dry pyridine (150 ml) and thereaction mixture cooled to $-10^{\circ} \mathrm{C}$ under a nitrogen atmosphere. Trifluoromethanesulphonic anhydride ( $20 \mathrm{~g}, 1.2$ equivs) was added to the 
stirred reaction mixture maintaining the temperature between $-10^{\circ}$ and $-20^{\circ} \mathrm{C}$. The resulting suspension was stirred at this temperature for a further $1 \mathrm{~h}$ at which time the reaction mixture had become homogeneous. The pyridine was diluted with ethyl acetate $(300 \mathrm{~m} 1)$, then washed successively with water $(300 \mathrm{~m} 1)$ and saturated aqueous sodium bicarbonate solution (300 m1), dried and the solvent evaporated to give the required triflate (5.8) as a yellow solid which was used directly without further purification for the conversion to the azido lactone (5.9). A small amount of the triflate was re-crystallised from ethanol to give white needles. m.p $172-173^{\circ} \mathrm{C}$ (decomp). $[a]_{D}^{20}$ $-128.6^{\circ}$ ( $\underline{c}, 0.56$, EtOAc). $v_{\max }\left(\right.$ nujol) $1770,1455,1410$ and $1090 \mathrm{~cm}^{-1}$. ${ }^{1} \mathrm{H}$ NMR $\delta 7.5-7.4(5 \mathrm{H}, \mathrm{m}, \mathrm{ArH}) ; 5.87(1 \mathrm{H}, \mathrm{s}, \mathrm{PhCH}) ; 5.35\left(1 \mathrm{H}, \mathrm{d}, \mathrm{H}-2, \mathrm{~J}_{23}\right.$ $3.4 \mathrm{~Hz}) ; 5.00\left(1 \mathrm{H}, \mathrm{dd}, \mathrm{H}-3, \mathrm{~J}_{34} 8.0 \mathrm{~Hz}\right) ; 4.79(1 \mathrm{H}, \mathrm{d}, \mathrm{H}-4) ; 4.68(1 \mathrm{H}, \mathrm{d}, \mathrm{H}-5$, $\left.\mathrm{J}_{55^{\prime}}, 13.6 \mathrm{~Hz}\right) ; 4.38\left(1 \mathrm{H}, \mathrm{dd}, \mathrm{H}_{-5}{ }^{\prime}, \mathrm{J}_{45}, 1.7 \mathrm{~Hz}\right) \cdot{ }^{13} \mathrm{C}$ NMR (d ${ }^{6}$ DMSO $) 67.84$ $(\mathrm{t}, \mathrm{C}-5) ; 73.7,74.3(2 \mathrm{~d}, \mathrm{C}-3,4) ; 80.9(\mathrm{~d}, \mathrm{C}-2) ; 103.6(\mathrm{~d}, \mathrm{PhCH}) ; 119.0$ (q, $\mathrm{CF}_{3}$, not proton decoupled); 127.2 (d), 128.5 (d), 130.3 (d), 135.3 (s) $(\operatorname{ArC}) ; 164.8(\mathrm{~s}, \mathrm{C}-1) . \underline{\mathrm{m} / \mathrm{z}}: 386\left(\mathrm{M}+\mathrm{NH}_{4}^{+}, 100 \%\right)$. Found $\mathrm{C}, 42.41 ; \mathrm{H}, 2.97$. $\mathrm{C}_{13} \mathrm{H}_{11} \mathrm{~F}_{3} \mathrm{O}_{7} \mathrm{~S}$ requires $\mathrm{C}, 42.39 ; \mathrm{H}, 2.99$.

The crude triflate was dissolved in DMF (100 ml) and stirred with sodium azide $(6.4 \mathrm{~g}, 98.5 \mathrm{mmol})$ at room temperature for $1.5 \mathrm{~h}$. The DMF was evaporated and the residue was partitioned between ethyl acetate $(300 \mathrm{ml})$ and water $(300 \mathrm{~m} 1)$. The organic layer was dried, and the solvent removed to give, after recrystallisation from ethanol, the azide (5.9) (9.8 g, 64\% from (5.6)). $\mathrm{m} \cdot \mathrm{p} 145^{\circ} \mathrm{C}(\mathrm{dec}) \cdot[\mathrm{dr}]_{\mathrm{D}}^{20}-245.5^{\circ}\left(\underline{c}, 0.42, \mathrm{CHCl}_{3}\right) \cdot v_{\max } 2110,1755,1460$, 1405, 1160 and $1090 \mathrm{~cm}^{-1}$. $1_{\mathrm{H} \mathrm{NMR}} \delta 7.5-7.4(5 \mathrm{H}, \mathrm{m}, \operatorname{ArH}) ; 5.78(1 \mathrm{H}, \mathrm{s}, \mathrm{PhCH})$; $4.91\left(1 \mathrm{H}, \mathrm{dd}, \mathrm{H}-3, \mathrm{~J}_{34} 8.0 \mathrm{~Hz}, \mathrm{~J}_{23} 3.3 \mathrm{~Hz}\right) ; 4.67(1 \mathrm{H}, \mathrm{dd}, \mathrm{H}-4) ; 4.61(1 \mathrm{H}, \mathrm{d}$, $\left.\mathrm{H}-5, \mathrm{~J}_{55}, 13.4 \mathrm{~Hz}\right) ; 4.25\left(1 \mathrm{H}, \mathrm{dd}, \mathrm{H}-5^{\prime}, \mathrm{J}_{45^{\prime}}, 1.7 \mathrm{~Hz}\right) ; 3.95(1 \mathrm{H}, \mathrm{d}, \mathrm{H}-2)$. ${ }^{13}$ C NMR $\delta 58.9(d, C-2) ; 67.3(t, C-5) ; 73.1,76.3(2 d, C-3,4) ; 104.6(d$, $\mathrm{PhCH}) ; 127.1$ (d), 128.6 (d), 130.3 (d), $134.4(\mathrm{~s})(\mathrm{ArC}) ; 166.4(\mathrm{~s}, \mathrm{C}-1)$. 
$\underline{\mathrm{m} / \mathrm{z}}: 279\left(\mathrm{M}+\mathrm{NH}_{4}^{+}\right) ; 234\left(\mathrm{M}+\mathrm{H}^{+}-\mathrm{N}_{2}, 100 \%\right)$. Found $\mathrm{C}, 55.08 ; \mathrm{H}, 4.23$; $\mathrm{N}, 15.97 . \mathrm{C}_{12} \mathrm{H}_{11} \mathrm{~N}_{3} \mathrm{O}_{4}$ requires $\mathrm{C}, 55.17 ; \mathrm{H}, 4.21 ; \mathrm{N}, 16.09$.

2- Azido- 2- deoxy- D- ribono- 1,4- lactone (5.10)

Azide (5.9) (5 g, $19.2 \mathrm{mmol})$ was dissolved in a mixture of trifluoroacetic acid $(26 \mathrm{ml})$ and water $(13 \mathrm{ml})$ by stirring at $50^{\circ} \mathrm{C}$ for $1.5 \mathrm{~h}$. Evaporation of the solvent, followed by flash chromatography of the residue (ethyl acetate : hexane, $3: 2$ ) afforded the azido diol (5.10) (3.1 g, 94\%). m.p 84-85 ${ }^{\circ} \mathrm{C}$ (from ether). $[a]_{D}^{20}+54.2^{\circ}$ (c, 0.28, EtOAc). $v_{\max } 3400(\mathrm{br}), 2105,1765 \mathrm{~cm}^{-1}$.

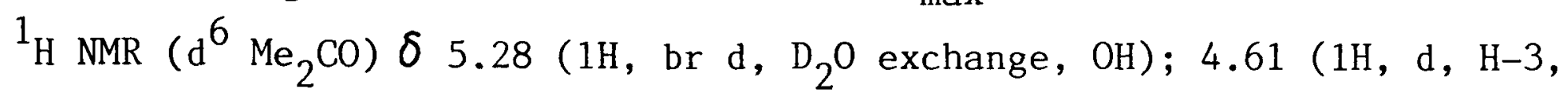
$\left.\mathrm{J}_{23} 5.3 \mathrm{~Hz}\right) ; 4.50(1 \mathrm{H}, \mathrm{t}, \mathrm{H}-4) ; 4.44(1 \mathrm{H}, \mathrm{d}, \mathrm{H}-2) ; 3.83\left(2 \mathrm{H}, \mathrm{d}, \mathrm{H}-5,5^{\prime}, \mathrm{J}_{45}\right.$ $3.0 \mathrm{~Hz}) ; 2.98\left(1 \mathrm{H}\right.$, br s, D 20 exchange, OH). ${ }^{13} \mathrm{C}$ NMR (d ${ }^{6}$ DMSO) $\delta 62.04(\mathrm{t}, \mathrm{C}-5)$; $62.26(\mathrm{~d}, \mathrm{C}-2) ; 72.17,(\mathrm{~d}, \mathrm{C}-3) ; 88.51(\mathrm{~d}, \mathrm{C}-4) ; 174.5(\mathrm{~s}, \mathrm{C}-1) . \underline{\mathrm{m} / \mathrm{z}}: 191$ $\left(\mathrm{M}+\mathrm{NH}_{4}^{+}, 100 \%\right), 146$. Found $\mathrm{C}, 34.74 ; \mathrm{H}, 4.03 ; \mathrm{N}, 24.15 . \mathrm{C}_{5} \mathrm{H}_{7} \mathrm{~N}_{3} \mathrm{O}_{4}$ requires C, 34.68; H, 4.05; N, 24.28.

2- Azido- 2- deoxy- 5- $\underline{0}-$ methanesulphony1- D- ribono- 1,4- lactone (5.11) The azido diol (5.10) (1.07 g, $6.17 \mathrm{mmol})$ in dry pyridine $(40 \mathrm{ml})$ at $-20^{\circ} \mathrm{C}$ under nitrogen was treated with methanesulphonyl chloride $(0.49 \mathrm{ml}, 1.1$ equivs $)$ and the reaction mixture was allowed to stand overnight. The bulk of the pyridine was evaporated and the residue diluted with ethy 1 acetate $(100 \mathrm{ml})$; the solution was then washed successively with aqueous hydrochloric acid $(2 \mathrm{M}, 50 \mathrm{ml})$, water $(100 \mathrm{ml})$ and saturated aqueous sodium bicarbonate solution $(100 \mathrm{ml})$ and dried. Evaporation of the solvent, followed by flash chromatography of the residue (ethyl acetate : hexane, $2: 1$ ) gave unreacted starting material $(0.18 \mathrm{~g}, 7 \%)$ and the title compound $(5.11)(1.1 \mathrm{~g}, 71 \%)$. m.p $68-69^{\circ} \mathrm{C}$ $\left(\right.$ from $\left.\mathrm{CHCl}_{3}\right) \cdot[a]_{\mathrm{D}}^{20}+37.3^{\circ}$ (c $\left., 0.48, \mathrm{EtOAc}\right) \cdot v_{\max } 3450(\mathrm{br}), 2110,1780$, 
$1350,1165 \mathrm{~cm}^{-1} .{ }^{1} \mathrm{H}$ NMR $\delta 4.67(1 \mathrm{H}, \mathrm{m}, \mathrm{H}-4) ; 4.52(1 \mathrm{H}, \mathrm{dd}, \mathrm{H}-3) ; 4.50-4.45$ $\left(3 \mathrm{H}, \mathrm{m}, \mathrm{H}-2,5,5^{\prime}\right) ; 3.09\left(3 \mathrm{H}, \mathrm{s}, \mathrm{CH}_{3} \mathrm{~S}\right) ; 2.9(1 \mathrm{H}, \mathrm{br} \mathrm{s}, \mathrm{OH}) .{ }^{13} \mathrm{C} \mathrm{NMR}\left(\mathrm{d}^{4} \mathrm{MeOH}\right) \delta$ $37.39\left(\mathrm{q}, \mathrm{CH}_{3}\right) ; 61.61(\mathrm{~d}, \mathrm{C}-2) ; 69.06(\mathrm{t}, \mathrm{C}-5) ; 71.17(\mathrm{~d}, \mathrm{C}-3) ; 84.70(\mathrm{~d}$, $\mathrm{C}-4) ; 174(\mathrm{~s}, \mathrm{C}-1) . \underline{\mathrm{m} / \mathrm{z}}: 269\left(\mathrm{M}+\mathrm{NH}_{4}^{+}, 100 \%\right), 224$. Found $\mathrm{C}, 28.4 ; \mathrm{H}, 3.5$; $\mathrm{N}, 16.4 . \mathrm{C}_{6} \mathrm{H}_{9} \mathrm{~N}_{3} \mathrm{O}_{6} \mathrm{~S}$ requires $\mathrm{C}, 28.7 ; \mathrm{N}, 3.6 ; \mathrm{N}, 16.7$.

2R, 3S, 4R- 3, 4- Dihydroxyproline (5.1)

The azido mesylate $(5.11)(0.72 \mathrm{~g}, 2.8 \mathrm{mmol})$ was dissolved in ethyl acetate $(8 \mathrm{~m} 1)$ and stirred at room temperature in a hydrogen atmosphere in the presence of palladium black $(0.1 \mathrm{~g})$. After $24 \mathrm{~h}$, the ethyl acetate was removed and the residue was suspended in water $(30 \mathrm{~m} 1)$. Aqueous sodium hydroxide $(2 \mathrm{M}, 1.4 \mathrm{~m} 1$, $2.8 \mathrm{mmol}$ ) was added and the suspension was stirred for $24 \mathrm{~h}$ until only catalyst remained undissolved. The solution was then filtered and evaporated to a brown syrup which was purified by ion exchange chromatography (procedure 1 , elute with aqueous pyridine) to give, after freeze drying, the title compound (5.1) $(0.21 \mathrm{~g}, 51 \%)$ as a white solid (from aqueous acetone or ethanol) which decomposes without melting at $247^{\circ} \mathrm{C} .[a]_{\mathrm{D}}^{20}-6.8^{\circ}\left(\underline{c}, 0.43, \mathrm{H}_{2} 0\right) . v_{\max }(\mathrm{KBr})$ $3401,3099,3036,2927,2713,2565,2427,1652,1615,1568 \mathrm{~cm}^{-1} \cdot 1_{\mathrm{H} \text { NMR }}\left(\mathrm{D}_{2} \mathrm{O}\right)$ $\delta 4.25-4.2(2 \mathrm{H}, \mathrm{m}, \mathrm{H}-3,4) ; 3.85\left(1 \mathrm{H}, \mathrm{d}, \mathrm{H}-2, \mathrm{~J}_{23} 5.0 \mathrm{~Hz}\right) ; 3.41(1 \mathrm{H}, \mathrm{dd}$, $\left.\mathrm{H}-5^{\prime}, \mathrm{J}_{45}, 4.9 \mathrm{~Hz}\right) ; 3.17\left(1 \mathrm{H}, \mathrm{dd}, \mathrm{H}-5, \mathrm{~J}_{45} 4.2 \mathrm{~Hz}, \mathrm{~J}_{55}, 12.4 \mathrm{~Hz}\right) .{ }^{13} \mathrm{C} \mathrm{NMR}\left(\mathrm{D}_{2} \mathrm{O}\right)$ $\delta 48.21(\mathrm{t}, \mathrm{C}-5) ; 64.13(\mathrm{~d}, \mathrm{C}-2) ; 69.77(\mathrm{~d}, \mathrm{C}-4) ; 73.92(\mathrm{~d}, \mathrm{C}-3) ; 171.9$ (s, $\mathrm{C}-1) . \underline{\mathrm{m} / \mathrm{z}}(\mathrm{FAB}+): 148\left(\mathrm{M}+\mathrm{H}^{+}, 100 \%\right)$. Found $\mathrm{C}, 40.90 ; \mathrm{H}, 6.28 ; \mathrm{N}, 9.84$. $\mathrm{C}_{5} \mathrm{H}_{9} \mathrm{NO}_{4}$ requires $\mathrm{C}, 40.82 ; \mathrm{H}, 6.12 ; \mathrm{N}, 9.52$. 
2- Azido- 2- deoxy- 5- $\underline{0}-$ p-toluenesulphony1- D- ribono- 1,4- lactone (5.12) Azido diol (5.10) (0.35 g, $2.0 \mathrm{mmo} 1)$ was dissolved in dry pyridine $(3 \mathrm{~m} 1)$ and

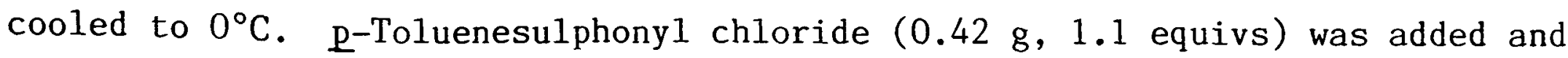
the solution slowly allowed to warm to room temperature. After $14 \mathrm{~h}, \mathrm{t.1.c}$ (ethyl acetate : hexane, $1: 1$ ) showed that some starting material remained $\left(R_{f} 0.2\right)$ and 2 products $\left(R_{f} 0.5,0.8\right)$ had been produced. The solution was diluted with dichloromethane $(25 \mathrm{ml})$ and washed successively with hydrochloric acid (2M aq, $20 \mathrm{ml})$ and water $(25 \mathrm{ml})$. The organic layer was dried and concentrated to a syrup. Purification by flash chromatography (ethyl acetate : hexane, $1: 2)$ afforded the title compound (5.12) (0.21 g, 31\%) a syrup, together with other products. ${ }^{1} \mathrm{H}$ NMR $\delta 7.76,7.39(4 \mathrm{H}, 2 \mathrm{~d}, \mathrm{ArH})$; $4.58(1 \mathrm{H}, \mathrm{m}, \mathrm{H}-4) ; 4.50(1 \mathrm{H}, \mathrm{dd}, \mathrm{H}-3) ; 4.40(1 \mathrm{H}, \mathrm{d}, \mathrm{H}-2) ; 4.31(1 \mathrm{H}, \mathrm{dd}, \mathrm{H}-5)$; $4.21\left(1 \mathrm{H}, \mathrm{dd}, \mathrm{H}-5^{\prime}\right) ; 2.9(1 \mathrm{H}$, br s, OH $) ; 2.47\left(3 \mathrm{H}, \mathrm{s}, \mathrm{CH}_{3}\right)$.

2- Benzyloxycarbonylamino- 3,4- $\underline{0}-$ benzylidene- 2- deoxy- D- ribono- 1,5-

lactone (5.13)

Azide (5.9) (0.22 g, $0.84 \mathrm{mmol})$ was dissolved in ethyl acetate $(10 \mathrm{~m} 1)$ and hydrogenated with palladium black (30 mg) at atmospheric pressure. After 30 min the catalyst was removed by filtration and the solvent evaporated. The crude amine was dissolved in ether : saturated aqueous sodium bicarbonate solution $(5: 2,7 \mathrm{ml})$ and cooled to $0^{\circ} \mathrm{C}$. Benzyl chloroformate $(0.18 \mathrm{~m} 1$, 1.5 equivs) was added and the mixture stirred vigorously for $30 \mathrm{~min}$. The layers were separated and the aqueous phase extracted with further ether $(3 \times 5 \mathrm{ml})$. The organic extracts were combined, dried and evaporated to a syrup. Purification by flash chromatography (ethyl acetate : hexane, 1 : 1) gave the title compound $(5.13)(0.29 \mathrm{~g}, 95 \%) . \mathrm{m} . \mathrm{p} 118^{\circ} \mathrm{C} .[\mathrm{a}]_{\mathrm{D}}^{20}-219.5^{\circ}$ 
$\left(\underline{c}, 0.2, \mathrm{CHCl}_{3}\right) . v_{\max } 1750,1700 \mathrm{~cm}^{-1} \cdot 1_{\mathrm{H} N \mathrm{NMR}} \delta .46-7.34(10 \mathrm{H}, \mathrm{m}, \mathrm{ArH})$; $5.77(1 \mathrm{H}$, br d, NH $) ; 5.76(1 \mathrm{H}, \mathrm{s}, \mathrm{PhCH}) ; 5.15\left(2 \mathrm{H}, \mathrm{s}, \mathrm{PhCH}_{2}\right) ; 4.91(1 \mathrm{H}, \mathrm{dd}$, $\left.\mathrm{H}-3, \mathrm{~J}_{23} 3.2 \mathrm{~Hz}\right) ; 4.71-4.68(2 \mathrm{H}, \mathrm{m}, \mathrm{H}-2,4) ; 4.66(1 \mathrm{H}, \mathrm{dd}, \mathrm{H}-5) ; 4.35(1 \mathrm{H}, \mathrm{dd}$ $\left.\mathrm{H}-5^{\prime}\right) . \underline{\mathrm{m} / \mathrm{z}}: 387\left(\mathrm{M}+\mathrm{NH}_{4}^{+}\right), 370,326,91$ (100\%). Found $\mathrm{C}, 65.41 ; \mathrm{H}, 5.14$; $\mathrm{N}, 3.75 . \mathrm{C}_{20} \mathrm{H}_{19}{ }^{\mathrm{NO}} 6$ requires $\mathrm{C}, 65.04 ; \mathrm{H}, 5.15 ; \mathrm{N}, 3.79$.

2- Benzyloxycarbonylamino- 2- deoxy- D- ribono- 1,4- lactone (5.14)

Acetal (5.13) (0.14 $\mathrm{g}, 0.38 \mathrm{mmol})$ was dissolved in a mixture of trifluoroacetic acid $(4 \mathrm{ml})$ and water $(2 \mathrm{ml})$ and left at room temperature for $14 \mathrm{~h}$. The solvent was evaporated and purification by flash chromatography (ethyl acetate) gave the title compound $(5.14)(0.1 \mathrm{~g}, 91 \%)$ as a syrup. ${ }^{1} \mathrm{H}$ NMR $\delta$ $7.4-7.3(5 \mathrm{H}, \mathrm{m}, \mathrm{ArH}) ; 5.54(1 \mathrm{H}, \mathrm{br} \mathrm{d}, \mathrm{NH}) ; 5.13\left(2 \mathrm{H}, \mathrm{s}, \mathrm{PhCH}_{2}\right) ; 4.77(1 \mathrm{H}, \mathrm{dd}$ $\mathrm{H}-2) ; 4.52(2 \mathrm{H}, \mathrm{m}, \mathrm{H}-3,4) ; 3.93(1 \mathrm{H}, \mathrm{dd}, \mathrm{H}-5) ; 3.83\left(1 \mathrm{H}, \mathrm{dd}, \mathrm{H}-5^{\prime}\right) ; 3.1$ $(1 \mathrm{H}$, br s, OH $) ; 2.8(1 \mathrm{H}$, br s, OH $) . \underline{\mathrm{m} / \mathrm{z}}: 282\left(\mathrm{M}+\mathrm{H}^{+}\right), 265(100 \%)$.

2- Benzyloxycarbonylamino- 2- deoxy- 5- 0 - methanesulphony1- D- ribono-

1,4- lactone (5.15)

Diol (5.14) ( $48 \mathrm{mg}, 0.17 \mathrm{mmol}$ ) was dissolved in pyridine ( $1 \mathrm{ml}$ ) and cooled to $0^{\circ} \mathrm{C}$. Methanesulphony 1 chloride $(0.017 \mathrm{ml}, 1.3$ equivs $)$ was added dropwise with stirring and the solution stirred at $0^{\circ} \mathrm{C}$ for $12 \mathrm{~h}$. The solution was diluted with dichloromethane $(20 \mathrm{~m} 1)$ and washed successively with hydrochloric acid $(2 \mathrm{M}, 10 \mathrm{ml})$ and water $(20 \mathrm{ml})$. The dichloromethane was evaporated and the residue purified by flash chromatography (ethyl acetate : hexane, $3: 1$ ) to afford the title compound (5.15) (43 $\mathrm{mg}, 71 \%)$ together with unreacted dio1 (5.14). (5.15) : m.p 108-111 ${ }^{\circ} \mathrm{C} . V_{\max } 3520,3300,1790,1690 \mathrm{~cm}^{-1}$. $1_{\mathrm{H} N \mathrm{NMR}} \delta 7.37(5 \mathrm{H}, \mathrm{m}, \mathrm{ArH}) ; 5.3(1 \mathrm{H}, \mathrm{br} \mathrm{s}, \mathrm{NH}) ; 5.16\left(2 \mathrm{H}, \mathrm{s}, \mathrm{PhCH}_{2}\right) ; 4.71$ 
$(1 \mathrm{H}, \mathrm{m}, \mathrm{H}-4) ; 4.6-4.46\left(4 \mathrm{H}, \mathrm{m}, \mathrm{H}-2,3,5,5^{\prime}\right) ; 3.1(1 \mathrm{H}, \mathrm{br} \mathrm{s}, \mathrm{OH}) ; 3.08$ $\left(3 \mathrm{H}\right.$, br s, $\left.\mathrm{CH}_{3} \mathrm{~S}\right) . \underline{\mathrm{m} / \mathrm{z}}\left(\mathrm{CI}, \mathrm{NH}_{3}\right): 377\left(\mathrm{M}+\mathrm{NH}_{4}^{+}, 100 \%\right), 360,316,269$. Found $\mathrm{C}, 46.98 ; \mathrm{H}, 4.77 ; \mathrm{N}, 3.82 . \mathrm{C}_{14} \mathrm{H}_{17} \mathrm{NO}_{8} \mathrm{~S}$ requires $\mathrm{C}, 46.80 ; \mathrm{H}, 4.74$; $\mathrm{N}, 3.90$.

2- Azido- 2- deoxy- 3,4- $\underline{0}-$ benzylidene- D- ribonic acid hydrazide (5.16)

Azido lactone (5.9) (0.2 g, $0.77 \mathrm{mmol})$ was dissolved in dioxane (10 ml) and hydrazine monohydrate $(0.041 \mathrm{ml}, 1.1$ equivs) added under a stream of nitrogen at room temperature. After $14 \mathrm{~h}$, the solution was neutralised with hydrochloric acid (2M, aq), evaporated and the residue partitioned between ethyl acetate $(20 \mathrm{ml})$ and water $(5 \mathrm{ml})$. Purification of the residue by flash chromatography (ethyl acetate) gave starting material (5.9) (51 $\mathrm{mg}, 25 \%$ ) and the title compound $(5.16)(91 \mathrm{mg}, 40 \%)$. m.p $103-104^{\circ} \mathrm{C} .[a]_{\mathrm{D}}^{20}-53.2^{\circ}$ (c,

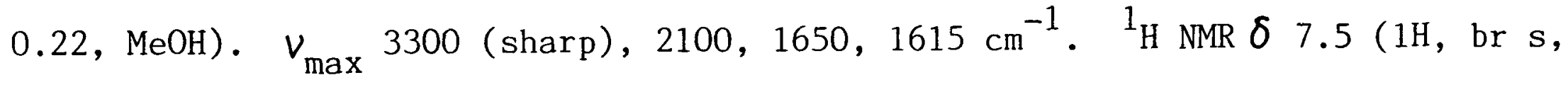
$\mathrm{NH})$; $7.4-7.3(5 \mathrm{H}, \mathrm{m}, \mathrm{ArH}) ; 5.9(1 \mathrm{H}, \mathrm{s}, \mathrm{PhCH}) ; 4.7(1 \mathrm{H}, \mathrm{dd}, \mathrm{H}-3) ; 4.4(1 \mathrm{H}, \mathrm{dt}$, $\mathrm{H}-4) ; 4.3(1 \mathrm{H}, \mathrm{d}, \mathrm{H}-2) ; 3.95(1 \mathrm{H}, \mathrm{dd}, \mathrm{H}-5) ; 3.90\left(1 \mathrm{H}, \mathrm{dd}, \mathrm{H}-5^{\prime}\right) ; 2.2(1 \mathrm{H}, \mathrm{br} \mathrm{s}$, $\mathrm{OH}) ; 1.7\left(2 \mathrm{H}\right.$, br s, $\left.\mathrm{NH}_{2}\right) . \underline{\mathrm{m} / \mathrm{z}}: 311\left(\mathrm{M}+\mathrm{NH}_{4}^{+}\right), 294,266(100 \%)$. Found $\mathrm{C}, 49.40 ; \mathrm{H}, 5.16 ; \mathrm{N}, 23.68 . \mathrm{C}_{12} \mathrm{H}_{15} \mathrm{~N}_{5} \mathrm{O}_{4}$ requires $\mathrm{C}, 49.15 ; \mathrm{H}, 5.12 ; \mathrm{N}, 23.89$.

2,5- Anhydro- 3,4- $\underline{0}-$ benzylidene- D- arabinonamide (5.19)

Triflate (5.8) (0.2 g, $0.54 \mathrm{mmol})$ was dissolved in dioxane (10 m 1$)$ and ammonia solution (SG 0.88)(1 ml) added. After $1 \mathrm{~h}$, the solvent was removed and purification by flash chromatography (ethyl acetate) gave the title compound (5.19) (50 mg, 40\%). ${ }_{1} \mathrm{H} \operatorname{NMR} \delta 7.6-7.3(5 \mathrm{H}, \mathrm{m}, \mathrm{ArH}) ; 6.6,5.9(2 \mathrm{H}, 2 \mathrm{br} \mathrm{s}$, $\left.\mathrm{NH}_{2}\right) ; 5.85(1 \mathrm{H}, \mathrm{s}, \mathrm{PhCH}) ; 5.2(1 \mathrm{H}, \mathrm{d}, \mathrm{H}-3) ; 4.9(1 \mathrm{H}, \mathrm{dd}, \mathrm{H}-4) ; 4.75(1 \mathrm{H}, \mathrm{s}$, $\mathrm{H}-2) ; 4.2(1 \mathrm{H}, \mathrm{d}, \mathrm{H}-5) ; 3.9\left(1 \mathrm{H}, \mathrm{dd}, \mathrm{H}-5^{\prime}\right) . \underline{\mathrm{m} / \mathrm{z}}: 253\left(\mathrm{M}+\mathrm{NH}_{4}^{+}, 100 \%\right), 236$. 
3,5- Di- $\underline{0}-$ benzyl- $1,2-\underline{0}-$ isopropylidene- $a-\underline{D}-$ ribofuranose (5.21)

Diacetone allose $(5.04 \mathrm{~g}, 19.4 \mathrm{mmol})$ was dissolved in acetic acid : water : methanol $(1: 1: 1,120 \mathrm{ml})$ and warmed to $50^{\circ} \mathrm{C}$. After $3 \mathrm{~h}$, the solvent was evaporated and the crude triol was dissolved in ethanol : water $(3: 1,100 \mathrm{~m} 1)$ and treated with sodium periodate $(8.13 \mathrm{~g}, 2$ equivs) at room temperature. After $1 \mathrm{~h}$, sodium borohydride $(0.7 \mathrm{~g}, 1$ equiv) was added and the solution stirred for a further $30 \mathrm{~min}$. The precipitated inorganics were removed by filtration and the solution concentrated. The crude residue was extracted with ethyl acetate and filtered through a silica plug to yield crude 1,2O- isopropylidene- $a-\underline{D}-$ ribofuranose $(3.01 \mathrm{~g})$. The crude diol was dissolved in DMF $(50 \mathrm{ml})$ and stirred in the dark with silver (I) oxide $(14 \mathrm{~g})$ and benzyl bromide $(7.5 \mathrm{ml})$. After $24 \mathrm{~h} \mathrm{t.1.c} \mathrm{(ethyl}$ acetate : hexane, $1: 4)$ showed no starting material $\left(\mathrm{R}_{f} 0\right)$ and one product $\left(R_{f} 0.3\right)$. The solution was diluted with ether $(50 \mathrm{ml})$, filtered through celite and concentrated to a syrup. Purification by flash chromatography (ethyl acetate : hexane, 1 : 4) gave the title compound (5.21) (4.20 g, 59\% from diacetone allose) an oil. $[a]_{\mathrm{D}}^{20}+88.4^{\circ}\left(\underline{c}, 0.57, \mathrm{CHCl}_{3}\right) \cdot 1_{\mathrm{H} \mathrm{NMR}} \delta$ $7.38-7.29(10 \mathrm{H}, \mathrm{m}, \mathrm{ArH}) ; 5.78\left(1 \mathrm{H}, \mathrm{d}, \mathrm{H}-1, \mathrm{~J}_{12} 3.7 \mathrm{~Hz}\right) ; 4.65\left(2 \mathrm{H}, \mathrm{ABq}, \mathrm{PhCH}_{2}\right)$; $4.54\left(3 \mathrm{H}, \mathrm{m}, \mathrm{PhCH}_{2}, \mathrm{H}-2\right) ; 4.21(1 \mathrm{H}, \mathrm{ddd}, \mathrm{H}-4) ; 3.88(1 \mathrm{H}, \mathrm{dd}, \mathrm{H}-3) ; 3.79$ $(1 \mathrm{H}, \mathrm{dd}, \mathrm{H}-5) ; 3.59\left(1 \mathrm{H}, \mathrm{dd}, \mathrm{H}-5^{\prime}\right) ; 1.5,1.3\left(6 \mathrm{H}, 2 \mathrm{~s}, \mathrm{CH}_{3} \mathrm{C}\right) . \mathrm{m} / \mathrm{z}: 388\left(\mathrm{M}+\mathrm{NH}_{4}^{+}\right.$ $370,91(100 \%)$.

3,5- di- $\underline{0}-$ benzyl- D- ribono- $1,4-$ lactone (5.20)

Acetonide (5.21) (0.39 g, $1.05 \mathrm{mmol})$ was dissolved in $50 \%$ aqueous trifluoroacetic acid $(6 \mathrm{ml})$ and heated to $50^{\circ} \mathrm{C}$. After $2 \mathrm{~h}$, the solvent was removed to give the crude lactol $\left(\underline{\mathrm{m} / \mathrm{z}}: 348\left(\mathrm{M}+\mathrm{NH}_{4}{ }^{+}\right), 330(100 \%)\right)$, which was dissolved in dioxane : water $(2: 1,6 \mathrm{ml})$ and cooled to $0^{\circ} \mathrm{C}$. Barium carbonate ( $0.53 \mathrm{~g}, 3$ equivs) was added and then bromine $(0.069 \mathrm{ml}, 1.5$ equivs $)$ dropwise. 
The mixture was stirred in the dark for $24 \mathrm{~h}$. Excess bromine was destroyed by dropwise addition of sodium thiosulphate solution (1M) and the precipitated sulphur was removed by centrifugation. Thr resulting clear solution was diluted with ethyl acetate $(10 \mathrm{ml})$ and the layers separated. The organic layer was dried and concentrated to a syrup. Purification by flash chromatography (ethyl acetate : hexane, $1: 2)$ gave the title compound (5.20) (0.22 g, $64 \%$ ) a syrup. $V_{\max } 3450(\mathrm{br}), 1770 \mathrm{~cm}^{-1} \cdot{ }_{\mathrm{H}} \operatorname{NMR} \delta 7.4-7.3(10 \mathrm{H}, \mathrm{m}, \operatorname{ArH})$; 4.74- $4.47(6 \mathrm{H}, \mathrm{m}) ; 4.19\left(1 \mathrm{H}, \mathrm{d}, \mathrm{H}-2, \mathrm{~J}_{23} 5.8 \mathrm{~Hz}\right) ; 3.69(1 \mathrm{H}, \mathrm{dd}, \mathrm{H}-5) ; 3.57$ $\left(1 \mathrm{H}, \mathrm{dd}, \mathrm{H}-5^{\prime}\right) ; 2.89(1 \mathrm{H}, \mathrm{br} \mathrm{d}, \mathrm{OH}) . \underline{\mathrm{m} / \mathrm{z}}: 346\left(\mathrm{M}+\mathrm{NH}_{4}^{+}\right), 237,181,91(100 \%)$.

2- Trifluoroacetamido- 3,4- $\underline{0}-$ benzylidene- $2-$ deoxy- D- ribono- 1,5-

lactone (5.22)

Azide (5.9) (0.2 $\mathrm{g}, 0.77 \mathrm{mmol})$ was reduced as before. The crude amine was dissolved in trifluoroacetic anhydride $(1 \mathrm{~m} 1)$ at $0^{\circ} \mathrm{C}$. After $10 \mathrm{~min}$ the solvent was removed. Purification by flash chromatography gave the title compound $(5.22)(0.2 \mathrm{~g}, 80 \%) . \mathrm{m} \cdot \mathrm{p} 180^{\circ} \mathrm{C}, V_{\max } 3320,1750,1700 \mathrm{~cm}^{-1}$. $1_{\mathrm{H} N \mathrm{NMR}} \delta 7.47-7.42(5 \mathrm{H}, \mathrm{m}, \mathrm{ArH}) ; 7.3(1 \mathrm{H}, \mathrm{br} \mathrm{d}, \mathrm{NH}) ; 5.79(1 \mathrm{H}, \mathrm{s}, \mathrm{PhCH})$; $5.0(1 \mathrm{H}, \mathrm{dd}, \mathrm{H}-3) ; 4.9(1 \mathrm{H}, \mathrm{dd}, \mathrm{H}-2) ; 4.8(1 \mathrm{H}, \mathrm{dd}, \mathrm{H}-4) ; 4.7(1 \mathrm{H}, \mathrm{d}, \mathrm{H}-5)$; $4.4\left(1 \mathrm{H}, \mathrm{dd}, \mathrm{H}-5^{\prime}\right) . \underline{\mathrm{m} / \mathrm{z}}: 349\left(\mathrm{M}+\mathrm{NH}_{4}^{+}, 100 \%\right), 245$. Found $\mathrm{C}, 50.49$; $\mathrm{H}, 3.25 ; \mathrm{N}, 4.42 . \mathrm{C}_{14} \mathrm{H}_{12} \mathrm{NO}_{5} \mathrm{~F}_{3}$ requires $\mathrm{C}, 50.76 ; \mathrm{H}, 3.63 ; \mathrm{N}, 4.23$.

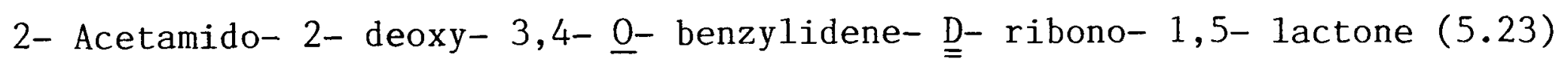
Azide $(5.9)(0.1 \mathrm{~g}, 0.38 \mathrm{mmol})$ was hydrogenated in ethyl acetate $(3 \mathrm{ml})$ with palladium black ( $10 \mathrm{mg}$ ). After $1 \mathrm{~h}$, the catalyst was filtered and the solvent evaporated. The crude amine was dissolved in acetic anhydride ( $1 \mathrm{~m} 1$ ) at room temperature. After 15 min the solvent was removed and purification 
by flash chromatography (ethyl acetate : hexane, $1: 1$ ) gave the title compound (5.23) (78 mg, 74\%). m.p $159-160^{\circ} \mathrm{C} .[a]_{\mathrm{D}}^{20}-272.6^{\circ}(\underline{c}, 0.19, \mathrm{MeOH})$

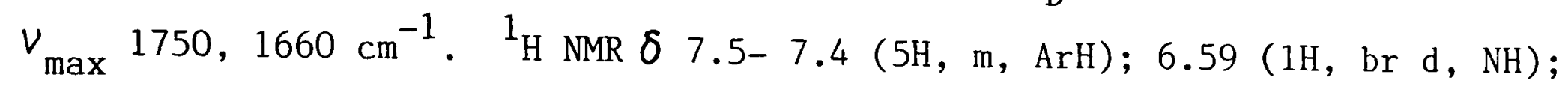
$5.74(1 \mathrm{H}, \mathrm{s}, \mathrm{PhCH}) ; 4.96\left(1 \mathrm{H}, \mathrm{dd}, \mathrm{H}-3, \mathrm{~J}_{23} 3.3 \mathrm{~Hz}\right) ; 4.87(1 \mathrm{H}, \mathrm{dd}, \mathrm{H}-2) ; 4.66$ $(1 \mathrm{H}, \mathrm{m}, \mathrm{H}-4) ; 4.35(1 \mathrm{H}, \mathrm{dd}, \mathrm{H}-5) ; 4.61\left(1 \mathrm{H}, \mathrm{H}-5^{\prime}\right)$. Found $\mathrm{C}, 60.93 ; \mathrm{H}, 5.53$; $\mathrm{N}, 5.26 . \mathrm{C}_{14} \mathrm{H}_{15} \mathrm{NO}_{5}$ requires $\mathrm{C}, 60.65 ; \mathrm{H}, 5.42 ; \mathrm{N}, 5.05$.

3- Azido- 3- ene- 5ㅇ- hydroxy- Pyran- 2- one (5.24)

Benzylidene azido lactone (5.9) (30 mg, $0.115 \mathrm{mmol}$ ) was dissolved in $\mathrm{CDCl}_{3}$ $(1 \mathrm{ml})$, and the NMR spectrum $(60 \mathrm{MHz})$ recorded. 1,8 Diazabicyclo $[5,4,0]$ undec- 7 - ene (DBU) $(0.017 \mathrm{ml}, 1$ equiv) was added and the disappearance of the starting material monitored by NMR. The reaction was complete in 5 min and a rapid darkening of the solution was observed. The solvent was removed and purification by flash chromatography (ethyl acetate : hexane, 1 : 1) gave the title compound $(5.24)(8 \mathrm{mg}, 44 \%)$ as a syrup. $1_{\mathrm{H}} \mathrm{NMR} \delta 6.3(1 \mathrm{H}, \mathrm{m}, \mathrm{H}-4)$; $4.5\left(3 \mathrm{H}, \mathrm{m}, \mathrm{H}-5,6,6^{\prime}\right) ; 2.5(1 \mathrm{H}, \mathrm{br} \mathrm{s}, \mathrm{OH})$.

3- Benzyloxycarbonylamino- 3- ene- 5- hydroxy- Pyran- 2- one (5.25)

Benzylidene $Z$ lactone (5.13) (0.12 g, $0.33 \mathrm{mmol})$ was dissolved in $\mathrm{CDCl}_{3}(1.5$ $\mathrm{m} 1)$. DBU $(0.048 \mathrm{ml}, 1.0$ equivs $)$ was added and the progress of the reaction monitored by NMR. After 30 min all the starting material had been consumed and the solvent was evaporated. Purification by flash chromatography (ethyl acetate : hexane, $1: 2)$ gave the title compound $(5.25)(0.08 \mathrm{~g}, 68 \%)$ as a syrup. $V_{\max } 3400(\mathrm{br}), 1720,1640(\mathrm{w}), 1520 \mathrm{~cm}^{-1} \cdot 1_{\mathrm{H} \text { NMR }} \delta 7.5-7.4$ $(5 \mathrm{H}, \mathrm{m}, \mathrm{ArH}) ; 7.2(1 \mathrm{H}, \mathrm{br} \mathrm{d}, \mathrm{H}-4) ; 5.1\left(2 \mathrm{H}, \mathrm{ABq}, \mathrm{PhCH}_{2}\right) ; 4.47\left(3 \mathrm{H}, \mathrm{m}, \mathrm{H}-5,6,6^{\prime}\right)$; $2.8(1 \mathrm{H}$, br d, OH $) .{ }^{13} \mathrm{C}$ NMR $\delta 61.14(\mathrm{~d}, \mathrm{C}-4) ; 67.42\left(\mathrm{t}, \mathrm{PhCH}_{2}\right) ; 72.57(\mathrm{t}, \mathrm{C}-5)$; 
$119.20(\mathrm{~d}, \mathrm{C}-3) ; 126.55(\mathrm{~s}), 128.19(\mathrm{~d}), 128.49(\mathrm{~d}), 128.61(\mathrm{~d})(\operatorname{ArC})$;

$135.40(\mathrm{~s}, \mathrm{C}-1) ; 152.98(\mathrm{~s}, \mathrm{NHCOO}) ; 161.10(\mathrm{~s}, \mathrm{C}-2) . \underline{\mathrm{m} / \mathrm{z}}: 281\left(\mathrm{M}+\mathrm{NH}_{4}^{+}\right)$, $264,91(100 \%)$.

3- Trifluoroacetamido- 3- ene- 5- hydroxy- Pyran- 2- one (5.26)

Amide (5.22) (20 mg, $0.06 \mathrm{mmol}$ ) was eliminated in exactly the same way as described above with DBU $(0.009 \mathrm{ml})$. Purification by flash chromatography gave the title compound $(5.26)(7.3 \mathrm{mg}, 37 \%)$ together with a lower running impurity which was not identified. ${ }^{1} \mathrm{H}$ NMR $\delta 8.61(1 \mathrm{H}, \mathrm{br} \mathrm{s}, \mathrm{NH}) ; 7.70$ $\left(1 \mathrm{H}, \mathrm{d}, \mathrm{H}-4, \mathrm{~J}_{45} 5.4 \mathrm{~Hz}\right) ; 4.63(1 \mathrm{H}, \mathrm{m}, \mathrm{H}-5) ; 4.57(2 \mathrm{H}, \mathrm{m}, \mathrm{H}-6) ; 2.1(1 \mathrm{H}, \mathrm{m}, \mathrm{OH})$. 


\section{SUMMARY}

D- ribonolactone was converted into the D- amino acid (2R, 3S, 4R) 3,4dihydroxyproline (5.1). The key step of the synthesis was an azide displacement at the $\mathrm{C} 2$ position which unexpectedly occurred with retention of configuration. Approaches to the synthesis of the epimer (5.2) and the 4- hydroxyproline (5.29) from ribonolactone derivatives were also discussed.

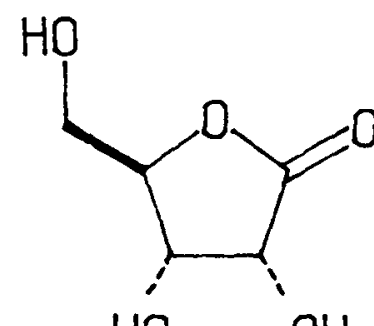

$\mathrm{HO} \quad \mathrm{OH}$

D-ribonolactone

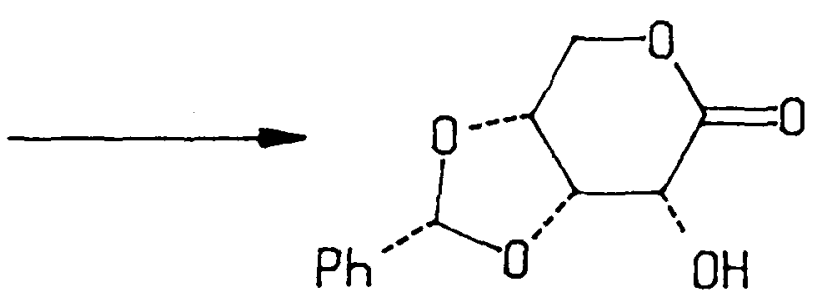

$(5.6)$
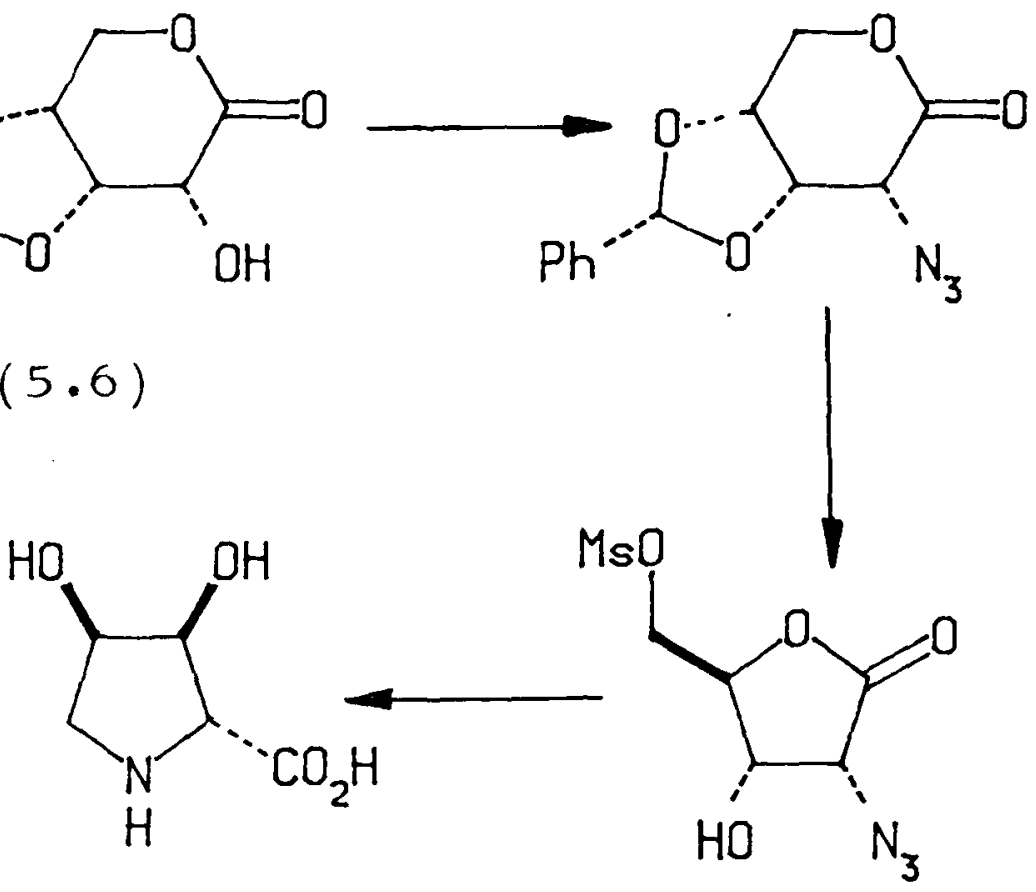

$(5 \cdot 1)$

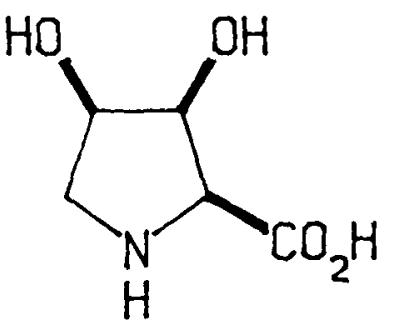

$(5.2)$

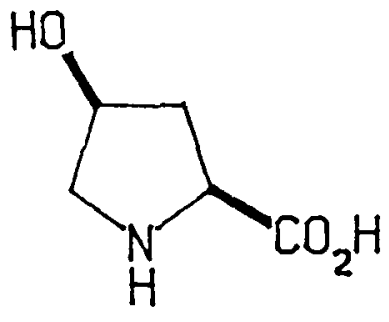

$(5.29)$

CHAPTER 5 SUMMARY 


\section{CHAPTER 5 REFERENCES}

1. J-U.Kar1 and T.Wieland, Liebigs.Ann.Chem., 1981, 1445; A.Buku, H.Faulstich, T.Wieland and J.Dabrowski, Proc.Nat1.Acad.Sci.U.S.A., 1980, 77, 2370.

2. T.Nakajima and B.E.Volcani, Science., 1969, 164, 1400; I.L.Karle, J.W.Daly and B.Witkop, Science., 1969, 164, 1401.

3. Y.Ohfune and N.Kurokawa, Tetrahedron.Lett., 1985, 26, 5307.

4. C.B.Hudson, A.V.Robertson and W.R.J.Simpson, Aust.J.Chem., 1975, 28, 2479.

5. C.B.Hudson, A.V.Robertson and W.R.J.Simpson, Aust.J.Chem., 1968, 21, 769.

6. H.Zinner, H.Voight and J.Voight, Carbohydr.Res., 1968, ㄱ, 38.

7. Y.S.Chen and M.M.Jouillie, J.Org.Chem., 1984, 49, 2168.

8. N.Baggett, J.G.Buchanan, M.Y.Fatah, K.J.McCullough and J.M.Webber, J.Chem. Soc.Chem.Commun., 1985, 1826.

9. G.W.J.Fleet and B.P.Bashyal, unpublished results.

10. The structures of these compounds were incorrectly assigned as 1,4lactones.

11. J.D.Stevens 'Methods in Carbohydrate Chemistry' Vol 6, p 128 (Academic press, 1972).

12. G.Ritzmann, R.S.K1ein, D.H.Hollenberg and J.J.Fox, Carbohydr.Res,, 1975, $\underline{39}, 227$.

13. R.Kuhn, I.Low and H.Trischman, Chem.Ber., 1957, 90, 203.

14. G.W.J.Fleet and B.P.Bashyal, personal communication. 


\section{APPENDIX}

\section{Publications arising from this thesis.}

1. 'Enantiospecific syntheses of deoxymannojirimycin, fagomine and 2R, 5Rdihydroxymethy1-3R, 4R- dihydroxypyrrolidine from D- glucose.' G.W.J.Fleet and P.W.Smith, Tetrahedron.Lett., 1985, 26, 1469.

2. 'Synthesis of 2- acetamido- 1,5- imino- 1,2, 5- trideoxy- D- mannitol and of 2- acetamido- 1,5- imino- 1,2,5- trideoxy- D- glucitol, a potent and specific inhibitor of a number of $\beta$-N-acetylglucosaminidases.' G.W.J.Fleet, P.W.Smith, R.J.Nash, L.E.Fellows, R.J.Parekh and T.W.Rademacher, Chem.Lett., 1986, 1051. 3. 'Potent and competitive inhibition of $a$ galactosidase and $a$ glucosidase activity by 1,4- dideoxy- 1,4- imino- pentitols: synthesis of 1,4- dideoxy1,4- imino- D- 1yxitol and of both enantiomers of 1,4- dideoxy- 1,4- iminoarabinitol.' G.W.J.Fleet, P.W.Smith, S.V.Evans, L.E.Fellows and R.J.Nash, Tetrahedron.Lett., 1985, 26, 3127.

4. 'The synthesis from D- xylose of the potent and specific enantiomeric glucosidase inhibitors, 1,4- dideoxy- 1,4- imino- D- arabinitol and 1,4- dideoxy1,4- imino- L- arabinitol.' G.W.J.Fleet and P.W.Smith, Tetrahedron., 1986, 42,5685 .

5. 'Synthesis of $2 \mathrm{R}, 3 \mathrm{~S}, 4 \mathrm{R}$-dihydroxyproline from D-ribonolactone.' J.C.Dho, G.W.J.Fleet, J.M.Peach, K.Prout and P.W.Smith, Tetrahedron.Lett., 1986, 27, 3203. (Full paper in press- J.Chem.Soc.Perkin I.)

Other papers are currently in preparation. 